Trepostome and Cystoporate Bryozoans from the Lexington Limestone and the Clays Ferry Formation (Middle and Upper Ordovician) of Kentucky

GEOLOGICAL SURVEY PROFESSIONAL PAPER 1066-I

Prepared in cooperation with the

Commonwealth of Kentucky,

University of Kentucky,

Kentucky Geological Survey

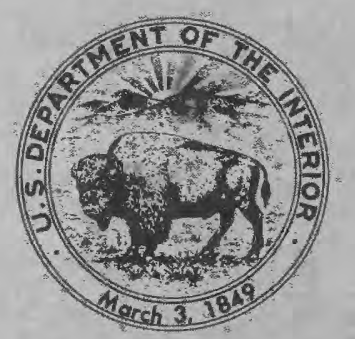





\title{
Trepostome and Cystoporate Bryozoans from the Lexington Limestone and the Clays Ferry Formation (Middle and Upper Ordovician) of Kentucky
}

\author{
By O. L. KARKLINS
}

CONTRIBUTIONS TO THE ORDOVICIAN PALEONTOLOGY OF
KENTUCKY AND NEARBY STATES

Edited by JOHN POJETA, JR.

GE O L O I C A L S URVEY PROFESSIONALA A PER 1066 - I

Prepared in cooperation with the

Commonwealth of Kentucky,

University of Kentucky,

Kentucky Geological Survey

Descriptions and illustrations of

36 bryozoan taxa, including

1 new genus, and 6 new species, with discussions of their

biostratigraphic significance 


\title{
UNITED STATES DEPARTMENT OF THE INTERIOR
}

\author{
WILLIAM P. CLARK, Secretary
}

\section{GEOLOGICAL SURVEY}

Dallas L. Peck, Director

\section{Library of Congress Cataloging in Publication Data}

Karklins, Olgerts L., 1924-

Trepostome and cystoporate bryozoans from the Lexington Limestone and the Clays Ferry formation (Middle-Upper Ordovician) of Kentucky.

(Geological Survey professional paper ; 1066-I)

(Contributions to the Ordovician paleontology of Kentucky and nearby states)

Bibliography: $p$.

Supt. of Docs. no.: I 19.16:1066I

1. Trepostomata. 2. Cystoporata. 3. Paleontology-Ordovician. 4. Paleontology-Kentucky. I. Title. II. Series. III. Series: Contributions to the Ordovician paleontology of Kentucky and nearby states. $\begin{array}{llll}\text { QE799.T7K37 } & 1984 & 561^{\prime} .8 & 83-600266\end{array}$

For sale by the Distribution Branch, U.S. Geological Survey, 604 South Pickett Street, Alexandria, VA 22304 


\section{CONTENTS}

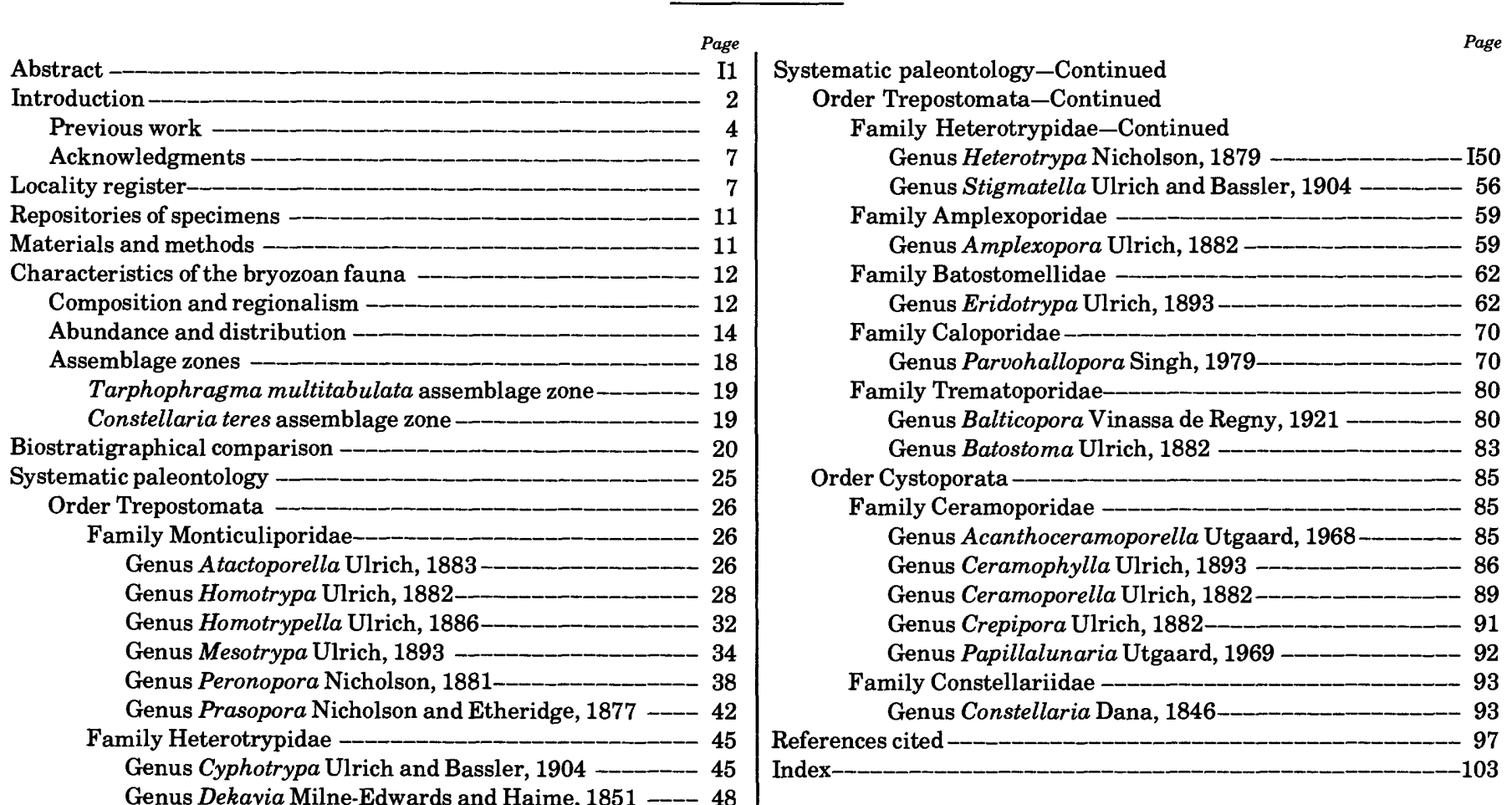

\section{ILLUSTRATIONS}

[Plates 1-3 are in pocket; plates 4-41 follow Index]

Plate 1. Stratigraphic cross sections showing distribution of bryozoan species.

2. Charts showing composite ranges of bryozoan species.

3. Tables showing measured sections, distribution of bryozoan species, and relative abundance of bryozoan species.

4. Atactoporella

5. Atactoporella, Homotrypa

6, 7. Homotrypa

8. Homotrypella

9. Mesotrypa

10. Mesotrypa, Peronopora

11, 12. Peronopora

13, 14. Prasopora

15, 16. Heterotrypa, Cyphotrypa

17. Dekayia

18. Dekayia, Stigmatella

19, 20. Heterotrypa

21. Stigmatella

22. Amplexopora, Batostoma

23. Amplexopora

24-28. Eridotrypa

29-31. Parvohallopora 
Plate 32, 33. Tarphophragma

34. Balticopora

35. Balticopora, Constellaria

36. Balticopora

37. Ceramophylla, Acanthoceramoporella

38. Ceramoporella, Ceramophylla, Crepipora

39. Crepipora, Papillalunaria

40, 41. Constellaria

1. Index map showing the location of the study area -

2. Index map of counties in central Kentucky - 5

3. Index map of 71/2-minute quadrangles in central Kentucky

\section{TABLES}

1. Atactoporella newportensis Ulrich

2. Atactoporella newportensis Ulrich

3. Homotrypa similis Foord

4. Homotrypa similis Foord

5. Homotrypa similis Foord

6. Homotrypa cressmani $\mathrm{n}$. sp.

7. Homotrypa cressmani $\mathrm{n}$. sp.

8. Comparison of zoarial characters in Homotrypa cressmani and related species

9-37. Summarized measurements of specimens of-

9. Homotrypella granulifera (Ulrich)

10. Homotrypella mundula Ulrich

11. Mesotrypa angularis Ulrich and Bassler

12. Mesotrypa angularis Ulrich and Bassler

13. Mesotrypa spinosa Ulrich

14. Mesotrypa sp.

15. Peronopora milleri Nickles

16. Peronopora milleri Nickles

17. Peronopora vera Ulrich

18. Prasopora falesi (James)

19. Prasopora falesi (James)

20. Prasopora falesi (James)

21. Cyphotrypa acervulosa (Ulrich)

22. Cyphotrypa acervulosa (Ulrich)

23. Cyphotrypa switzeriensis $\mathrm{n}$. sp.

24. Cyphotrypa switzeriensis $\mathrm{n}$. $\mathrm{sp}$

25. Dekayia epetrima $\mathrm{n}$. sp.

26. Dekayia sp.

27. Heterotrypa foliacea (Ulrich and Bassler)

28. Heterotrypa foliacea (Ulrich and Bassler)

29. Heterotrypa foliacea (Ulrich and Bassler)

30. Heterotrypa trentonensis (Ulrich)

31. Heterotrypa trentonensis (Ulrich)

32. Stigmatella clavis (Ulrich)

33. Stigmatella clavis (Ulrich)

34. Stigmatella multispinosa Brown

35. Stigmatella sp.

36. Amplexopora persimilis Nickles

37. Amplexopora aff. A. winchelli Ulrich

38. Differences between arithmetic means from $A$. winchelli Ulrich and confidence intervals of means from A. aff. A. winchelli

39-44. Summarized measurements of specimens of-

39. Eridotrypa mutabilis Ulrich

40. Eridotrypa mutabilis Ulrich

41. Eridotrypa mutabilis Ulrich 
42. Eridotrypa trentonensis (Nicholson)

43. Eridotrypa trentonensis (Nicholson)

44. Eridotrypa trentonensis (Nicholson)

45. Differences between 95 percent confidence interval of means of characters in Eridotrypa mutabilis, E. trentonensis, and $E$. sadievillensis

46-69. Summarized measurements of specimens of-

46. Eridotrypa sadievillensis $\mathrm{n}$. $\mathrm{sp}$.

47. Parvohallopora nodulosa (Nicholson) - _ _

48. Parvohallopora onealli (James)

49. Parvohallopora onealli (James)

50. Parvohallopora onealli (James)

51. Tarphophragma multitabulata (Ulrich)

52. Tarphophragma multitabulata (Ulrich)

53. Tarphophragma multitabulata (Ulrich)

54. Balticopora tenuimurale (Ulrich)

55. Balticopora tenuimurale (Ulrich)

56. Balticopora tenuimurale (Ulrich)

57. Balticopora arcuatilis $\mathrm{n}$. $\mathrm{sp}$.

58. Balticopora arcuatilis $\mathrm{n}$. sp.

59. Acanthoceramoporella valliensis $\mathrm{n}$. $\mathrm{sp}$.

60. Ceramophylla alternatum (James)

61. Ceramophylla alternatum (James)

62. Ceramophylla alternatum (James)

63. Ceramoporella distincta Ulrich

64. Ceramoporella distincta Ulrich-

65. Crepipora venusta (Ulrich)

66. Papillalunaria spatiosa (Ulrich)

67. Constellaria fischeri Ulrich-

68. Constellaria teres Hayes and Ulrich

69. Constellaria teres Hayes and Ulrich

\section{SYSTEM OF MEASUREMENT UNITS}

The investigations underlying this series of reports were made over a period of years, and distances and stratigraphic measurements appear fairly uniformly in English units. Measurements of fossil specimens, on the other hand, follow the longstanding convention of appearing in metric units. Because of the dates of the investigations and the amount of resulting data, the English measurements have been retained. Conversions to metric units may be made by using the following conversion table.

To convert English unit:

Mile (mi)

Foot (ft)

Inch (in.)
To metric unit:

Kilometer $(\mathrm{km})$

Meter (m)

Centimeter $(\mathrm{cm})$
Multiply by:

1.61

.305

.394 



\title{
TREPOSTOME AND CYSTOPORATE BRYOZOANS FROM THE LEXINGTON LIMESTONE AND THE GLAYS FERRY FORMATION (MIDDLE AND UPPER ORDOVICIAN) OF KENTUGKY
}

\author{
By O. L. KARKLINS
}

\section{ABSTRACT}

The Lexington Limestone and the Clays Ferry Formation of Kentucky contain an abundant and diversified fossil invertebrate fauna. This report is concerned with the trepostome and cystoporate bryozoans that constitute a major part of that fauna. The Lexington Limestone, largely a biofragmental fossiliferous limestone, rests disconformably on the Tyrone Limestone (Middle Ordovician). The Clays Ferry Formation consists of approximately equal amounts of biofragmental limestone and shale, and it overlies conformably, or intertongues with, the upper part of the Lexington Limestone. The Clays Ferry Formation is overlain by the Garrard Siltstone (Upper Ordovician) in central Kentucky and intertongues with the Kope Formation (Upper Ordovician) in northern Kentucky. The MiddleUpper Ordovician boundary falls within the upper part of the Lexington Limestone and laterally equivalent strata of the Clays Ferry Formation.

The Lexington Limestone has been divided into 12 members, consisting of calcarenites, calcisiltites, calcilutites, nodular limestones, and shales in various amounts, that intertongue complexly. Because of the great abundance of bryozoans this study is generally limited to bryozoans recovered from, in ascending order, the Grier Limestone Member, the Perryville Limestone Member, the Brannon Member, the Tanglewood Limestone Member, and the Millersburg Member of the Lexington Limestone and from the Clays Ferry Formation and its Point Pleasant Tongue.

The trepostome and cystoporate bryozoans discussed are referred to 36 species belonging to 22 genera. The trepostome component includes 29 species belonging to 16 genera: Amplexopora, Atactoporella, Balticopora, Batostoma, Cyphotrypa, Dekayia, Eridotrypa, Heterotrypa, Homotrypa, Homotrypella, Mesotrypa, Parvohallopora, Peronopora, Prasopora, Stigmatella, and Tarphophragma, a new genus. Five of the trepostome species are new: Balticopora arcuatilis, Cyphotrypa switzeriensis, Dekayia epetrima, Eridotrypa sadievillensis, and Homotrypa cressmani. The cystoporate bryozoans include 7 species belonging to 6 genera: Acanthoceramoporella, Ceramophylla, Ceramoporella, Constellaria, Crepipora, and Papillalunaria. One cystoporate species is new: Acanthoceramoporella valliensis.

The trepostome and cystoporate fauna on the generic level is, with few exceptions, cosmopolitan. Five genera, Eridotrypa, Parvohallopora, Heterotrypa, Constellaria, and Peronopora, dominate the fauna, comprising about 77 percent of the thin-sectioned specimens. On the species level the fauna is endemic to the Ordovician of eastern North America and is biostratigraphically restricted to strata of late Black- riveran Stage (Middle Ordovician) to early Maysvillian Stage (middle Late Ordovician). In Kentucky the species of this fauna are restricted to strata between the base of the Lexington Limestone (Kirkfieldian Stage, Middle Ordovician) and the top of the Clays Ferry Formation and its lateral equivalent the Kope Formation (Edenian Stage, lower Upper Ordovician), with few species ranging into strata of early Maysvillian Stage (middle Late Ordovician) in adjacent areas of Indiana and Ohio.

On the basis of the known geographic distribution of the various species, the fauna in Kentucky consists of an intermingling of immigrant and endemic species. The immigrant component (11 species) is generally limited to the lower half of the Lexington-Clays Ferry depositional sequence and permits the establishment of a degree of biostratigraphic equivalence with outcrop areas in Minnesota-Iowa and New York. On the species level the fauna in Kentucky is dominated by four: Constellaria teres, Heterotrypa foliacea, Parvohallopora nodulosa, and Eridotrypa mutabilis, in decreasing relative abundance. The first three species are restricted to the upper part of the Lexington Limestone and the Clays Ferry Formation. Eridotrypa mutabilis is restricted to the middle part of the Lexington Limestone and the lower half of the Clays Ferry Formation.

On the basis of the compiled composite ranges from 29 localities, the species of this fauna appear to be characterized by different, but restricted, stratigraphical ranges. It has not been possible to associate the appearance or disappearance of the various species with the changes in depositional environments depicted by the various lithic units of the Lexington Limestone and the Clays Ferry Formation.

Two bryozoan assemblage zones, in ascending order the Tarphophragma multitabulata and the Constellaria teres, have been recognized on the basis of the restricted ranges and the geographic occurrences of the characteristic species. The base of the T. multitabulata zone is marked by the first appearance of this species in the Curdsville Limestone Member of the Lexington Limestone. This zone includes most of the lower half of the Lexington Limestone. The immigrant species present in the $T$. multitabulata zone indicate that the strata of this zone are biostratigraphically approximately equivalent to the uppermost part of the Decorah Shale and the overlying lower part of the Galena Dolomite (upper Middle Ordovician) in Minnesota; the laterally equivalent strata in Iowa; and the "Rockland," "Kirkfield," "Shoreham," and "Denmark" Formations of late Middle Ordovician age in New York State.

The base of the succeeding Constellaria teres zone is marked by the first appearance of $C$. teres, at the stratigraphical horizon about 180 $\mathrm{ft}$ above the base of the Lexington Limestone. This zone is character- 
ized by the presence of species of the Edenian Stage as defined by the Kope Formation at Cincinnati. Strata in the lower half of the $C$. teres zone record the disappearance of some typical species of late Middle Ordovician age as defined by the formations in New York State and the earliest appearance of several species typical of the Edenian Stage at about the $200 \mathrm{ft}$ stratigraphical horizon above the base of the Lexington Limestone. Thus the Middle-Upper Ordovician boundary as defined on conodonts occurs within the stratigraphic interval of overlap of disappearing species of the Shermanian Stage (Middle Ordovician) and appearing species of the Edenian Stage (Late Ordovician) in the $C$. teres zone.

Descriptions of previously erected species are revised and new species and a new genus are described. The cystoporate genera are grouped into recently revised families of the order Cystoporata. The grouping of the trepostome genera into the families of the order Trepostomata are informal and subject to revisions in concept for these families as further studies are made.

\section{INTRODUCTION}

The trepostome and cystoporate bryozoans are the most abundant and diversified groups in the bryozoan fauna from the Lexington Limestone, the Clays Ferry Formation, and the equivalent strata in the Blue Grass region of Kentucky. Cryptostome bryozoans occur throughout the section as well, but they constitute only a minor part of the bryozoan fauna in these rocks (Karklins, 1983). Next to brachiopods the trepostomes and cystoporates appear to be the most abundant megafossils in the area of this study (fig. 1).

The Lexington Limestone, made up largely of biofragmental carbonates, and the Clays Ferry Formation, consisting of about equal amounts of biofragmental limestone and shale, underlie most of the Blue Grass region of Kentucky. The Lexington-Clays Ferry depositional sequence forms the stratigraphical interval between the top of the Tyrone Limestone (Middle Ordovician) and the base of the Garrard Siltstone (Upper Ordovician) in central Kentucky and its equivalent strata in the Kope Formation (Upper Ordovician) in northern Kentucky (pl. 1).

The Lexington Limestone and the Clays Ferry Formation in ascending order in central Kentucky and the equivalent strata of the Kope Formation of early Late Ordovician age (Edenian Stage) in northern Kentucky are in stratigraphical continuity (Sweet, 1979) with overlying rocks of middle Late Ordovician age (Maysvillian Stage), succeeded by rocks of late Late Ordovician age (Richmondian Stage), in the tristate area of Kentucky, Ohio, and Indiana. This area is termed the Cincinnati region by Sweet (1979); and the Ordovician strata exposed constitute historically (Sweet and Bergström, 1971) the standard reference sections of the Edenian, Maysvillian, and Richmondian Stages of Late Ordovician age for North America.

Most of the significant early studies of Paleozoic bryozoan morphology and systematics and Ordovician bryozoan biostratigraphy (Ulrich, 1882-1884, 1890; Nickles, 1902, 1905; Cumings, 1902, 1908, 1912; Cumings and Galloway, 1913, 1915) were based generally on species occurring in strata of the Edenian, Maysvillian, and Richmondian Stages exposed near Cincinnati. The bryozoan fauna of the LexingtonClays Ferry depositional sequence is stratigraphically older and probably ancestral to the taxonomically and biostratigraphically significant bryozoan faunas in the succeeding strata of the Upper Ordovician in the tristate area of Kentucky, Ohio, and Indiana.

The Lexington-Clays Ferry bryozoan fauna is biostratigraphically significant because many of its species disappear, or appear for the first time, in close proximity to the biostratigraphical boundary between Middle and Late Ordovician, as defined by Sweet and Bergström (1971) and Sweet (1979) in the tristate area of Kentucky, Indiana, and Ohio. In addition, the Lexington-Clays Ferry fauna records the disappearance of some bryozoan species that characterize upper Middle Ordovician strata in New York and Minnesota-Iowa, and records as well the earliest appearances of some species typical of the Edenian Stage (early Late Ordovician) as defined on the Kope Formation in the Kentucky-Ohio-Indiana tristate area (Sweet and Bergström, 1971; Sweet, 1979).

Previous studies of bryozoans from the Blue Grass region of Kentucky have been hindered by lack of both accurately measured lithic sections and a sound lithostratigraphic framework for the complexly intertonguing lithic units that characterize the Lexington Limestone in its spatial relation to the Clays Ferry Formation and the Clays Ferry Formation and in its relation to the Kope. The U.S. Geological Survey, in cooperation with the Kentucky Geological Survey, geologically mapped the State of Kentucky quadrangle by quadrangle on a scale of 1:24,000 between 1960 and 1978.

The geologic mapping program in Kentucky resulted in intensive studies of the lithostratigraphy and depositional environments of the various lithic units of the Lexington Limestone and the Clays Ferry Formation (Black, Cressman, and Macquown, 1965; Weir and Greene, 1965; Cressman, 1973; Black and Cuppels, 1973). During the mapping program a great many invertebrate fossils, including bryozoans, were recovered and used extensively in local correlations of the lithic sections. Most of the collections containing bryozoans used in the present study were recovered between 1965 and 1972. Preliminary determination of the stratigraphical distribution of some bryozoans in the Lexington Limestone has been made by Karklins (Cressman and Karklins, 1970). 


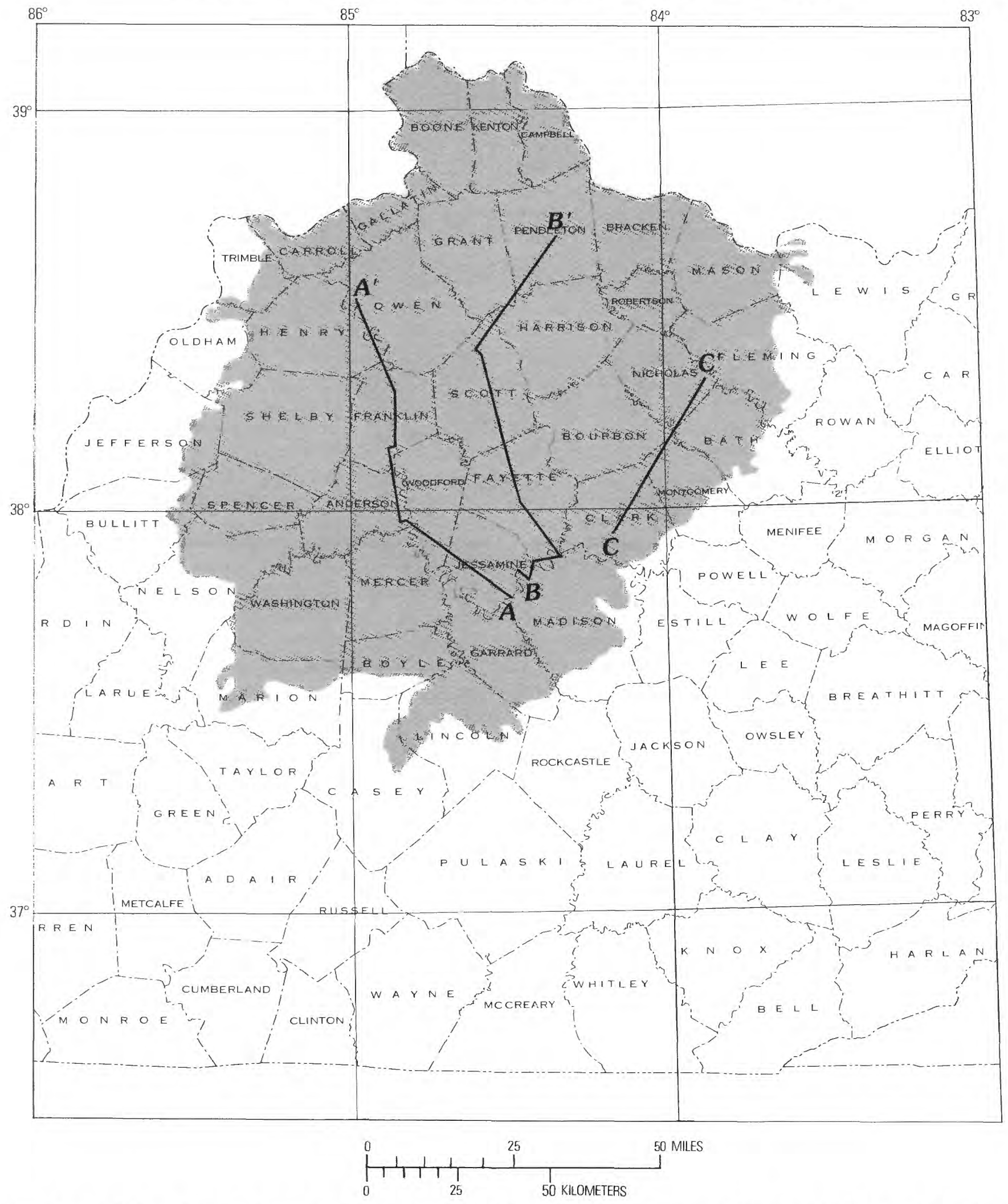

FigURE 1.-Index map showing location of the study area, outline of the surface extent of the Ordovician rocks in northern Kentucky, and the three lines of section, A-A', B-B', and C-C', in the Lexington Limestone and the Clays Ferry and Kope Formations. Map is modified from the Generalized Geologic Map of Kentucky, Kentucky Geological Survey, 1979. 
This report summarizes the geographic and stratigraphic distribution of the trepostome and cystoporate species in the bryozoan fauna of the Lexington Limestone and the Clays Ferry Formation in Kentucky and compares these formations biostratigraphically with equivalent strata in the adjacent areas of Indiana and Ohio and with more distant Ordovician outcrop areas in Minnesota-Iowa and New York on the basis of the species common to those areas (pl. 2). Previously established species found during this study are redescribed and new taxa-Acanthoceramoporella valliensis $\mathrm{n}$. sp., Balticopora arcuatilis n. sp., Cyphotrypa switzeriensis n. sp., Dekayia epetrima n. sp., Eridotrypa sadievillensis n. sp., Homotrypa cressmani n. sp., and Tarphophragma n. gen.-are proposed.

When this work began I hoped that the species of three bryozoan orders-Trepostomata, Cystoporata, and Cryptostomata-present in collections could be described and their ranges indicated in many of the measured sections in Kentucky. This goal could not be achieved because of the great abundance of bryozoans in most collections. Therefore this study is limited to the trepostome and cystoporate specimens constituting a fraction of most collections and to a relatively small number of measured sections or segments of sections (see the Locality register and pl. 3A) having lithologies representative of the major lithic units and their boundaries. Most of the bryozoan specimens are from the area of the Blue Grass region circumscribed by lines of section A-A' and C-C' and the endpoints of lines of sections A-A', B-B' and C-C' (figs. 1, 2). Cressman (1973) discussed 12 members and their depositional environments of the Lexington Limestone and of the Clays Ferry Formation (Weir and Greene, 1965). Bryozoans discussed in the present paper are from the Curdsville Limestone, Grier Limestone, Perryville Limestone, Sulphur Well, Brannon, Tanglewood Limestone, and Millersburg Members of the Lexington Limestone; a tongue of the Clays Ferry Formation; and the Kope Formation (pl. 3B).

This report is part 10 of the "Contributions to the Paleontology of Kentucky and Nearby States," under the general editorship of John Pojeta, Jr. (1979), of the U.S. Geological Survey.

Pojeta (1979, p. A1-A15), in the introduction to the "Contributions," reviewed the history of the recent paleontological studies that have resulted from the geologic mapping of the State of Kentucky by the U.S. Geological Survey in cooperation with the Kentucky Geological Survey. In addition, he briefly summarized recent studies on lithostratigraphy and biostratigraphy and discussed the major trends in thought about biostratigraphic stages of the late Middle and Late Ordovician and the biostratigraphic boundary between the
Middle and Late Ordovician in the tristate area of Kentucky, Indiana, and Ohio. This introduction to the "Contributions" is not repeated here; the interested reader is referred to it.

\section{PREVIOUS WORK}

Early investigations of bryozoan fauna from the Middle and Upper Ordovician rocks of Kentucky are closely associated with the intensive studies of Ordovician bryozoans made in other parts of eastern North America in the late 19th and early 20 th centuries. During that time interest in bryozoans was heightened by a vigorous debate over whether Paleozoic Trepostomata were corals or bryozoans. The great diversity and abundance of well-preserved bryozoans in the Middle and Upper Ordovician strata near Cincinnati, and in adjacent areas of Indiana and Kentucky attracted the attention of the leading paleontologists of the day, including H. N. Nicholson, U. P. James, J. F. James, E. O. Ulrich, J. M. Nickles, R. S. Bassler, E. R. Cumings, and J. J. Galloway. Although the early works dealt mostly with bryozoans in the Ordovician strata of Indiana and Ohio, some of the works included occasional descriptions of bryozoans that had been found in the Ordovician of Kentucky.

James $(1871,1875)$ compiled lists of invertebrate fossils that included bryozoans from exposed Ordovician rocks in the banks on both sides of the Ohio River near Cincinnati. Subsequently, James (1883, 1884) described bryozoans including such trepostomes as Tarphophragma multitabulata ("Monticulipora kentuckiensis" James, 1884) and Prasopora falesi ("Monticulipora falesi" James, 1884) from Ordovician strata near Paris and Danville, Ky. (Bassler, 1906). Later, Bassler (1906) redescribed the primary type material of the above species and reassigned them to Hallopora and Prasopora, respectively.

Early works of Ulrich $(1878,1879)$ included the first descriptions of a ceramoporid species, Crepipora venusta ("Chaetetes venustus" Ulrich, 1878) and of a trepostome, Atactopora hirsuta Ulrich, 1879, from the Kope Formation (= Eden Formation or Shale of authors), near Covington, Ky. Spjeldnaes (1963) established that Ulrich's "Chaetetes venustus" was, by monotypy, the type species of Crepipora and thus defined the concept for this genus. Atactopora hirsuta was not found during the present study.

Ulrich $(1882,1883,1884)$, in a series from his significant publication entitled "American Paleozoic Bryozoa," subsequently erected the genus Atactoporella and its type species A. typicalis Ulrich (1883), and named another species, A. newportensis Ulrich (1883), from the Kope Formation at Covington, Ky. In the same 


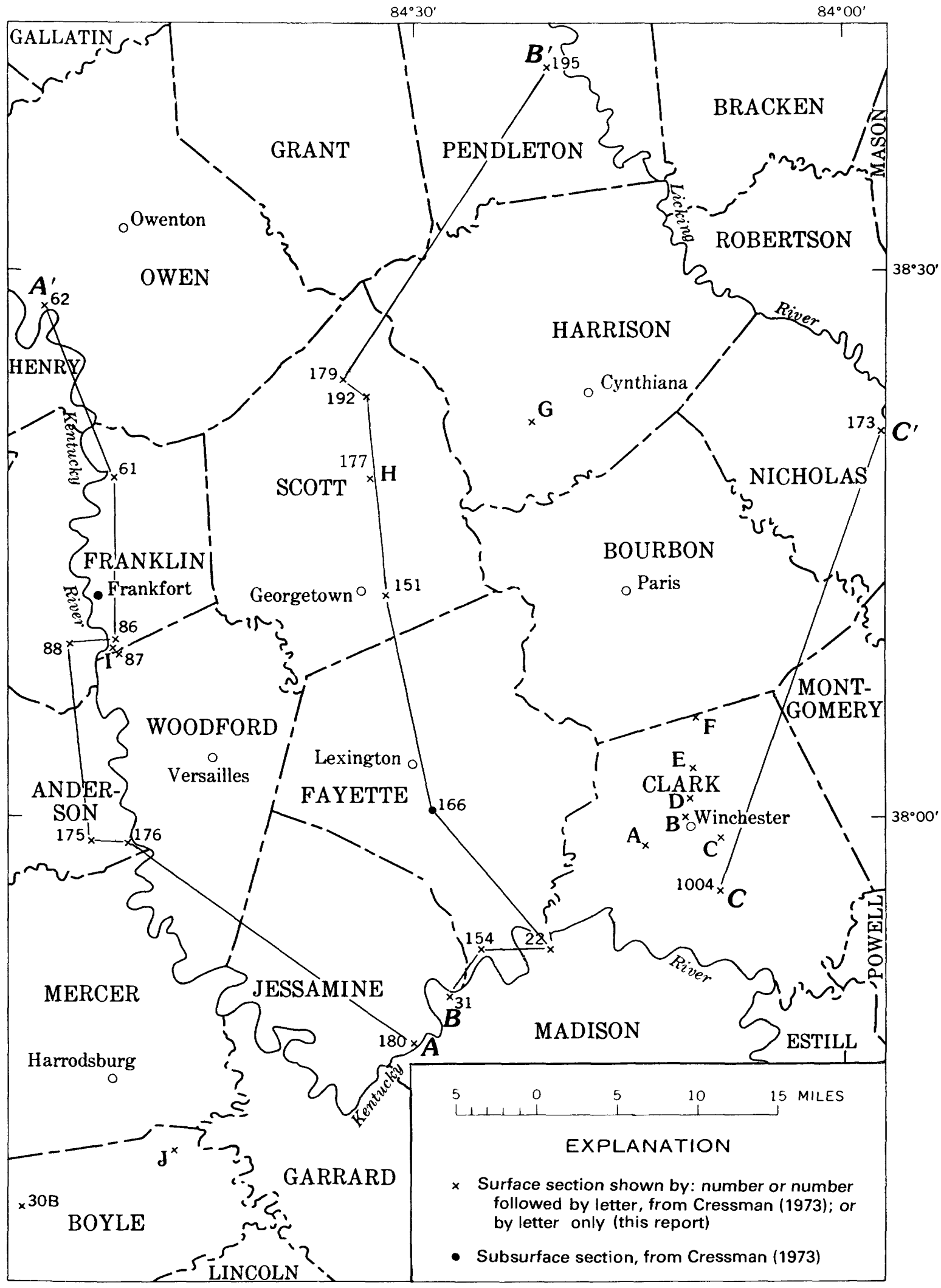

FIGURE 2.-Index map of central Kentucky, showing counties, location of collected sections, and lines of section. Locality data of collected sections shown in lines of section $A-A^{\prime}, B_{-} B^{\prime}$, and $C_{-} C^{\prime}$ in plate $3 A$ are indicated by section number. Locality data of collected sections designated by a letter in the register of localities are indicated under section name. 
publication, Ulrich (1883) described Heterotrypa trentonensis (as "Dekayia trentonensis") from his "upper beds of the Trenton Group" near Burgin, Ky., a stratigraphic horizon that appears to be roughly equivalent to the Perryville Limestone Member of the Lexington Limestone (Cressman, 1973).

Later Ulrich (1886) began his study of Ordovician bryozoans from the Decorah Shale and the lower part of the Galena Dolomite in Minnesota and Iowa and completed it with a major publication in 1893 . These works by Ulrich included descriptions of bryozoans from both Minnesota and Kentucky.

Ulrich (1886) erected Tarphophragma multitabulata (as "Monotrypella multitabulata") and subsequently established (Ulrich, 1893) the concept for the genus Eridotrypa, of which E. mutabilis Ulrich is the type species. He also described Cyphotrypa acervulosa ("Leptotrypa ?acervulosa" Ulrich, 1893) from Minnesota and Kentucky and erected Crepipora spatiosa Ulrich, 1893, from his "top of the Trenton" rocks at Harrodsburg and Frankfort in Kentucky. Utgaard (1969), in a restudy of the ceramoporoid bryozoans, designated $C$. spatiosa as the type species of Papillalunaria Utgaard. In addition to the above taxa, Ulrich (1893) named several other trepostome species from the Ordovician rocks in Minnesota-Iowa and Kentucky.

In 1904 Ulrich, in collaboration with Bassler, essentially completed his major contributions to the study of the Paleozoic bryozoans in North America with a revision of the then-existing classification of the bryozoan order Trepostomata. In this work Ulrich and Bassler (1904) described several new trepostome species, including Mesotrypa angularis and Heterotrypa foliacea (Dekayella foliacea Ulrich and Bassler, 1904), from their "Lexington Limestone" in central Kentucky.

Nickles and Bassler (1900) published "A Synopsis of American Fossil Bryozoa," containing a valuable bibliography of published work on bryozoans in North America and other parts of the world to the end of the 19 th century. This work is indispensable in evaluating the early synonymies and stratigraphic data on bryozoans found in the Ordovician strata of Kentucky.

Later, Nickles (1902) proposed a revised stratigraphic classification for the Upper Ordovician rocks in the tristate area of Kentucky, Ohio, and Indiana near Cincinnati, in which the units were defined by faunal zones based on bryozoans and brachiopods in combination with gross lithological characteristics.

Subsequently, Nickles (1905) published the first study of bryozoan fauna from the Upper Ordovician rocks of Kentucky, and listed the occurrences of previously erected bryozoan species in his Middle Ordovician "Lexington Group" of rocks in Kentucky. In this study, Nickles erected several new bryozoan species, including Peronopora milleri from his "Winchester Group" (upper part of the Lexington Limestone and the Clays Ferry Formation of this report) of central Kentucky and Heterotrypa foerstei (herein considered to be a subjective junior synonym of $H$. foliacea Ulrich and Bassler) from his "Eden" rocks at Rogers Gap in north-central Kentucky. In addition, Nickles (1905) indicated the presence of Amplexopora persimilis and Dekayella ulrichi (now Heterotrypa ulrichi, see Boardman and Utgaard, 1966) in his "Eden" strata near Covington, Ky. Nickles (1905, p. 25) concluded, however, that his previously established faunal subdivisions in the "Utica" shales (the Kope Formation of current usage) near Cincinnati could not be recognized in his laterally adjacent "Eden" shales in northern Kentucky for lack of distinctive differentiation among succeeding bryozoan faunas.

Subsequently, Bassler (1906) renamed the faunal subdivisions of Nickles (1902) in ascending order: the Economy Member, the Southgate Member, and the McMicken Member of the Eden Formation of Bassler. These subdivisions are indicated in plate $2 C$.

Utgaard and Perry (1964, p. 11-13) reviewed the general history of the study of bryozoans from the Ordovician rocks in the vicinity of Cincinnati.

Foerste $(1905,1909,1910,1912,1913,1914)$ noted the abundance and great diversity of bryozoans and listed but did not describe a number of previously named species as occurring in the various lithic units of the Ordovician strata roughly equivalent stratigraphically to the upper part of the Lexington Limestone and the Clays Ferry Formation of current usage in north-central Kentucky.

Later, McFarlan (1931) reviewed the fossil invertebrate fauna from the Middle and Upper Ordovician strata of Kentucky. McFarlan's review included brief descriptions of previously defined bryozoan species that characterized the various lithic units of the Middle and Upper Ordovician strata in central and northern Kentucky. McFarlan (1931, p. 98) in this work erected a trepostome species, Dekayella milleri (herein considered to be a subjective junior synonym of Heterotrypa foliacea Ulrich and Bassler), from his "Cynthiana Formation" near Lexington, Ky. The "Cynthiana Formation" appears to be the approximate equivalent of the upper part of the Lexington Limestone or the lower part of the Clays Ferry Formation of current usage (Black and others, 1965, fig. 3).

Subsequently, McFarlan and Freeman (1935), McFarlan (1938, 1943), and McFarlan and White (1948) described the stratigraphic units that constituted the interval between the Tyrone Limestone (Middle Ordovician) below and rocks of the Maysvillian Stage (Late Ordovician) above in central Kentucky. 
Their works included lists of various bryozoan species and other invertebrate phyla that characterized the different units.

Brown (1965) published the first detailed contemporary study of the trepostome bryozoans from his undivided "Logana and Jessamine Limestone Members" (the Logana and Grier Limestone Members of current usage) of the Lexington Limestone in the inner Blue Grass region of central Kentucky. Brown (1965) established that the trepostome fauna consisted of 20 species, including six that were new, and one subspecies. In the same study, Brown recognized and redescribed 7 species that had been recorded previously from the Lexington Limestone and found 8 other species that had been described elsewhere. In addition, Brown (1965) noted that the trepostome fauna in his area of study was characterized by the relative abundance of Hallopora multitabulata (herein redescribed as Tarphophragma multitabulata), Prasopora falesi, and Eridotrypa aedilis (reassigned herein to E. trentonensis). Many species that Brown (1965) recorded from his Lexington Limestone in the inner Blue Grass regions were also found in the lower half of the Lexington Limestone during the present study.

Anstey and Perry (1973) published a thorough study of the trepostome component, and a single cystoporate (Constellaria sp.) of the bryozoan fauna from the Kope Formation in southeastern Indiana and adjacent areas in Ohio and northern Kentucky. They determined from a detailed qualitative and semiquantitative analysis that the trepostome component consisted of 11 previously named species of 11 different genera. Hallopora nodulosa (Nicholson) (Parvohallopora herein), Heterotrypa ulrichi (Nicholson), Peronopora vera Ulrich, and Amplexopora septosa (Ulrich) dominate the fauna, and Hallopora nodulosa and Heterotrypa ulrichi constitute about 55 percent of the recovered specimens. According to Anstey and Perry (1973), Hallopora nodulosa and Peronopora vera range virtually throughout the Kope Formation laterally and vertically. The other two species, Heterotrypa ulrichi and Amplexopora septosa, are absent in the basal $45 \mathrm{ft}$ of the Kope Formation, but in Indiana they occur throughout the rest of the Kope Formation.

Anstey and Perry (1973) recognized five trepostome bryozoan assemblage zones in the Kope Formation in their area of study. In ascending order, they are the Eridotrypa mutabilis zone, the Stigmatella clavis zone, the Balticoporella whitfieldi zone, the Batostoma jamesi zone, and the Dekayia aspera zone (pl. 2C). Anstey and Perry (1973) posited that the associations of species that constitute these zones reflect to a degree variations in water turbulence, water depth, and rates of sedimentation in the depositional environment of the
Kope Formation. They indicated further that the three higher zones shifted stratigraphically upward from north to south. They postulated that the upward shift of the zones resulted from a gradual shallowing of the depositional basin of the Kope Formation toward the south. The zonal index species of the three upper zones have not been found in the area of the present study in Kentucky.

The above summary of previous investigations of the bryozoan fauna from the Lexington Limestone, the Clays Ferry Formation, and their stratigraphical equivalents indicates that the preponderance of the species were discovered and erected during the late 19 th and early 20 th centuries. The relatively small number of new species added during subsequent studies is evidence of the thoroughness of the work of the early paleontologists.

\section{ACKNOWLEDGMENTS}

I am grateful to John Pojeta, Jr., Jean M. Berdan, and Earle R. Cressman of the U.S. Geological Survey and to Frank K. McKinney of the Appalachian State University for helpful discussions and thorough technical criticism that helped considerably to improve this report.

Members of the U.S. Geological Survey who contributed significantly to discussions of lithostratigraphy and to the collecting of the Ordovician bryozoans in the area of study are D. F. B. Black, E. R. Cressman, N. P. Cuppels, R. C. Greene, A. B. Gibbons, S. J. Luft, R. B. Neuman, W. F. Outerbridge, John Pojeta, Jr., R. J. Ross, Jr., W. C. Swadley, G. W. Weir, the late D. E. Wolcott, and E. L. Yochelson. L. J. Vigil of the U.S. Geological Survey and the late Jesse E. Merida, formerly of the U.S. Geological Survey, prepared most of the fossil material. R. H. McKinney and H. E. Mochizuki of the U.S. Geological Survey advised on photography and developed and printed the photographed material.

I want to express my sincere appreciation to the following persons and institutions for giving permission to examine numerous specimens or arranging loans of specimens: Richard S. Boardman of the Department of Paleobiology, Smithsonian Institution, Washington, D.C.; Eugene S. Richardson, Jr., and Matthew H. Nitecki of the Field Museum of Natural History, Chicago; and Alan S. Horowitz of the Department of Geology, Indiana University, Bloomington, Ind.

\section{LOCALITY REGISTER}

In all, 402 collections were made from 29 localities in twenty $7 \frac{1}{2}$-minute quadrangles in Kentucky. Most of 
the collections were from measured sections. All collections are designated by a collection number in the U.S. Geological Survey register of Cambrian and Ordovician localities (-CO). The letter $\mathrm{D}$ before a collection number indicates that this number is entered in the U.S. Geological Survey Cambrian and Ordovician locality register kept in Denver. All other collection numbers are entered in the U.S. Geological Survey Cambrian and Ordovician locality register kept in Washington, D.C.

Localities and stratigraphic positions of the collections are indicated in two ways in this report. Localities of sections included within the lines of section shown graphically in plate 1 are arranged sequentially by number in plate $3 A$. Collections and their stratigraphic positions within those sections listed in plate $3 A$ are shown in plate 1 .

Collections recovered from sections not shown graphically are arranged sequentially below. The geographic position of each locality is indicated by a letter or number in figures 2 and 3 . Each locality is described by a set of coordinates given in millimeters, measured first east, then north, from the lower left corner of the 1:24,000-scale quadrangle map on which the locality occurs. All localities listed are described by this method (Pojeta, 1979). Other data provided for each collection include the collection number; the geographic name of the section, if given; the name of the lithic unit; and the stratigraphic position of a collection within the lithic unit, if available.

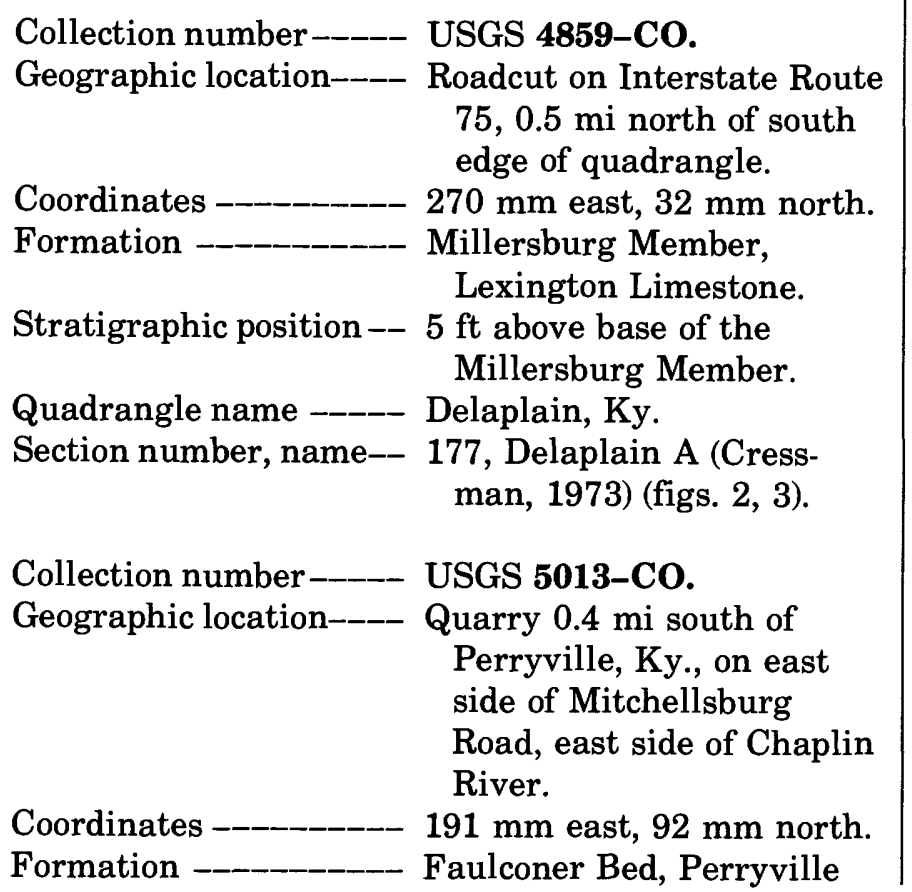

Limestone Member, Lexington Limestone.

Stratigraphic position -- $5 \mathrm{ft}$ above base of the Faulconer Bed.

Quadrangle name ----- Perryville, Ky. Section number, name-- 30B, Perryville B (Perryville South) (Cressman, 1973) (figs. 2, 3).

Collection number--_-_ USGS 5016-CO.

Geographic location--_- The same as for 5013-CO.

Coordinates --_-_-_-_ Do.

Formation -_______ Cornishville Bed, Perryville Limestone Member, Lexington Limestone.

Stratigraphic position -- $14 \mathrm{ft}$ above base of the Salvisa Bed, Perryville Limestone Member, Lexington Limestone.

Quadrangle name -_-_- Perryville, Ky.

Section number, name-- 30B, Perryville B (Perryville South) (Cressman, 1973) (figs. 2, 3).

Collection number USGS 5066-CO.

Geographic location---- Colby Road west of Winchester, Ky., to junction with McClure Road; southwest of McClure Rd. 1.9 mi from junction with Colby Rd.; dump pit on north side of road.

Coordinates $65 \mathrm{~mm}$ east, $452 \mathrm{~mm}$ north.

Formation Millersburg Member, Lexington Limestone.

Quadrangle name --_-- Winchester, Ky.

Section name -___- Rose's Farm; locality A in figs. 2, 3.

Collection number USGS 6132-CO.

Geographic locationSection on Kentucky Route 33 , just north of bridge crossing Mocks Branch $2.5 \mathrm{mi}$ north of Danville, $\mathrm{Ky}$.

Coordinates -_-____ $405 \mathrm{~mm}$ east, $307 \mathrm{~mm}$ north.

Formation -______ Lower part of Grier Limestone Member, Lexington Limestone.

Stratigraphic position -- Approximately $40 \mathrm{ft}$ above the Tyrone LimestoneLexington Limestone contact. 
BRYOZOANS, LEXINGTON LIMESTONE, CLAYS FERRY FORMATION, KENTUCKY

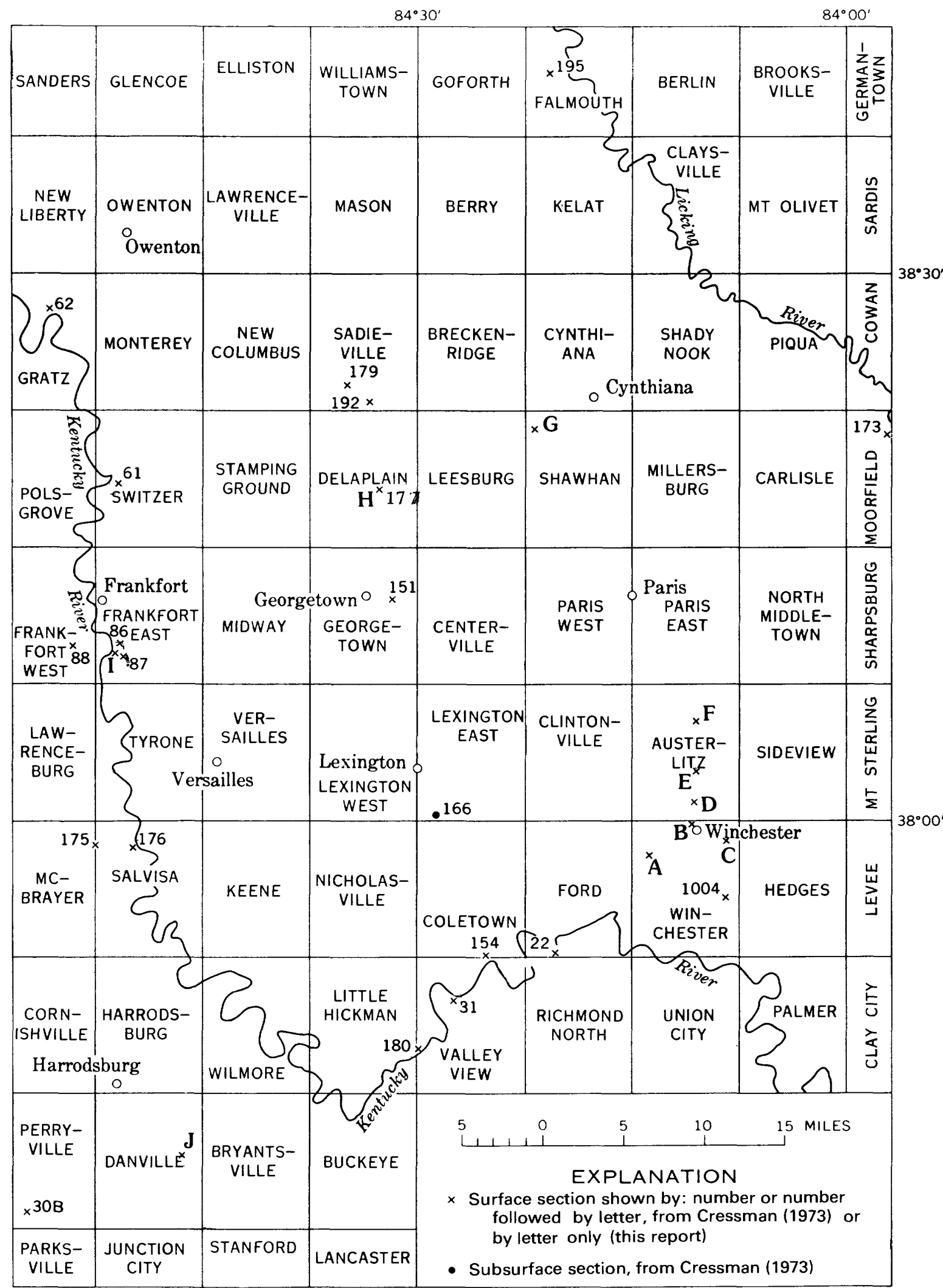

FIGURE 3.-Index map of 71/2-minute quadrangles and locations of collected sections. Locality data of collected sections designated by a number are indicated in plate $3 A$. Locality data of collected sections designated by a letter are indicated in the register of localities under the section name. 
Quadrangle name -_-_- Danville, Ky.

Section name-_-_-_ Locality $\mathrm{J}$ in figs. 2, 3.

Collection number USGS 6751-CO.

Geographic location

Excavation on hillside north from main gate, Old Crow Distillery, approximately on county line between Franklin and Woodford Counties, Ky.

Coordinates $101 \mathrm{~mm}$ east, $116 \mathrm{~mm}$ north.

Formation Curdsville Limestone Member, Lexington Limestone.

Stratigraphic position -- 14-17 ft above the base of the Curdsville Limestone Member.

Quadrangle name -_-_- Frankfort East, Ky.

Section name -_-_-__- Locality I in figs. 2, 3.

Collection number--_-_ USGS 7310-CO.

Geographic location-_-_ Outcrop $1,700 \mathrm{ft}$ east of Kentucky Route 89, 1.5 mi southeast of Winchester, Ky.

Coordinates $413 \mathrm{~mm}$ east, $497 \mathrm{~mm}$ north.

Formation Strodes Creek Member, Lexington Limestone.

Quadrangle name -_-_- Winchester, Ky.

Section name -_____ Locality $\mathrm{C}$ in figs. 2, 3.

Collection number USGS 7314-CO.

Geographic location

Roadcuts along Maple Street, U.S. Route 227, northern outskirts of Winchester, $\mathrm{Ky}$.

Coordinates -______ Base of section at $268 \mathrm{~mm}$ east, $567 \mathrm{~mm}$ north.

Formation -_____ Millersburg Member, Lexington Limestone.

Stratigraphic position -- $2.5 \mathrm{ft}$ above base of section. Quadrangle name -___- Winchester, Ky.

Section name -_____- Locality B (Black and Cuppels, 1973) (B in figs. $2,3)$.

Collection number USGS 7319-CO. Geographic location-_-_ The same as for 7314-CO. Coordinates Do.

Formation Millersburg Member, Lexington Limestone. Stratigraphic position -- $13 \mathrm{ft}$ above base of section.
Quadrangle name -_-_- Winchester, Ky.

Section name -__-_ The same as for 7314-CO.

Collection number-___- USGS 7320-CO.

Geographic location-_-_ The same as for 7314-CO.

Coordinates -__-__ Do.

Formation -_______ Millersburg Member, Lexington Limestone.

Stratigraphic position -- $5 \mathrm{ft}$ above base of section.

Quadrangle name -__- Winchester, Ky.

Section name - _-__- The same as for 7314-CO.

Collection number-_-_- USGS 7321-CO.

Geographic location--_- The same as for 7314-CO.

Coordinates -______ Do.

Formation -_____ Millersburg Member, Lexington Limestone.

Stratigraphic position -- $21 \mathrm{ft}$ above base of section.

Quadrangle name -_-_- Winchester, Ky.

Section name -_-_-_-_- The same as for 7314-CO.

Collection number-_-_- USGS 7322-CO.

Geographic location-_-_ The same as for 7314-CO.

Coordinates -_____ Do.

Formation -_______ Millersburg Limestone, Lexington Limestone.

Stratigraphic position -- $32 \mathrm{ft}$ above base of section.

Quadrangle name -...- Winchester, Ky.

Section name -___ The same as for 7314-CO.

Collection number-_-_- USGS 7324-CO.

Geographic location-_-- Exposure on U.S. Route 227 (Maple Street, Winchester, Ky., extended) $0.6 \mathrm{mi}$ north of Interstate Route 64.

Coordinates ______ $266 \mathrm{~mm}$ east, $93 \mathrm{~mm}$ north.

Formation Strodes Creek Member, Lexington Limestone.

Quadrangle name --_-- Austerlitz, Ky.

Section name -______ Locality D in figs. 2, 3.

Collection number-_-_- USGS 7328-CO.

Geographic location-_-_ Exposure on U.S. Route 227 (Maple Street, Winchester, Ky., extended) $2.6 \mathrm{mi}$ north of Interstate Route 64.

Coordinates -_____ $270 \mathrm{~mm}$ east, $221 \mathrm{~mm}$ north.

Formation -______-_ Strodes Creek Member, Lexington Limestone.

Quadrangle name _._._. Austerlitz, Ky.

Section name -___-_ Locality $\mathrm{E}$ in figs. 2, 3. 
Collection number -

Geographic location

7330-CO.

Outcrops on U.S. Route 227

from crossing of Strodes

Creek to $0.8 \mathrm{mi}$ southeast of crossing.

Coordinates -____-_ Top of section at $268.5 \mathrm{~mm}$ east, $422 \mathrm{~mm}$ north.

Formation -_____-_ Millersburg Member, Lexington Limestone.

Stratigraphic position -- $93 \mathrm{ft}$ above base of section.

Quadrangle name --_- Austerlitz, Ky.

Section name -_-___-_ Type section, Strodes Creek

Member, Lexington Limestone (locality $\mathbf{F}$ in fig.

$2,3)$.

Collection number-

Geographic location

Coordinates

Formation

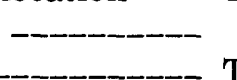

\section{USGS 7333-CO.}

The same as for 7330-CO.

Do.

Tongue of Clays Ferry

Formation.

Stratigraphic position -- $71 \mathrm{ft}$ above base of section.

Quadrangle name --_-_ Austerlitz, Ky.

Section name -____- The same as for 7330-CO.

Collection number--_-- USGS 7334-CO.

Geographic location--_- The same as for 7330-CO.

Coordinates -____ Do.

Formation -_-____-_ Millersburg Member,

Lexington Limestone.

Stratigraphic position -- $66 \mathrm{ft}$ above base of section.

Quadrangle name -_._- Austerlitz, Ky.

Section name -_-__- The same as for 7330-CO.

Collection number-___- USGS 7336-CO.

Geographic location--- The same as for 7330-CO.

Coordinates -_____ Do.

Formation - ______ Millersburg Member,

Lexington Limestone.

Stratigraphic position -- $32 \mathrm{ft}$ above base of section

in Allonychia flanaganen-

sis zone.

Quadrangle name -_._- Austerlitz, Ky.

Section name -_-___- The same as for 7330-CO.

Collection number-_-_- USGS 7337-CO.

Geographic location--_- The same as for 7330-CO.

Coordinates -_____ Do.

Formation -________ Tanglewood Limestone

Member, Lexington

Limestone.

Stratigraphic position -- $22 \mathrm{ft}$ above base of section.

Quadrangle name --_- Austerlitz, Ky.

Section name
Collection number USGS 7346-CO.

Geographic location-

$4,300 \mathrm{ft}$ east, $6,300 \mathrm{ft}$ south of the northwest corner of the Shawhan quadrangle, Ky.

Coordinates -_____-_ $54 \mathrm{~mm}$ east, $493 \mathrm{~mm}$ north.

Formation Tongue of Clays Ferry Formation.

Stratigraphic position -- $2 \mathrm{ft}$ above $810 \mathrm{ft}$ contour.

Quadrangle name --_-_ Shawhan, Ky.

Section name-_-__-_- Locality G in figs. 2, 3.

Collection number-_-_- USGS 8130-CO.

Geographic location---- Exposure in railroad track about $1 / 4 \mathrm{mi}$ south of Roger Gap railroad station, Delaplain quadrangle, Ky.

Coordinates $315 \mathrm{~mm}$ east, $230 \mathrm{~mm}$ north.

Formation Clays Ferry Formation.

Quadrangle name -_-_- Delaplain, Ky.

Section name-_-_-_- Rogers Gap, locality $\mathrm{H}$ in figs. 2,3 .

\section{REPOSITORIES OF SPECIMENS}

Holotypes, paratypes, and hypotypes, and designated lectotypes, paralectotypes, and hypotypes of previously described species are deposited in the U.S. National Museum of Natural History (USNM), Smithsonian Institution, Washington, D.C. Specimens for study were loaned from the repositories at the Department of Geology, Indiana University, Bloomington, Ind. (IU); the Field Museum of Natural History, Chicago (UC); and the U.S. National Museum of Natural History, Smithsonian Institution, Washington, D.C. (USNM).

\section{MATERIALS AND METHODS}

The study of the bryozoan fauna from the Lexington Limestone and the Clays Ferry Formation was undertaken in connection with the geologic mapping of Kentucky by the U.S. Geological Survey in cooperation with the Kentucky Geological Survey. In order to obtain precise information on the stratigraphic distribution of bryozoans for the purpose of correlating widely separated areas of outcrop, bryozoans were collected by the mapping parties. Paleontologists of the U.S. Geological Survey augmented these collections.

The study includes bryozoan samples from 29 measured lithologic sections, including the reference sections for the Lexington Limestone, No. 86, and the Clays Ferry Formation, No. 22, and one subsurface section (pl. 3A). The sampled sections were distributed 
geographically over an area of about $3,500 \mathrm{mi}^{2}$ (figs. 1, 3).

Most of the bryozoan zoaria were recovered from 17 sections of Cressman, 1973, aligned in three lines of section. Two lines of section, $\mathrm{A}-\mathrm{A}^{\prime}$ and $\mathrm{B}-\mathrm{B}^{\prime}(\mathrm{pl} .1 \mathrm{~A}, \mathrm{~B})$, trend roughly south-north for about $60 \mathrm{mi}$, and one line of section, C-C' (pl. 1C), trends roughly southwestnortheast for about $30 \mathrm{mi}$ (figs. 1, 2).

Because of the general abundance of byrozoans in most of the sections, sampling for them had to be limited to selected stratigraphical intervals and parts of some sections. Bryozoans were collected from strictly in-place material and generally at stratigraphic intervals vertically 5-10 ft apart along the lateral extent of a section, or at other intervals as indicated in plate 1 . Each sample from most of the surface sections contained a "block" of strata of irregular width approximately 6-12 in. that consisted mostly of broken limestone and some shale. The bryozoans from the only subsurface section, Lexington East 1 (pl. 3A), were obtained from a diamond drill core, $2 \frac{1}{8}$ in. in diameter, taken at intervals indicated on plate $1 B$. In the sections the stratigraphic position of each collection containing bryozoans is indicated by a collection number. The same collection numbers used herein are used on the geologic quadrangle maps of Kentucky and in Cressman (1973).

Most bryozoan zoaria, or their fragments, were embedded in the rock matrix. A number of zoaria considered to be representative of a collection were removed from the rock by trimming off excess matrix and were prepared by using standard and modified thinsectioning methods (Nye, Dean, and Hinds, 1972). In addition, acetate peel "replicas" were prepared from a few zoaria using the method described by Boardman and Utgaard (1964).

Taxonomic interpretations of the various bryozoan species in this study are based on the internal morphological characteristics of 1,783 thin-sectioned zoaria recovered from 402 collections. Standard measurements were made of various morphological characters observed in the properly oriented thin sections as an aid in interpretation of the species and for comparison with primary type materials and published data.

The stratigraphic ranges of the various species were determined for each lithic section as indicated in plate 1. Stratigraphic ranges of the various species in the different sections are combined in plate $2 A$ into one composite section for the area of study in Kentucky. Ranges of all species are referred to the base of the Lexington Limestone as determined in Cressman (1973).

The relative abundance of each species in this study has been estimated on the basis of the percentage it formed of the total number of thin-sectioned zoaria.
The number of thin-sectioned specimens of each species and the relative abundance (number of specimens in percent) of each species in the thin-sectioned fauna are indicated in the right side of plate $3 B$, as are the number and distribution of each species sectioned in the different lithic units of the Lexington Limestone, the Clays Ferry Formation, and the Kope Formation. The number of thin-sectioned specimens from each lithic unit appears at the bottom of plate $3 B$. Bryozoans from the Logana member of the Lexington Limestone were not recovered.

The number of thin-sectioned specimens of each species of the fauna in the measured sections at the geographic localities along lines of section A-A', B-B', and $\mathrm{C}-\mathrm{C}^{\prime}$ (pl. 1; fig. 2) is indicated in plate $3 C$. The number of specimens along the lines of section $A-A^{\prime}$ and $B-B^{\prime}$ is listed separately for the lower $200 \mathrm{ft}$ of strata of the Lexington Limestone and for the stratigraphic interval between the 200 -ft stratigraphic level and the top of the section above the base of the Lexington Limestone.

\section{GHARACTERISTICS OF THE BRYOZOAN FAUNA}

\section{COMPOSITION AND REGIONALISM}

The bryozoan fauna of the Lexington Limestone, the Clays Ferry Formation, and related rocks, late Middle and early Late Ordovician, in the Blue Grass region of Kentucky consists of three extinct bryozoan orders: the Trepostomata, the Cystoporata, and the Cryptostomata. The Trepostomata and the Cystoporata are the major constituents of this fauna. The Cryptostomata forms a minor part of the bryozoan fauna and is discussed elsewhere (Karklins, 1983).

The trepostome bryozoans dominate the fauna and are referred to 29 species of 16 genera: Amplexopora, Atactoporella, Balticopora, Batostoma, Calopora, Cyphotrypa, Dekayia, Eridotrypa, Heterotrypa, Homotrypa, Homotrypella, Mesotrypa, Peronopora, Prasopora, Stigmatella, and Tarphophragma, a new genus. Five of the 29 trepostome species are new. They are Balticopora arcuatilis, Cyphotrypa switzeriensis, Dekayia epetrima, Eridotrypa sadievillensis, and Homotrypa cressmani. The cystoporate bryozoans are referred to 7 species of 6 genera: Acanthoceramoporella, Ceramophylla, Ceramoporella, Constellaria, Crepipora, and Papillalunaria. One of the 7 cystoporate species, Acanthoceramoporella valliensis, is new.

On the generic level the bryozoan fauna of the Lexington-Clays Ferry depositional sequence occur globally. Recent compilations of data on the geographic distribution of its trepostome and cystoporate genera (Astrova, 1965, 1978; McKinney, 1969, 1974) show that 
with few exceptions these genera occur worldwide and in regions widely separated at the present time.

The fauna, in general, is dominated by five genera: Eridotrypa, Parvohallopora, Heterotrypa, Constellaria, and Peronopora. These genera comprise approximately 77 percent of the thin-sectioned fauna. Eridotrypa is represented by three species that constitute about 20.25 percent of the fauna. Parvohallopora, Heterotrypa, and Constellaria are represented by two species each and include about 19.40,15.76, and 15.24 percent, respectively, of the thin-sectioned fauna. Peronopora also comprises two species that constitute approximately 6.17 percent of the sectioned material. The other 17 genera are represented by 1 species each and constitute 23 percent of the sectioned bryozoan fauna.

On the species level, the bryozoan fauna of the Lexington Limestone, the Clays Ferry Formation, and related rocks is endemic to the Ordovician rocks of eastern North America. The few reported occurrences outside North America of the species discussed herein cannot be verified on the basis of the published material (Bassler, 1911; Astrova, 1965) or from comparisons among the specimens from outside North America in collections at the U.S. National Museum of Natural History.

The known geographic and stratigraphic distribution of the species described here (in the systematic paleontology section) indicates that the bryozoan fauna of the Lexington-Clays Ferry depositional sequence is the result of intermingling of species endemic to the tristate area of Kentucky, Ohio, and Indiana and Kentucky's Blue Grass region with immigrant species from the Ordovician of New York-Ontario, Minnesota-Iowa, and Tennessee. The immigrant bryozoan species are those that are common to the Blue Grass region and adjacent areas but that first occur elsewhere in rocks older than those in which they are found in the areas under study.

Bergström and Sweet (1966, p. 294, fig. 6) and Sweet and Bergström (1971) demonstrated by conodonts that the base of the Lexington Limestone correlates with a horizon of early Kirkfieldian Age, Middle Ordovician, in the uppermost part of the "Rockland Formation" of the Trenton Group in New York. Jacobson (1979) reached the same conclusion from a study of the distribution of acritarchs in the Lexington-Clays Ferry sequence in Kentucky and in the Trenton Group in New York. Bergström and Sweet (1966) also showed that the Decorah Shale, Middle Ordovician, of Minnesota is the approximate stratigraphic equivalent of their "Rockland Formation" of the Rocklandian Stage, Middle Ordovician, at the base of the Trenton Group.

Eleven of the 36 species (pls. $2 A, 3 B$ ) of this report are considered to be immigrants. Of those, three are from rocks of the Blackriveran Stage of the New YorkOntario Middle Ordovician basins, and seven are from the Rocklandian Stage or younger rocks of the Middle Ordovician basins of the New York-Ontario and Minnesota-Iowa regions. One immigrant species, Constellaria teres, is from the Middle Ordovician rocks of central Tennessee (Cutler, 1968).

The species whose first occurrence elsewhere is in Blackriveran strata include Tarphophragma multitabulata (Hallopora of authors), Homotrypa similis, and Ceramophylla alternatum (Coeloclema alternatum of Ross, 1969). Fritz (1957) reported T. multitabulata (as Hallopora) and $H$. similis from what she termed the Pamelia beds, Blackriveran Stage (Liberty, 1969), Middle Ordovician, of the Ottawa-St. Lawrence region in Canada. Ross (1969) established that C. alternatum appeared for the first time in the "Chaumont Formation" of the Blackriveran Stage and then ranged into the "Cobourg Formation" (Edenian Stage) of the Trenton Group in New York. In Kentucky, T. multitabulata first occurs about $14 \mathrm{ft}$ above the base of the Lexington Limestone in the Kirkfieldian Stage. However, $C$. alternatum and $H$. similis first appear 160 and $184 \mathrm{ft}$, respectively, above the base of the Lexington Limestone in the Shermanian Stage. (See pl. 2A.)

The seven immigrants to the study area that have been reported as first occurring in rocks of the Rocklandian or subsequent stages are discussed in the following paragraphs. Ross (1967b, 1970a) demonstrated that Eridotrypa mutabilis and Balticopora tenuimurale (Hemiphragma of Wilson, 1921, and of Ross, 1970a) first occur at the base of the "Rockland Formation," Rocklandian Stage, in the Trenton Group of the Middle Ordovician in the New York-Ontario region. It is possible, however, that $E$. mutabilis originated earlier than the Rocklandian Stage, because Sardeson (1936) reported it from the Platteville Formation of Blackriveran age, Middle Ordovician, of Minnesota. This occurrence, however, needs to be verified. In Kentucky the earliest appearances of $B$. tenuimurale and $E$. mutabilis are at approximately 110 and $140 \mathrm{ft}$, respectively, above the base of the Lexington Limestone in the Shermanian Stage (pl. 2A).

Parvohallopora onealli is considered to be an immigrant species in the area studied. Ross (1969) determined that $P$. onealli (as Calopora of Ross) is present in the "Shoreham Formation," Shermanian Stage, Middle Ordovician, of the Trenton Group in New York. In the Lexington-Clays Ferry depositional sequence $P$. onealli is present above the 200 -ft stratigraphic level in the composite section (pl. 2A). This level in the current usage of the biostratigraphic classification of Sweet (1979) is nearly at the top of the Shermanian Stage; thus in the stratigraphic section of the Blue Grass 
region it is above the "Shoreham Formation" of Ross (1969) in the Trenton Group of New York.

Two species, Eridotrypa trentonensis and Mesotrypa angularis, are possible immigrants from the Middle Ordovician depositional sequence of Ontario. Nicholson (1881) reported E. trentonensis from his "Trenton" strata near Peterboro, Ontario, and Foord (1883, as Monotrypella) described it from his "Trenton Formation" at Peterboro and Ottawa. $M$. angularis had been reported by Ulrich and Bassler (1904) from their "Trenton" strata near Ottawa and Peterboro. However, the stratigraphic positions are only approximate and cannot be verified at this time; both species are from Middle Ordovician strata that may be slightly older than or similar in age to those in the Blue Grass region of Kentucky.

In Kentucky, $M$. angularis and $E$. trentonensis appear at stratigraphic levels 40 and $56 \mathrm{ft}$, respectively, above the base of the Lexington Limestone (pl. 2A) in the Kirkfieldian Stage, Middle Ordovician.

Two immigrants to the study area are from the Middle Ordovician rocks of the Upper Mississippi Valley region. They include Heterotrypa trentonensis (Dekayia of Ulrich, 1893) from the Decorah Shale, Rocklandian Stage (Bergström and Sweet, 1966), in Minnesota and Cyphotrypa acervulosa (Leptotrypa? acervulosa Ulrich, 1893) from the lower part of the Galena Dolomite ("lower part of the Galena shales" of Ulrich, 1893). In Kentucky, $H$. trentonensis and C. acervulosa appear for the first time at 56 and $80 \mathrm{ft}$, respectively, above the base of the Lexington Limestone in the Kirkfieldian Stage (pl. 2A).

Only one species, Constellaria teres, among the immigrants to the Blue Grass region is from the Middle Ordovician rocks of central Tennessee, although the regions are close geographically and had been connected by open seas during Middle Ordovician time (Cressman, 1973, and Borella and Osborne, 1978). Cutler (1968) demonstrated that $C$. teres arose in the Bigby Limestone-Cannon Limestone sequence of central Tennessee and subsequently migrated to the depositional basin of the Lexington Limestone in the Blue Grass region of Kentucky. The Bigby-Cannon sequence in the classification of Borella and Osborne (1978) is stratigraphically equivalent to the Grier Limestone Member and the lower half of the Brannon Member of the Lexington Limestone in Kentucky. Sweet and Bergström (1976, p. 148, 149), however, on the basis of their conodont studies, inferred biostratigraphical equivalence between the Bigby-Cannon sequence of Tennessee and the upper part of the Lexington Limestone (roughly from the Brannon Member of the Lexington Limestone to the top of the formation) in Kentucky.
In Kentucky $C$. teres is the most abundant bryozoan species, and appears for the first time in the middle of the Lexington Limestone at $180 \mathrm{ft}$ above the base of the formation in the Shermanian Stage (pl. 2A). This level is the approximate stratigraphical equivalent of the top of the Bigby-Cannon sequence of central Tennessee and thus is younger in age than the horizon in the Bigby-Cannon sequence at which $C$. teres originated in Tennessee (Cutler, 1968).

The assemblage of immigrant species just defined constitutes slightly less than one-third of the bryozoan fauna under discussion. The species are significant stratigraphically, however, because their appearance in the lower half of the Lexington Limestone permits the establishment, to a degree, of the biostratigraphic position of the Lexington Limestone in comparison with the Middle Ordovician standard section in New York and the sequence of Middle Ordovician rocks in the Upper Mississippi Valley (pl. 2C).

The endemic component with which the immigrant taxa intermingle is an assemblage of 25 species known to occur only in the Lexington Limestone, the Clays Ferry Formation, and related rocks in Kentucky and in equivalent strata of the general tristate area of Ohio, Indiana, and Kentucky (pl. 2A). Thirteen species of the endemic assemblage, including the 6 new species, are known only from the Blue Grass region of Kentucky at present. The new species are Acanthoceramoporella valliensis, Balticopora arcuatilis, Cyphotrypa switzeriensis, Dekayia epetrima, Eridotrypa sadievillensis, and Homotrypa cressmani. Seven indigenous species common to the Blue Grass and the Cincinnati regions of the tristate area have their earliest appearances recorded in the Lexington-Clays Ferry sequence of the Blue Grass region. These taxa include, in ascending order of first appearances, Crepipora venusta, Ceramoporella distincta, Parvohallopora nodulosa, Stigmatella clavis, Peronopora vera, Atactoporella newportensis, and Amplexopora persimilis (pl. 2C).

\section{ABUNDANCE AND DISTRIBUTION}

The bryozoan fauna from the Lexington Limestone, the Clays Ferry Formation, and related rocks is characterized by great abundance of specimens and relatively gradual appearance of the various species (pls. $2 A, 3 B$ ). The profusion of bryozoans in the sampled lithic units is evidence that the depositional environments represented by the various lithologies, substrates of the sea bottom, were advantageous.

Although most of the bryozoan colonies are broken, their fragments did not scatter widely. Fragments of large and small colonies commonly found together in most samples indicate that little sorting had occurred. 
They generally show little or no abrasion or rounding, which indicates a general lack of transport as well. The numerous branching colonies found in thin shale partings in limestones (in the Grier Limestone Member of the Lexington Limestone, for example) probably tipped over in situ, became embedded in soft muds at the bottom of the sea, and then were broken up by compaction. Most of these colonies came apart during sampling. Thus the general appearance and state of preservation of the bryozoan colonies indicate that they were found nearly in situ.

On the basis of the sectioned material, the bryozoan fauna in the Lexington Limestone-Clays Ferry depositional sequence and related rocks can be said to be dominated by four species: Constellaria teres, Heterotrypa foliacea, Parvohallopora nodulosa, and Eridotrypa mutabilis, in decreasing order of abundance. Specimens from these four species constitute about 54 percent of the total fauna. Most of the specimens referred to $C$. teres, $H$. foliacea, and $P$. nodulosa are recovered from the stratigraphic interval between $200 \mathrm{ft}$ above the base of the Lexington Limestone and a point near the top of the composite section (pl. 2A). Eridotrypa mutabilis is abundant in the stratigraphic interval between 140 and $376 \mathrm{ft}$ above the base of the Lexington Limestone.

Specimens of $C$. teres constitute almost 15 percent of the sectioned material. It ranges from about $180 \mathrm{ft}$ to $430 \mathrm{ft}$ above the base of the Lexington Limestone in the composite section (pl. $2 A, B$ ). C. teres predominates in the Tanglewood Limestone Member of the Lexington Limestone, comprising about 36 percent of the recovered specimens.

Geographically, C. teres is distributed widely within the stratigraphic interval of its range, but it is generally more abundant in the central and eastern parts than the northern part of the region under study here (pl. 3C). It has not, however, been found in the Falmouth A section (pl. 1B).

Constellaria occur in unusual concentrations in a rock layer up to $5 \mathrm{ft}$ thick in parts of the Frankfort East, Frankfort West, and Versailles quadrangles of central Kentucky. Cressman (1973) informally named this rock layer the Constellaria bed. The Constellaria bed occurs stratigraphically between the Tanglewood Limestone Member, below, and the Devils Hollow Member, above, in the Lexington Limestone. It contains abundant $C$. teres in addition to other bryozoan species common to the upper half of the Lexington Limestone and the Clays Ferry Formation. Zoaria of Constellaria in the Constellaria bed, including $C$. teres, occur in thickets that are variable in size and irregularly spaced. The thickets of Constellaria are generally in the upright growth position within the rock matrix.
The tops of thickets exposed on weathered horizontal rock surfaces are up to $1 \mathrm{ft}$ in diameter. The rock matrix between thickets of Constellaria and among branches of zoaria within the thickets contains pieces of other bryozoans in addition to fragments of Constellaria.

The general absence of Constellaria in the Kope Formation at the Falmouth A section (pls. $1 B, 3 C$ ) provides evidence that the occurrer se of Constellaria is restricted environmentally to this geographic region. In a major study of the genus Constellaria, Cutler (1968) noted that its species are abundant in depositional environments formed of limestone and shaly limestones, as are those of the Lexington Limestone in Tennessee, Kentucky, Ohio, and Indiana, but are absent in depositional environments formed predominantly of shales, as is that of the Kope Formation. Subsequent study of the bryozoan fauna of the Kope Formation by Anstey and Perry (1973) confirms the absence of Constellaria except near the very base of the formation. The Kope Formation (Eden Shale of Anstey and Perry, 1973) consists of about 75-90 percent shale and minor amounts of limestone.

In Kentucky, C. teres (pl. 2B) ranges through most of the Clays Ferry Formation, which is made up of about 50 percent shale and 50 percent thin-bedded limestones (Weir and Greene, 1965; Cressman, 1973). Thus, the evidence indicates that Constellaria thrived in those depositional environments in which shales constitute less than 75 percent of the rock unit and the remainder is carbonate. The northern limit of occurrence of Constellaria is probably between the Sadieville A and C sections and the Falmouth A section in northern Kentucky (pl. 1B, fig. 2) during Edenian time.

Heterotrypa foliacea is indigenous to Kentucky and is the second most abundant species in the bryozoan fauna (pls. $2 B, 3 B$ ). The established range of $H$. foliacea is from $184 \mathrm{ft}$ to about $440 \mathrm{ft}$ above the base of the Lexington Limestone in the Blue Grass region. The stratigraphical level of the first appearance of $H$. foliacea coincides approximately with the upper part of the Sulphur Well Member and the Brannon Member of the Lexington Limestone. $H$. foliacea is common in the stratigraphical interval from $200 \mathrm{ft}$ above the base of the Lexington Limestone and to the top of the composite section. It is generally more abundant in the southern part of the Blue Grass region than in the northern part (figs. 1,2); in the northern part it is present in a few samples from the Millersburg Member of the Lexington Limestone at the Gratz A section (pl. 1A), and in some samples from the Clays Ferry Formation and the Kope Formation at the Falmouth A section (pl. 1B). Whether the apparent decrease of $H$. foliacea should be seen as an effect of the increase in the shale content of the rocks or as the result of inadequate sampling can- 
not be determined at present. In the southern part of the study area, $\boldsymbol{H}$. foliacea is the predominant species in the Sulphur Well Member of the Lexington Limestone. The stratigraphic positions of the Sulphur Well Member and its lateral equivalents in the Lexington Limestone are shown in plate $1 A, B$. Geographically, the Sulphur Well Member is limited to the southwestern part of the Blue Grass region (Cressman, 1973, fig. 31).

Cressman (1973, p. 37) noted that the Sulphur Well Member of the Lexington Limestone is characterized by an extraordinary concentration of bryozoans. $\mathrm{He}$ described it as being formed of poorly washed biosparudite bryozoan limestone. Lithologically the Sulphur Well Member is similar to the Grier Limestone Member, also of the Lexington Limestone, but it differs from the Grier in its unusual abundance of bryozoans (Cressman, 1973, p. 37, table 3). According to Cressman, other invertebrate fossils in the Sulphur Well Member are sparse.

Heterotrypa foliacea in the Sulphur Well Member of the Lexington Limestone occurs together with Peronopora milleri, Eridotrypa mutabilis, Homotrypa cressmani, Parvohallopora nodulosa, and a few specimens of Prasopora falesi, Eridotrypa trentonensis, Constellaria teres, Acanthoceramoporella valliensis, and Stigmatella clavis (pl. $3 B$ ). Of these species, A. valliensis and $S$. clavis appear for the first time in the Blue Grass region at the stratigraphic level of the Sulphur Well Member.

The paleoecological conditions that caused the unusual abundance of bryozoans in the depositional environment of the Sulphur Well Member have not yet been studied. In terms of species content, however, the bryozoan assemblage of the Sulphur Well Member has been observed to differ from that of the lithologically similar Grier Limestone Member in lacking the immigrants Balticopora tenuimurale, Cyphotrypa acervulosa, and Tarphophragma multitabulata. Elsewhere in the Blue Grass region these species range across stratigraphical levels equivalent to the Sulphur Well Member. Whether the absence of these immigrant species in the Sulphur Well Member assemblage is significant or is due to inadequate sampling cannot be determined at this time.

In terms of the growth habits of bryozoans, the assemblage of the Sulphur Well Member of the Lexington Limestone is similar to bryozoan assemblages from other depositional environments in the Lexington Limestone and the Clays Ferry Formation. Biostratigraphically, however, the bryozoan assemblage in the Sulphur Well Member is significant, because it is at this level in the Blue Grass region of Kentucky that the characteristic bryozoans of the Edenian Stage begin to appear.
Parvohallopora nodulosa is indigenous to the Blue Grass region and the tristate area of Kentucky, Ohio, and Indiana. $P$. nodulosa ranges from $200 \mathrm{ft}$ above the base of the Lexington Limestone to the top of the composite section (pl. 2A). It comprises roughly 13 percent of the fauna and is abundant in most samples from different depositional environments ( $\mathrm{pl}$. 3B, C). P. nodulosa is the predominant species in the bryozoan assemblage from the Clays Ferry Formation (pl. $3 B$; Ford A section 22, type section of the Clays Ferry Formation; Sadieville $A$ and $C$ sections, Nos. 179 and 192, respectively, pl. $1 B$ ). The majority of specimens assigned to $P$. nodulosa in the Blue Grass region are from the Tanglewood Limestone Member of the Lexington Limestone (pl. $3 B$ ).

Eridotrypa mutabilis comprises roughly 12 percent of the sectioned material from the Lexington Limestone, the Clays Ferry Formation, and the Kope Formation (pl. $3 B$ ). E. mutabilis ranges between $140 \mathrm{ft}$ and $376 \mathrm{ft}$ above the base of the Lexington Limestone (pl. $2 A$ ). It is widespread and is present in the various lithologies within its stratigraphic interval (pls. 1, 3C). In the Lexington Limestone, E. mutabilis predominates in the bryozoan assemblage from the Brannon Member of the formation and is prevalent in the Tanglewood Limestone Member. In addition, E. mutabilis is one of the more abundant species in the Clays Ferry Formation (pl. $3 B$ ) and in the few samples from the Point Pleasant Tongue of the Clays Ferry (pl. $3 B$; Falmouth A section 195 , plate $1 B$ ).

Although $E$. mutabilis is relatively abundant in the various depositional environments of the Lexington Limestone and the Clays Ferry Formation in the Blue Grass region, its abundance in the tristate area of Kentucky, Ohio, and Indiana appears to be inversely related, to a degree, to the amounts of shale in the lithic units. Anstey and Perry $(1973$, p. 36) noted the absence of $E$. mutabilis in the Kope Formation (their Eden Shale) in the tristate area and attributed that absence to the depositional environment of the Kope Formation, which was probably deeper and muddier than that of the Point Pleasant Tongue of the Clays Ferry Formation (their Clays Ferry Tongue of the Eden Shale).

Specimens referred to Tarphophragma multitabulata, Eridotrypa trentonensis, Prasopora falesi, and Homotrypa cressmani, from the lower two-thirds of the Lexington-Clays Ferry depositional sequence and related strata, and to Parvohallopora onealli and Peronopora vera, from the upper half, constitute roughly 27 percent of the sectioned bryozoan specimens. Each of these four species represents about 3-6 percent of the fauna in the collections.

Tarphophragma multitabulata is the earliest appear- 
ing bryozoan species in the Lexington Limestone, ranging from 14 to $198 \mathrm{ft}$ above the base of the Lexington (pl. 2A). T. multitabulata is the predominant bryozoan species in the Grier Limestone Member of the Lexington Limestone (pl. $3 B$ ), and the majority of specimens are from the stratigraphic interval between 56 and 198 $\mathrm{ft}$ above the base of the Lexington Limestone. This species has not been found in the Clays Ferry Formation. Geographically, T. multitabulata occurs mostly in the southern and western part of the Blue Grass region (pl. 1A; Valley View C, Salvisa B, Frankfort East A and $\mathrm{B}$ sections, pls. $1 A, 3 C$; Coletown A section, pl. $1 B$ ). It has been reported by Foerste (1905, p. 152, as Hallopora), however, from below his "Point Pleasant Bed" near Moscow, Carnestown, and Foster in northern Kentucky. These occurrences, if verified, would suggest that $T$. multitabulata is more widespread in Kentucky than present sampling indicates.

Eridotrypa trentonensis is common locally in the Grier Limestone Member of the Lexington Limestone and in the lower part of the Clays Ferry Formation (pl. $2 A)$. Its stratigraphic range is from 56 to $330 \mathrm{ft}$ above the base of the Lexington Limestone (pl. 2A). Geographically, $E$. trentonensis is found to be common in samples from the southern part of the Blue Grass region (Valley View C, Salvisa B sections, plate $1 A$ ) and is sparingly present in other parts of the study area (pl. 3C).

Prasopora falesi is indigenous, as far as is known, to the Blue Grass region. Most of the specimens of $P$. falesi are from the Grier Limestone Member of the Lexington Limestone (Salvisa B and Frankfort East A section, pl. $1 A$ ). Its stratigraphic range is from $56 \mathrm{ft}$ to 238 $\mathrm{ft}$ above the base of the Lexington Limestone (pl. 2A). $P$. falesi occurs sparingly in the upper part of the Lexington Limestone and the lower part of the Clays Ferry Formation (pl. 3B).

Homotrypa cressmani is indigenous to the Blue Grass region and occurs sparingly in the Grier Limestone Member and in succeeding lithic units of the Lexington Limestone and the Clays Ferry Formation (pl. 3B). The stratigraphic range of $H$. cressmani is from $116 \mathrm{ft}$ to $344 \mathrm{ft}$ above the base of the Lexington Limestone. Most of the specimens of $H$. cressmani are from the Tanglewood Limestone Member of the Lexington Limestone (pl. $3 B$ ). Geographically, $H$. cressmani is more common in samples from the eastern part than from the western and southern parts of the Blue Grass region (figs. 1, 2; pl. 3C).

Parvohallopora onealli and Peronopora vera occur commonly in most samples that have been recovered from the upper half of the Lexington Limestone and the Clays Ferry Formation. The stratigraphic range of $P$. onealli is from slightly above the 200 -ft level above the base of the Lexington Limestone to the top of the composite section (pl. 2A). P. onealli is the second most abundant species (pl. $3 B$ ) in the Point Pleasant Tongue of the Clays Ferry Formation, after Eridotrypa mutabilis (Sadieville sections A, C, pl. 1B).

Peronopora vera is indigenous to the Blue Grass region and the tristate area of Kentucky, Ohio, and Indiana. Its range in the Blue Grass region is from 220 $\mathrm{ft}$ above the base of the Lexington Limestone to the top of the composite section ( $\mathrm{pl}$. 2A). In the Blue Grass region $P$. vera is relatively abundant in the Millersburg Member of the Lexington Limestone (pl. $3 B$; Sadieville $\mathrm{A}$ and $\mathrm{C}$ sections, pl. $1 B$; Winchester A section, pl. $1 C$ ).

The 10 species discussed above form the main component of the bryozoan fauna in the Blue Grass region. The remainder of the bryozoan fauna from the Lexing. ton-Clays Ferry sequence and related rocks consists of 26 species that form about 18 percent of the sectioned material.

Characteristics of distribution of these 26 species follow.

Four species-Heterotrypa trentonensis, Mesotrypa angularis, Homotrypella granulifera, and Cyphotrypa switzeriensis-have been recovered only from the Grier Limestone Member of the Lexington Limestone at a number of localities along lines of section $\mathbf{A}-\mathbf{A}^{\prime}$ and B-B' (fig. 1 ; pl. $1 A, B$ ). $H$. trentonensis is relatively common throughout the Grier Limestone Member of the Lexington Limestone (pl. $3 B, C$ ). The other three species, Mesotrypa angularis, Homotrypella granulifera, and Cyphotrypa switzeriensis, occur sparingly and each has been found at only two localities (pls. $1 A, B ; \mathrm{pl} .3 C$ ).

Seven species-Amplexopora aff. A. winchelli, Balticopora tenuimurale, Homotrypa similis, Dekayia epetrima, Cyphotrypa acervulosa, Stigmatella multispinosa, and Balticopora arcuatilis-are found generally in the Grier Limestone Member and sparingly in the successive lithic units of the Lexington Limestone (pl. 3B). Among them Balticopora tenuimurale is relatively common at six localities and Amplexopora aff. $A$. winchelli is relatively common at three (pl. $3 B, C)$. The other five species are sparingly present in two to three localities each (pl. 3C).

Eight species have been recovered only from the stratigraphic interval from $180 \mathrm{ft}$ above the base of the Lexington Limestone to the top of the composite section; these are Eridotrypa sadievillensis, Peronopora milleri, Atactoporella newportensis, Amplexopora persimilis, Constellaria fisheri, Dekayia sp., Stigmatella clavis, and Acanthoceramoporella valliensis (pl. 2A). Of these, Peronopora milleri and Atactoporella newportensis are relatively widespread and have been recovered from 10 and 5 localities, respectively (pl. $3 C$ ). The other six species are sparingly present in one to three locali- 
ties each (pl. 3C).

Crepipora venusta, Ceramophylla alternatum, and Ceramoporella distincta occur sparingly throughout the Lexington-Clays Ferry sequence of the Blue Grass region. Crepipora venusta is relatively common and has been found at five localities (pl. 3C), Ceramophylla alternatum at three localities, and Ceramoporella distincta at two localities (pl. 3C; Systematic Paleontology section).

Four species-Papillalunaria spatiosa, Batostoma $\mathrm{cf}$. B. jamesi, Mesotrypa sp., and Stigmatella.sp.-are from the stratigraphic interval between $180 \mathrm{ft}$ above the base of the Lexington Limestone and the top of the composite section. Each of these species is represented by only a single specimen. Papillalunaria spatiosa has been recovered from the Brannon Member of the Lexington Limestone in the Valley View A section (pl. 1B). McFarlan and White (1948, p. 1636, fig. 3), however, found that $P$. spatiosa (as Crepipora spatiosa) was concentrated in the southern part of Jessamine County, $\mathrm{Ky}$., at a similar stratigraphic level in their "Cynthiana Formation," so $P$. spatiosa may be widespread and more abundant than indicated herein.

The single specimen of Batostoma cf. B. jamesi is too inadequately preserved to make a definite assignment at the species level. Anstey and Perry (1973) found that B. jamesi was abundant in the upper part of the Kope Formation (Eden Shale of Anstey and Perry) in the tristate area of Kentucky, Ohio, and Indiana. They also noted that it was prevalent in depositional environments of abundant shale and lacking in environments in which carbonate sediments predominated.

It seems likely that the absence of $B$. jamesi in the Blue Grass region of Kentucky is due to incomplete sampling, but it may also be due to the high shale-tolimestone ratios in the Clays Ferry Formation and equivalent rocks.

The single specimens of Stigmatella sp. from the Tanglewood Limestone Member (Valley View C section, pl. 1A) and of Mesotrypa sp. from the Millersburg Member (Moorefield A section, pl. 1C) of the Lexington Limestone are inadequate for assignment at the specific level. These specimens, however, are unlike the described species of the respective genera.

\section{ASSEMBLAGE ZONES}

The bryozoan fauna of the Lexington LimestoneClays Ferry Formation and related rocks in the Blue Grass region is characterized by an association of species having different but restricted vertical ranges and different geographic origins. The individual species appear at different stratigraphic levels and are replaced in the successive rocks by species that are mostly of different genera. None of the species are known to occur in rocks of pre-Lexington time in the Blue Grass region, and only a few species range into strata of the Maysvillian Stage of the tristate area of Kentucky, Ohio, and Indiana.

On the basis of the restricted vertical ranges and geographical occurrences of individual taxa, two distinct bryozoan assemblages can be recognized. The stratigraphically lower assemblage zone, herein named the Tarphophragma multitabulata zone, comprises the suite of rocks from $14 \mathrm{ft}$ above the base of the Lexington Limestone to the stratigraphic level at approximately the bottom of the Brannon Member of the Lexington Limestone. Thus, the lower assemblage zone includes the upper parts of the Curdsville Limestone, Logana, and Grier Limestone Members of the Lexington Limestone and a few feet of the overlying rock units (pl. 2B). The upper assemblage zone, herein named the Constellaria teres zone, comprises the succession of rocks between the approximate stratigraphic level of the bottom of the Brannon Member and the top of the Clays Ferry Formation or the highest occurring samples in the Kope Formation. Thus, the upper assemblage zone includes the Brannon Member, the lithic units of the Lexington Limestone above its Brannon Member, the Clays Ferry Formation, and the laterally equivalent or overlying beds of the Kope Formation. The boundary between the lower and upper assemblage is located approximately $180 \mathrm{ft}$ above the base of the Lexington Limestone (pl. $2 B$ ).

The vertical ranges of the species are referred to the base of the Lexington Limestone and are summarized in a composite section for the Blue Grass region ( $\mathrm{pl}$. $2 A$ ). The association of species and the vertical ranges characteristic of the lower and upper assemblage zones are summarized in the composite section of pl. $2 B$.

The base of the Lexington Limestone is recognizable in areas of surface outcrop and below the surface at several localities throughout the Blue Grass region (Black, Cressman, and MacQuown, 1965; Bergström and Sweet, 1966, p. 296; Luft, 1971; Gibbons, 1972; Cressman, 1973; Sweet, 1979). Miller (1925), McFarlan (1938), and Black, Cressman, and MacQuown (1965) showed that the contact between the Lexington Limestone and the underlying Tyrone Limestone was disconformable. On the basis of lithic relationships between the basal layers of the Lexington Limestone, the top layers of the underlying Tyrone Limestone, and the stratigraphic position of associated bentonite layers along the contact, Cressman (1973) and Borella and Osborne (1978) estimated that the disconformable contact probably represented a small time interval and thus could be considered to be virtually isochronous. 
TARPHOPHRAGMA MULTITABULATA ASSEMBLAGE ZONE

The Tarphophragma multitabulata assemblage zone comprises the following species in order of first occurrence: T. multitabulata, Mesotrypa angularis, Prasopora falesi, Heterotrypa trentonensis, Homotrypella granulifera, Cyphotrypa acervulosa, C. switzeriensis, Balticopora arcuatilis, and Stigmatella sp. (pl. 2B).

The base of the Tarphophragma multitabulata assemblage zone is placed at the lowermost known occurrence of the species, $14 \mathrm{ft}$ above the base of the Lexington Limestone in its Curdsville Limestone Member (pl. 2B). The top of the zone is defined by the uppermost appearance of the characteristic species of the succeeding Constellaria teres assemblage zone, and is $180-200 \mathrm{ft}$ above the base of the Lexington Limestone (pl. 2B).

$H$. trentonensis appears at about $56 \mathrm{ft}$ above the base of the Lexington Limestone in its Grier Limestone Member (pl. 2A). T. multitabulata and $H$. trentonensis are relatively widespread and common in the lower assemblage zone (pl. $3 \mathrm{C}$ ). Both species disappear at nearly $200 \mathrm{ft}$ above the base of the Lexington Limestone (pl. $2 B$ ), probably becoming extinct in the Lexington-Clays Ferry sequence at this level; they are not known to occur at a higher stratigraphic level anywhere in the equivalent Ordovician strata.

Other species restricted to the Tarphophragma multitabulata zone are Mesotrypa angularis and Homotrypella granulifera, both of which disappear within the stratigraphical interval of this zone. Cyphotrypa switzeriensis, Balticopora arcuatilis, Stigmatella sp., Prasopora falesi, and Cyphotrypa acervulosa are generally restricted to this zone, but they extend upward into the succeeding assemblage zone for short interval distances and disappear within or just slightly above the stratigraphical interval between 180 and $200 \mathrm{ft}$, above the base of the Lexington Limestone (pl. 2B). The lateral distribution of these species in the Blue Grass region within the Tarphophragma multitabulata zone is indicated in plates 1 and $3 C$. Other species, however, range across the zonal boundary for various vertical distances. These species include, in ascending order (pl. 2A), Eridotrypa trentonensis, Balticopora tenuimurale, Homotrypa cressmani, E. mutabilis, Dekayia epetrima, Stigmatella multispinosa, Crepipora venusta, Ceramophylla alternatum, and Amplexopora aff. A. winchelli. These species generally are common to the upper part of the Tarphophragma multitabulata assemblage zone and the lower half of the succeeding Constellaria teres zone.

CONSTELLARIA TERES ASSEMBLAGE ZONE

The Constellaria teres assemblage zone is named after the most abundant species of the Lexington-Clays Ferry fauna. The zone comprises the following species in ascending order: $C$. teres, Homotrypa similis, Peronopora milleri, Heterotrypa foliacea, Ceramoporella distincta, Parvohallopora nodulosa, Acanthoceramoporella valliensis, Papillalunaria spatiosa, Eridotrypa sadievillensis, Parvohallopora onealli, Stigmatella clavis, Peronopora vera, Dekayia sp., Constellaria fischeri, Atactoporella newportensis, Mesotrypa sp., Amplexopora persimilis, and Batostoma cf. B. jamesi. The base of the $C$. teres assemblage zone is placed at the first appearances of the zonal index species $C$. teres, approximately $180 \mathrm{ft}$ above the base of the Lexington Limestone in the composite section for the Blue Grass region (pl. 2B), as shown in the Valley View $\mathrm{C}$ section (pl. 1A). The top of the Constellaria teres assemblage zone is placed at the contact between the Clays Ferry Formation and the overlying Garrard Siltstone (Upper Ordovician), as indicated in the type section of the Clays Ferry Formation (Ford A section, pl. 1B). Although the bryozoan fauna from the Garrard Siltstone have not been studied for this report, preliminary sampling indicates that the bryozoans occur sparingly and irregularly in scattered thin stringers of limestone in the siltstone of the formation. Recovered specimens from these limestone stringers in the Garrard Siltstone are poorly preserved and in general are not suitable for making specific determinations.

Where the Garrard Siltstone is absent, the top of the Constellaria teres assemblage zone is placed arbitrarily at the highest stratigraphical level sampled for the bryozoans in the Clays Ferry Formation, as in the Frankfort East A, B section (pl. 1A) or in the Falmouth A section (pl. 1B).

The Constellaria teres assemblage zone in the Blue Grass region of Kentucky is significant biostratigraphically because it includes bryozoan species that characterize the Edenian Stage as based on the bryozoan fauna of the Kope Formation (Eden Shale or Formation of authors) in the tristate area of Kentucky, Ohio, and Indiana. Furthermore, the strata included in this zone record the lowest known appearances of some typical Edenian bryozoan species. In addition, the stratigraphical interval of this zone records the disappearance of Balticopora tenuimurale and Eridotrypa mutabilis, two species which characterize the Rocklandian, Kirkfieldian, and Shermanian Stages of the standard section for the late Middle Ordovician of North America in New York State (Ross, 1967b, 1970a), and of Cyphotrypa acervulosa, a species which occurs in the lower part of the Galena Dolomite, upper Middle Ordovician, in Minnesota and Iowa (Ulrich, 1893).

Species of Edenian Stage that characterize the Con- 
stellaria teres assemblage zone include Parvohallopora nodulosa, (Calopora of authors), Peronopora vera, and Stigmatella clavis. Anstey and Perry (1973) established that these species range virtually throughout the Kope Formation (the Eden Shale of Anstey and Perry) in the tristate area of Kentucky, Ohio, and Indiana. Other species in this assemblage zone that are characteristic of the Edenian Stage include Amplexopora persimilis, Atactoporella newportensis, and Ceramoporella distinc$t a$. The ranges of these species in the composite section for the Blue Grass region are shown in plate $2 A, B$, and their ranges in the Kope Formation of the tristate area, as reported by others in the literature (see occurrence data in the taxonomic section), in plate $2 C$.

This assemblage zone also includes Parvohallopora onealli, a species which conventionally has been considered to be typical of the Edenian Stage. In New York, Ross (1969) found that $P$. onealli (her Calopora) is present in the "Shoreham Formation" of the Shermanian Stage (upper Middle Ordovician), but not in the "Cobourg Formation" of the Edenian Stage (Upper Ordovician) of Sweet and Bergström (1971).

In the Blue Grass region of Kentucky, however, $P$. onealli is restricted to the Constellaria teres assemblage zone, and in the tristate area of Kentucky, Indiana, and Ohio to the Kope Formation of Edenian Stage. Thus, in Kentucky $P$. onealli occurs in the late Shermanian and Edenian Stages, and in adjacent areas of Indiana and Ohio it occurs in strata of early Late Ordovician age.

In addition, a number of species are restricted to the Constellaria teres assemblage zone and are known only from this zone in the Blue Grass region. These species include Heterotrypa foliacea, Peronopora milleri, Eridotrypa sadievillensis, Dekayia sp. (see remarks in the taxonomic section), Acanthoceramoporella valliensis, and Constellaria fischeri (pls. 2B, 3C). In this assemblage zone, Batostoma cf. B. jamesi, Mesotrypa sp., and Papillalunaria spatiosa are represented by a single specimen each, and thus their stratigraphic ranges cannot be determined at present. Several species that appear for the first time in the preceding zone of Tarphophragma multitabulata and extend various vertical distances into the overlying zone of Constellaria teres (pl. 2B) are referred to in the discussion of the former.

\section{BIOSTRATIGRAPHICAL COMPARISON}

Biostratigraphical equivalence based on bryozoans between the various individual sections of the Lexington Limestone, Clays Ferry Formation, and Kope Formation (pl. 1) in the Blue Grass region of Kentucky is also confirmed by correlations based on conodonts and by the lateral continuity of complexly intertonguing lithic units within the Lexington Limestone and between the Lexington Limestone and the Clays Ferry Formation.

Bergström and Sweet (1966), Sweet and Bergström (1971), and Sweet (1979) developed a technique for charting fluctuations in relative abundance of wideranging and widely distributed conodont species in the Middle and Upper Ordovician rocks in the tristate area of Kentucky, Ohio, and Indiana; in New York State; and in Minnesota and Iowa. They demonstrated that the major fluctuations in relative abundances of several conodont species have a pattern that is recognizable from section to section within a region. They reasoned that these fluctuations probably reflect subtle regionwide changes in the marine environment and that they are thus suitable stratal events to use in correlating rocks. Sweet and Bergström summarized the results in composite sections for each region they studied, and showed that the patterns of fluctuation even in widely separated geographic regions are grossly comparable.

Sweet and Bergström (1971) demonstrated further that the biostratigraphical equivalence of the composite sections for the Cincinnati region and New York State can also be established on the basis of evolutionary transitions between selected conodont species common to these regions.

As a result of these studies, Sweet and Bergström (1971) and Sweet (1979) concluded that the Cobourgian Stage in the biostratigraphical classification of Kay (1968) overlaps the Edenian Stage that is the basal stage of the Cincinnatian Provincial Series (Late Ordovician) in the Cincinnati region. Consequently, Sweet and Bergström (1971) and Sweet (1979) adapted a biostratigraphical classification modified after Kay (1968) for the Champlainian Provincial Series (late Middle Ordovician) in New York State and redefined the Cincinnatian Provincial Series (Late Ordovician) in the Cincinnati region. Thus the North American standard section for the late Middle Ordovician in New York State is subdivided, in ascending order, into the Blackriveran, Rocklandian, Kirkfieldian, and Shermanian Stages and is overlain by the Edenian Stage, as defined mainly on the Kope Formation of the Cincinnatian Provincial Series in Kentucky and Ohio by Sweet and Bergström (1971, figs. 2, 3). The Cincinnatian (North American standard for the Late Ordovician) in the revised classification of Sweet and Bergström (1971) is subdivided into the Edenian, Maysvillian, and Richmondian Stages as based on the formations in the tristate area of Kentucky, Indiana, and Ohio (see Sweet, 1979, p. G9, G10, G22, fig. 1, for geographic locations of representative sections). 
Sweet and Bergström (1971) and Sweet (1979) placed the base of the Lexington Limestone in the Kirkfieldian Stage of the Champlainian Provincial Series (Middle Ordovician) and determined that the base of the Edenian Stage of the Cincinnatian Provincial Series (Late Ordovician) was approximately 70-80 ft below the top of the Lexington Limestone, and at a stratigraphically similar level in the Clays Ferry Formation. Thus the base of the Edenian Stage is approximately $300 \mathrm{ft}$ above the base of the Lexington Limestone in the composite section for the Blue Grass region of Kentucky.

Bergström and Sweet (1966, fig. 6) in their preliminary biostratigraphical classification indicated that the Decorah Shale and the overlying "Cummingsville Member" of the Galena Dolomite of Minnesota and Iowa were the approximate stratigraphical equivalents of the "Rockland" and "Kirkfield" Formations, respectively, in New York State.

Cressman (1973) described the various members of the Lexington Limestone and demonstrated that tongues of the lithic units were approximately parallel to the time-rock horizons of Sweet and Bergström (1971) and virtually parallel to the base of the Lexington Limestone (Cressman, 1973, pl. 7, 10). Black and others $(1965$, p. C21) showed that the base of the Brannon Member of the Lexington Limestone (pl. $1 A, B$ ) is isochronous.

Borella and Osborne (1978) concluded that the stratigraphical interval between the base of the Lexington Limestone and the base of the Brannon Member of the Lexington Limestone is formed of a lithic unit approximately $200 \mathrm{ft}$ thick that is virtually isochronous over a wide area in the Blue Grass region of Kentucky and nearby Tennessee. This stratigraphical interval includes the Kirkfieldian and the lower part of the Shermanian Stages of Sweet and Bergström (1971) and Sweet (1979), and is characterized by the bryozoan assemblage zone of Tarphophragma multitabulata in Kentucky.

The biostratigraphical equivalence between the Lexington-Clays Ferry depositional sequence in the Blue Grass region of Kentucky and the Kope Formation in northern Kentucky and the adjacent region in Ohio and Indiana is established on the basis of 27 percent of the species of the Lexington-Clays Ferry bryozoan fauna that are common to these areas. Most of the comparable species occurring in the Kope Formation are limited to the upper part of the Lexington Limestone and the Clays Ferry Formation of Kentucky.

The Clays Ferry Formation of central Kentucky grades laterally into the Kope Formation of northern Kentucky (Sweet and Bergström, 1971; Cressman, 1973; Sweet, 1979). The Kope Formation (the Eden
Formation or Shale of authors) as a lithic unit extends in a northerly direction in southeastern Indiana and southwestern Ohio (Brown and Lineback, 1966; Ford, 1968; Anstey and Fowler, 1969). Because the Kope Formation in Cincinnati, Ohio, and Latonia, Ky. (Bergström and Sweet, 1966, p. 296) defines the Edenian Stage of the Cincinnatian Provincial Series of Sweet and Bergström (1971) and Sweet (1979), the bryozoan species common to northern Kentucky and adjacent areas of Ohio and Indiana are evidence of the presence in central Kentucky of the Edenian Stage and indicate its possible stratigraphical extent.

Anstey and Perry (1973) thoroughly analyzed the content and distribution of trepostomatous bryozoan fauna in the Kope Formation in an area extending approximately $35 \mathrm{mi}$ north from northern Kentucky Patriot quadrangle, Gallatin County, to the vicinity of West Harrison in southeastern Indiana and Miamitown in southwestern Ohio (Anstey and Perry, 1973, fig. 1). The stratigraphical distribution of the bryozoan species common to the Kope Formation in the area studied by Anstey and Perry and to the LexingtonClays Ferry sequence of central Kentucky is compared in plate $2 C$. Plate $2 C$, column $\mathrm{B}$, summarizes the stratigraphic ranges of bryozoans from Nickles $(1902,1905)$ and Bassler (1906), and is modified after Bassler (1906). Column $\mathrm{C} 1$ in plate $2 C$ summarizes the stratigraphical ranges of comparable bryozoan species in the Patriot quadrangle, Kentucky, and the adjacent area of Indiana, from Anstey and Perry (1973). Column C2 in plate $2 C$ summarizes the stratigraphical ranges from Cumings (1908) and Cumings and Galloway (1913), and is modified after Anstey and Perry (1973).

In reference to the two bryozoan assemblage zones in the Lexington-Clays Ferry sequence, most of the species that characterize the Constellaria teres assemblage zone are also typical of the Edenian Stage as defined on the Kope Formation in Ohio and Kentucky (Bergström and Sweet, 1966; Sweet, 1979). However, the two most abundant species in this zone, C. teres and Heterotrypa foliacea, have not been found in the Kope Formation of Ohio and Indiana. In addition, some of the bryozoan species typical of the Edenian Stage in Indiana and Ohio occur in the Blue Grass region of central Kentucky at stratigraphical levels below the base of the Kope Formation or its lateral equivalent in the Clays Ferry Formation (pl. 2C).

Similarities and differences in the distribution of the bryozoan species between the Lexington-Clays Ferry sequence of late Shermanian and Edenian Age in Kentucky and the laterally adjacent Kope Formation of Edenian age in Indiana and Ohio are summarized as follows:

C. teres is the dominant species in the bryozoan 
assemblage of central Kentucky, but it is absent through most of the Kope Formation in northern Kentucky, Indiana, and Ohio. C. teres in central Kentucky ranges from about 180 to $430 \mathrm{ft}$ above the base of the Lexington Limestone and is relatively common in the Clays Ferry Formation of Edenian age (pl. 2A, B). However, $C$. teres gradually decreases in relative abundance (pl. $3 C$ ) in a northern direction from central Kentucky and has not been found in the Falmouth A section (pl. 1B) in northern Kentucky.

Anstey and Perry (1973) found only a few specimens of an unnamed Constellaria sp. in the basal $6 \mathrm{ft}$ of the Kope Formation in northern Kentucky (Gallatin County) and noted that Constellaria was lacking throughout the main part of the Kope Formation in their study area in southeastern Indiana and southwestern Ohio. Their detailed investigation of the bryozoan fauna of the Kope Formation confirms the finding of an earlier study by Cutler (1968). Cutler (1968) concluded from a major study of Constellaria that its stratigraphical distribution was controlled environmentally because Constellaria generally was absent in Middle and Late Ordovician depositional environments in which shale was the predominant rock type.

Similarly, the stratigraphical distribution of Eridotrypa mutabilis is probably controlled environmentally to some degree in strata of the Edenian Stage in the tristate area of Kentucky, Indiana, and Ohio. E. mutabilis occurs in part of the Lexington Limestone that is of Shermanian age, and ranges from about $140 \mathrm{ft}$ to about $376 \mathrm{ft}$ above the base of the Lexington Limestone into the Edenian Stage in Kentucky (pl. 2A). It is relatively common in the Edenian-Age part of the Clays Ferry Formation and the laterally adjacent Kope Formation (pl. 3B, C). Anstey and Perry (1973) also showed that $E$. mutabilis was relatively common in the basal $24 \mathrm{ft}$ of the Kope Formation (the Eridotrypa mutabilis zone of Anstey and Perry, 1973) in northern Kentucky, but that it was lacking throughout the Kope Formation in their study area of Indiana and Ohio. Anstey and Perry (1973) attributed the relatively abrupt disappearance of $E$. mutabilis laterally and stratigraphically to possible environmental factors associated with a large increase in the volume of accumulating muds in the depositional environment of the Kope Formation.

The disappearance of $E$. mutabilis is evident over a wide area, but it takes place in central Kentucky at a stratigraphical horizon higher than in northern Kentucky and adjacent Indiana. McFarlan and Freeman (1935) reported, as noted by Anstey and Perry (1973), that $E$. mutabilis was generally absent in strata above a horizon roughly equivalent to that of the middle part of the Clays Ferry Formation (of current usage) in Kentucky. The highest recorded occurrence of $E$. mutabilis in Kentucky in the present study (Ford A section, pl. $1 B$ ) is approximately $376 \mathrm{ft}$ above the base of the Lexington Limestone. In addition, Ross (1967b) reported that $E$. mutabilis ranged from the base of the Trenton Group (upper Champlainian Provincial Series) and disappeared in the "Cobourg Formation" (Edenian Stage of Sweet and Bergström, 1971) of the Trenton Group in New York State. As far as is known at present, $E$. mutabilis has not been reported from strata of postEdenian Age anywhere. This stratigraphical distribution of $E$. mutabilis suggests that it probably became extinct over a wide geographical area during the early part of the Edenian Stage.

Parvohallopora nodulosa and Peronopora vera appear for the first time at approximately the $200 \mathrm{ft}$ stratigraphical level above the base of the Lexington Limestone and range to near the top of the Clays Ferry Formation in the Edenian Stage in Kentucky (pl. 2B). Both species are relatively abundant throughout the interval of their stratigraphical ranges (pl. 3B). Anstey and Perry (1973) showed that $P$. nodulosa (as Hallopora) and $P$. vera were among the most abundant species in the Kope Formation and that both ranged through the Kope Formation in northern Kentucky and southeastern Indiana. The two species also have been reported as ranging from the Kope Formation for a short vertical distance into the overlying strata of the Maysvillian Stage at Tanners Creek in Indiana (pl. 2C) (Cumings and Galloway, 1913). They have not been found, however, in the post-Edenian strata above the Clays Ferry Formation in Kentucky. Thus, $P$. nodulosa and $P$. vera are widely distributed and are typical of the Edenian Stage in the tristate area of Kentucky and Indiana and Ohio. However, both species range from below the Edenian Stage in central Kentucky and apparently become extinct in the early part of the Maysvillian Stage in Indiana.

Similarly, Stigmatella clavis ranges from about 200 $\mathrm{ft}$ above the base of the Lexington Limestone into the Clays Ferry Formation of the Edenian Stage. This species, however, is found only in central Kentucky, where it occurs in Valley View A section and Ford A section (pl. 1B). Anstey and Perry (1973) reported S. clavis from the basal and upper part of the Kope Formation and noted its absence in the middle part of the Kope Formation in their study area of northern Kentucky and southeastern Indiana. Cumings and Galloway (1913) recorded $S$. clavis as ranging from the upper part of the Kope Formation into the early part of the overlying strata of the early Maysvillian Stage at Tanners Creek in Indiana.

Ceramoporella distincta has been reported as ranging from the upper part of the Kope Formation into the early part of the succeeding Maysvillian Stage at Tan- 
ners Creek, Ind. (Cumings and Galloway, 1913). This species, however, is found only in the late part of the Shermanian Stage in central Kentucky (pl. 2A).

Crepipora venusta is relatively rare in Kentucky, where it ranges from about $154 \mathrm{ft}$ above the base of the Lexington Limestone (Shermanian Stage) into the Clays Ferry Formation of the early part of the Edenian Stage (pl. 2A). C. venusta has been reported as occurring in the lower half of the Kope Formation in northern Kentucky and the adjacent area in Ohio and Indiana (pl. $2 C$ ). Of the species typical of the Kope Formation, $C$. venusta is the earliest occurring to be found in the Lexington Limestone of Kentucky in the area under study.

Heterotrypa, Amplexopora, and Atactoporella, three genera that occur in the Lexington-Clays Ferry sequence of the Edenian Stage in Kentucky and in the Kope Formation in Indiana and Ohio, are represented by different species in these areas.

$H$. foliacea is the second most abundant species in the Lexington-Clays Ferry sequence of Kentucky and $H$. ulrichi is one of the dominant species in the Kope Formation of Indiana (Anstey and Perry, 1973). In Kentucky, $H$. foliacea appears for the first time at approximately $180 \mathrm{ft}$ above the base of the Lexington Limestone and ranges into the Clays Ferry Formation of the Edenian Stage (pl. 2A). Although $H$. foliacea is generally common throughout the section, it appears to decrease in relative abundance to the north, as indicated at Falmouth A section (pl. 1B, 3C), and is less common in the Kope Formation than in the Clays Ferry Formation (pl. 3B, C).

Anstey and Perry (1973) established that $H$. ulrichi appeared for the first time approximately $45 \mathrm{ft}$ above the base of the Kope Formation, or about $335 \mathrm{ft}$ above the estimated position of the base of the Lexington Limestone in southern Indiana and northern Kentucky. Although they found only a single specimen of H. ulrichi in the Kope Formation in northern Kentucky, they showed that the species became abundant in the Kope Formation in southeastern Indiana, where it disappeared at the top of the Kope Formation.

Amplexopora persimilis is relatively rare in Kentucky, where it occurs mainly in the Clays Ferry Formation (pl. $3 B$ ). Its known range is from about 270 to $410 \mathrm{ft}$ above the base of the Lexington Limestone (pl. $2 B)$.

Anstey and Perry (1973) found that A. septosa is one of the abundant species in the stratigraphical interval between $45 \mathrm{ft}$ above the base and the top of the Kope Formation in southeastern Indiana, and showed that it was virtually nonexistent in the Kope Formation in northern Kentucky in their study area.

Thus, A. persimilis ranges into the Clays Ferry Formation of the Edenian Stage in Kentucky, but in the
Kope Formation in southeastern Indiana was apparently replaced by $A$. septosa. However, A. persimilis has been reported as occurring in the Kope Formation in southwestern Ohio (pl. 2C).

Atactoporella newportensis is sparingly present in strata of the Edenian Stage in central Kentucky, and A. typicalis, as reported by Anstey and Perry (1973), is uncommon in the Kope Formation of northern Kentucky and southeastern Indiana. Anstey and Perry (1973) found that A. typicalis occurs in the lower part of the Kope Formation; however, they considered $A$. newportensis to be an informal subjective synonym of $A$. typicalis.

A. newportensis is regarded herein as a separate species. It occurs mainly in the upper part of the Lexington Limestone and in the Clays Ferry Formation (pl. $3 B$ ) in central Kentucky, where it ranges from about $260 \mathrm{ft}$ above the base of the Lexington Limestone to nearly the top of the Clays Ferry Formation (pl. 2B). A. newportensis has also been reported as occurring in the lower part of the Kope Formation near Covington, $\mathrm{Ky}$. (pl. 2C). Thus, it ranges across the base of the Edenian Stage into the lower half of the Edenian Stage in central Kentucky. A. typicalis, however, is limited to the lower part of the Kope Formation (lower Edenian Stage) in northern Kentucky and southern Indiana (Anstey and Perry, 1973).

In addition, Anstey and Perry (1973) reported on three species that occurred in the Kope Formation of southeastern Indiana but that have not been found in stratigraphically equivalent strata of Kentucky during the present study; they are Balticoporella whitfieldi (James), Dekayia aspera Milne-Edwards and Haime, and Batostoma jamesi (Nicholson). However, a single specimen of Batostoma, assigned herein to $B$. cf. $B$. jamesi because of its poor state of preservation, was found in the Clays Ferry Formation (Ford A section, pl. $1 B$ ) of the Edenian Stage in central Kentucky, at the stratigraphical level about $410 \mathrm{ft}$ above the base of the Lexington Limestone (pl. 2B).

According to Anstey and Perry (1973), B. jamesi appears for the first time approximately $115 \mathrm{ft}$ above the base of the Kope Formation, or about $405 \mathrm{ft}$ above the estimated position of the base of the Lexington Limestone in the southern part of Indiana. Thus, stratigraphically, the occurrence of $B$. cf $B$. jamesi in Kentucky coincides roughly with the appearance of $B$. jamesi in the Kope Formation in southern Indiana. $B$. jamesi has been also reported from the upper part of the Kope Formation at Tanners Creek in Indiana (Cumings and Galloway, 1913).

The above-indicated association of bryozoan species in the upper part of the Lexington Limestone and the Clays Ferry Formation in central Kentucky and in the 
Kope Formation in northern Kentucky, southeastern Indiana, and southwestern Ohio characterizes the Edenian Stage. Taking into account their lower stratigraphical limits in central Kentucky and their upper stratigraphical limits in Indiana, these species differentiate the Edenian Stage, early Late Ordovician, from the underlying Shermanian Stage, late Middle Ordovician, and the succeeding Maysvillian Stage, middle Late Ordovician, in the tristate area of Kentucky, Ohio, and Indiana.

The presence in Ordovician rock sequences in the Minnesota-Iowa region and in New York State of two or more bryozoan species that occur also in the Lexing. ton-Clays Ferry depositional sequence in Kentucky establishes to a degree the biostratigraphical equivalence of these regions. Species common to these regions that also occur in areas of Indiana and Ohio adjacent to Kentucky are summarized in stratigraphical order of appearance in plate $2 C$.

The number of species common to Kentucky, New York State, and the Minnesota-Iowa region is relatively small, although these regions were covered by interconnecting shallow seas during the late Middle and early Late Ordovician time (Cressman, 1973). The lack of any greater similarity among the bryozoan faunas from these regions at the species level than is indicated herein is probably due both to differential sampling of strata and to paleoecological factors or broad geographical controls, such as provincialism, that have not been studied.

Of the species of bryozoan fauna of the LexingtonClays Ferry region, about 19 percent also occur in the middle and upper part of the Decorah Shale and the overlying "Cummingsville Member" of the Galena Dolomite in Minnesota and in their lateral equivalents in Iowa. The stratigraphical ranges of these species are shown in plate $2 C$. The lower stratigraphical limits of these species in Minnesota and Iowa are reasonably well established, but in the Galena Dolomite their upper stratigraphical limits cannot be determined because the bryozoan fauna there is poorly preserved.

Cyphotrypa acervulosa, Eridotrypa mutabilis, and Balticopora tenuimurale are limited, as far as is presently known, to the "Cummingsville Member" of the Galena Dolomite (the "Galena shales" of Ulrich, 1893) in Minnesota and Iowa. Heterotrypa trentonensis occurs in the upper part of the Decorah Shale and ranges into the "Cummingsville Member" of the Galena Dolomite. Tarphophragma multitabulata and Ceramophylla alternatum are limited to the middle and upper part of the Decorah Shale (the Guttenberg and Ion Formations of Bork and Perry, 1968, in Iowa). This association of species in the upper part of the Decorah Shale and in the "Cummingsville Member" of the Galena Dolomite supports in general the biostratigraphical classification proposed by Bergström and Sweet (1966), in which the lower part of the Lexington Limestone in Kentucky is considered to be coeval with the "Cummingsville Member" of the Galena Dolomite in Minnesota and Iowa.

However, the effective stratigraphical range of $T$. multitabulata in the Minnesota-Iowa region suggests also that the lower half of the Lexington Limestone can be biostratigraphically equivalent to the middle and upper part of the Decorah Shale and the "Cummingsville Member" of the Galena Dolomite.

About 11 percent of the species constituting the Lexington-Clays Ferry bryozoan fauna of Kentucky are also present in the Trenton Group of New York State. These species include Eridotrypa mutabilis, Balticopora tenuimurale, Ceramophylla alternatum, and Parvohallopora onealli. The stratigraphical ranges of these species in the Trenton Group and in the LexingtonClays Ferry sequence are compared in plate $2 C$. Ross (1967a,b; 1969; 1970a) extensively described the trepostome-cystoporate component of the bryozoan fauna from the Champlainian Provincial Series, Middle Ordovician of New York; the stratigraphical ranges indicated in plate $2 C$ are based on the data in those works.

The Trenton Group (Ross, 1967a, b; 1969; 1970a) in New York State comprises, in ascending order, the "Rockland," "Kirkfield," "Shoreham," and "Denmark" Formations of the upper Champlainian Provincial Series, Middle Ordovician, and the "Cobourg Formation" of the lower Cincinnatian Provincial Series, Upper Ordovician (Sweet and Bergström, 1971). Ross (1967a, text-fig. 3; 1967b, text-fig. 2; 1969, text-fig. 1; $1970 \mathrm{a}$, text-fig. 8) showed that the base of the Rocklandian Stage (the base of her "Rockland Formation" and Trenton Group) is marked by first appearance of no less than 8 of the approximately 29 bryozoan species that constitute the trepostome-cystoporate bryozoan fauna of the Trenton Group. However, the stages that succeed the Rocklandian have not been differentiated on the basis of bryozoan species distribution.

Eridotrypa mutabilis and Balticopora tenuimurale are among a group of species appearing for the first time in the section at the base of the Rocklandian Stage (Ross, 1967b, 1970a). Both species range throughout the Trenton Group and disappear in the "Cobourg Formation" (Ross, 1967b, 1970a) (the Edenian Stage of Sweet and Bergström, 1971). Ceramophylla alternatum, appearing for the first time in the "Chaumont Formation" (Ross, 1969) (upper part of the Blackriveran Stage of Sweet and Bergström, 1971) has a similar range throughout the Trenton Group and also disappears in the "Cobourg Formation" of Ross. Parvo- 
hallopora onealli occurs in the "Shoreham Formation" (Ross, 1969, p. 273, as Calopora) (lower part of the Shermanian Stage of Sweet and Bergström, 1971) and is apparently limited to this stratigraphical level in the Trenton Group of New York. These four species thus permit the establishment of a gross biostratigraphical correlation between the Lexington-Clays Ferry sequence in the Blue Grass region and the Trenton Group in New York State (pl. 2C).

Bryozoan species that characterize the Edenian Stage in Kentucky, Indiana, and Ohio apparently are absent, as far as is known at present, in the "Cobourg Formation" (Ross, 1970a) (Edenian Stage of Sweet and Bergström, (1971) in New York). Parvohallopora onealli is a typical Edenian species in the area of Cincinnati, Ohio, but it is known only from the Shermanian Stage ("Shoreham Formation" in Ross, 1969, p. 273) in New York. However, the presence of the Edenian Stage near the top of the Trenton Group in New York can be inferred tentatively on the basis of the last occurrences of Eridotrypa mutabilis and Balticopora tenuimurale. These species are not known to occur anywhere in postEdenian strata. In Kentucky B. tenuimurale disappears in rocks of late Shermanian age just below the Middle-Late Ordovician boundary, E. mutabilis in rocks of early Edenian age. In New York, both species disappear within the upper part of the "Cobourg Formation." The disappearance of $E$. mutabilis, therefore, implies an Edenian age for these strata.

\section{SYSTEMATIC PALEONTOLOGY}

The classification of the Paleozoic trepostome and cystoporate bryozoans has a long and complex history. A review of this history is beyond the scope of this report. Bryozoan genera of this report are assigned on the ordinal level to the order Trepostomata Ulrich, 1882 , in the generally accepted classification of Bassler (1953) and to the order Cystoporata Astrova, 1964. Astrova (1964) established Cystoporata and originally placed in it the families Ceramoporidae Ulrich, 1882 and Fistuliporidae Ulrich, 1882, from the order Cyclostomata; the family Constellariidae Ulrich, 1893, from the order Trepostomata in the classification of Bassler (1953); and the family Dianulitidae Vinassa de Regny, 1920, in the classification of Vinassa de Regny (1920). Although objections have been raised to including Constellariidae and Dianulitidae (Ross, 1966, p. 220; Utgaard, 1968a, p. 1035) in the order Cystoporata, the order has gradually gained general acceptance among bryozoologists (Utgaard, 1968b, p. 1444; 1973, p. 318-319; Ryland, 1970, p. 157; McKinney, 1971, p. 291; 1977, p. 323; Tavener-Smith and Williams, 1972, p. 144; Cutler, 1973; Healy and Utgaard, 1979) and has been reviewed thoroughly (Utgaard, 1983a, b) in the revised bryozoan volume of the "Treatise on Invertebrate Paleontology."

The grouping of trepostome genera into the families generally recognized at present has long been considered to be unsatisfactory, as noted by McKinney (1971, p. 221) and several other contemporary workers (Boardman, 1960a, p. 26, 27; Ross, 1963a, p. 57; 1963c, p. 857; Bork and Perry, 1967, p. 1376; Anstey and Perry, 1973, p. 18; Singh, 1979, p. 174).

Recent advances in interpretive studies of the microstructures of bryozoan zoarial skeletons (Boardman, 1960a; Ross, 1964; Boardman and Cheetham, 1969; Tavener-Smith, 1969; Tavener-Smith and Williams, 1972, p. 139-143; Singh, 1979, p. 174-184) and the mode of growth of bryozoan zoaria (Boardman and Utgaard, 1966; Ross, 1967a; Boardman, 1971, p. 8-22; Boardman and Cheetham, 1973, p. 134-160; Boardman and McKinney, 1976; McKinney, 1977) have provided new information that must be considered in any comprehensive review of the classification of the trepostome genera at the familial level.

McKinney (1971, p. 219-222) discussed briefly the problems associated with recognition of useful characters in the phylogenetic classification of bryozoans on the generic and higher taxonomic levels. He noted the taxonomic inadequacy of the trepostome families, but concluded that most of the traditional families in the classification of Bassler (1953) probably represented phylogenetic groups that could be placed at other levels in later revisions of their suprageneric classification. McKinney's interpretation is followed here, and unless otherwise indicated the trepostome genera in this report are assigned informally to the families in the classification of Bassler (1953).

Utgaard (1968a, b; 1969; 1983a, b) has recently reviewed the suprageneric classification of the Cystoporata, and that classification is used here.

Descriptions are provided for the species previously described, the new species, and a new genus. Most descriptive terms used in this paper were defined or illustrated by Bassler (1953), Boardman (1959, 1960a, 1971), Boardman and Utgaard (1966), Boardman and Cheetham (1983) and Utgaard (1973, 1983a, b). The descriptive meaning of certain morphological terms has been slightly modified here.

The term mesozooecium (Ross, 1964, p. 940) refers to a polymorphic zooecium having abundant, closely spaced diaphragms and much smaller or larger diameter in cross section than a normal autozooecium. The term exilazooecium (Utgaard, 1973, p. 339) refers to a polymorphic zooecium having much smaller cross-sectional diameter than a normal autozooecium and lacking or having very few diaphragms. These two terms 
replace the "mesopore" of authors. "Macula" is used here to describe groups or clusters of polymorphs (mesozooecia or exilazooecia), zoarial skeleton, or combinations of both that commonly form protuberant, flush, or depressed areas on zoarial surfaces. Macula as used here replaces the macula and "monticule" of authors. "Style" refers to a rodlike structure of varying length in the zoarial skeleton, approximately parallel to adjacent zooecia, that can project above the zoarial surface. Style as used here replaces the "acanthopore," "acanthostyle," and "acanthorod" of authors.

\section{Order TREPOSTOMATA Family MONTICULIPORIDAE Genus ATACTOPORELLA Ulrich, 1883}

Type species.-Actactoporella typicalis Ulrich, 1883, p. 247 , by original designation; Edenian Stage, Late Ordovician.

Remarks.-Bassler (1953, p. G95) redefined the genus. Subsequently, Astrova (1978, p. 98) redescribed Atactoporella in her posthumous monograph on the Order Trepostomata. Astrova's definition of Atactoporella is essentially the same as that of Bassler (1953), which is followed herein.

Atactoporella newportensis Ulrich, 1883

Plate 4; plate 5, figures 1,4

Atactoporella newportensis Ulrich, 1883, p. 250, pl. 12, fig. 4, 4a, b. Cumings, 1908 , p. 771,772 , pl. 7, fig. 4, pl. 26, fig. 7 .

Atactoporella newportensis Ulrich. Anstey and Perry, 1973, in part, p. 22, not pl. 4, figs. 3-7.

Monticulipora newportensis (Ulrich). James, U. P., and James, J. F., 1888, p. 183; James, J. F., 1894, p. 206.

Description.-Zoaria subdendroid, having relatively thick primary branches, thinner secondary lateral branches, occasionally encrusting, and, commonly, conspecific overgrowth consisting of one or more layers; branches arising from encrusting portions relatively small.

In endozones, autozooecia contiguous, curving gently outward, generally five- to six-sided in cross section; walls slightly irregularly sinous and crenulated local- ly. Basal diaphragms sparse, locally more common in late endozones; cystiphragms sparse, generally absent. Zones of rejuvenation of autozooecia sparse; few basal diaphragms and occasional exceedingly small styles. Endozones of overgrowths narrow, poorly differentiated.

In exozones, autozooecia forming an angle between $70^{\circ}$ and $90^{\circ}$ with zoarial surface, subcircular to subelliptical in cross section, contiguous or partly contiguous, separated by mesozooecia, without preferred orientation. Autozooecial walls slightly sinuous and locally variable in thickness in early exozones, generally of uniform thickness in late exozones. Autozooecial boundaries narrowly serrated, commonly poorly defined in late exozones. Styles abundant to common, with small, well-defined cores and thin sheaths, generally arising in autozooecial boundaries and commonly inflecting autozooecial chambers or projecting locally into chambers. Styles locally absent in parts of zoaria. Basal diaphragms common, straight to slightly curved, at right angles to chamber axis, generally scattered in autozooecia; cystoidal diaphragms common, scattered in zoaria. Cystiphragms common, scattered, occurring in overlapping series or singly, generally extending less than half the circumference of autozooecia along distal walls, lacking in some autozooecia. Terminal diaphragms scattered in zoaria.

Autozooecial chambers subcircular to slightly petaloid in cross section, commonly inflected by styles.

Mesozooecia abundant in inner exozones, irregularly variable of shape in cross section, locally coalescing and almost completely separating autozooecia, commonly terminated by zooecial skeletal deposits in outer exozones. Mesozooecial diaphragms closely and evenly spaced, generally about $0.04 \mathrm{~mm}$ thick; slightly convex distally, occasionally continuous between mesozooecia, locally overlapping.

Maculae common, subconical or irregularly shaped, consisting of mesozooecia and larger polymorphs in varying combinations; regularly distributed in some zoaria.

Measurements.-Measurements are summarized in tables 1 and 2.

TABLE 1.-Summarized measurements of specimens of Atactoporella newportensis Ulrich

[Lectotype USNM 40193 and paralectotype USNM 308305; all measurements in millimeters unless otherwise indicated]

\begin{tabular}{|c|c|c|c|c|c|c|c|}
\hline & $\begin{array}{c}\text { Arithmetic } \\
\text { mean }\end{array}$ & $\begin{array}{c}\text { Standard } \\
\text { deviation } \\
\text { of mean }\end{array}$ & $\begin{array}{c}\text { Coefficient } \\
\text { of } \\
\text { variation }\end{array}$ & $\begin{array}{c}\text { 95-percent } \\
\text { confidence } \\
\text { interval } \\
\text { of mean } \\
\end{array}$ & Range & $\begin{array}{c}\begin{array}{c}\text { Number } \\
\text { of } \\
\text { measurements }\end{array} \\
\end{array}$ & $\begin{array}{c}\text { Number } \\
\text { of } \\
\text { zoaria } \\
\text { measured }\end{array}$ \\
\hline Autozooecial chamber maximum diameter & 0.150 & 0.0144 & 9.43 & $0.13-0.17$ & $0.13-0.17$ & 5 & 1 \\
\hline Autozooecial chamber minimum diameter & .130 & .0114 & 9.82 & $.10-.13$ & $.10-.13$ & $\mathbf{5}$ & $\mathbf{1}$ \\
\hline Autozooecial wall thickness between chambers- & .058 & .1643 & 28.33 & $.04-.08$ & $.04-.08$ & 5 & 1 \\
\hline Autozooecia (number per $\mathrm{mm}^{2}$ ) & 24 & & & & & & 1 \\
\hline Zoarial branch diameter - & 3.9250 & .3594 & 9.16 & $3.35-4.50$ & $3.40-4.20$ & 4 & 2 \\
\hline Endozone width - & 3.4750 & .3304 & 9.51 & $2.95-4.00$ & $3.10-3.80$ & 4 & $\overline{2}$ \\
\hline Exozone width (one side only) & .2125 & .0835 & 39.27 & $.14-.28$ & $.10-.40$ & 8 & 2 \\
\hline Styles in autozooecium (number) & 4.60 & .8944 & 19.44 & $3.49-5.71$ & $\begin{array}{ll}4 & -6\end{array}$ & 5 & $\overline{2}$ \\
\hline
\end{tabular}


TABLE 2.-Summarized measurements of specimens of Atactoporella newportensis Ulrich

[Hypotypes USNM 308308 (USGS colln. 5027-CO), 308309-308312 (USGS colln. 5030-CO), 308313, 308314 (USGS colln. 5031-CO). All measurements in millimeters unless otherwise indicated]

\begin{tabular}{|c|c|c|c|c|c|c|c|}
\hline & $\begin{array}{c}\text { Arithmetic } \\
\text { mean }\end{array}$ & $\begin{array}{l}\text { Standard } \\
\text { deviation } \\
\text { of mean }\end{array}$ & $\begin{array}{c}\text { Coefficient } \\
\text { of } \\
\text { variation }\end{array}$ & $\begin{array}{l}\text { 95-percent } \\
\text { confidence } \\
\text { interval } \\
\text { of mean }\end{array}$ & Range & $\begin{array}{c}\begin{array}{c}\text { Number } \\
\text { of } \\
\text { measurements }\end{array} \\
\end{array}$ & $\begin{array}{c}\text { Number } \\
\text { of } \\
\text { zoaria } \\
\text { measured }\end{array}$ \\
\hline Autozooecial chamber maximum diameter & 0.1330 & 0.0234 & 17.58 & $0.12-0.14$ & $0.10-0.20$ & 30 & 6 \\
\hline Autozooecial chamber minimum diameter & .0977 & .0236 & 24.30 & $.09-.11$ & $.06-.16$ & 30 & 6 \\
\hline Autozooecial wall thickness between chambers- & .0456 & .0173 & 38.03 & $.04-\quad .05$ & $.02-.08$ & 25 & \\
\hline Autozooecia (number per $\mathrm{mm}^{2}$ ) & & 3.2106 & 11.89 & $25.15-28.85$ & $21-33$ & 14 & 5 \\
\hline Zoarial branch diameter & 6.2456 & 3.7808 & 60.54 & $3.71-8.79$ & $2.20-15.00$ & 11 & 4 \\
\hline Endozone width - & 4.20 & 2.8973 & 68. & $2.36-6.04$ & $1.70-12.00$ & 1 & \\
\hline Exozone width (one side 0 & .750 & .2403 & 41.80 & $.46-.69$ & $.20-1.100$ & 20 & 4 \\
\hline Styles in autozooecium (number) & 4.60 & 1.4541 & 31.61 & $3.79-5.40$ & $2-8$ & 15 & 4 \\
\hline
\end{tabular}

Geographic and stratigraphic distribution.-A. newportensis is known from the upper part of the Lexington Limestone and the Clays Ferry Formation in Kentucky and the Kope Formation of current usage in Ohio and Indiana.

Occurrence in Kentucky.-Millersburg Member: Shermanian Stage (USGS colln. 5027-CO, 5030-CO; 5854-CO; 7044-CO, 7060-CO; 7453-CO), Edenian Stage (USGS colln. 7065-CO, 7067-CO, 7070-CO), of Lexington Limestone. Tongue of Clays Ferry Formation, Shermanian Stage (USGS colln. 7458-CO, 7459-CO; 7346-CO). Tanglewood Limestone Member, Shermanian Stage (USGS colln. 7462-CO), of Lexington Limestone. Nicholas Bed of Tanglewood Limestone Member: Shermanian Stage (USGS colln. 5031-CO), Edenian Stage (USGS colln. 5033-CO, 5035-CO), of Lexington Limestone. Clays Ferry Formation: Shermanian Stage (USGS colln. 6714-CO), Edenian Stage (USGS colln. 6731-CO, D1187-CO, 6744-CO; 7474-CO, 7475-CO).

Ulrich (1883, p. 251) found $A$. newportensis in his "shaly beds of the Cincinnati Group" at a level approximately $125 \mathrm{ft}$ above what was then the low-water level of the Ohio River, near Newport. According to Bassler $(1906$, p. 8) this stratigraphic level is the approximate equivalent of the "Southgate Member of the Eden Formation" of paleontologists of the early 20th century (the middle part of the Kope Formation of current usage).

Occurrence outside Kentucky.-Cumings (1908, p. 771) and Cumings and Galloway $(1913$, p. 48) reportedly found $A$. newportensis in their "lower part of the Eden Group" deposits at Tanner Creek, Ind.

Studied material.-Lectotype, USNM 40193, designated herein from the syntype suite USNM 40193, "Economy Member of the Eden Shale," (the lower part of Kope Formation of current usage), Upper Ordovician, Newport, Ky. Paralectotypes, USNM 308305, thin section and peel from the specimen figured by Ulrich, 1883, pl. 12, fig. 4; USNM 308306, peel from specimen figured by Ulrich, 1883, pl. 12, fig. 4b, from the syntype suite USNM 40193, from the "Economy Member of the Eden Shale," Upper Ordovician, Newport, Ky.; USNM 308307 , thin section prepared by E. O. Ulrich from the syntype suite USNM 43627, from the "Cincinnati Group", Upper Ordovician, Newport, Ky.

Hypotypes USNM 308308 (USGS colln. 5027-CO), 308309-308312 (USGS colln. 5030-CO), 308313-308315 (USGS colln. 5031-CO), 308316 (USGS colln. 5033-CO), 308317 (USGS colln. 5035-CO), 308318 (USGS colln. 5854-CO), 308319 (USGS colln. 6714-CO), 308320 (USGS colln. 6731-CO), 308321 (USGS colln. D1187-CO), 308322 (USGS colln. 6744-CO), 308323 (USGS colln. 7044-CO), 308324 (USGS colln. 7060-CO), 308325 (USGS colln. 7065-CO), 308326 (USGS colln. 7067-CO), 308327 (USGS colln. 7070-CO), 308328 (USGS colln. 7346-CO), 308329 (USGS colln. 7453-CO), 308330 (USGS colln. 7458-CO), 308331 (USGS colln. 7459-CO), 308332 (USGS colln. 7462-CO), 308333 (USGS colln. 7474-CO), 308334 (USGS colln. 7475-CO).

Remarks.-Atactoporella newportensis is most closely related to A. typicalis, the type species of Atactoporella. A. newportensis differs from A. typicalis (Anstey and Perry, 1973, pl. 4, figs. 3-6) in having robust zoaria that are more commonly erect (pl. 4, fig. 2a) than encrusting and in having autozooecia with fewer and less regularly occurring basal diaphragms and cystiphragms (pl. 4, figs. 1d, 2b). Autozooecial and mesozooecial walls in exozones are generally thicker, and mesozooecia possess thicker diaphragms in $A$. newportensis (pl. 4, fig. 1d) than in A. typicalis (Anstey and Perry, 1973, pl. 4, figs. $3,6)$. The shape in cross section of autozooecia tends to be subcircular in A. newportensis (pl. 5, fig. 4a), rather than petaloid as it is in A. typicalis (Anstey and Perry, 1973, pl. 4, fig. 5).

Anstey and Perry (1973), whose data base and calculations were computerized, informally considered $A$. newportensis to be a junior synonym of $A$. typicalis. In the present paper $A$. newportensis is retained as a separate species because of slight but consistent differences in zoarial growth habit, cross-sectional shape of autozooecia, zooecial wall thickness, and distribution of basal diaphragms and cystiphragms from those speci- 
mens placed in A. typicalis (Anstey and Perry, 1973, tables 2-5).

\section{Genus HOMOTRYPA Ulrich, 1882}

Type species.-Homotrypa curvata Ulrich 1882, p. 241, by original designation; Maysvillian Stage, Late Ordovician.

Remarks.-The two species of Homotrypa described here, $H$. similis Foord and $H$. cressmani n. sp., conform closely to the emended diagnosis for the genus Homotrypa made by Ross (1970a, p. 373) that is followed here. Both species have autozooecia that are polygonal or subpolygonal in cross section in exozones and cystiphragms in exozones; $H$. similis has cystiphragms in outer endozones (subperipheral region of Ross, 1970a). The basal autozooecial diaphragms are present in the endozones of both species, but they vary in distribution. Styles (acanthopores of Ross, 1970a) are scattered and mesozooecia are sparse in both species.

\section{Homotrypa similis Foord, 1883}

Plate 5, figure 2; plate 6, figures 1, 4-6

Homotrypa similis Foord, 1883, p. 10, pl. 2, figs. 2-2d; Ulrich, 1893, p. 242, pl. 20, figs. 28-33; Bassler, 1911, text-fig. 97 (not text-fig. 98); Fritz, 1957, p. 23, pl. 14, figs. 4, 5; Bork and Perry, 1968b, p. 1052, pl. 135, figs. 6-9.

Homotrypa similis Foord, 1883. Astrova, 1965, p. 200, pl. 35, fig. 1a-1d.

Description.-Zoaria irregularly dendroid, locally anastomosing; branches subcylindrical to slightly flattened; conspecific overgrowth sparse.

In endozones, autozooecia subparallel to branch axis, contiguous, irregularly polygonal in cross section, curving gently outward in outer endozones. Autozooecial walls straight to slightly crenulated locally. Basal diaphragms generally abundant and evenly spaced, scattered in endozones of some zoaria; planar in early endozones, slightly curved, convex distally in outer endozones; moderately large cystiphragms common in outer endozones and inner exozones. Zones of rejuvenation of autozooecia sparse, containing basal diaphragms more closely spaced than in endozones between them.

In exozones, autozooecia contiguous, occurring obliquely or at right angles to zoarial surface, polygonal to subpolygonal in cross section, generally without pre- ferred orientation. Autozooecial walls locally uneven in thickness; cortical laminae narrowly curved in profile, slightly variable in thickness locally. Autozooecial boundaries well defined in profile, narrowly serrated, slightly sinuous or jagged locally. Styles poorly defined, small, with indistinct cores; common along autozooecial boundaries and in autozooecial corners, lacking locally. Pustules common along autozooecial boundaries. Basal diaphragms common, generally closely and evenly spaced, planar to slightly curved, abutting walls and cystiphragms; locally scattered or lacking in some autozooecia. Cystiphragms common, occasionally lacking in some autozooecia, occurring commonly along distal autozooecial walls, sparingly along proximal walls. Cystiphragms closely appressed in longitudinal series, locally thickened in some autozooecia, extending approximately two-thirds the circumference of autozooecial walls, occasionally occurring in double series in early exozones. Single cystiphragms, cystoidal diaphragms sparse. Autozooecial linings generally absent.

Autozooecial chambers polygonal to subcircular in early exozones, subcircular, subelliptical to subcrescent in cross section in middle and late exozones.

Mesozooecia sparse or absent, subpolygonal or irregularly shaped in cross section.

Maculae sparse, slightly elevated locally, poorly defined in cross section, consisting of polymorphs slightly larger than autozooecia with scattered styles and laminated skeletal deposits at approximate centers of maculae.

Measurements.-Measurements are summarized in tables 3-5.

Geographic and stratigraphic distribution. Occurrence in Kentucky.-Lexington Limestone, undivided, Shermanian Stage (USGS colln. D1306-CO); Grier Limestone Member, Shermanian Stage (USGS colln. 4697-CO; 4968-CO, 4971-CO), of the Lexington Limestone.

Occurrence outside Kentucky.-Foord (1883, p. 10) found $H$. similis in his "Trenton Formation" in Ottawa and Fritz (1957, p. 23) reported it from her Ottawa Formation, Middle Ordovician, in Ottawa and its vicinity in Ontario, Canada. Ulrich (1893, p. 243) described $H$. similis from his "Galena Shales," Middle Ordovician, in Minnesota. Bork and Perry (1968b, p. 1053) found $H$.

TABLE 3.-Summarized measurements of specimens of Homotrypa similis Foord

[Hypotypes USNM 308335 and 309661 . All measurements in millimeters unless otherwise indicated]

\begin{tabular}{|c|c|c|c|c|c|c|c|}
\hline & $\begin{array}{c}\text { Arithmetic } \\
\text { mean }\end{array}$ & $\begin{array}{l}\text { Standard } \\
\text { deviation } \\
\text { of mean }\end{array}$ & $\begin{array}{c}\text { Coefficient } \\
\text { of } \\
\text { variation }\end{array}$ & $\begin{array}{l}\text { 95-percent } \\
\text { confidence } \\
\text { interval } \\
\text { of mean }\end{array}$ & Range & $\begin{array}{c}\begin{array}{c}\text { Number } \\
\text { of } \\
\text { measurements }\end{array} \\
\end{array}$ & $\begin{array}{c}\text { Number } \\
\text { of } \\
\text { zoaria } \\
\text { measured }\end{array}$ \\
\hline Autozooecial chamber maximum diameter & 0.1220 & 0.0187 & 15.36 & $0.11-0.14$ & $0.10-0.16$ & 10 & 2 \\
\hline Autozooecial chamber minimum diameter & .0870 & .0160 & 13.32 & $.08-\quad .01$ & $.07-\quad .10$ & 10 & 2 \\
\hline Autozooecial wall thickness, exozone & .1060 & .0135 & 12.74 & $.10-.12$ & $.08-.12$ & 10 & $\overline{2}$ \\
\hline Autozooecia (number per $2 \mathrm{~mm}$ ) & 8.6667 & .8165 & 9.42 & $7.81-9.52$ & $8-10$ & 6 & $\overline{2}$ \\
\hline Autozooecia (number per $\mathrm{mm}^{2}$ ) & 18.17 & 2.1370 & 11.76 & $15.92-20.41$ & -21 & 6 & $\overline{2}$ \\
\hline Diaphragms (number per $\mathrm{mm}$ ) in endozone - & 3.750 & .8864 & 23.64 & $3.0-4.49$ & -5 & 8 & 2 \\
\hline
\end{tabular}


TABLE 4.-Summarized measurements of a specimen of Homotrypa similis Foord [Hypotype USNM 308340. All measurements in millimeters unless otherwise indicated]

\begin{tabular}{|c|c|c|c|c|c|c|c|}
\hline & $\begin{array}{l}\text { Arithmetic } \\
\text { mean }\end{array}$ & $\begin{array}{c}\text { Standard } \\
\text { deviation } \\
\text { of mean }\end{array}$ & $\begin{array}{c}\text { Coefficient } \\
\text { of } \\
\text { variation }\end{array}$ & $\begin{array}{l}\text { 95-percent } \\
\text { confidence } \\
\text { interval } \\
\text { of mean } \\
\end{array}$ & Range & $\begin{array}{c}\begin{array}{c}\text { Number } \\
\text { of } \\
\text { measurements }\end{array} \\
\end{array}$ & $\begin{array}{c}\text { Number } \\
\text { of } \\
\text { zoaria } \\
\text { measured }\end{array}$ \\
\hline Autozooecial chamber maximum diameter _-__-_-_ & 0.1460 & 0.0167 & 11.46 & $0.13-0.17$ & $0.12-0.16$ & 5 & 1 \\
\hline Autozooecial chamber minimum diameter & .0960 & .0089 & $\begin{array}{r}1.400 \\
9.32\end{array}$ & $.08-.11$ & $8-10$ & 5 & 1 \\
\hline Autozooecial wall thickness, exozone - & .1020 & .0130 & 12.78 & $.09-\quad .12$ & $.09-\quad .12$ & 5 & 1 \\
\hline Autozooecia (number per $2 \mathrm{~mm}$ ) & $8^{-000}$ & - & - & & & 1 & 1 \\
\hline Autozooecia (number per $\mathrm{mm}^{2}$ ) & 17 & - & - & - & - - - - & 1 & 1 \\
\hline Diaphragms (number per $\mathrm{mm}$ ) in endozone & 3.20 & .4472 & $\overline{13.98}$ & $2.64-3.78$ & $3-4$ & $\frac{1}{5}$ & 1 \\
\hline Diaphragms (number per $\mathrm{mm}$ ) in exozone & 13.40 & .5477 & 4.09 & $12.72-14.08$ & $13-14$ & 5 & 1 \\
\hline Zoarial branch diameter - & 5.050 & .3536 & 7.0 & $1.87-8.23$ & $4.80-5.30$ & 2 & 1 \\
\hline Endozone width - & 3.50 & .2828 & 8.08 & $.96-6.04$ & $3.30-3.70$ & 2 & 1 \\
\hline Exozone width (one side only) & .750 & .10 & 13.33 & $.60-\quad .91$ & $.70-\quad .90$ & 4 & 1 \\
\hline Autozooecial angle ${ }^{a}$ & 35.80 & 2.39 & 6.67 & $32.83-38.76$ & $32-38$ & 5 & 1 \\
\hline
\end{tabular}

aThe angle at which autozooecia intersect the surface of the zoarium; measured in the plane of longitudinal thin section from the approximate center of the zoarial branch of a zoarium.

TABLE 5.-Summarized measurements of specimens of Homotrypa similis Foord [Hypotypes USNM 308345-308347 (USGS colln. 4697-CO), 308349, 308350 (USGS colln. 4971-CO). All measurements in millimeters unless otherwise indicated]

\begin{tabular}{|c|c|c|c|c|c|c|c|}
\hline & $\begin{array}{c}\text { Arithmetic } \\
\text { mean }\end{array}$ & $\begin{array}{c}\text { Standard } \\
\text { deviation } \\
\text { of mean }\end{array}$ & $\begin{array}{c}\text { Coefficient } \\
\text { of } \\
\text { variation }\end{array}$ & $\begin{array}{c}\text { 95-percent } \\
\text { confidence } \\
\text { interval } \\
\text { of mean }\end{array}$ & Range & $\begin{array}{c}\begin{array}{c}\text { Number } \\
\text { of } \\
\text { measurements }\end{array} \\
\end{array}$ & $\begin{array}{c}\text { Number } \\
\text { of } \\
\text { zoaria } \\
\text { measured }\end{array}$ \\
\hline Autozooecial chamber maximum diameter -_- & 0.1360 & 0.0138 & 10.18 & $0.13-0.14$ & $0.11-0.17$ & 25 & 5 \\
\hline Autozooecial chamber minimum diameter & .1068 & .0184 & 17.25 & $.10-.11$ & $.07-\quad .13$ & 25 & 5 \\
\hline Autozooecial wall thickness, exozone & .0648 & .0148 & 22.77 & $.06-\quad .07$ & $.04-\quad .10$ & 25 & 5 \\
\hline Monticular polymorph chamber maximum diameter -- & .2014 & .0297 & 14.74 & $.17-\quad .23$ & $.15-\quad .23$ & 7 & 3 \\
\hline Monticular polymorph chamber minimum diameter -- & .1729 & .0335 & 19.39 & $.14-\quad .20$ & $.12-.21$ & 7 & 3 \\
\hline Autozooecia (number per $2 \mathrm{~mm}$ ) & 9.6875 & .4787 & 4.94 & $9.43-9.94$ & $9^{.12}-10^{.21}$ & 16 & 5 \\
\hline Autozooecia (number per $\mathrm{mm}^{2}$ ) & 27.846 & 3.3874 & 12.17 & $25.80-29.90$ & -36 & 13 & 5 \\
\hline Diaphragms (number per $\mathrm{mm}$ ) in endozone - & 3.7368 & .9335 & 24.98 & $3.29-4.19$ & -6 & 19 & 4 \\
\hline Diaphragms (number per $\mathrm{mm}$ ) in exozone & 13.40 & 2.0736 & 1.55 & $10.83-16.0$ & $11-16$ & 5 & 2 \\
\hline Cystiphragms (number per $\mathrm{mm}$ ) - & 11.0 & 2.53 & 23.0 & $8.34-13.66$ & $8.34-13.66$ & 6 & 2 \\
\hline Zoarial branch diameter & 7.160 & 1.8298 & 25.56 & $4.89-9.43$ & $5.50-9.20$ & 5 & 3 \\
\hline Endozone width - & 5.250 & 1.3308 & 25.35 & $3.85-6.65$ & $3.70-6.90$ & 6 & 3 \\
\hline Exozone width (one side only) - & .7750 & .2989 & 38.56 & $.59-\quad .96$ & $.4-1.3$ & 12 & 3 \\
\hline Autozooecial anglea (in degrees) - & 61.867 & 8.3655 & 13.52 & $57.23-66.50$ & -75 & 15 & 3 \\
\hline
\end{tabular}

aDefinition of zooecial angle in table 4.

similis in their "Guttenberg" and "Ion" Formations, Middle Ordovician, in Iowa, and in their "Quimbys Mill" and "Guttenberg" Formations, Middle Ordovician, in Wisconsin.

Studied material.-Hypotypes USNM 308335 (thin section marked "type section," figured by Ulrich, 1893, pl. 20, figs. 29, 30), and 309661 from hypotype suite USNM 43995, the "Trenton" strata, Middle Ordovician, Ottawa, Ontario; hypotypes USNM 308336 (thin section figured by Ulrich, 1893, pl. 20, figs. 31, 32), 308337-308341, from hypotype suite USNM 43575, the "Nematopora bed of the Trenton" (the "Cumingsville Member" of the Galena Dolomite of current usage), Middle Ordovician, near Cannon Falls, Minn. Hypotypes USNM 308342, 308343, from the hypotype suite USNM 57273, the "Wassalem Beds," D3, Middle Ordovician, Uxnorm, Estonia, U.S.S.R. Hypotypes USNM 308344 (USGS colln. D1306-CO), 308345308347 (USGS colln. 4697-CO), 308348 (USGS colln. 4968-CO), 308349-308351 (USGS colln. 4971-CO).

Remarks.-Specimens of Homotrypa that are assigned herein to $H$. similis Foord conform in general to the concept that Foord (1883, p. 100) established for $H$. similis. Ulrich (1893, p. 242) redefined $H$. similis and Bork and Perry (1968b, p. 1052) redescribed it.

Bassler (1911, p. 185, text-fig. 98) reportedly found $H$. similis in the Middle Ordovician strata of Estonia, U.S.S.R. These specimens (USNM 308342 and 308343) differ, however, in several morphological respects from those occurring in North American Ordovician deposits. Autozooecia in specimens from Estonia have relatively broadly serrated autozooecial boundaries (pl. 5, fig. 3b) and well-defined styles that commonly inflect autozooecial walls (pl. 5, fig, 3a). Autozooecia specimens from North America have narrowly serrated boundaries (pl. 5, fig. 2b) and poorly defined styles that generally do not inflect autozooecial walls and are commonly lacking in parts of a zoarium. Cystiphragms in the Estonian specimens generally originate early in endozones and are more closely spaced in exozones of autozooecia than are those in specimens from North America. Furthermore, cystiphragms in the Estonian specimens commonly occur in two or three longitudinal series in an autozooecium, while those in specimens from North America generally occur in single series (pl. 6 , fig. 4b) and are somewhat irregular in appearance. 
The differences between North American and Estonian specimens in microstructure of autozooecial walls, appearance of styles, and distribution and arrangement of cystiphragms suggest that the Estonian specimens probably belong to a different species and that $H$. similis does not occur in the Middle Ordovician strata of Estonia.

Astrova (1965, p. 201) reported $H$. similis from the Middle Ordovician strata of the Western Arctic Province of the U.S.S.R. These specimens appear to differ from those in North American deposits of similar age in having relatively large zoaria with thick exozones. In addition, basal diaphragms and cystiphragms are arranged much more regularly in specimens from the Western Arctic Province than in those from North America. Because of these differences in general appearance of zoaria, the assignment of the Western Arctic specimens to $H$. similis remains questionable until they become available for comparison.

Homotrypa cressmani n. sp.

Plate 7

Homotrypa obliqua Ulrich, 1882, of Brown, 1965, p. 979, pl. 111, figs. 1-3.

Etymology.-This species is named for Earle R. Cressman of the U.S. Geological Survey, who published extensively on rocks of Middle Ordovician age of Kentucky.

Description.-Zoaria dendroid with subcylindrical branches, occasionally flattened locally; conspecific overgrowth sparse.

In endozones, autozooecia approximately parallel to branch axis, curving gently outward in outer endozones, contiguous, irregularly polygonal in cross section. Autozooecial walls straight to slightly sinuous, occasionally sparingly crenulated locally. Basal diaphragms sparse to absent, planar, at right angles to chamber axis, occurring irregularly, generally more common in zones of rejuvenation of autozooecia. Cystiphragms absent; zones of rejuvenation of autozooecia sparse.

In exozones, autozooecia generally contiguous, subpolygonal in cross section, locally indistinctly aligned in growth direction of branch. Autozooecial walls relatively straight, slightly uneven in thickness locally. Autozooecial boundaries well defined, narrowly serrated, showing indistinct pustules. Styles sparse to common; well-defined cores and indistinct sheaths; arising locally in outer endozones and occurring irregularly in corners of junctions between autozooecia, occasionally in autozooecial walls between junctions, locally slightly inflecting autozooecial walls. Basal diaphragms common, planar, abutting autozooecial walls or cystiphragms, locally evenly spaced; commonly scattered, lacking in a few autozooecia. Cystiphragms common to sparse, lacking in some autozooecia, occurring in longitudinal series and extending approximately one-half to two-thirds the circumference of distal autozooecial walls, occasionally superimposed in early exozones or occurring singly. Autozooecial linings generally lacking.

Autozooecial chambers subcircular to subcrescent in cross section.

Mesozooecia sparse, poorly defined, subcircular or irregularly shaped in cross section, scattered throughout exozones, generally occurring in twos or threes in maculae. Maculae sparse, poorly defined, generally low, indistinct in cross section, consisting of few mesozooecia in centers and slightly larger polymorphs in margins.

Measurements.-Measurements are summarized in tables 6 and 7.

Geographic and stratigraphic distribution. $-H$. cressmani is known only from rocks of the Shermanian Stage, Middle Ordovician, and the early Edenian Stage, Late Ordovician, in Kentucky.

TABLE 6.-Summarized measurements of specimens of Homotrypa cressmani $n$. sp.

[Holotype USNM 308352 (USGS colln. 4981-CO) paratypes USNM 308353, 308356, 308358 (USGS colln. 4981-CO), 308360, 308363, 308365 USGS colln. 4979-CO), and hypotype USNM 308371 (USGS colln. D1161-CO). All measurements in millimeters unless otherwise indicated]

\begin{tabular}{|c|c|c|c|c|c|c|c|}
\hline & $\begin{array}{c}\text { Arithmetic } \\
\text { mean }\end{array}$ & $\begin{array}{c}\text { Standard } \\
\text { deviation } \\
\text { of mean }\end{array}$ & $\begin{array}{c}\text { Coefficient } \\
\text { of } \\
\text { variation }\end{array}$ & $\begin{array}{l}\text { 95-percent } \\
\text { confidence } \\
\text { interval } \\
\text { of mean }\end{array}$ & Range & $\begin{array}{c}\begin{array}{c}\text { Number } \\
\text { of } \\
\text { measurements }\end{array}\end{array}$ & $\begin{array}{c}\text { Number } \\
\text { of } \\
\text { zoaria } \\
\text { measured }\end{array}$ \\
\hline Autozooecial chamber maximum diameter - & 0.1260 & 0.0124 & 9.81 & $0.12-0.13$ & $0.10-0.17$ & 40 & 8 \\
\hline Autozooecial chamber minimum diameter & .0903 & .0144 & 15.97 & $.09-\quad .09$ & $.07-.12$ & 40 & 8 \\
\hline Autozooecial wall thickness, exozone & .0845 & .0201 & 23.81 & .08 & $.05-.13$ & 40 & 8 \\
\hline Macular polymorph chamber maximum diameter & .1738 & .020 & 11.49 & $.16-$ & $15.0-20.0$ & 8 & 3 \\
\hline Macular polymorph chamber minimum diameter & .1375 & .0219 & 15.91 & $.12-$ & $10.0-16.0$ & 8 & 3 \\
\hline Mesozooecial chamber maximum diameter & .0550 & .0212 & 38.57 & -__- & $.04-.07$ & 2 & 1 \\
\hline Autozooecia (number per $2 \mathrm{~mm}$ ) & 9.6522 & .7751 & 8.03 & $9.32-9.99$ & $8^{.011}-11$ & 23 & 7 \\
\hline Autozooecia (number per $\mathrm{mm}^{2}$ ) & 25.778 & 3.0011 & 11.64 & $24.29-27.27$ & -34 & 18 & 6 \\
\hline Diaphragms (number per $\mathrm{mm}$ ) in exozone & 9.50 & 2.1213 & 22.33 & & $8-11$ & 2 & 2 \\
\hline Zoarial branch diameter & 5.40 & 1.1824 & 21.90 & $4.65-6.15$ & $3.20-7.30$ & 12 & 8 \\
\hline Endozone width - & 4615 & .9820 & 28.37 & $2.87-4.06$ & $2.0-5.30$ & 13 & 9 \\
\hline Exozone width (one side only) & 1.020 & .2432 & 23.85 & $.92-1.12$ & $.60-1.50$ & 25 & 9 \\
\hline Autozooecial ang & 66.545 & 10.093 & 15.17 & $59.77-73.32$ & $55-85$ & 11 & 3 \\
\hline
\end{tabular}

aDefinition of autozooecial angle in table 4 
TABLE 7.-Summarized measurements of specimens of Homotrypa cressmani $n$. $s p$.

[Hypotypes USNM 308389 (USGS colln. 7050-CO), 308390 (USGS colln. 7055-CO), 308392 (USGS colln. 7070-CO), 308393 (USGS colln. 7071-CO). All measurements in millimeters unless otherwise indicated

\begin{tabular}{|c|c|c|c|c|c|c|c|}
\hline & $\begin{array}{c}\text { Arithmetic } \\
\text { mean }\end{array}$ & $\begin{array}{c}\text { Standard } \\
\text { deviation } \\
\text { of mean }\end{array}$ & $\begin{array}{c}\text { Coefficient } \\
\text { of } \\
\text { variation }\end{array}$ & $\begin{array}{l}\text { 95-percent } \\
\text { confidence } \\
\text { interval } \\
\text { of mean }\end{array}$ & Range & $\begin{array}{c}\begin{array}{c}\text { Number } \\
\text { of } \\
\text { measurements }\end{array}\end{array}$ & $\begin{array}{c}\text { Number } \\
\text { of } \\
\text { zoaria } \\
\text { measured }\end{array}$ \\
\hline Autozooecial chamber maximum diameter - & 0.1255 & 0.0164 & 13.05 & $0.12-0.13$ & $0.10-0.16$ & 20 & 4 \\
\hline Autozooecial chamber minimum diameter & .0860 & .0185 & 21.47 & $.08-\quad .09$ & $.05-\quad .12$ & 20 & 4 \\
\hline Autozooecial wall thickness, exozone- & .0750 & .0147 & 19.59 & $.07-$ & $.05-$ & 20 & 4 \\
\hline Macular polymorph chamber maximum diameter & .1750 & .0129 & 7.38 & $.15-$ & $.16-$ & 4 & 2 \\
\hline Macular polymorph chamber minimum diameter & .1175 & .0150 & 12.76 & .09 & $.11-$ & 4 & 2 \\
\hline Mesozooecial chamber maximum diameter - & .0531 & .0138 & 25.95 & $.04-\quad .06$ & $.03-\quad .08$ & 13 & 4 \\
\hline Autozooecia (number per $2 \mathrm{~mm}$ ) & 9.8333 & .4083 & 4.15 & $9.40-10.26$ & $9-10$ & 6 & 4 \\
\hline Autozooecia (number per $\mathrm{mm}^{2}$ ) & 26.0 & 3.3166 & 12.75 & $23.45-28.55$ & $21-31$ & 9 & 4 \\
\hline Zoarial branch diameter ________ & 4.30 & .9943 & 23.12 & $3.47-5.13$ & $2.80-5.70$ & 8 & 4 \\
\hline Endozone width & 2.625 & .8259 & 31.46 & $1.93-3.32$ & $1.50-3.80$ & 8 & 4 \\
\hline Exozone width (one side only) & .8875 & .150 & 16.90 & $.81-.97$ & $.70-1.10$ & 16 & 4 \\
\hline
\end{tabular}

Occurrence in Kentucky.-Lexington Limestone: Grier Limestone Member, Shermanian Stage (USGS colln. 4954-CO); Brannon Member, Shermanian Stage (USGS colln. D1161-CO); Sulphur Well Member, Shermanian Stage (USGS colln. D1163-CO, 4891-CO); Tanglewood Limestone Member, Shermanian Stage (USGS colln. D1206-CO; 4979-CO, 4980-CO-4983-CO, 4985-CO, 4897-CO, 5048-CO, 5845-CO), Edenian Stage (USGS colln. 5031-CO, 5032-CO, 5034-CO, 5035-CO; 5060-CO); Millersburg Member, Shermanian Stage (USGS colln. 5027-CO, 7050-CO, 7055-CO, 7062-CO, 7330-CO); Perryville Limestone Member, Shermanian Stage (USGS colln. 5013-CO).

Millersburg Member of Lexington Limestone: tongue of Tanglewood Limestone Member, Shermanian Stage (USGS colln. 7062-CO), Edenian Stage (USGS colln. 7070-CO, 7071-CO); tongue of Clays Ferry Formation, Shermanian Stage (USGS colln. 7333-CO).

Clays Ferry Formation, Edenian Stage (USGS colln. D1177-CO, 6722-CO).

Studied material.-Holotype USNM 308352 (USGS colln. 4981-CO); paratypes USNM 308353-308358 (USGS colln. 4981-CO), 308359-308365 (USGS colln. 4979-CO), 308366 (USGS colln. 4980-CO), 308367 (USGS colln. 4982-CO), 308368 (USGS colln. 4985-CO), 308369 (USGS colln. 4987-CO), 308370 (USGS colln. D1206-CO).

Hypotypes USNM 308371 (USGS colln. D1161-CO), 308372 (USGS colln. D1162-CO), 308373 (USGS colln. D1163-CO), 308374 (USGS colln. D1164-CO), 308375 (USGS colln. D1177-CO), 308376 (USGS colln. 6721-CO), 308377 (USGS colln. 6722-CO), 308378 (USGS colln. 4891-CO), 308379 (USGS colln. 4954-CO), 308380 (USGS colln. 5013-CO), 308381 (USGS colln. 5027-CO), 308382 (USGS colln. 5031-CO), 308383 (USGS colln. 5032-CO), 308384 (USGS colln. 5034-CO), 308385 (USGS colln. 5035-CO), 308386 (USGS colln. 5048-CO), 308387 (USGS colln. 5845-CO), 308388 (USGS colln. 5860-CO), 308389 (USGS colln. 7050-CO),
308390 (USGS colln. 7055-CO), 308391 (USGS colln. 7062-CO), 308392 (USGS colln. 7070-CO), 308393 (USGS colln. 7071-CO), 308394 (USGS colln. 7330-CO), 308395 (USGS colln. 7333-CO).

Homotrypa obliqua Ulrich, 1882, hypotype USNM 308396 from hypotype suite USNM 41736, "Lorraine Group" (Maysvillian Stage of current usage), Upper Ordovician, at Cincinnati.

Homotrypa obliqua Ulrich of Brown, 1965, hypotype IU 8237-1, from undivided "Logana-Jessamine Limestone Members" of the Lexington Limestone of Brown (1965, p. 980) (the Logana and Grier Limestone Members, respectively, of the Lexington Limestone of current usage), Middle Ordovician, Garrard County, Ky.

Remarks.-Homotrypa cressmani is similar to a group of species of Homotrypa from the Maysvillian Stage, Late Ordovician, in Indiana, Ohio, and Kentucky. That group of species includes $H$. obliqua Ulrich, 1882 (Bassler, 1903, pl. 23, figs. 12-14; Singh, 1979, p. 219; this paper, pl. 6, figs. 2, 3); the type species of the genus, $H$. curvata Ulrich $(1882$, pl. 10 , figs. $7 \mathrm{a}-7 \mathrm{~d}$; Singh, 1979 , p. 217), and $H$. alta Cumings and Galloway $(1913$, pls. 9,10$)$.

$H$. cressmani appears morphologically and stratigraphically to be intermediate between $H$. similis Foord of the Champlainian Provincial Series, Middle Ordovician, on the one hand, and H. obliqua, H. curvata, and $H$. alta of the Maysvillian Stage, Late Ordovician, on the other. Consistent occurrence of a combination of characters distinguishes $H$. cressmani from the four species; the characters include shape of zoarial branches, appearance of autozooecia in cross section, appearance and distribution of styles in exozone, distribution of basal diaphragms and cystiphragms in zoaria, and distribution of mesozooecia and structure of maculae in exozones. Some of these characters are compared in table 8.

The zoarial branches of $H$. similis and $H$. cressmani, and, in part, of $H$. obliqua (Bassler, 1903, pl. 23, fig. 14) 
TABLE 8.-Comparison of zoarial characters in Homotrypa cressmani and related species

\begin{tabular}{|c|c|c|c|c|c|c|c|c|c|c|c|c|c|}
\hline \multirow[t]{2}{*}{$\begin{array}{r}\text { Zoarial } \\
\text { character }\end{array}$} & \multicolumn{2}{|c|}{$\begin{array}{c}\text { Shape of zoarial } \\
\text { branches }\end{array}$} & \multicolumn{3}{|c|}{$\begin{array}{l}\text { Autozooecial walls } \\
\text { in endozone in } \\
\text { longitudinal section }\end{array}$} & \multicolumn{3}{|c|}{$\begin{array}{l}\text { Basal diaphragms } \\
\text { in endozone }\end{array}$} & \multicolumn{3}{|c|}{$\begin{array}{c}\text { Styles } \\
\text { in exozone }\end{array}$} & \multicolumn{2}{|c|}{$\begin{array}{c}\text { Mesozooecia } \\
\text { in exozone }\end{array}$} \\
\hline & Subcylindrical & Flattened & Straight & $\begin{array}{l}\text { Straight to } \\
\text { sinuous }\end{array}$ & Sinuous & Common & Sparse & $\begin{array}{c}\text { Generally } \\
\text { absent }\end{array}$ & Abundant & $\begin{array}{l}\text { Common } \\
\text { to sparse }\end{array}$ & Sparse & Sparse & $\begin{array}{c}\text { Generally } \\
\text { absent }\end{array}$ \\
\hline H. alta & & $\times$ & & & $x$ & & & $\times$ & & $\times$ & $x$ & & $x$ \\
\hline H. curvata & & $x$ & & & $x$ & $x$ & & & $x$ & & & & $\times$ \\
\hline H. obliqua & $x$ & $\times$ & $x$ & $x$ & & & & $x$ & $\times$ & & & & $x$ \\
\hline H. cressmani & $x$ & & $\times$ & $\times$ & & & $x$ & & & $x$ & & $x$ & \\
\hline H. similis & $x$ & & $x$ & & & $x$ & & & & & $\times$ & $\times$ & \\
\hline
\end{tabular}

are subcylindrical; they are flattened in $H$. curvata (Ulrich, 1882, pl. 10, fig. 7) and H. alta (Cumings and Galloway, 1913, pl. 9, fig. 1).

Autozooecial walls in endozones of $H$. similis (pl. 6, fig. 6) are generally straight. Autozooecial walls in $H$. cressmani (pl. 7, fig. 5) and $H$. obliqua (Singh, 1979, pl. 34 , fig. 1c; this paper, pl. 6 , fig. 3) are straight or slightly sinuous; they are generally sinuous in $H$. curvata (Ulrich, 1882, pl. 10, fig. 7; Singh, 1979, pl. 32, fig. 2a) and $H$. alta (Cumings and Galloway, 1913, pl. 9, fig. 1b).

H. similis possesses abundant and evenly spaced basal diaphragms throughout endozones. Basal diaphragms of $H$. similis generally are lacking in the endozones of $H$. obliqua (Singh, 1979, pl. 34, fig. 1c; this paper, pl. 6, fig. 3) and $H$. alta (Cumings and Galloway, 1913, pl. 9, fig. 1b). They are present sparingly in the endozones of $H$. cressmani (pl. 7, fig. 3c), but are more common in $H$. curvata (Singh, 1979, pl. 32, fig. 1b). Basal diaphragms and cystiphragms are common in the exozones of all five species, but they are less regularly distributed in $H$. cressmani (pl. 7, fig. 4a) and $H$. alta than in $H$. obliqua (pl. 6, fig. 3) and $H$. curvata (Ulrich, 1882, pl. 10, fig. 7c; Singh, 1979, pl. 32, fig. 2a). Styles are relatively common and well defined in $H$. cressmani (pl. 7, fig. 4b), and are relatively abundant (Singh, 1979, pl. 32, fig. 2b) and commonly inflect autozooecial walls in $H$. curvata. Styles in $H$. similis, $H$. obliqua (Singh, 1979, pl. 35, fig. 1b), and H. alta, however, are inconspicuous and locally absent.

Mesozooecia occur sparingly in $H$. cressmani, are uncommon in $H$. similis, and are generally absent in the intermacular areas of $H$. obliqua (Singh, 1979, p. 219) and $H$. alta. Mesozooecia in $H$. alta generally occur in clusters in centers of maculae. In $H$. curvata (Singh, 1979, p. 217), mesozooecia are generally absent.

Stratigraphically, $H$. cressmani occurs in rocks of the late Shermanian Stage, Middle Ordovician, and early Edenian Stage, Late Ordovician, and is younger than $H$. similis, which occurs in rocks of the Blackriveran to Shermanian Stages, Middle Ordovician. It is older, however, than H. obliqua (Bassler, 1903, p. 576;
Cumings and Galloway, 1913, p. 51; not Brown, 1965, p. 979), H. curvata (Bassler, 1903, p. 575; Cumings and Galloway, 1913, p. 51), and $H$. alta (Cumings and Galloway, 1913, p. 77), which occur in rocks of the Maysvillian Stage, Late Ordovician.

Brown (1965, p. 979) reportedly found $H$. obliqua in his undivided "Logana-Jessamine Limestone Members" of the Lexington Limestone (the Logana and Grier Limestone Members, respectively, of the Lexington Limestone of current usage) in the central Blue Grass region of Kentucky. His material (Brown, 1965, pl. 111, figs. 1-3), however, shows the combination of morphological characters typical of $H$. cressmani; it is, therefore, reassigned herein to $H$. cressmani, and $H$. obliqua remains restricted to rocks of the Maysvillian Stage, Late Ordovician.

\section{Genus HOMOTRYPELLA Ulrich, 1886}

Type species.-Homotrypella instabilis Ulrich, 1886, p. 83; by original designation; Decorah Shale, Rocklandian Stage, Middle Ordovician.

Remarks. - The taxonomic status of the genus Homotrypella is somewhat uncertain, but the concept for the genus has been used in studies of bryozoan fauna from the Upper Ordovician strata in Indiana (Utgaard and Perry, 1964, p. 61). Subsequently, Astrova (1978, p. 94) reevaluated the genera Homotrypa and Homotrypella mainly on the basis of material from the Middle Ordovician (D2 of Astrova) and Upper Ordovician (D3 of Astrova) rocks of the U.S.S.R., and considered Homotrypella to be a subjective junior synonym of Homotrypa. However, Homotrypella is herein retained as a separate genus. The definition of Homotrypella by Ulrich (1893, p. 228) is followed herein in sensu lato until additional material of Homotrypella instabilis Ulrich, the type species of Homotrypella, is redescribed and is compared with Homotrypa curvata Ulrich, 1882, the type species of Homotrypa.

\footnotetext{
Homotrypella granulifera (Ulrich, 1879)

Plate 8, figures 1, 2, 4
}

Chaetetes granuliferus Ulrich, 1879, p. 128, pl. 12, figs. 9-9b. 
Batostomella granulifera (Ulrich), Ulrich, 1882, p. 141.

Homotrypella granulifera (Ulrich), Ulrich, 1886, p. 83 (trivial name grameliferus misspelled; corrected herein)

Homotrypella granulifera (Ulrich), Miller, 1889, p. 310.

Homotrypella mundula Ulrich of Brown, 1965, p. 980, pl. 111, figs. 4-6.

Monticulipora (Fistulipora) granulifera (Ulrich), James, 1896, p. 120.

Description.-Zoaria dendroid, branches subcylindrical to slightly flattened, irregularly variable in size; conspecific overgrowth sparse to common.

In endozones, autozooecia subparallel to branch axis, gently curving outward, irregularly polygonal in cross section. Autozooecial walls straight to slightly sinuous, occasionally irregularly crenulated. Basal diaphragms sparse to common, planar to slightly curved, generally at right angles to chamber axis, scattered. Cystiphragms sparse to absent, occurring singly in axial parts of endozone, more commonly in short series or singly in endozone periphery along distal autozooecial walls. Zones of rejuvenation common, scattered, commonly having few basal diaphragms and exceedingly small styles.

In exozones, autozooecia generally at right angles to zoarial surface, subelliptical to subcircular in cross section, without preferred orientation, partly contiguous, separated by mesozooecia.

Autozooecial walls slightly variable in thickness, commonly thickened in early and in late growth stages of exozones. Laminae of cortex broadly $U$-shaped in profile; autozooecial boundaries narrowly serrated in early exozone, becoming broadly serrated and poorly defined in late exozones. Styles common, small, having well-defined cores, slightly variable in thickness, and indistinct sheaths; occurring commonly along autozooecial boundaries, locally slightly inflecting autozooecial walls. Autozooecial basal diaphragms sparse to common, planar to slightly curved, abutting autozoo- ecial walls or cystiphragms; commonly evenly spaced in early exozones of branches and in autozooecia of subsequent overgrowths, lacking in a few autozooecia. Cystoidal diaphragms rare. Cystiphragms sparse, oc. curring in short, discontinuous series or singly; extending one-half to one-third the circumference of autozooecia along distal autozooecial walls; absent in a few autozooecia. Autozooecial lining indistinct, generally absent.

Autozooecial chambers subelliptical to subcircular, locally petaloid in cross section, occasionally containing irregularly shaped brown bodies in outer exozones.

Mesozooecia abundant, subcircular or irregularly shaped in cross section, with scattered styles; mesozooecial walls adjacent to autozooecia generally straight, slightly sinuous between mezooecia. Mesozooecial disphragms unevenly spaced in early exozones, generally thickening ontogenetically, commonly coalescing and filling mesozooecial chambers in late exozones.

Maculae common, low, having filled mesozooecia in their centers and slightly larger polymorphs, irregularly shaped in cross section, along margins.

Measurements.-Measurements are summarized in table 9.

Geographic and stratigraphic distribution.-Homotrypella granulifera is known only from Kentucky, where it occurs only in the Grier Limestone Member (Shermanian Stage, upper Middle Ordovician) of the Lexington Limestone. It occurs in USGS collns. 4680-CO-4682-CO, 4688-CO; 4945-CO, 4948-CO, and 4949-CO.

Ulrich $(1879$, p. $129 ; 1886$, p. 83$)$ reported $H$. granulifera from his "Trenton shaly limestone" near Frankfort and Burgin, $\mathrm{Ky}$.

Studied material.-Homotrypella granulifera (Ulrich), lectotype USNM 43669, designated herein from syntype suite USNM 43669, "Trenton (Wilmore)" strata,

TABLE 9.-Summarized measurements of specimens of Homotrypella granulifera (Ulrich)

[Hypotypes USNM 308397 (USGS colln. 4680-CO), 308398, 308399 (USGS colln. 4681-CO), 308400 (USGS colln. 4682-CO), 308402 (USGS colln. 4945-CO). All measurements in millimeters unless otherwise indicated]

\begin{tabular}{|c|c|c|c|c|c|c|c|}
\hline & $\begin{array}{c}\text { Arithmetic } \\
\text { mean }\end{array}$ & $\begin{array}{c}\text { Standard } \\
\text { deviation } \\
\text { of mean }\end{array}$ & $\begin{array}{c}\text { Coefficient } \\
\text { of } \\
\text { variation }\end{array}$ & $\begin{array}{c}\text { 95-percent } \\
\text { confidence } \\
\text { interval } \\
\text { of mean }\end{array}$ & Range & $\begin{array}{c}\begin{array}{c}\text { Number } \\
\text { of } \\
\text { measurements }\end{array}\end{array}$ & $\begin{array}{c}\text { Number } \\
\text { of } \\
\text { zoaria } \\
\text { measured }\end{array}$ \\
\hline Autozooecial chamber maximum diameter _-_ & 0.1384 & 0.0180 & 12.97 & $0.13-0.14$ & $0.11-0.19$ & 25 & 5 \\
\hline Autozooecial chamber minimum diameter _-_ & .1084 & .0186 & 17.19 & $.10-\quad .12$ & $.07-.14$ & 25 & 5 \\
\hline Autozooecial wall thickness, exozone & .0880 & .0210 & 23.88 & $.08-$ & $.04-$ & 25 & 5 \\
\hline Macular polymorph chamber maximum diameter _- & .170 & .0082 & 4.80 & $.16-$ & $.16-$ & 4 & 3 \\
\hline Macular polymorph chamber minimum diameter & .1425 & .0206 & 14.47 & $.11-$ & $.12-$ & $\ddot{4}$ & 3 \\
\hline Mesozooecial chamber maximum diameter - & .0756 & .0204 & 26.94 & $.07-.09$ & $.05-.11$ & 18 & 4 \\
\hline Autozooecia (number per $2 \mathrm{~mm}$ ) & 9.250 & .9653 & 10.44 & $8.64-9.86$ & $8-11$ & 12 & 5 \\
\hline Autozooecia (number per $\mathrm{mm}^{2}$ ) & 21.071 & 3.6048 & 17.11 & $18.99-23.15$ & -26 & 14 & 5 \\
\hline Zoarial branch diameter & 4.550 & 1.3699 & 30.11 & $2.37-6.73$ & $2.9-6.10$ & 4 & 4 \\
\hline Endozone width _______________ & 2.640 & .6841 & 25.91 & $1.79-3.49$ & $2.10-3.80$ & 5 & 4 \\
\hline Exozone width (one side only) _-_ & 1.3111 & .3551 & 27.09 & $1.04-1.58$ & $.80-1.90$ & 9 & 4 \\
\hline Styles in autozooecium (number) & 3.5714 & .6462 & 18.09 & $3.20-3.94$ & $3.0-5.0$ & 14 & 4 \\
\hline
\end{tabular}


Middle Ordovician, Frankfort, Ky.; figured by Ulrich, 1879 , pl. 12, fig. 9 .

Hypotypes USNM 308397 (USGS colln. 4680-CO), 308398, 308399, (USGS colln. 4681-CO), 308400 (USGS colln. 4682-CO), 308401 (USGS colln. 4688-CO), 308402, 308403 (USGS colln. 4945-CO), 308404 (USGS colln. 4948-CO), 308405 (USGS colln. 4949-CO).

Homotrypella mundula Ulrich, of Brown, 1965, p. 980, hypotypes IU $8242-1$ and $8242-2$ from the undivided "Logana-Jessamine Limestone Members" of the Lexington Limestone of Brown, 1965 (the Logana and Grier Limestone Members, respectively, of the Lexington Limestone of current usage), Middle Ordovician, central Kentucky.

Homotrypella mundula Ulrich, 1893, holotype USNM 43560 , from the "Trenton Group," Middle Ordovician, Decorah, Iowa; figured by Ulrich (1893, p. 232, text-fig. 12).

Remarks. $-H$. granulifera differs from the type species of the genus $H$. instabilis Ulrich in having subcircular to subelliptical autozooecia with occasionally petaloid chambers in cross section (pl. 8 , fig. $2 b$ ), narrowly serrated and indistinct autozooecial boundaries, irregular distribution of basal diaphragms and cystiphragms (pl. 8, fig. 4d), poorly defined maculae (pl. 8, fig. $2 b$ ), small styles in endozones of autozooecia (pl. 8, fig. $4 b$ ).

Autozooecia of $H$. instabilis are generally subpolygonal with subelliptical chambers in cross section (Ulrich, 1893, pl. 18, figs. 13, 14) and have well-defined autozooecial boundaries with relatively large styles (Ulrich, 1893, pl. 18, figs. 13, 14). Cystiphragms and basal diaphragms occur regularly in exozones of autozooecia of H. instabilis (Ulrich, 1893, pl. 18, figs. 15, 17). Maculae in $H$. instabilis are generally well defined (Ulrich, 1893, pl. 18, fig. 18).

Brown (1965, p. 980) reportedly found $H$. mundula in his undivided "Logana-Jessamine Limestone Members" of the Lexington Limestone (the Logana and Grier Limestone Members, respectively, of the Lexington Limestone of current usage), Middle Ordovician, in central Kentucky. These specimens (Brown, 1965, pl. 111, figs. 4-6) have characters typical of those of $H$. granulifera, however, and therefore are reassigned herein to $H$. granulifera. $H$. mundula Ulrich (1893, text. fig. 12; this paper, pl. 8, fig. 3 ; table 10 ) and $H$. granulifera are approximately similar in size of autozooecia in cross section but differ in number of autozooecia in unit length and in the width of endozones (compare tables 9 and 10). $H$. mundula differs further from $H$. granulifera in having autozooecial walls that are relatively straight in endozones and of uniform thickness in exozones (pl. 8, fig. 3a).

\section{Genus MESOTRYPA Ulrich, 1893}

Type species.-Diplotrypa infida Ulrich, 1886, p. 88, subsequently designated by Ulrich (1893, p. 257); Decorah Shale of current usage, Middle Ordovician, Minnesota.

Remarks.-The two taxa assigned to Mesotrypa conform to the emended concept for the genus Mesotrypa by Ross (1970a, p. 365) that is followed herein.

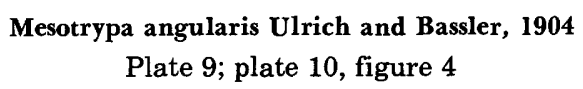

Mesotrypa angularis Ulrich and Bassler, 1904, p. 23, pl. 7, figs. 7-9. M. spinosa Ulrich, 1893, of Brown, 1965, p. 981, pl. 111, figs. 7-9.

Description.-Zoaria subdomal to subconical or discoidal, unbranched, with exceedingly thin basal layers. Basal layers of zoaria straight to curved, concave proximally, imperforate, nonlaminate or granular proximally, laminated distally, forming basal walls of autozooecia in endozones.

Endozones narrow. Autozooecia in endozones generally contiguous, occasionally partly separated by mesozooecia, arising from basal layers, recumbent for short distances along basal layers, becoming erect at base of exozones. Basal diaphragms sparse, generally lacking. In exozones, autozooecia in midpart of zoaria at right angles, in lateral parts slightly oblique, to basal layers, occasionally intercalated or arising locally from mesozooecia within exozones. Autozooecia subparallel, part-

TABLE 10.-Summarized measurements of a specimen of Homotrypella mundula Ulrich, 1893 [Holotype USNM 43560. All measurements in millimeters unless otherwise indicated]

\begin{tabular}{|c|c|c|c|c|c|c|c|}
\hline & $\begin{array}{c}\text { Arithmetic } \\
\text { mean }\end{array}$ & $\begin{array}{c}\text { Standard } \\
\text { deviation } \\
\text { of mean }\end{array}$ & $\begin{array}{c}\text { Coefficient } \\
\text { of } \\
\text { variation }\end{array}$ & $\begin{array}{l}\text { 95-percent } \\
\text { confidence } \\
\text { interval } \\
\text { of mean }\end{array}$ & Range & $\begin{array}{c}\begin{array}{c}\text { Number } \\
\text { of } \\
\text { measurements }\end{array} \\
\end{array}$ & $\begin{array}{c}\text { Number } \\
\text { of } \\
\text { zoaria } \\
\text { measured }\end{array}$ \\
\hline Autozooecial chamber maximum diameter ___ & 0.1720 & 0.0327 & 19.02 & $0.13-0.21$ & $0.13-0.21$ & 5 & 1 \\
\hline Autozooecial chamber minimum diameter & .1180 & .0327 & 27.72 & $.07-\quad .16$ & $.09-\quad .17$ & 5 & 1 \\
\hline Autozooecial wall thickness, exozone - & .080 & .0235 & 29.32 & $.05-.11$ & $.06-\quad .11$ & 5 & 1 \\
\hline Autozooecia (number per $2 \mathrm{~mm}$ ) - & 7.333 & .5773 & 7.87 & $5.90-8.77$ & $7-8$ & 3 & 1 \\
\hline Autozooecia (number per $\mathrm{mm}^{2}$ ) & 15.50 & 12.91 & 8.33 & $13.45-17.55$ & $14-17$ & 4 & 1 \\
\hline Zoarial diameter-_-_ & 3.80 & .2824 & 7.44 & $1.26-6.34$ & $3.60-4.00$ & 2 & 1 \\
\hline Endozone width --_-_-_ & 2.25 & .2121 & 9.43 & $.34-.42$ & $2.10-2.40$ & $\overline{2}$ & 1 \\
\hline Exozone width (one side only) - & .8250 & .2062 & 24.99 & $.50-1.15$ & $.60-1.0$ & 4 & 1 \\
\hline Styles in autozooecium (number) & 3.6 & 1.140 & 31.67 & $2.18-5.02$ & $2-5$ & 5 & 1 \\
\hline
\end{tabular}


ly contiguous, separated by mesozooecia, subpolygonal with slightly curved walls in cross section, without preferred alignment. Autozooecial walls exceedingly thin, locally thickened and occasionally inflected by styles. Autozooecial boundaries thin, narrowly serrated. Styles common throughout exozones, with small, well-defined nonlaminated cores, relatively thick sheaths; occurring in corners of autozooecia and mesozooecia, occasionally extending into zooecial chambers; locally discontinuous. Basal diaphragms of autozooecia common, planar to curved, generally convex distally, forming oblique or right angles with chamber axis, generally scattered, occurring locally, evenly spaced, in zones, occasionally extending across several autozooecia.

Cystiphragms sparse to absent, generally occurring singly in some autozooecia; cystoidal diaphragms rare. Autozooecial linings generally absent.

Autozooecial chambers subpolygonal to subcircular in cross section.

Mesozooecia common throughout exozones, locally arising in endozones, irregularly shaped in cross sections, slightly moniloid proximally. Mesozooecia partly separate autozooecia, commonly replaced by autozooecia within exozones. Mesozooecial diaphragms closely and evenly spaced, slightly curved, generally concave distally.

Maculae abundant, closely spaced, occurring regularly, indistinct in cross section, having polymorphs slightly larger than autozooecia in their centers. Polymorphs in margins of maculae gradational in size with autozooecia of intermacular areas; mesozooecia scattered.

Measurements.-Measurements are summarized in tables 11 and 12.

Geographic and stratigraphic distribution. $-M$. angularis occurs in strata of Middle Ordovician age in widely separated geographic regions.

Occurrence in Kentucky.-Grier Limestone Member, Shermanian Stage (USGS collns. D1222-CO; 4875-CO; 6132-CO) of the Lexington Limestone.

Ulrich and Bassler (1904, p. 23) erected $M$. angularis on the basis of material occurring in their "shaly lower half of the Lexington Limestone" at Frankfort, Ky., and also found it in Ordovician strata near Burgin and Curdsville, $\mathrm{Ky}$.

TABLE 11.-Summarized measurements of a specimen of Mesotrypa angularis Ulrich and Bassler [Holotype USNM 43182. All measurements in millimeters unless otherwise indicated]

\begin{tabular}{|c|c|c|c|c|c|c|c|}
\hline & $\begin{array}{l}\text { Arithmetic } \\
\text { mean }\end{array}$ & $\begin{array}{c}\text { Standard } \\
\text { deviation } \\
\text { of mean }\end{array}$ & $\begin{array}{c}\text { Coefficient } \\
\text { of } \\
\text { variation }\end{array}$ & $\begin{array}{l}\text { 95-percent } \\
\text { confidence } \\
\text { interval } \\
\text { of mean }\end{array}$ & Range & $\begin{array}{c}\begin{array}{c}\text { Number } \\
\text { of } \\
\text { measurements }\end{array}\end{array}$ & $\begin{array}{c}\text { Number } \\
\text { of } \\
\text { zoaria } \\
\text { measured }\end{array}$ \\
\hline Autozooecial chamber maximum diameter _- & 0.2450 & 0.0184 & 7.51 & $0.23-0.26$ & $0.22-0.28$ & 10 & 1 \\
\hline Autozooecial chamber minimum diameter & .2140 & .0196 & 9.14 & $.20-.23$ & $.18-.25$ & 10 & 1 \\
\hline Macular polymorph chamber maximum diameter & .4375 & .0483 & 11.05 & $.40-$ & $.37-$ & 8 & 1 \\
\hline Macular polymorph chamber minimum diameter - & .3350 & .0342 & 10.22 & $.31-$ & $.27-$ & 8 & $\overline{1}$ \\
\hline Mesozooecial chamber maximum diameter _-_____ & .0940 & .0493 & 52.44 & $.03-.16$ & $.04-\quad .17$ & 5 & 1 \\
\hline Autozooecia (number per $2 \mathrm{~mm}$ ) _____ & 8 & .50 & 6.25 & $7.6-8.4$ & $7-9$ & 9 & 1 \\
\hline Autozooecia (number per $\mathrm{mm}^{2}$ ) _ _ & 15.889 & 1.6159 & 10.17 & $14.65-17.13$ & -18 & 9 & 1 \\
\hline Mesozooecia (number per $\mathrm{mm}^{2}$ ) & 7.2 & 4.9193 & 68.3 & $1.09-13.31$ & $3-15$ & 5 & 1 \\
\hline Diaphragms (number per mm) in mesozooecia - & 11.667 & 3.3267 & 28.51 & $8.18-15.16$ & $8.0-15.0$ & 6 & 1 \\
\hline Cystiphragms (number per $\mathrm{mm}$ ) & 6 & .6667 & 11.11 & $5.52-6.48$ & $5-7$ & 10 & 1 \\
\hline Styles in autozooecium (number) & 3.80 & .6325 & 16.64 & $3.35-4.25$ & $3-5$ & 10 & 1 \\
\hline 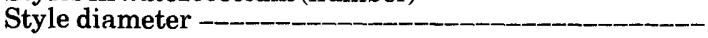 & .0590 & .0191 & 32.41 & $.05-.07$ & $.03-\quad .09$ & 10 & 1 \\
\hline
\end{tabular}

TABLE 12.-Summarized measurements of specimens of Mesotrypa angularis Ulrich and Bassler [Hypotypes USNM 308408 (USGS colln. 4875-CO) and 308409 (USGS colln. 6132-CO). All measurements in millimeters unless otherwise indicated]

\begin{tabular}{|c|c|c|c|c|c|c|c|}
\hline & $\begin{array}{l}\text { Arithmetic } \\
\text { mean }\end{array}$ & $\begin{array}{c}\text { Standard } \\
\text { deviation } \\
\text { of mean }\end{array}$ & $\begin{array}{c}\text { Coefficient } \\
\text { of } \\
\text { variation }\end{array}$ & $\begin{array}{l}\text { 95-percent } \\
\text { confidence } \\
\text { interval } \\
\text { of mean }\end{array}$ & Range & $\begin{array}{c}\begin{array}{c}\text { Number } \\
\text { of } \\
\text { measurements }\end{array} \\
\end{array}$ & $\begin{array}{c}\text { Number } \\
\text { of } \\
\text { zoaria } \\
\text { measured }\end{array}$ \\
\hline Autozooecial chamber maximum diameter & 0.240 & 0.0230 & 9.50 & $0.23-0.26$ & $0.22-0.27$ & 10 & 2 \\
\hline Autozooecial chamber minimum diameter & .2010 & .0208 & 10.34 & $.19-.22$ & $.16-.22$ & 10 & $\overline{2}$ \\
\hline Macular polymorph chamber maximum diameter - & .350 & .0424 & 12.12 & $.30-$ & $.31-$ & 5 & 1 \\
\hline Macular polymorph chamber minimum diameter - & .26 & .0353 & 13.60 & $.22-$ & $.22-$ & 5 & 1 \\
\hline Mesozooecial chamber maximum diameter -____-_- & .120 & .0278 & 24.83 & $.09-.13$ & $.08-\quad .17$ & 10 & 2 \\
\hline Autozooecia (number per $2 \mathrm{~mm}$ ) _- & 8.3333 & .5774 & 6.93 & $6.90-9.77$ & $8.00-9.00$ & 3 & 2 \\
\hline Autozooecia (number per $\mathrm{mm}^{2}$ ) - & 18.60 & 2.0736 & 11.15 & $16.02-21.17$ & $15 \quad-20$ & 5 & 2 \\
\hline Mesozooecia (number per $\mathrm{mm}^{2}$ ) - & 8.0 & & & & $2 \quad-19$ & 3 & 2 \\
\hline Diaphragms (number per $\mathrm{mm}$ ) in mesozooecia - & 14.286 & 2.1381 & 14.97 & $12.31-16.26$ & $12.0-17.0$ & 7 & 2 \\
\hline Cystiphragms (number per $\mathrm{mm}$ ) - & & & $-\infty$ & 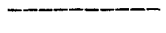 & 20 & & 1 \\
\hline Zoarial branch diameter - & 6.00 & -_- & --- & - & $2.0-10.0$ & 2 & 2 \\
\hline 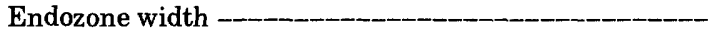 & .10 & - - & --- & - & $.10-$ & 2 & 2 \\
\hline Exozone width (one side only) - & 5.90 & & $\ldots$ & - & $1.90-9.90$ & 2 & 2 \\
\hline Styles in autozooecium (number) & 3.5 & 1.3784 & 39.38 & $2.05-4.95$ & $2-5$ & 6 & 2 \\
\hline Style diameter - & .060 & .0158 & 26.35 & $.04-\quad .08$ & $.04-\quad .08$ & 5 & 1 \\
\hline
\end{tabular}


Occurrence outside Kentucky.-Ulrich and Bassler (1904, p. 23) reported $M$. angularis from rocks of Middle Ordovician age near Ottawa and Peterboro, Ontario. Fritz (1957, p. 24) reported subspecies $M$. angularis parvatrypa (new variety of Fritz) from her Sherman Falls beds of the Ottawa Formation, Middle Ordovician, in Ontario.

Studied material.-Mesotrypa angularis Ulrich and Bassler, 1904, holotype USNM 43182 and paratype USNM 308406 from the primary type suite USNM 43182, "Trenton" strata, Middle Ordovician, near Frankfort, Ky.

Hypotypes USNM 308407 (USGS colln. D1222-CO), 308408 (USGS colln. 4875-CO), 308409 (USGS colln. 6132-CO).

Mesotrypa spinosa Ulrich, 1893, of Brown, 1965, p. 982; hypotype IU 8237-1 from the undivided "LoganaJessamine Limestone Members" of the Lexington Limestone of Brown, 1965 (the Logana and Grier Limestone Members of the Lexington Limestone of current usage), Middle Ordovician, Garrard County.

Mesotrypa? spinosa Ulrich, 1893, lectotype USNM 43546 from the "Black River" Group of Ulrich (the Decorah Shale of current usage), Middle Ordovician, from the syntype suite USNM 43456, Minneapolis.

Remarks. $-M$. angularis is related to several Mesotrypa species of Middle Ordovician age, including $M$. infida (Ulrich), the type species; $M$. regularis (Foord); $M$. maculosa Caley; and $M$. spinosa Ulrich; and to $M$. distincta Parks, of Late Ordovician age, by virtue of its subdomal growth habit and parallel autozooecial budding pattern (parallel type of zoaria of Männil, 1961), imperforate basal layers, and narrow endozones. Domal zoaria with parallel budding pattern have autozooecia that arise from imperforate basal layers, are approximately at right angles to basal layers, and are generally erect distally throughout exozones (Männil, 1961, p. 118).

M. infida (Ulrich, 1893, p. 258, pl. 17, figs. 1-8; from "the middle third of the Trenton Shales" of Ulrich, near Minneapolis and St. Paul, Minn.), Decorah Shale, Middle Ordovician, differs from $M$. angularis in having autozooecia less angular in cross section, more abundant basal diaphragms and cystiphragms, and abundant mesozooecia throughout exozones, including maculae. Mesozooecia in $\boldsymbol{M}$. infida commonly separate autozooecia and occur in clusters in maculae. Mesozooecia in $M$. angularis only partly separate autozooecia and occur sparingly in maculae (pl. 9, fig. 2a). Styles of $M$. angularis are larger in diameter on the average than those of $M$. infida.

M. regularis (Foord, 1883, p. 13, pl. 1, figs. 3-3c; from the "Trenton Formation" of Foord, at Ottawa), Middle Ordovician, differs from $M$. angularis in having zoaria with autozooecia in preferred alignment, abundant mesozooecia, and exceedingly small styles.

M. maculosa Caley (1936, p. 71, pl. 4, figs. 3, 4; from the "Trenton Formation" of Caley, Manitoulin Island, Ontario, Middle Ordovician, differs from $M$. angularis in having branching domal zoaria in which autozooecia have relatively thick walls, abundant and evenly spaced basal diaphragms, and a few infundibular diaphragms, which generally are absent in $M$. angularis. M. maculosa differs further from $M$. angularis in having mesozooecia mostly in maculae and generally lacking them in intermacular areas.

M. distincta Parks (1925, p. 36, pl. 4, 5; from the Humber Member of the Dundas Formation of Parks; Fritz, 1976, p. 7, figs. 2A, $B$ ), Upper Ordovician, differs from $M$. angularis in having domal zoaria that consist of several superimposed layers of autozooecia. $M$. distincta differs further from $M$. angularis in having autozooecia with relatively evenly spaced basal diaphragms, lack styles and are generally separated by mesozooecia.

Brown (1965, p. 982) reportedly found $M$. spinosa Ulrich, 1893, in his undivided "Logana-Jessamine Limestone Members" of the Lexington Limestone (the Logana and Grier Limestone Members respectively of the Lexington Limestone of current usage), Middle Ordovician, at several localities in central Kentucky. Specimens of $M$. spinosa of Brown (1965, pl. 11, figs. $7-9)$ are herein reassigned to $M$. angularis (pl. 9; pl. 10, fig. 4) because these specimens resemble those of $M$. angularis in cross-sectional shape of autozooecia in exozones, arrangement and distribution of basal diaphragms and cystiphragms in exozones, and shape and size of styles.

M. spinosa Ulrich (1893, p. 259, pl. 17, figs. 9-12; from "The middle third of the Trenton Shales" of Ulrich at Minneapolis and St. Paul, (now the approximate stratigraphic equivalent of the Stictopora mutabilis zone of Karklins, 1969, fig. 10, of Decorah Shale), Middle Ordovician, differs from $M$. angularis in having autozooecia that are more subcircular (pl. 10, fig. 2b) than polygonal in cross section, cystiphragms that are regularly aligned in some autozooecia (pl. 10, fig. 2a), and abundant basal diaphragms throughout exozones. $M$. spinosa (Ulrich, 1893) differs further from $M$. angularis in having autozooecia that are smaller in cross section size and have more abundant and larger mesozooecia (tables 11-13).

\section{Mesotrypa sp. \\ Plate 10, figure 1}

Description.-Zoarium subdomal, unbranched. Basal layer and endozone poorly defined. 
In exozones autozooecia approximately at right angles to basal layer, erect distally, partly contiguous, separated by mesozooecia, subcircular to subpolygonal in cross section, slightly elongate, without preferred alignment. Autozooecial walls relatively thick locally, with distinct cortex and well-defined serrated autozooecial boundaries. Styles abundant, relatively large with thick sheaths and thin nonlaminate cores, occurring along autozooecial boundaries and in zooecial corners, locally inflecting autozooecial walls or extending into their chambers. Basal diaphragms common, planar to slightly curved, variable in thickness locally, generally concave distally, occurring at right angles to chamber axis. Cystoidal diaphragms sparse; cystiphragms absent. Autozooecial linings thin, occurring commonly in chambers with thickened basal diaphragms.

Autozooecial chambers subcircular to subelliptical in cross section.

Mesozooecia common, irregularly polygonal in cross section, irregularly variable in size, partly separating autozooecia, terminating locally within exozone. Mesozooecial walls generally straight. Mesozooecial diaphragms closely and evenly spaced, relatively thick, generally concave distally.
Maculae scattered, consisting of larger polymorphs, having few mesozooecia in their centers. Polymorphs along margins of maculae gradational in size with autozooecia in intermediate areas.

Measurements.-Measurements are summarized in table 14

Geographic and stratigraphic distribution.-Mesotrypa sp. is known only from the Millersburg Member, Shermanian Stage, upper Middle Ordovician (USGS 5027-CO), of the Lexington Limestone in Kentucky.

Studied material.-USNM 308410 (USGS colln. 5027-CO).

Remarks.-The specimen assigned to Mesotrypa sp. is similar to those of $M$. angularis and closely related species in having subdomal growth form and parallel autozooecial budding pattern (Männil, 1961; see remarks under $M$. angularis).

This specimen of Mesotrypa differs from those of other species of Mesotrypa, including $M$. angularis and related taxa, in that its autozooecia have subcircular to subelliptical shapes, smaller diameters in cross section (pl. 10, fig. 1b; table 14), and thicker walls and basal diaphragms; the appearance and distribution of styles (pl. 10, fig. 1) are different; and the number of basal

TABLE 13.-Summarized measurements of a specimen of Mesotrypa spinosa Ulrich [Lectotype USNM 43546. All measurements in millimeters unless otherwise indicated]

\begin{tabular}{|c|c|c|c|c|c|c|c|}
\hline & $\begin{array}{l}\text { Arithmetic } \\
\text { mean }\end{array}$ & $\begin{array}{c}\text { Standard } \\
\text { deviation } \\
\text { of mean }\end{array}$ & $\begin{array}{c}\text { Coefficient } \\
\text { of } \\
\text { variation }\end{array}$ & $\begin{array}{l}\text { 95-percent } \\
\text { confidence } \\
\text { interval } \\
\text { of mean }\end{array}$ & Range & $\begin{array}{c}\begin{array}{c}\text { Number } \\
\text { of } \\
\text { measurements }\end{array} \\
\text {. }\end{array}$ & $\begin{array}{c}\text { Number } \\
\text { of } \\
\text { zoaria } \\
\text { measured }\end{array}$ \\
\hline Autozooecial chamber maximum diameter & 0.2160 & 0.0114 & 5.28 & $0.20-0.23$ & $0.20-0.23$ & 5 & 1 \\
\hline Autozooecial chamber minimum diameter ______ & .1720 & .0037 & 4.86 & $.16-.18$ & $.16-\quad .18$ & 5 & 1 \\
\hline Macular polymorph chamber maximum diameter & .330 & .010 & 3.0 & $.31-$ & $.32-$ & 3 & 1 \\
\hline Macular polymorph chamber minimum diameter & .290 & .0173 & 5.97 & $.25-$ & $.27-$ & 3 & 1 \\
\hline Mesozooecial chamber maximum diameter _- & .150 & .0570 & 38.0 & $.08-.22$ & $.11-$ & 5 & 1 \\
\hline Autozooecia (number per $2 \mathrm{~mm}$ ) & 8.00 & & & & $8^{.11-}$ & 3 & 1 \\
\hline Autozooecia (number per $\mathrm{mm}^{2}$ ) & 15.33 &.$\overline{5774}$ & 3.77 & $\overline{13.90-16.77}$ & -16 & 3 & 1 \\
\hline Mesozooecia (number per $\mathrm{mm}^{2}$ ) & 18.50 & 3.3166 & 17.93 & $13.22-23.78$ & -23 & 4 & 1 \\
\hline Diaphragms (number per $\mathrm{mm}$ ) in mesozooecia & 16.5 & 2.08 & 12.62 & $13.19-19.81$ & -19 & 4 & 1 \\
\hline Cystiphragms (number per mm) & 5.3333 & .5774 & 10.83 & $3.9-6.77$ & -6 & 3 & 1 \\
\hline Stereostyles in autozooecium (number) & 2.60 & .8944 & 34.40 & $1.49-3.71$ & $2-4$ & 5 & $\overline{1}$ \\
\hline Style diameter & .045 & .0173 & 38.49 & $.02-\quad .07$ & $.03-\quad .07$ & 4 & $\overline{1}$ \\
\hline
\end{tabular}

TABLE 14.-Summarized measurements of a specimen of Mesotrypa sp. [USNM 308410 (USGS colln. 5027-CO). All measurements in millimeters unless otherwise indicated]

\begin{tabular}{|c|c|c|c|c|c|c|c|}
\hline & $\begin{array}{c}\text { Arithmetic } \\
\text { mean }\end{array}$ & $\begin{array}{c}\text { Standard } \\
\text { deviation } \\
\text { of mean }\end{array}$ & $\begin{array}{c}\text { Coefficient } \\
\text { of } \\
\text { variation }\end{array}$ & $\begin{array}{l}\text { 95-percent } \\
\text { confidence } \\
\text { interval } \\
\text { of mean }\end{array}$ & Range & $\begin{array}{c}\begin{array}{c}\text { Number } \\
\text { of } \\
\text { measurements }\end{array} \\
\end{array}$ & $\begin{array}{c}\text { Number } \\
\text { of } \\
\text { zoaria } \\
\text { measured }\end{array}$ \\
\hline Autozooecial chamber maximum diameter _______ & 0.1860 & 0.0134 & 7.21 & $0.17-0.20$ & $0.17-0.20$ & 5 & 1 \\
\hline Autozooecial chamber minimum diameter & .1440 & .0089 & 6.21 & $.13-.16$ & $.13-.15$ & 5 & 1 \\
\hline Autozooecial wall thickness, exozone & .036 & .0089 & 24.85 & $.02-$ & $.03-$ & 5 & 1 \\
\hline Macular polymorph chamber maximum diameter ___ & .2680 & .033 & 12.49 & $.23-$ & $.23-$ & 5 & $\overline{1}$ \\
\hline Macular polymorph chamber minimum diameter & .1920 & .0192 & 10.02 & $.17-$ & $.17-$ & 5 & 1 \\
\hline Mesozooecial chamber maximum diameter & .0760 & .0251 & 33.03 & $.04-\quad .11$ & $.06-\quad .12$ & 5 & 1 \\
\hline Autozooecia (number per $2 \mathrm{~mm}$ ) & 8.60 & .5477 & 6.37 & $7.92-9.28$ & $8-9^{.00}$ & 5 & 1 \\
\hline Autozooecia (number per $\mathrm{mm}^{2}$ ) & 19.80 & 2.490 & 12.58 & $16.71-22.89$ & -24 & $\mathbf{5}$ & 1 \\
\hline Mesozooecia (number per $\mathrm{mm}^{2}$ ) & 8.80 & 2.49 & 28.30 & $5.71-11.90$ & -13 & $\mathbf{5}$ & 1 \\
\hline Diaphragms (number per $\mathrm{mm}$ ) & 21.0 & 2.8284 & 13.47 & & $19-23$ & $\mathbf{5}$ & 1 \\
\hline Cystiphragms (number per $\mathrm{mm}$ ) & 11.50 & 1.2910 & 11.23 & $9.45-13.55$ & $10.0-13.0$ & 5 & $\overline{1}$ \\
\hline Stereostyles in autozooecium (number) & 4.40 & .5477 & 12.45 & $3.72-5.08$ & $4-5$ & 5 & 1 \\
\hline Style diameter & .06 & .0179 & 26.31 & $.05-\quad .09$ & $.05-.09$ & $\mathbf{5}$ & 1 \\
\hline
\end{tabular}


diaphragms and mesozooecial diaphragms per unit length (table 14) is different.

The differences in appearance and in cross-sectional size and shape of autozooecia suggest that the specimen probably represents a new taxon. A new species, however, is not established for lack of additional material.

\section{Genus PERONOPORA Nicholson, 1881}

Type species.-Chaetetes decipiens Rominger, 1866, p. 115; subsequent designation by ICZN (1968, Opinion 838) upon application submitted by Utgaard and Boardman (1965); "Corryville Member of the McMillan Formation, Maysville Group, Upper Ordovician" (Boardman and Utgaard, 1966).

Remarks.-Boardman and Utgaard (1966) discussed the zoarial development of Peronopora and revised the concept for the genus. The definition of the genus Peronopora as given by Boardman and Utgaard (1966) is followed here.

Peronopora milleri Nickles, 1905

Plate 10, figure 3; plate 11

Peronopora milleri Nickles, 1905, p. 43, pl. 1, fig. 6; McFarlan, 1931, p. 96.

Description.-Zoaria explanate, bifoliate, flattened, commonly irregularly convolate with lateral expansions at right angles to vertical growth direction. Mesothecae exceedingly thin, straight to irregularly sinuous, without discrete median rods, generally extending throughout zoaria, occasionally absent locally.

In endozones, autozooecia contiguous, subrectangular in cross section, having slightly sinuous lateral, relatively straight transverse walls, occurring alternately in longitudinal ranges. Autozooecial boundaries distinct, narrowly serrated. Basal diaphragms common, one or two occurring in most autozooecia; cystiphragms common, relatively large, decreasing in size distally, two or three occurring in most autozooecia.
In exozones, autozooecia approximately at right angles to mesotheca, subcircular to subpolygonal in cross section, partly contiguous, separated by mesozooecia. Autozooecial walls generally thin, relatively straight, occasionally irregularly thickened locally in late exozones. Autozooecial boundaries narrowly serrated and well defined throughout exozones. Styles common to absent, generally small, having thin cores and thin sheaths, occurring mostly along autozooecial boundaries, occasionally inflecting autozooecial walls locally or extending into zooecial chambers. Basal diaphragms common to sparse, generally scattered, occurring at right angles to chamber axis, abutting laminated walls or cystiphrgams. Cystiphragms abundant, occurring in regular series, occasionally singly, generally extending approximately two-thirds the circumference of distal autozooecial walls, occasionally along entire autozooecium locally. Autozooecial linings absent.

Autozooecial chambers subcircular in cross section, subcrescent where partly constricted by cystiphragms; occasionally containing brown bodies.

Mesozooecia common throughout early exozones, subpolygonal to subcircular in cross section, commonly coalescing, partly surrounding autozooecia, locally terminated by zooecial skeletal deposits in outer exozones. Mesozooecial diaphragms abundant, closely and evenly spaced, straight to slightly curved, convex distally, overlap laterally in coalescing mesozooecia; occasionally thicker than basal diaphragms of autozooecia.

Maculae common, scattered, locally absent, commonly indistinct in cross section, consisting of slightly larger polymorphs and mesozooecia in various combinations.

Measurements.-Measurements are summarized in tables 15 and 16.

Geographic and stratigraphic distribution.-Peronopora milleri is known only from Kentucky, where it occurs in rocks of the Shermanian Stage, upper Middle Ordovician, and the Edenian Stage, lower Upper Ordo-

TABLE 15.-Summarized measurements of specimens of Peronopora milleri Nickles [Lectotype USNM 96562 and hypotypes USNM 308411, 308412, 308413. All measurements in millimeters unless otherwise indicated]

\begin{tabular}{|c|c|c|c|c|c|c|c|}
\hline & $\begin{array}{c}\text { Arithmetic } \\
\text { mean }\end{array}$ & $\begin{array}{c}\text { Standard } \\
\text { deviation } \\
\text { of mean }\end{array}$ & $\begin{array}{c}\text { Coefficient } \\
\text { of } \\
\text { variation }\end{array}$ & $\begin{array}{l}\text { 95-percent } \\
\text { confidence } \\
\text { interval } \\
\text { of mean }\end{array}$ & Range & $\begin{array}{c}\begin{array}{c}\text { Number } \\
\text { of } \\
\text { measurements }\end{array}\end{array}$ & $\begin{array}{c}\text { Number } \\
\text { of } \\
\text { zoaria } \\
\text { measured }\end{array}$ \\
\hline Autozooecial chamber maximum diameter ___ & 0.1780 & 0.017 & 9.54 & $0.17-0.19$ & $0.16-0.21$ & 15 & 3 \\
\hline Autozooecial chamber minimum diameter _-_ & .144 & .0172 & 11.97 & $.13-\quad .15$ & $.11-.18$ & 15 & 3 \\
\hline Autozooecial wall thickness, exozone _-___- & .0420 & .0086 & 20.52 & $.04-$ & $.03-$ & 15 & 3 \\
\hline Macular polymorph chamber maximum diameter -_- & .2450 & .0129 & 5.27 & $.22-$ & $.23-$ & 4 & 1 \\
\hline Macular polymorph chamber minimum diameter & .210 & .0115 & 5.50 & $.19-$ & $.20-$ & 4 & 1 \\
\hline Mesozooecial chamber maximum diameter _-_____-_ & .0942 & .0294 & 31.19 & $.08-.11$ & $.04-$ & 12 & 3 \\
\hline Autozooecia (number per $2 \mathrm{~mm}$ ) _.__ & 8.2727 & .6467 & 7.82 & $7.84-8.70$ & $7-9$ & 11 & 3 \\
\hline Autozooecia (number per $\mathrm{mm}^{2}$ ) & 15.545 & 2.77 & 17.82 & $13.69-17.41$ & -20 & 11 & 3 \\
\hline Mesozooecia (number per $\mathrm{mm}^{2}$ ) & 9.3750 & 6.80 & 72.56 & $3.69-15.06$ & -25 & 8 & 3 \\
\hline Cystiphragms (number per $\mathrm{mm}$ ) - & 11.50 & 1.7431 & 15.16 & $10.49-12.51$ & -.14 & 14 & 3 \\
\hline Mesozooecial diaphragms (number per $\mathrm{mm}$ ) & 16.643 & 1.5984 & 9.60 & $15.72-17.56$ & $15-20$ & 14 & 3 \\
\hline 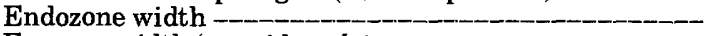 & .1047 & .0227 & 21.65 & $.09-\quad .12$ & $.06-\quad .15$ & 17 & 4 \\
\hline Exozone width (one side only) & 1.6687 & .3478 & 20.84 & $1.48-1.85$ & $1.10-2.40$ & 16 & 4 \\
\hline
\end{tabular}


TABLE 16.-Summarized measurements of specimens of Peronopora milleri Nickles [Hypotypes USNM 308428 (USGS colln. 4930-CO), 308434 (USGS colln. 4939-CO), 308429 (USGS colln. 4931-CO), 308431 (USGS colln. 4932-CO), 308432 (USGS colln. 4933-CO). All measurements in millimeters unless otherwise indicated]

\begin{tabular}{|c|c|c|c|c|c|c|c|}
\hline & $\begin{array}{c}\text { Arithmetic } \\
\text { mean }\end{array}$ & $\begin{array}{c}\text { Standard } \\
\text { deviation } \\
\text { of mean }\end{array}$ & $\begin{array}{c}\text { Coefficient } \\
\text { of } \\
\text { variation }\end{array}$ & $\begin{array}{c}\text { 95-percent } \\
\text { confidence } \\
\text { interval } \\
\text { of mean }\end{array}$ & Range & $\begin{array}{c}\begin{array}{c}\text { Number } \\
\text { of } \\
\text { measurements }\end{array} \\
\end{array}$ & $\begin{array}{c}\text { Number } \\
\text { of } \\
\text { zoaria } \\
\text { measured }\end{array}$ \\
\hline Autozooecial chamber maximum diameter _-_._._. & 0.1845 & 0.0211 & 11.46 & $0.17-0.19$ & $0.15-0.23$ & 20 & 4 \\
\hline Autozooecial chamber minimum diameter ___ & .1335 & .0150 & 11.21 & $.13-.14$ & $.11-.17$ & 20 & 4 \\
\hline Autozooecial wall thickness, exozone - & .06 & .0173 & 28.87 & $.05-$ & $.03-$ & 15 & 3 \\
\hline Macular polymorph chamber maximum diameter - & .2856 & .0251 & 8.77 & $.27-$ & $.24-$ & 9 & 3 \\
\hline Macular polymorph chamber minimum diameter & .2422 & .0380 & 15.69 & $.21-$ & $.16-$ & 9 & 3 \\
\hline Mesozooecial chamber maximum diameter & .0820 & .0233 & 28.42 & $.07-.09$ & $.04-.12$ & 20 & 4 \\
\hline Autozooecia (number per $2 \mathrm{~mm}$ ) & 6.9167 & .5149 & 7.44 & $6.59-7.24$ & $6.0-8.0$ & 12 & 3 \\
\hline Autozooecia (number per $\mathrm{mm}^{2}$ ) & 13.786 & 1.7619 & 12.78 & $12.77-14.80$ & $11-17$ & 14 & 4 \\
\hline Mesozooecia (number per $\mathrm{mm}^{2}$ ) & 15.63 & 3.0677 & 19.63 & $13.06-18.19$ & -19 & 8 & 3 \\
\hline Cystiphragms (number per mm) & 11.1190 & 1.2091 & 10.80 & $10.64-11.74$ & -13 & 21 & 6 \\
\hline Mesozooecial diaphragms (number per $\mathrm{mm}$ ) & 15.050 & 1.9050 & 12.66 & $14.16-15.94$ & $11-18$ & 20 & 5 \\
\hline Endozone width - & .1268 & .0247 & 19.50 & $.11-.13$ & $.09-\quad .20$ & 19 & 4 \\
\hline Exozone width (one side only) & 1.770 & .5602 & 31.65 & $1.51-2.03$ & $1.0-2.80$ & 20 & 5 \\
\hline
\end{tabular}

vician. It occurs in the Brannon Member, Shermanian Stage (USGS colln. D1157-CO, D1202-CO, 4930-CO), Sulphur Well Member, Shermanian Stage (USGS collns. 4888-CO-4891-CO; 4931-OC-4934-CO, 4939-CO, 4962-CO), and Tanglewood Limestone member, Shermanian Stage (USGS collns. 4976-CO, 4992-CO, 4998-CO; 5850-CO, 5854-CO), of the Lexington Limestone; and in the Clays Ferry Formation, Shermanian Stage (USGS collns. 6714-CO, D1170-CO; D1311-CO; 4894-CO, 4896-CO; 4999-CO) and Edenian Stage (USGS colln. 4922-CO).

Nickles $(1905$, p. 44) reported $P$. milleri from his "Winchester Group," Middle or Upper Ordovician, near Lexington. McFarlan (1931, p. 96) thought he had found P. milleri in the lower part of his "Cynthiana" and "Brannon" rocks in Kentucky.

Studied material.-Lectotype USNM 96562 (thin section marked "holotype"; Nickles (1905, p. 43), however, did not formally designate the holotype when he erected this species) from syntype suite 96562 , "Cynthiana" strata, Middle or Upper Ordovician, near Lair station, Kentucky.

Hypotypes USNM 308411 from hypotype suite USNM 96554, "Trenton" strata, Middle Ordovician, near Lexington, Ky.; 308412 and 308413 from the "Trenton Group" near Frankfort, Ky.

Hypotypes USNM 308414 (USGS colln. D1157-CO), 308415 (USGS colln. D1159-CO), 308416 (USGS colln. D1160-CO), 308417, 308418 (USGS colln. D1202-CO), 308419 (USGS colln. D1311-CO), 308420 (USGS colln. 4888-CO), 308421, 308422 (USGS colln. 4890-CO), 308423 (USGS colln. 4893-CO), 308424 (USGS colln. 4891-CO), 308425 (USGS colln. 4894-CO), 308426 (USGS colln. 4896-CO), 308427 (USGS colln. 4922-CO), 308428 (USGS colln. 4930-CO), 308429 (USGS colln. 4931-CO), 308430, 308431 (USGS colln. 4932-CO), 308432 (USGS colln. 4933-CO), 308433 (USGS colln. 4934-CO), 308434 (USGS colln. 4939-CO), 308435 (USGS colln. 4962-CO), 308436
(USGS colln. 4976-CO), 308437 (USGS colln. 4992-CO), 308438 (USGS colln. 4998-CO), 308439 (USGS colln. 4999-CO), 308440 (USGS colln. 5850-CO), 308441 (USGS colln. 5854-CO), 308442 (USGS colln. 6714-CO), 308443 (USGS colln. D1170-CO).

Remarks. $-P$. milleri is most closely related to $P$. vera Ulrich and $P$. decipiens (Rominger), the type species of the genus.

P. milleri, appearing first in the Brannon Member, Shermanian Stage, Middle Ordovician, of the Lexington Limestone in Kentucky, is the oldest of the three species and is probably ancestral to $P$. vera.

$P$. vera appears for the first time later, in the Millersburg Member of late Shermanian age, Middle Ordovician, of the Lexington Limestone in Kentucky, and ranges throughout the lateral stratigraphic equivalents of the Millersburg Member, including the Clays Ferry Formation, in central Kentucky. $P$. vera also occurs throughout the Eden Shale (the Kope Formation of current usage) of Anstey and Perry (1973, fig. 8). $P$. decipiens is known to occur in the Upper Ordovician strata (Boardman and Utgaard, 1966, p. 1097; Utgaard and Perry, 1964, p. 70), considered to be of Maysvillian and Richmondian age, Late Ordovician, respectively, in Ohio and Indiana. Singh $(1979$, p. 234) redescribed $P$. decipiens from his Bellevue Limestone, Maysvillian Stage, Upper Ordovician, in the tristate area of Ohio, Indiana, and Kentucky.

$P$. milleri, $P$. vera, and $P$. decipiens are similar in general shape of zoaria, approximate shape and size of autozooecia and mesozooecia, and presence of styles, but they differ in width of endozones, appearance and thickness of autozooecial and mesozooecial walls in exozones, abundance of mesozooecia, and approximate size and distribution of styles.

Zoaria of $P$. milleri characteristically have relatively narrow endozones, autozooecia with relatively thin walls of uniform appearance (pl. 11, fig. $4 b$ ), and small 
styles. Mesozooecia in P. milleri are common, but they are not abundant in zoaria.

$P$. milleri differs from $P$. vera in having autozooecia with slightly thinner walls, and mesozooecia in unit area that are fewer and commonly smaller in diameter and have fewer diaphragms in unit length (tables 15-17). Cystiphragms in autozooecia of $P$. milleri (pl. 11 , fig. $4 b$ ) are generally more uniform in size and shape than those of $P$. vera (pl. 12, fig. 4).

Styles are common in both species, but differ in their size and distribution. Styles in P. milleri are generally small, approximately $0.01 \mathrm{~mm}$ or less in diameter, and commonly are absent in parts of a zoarium. Styles in $P$. vera are regularly present throughout exozones, are generally larger than 0.01 in diameter and more variable in size than those of $P$. milleri (pl. 12, fig. $2 b$ ), and are commonly offset from autozooecial boundaries and inflect autozooecial walls.

Anstey and Perry (1973, p. 22), in a study in which data calculations and comparisons were made by computer, informally regarded $P$. milleri as a subjective junior synonym of $P$. vera. $P$. milleri is considered herein to be a separate species because of the differences in morphology indicated above.

$P$. milleri differs from $P$. decipiens in having a thin mesotheca with exceedingly thin median hyaline calcitic layer and lacking discrete median rods. Endozones of $P$. milleri are narrower than those in $P$. decipiens (Boardman and Utgaard, 1966, text-fig. 7), generally less than $0.15 \mathrm{~mm}$ in width (tables 15,16$). P$. milleri differs further from $P$. decipiens (Boardman and Utgaard, 1966, pl. 135, table 2) in having thin autozooecial walls (tables 15, 16), few mesozooecia in intermacular and macular areas, and few and small styles. Mesozooecial diaphragms in $P$. decipiens (Boardman and Utgaard, 1966, pl. 135) appear to be more variable in thickness than those in P. milleri (pl. 11, fig. 4).

Morphologically, $P$. vera appears to be an intermediate form between $P$. milleri and $P$. decipiens. For morphological differences between $P$. vera and $P$. decipiens, see remarks under $P$. vera and the comparative description by Anstey and Perry (1969, p. 249).

\section{Peronopora vera Ulrich, 1888}

Plate 12

Peronopora vera Ulrich, 1888, p. 40 (an indication); Nickles, 1905, p. 46, pl. 2, fig. 1; Cumings, 1908, p. 867, pl. 22; figs. 2-2b, pl. 31, fig. 5; Cumings and Galloway, 1913, p. 52, pl. 17, figs. 2-2a; McFarlan, 1931, p. 96; Boardman and Utgaard, 1966, p. 1096; Anstey and Perry, 1969 , p. 245 , pls. 31,$32 ; 1973$, p. 22, pl. 19, figs. 1, 2, pl. 20, pl. 21, figs. 1-4.

Peronopora vera Ulrich; Parks and Dyer, 1922, p. 7, pl. 1, figs. 4, 5; pl. 5, fig. 3.

Peronopora vera Ulrich (not Nickles 1905); Fritz, 1976, p. 10, fig. 3a-d. not Peronopora vera Ulrich, Cumings and Galloway, 1915, p. 11, figs. 18, 20, pl. 12, fig. 22 (Anstey and Perry, 1969, p. 245).

Description.-Zoaria explanate, bifoliate, flattened, with explanate lateral expansions at right angles to vertical growth direction, occasionally convoluted, having conspecific overgrowth; parts of zoaria encrusting locally. Mesothecae thin, locally discontinuous, bifurcating occasionally, with exceedingly thin median layers without median rods. Mesothecae constitute imperforate basal layers of encrusting portions of zoaria.

In endozones, autozooecia contiguous, occurring alternately in longitudinal ranges, subrectangular in cross section with straight to slightly sinuous transverse and lateral walls. One to four basal diaphragms in most autozooecia. Cystiphragms few to common, two or more in most autozooecia, arising locally from mesotheca, decreasing in size distally.

In exozones, autozooecia in indistinct rhombic pattern, generally subcircular in cross section, partly contiguous, separated by mesozooecia.

Autozooecial walls relatively thick, locally irregularly variable in thickness, relatively thin in encrusting portions of zoaria and in conspecific overgrowth, commonly inflected by styles. Autozooecial boundaries narrowly to broadly serrated locally. Styles common, generally with thin cores, thickened sheaths, irregularly variable in thickness in some zoaria, generally occurring along autozooecial boundaries, locally offset, inflecting autozooecial walls, locally extending into zooecial chambers. Basal diaphragms common, planar to slightly curved, occurring at slightly oblique or right angles to chamber axis, generally scattered in autozooecia, locally evenly spaced, lacking in outer exozones of some autozooecia. Cystiphragms abundant, locally variable in size and shape, occurring in longitudinal, locally superimposed series, extending approximately twothirds of circumference of autozooecia along distal autozooecial walls, occasionally along entire autozooecium. Autozooecial lining thin, discontinous, occurring locally in some autozooecia.

Autozooecial chambers subcircular to subelliptical, locally irregularly variable in cross section, containing occasional poorly defined, elongated brown bodies.

Mesozooecia abundant, subcircular to subpolygonal in cross section, variable in size, locally coalescing, occasionally partly separating or surrounding some autozooecia. Mesozooecial diaphragms closely and evenly spaced, planar to slightly curved, concave distally, locally thickened, occasionally overlapping among coalescing mesozooecia.

Maculae common, indistinct, occurring regularly throughout exozones, consisting of polymorphs slightly larger and less regularly shaped than autozooecia and of mesozooecia variable in size and locally filled with 
zooecial skeletal deposits, occasionally having relatively large styles, in various combinations.

Measurements.-Measurements are summarized in table 17.

Geographic and stratigraphic distribution. $-P$. vera occurs in rocks of the Shermanian Stage, upper Middle Ordovician, in Kentucky and in rocks of the Edenian and Maysvillian stages, Upper Ordovician, in Kentucky, Ohio, and Indiana. The occurrence of $P$. vera in rocks of Late Ordovician age in Ontario needs to be verified (see below).

Occurrence in Kentucky.-Lexington Limestone: Millersburg Member; Shermanian Stage (USGS collns.: 7453-CO-7455-CO; 5066-CO; 7039-CO, 7041-CO7043-CO, 7046-CO, 7048-CO, 7059-CO, 7060-CO, 7065-CO; 7336-CO, 7337-CO), Edenian Stage (USGS collns. 7067-CO, 7070-CO, 7071-CO; 7320-CO, 7322-CO); Tanglewood Limestone Member, Edenian Stage (USGS colln. D1133-CO), and its Nicolas Bed, Edenian Stage (USGS colln. 5031-CO, 5032-CO). Clays Ferry Formation: Shermanian Stage (USGS collns. 7467-CO, 7469-CO, 7470-CO), Edenian Stage (USGS 5186-CO, 7472-CO, 5053-CO; 4907-CO, 5883-CO, 7478-CO). Point Pleasant Tongue, Shermanian Stage (USGS colln. 6922-CO), of the Clays Ferry Formation. Kope Formation, Edenian Stage (USGS colln. 6933-CO).

Specimens that appear to be morphologically intermediate between $P$. vera and $P$. milleri are tentatively assigned to $P$. vera. These specimens occur in the Millersburg Member, Shermanian Stage (USGS collns. D1208-CO; 4857-CO, 4858-CO), of the Lexington Limestone; the Clays Ferry Formation; Shermanian (USGS colln. D1312-CO) and Edenian stages (USGS collns. D1177-CO, D1190-CO; 6727-CO, 6743-CO, 6744-CO); the Point Pleasant Tongue, Edenian Stage (USGS colln. 6929-CO), of the Clays Ferry Formation; and the Kope Formation, Edenian Stage (USGS colln. 6930-CO).

Ulrich $(1888$, p. 40$)$ found $P$. vera in his "division Xlla" of the Upper Ordovician strata, approximately 270-275 ft above what was then the low-water mark of the Ohio River, near Covington and Newport, Ky. and Cincinnati, Ohio. The stratigraphic horizon at this level is roughly equivalent to that of deposits considered to be of the "McMicken" strata of the Eden Shale (the upper part of the Kope Formation of current usage) of Bassler (1906, p. 8). Nickles (1905, p. 47) noted that $P$. vera ranged through his "Eden" strata in Kentucky.

Anstey and Perry (1973, fig. 8) established that $P$. vera ranged throughout their Eden Shale (the Kope Formation of current usage) in Gallatin County, Ky.

Occurrence outside Kentucky. Cumings (1908, p. 868) and Cumings and Galloway (1913, p. 52) reportedly found P. vera in their "Eden," "Mt. Hope," and "Fairmount" strata, Upper Ordovician, at Tanners Creek in Indiana. Nickles $(1905$, p. 47) found $P$. vera in his "Eden" and "Mt. Hope" strata, Upper Ordovician, near Cincinnati.

Parks and Dyer (1922, p. 7) reported $P$. vera from the Danforth and Humber Members of the Dundas Formation of Parks (1925, p. 104), Upper Ordovician, at Toronto in Ontario. Fritz (1976) redescribed the material collected by Park and Dyer. These specimens, although similar to those occurring in the Upper Ordovician deposits in Kentucky, Indiana, and Ohio in zoarial growth habit and general zoarial morphology, differ from specimens in Kentucky and adjacent areas in lacking distinct styles and well-developed cystiphragm series (Fritz, 1976, fig. 3B, C). Furthermore, specimens of $P$. vera from the Dundas Formation, Ontario, appear to have autozooecia and mesozooecia with thicker walls, thicker basal diaphragms, and probably

TABLE 17.-Summarized measurements of specimens of Peronopora vera Ulrich

[Hypotypes USNM 308457 (USGS colln. 7453-CO), 308459, 308460 (USGS colln. 7454-CO), 308461 (USGS colln. 7455-CO), 308462 (USGS colln 7467_CO), 308464 (USGS colln . 7469-CO), 308454 (USGS colln. 5053-CO), 308483 (USGS colln. 7071-CO), 308488, 308489 (USGS colln. 7322-CO), 308453 (USGS colln. 5066-CO), 308490 (USGS colln. 7336-CO) All measurements in millimeters unless otherwise indicated

\begin{tabular}{|c|c|c|c|c|c|c|c|}
\hline & $\begin{array}{l}\text { Arithmetic } \\
\text { mean }\end{array}$ & $\begin{array}{c}\text { Standard } \\
\text { deviation } \\
\text { of mean }\end{array}$ & $\begin{array}{c}\text { Coefficient } \\
\text { of } \\
\text { variation }\end{array}$ & $\begin{array}{l}\text { 95-percent } \\
\text { confidence } \\
\text { interval } \\
\text { of mean }\end{array}$ & Range & $\begin{array}{c}\begin{array}{c}\text { Number } \\
\text { of } \\
\text { measurements }\end{array} \\
\end{array}$ & $\begin{array}{c}\text { Number } \\
\text { of } \\
\text { zoaria } \\
\text { measured }\end{array}$ \\
\hline Autozooecial chamber maximum diameter _-____ & 0.1860 & 0.0205 & 11.03 & $0.18-0.19$ & $0.14-0.23$ & 60 & 12 \\
\hline Autozooecial chamber minimum diameter - & .1475 & .0202 & 13.71 & $.14-.15$ & $.12-\quad .20$ & 60 & 12 \\
\hline Autozooecial wall thickness, exozone - & .0583 & .0139 & 27.42 & $.047-$ & $.02-$ & 60 & 12 \\
\hline Macular polymorph chamber maximum diameter -- & .2645 & .0211 & 7.99 & $.25-$ & $.23-$ & 20 & 8 \\
\hline Macular polymorph chamber minimum diameter -- & .2150 & .0291 & 13.54 & $.20-$ & $.16-$ & 20 & 8 \\
\hline Mesozooecial chamber maximum diameter - & .0930 & .0278 & 29.91 & $.09-$ & $.04-$ & 56 & 12 \\
\hline Autozooecia (number per $2 \mathrm{~mm}$ ) _- & 8.4468 & .9043 & 10.71 & $8.19-8.71$ & $7-10$ & 47 & 12 \\
\hline Autozooecia (number per $\mathrm{mm}^{2}$ ) - & 16.158 & 1.8384 & 11.38 & $15.56-16.76$ & -20 & 38 & 12 \\
\hline Mesozooecia (number per $\mathrm{mm}^{2}$ ) & 17.66 & 7.76 & 43.95 & $15.11-20.21$ & -39 & 38 & 12 \\
\hline Diaphragms (number per $\mathrm{mm}$ ) _-__- & 12.571 & .9759 & 7.76 & $11.67-13.47$ & -14 & 7 & 3 \\
\hline Cystiphragms (number per mm) & 12.452 & 2.0743 & 16.66 & $11.81-13.10$ & -17 & 42 & 11 \\
\hline Mesozooecial diaphragms (number per mm) & 18.57 & 2.8037 & 15.10 & $\begin{array}{ll}17.70 & -19.45\end{array}$ & -27 & 42 & 11 \\
\hline Endozone width - & .1287 & .0291 & 22.60 & $.12-.14$ & $.08-.20$ & 37 & 10 \\
\hline Exozone width (one side only) _-_-_- & 1.6184 & .8299 & 51.28 & $1.31-1.92$ & $.10-3.60$ & 31 & 9 \\
\hline
\end{tabular}


more mesozooecia per unit of area. Because of these differences in zoarial morphology, specimens occurring in the Dundas Formation in Ontario are questionably retained in $P$. vera.

Studied material.-Lectotype USNM 43943-2, designated by Anstey and Perry (1969, p. 249); paralectotypes USNM 308444-308447, from syntype suite USNM 43943, the upper part of their Eden Shale (approximate upper part of the Kope Formation of current usage), Upper Ordovician, Cincinnati.

Hypotypes USNM 308448 (USGS colln. D1133-CO), 308449 , 308450 (USGS colln. 4907-CO), 308451 (USGS colln. 5031-CO), 308452 (USGS colln. 5032-CO), 308453 (USGS colln. 5066-CO), 308454 (USGS colln. 5053-CO), 308455 (USGS colln. 5186-CO), 308456308458 (USGS colln. 7453-CO), 308459, 308460 (USGS colln. 7454-CO), 308461 (USGS colln. 7455-CO), 308462, 308463 (USGS colln. 7467-CO), 308464 (USGS colln. 7469-CO), 308465 (USGS colln. 7470-CO), 308466 (USGS colln. 7472-CO), 308467 (USGS colln. 7478-CO), 308468 (USGS colln. 6922-CO), 308469 (USGS colln. 6933-CO), 308470 (USGS colln. 5883-CO), 308471 (USGS colln. 7039-CO), 308472 (USGS colln. 7040-CO), 308473 (USGS colln. 7041-CO), 308474 (USGS colln. 7042-CO), 308475 (USGS colln. 7043-CO), 308476 (USGS colln. 7046-CO), 308477 (USGS colln. 7048-CO), 308478 (USGS colln. 7059-CO), 308479 (USGS colln. 7060-CO), 308480 (USGS colln. 7065-CO), 308481 (USGS colln. 7067-CO), 308482 (USGS colln. 7070-CO), 308483 (USGS colln. 7071-CO), 308484 (USGS colln. 7075-CO), 308485-308487 (USGS colln. 7320-CO), 308488, 308489 (USGS colln. 7322-CO), 308490, 308491 (USGS colln. 7336-CO), 308492 (USGS colln. 7337-CO), 308493 (USGS colln. D1208-CO), 308494 (USGS colln. D1177-CO), 308495 (USGS colln. 6727-CO), 308496 (USGS colln. 6733-CO), 308497 (USGS colln. 6744-CO), 308498 (USGS colln. D1312-CO), 308499 (USGS colln. 4857-CO), 308500 (USGS colln. 4858-CO), 308501 (USGS colln. 6929-CO), 308502 (USGS colln. 6930-CO).

Remarks. $-P$. vera has bifoliate zoaria that characteristically have relatively thin endozones and relatively thick, commonly uneven autozooecial walls in exozones and styles that are variable in size (pl. 12, fig. $2 b$ ).

$P$. vera is most closely related to $P$. milleri and $P$. decipiens (Anstey and Perry, 1969, p. 249). Morphologically and stratigraphically (see remarks under $P$. milleri), $P$. vera appears to be intermediate between $P$. milleri and $P$. decipiens.

$P$. vera and $P$. milleri have relatively thin mesothecae whose exceedingly thin median layers lack median rods, and have autozooecial and mesozooecial chambers of similar size (tables 15-17). They differ, however, in abundance of mesozooecia (tables 15-17), in size and distribution of styles, and, to a degree, width of endozones and thickness and appearance of autozooecial walls in exozones (see remarks under P. milleri).

$P$. vera and $P$. decipiens resemble one another in shape of autozooecia and mesozooecia, appearance of basal diaphragms and cystiphragms (pl. 12, figs. 2a, 4; Boardman and Utgaard, 1966, pl. 135, fig. 1f), and distribution of styles.

$P$. vera differs from $P$. decipiens (Boardman and Utgaard, 1966, pl. 135, fig. 1a, text-fig. 7; Singh; 1979, pl. 44, figs. $1 b, 2$ ), however, in having thin mesothecae without median rods and narrow endozones.

Anstey and Perry (1969, p. 249) showed in their redescription of primary types of $P$. vera that it differs further from $P$. decipiens in having fewer mesozooecia and styles in unit area and thicker autozooecial walls.

The morphological differences among zoaria of $P$. milleri, $P$. vera, and $P$. decipiens, which occur in stratigraphically ascending order from the Shermanian Stage, Middle Ordovician, to the Richmondian Stage, Late Ordovician, seem to exhibit a trend toward increase in thickness of mesothecae and zooecial walls and in number of mesozooecia and styles in unit area of a zoarium that follows the stratigraphical progression.

\section{Genus PRASOPORA Nicholson and Etheridge, 1877}

Type species.-Prasopora grayae Nicholson and Etheridge 1877, p. 392; "Craighead beds, Craighead Quarry, Ayrshire," Great Britain.

Remarks.-Ross (1967a) emended the concept for the genus Prasopora; her diagnosis for the genus is followed herein.

\section{Prasopora falesi (James, 1884)}

Plates 13, 14

Monticulipora falesi James, 1884, p. 138, pl. 7, figs. 2-2d; James and James, 1888, p. 168; James, J. F., 1894, p. 185.

Prasopora falesi (James). Bassler, 1906, p. 48, pl. 1, figs. 1-4; McFarlan, 1931, p. 95, pl. 2, figs. 11-12; Brown, 1965, p. 985, pl. 112, figs. 3, 5-7; Marintsch, 1981, p. 957, pls. 1-2.

Prasopora simulatrix? Ulrich, 1886, of Brown 1965, p. 983, pl. 112, figs. $1,2,4,8$.

Description.-Zoaria discoidal to hemispherical, variable in size, approximately $10-100 \mathrm{~mm}$ wide at base, $10-30 \mathrm{~mm}$ high on the average, commonly with concave lateral surfaces locally.

Zoarial basal layers exceedingly thin, imperforate, thinly laminated or nonlaminate locally. Basal layers occasionally bifurcated in some zoaria, extending distally, forming mesothecalike budding surfaces from which autozooecia bud in opposite directions.

Endozones narrow, indistinct. In endozones, autozooecia recumbent for short distances, becoming erect at 
base of exozones, generally extending distally at right or slightly oblique angles to basal layers.

In exozones, autozooecia erect in zoarial centers, slightly curving outward laterally, occurring at right angles to zoarial surface, sparingly intercalated in inner exozones, more commonly in outer exozones; arising occasionally from mesozooecia; zones of autozooecial rejuvenation sparse.

Autozooecia straight to slightly sinuous, subpolygonal to subcircular in cross section, without preferred alignment, partly contiguous, separated by mesozooecia, locally contiguous in outer exozones. Autozooecial walls generally thin, approximately $0.01-0.02 \mathrm{~mm}$ thick on the average, thickened locally by styles. Autozooecial boundaries narrowly serrated throughout zoaria. Styles common, scattered, occurring generally in autozooecial and mesozooecial corners, occasionally inflecting zooecial walls, projecting locally into zooecial chambers. Style cores exceedingly thin, nonlaminated; sheaths laminated, variable in thickness; sheath laminae occasionally transecting cores locally.

Cystiphragms abundant, occurring generally in longitudinal, rarely superimposed series, extending approximately two-thirds to three-fourths of circumference of autozooecia, locally around entire autozooecium. Cystiphragms occasionally occurring singly or lacking locally in outer exozones of some autozooecia.

Basal diaphragms abundant, planar or slightly curved, concave distally, occurring at right angles to chamber axis, abutting autozooecial walls and cystiphragms; generally evenly spaced, occasionally scattered or lacking in late exozones of some autozooecia.

Mesozooecia common to abundant, polygonal to subpolygonal in cross section, variable in size, partly separating, locally surrounding autozooecia in intermacular areas, occurring in clusters in maculae. Mesozooecia arising and terminating throughout exozones, terminating more commonly in outer exozones, occasionally extending distally as autozooecia. Mesozooecial walls straight or slightly inflected at junctions with diaphragms, locally thickened by styles. Mesozooecial diaphragms abundant, evenly and closely spaced.

Maculae common, generally on level with zoarial surface, centers approximately 3-4 mm apart, occurring in rhombic pattern. Maculae consisting of clusters of mesozooecia, variable in size, at centers and of polymorphs slightly larger than autozooecia in margins, intergrading gradually in size with autozooecia. Chambers of polymorphs generally extending along zooecial walls facing centers of maculae.

Measurements.-Measurements are summarized in tables 18-20.

Geographic and stratigraphic distribution.-Prasopora falesi is found only in Kentucky, where it occurs in rocks of Kirkfieldian and Shermanian stages, Middle Ordovician. In the Lexington Limestone it occurs in the Grier Limestone Member, Kirkfieldian (USGS collns. D1235-CO-D1237-CO; D1198-CO; 4944-CO, $4947-\mathrm{CO}, 4948-\mathrm{CO}$ ) and Shermanian stages (USGS collns. D1294-CO; 4680-CO-4682-CO, 4688-CO, 4689-CO, 4691-CO, 4693-CO; 4863-CO, 4866-CO, 4870-CO, 4872-CO, 4878-CO; D1153-CO; 4954-CO, 4957-CO, 4958-CO, 4927-CO; D1110-CO; 4963-CO); the Brannon Member, Shermanian Stage (USGS colln. 4973-CO); the Sulphur Well Member, Shermanian Stage (USGS collns. D1163-CO; 4935-CO); Tanglewood Limestone Member, Shermanian Stage (USGS colln. 4976-CO). In the Clays Ferry Formation, it occurs in the Shermanian Stage (USGS collns. 4893-CO, 7476-CO).

Studied material.-Monticulipora falesi James, 1884, lectotype Field Museum of Natural History No. 740, "Lexington Limestone" of Bassler, 1906, p. 48, near Danville, Ky.

Hypotypes USNM 308503 from the hypotype suite USNM 44237, "Trenton" strata, Middle Ordovician, near Danville.

Hypotypes USNM 308504 (USGS colln. D1198-CO),

TABLE 18.-Summarized measurements of specimens of Prasopora falesi (James)

[Hypotypes USNM 308537 (USGS colln. 4863_CO), 308541-308543 (USGS colln. 4867-CO), 308546, 308547 (USGS colln. 4872_CO), 308549 (USGS colln. 4893 -CO), 308548 (USGS colln. 4878-CO), 308538 (USGS colln. 4863-CO), 308545 (USGS colln. 4870-CO). All measurements in millimeters unless otherwise indicated)

\begin{tabular}{|c|c|c|c|c|c|c|c|}
\hline & $\begin{array}{l}\text { Arithmetic } \\
\text { mean }\end{array}$ & $\begin{array}{l}\text { Standard } \\
\text { deviation } \\
\text { of mean }\end{array}$ & $\begin{array}{c}\text { Coefficient } \\
\text { of } \\
\text { variation }\end{array}$ & $\begin{array}{l}\text { 95-percent } \\
\text { confidence } \\
\text { interval } \\
\text { of mean }\end{array}$ & Range & $\begin{array}{c}\begin{array}{c}\text { Number } \\
\text { of } \\
\text { measurements }\end{array} \\
\text { S }\end{array}$ & $\begin{array}{c}\text { Number } \\
\text { of } \\
\text { zoaria } \\
\text { measured }\end{array}$ \\
\hline Autozooecial chamber maximum diameter & 0.2427 & 0.0229 & 9.42 & $0.24-0.25$ & $0.21-0.29$ & 40 & 8 \\
\hline Autozooecial wall thickness, exozone & .0260 & .0106 & 41.34 & $.02-.03$ & $.01-.04$ & 10 & 2 \\
\hline Macular polymorph chamber maximum diameter -_- & .3295 & .0536 & 16.28 & $.31-.35$ & $.21-$ & 38 & 8 \\
\hline Macular polymorph wall thickness & .0280 & .0216 & 77.42 & $.001-$ & $.01-$ & 5 & 1 \\
\hline Mesozooecial chamber maximum diameter & .0595 & .0247 & 41.51 & $.05-.07$ & $.02-.12$ & 40 & 8 \\
\hline Autozooecial diaphragms (number per $\mathrm{mm}$ ) & 8.2195 & 1.8909 & 23.0 & $7.62-8.82$ & $4-12$ & 41 & 8 \\
\hline Autozooecia (number per $\mathrm{mm}^{2}$ ) & 11.250 & 1.730 & 15.38 & $10.67-11.84$ & -15 & 36 & 8 \\
\hline Mesozooecia (number per $\mathrm{mm}^{2}$ ) & 17.333 & 4.3293 & 24.98 & $15.87-18.80$ & -26 & 36 & 8 \\
\hline Mesozooecial diaphragms (number per $\mathrm{mm}$ ) & 20.286 & 3.3806 & 16.67 & $19.23-21.34$ & -29 & 42 & 9 \\
\hline Cystiphragms (number per $\mathrm{mm}$ ) - & 9.0222 & 1.4379 & 15.94 & $8.59-9.45$ & $6-13$ & 45 & 9 \\
\hline Distance between centers of maculae & 3.550 & .0707 & 1.99 & $2.91-4.19$ & $3.50-3.60$ & 2 & 1 \\
\hline Styles (number per $\mathrm{mm}^{2}$ ) - & 6.5517 & 3.3973 & 51.85 & $5.26-7.84$ & $2-18$ & 29 & 6 \\
\hline
\end{tabular}


TABLE 19.-Summarized measurements of specimens of Prasopora falesi (James)

[Hypotypes USNM 308504 (USGS colln. D1198-CO), 308508 (USGS colln. 4680-CO), 308510 (USGS colln. 4681-CO), 308512 (USGS colln. 4682-CO), 308514-308517 (USGS colln. 4688-CO), 308518, 308519 (USGS colln. 4689-CO). All measurements in millimeters unless otherwise indicated]

\begin{tabular}{|c|c|c|c|c|c|c|c|}
\hline & $\begin{array}{c}\text { Arithmetic } \\
\text { mean }\end{array}$ & $\begin{array}{c}\text { Standard } \\
\text { deviation } \\
\text { of mean }\end{array}$ & $\begin{array}{c}\text { Coefficient } \\
\text { of } \\
\text { variation }\end{array}$ & $\begin{array}{c}\text { 95-percent } \\
\text { confidence } \\
\text { interval } \\
\text { of mean } \\
\end{array}$ & Range & $\begin{array}{c}\begin{array}{c}\text { Number } \\
\text { of } \\
\text { measurements }\end{array} \\
\end{array}$ & $\begin{array}{c}\text { Number } \\
\text { of } \\
\text { zoaria } \\
\text { measured }\end{array}$ \\
\hline Autozooecial chamber maximum diameter _-_____ & 0.2582 & 0.0226 & 8.74 & $0.25-0.26$ & $0.21-0.31$ & 50 & 10 \\
\hline Autozooecial wall thickness, exozone - & .0173 & .008 & 46.09 & $.01-\quad .02$ & $.01-.03$ & 15 & 3 \\
\hline Macular polymorph chamber maximum diameter --_ & .3463 & .0523 & 15.10 & $33-$ & $.21-$ & 40 & 8 \\
\hline Macular polymorph wall thickness & .0235 & .0127 & 53.96 & $.02-$ & $.01-$ & 20 & 4 \\
\hline Mesozooecial chamber maximum diameter _________ & .0680 & .0286 & 42.02 & $.06-.08$ & $.03-.15$ & 50 & 10 \\
\hline Autozooecial diaphragms (number per $\mathrm{mm}$ ) & 6.8182 & 1.3686 & 20.07 & $6.40-7.23$ & $4-10$ & 44 & 9 \\
\hline Autozooecia (number per $\mathrm{mm}^{2}$ ) - & 11.575 & 1.8382 & 15.88 & $10.99-12.16$ & -16 & 40 & 8 \\
\hline Mesozooecia (number per $\mathrm{mm}^{2}$ ) & 24.564 & 8.6657 & 35.28 & $21.75-27.37$ & -41 & 39 & 8 \\
\hline Mesozooecial diaphragms (number per $\mathrm{mm}$ ) & 19.958 & 5.0189 & 25.15 & $18.50-21.42$ & -39 & 48 & 10 \\
\hline Cystiphragms (number per $\mathrm{mm}$ ) & 9.3125 & 3.4342 & 36.87 & $8.32-10.31$ & $6-23$ & 48 & 10 \\
\hline Distance between centers of maculae & 3.150 & .3697 & 11.74 & $2.56-3.74$ & $3.10-4.20$ & 4 & 1 \\
\hline Styles (number per $\mathrm{mm}^{2}$ ) & 3.50 & 2.6458 & 75.59 & $1.82-5.18$ & $1-10$ & 12 & 4 \\
\hline
\end{tabular}

TABLE 20.-Summarized measurements of specimens of Prasopora falesi (James)

[Hypotypes USNM 308550, 308551 (USGS colln. 4944_CO), 308552, 308553 (USGS colln. 4945_CO), 308554, 308555 (USGS colln. 4947-CO), 308556-308558 (USGS colln. 4948-CO), 308559 (USGS colln. 4954-CO), 308560 (USGS colln. 4957-CO), 308562 (USGS colln. 4958-CO), 308563, 308564 (USGS colln. 4927-CO), 308565 (USGS colln. 4939-CO), 308566 (USGS colln. 4935-CO). All measurements in millimeters unless otherwise indicated)

\begin{tabular}{|c|c|c|c|c|c|c|c|}
\hline & $\begin{array}{c}\text { Arithmetic } \\
\text { mean }\end{array}$ & $\begin{array}{c}\text { Standard } \\
\text { deviation } \\
\text { of mean }\end{array}$ & $\begin{array}{c}\text { Coefficient } \\
\text { of } \\
\text { variation }\end{array}$ & $\begin{array}{c}\text { 95-percent } \\
\text { confidence } \\
\text { interval } \\
\text { of mean }\end{array}$ & Range & $\begin{array}{c}\begin{array}{c}\text { Number } \\
\text { of } \\
\text { measurements }\end{array} \\
\end{array}$ & $\begin{array}{c}\text { Number } \\
\text { of } \\
\text { zoaria } \\
\text { measured }\end{array}$ \\
\hline Autozooecial chamber maximum diameter _-_____- & 0.2513 & 0.0185 & 7.35 & $0.25-0.26$ & $0.22-0.29$ & 75 & 15 \\
\hline Macular polymorph chamber maximum diameter - - - & .3297 & .0454 & 13.78 & $.32-\quad .34$ & $.18-.42$ & 60 & 12 \\
\hline Mesozooecial chamber maximum diameter - & .0696 & .0293 & 42.15 & $.06-.07$ & $.02-\quad .14$ & 75 & 15 \\
\hline Autozooecial diaphragms (number per $\mathrm{mm}$ ) & 7.8936 & 1.6317 & 20.67 & $7.41-8.37$ & $5-12$ & 47 & 11 \\
\hline Autozooecia (number per $\mathrm{mm}^{2}$ ) & 10.844 & 1.2875 & 11.873 & $10.52-11.17$ & -15 & 64 & 15 \\
\hline Mesozooecia (number per $\mathrm{mm}^{2}$ ) & 13.422 & 5.1665 & 38.49 & $12.13-14.71$ & -27 & 64 & 15 \\
\hline Mesozooecial diaphragms (number per $\mathrm{mm}$ ) _.... & 18.034 & 2.5862 & 14.34 & $17.36-18.71$ & -24 & 59 & 14 \\
\hline Cystiphragms (number per $\mathrm{mm}$ ) & 8.5143 & 2.1585 & 25.35 & $8.0-9.02$ & -16 & 70 & 14 \\
\hline Styles (number per $\mathrm{mm}^{2}$ ) - & 4.7593 & 3.0649 & 64.40 & $3.92-5.60$ & -18 & 54 & 14 \\
\hline
\end{tabular}

308505-308509 (USGS colln. 4680-CO), 308510, 308511 (USGS colln. 4681-CO), 308512, 308513(USGS colln. 4682-CO), 308514-308517 (USGS colln. 4688-CO), 308518, 308519 (USGS colln. 4689-CO), 308520 (USGS colln. 4691-CO), 308521 (USGS colln. 4691-CO), 308522 (USGS colln. 4691-CCO), 308523 (USGS colln. 4693-CO), 308524 (USGS colln. 4963-CO), 308525 (USGS colln. 4973-CO), 308526 (USGS colln. 4976-CO), 308527 (USGS colln. D1110-CO), 308528 (USGS colln. D1294-CO), 308529 (USGS colln. D1295-CO), 308530 (USGS colln. D1299-CO), 308531 (USGS colln. D1235-CO), 308532 (USGS colln. D1236-CO), 308533 (USGS colln. D1237-CO), 308534 (USGS colln. D1153-CO), 308535 (USGS colln. D1163-CO), 308536-308538 (USGS colln. 4863-CO), 308539 (USGS colln. 4866-CO), 308540308544 (USGS colln. 4867-CO), 308545 (USGS colln. 4870-CO), 308546, 308547 (USGS colln. 4872-CO), 308548 (USGS colln. 4878-CO), 308549 (USGS colln. 4893-CO), 308550, 308551 (USGS colln. 4944-CO), 308552, 308553 (USGS colln. 4945-CO), 308554, 308555 (USGS colln. 4947-CO), 308556-308558 (USGS colln. 4948-CO), 308559 (USGS colln. 4954-CO), 308560 (USGS colln. 4957-CO), 308561, 308562 (USGS colln. 4958-CO), 308563, 308564 (USGS colln. 4927-CO), 308565 (USGS colln. 4939-CO), 308566
(USGS colln. 4935-CO), 308567 (USGS colln. 7467-CO)

Remarks.-Prasopora falesi characteristically has distinct small and relatively large styles as well as abundant mesozooecia throughout intermacular areas and in clusters in maculae and proximately onlapping cystiphragms in regular series, extending two-thirds to three-fourths the circumference of autozooecia (cystiphragm type 1 of Ross, 1967 a, p. 406) in most parts of exozones. Cystiphragms, however, occasionally occur singly and are restricted laterally in outer exozones of autozooecia of $P$. falesi.

$P$. falesi is closely related to $P$. simulatrix Ulrich. The species are similar in their hemispherical growth habits, the shape and size of their autozooecia, the distribution of their basal diaphragms, the shape and general arrangement of their cystiphragms, and their polymorphism.

$P$. falesi differs from $P$. simulatrix, however, in having distinct styles throughout exozones. Styles in $P$. simulatrix (acanthopores of Bork and Perry, 1968b, p. 1058) are commonly lacking, or are exceedingly small and occur, sparingly, only in peripheral parts of zoaria (the acanthoporelike structures of Ross, 1967a, p. 412).

$P$. falesi and $P$. simulatrix both have cystiphragms of type 1 of Ross (1967a). P. falesi, however, differs from 
P. simulatrix in having cystiphragms that occasionally occur singly or in pairs and are locally restricted laterally.

Both species have numerous mesozooecia that partly separate autozooecia, but $P$. falesi has fewer mesozooecia than $P$. simulatrix. $P$. falesi has approximately 20 mesozooecia per unit of area in exozones (tables 18-20), whereas $P$. simulatrix has approximately 27 (Bork and Perry, 1968b, tables 12-14), or between 22 and 50 per unit of area on the average (Ross, 1967a, table 1) in intermacular areas.

Brown (1965, p. 983) found specimens of Prasopora with exceedingly small styles throughout exozones in his undivided "Logana-Jessamina Limestone members" of the Lexington Limestone (the Logana and Grier Limestone Members, respectively, of the Lexington Limestone of current usage) in central Kentucky, and tentatively assigned them to $P$. simulatrix? Ulrich.

Specimens (pl. 13, fig. 4) of this study that are similar to $P$. simulatrix? Ulrich of Brown occur together with typical $P$. falesi specimens in the same collections or occur in separate collections from alternate superimposed strata at several localities in central Kentucky. Zoaria having small and large styles are thus found together in the same collections or in separate collections from vertically and laterally adjacent strata. Because these specimens do not differ qualitatively or quantitatively in characters other than size of styles, they appear to be from the same hypothetical population and thus are regarded as belonging to the same species and are assigned $P$. falesi.

In addition to $P$. falesi, $P$. discula (Coryell, 1921, p. 283), from the Pierce Limestone, Middle Ordovician, Tennessee, and the Lower Chickamauga Group as used by McKinney, 1971, Middle Ordovician, Alabama and several other species of Prasopora possess distinct styles (the acanthopores of authors). They include $P$. compacta (Coryell, 1921, p. 283; McKinney, 1971, p. 229) from the Pierce Limestone, Middle Ordovician, Tennessee; $P$. nodosa Ulrich $(1882$, p. 245) from the "Safford's Orthis bed" of Ulrich, Tennessee (now Hermitage Formation, Middle Ordovician, Wilmarth, 1957, p. 1564); P. hybrida Fritz (1957, p. 32) from the Cobourg beds, Ottawa Formation of Fritz, Middle Ordovician, Ottawa-St. Lawrence Lowland, Ontario; and $P$. richmondensis Fritz (1976, p. 18) from the Meaford Formation of Fritz, Upper Ordovician, in Ontario.

$P$. discula differs from $P$. falesi in having more cystiphragms in unit length of autozooecia, fewer and larger mesozooecia, and maculae without clusters of mesozooecia. Styles are present or absent in P. discula (McKinney, 1971).

$P$. compacta (Coryell) differs from $P$. falesi in having irregular dendroid growth habit, autozooecia and mesozooecia with crenulated walls locally, few mesozooecia and to a degree in appearance of zooecial wall microstructure (Coryell, 1921, pl. 4, figs. 5, 6).

$P$. nodosa Ulrich differs from $P$. falesi in having cystiphragms that are irregularly shaped and generally isolated distally and laterally (Ulrich, 1882, pl. 11, fig. 1a). Maculae (the monticules of Ulrich) in P. nodosa are slightly raised and irregularly shaped, and commonly coalesce. Maculae in $P$. falesi are discrete and on a level with the zoarial surface.

$P$. hybrida Fritz differs from $P$. falesi in having maculae without clustered mesozooecia. $P$. richmondensis Fritz (1976, table 5) has smaller autozooecia than those of $P$. falesi and irregularly shaped maculae that are raised and lack clusters of mesozooecia.

Ross (1967a) recognized that the changes in shape and general arrangement of cystiphragms in Prasopora reflect significant evolutionary trends. Cystiphragms type 1 of Ross (1967a) onlap proximately in regular longitudinal series, extending around three-fourths to four-fifths of the circumference of autozooecia, and appear first in species of Prasopora of Wilderness age, Middle Ordovician (McKinney, 1971, p. 225), ranging throughout the "Trenton" rocks of Ross (1967a), Middle Ordovician. In the upper part of the Trenton Group, cystiphragms in species of Prasopora become gradually more separated distally and laterally in outer exozones. This trend resulted in one lineage with isolate and bulbous cystiphragms (cystiphragms type 3 of Ross, 1967a).

$P$. falesi, $P$. simulatrix, and $P$. discula have cystiphragms of type 1 of Ross, but in $P$. falesi (pl. 13, fig. 1b) cystiphragms tend to become separated and restricted laterally in outer exozones of autozooecia (McKinney, 1971 , p. 225). Thus $P$. falesi appears to be a stage in the development of cystiphragms that resulted in the evolution of the cystiphragm type 3 of Ross in strata of the upper part of the Trenton Group of Ross (1967a).

McKinney (1971, p. 225) thought he recognized this trend toward gradual separation of cystiphragms vertically and restriction laterally from $P$. discula to $P$. falesi, and suggested that $P$. falesi might have descended from $P$. discula. The trend apparently was accompanied in $P$. falesi by reduction in the number of cystiphragms per unit of length (tables 18-20) (McKinney, 1971, tables 9, 10).

\section{Family HETEROTRYPIDAE Genus CYPHOTRYPA Ulrich and Bassler, 1904}

Type species.-Leptotrypa acervulosa Ulrich, 1893, p. 318; subsequently designated by Ulrich and Bassler, 1904, p. 29; "Galena Shales" of Ulrich, 1893 (the approximate stratigraphic equivalent of the "Cummings- 
ville Member" of the Galena Dolomite of current usage), Middle Ordovician, Decorah, Iowa.

Remarks.-The original definition of the genus Cyphotrypa, by Ulrich and Bassler (1904, p. 29), is followed here. Ulrich and Bassler (1904) characterized Cyphotrypa as having massive zoaria in which autozooecia have thin walls, polygonal shapes in cross section, and abundant basal diaphragms and styles (acanthopore of Ulrich and Bassler), but lack mesozooecia (their mesopores). C. switzeriensis $\mathbf{n}$. sp. described here, conforms to this characterization except for its apparent absence of styles in zoaria.

\section{Cyphotrypa acervulosa (Ulrich, 1893) \\ Plate 15, figures $3-5$}

Leptotrypa acervulosa Ulrich, 1893, p. 318, pl. 27, figs. 24, 25.

Cyphotrypa acervulosa (Ulrich). Ulrich and Bassler, 1904, p. 30, pl. 8,

figs. 1-3; Brown, 1965, p. 986, pl. 113, figs. 1-3.

Description.-Zoaria globular to subglobular, irregularly variable in size.

Endozones and exozones poorly differentiated. Autozooecia contiguous, polygonal in cross section, five- to six-sided throughout zoaria.

In endozones, autozooecia subparallel, approximately at right angles to basal layer, with exceedingly thin walls. Basal diaphragms abundant, generally planar, evenly spaced.

In exozones, autozooecia sparingly intercalated, straight, erect, gently curving outward in outer exozones. Autozooecial walls broadly sinuous, only slightly thicker in exozones than endozones, with slightly swelled portions locally. Autozooecial boundaries poorly defined or obscured, commonly narrowly serrated, locally broadly serrated in swelled portions of autozooecial walls. Styles common, inconspicuous, generally less than $0.01 \mathrm{~mm}$ in cross section, with exceedingly thin cores; occurring in corners between autozooecia, occasionally extending into autozooecial chambers. Basal diaphragms abundant, planar to slightly curved, commonly convex distally, evenly and more closely spaced in exozones than endozones; occurring approximately at right angles to chamber axis. Cystoidal diaphragms scattered throughout exozones. Zones of closely spaced basal diaphragms and a few cystoidal diaphragms occurring locally. Zones of rejuvenation of autozooecia scattered, locally occurring distally to zones of closely spaced basal and cystoidal diaphragms.

Maculae sparse to absent, poorly defined in cross section, consisting of polymorphs slightly larger than autozooecia, polygonal in cross section.

Measurements.-Measurements are summarized in tables 21 and 22.

Geographic and stratigraphic distribution.-C. acervulosa appears to be widely distributed in rocks of late Champlainian age, Middle Ordovician, in northeastern North America.

Occurrence in Kentucky.-Grier Limestone Member: Kirkfieldian Stage (USGS colln. D1237-CO) and Shermanian Stage (USGS colln. 4968-CO, 4969-CO, 4971-CO); Brannon Member, Shermanian Stage (USGS colln. 4974-CO); and Tanglewood Limestone Member, Shermanian Stage (USGS colln. 4976-CO), of the Lexington Limestone.

Ulrich (1893, p. 318) reported C. acervulosa (as Leptotrypa) from his "shaly part of the Trenton" at Frankfort and Burgin, Ky. Brown (1965, p. 987) described $C$. acervulosa from his undivided "Logana-Jessamine Limestone Members" of the Lexington Limestone in Woodford County (the Logana and Grier Limestone Members, respectively, of the Lexington Limestone of current usage).

Occurrence outside Kentucky.-Ulrich (1893, p. 318)

TABLE 21.-Summarized measurements of specimens of Cyphotrypa acervulosa (Ulrich) [Holotype USNM 43189, paratype USNM 308568, and hypotypes USNM 308569, 308570. All measurements in millimeters unless otherwise indicated]

\begin{tabular}{|c|c|c|c|c|c|c|c|}
\hline & $\begin{array}{l}\text { Arithmetic } \\
\text { mean }\end{array}$ & $\begin{array}{c}\text { Standard } \\
\text { deviation } \\
\text { of mean }\end{array}$ & $\begin{array}{c}\text { Coefficient } \\
\text { of } \\
\text { variation }\end{array}$ & $\begin{array}{l}\text { 95-percent } \\
\text { confidence } \\
\text { interval } \\
\text { of mean }\end{array}$ & Range & $\begin{array}{c}\begin{array}{c}\text { Number } \\
\text { of } \\
\text { measurements }\end{array}\end{array}$ & $\begin{array}{c}\text { Number } \\
\text { of } \\
\text { zoaria } \\
\text { measured }\end{array}$ \\
\hline Autozooecial chamber maximum diameter & 0.2687 & 0.0423 & 15.75 & $0.25-0.28$ & $0.20-0.36$ & 30 & 5 \\
\hline Autozooecial chamber minimum diameter & .2243 & .0396 & 17.66 & $.21-.24$ & $.16-.33$ & 30 & 5 \\
\hline Autozooecia (number per $\mathrm{mm}^{2}$ ) & 16.545 & 2.3447 & 14.17 & $15.51-17.59$ & $12-21$ & 22 & 5 \\
\hline Diaphragms (number per mm) - & 6.6333 & 1.5862 & 23.91 & $6.04-7.23$ & -10 & 30 & $\mathbf{5}$ \\
\hline
\end{tabular}

TABLE 22.-Summarized measurements of specimens of Cyphotrypa acervulosa (Ulrich) [Hypotypes USNM 308571, 308572 (USGS colln. 4968-CO), 308574 (USGS colln. 4971-CO). All measurements in millimeters unless otherwise indicated]

\begin{tabular}{|c|c|c|c|c|c|c|c|}
\hline & $\begin{array}{c}\text { Arithmetic } \\
\text { mean }\end{array}$ & $\begin{array}{c}\text { Standard } \\
\text { deviation } \\
\text { of mean }\end{array}$ & $\begin{array}{c}\text { Coefficient } \\
\text { of } \\
\text { variation }\end{array}$ & $\begin{array}{c}\text { 95-percent } \\
\text { confidence } \\
\text { interval } \\
\text { of mean }\end{array}$ & Range & $\begin{array}{c}\begin{array}{c}\text { Number } \\
\text { of } \\
\text { measurements }\end{array} \\
\end{array}$ & $\begin{array}{c}\text { Number } \\
\text { of } \\
\text { zoaria } \\
\text { measured }\end{array}$ \\
\hline Autozooecial chamber maximum diameter - & 0.2775 & 0.0382 & 13.78 & $0.26-0.30$ & $0.22-0.34$ & 20 & 4 \\
\hline Autozooecial chamber minimum diameter -__ & .2210 & .0259 & 14.75 & $.21-.24$ & $.16-\quad .28$ & 20 & 4 \\
\hline Autozooecia (number per $\mathrm{mm}^{2}$ ) & 13.60 & 2.5906 & 19.05 & $11.75-15.45$ & $10-18$ & 10 & 4 \\
\hline Diaphragms (number per $\mathrm{mm}$ ) & 6.9375 & 2.7195 & 39.20 & $5.49-8.39$ & -14 & 16 & 4 \\
\hline
\end{tabular}


found C. acervulosa (as Leptotrypa) in his "Galena Shales" (the approximate stratigraphic equivalent of the "Cummingsville Member" of the Galena Dolomite), Middle Ordovician, at Decorah, Iowa, and in Goodhue County, Minn. In addition, Ulrich and Bassler (1904, p. 31 indicated that $C$. acervulosa apparently occurred in their "Trenton" strata, Middle Ordovician, in Ontario.

Studied material.-Holotype USNM 43189 and paratype USNM 308568 from the primary type suite USNM 43189, "Galena Shales" of Ulrich, 1893, Middle Ordovician, Decorah, Iowa.

Hypotypes USNM 308569, 308570 from the "Trenton Group," Middle Ordovician, Decorah, Iowa.

Hypotypes USNM 308571, 308572 (USGS colln. 4968-CO), 308573 (USGS colln. 4969-CO), 308574 (USGS colln. 4971-CO), 308575 (USGS colln. 4974-CO), 308576 (USGS colln. 4976-CO), 308577 (D1237-CO).

$$
\begin{gathered}
\text { Cyphotrypa switzeriensis n. sp. } \\
\text { Plate 16, figures } 2,3
\end{gathered}
$$

Etymology.-The trivial name of Cyphotrypa switzeriensis is derived from the name of the Switzer quadrangle, one of the quadrangles where the species is found in Kentucky.

Description.-Zoaria globular to subglobular, irregularly variable in size, one specimen approximately 3-4 $\mathrm{cm}$ wide at base, $3 \mathrm{~cm}$ in height at center of zoarium.

Endozones and exozones poorly differentiated. Autozooecia in endozones generally straight, erect, subparallel, contiguous, polygonal, five- to six-sided in cross section, with exceedingly thin walls throughout zoaria. Zones of rejuvenation sparse to absent.

In exozones autozooecia intercalated sparingly; autozooecial walls straight to irregularly crenulated locally; intercalated autozooecia occasionally having crenulated proximal wall portions. Autozooecial boundaries commonly obscured, locally narrowly serrated. Basal diaphragms sparse to absent, planar to slightly curved, generally at right angles to autozooecial chamber axis. Basal diaphragms occurring singly or in zones of two to three locally at similar ontogenetic stages in late exozones. Cystoidal diaphragms absent. Autozooecial chambers polygonal in cross section. Maculae generally absent.

Measurements.-Measurements are summarized in tables 23 and 24.

Geographic and stratigraphic distribution.-C. switzeriensis is known only from Kentucky, where it occurs in the Grier Limestone Member, Shermanian Stage (USGS collns. D1113-CO, D1117-CO; D1306-CO, D1307-CO), of the Lexington Limestone.

Studied material.-Holotype USNM 308578 (USGS colln. D1113-CO) and paratypes USNM 308579-308581 (USGS colln. D1117-CO), 308582 (USGS colln. D1306-CO), 308583 (USGS colln. D1307-CO).

Remarks.-Specimens assigned to C. switzeriensis $\mathrm{n}$. sp. are considered to be Cyphotrypa because these zoaria have autozooecia whose thin walls consist of indistinct and broadly curved laminae, are polygonal in cross section, and lack mesozooecia (pl. 16, figs. 2, 3). In addition, these specimens show the globular zoarial growth habit common to Cyphotrypa.

C. switzeriensis is closely related to C. acervulosa (Ulrich), the type species of the genus, which has autozooecia that are similar in polygonal shape in cross section (pl. 15, fig. $4 a$; pl. 16, fig. $3 d$ ) and in autozooecial chamber size (tables 21-24). Both species also have globular growth habit and poorly differentiated endozones and exozones, and lack mesozooecia.

C. switzeriensis $\mathrm{n}$. sp. differs from C. acervulosa and other Cyphotrypa species in its autozooecial walls, which are locally crenulated, in the sparseness and distribution of its basal diaphragms, and in its lack of

TABLE 23.-Summarized measurements of specimens of Cyphotrypa switzeriensis $n$. sp.

\begin{tabular}{|c|c|c|c|c|c|c|c|}
\hline & $\begin{array}{c}\text { Arithmetic } \\
\text { mean }\end{array}$ & $\begin{array}{c}\text { Standard } \\
\text { deviation } \\
\text { of mean }\end{array}$ & $\begin{array}{c}\text { Coefficient } \\
\text { of } \\
\text { variation }\end{array}$ & $\begin{array}{l}\text { 95-percent } \\
\text { confidence } \\
\text { interval } \\
\text { of mean }\end{array}$ & Range & $\begin{array}{c}\begin{array}{c}\text { Number } \\
\text { of } \\
\text { measurements }\end{array}\end{array}$ & $\begin{array}{c}\text { Number } \\
\text { of } \\
\text { zoaria } \\
\text { measured }\end{array}$ \\
\hline $\begin{array}{l}\text { Autozooecial chamber maximum diameter } \\
\text { Autozooecial chamber minimum diameter } \\
\text { Autozooecia (number per } \mathrm{mm}^{2} \text { ) }\end{array}$ & $\begin{array}{r}0.2667 \\
.2230 \\
15.174\end{array}$ & $\begin{array}{r}0.0415 \\
.4388 \\
.2964\end{array}$ & $\begin{array}{l}15.58 \\
19.68 \\
19.54\end{array}$ & $\begin{array}{r}0.25-0.28 \\
.21-\quad .24 \\
13.89-16.46\end{array}$ & $\begin{array}{r}0.21-0.36 \\
.15-.33 \\
10.0-21.0\end{array}$ & $\begin{array}{l}30 \\
30 \\
23\end{array}$ & $\begin{array}{l}4 \\
4 \\
4\end{array}$ \\
\hline
\end{tabular}
[Holotype USNM 308578 (USGS colln. D1113-CO) and paratypes USNM 308579-308581 (USGS colln. D1117-CO). All measurements in millimeters unless otherwise indicated]

TABLE 24.-Summarized measurements of specimens of Cyphotrypa switzeriensis $n$. sp.

\begin{tabular}{|c|c|c|c|c|c|c|c|}
\hline & $\begin{array}{c}\text { Arithmetic } \\
\text { mean }\end{array}$ & $\begin{array}{c}\text { Standard } \\
\text { deviation } \\
\text { of mean }\end{array}$ & $\begin{array}{c}\text { Coefficient } \\
\text { of } \\
\text { variation }\end{array}$ & $\begin{array}{c}\text { 95-percent } \\
\text { confidence } \\
\text { interval } \\
\text { of mean }\end{array}$ & Range & $\begin{array}{c}\begin{array}{c}\text { Number } \\
\text { of } \\
\text { measurements }\end{array} \\
\end{array}$ & $\begin{array}{c}\text { Number } \\
\text { of } \\
\text { zoaria } \\
\text { measured }\end{array}$ \\
\hline $\begin{array}{l}\text { Autozooecial chamber maximum diameter } \\
\text { Autozooecial chamber minimum diameter } \\
\text { Autozooecia (number per } \mathrm{mm}^{2} \text { ) }\end{array}$ & $\begin{array}{r}0.2630 \\
.2150 \\
18.70\end{array}$ & $\begin{array}{l}0.0383 \\
.033 \\
2.6687\end{array}$ & $\begin{array}{l}14.57 \\
15.39 \\
14.27\end{array}$ & $\begin{array}{r}0.24-0.29 \\
.19-\quad .24 \\
16.79-20.61\end{array}$ & $\begin{array}{l}0.22-0.32 \\
.15-\quad .26 \\
14{ }^{.23}\end{array}$ & $\begin{array}{l}10 \\
10 \\
10\end{array}$ & $\begin{array}{l}2 \\
2 \\
2\end{array}$ \\
\hline
\end{tabular}
[Paratypes USNM 308582 (USGS colln. D1306-CO), 308583 (USGS colln. D1307-CO). All measurements in millimeters unless otherwise indicated] 
cystoidal diaphragms. C. switzeriensis also lacks styles and recognizable maculae, whereas $C$. acervulosa does have them, although they are indistinct. It has not been possible to observe the zoaria's basal layers or the autozooecial shape at the basal layers in the available specimens.

\section{Genus DEKAYIA Milne-Edwards and Haime, 1851}

Type species.-Dekayia aspera Milne-Edwards and Haime, 1851, by original designation, Late Ordovician.

Remarks.-Boardman and Utgaard (1966, p. 1103) redescribed the genus and emended its definition; their definition is followed herein.

\section{Dekayia epetrima n. sp. Plate 17}

Etymology.-The name is derived from epetrimos, the Greek word for thick, or dense, and it refers to the general appearance of the styles in the zooecial walls of this species.

Description.-Zoaria irregularly dendroid, having subcylindrical branches, occasionally encrusting, and conspecific overgrowths.

Endozones relatively wide, irregularly variable in width locally. In endozones autozooecia slightly undulatory, curving gradually outward. Autozooecial walls straight to sinuous, irregularly crenulated locally, commonly crenulated in proximal portions of intercalated autozooecia. Endostyles (the endocanthopores of authors) common, scattered, relatively large, with thick cores, smooth core boundaries, and thick sheaths; cores occasionally transected by sheath laminae. Endostyles occurring commonly in zones of rejuvenation of autozooecia, in outer endozones; extending into exozones, commonly terminating in endozones and exozones, occasionally rejuvenated in endozones. Basal diaphragms sparse to absent, planar, occasionally occurring at similar ontogenetic stages in indistinct zones.

Autozooecia in exozones almost at right angles to zoarial surface, generally aligned in distinct petaloid pattern, polygonal to subpolygonal in cross section, irregularly variable in size. Autozooecial walls relatively thin, except where thickened by endostyles, straight to slightly crenulated, slightly variable in thickness. Autozooecial boundaries broadly serrated. Endostyles common, generally large, with thick cores and sheaths, irregularly variable in length, scattered throughout exozones, occurring commonly in corners of autozooecia or in centers of petaloid clusters, sparingly between autozooecial corners. Exozonal styles sparse to absent. Basal diaphragms common, thin, straight to slightly curved, commonly convex distally, evenly spaced in most autozooecia. Autozooecial linings absent.

Autozooecial chambers subpolygonal in cross section. Mesozooecia rare, generally absent, subpolygonal in cross section.

Maculae sparse, indistinct in cross section, consisting of polymorphs slightly larger than autozooecia; zooecia of maculae gradational in size with intermacular autozooecia.

Measurements.-Measurements are summarized in table 25.

Geographic and stratigraphic distribution. $-D$. epetrima is only known to occur in Kentucky, in the Grier Limestone Member, Shermanian Stage (USGS colln. D1112-CO, D1115-CO, D1153-CO); the Tanglewood Limestone Member, Shermanian Stage (USGS collns. 5845-CO, 5855-CO); and the Millersburg Member, Shermanian Stage (USGS colln. 7453-CO), of the Lexington Limestone.

Studied material.-Holotype USNM 308584 (USGS colln. D1115-CO), paratypes USNM 308585 (USGS colln. D1112-CO), 308586 (USGS colln. D1153-CO), 308587 (USGS colln. D1153-CO), 308588 (USGS colln. 5854-CO), 308589 (USGS colln. 5855-CO), 308590 (USGS colln. 7453-CO).

Remarks.-D. epetrima is characterized by endozones that are irregular in width and by autozooecia having relatively straight, thin walls and numerous basal diaphragms in exozones. The exozonal autozooecial walls

TABLE 25.-Summarized measurements of specimens of Dekayia epetrima $n . s p$.

[Holotype USNM 308584 (USGS colln. D1115-CO) and paratype USNM 308585 (USGS colln. D1112-CO). All measurements in millimeters unless otherwise indicated]

\begin{tabular}{|c|c|c|c|c|c|c|c|}
\hline & $\begin{array}{c}\text { Arithmetic } \\
\text { mean }\end{array}$ & $\begin{array}{l}\text { Standard } \\
\text { deviation } \\
\text { of mean }\end{array}$ & $\begin{array}{c}\text { Coefficient } \\
\text { of } \\
\text { variation }\end{array}$ & $\begin{array}{l}\text { 95-percent } \\
\text { confidence } \\
\text { interval } \\
\text { of mean } \\
\end{array}$ & Range & $\begin{array}{c}\begin{array}{c}\text { Number } \\
\text { of } \\
\text { measurements }\end{array} \\
\end{array}$ & $\begin{array}{c}\text { Number } \\
\text { of } \\
\text { zoaria } \\
\text { measured }\end{array}$ \\
\hline $\begin{array}{l}\text { Autozooecial chamber maximum diameter - } \\
\text { Autozooecial chamber minimum diameter - } \\
\text { Autozooecial wall thickness, exozone- } \\
\text { Autozooecia (number per } \mathrm{mm}^{2} \text { ) } \\
\text { Diaphragms (number per } \mathrm{mm} \text { ) } \\
\text { Style diameter - } \\
\text { Style core diameter } \\
\text { Zoarial branch diameter } \\
\text { Endozone width - } \\
\text { Exozone width (one side only) } \\
\text { Styles }\left(\text { number per } \mathrm{mm}^{2} \text { ) }\right.\end{array}$ & $\begin{array}{c}0.2120 \\
.1567 \\
.0240 \\
20.57 \\
5.64 \\
.0807 \\
.0207 \\
11.0 \\
6.0 \\
3.0 \\
5.62\end{array}$ & $\begin{array}{l}0.0312 \\
.0311 \\
.0091 \\
1.9881 \\
1.804 \\
.0394 \\
.008 \\
9.54 \\
5.1962 \\
2.6771 \\
1.9226\end{array}$ & $\begin{array}{r}14.79 \\
19.85 \\
37.93 \\
9.66 \\
32.00 \\
48.80 \\
38.65 \\
86.72 \\
86.60 \\
89.23 \\
34.18\end{array}$ & $\begin{array}{c}0.19-0.23 \\
.14-\quad .17 \\
.02-\quad .03 \\
18.73-22.41 \\
4.42-6.85 \\
.06-.10 \\
.02-.03 \\
(-12.7-34.7) \\
(-6.91-18.90) \\
(-1.26-7.26) \\
4.02-7.23\end{array}$ & $\begin{array}{l}0.13-0.27 \\
.10-.19 \\
.01-.05 \\
19-25 \\
3-8 \\
.04-.18 \\
.01-.03 \\
19.0-25.0 \\
3.0-12.0 \\
1.5-7.0 \\
4=9\end{array}$ & $\begin{array}{r}15 \\
15 \\
15 \\
7 \\
11 \\
15 \\
15 \\
3 \\
3 \\
4 \\
8\end{array}$ & $\begin{array}{l}2 \\
2 \\
2 \\
2 \\
2 \\
2 \\
2 \\
2 \\
2 \\
2 \\
2\end{array}$ \\
\hline
\end{tabular}


of $D$. epetrima are only slightly variable in thickness. The species characteristically has very few mesozooecia in exozones and virtually no basal diaphragms in endozones. Endostyles are large and are common throughout zoaria. This combination of morphological characters distinguishes $D$. epetrima from $D$. aspera MilneEdwards and Haime, which is the type species (figured by Boardman and Utgaard, 1966, pl. 138) of Dekayia, and from other species of Dekayia.

$D$. epetrima is similar to $D$. appressa Ulrich, which Brown (1965, p. 993) reportedly found in his undivided "Logana-Jessamine Limestone Members" of the Lexington Limestone (the Logana and Grier Limestone Members, respectively, of the Lexington Limestone of current usage), Middle Ordovician, at several localities in central Kentucky. D. appressa Ulrich (pl. 18, figs. 1, 2 ) and $D$. epetrima (pl. 17) both have dendroid zoaria in which autozooecia have relatively thin walls and basal diaphragms in exozones. The two species are also similar in having very few mesozooecia. D. appressa $(\mathrm{pl} .18$, fig. 1; Brown, 1965, pl. 115, figs. 1-4) differs from $D$. epetrima, however, in having moniloid autozooecia in late endozones and early exozones and relatively small endostyles, and in sparseness of basal diaphragms in exozones. Furthermore, the exozonal autozooecial alignment appears different in the two species. Petaloid clusters of autozooecia are more distinctly delineated in D. epetrima than in D. appressa (pl. 17, fig. $3 d$, and pl. 18 , fig. $2 a$, respectively).

$D$. epetrima is thus considered to be an autonomous species and is consistent with the emended concept of Dekayia Boardman and Utgaard (1966, p. 1103).

\section{Dekayia sp. \\ Plate 18, figure 3}

Description.-Zoaria irregularly globular and encrusting, generally unbranched.

Endozones relatively narrow, irregularly variable in width. In endozones, autozooecia recumbent for short distances, slightly undulatory with straight to slightly sinuous walls. Basal diaphragms sparse to absent; styles lacking.

In exozones, autozooecia generally contiguous, curving gently outward, approximately at right angles to zoarial surface, generally without preferred alignment, irregularly polygonal in cross section. Autozooecial walls thin, straight, occasionally sinuous, slightly crenulated locally. Endostyles common, thin, short, with distinct small cores, commonly terminating within exozones, occurring mostly in inner exozones and generally in autozooecial corners, occasionally along autozooecial walls between corners. Basal diaphragms thin, common, generally straight, at right angles to chamber axis, scattered to evenly spaced, locally closely spaced in late exozones. Autozooecial linings absent.

Mesozooecia sparse to absent, generally subpolygonal in cross section, with moniloid proximal portions and few or no diaphragms.

Maculae apparently absent.

Measurements.-Summarized measurements appear in table 26.

Geographic and stratigraphic distribution.-Specimens assigned to Dekayia sp. are from the Millersburg Member, Shermanian Stage (USGS colln. 7040-CO, 7046-CO), of the Lexington Limestone in Kentucky.

Studied material.-Hypotype USNM 308591 (USGS colln. 7040-CO), 308592 (USGS colln. 7046-CO), 308593 (USGS colln. 7046-CO).

Remarks.-Specimens included in Dekayia sp. are not named formally because the available material is fragmentary and insufficient for determining their specifity. These specimens in general appear to be consistent with the emended definition of the genus Dekayia (Boardman and Utgaard, 1966, p. 1103) in having encrusting growth habit, polygonal autozooecia in cross section whose crenulated walls consist of broadly curved and commonly indistinct laminae in exozones. In addition, autozooecia of these specimens lack linings and zoaria have only a few mesozooecia. However, these specimens of Dekayia sp. differ from typical

TABLE 26.-Summarized measurements of specimens of Dekayia sp. [Hypotypes USNM 308591 (USGS colln. 7040-CO) and 308592 (USNM colln. 7046-CO). All measurements in millimeters unless otherwise indicated]

\begin{tabular}{|c|c|c|c|c|c|c|c|}
\hline & $\begin{array}{c}\text { Arithmetic } \\
\text { mean }\end{array}$ & $\begin{array}{l}\text { Standard } \\
\text { deviation } \\
\text { of mean }\end{array}$ & $\begin{array}{c}\text { Coefficient } \\
\text { of } \\
\text { variation }\end{array}$ & $\begin{array}{c}\text { 95-percent } \\
\text { confidence } \\
\text { interval } \\
\text { of mean }\end{array}$ & Range & $\begin{array}{c}\begin{array}{c}\text { Number } \\
\text { of } \\
\text { measurements }\end{array} \\
\end{array}$ & $\begin{array}{c}\text { Number } \\
\text { of } \\
\text { zoaria } \\
\text { measured }\end{array}$ \\
\hline Autozooecial chamber maximum diameter - & 0.2407 & 0.0194 & 8.08 & $0.23-0.25$ & $0.21-0.28$ & 15 & 2 \\
\hline Autozooecial chamber minimum diameter -_-_-_ & .1880 & .0163 & 8.58 & $.18-.20$ & $.16-.22$ & 15 & 2 \\
\hline Autozooecia (number per $\mathrm{mm}^{2}$ ) & 18.88 & 1.46 & 7.72 & $17.66-20.09$ & $17 \quad-21$ & 8 & 2 \\
\hline Diaphragms (number per $\mathrm{mm}$ ) & 6.2222 & 1.9861 & 31.92 & $4.70-7.75$ & $4.0-9.0$ & 9 & 2 \\
\hline Style diameter - & .0473 & .0172 & 26.91 & $.04-.06$ & $.03-\quad .07$ & 11 & 2 \\
\hline Style & .0118 & .0045 & 34.23 & $.009-.01$ & $.01-.02$ & 11 & 2 \\
\hline Zoarial branch diameter & 2.540 & .7369 & 29.01 & $1.63-3.45$ & $1.70-3.70$ & 5 & 2 \\
\hline 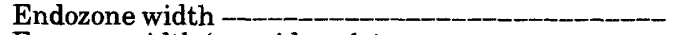 & .60 & .1414 & 23.57 & $(-.67-1.87)$ & $.50-.70$ & 2 & 1 \\
\hline Exozone width (one side only) & 1.45 & .0711 & 4.88 & $.81-2.09$ & $1.40-1.50$ & 2 & 1 \\
\hline Styles (number per & 5.6250 & 2.9731 & 52.86 & $3.14-8.11$ & $2.0-10.0$ & 8 & 2 \\
\hline
\end{tabular}


dekayid species in their thin autozooecial walls that are only slightly variable in thickness, their abundant basal diaphragms throughout exozones, and their lack of large endostyles in endozones.

From a comparison with the known species of Dekayia, specimens included in Dekayia sp. appear to be more closely related to $D$. sugarensis Ross, 1969 , than to any other species of Dekayia. D. sugarensis Ross occurs in the Middle Ordovician strata in New York, where it appears first at the base of the "Trenton Group" (Ross, 1969, p. 267, text-fig. 1) of the Champlainian Provincial Series, Middle Ordovician.

D. sugarensis Ross (1969, pls. 39, figs. 2-4, 9; pls. 40-42) and $D$. sp. (pl. 18, fig. 3) both have globular and encrusting growth habits, but $D$. species apparently lacks the subcylindrical branches that are present in D. sugarensis. Autozooecial chambers and styles are of approximately the same size in cross section in both forms (Ross, 1969, table 6; table 26 of this paper).

D. sugarensis Ross, however, differs from specimens of $D$. sp. in several morphological characters. Its exozonal autozooecial walls are generally thicker, approximately 0.01-0.02 mm thick (Ross, 1969, table 6), and are distinctly crenulated. Autozooecial walls in $D$. sp. are generally less than $0.01 \mathrm{~mm}$ thick, are only slightly crenulated in exozones, and are relatively straight in endozones.

Autozooecial linings apparently can be present in autozooecia of $D$. sugarensis (Ross, 1969, pl. 41, fig. 1), but are absent in $D$. sp. $D$. sugarensis, furthermore, has abundant exozonal styles (acanthopores of Ross) throughout exozones and relatively large endostyles (Ross, 1969, pl. 39, fig. 2) in exozones, whereas $D$. sp. generally lacks styles in endozones altogether.

\section{Genus HETEROTRYPA Nicholson, 1879}

Type species.-Monticulipora frondosa d'Orbigny, 1850; subsequent designation by ICZN (1968, Opinion 838) upon application submitted by Utgaard and Boardman (1965). "Fairmount Member of the Fairview Formation of the Maysville Group at Cincinnati, Ohio" (Boardman and Utgaard, 1966, p. 1106).

Remarks.-Boardman and Utgaard (1966) discussed the zoarial development of Heterotrypa and revised the concept for the genus. The definition of the genus Heterotrypa as given by Boardman and Utgaard (1966) is followed here.

Heterotrypa foliacea (Ulrich and Bassler, 1904)

Plate 15, figures 1, 2; plate 16, figure 1; plate 19

Dekayella foliacea Ulrich and Bassler, 1904, p. 28, pl. 7, figs. 10-12; McFarlan, 1931, p. 98.

Dekayella milleri McFarlan, 1931, p. 98, pl. 6, figs. 6-9.

Heterotrypa foliacea (Ulrich and Bassler, 1904), Boardman and Utgaard, 1966, p. 1105, pl. 141, fig. 2.
Heterotrypa foerstei Nickles, 1905, p. 48, pl. 2, fig. 5; Foerste, 1914, p. 126; Boardman and Utgaard, 1966, p. 1105.

Description.-Zoaria dendroid with flattened to subfrondescent locally encrusting and subcylindrical branches.

In endozones, autozooecia subparallel to branch axis, slightly undulatory, curving gently outward. Autozooecial walls irregularly sinuous and crenulated locally. Endostyles (endacanthopores) sparse to common, generally lacking in axial portions of some zoaria, common in outer endozones and extending into exozones, commonly obliquely across autozooecial walls. Basal diaphragms sparse, generally planar, at right angles to chamber axis, commonly lacking in axial part of endozones of many zoaria. Zones of autozooecial rejuvenation sparse, occasionally having endostyles and basal diaphragms in indistinct zones.

Exozones wide, having autozooecia generally at right angles to zoarial surface, partly occurring in indistinct petaloid alignment, subcircular to subpolygonal in cross section, contiguous or partly separated by mesozooecia. Autozooecial walls moderately thick, generally straight, occasionally moniloid locally. Autozooecial boundaries generally broadly serrated throughout exozones, with local mural pustules. Endostyles common, scattered, with thick sheaths and moderately thin cores, arising mostly in late endozones and early exozones, in autozooecial corners or centers of petaloid clusters, commonly terminating in outer exozones. Exozonal styles common, scattered, generally relatively small with distinct cores and sheaths, occurring in autozooecial corners and in walls between corners, locally lacking in parts of zoarium. Exozonal styles generally centered along autozooecial boundaries, occasionally inflecting autozooecial walls, extending into autozooecial chambers. Basal diaphragms abundant and evenly spaced throughout exozones, planar to slightly curved, mostly concave distally, moderately thick in some autozooecia of a zoarium. Cystoidal diaphragms sparse to absent. Autozooecial linings thin, commonly continuous throughout exozone of many autozooecia, locally lacking in some zoaria.

Autozooecial chambers subcircular to subpolygonal in cross section.

Mesozooecia sparse to common, scattered, subpolygonal to subcircular in cross section, occasionally having moniloid proximal parts locally. Mesozooecial diaphragms generally thin, closely and evenly spaced locally in some mesozooecia.

Maculae common, generally low, indistinct in cross section, consisting of mesozooecia or of clusters of mesozooecia and polymorphs slightly larger than autozooecia in various combinations. 
Measurements.-Measurements are summarized in tables 27-29.

Geographic and stratigraphic distribution. $-H$. foliacea is known only from Kentucky, where it occurs abundantly in rocks of the late Shermanian Stage, Middle Ordovician, and the Edenian Stage, Late Ordovician. $H$. foliacea occurs in members of the Lexington Limestone: Brannon Member, Shermanian Stage (USGS collns. D1157-CO, D1160-CO-D1162-CO; 4930-CO); Sulphur Well Member, Shermanian Stage (USGS collns. 4931-CO, 4932-CO, 4934-CO, 4935-CO; 4888-CO, 4890-CO-4893-CO; D1164-CO); Millersburg Member: Shermanian Stage (USGS collns. D1127-CO, D1208-CO; D1311-CO; 4858-CO; 5025-CO, 5027-CO, 5028-CO, 5030-CO; 7039-CO, 7040-CO, 7043-CO, 7046-CO-7048-CO, 7050-CO, 7054-CO-7056-CO, 7059-CO, 7061-CO; 7454-CO, 7455-CO), Edenian Stage (USGS collns. 7072-CO7075-CO, 7314-CO, 7319-CO); Tanglewood Limestone Member, Shermanian Stage (USGS collns. 7063-CO; D1130-CO, D1132-CO; 4855-CO; 4979-CO, 4981-CO-
4983-CO, 4985-CO, 4987-CO, 4991-CO-4993-CO, 4995-CO, 4997-CO, 4998-CO, 5842-CO, 5851-CO; 7337-CO; 7463-CO, 7464-CO, 7466-CO), and tongue of the Tanglewood Limestone Member, Shermanian Stage (USGS collns. 5046-CO, 5182-CO; 7448-CO, 7460-CO), Nicolas Bed of the Tanglewood Limestone Member: Shermanian Stage (USGS colln. 5031-CO), Edenian Stage (USGS collns. 5032-CO, 5034-CO, 5035-CO), and the Strodes Creek Member, Edenian Stage (USGS colln. 7328-CO), of the Lexington Limestone.

Clays Ferry Formation: Shermanian Stage (USGS collns. D1170-CO, D1172-CO; 4894-CO-4896-CO, 4898-CO; 6714-CO, 6717-CO, 6719-CO, 6720-CO, 7467-CO), Edenian Stage (USGS collns. D1177-CO, D1182-CO, D1187-CO, D1189-CO-D1191-CO; $\mathrm{D} 1211-\mathrm{CO}$, D1213-CO; 4920-CO, 4922-CO; 5002-CO, 5003-CO; 5057-CO, 5064-CO, 5065-CO, 5196-CO; 5867-CO, 5874-CO(?); 6721-CO, 6733-CO, 6735-CO, 6737-CO, 6738-CO, 6741-CO-6743-CO; $7471-\mathrm{CO}, 7472-\mathrm{CO}, 7474-\mathrm{CO})$; tongue of the Clays

TABLE 27.-Summarized measurements of a specimen of Heterotrypa foliacea (Ulrich and Bassler) [Holotype USNM 43187. All measurements in millimeters unless otherwise indicated]

\begin{tabular}{|c|c|c|c|c|c|c|c|}
\hline & $\begin{array}{l}\text { Arithmetic } \\
\text { mean }\end{array}$ & $\begin{array}{c}\text { Standard } \\
\text { deviation } \\
\text { of mean }\end{array}$ & $\begin{array}{c}\text { Coefficient } \\
\text { of } \\
\text { variation }\end{array}$ & $\begin{array}{l}\text { 95-percent } \\
\text { confidence } \\
\text { interval } \\
\text { of mean }\end{array}$ & Range & $\begin{array}{c}\begin{array}{c}\text { Number } \\
\text { of } \\
\text { measurements }\end{array} \\
\text {. }\end{array}$ & $\begin{array}{c}\text { Number } \\
\text { of } \\
\text { zoaria } \\
\text { measured }\end{array}$ \\
\hline Autozooecial chamber maximum diameter _ _ & 0.1764 & 0.0195 & 11.03 & $0.17-0.19$ & $0.15-0.20$ & 14 & 1 \\
\hline Autozooecial chamber minimum diameter _-___-_ & .1407 & .0173 & 12.30 & $.13-\quad .15$ & $.10-\quad .16$ & 14 & 1 \\
\hline Autozooecial wall thickness, exozone - & .0543 & .0128 & 23.65 & $.05-$ & $.04-$ & 14 & 1 \\
\hline Macular polymorph chamber maximum diameter -_- & .2360 & .0114 & 4.83 & $.22-$ & $.22-$ & 5 & 1 \\
\hline Macular polymorph chamber minimum diameter---- & .20 & .0173 & 8.66 & $.18-$ & $.17-$ & 5 & 1 \\
\hline Mesozooecial chamber maximum diameter & .070 & .0258 & 39.63 & $.05-\quad .08$ & $.03-.11$ & 12 & 1 \\
\hline Autozooecia (number per $2 \mathrm{~mm}$ ) _- & 9.2143 & .8018 & 8.70 & $8.75-9.68$ & $8.0-10.0$ & 14 & 1 \\
\hline Autozooecia (number per $\mathrm{mm}^{2}$ ) & 22.00 & 2.5690 & 11.67 & $20.27-23.72$ & $18-26$ & 11 & 1 \\
\hline Mesozooecia (number per $\mathrm{mm}^{2}$ ) & 4.2727 & 3.1334 & 73.34 & $2.17-6.38$ & -12 & 11 & $\overline{1}$ \\
\hline Diaphragms (number per $\mathrm{mm}$ ) - & 13.0 & 1.6641 & 12.80 & $12.04-13.96$ & $10-16$ & 14 & - \\
\hline Style diameter in exozone & .04 & .0214 & 53.62 & $.03-\quad .05$ & $.02-\quad .08$ & 11 & 1 \\
\hline Style diameter in endozone & .1157 & .0346 & 29.87 & $.08-\quad .15$ & $.04-\quad .14$ & 7 & 1 \\
\hline Zoarial branch diameter - & 7.750 & .3536 & 4.56 & $4.57-10.92$ & $7.50-8.0$ & 2 & $\overline{1}$ \\
\hline Endozone width - & 2.880 & .249 & 8.63 & $2.57-3.19$ & $2.50-3.10$ & 5 & 1 \\
\hline Exozone width (one side only) & 2.10 & .3109 & 14.81 & $1.81-2.39$ & $1.70-2.50$ & 7 & 1 \\
\hline Styles (number per $\mathrm{mm}^{2}$ ) & 10.556 & 1.589 & 1.5062 & $9.33-11.78$ & $9-14$ & $\dot{9}$ & 1 \\
\hline
\end{tabular}

TABLE 28.-Summarized measurements of specimens of Heterotrypa foliacea (Ulrich and Bassler)

[Hypotypes USNM 308620 (USGS colln. 4888-CO), 308621-308624 (USGS colln. 4890-CO), 308626 (USGS colln. 4892-CO), 308627-308633 (USGS colln. 4893-CO). All measurements in millimeters unless otherwise indicated

\begin{tabular}{|c|c|c|c|c|c|c|c|}
\hline & $\begin{array}{l}\text { Arithmetic } \\
\text { mean }\end{array}$ & $\begin{array}{c}\text { Standard } \\
\text { deviation } \\
\text { of mean }\end{array}$ & $\begin{array}{c}\text { Coefficient } \\
\text { of } \\
\text { variation }\end{array}$ & $\begin{array}{l}\text { 95-percent } \\
\text { confidence } \\
\text { interval } \\
\text { of mean }\end{array}$ & Range & $\begin{array}{c}\text { Number } \\
\text { of } \\
\text { measurements }\end{array}$ & $\begin{array}{c}\text { Number } \\
\text { of } \\
\text { zoaria } \\
\text { measured }\end{array}$ \\
\hline Autozooecial chamber maximum diameter _.__ & 0.1950 & 0.0177 & 9.08 & $0.19-0.20$ & $0.15-0.23$ & 60 & 12 \\
\hline Autozooecial chamber minimum diameter & .1640 & .0223 & 13.62 & $.16-.17$ & $.12-\quad .22$ & 60 & 12 \\
\hline Autozooecial wall thickness, exozone & .0496 & .0183 & 36.82 & $.04-$ & $.02-$ & 59 & 12 \\
\hline Macular polymorph chamber maximum diameter -- & .2610 & .0292 & 11.22 & $.25-$ & .20 & 38 & 12 \\
\hline Macular polymorph chamber minimum diameter - & .2126 & .0264 & 12.40 & $.20-$ & $.16-$ & 38 & 12 \\
\hline Mesozooecial chamber maximum diameter - _ _ & .0770 & .0265 & 34.42 & $.07-.08$ & $.02-.14$ & 60 & 12 \\
\hline Autozooecia (number per $2 \mathrm{~mm}$ ) & 8.6889 & .6682 & 7.69 & $8.49-8.90$ & $8-10$ & 45 & 12 \\
\hline Autozooecia (number per $\mathrm{mm}^{2}$ ) & 20.40 & 1.7761 & 8.71 & $19.87-20.93$ & -24 & 45 & 12 \\
\hline Mesozooecia (number per $\mathrm{mm}^{2}$ ) & 5.8333 & 3.1539 & 54.07 & $4.85-6.82$ & -16 & 42 & 12 \\
\hline Diaphragms (number per $\mathrm{mm}$ ) & 11.821 & 1.8620 & 15.75 & $11.22-12.42$ & $8-15$ & 39 & 9 \\
\hline Style diameter in exozone - & .0407 & .0152 & 37.39 & $.037-.045$ & $.01-.08$ & 57 & 11 \\
\hline Zoarial branch diameter - & 5.6923 & 1.2828 & 22.54 & $5.17-6.21$ & $3.80-8.10$ & 26 & 11 \\
\hline Endozone width & 3.350 & 1.1843 & 35.35 & $2.87-3.82$ & $1.00-5.30$ & 26 & 11 \\
\hline Exozone width (one side only) & 1.2260 & .4421 & 36.05 & $1.10-1.35$ & $.10-2.40$ & 50 & 11 \\
\hline Styles (number per $\mathrm{mm}^{2}$ ) & 8.7692 & 8.0409 & 9.17 & $6.16-11.38$ & $1-32$ & 39 & 12 \\
\hline
\end{tabular}


TABLE 29.-Summarized measurements of specimens of Heterotrypa foliacea (Ulrich and Bassler)

[Hypotypes USNM 308635-308637 (USGS colln. 4894-CO), 308639, 308641 (USGS colln. 4895-CO), 308642, 308643 (USGS colln. 4896-CO), 308644 (USGS colln. 4898-CO), 308646 (USGS colln. 4920-CO), 308648 (USGS colln. 4922-CO). All measurements in millimeters unless otherwise indicated

\begin{tabular}{|c|c|c|c|c|c|c|c|}
\hline & $\begin{array}{c}\text { Arithmetic } \\
\text { mean }\end{array}$ & $\begin{array}{l}\text { Standard } \\
\text { deviation } \\
\text { of mean }\end{array}$ & $\begin{array}{c}\text { Coefficient } \\
\text { of } \\
\text { variation }\end{array}$ & $\begin{array}{l}\text { 95-percent } \\
\text { confidence } \\
\text { interval } \\
\text { of mean }\end{array}$ & Range & $\begin{array}{c}\text { Number } \\
\text { of } \\
\text { measurements }\end{array}$ & $\begin{array}{c}\text { Number } \\
\text { of } \\
\text { zoaria } \\
\text { measured }\end{array}$ \\
\hline Autozooecial chamber maximum diameter _. & 0.1968 & 0.0194 & 9.87 & $0.19-0.20$ & $0.15-0.23$ & 50 & 10 \\
\hline Autozooecial chamber minimum diameter _______ & .1590 & .0210 & 13.22 & $.15-.16$ & $.12-\quad .20$ & 50 & 10 \\
\hline Autozooecial wall thickness, exozone - & .0547 & .0129 & 23.63 & $.05-$ & $.03-$ & 49 & 10 \\
\hline Macular polymorph chamber maximum diameter - - & .2604 & .0184 & 7.08 & $.25-.27$ & $.22-\quad .30$ & 26 & 10 \\
\hline Macular polymorph chamber minimum diameter- & .2154 & .0218 & 10.11 & $.21-$ & $.17-$ & 26 & 10 \\
\hline Mesozooecial chamber maximum diameter - & .0729 & .0227 & 30.56 & $.07-.08$ & $.03-\quad .12$ & 49 & 10 \\
\hline Autozooecia (number per $2 \mathrm{~mm}$ ) ___ & 8.5250 & .5986 & 7.02 & $8.33-8.72$ & $8-10$ & 40 & 10 \\
\hline Autozooecia (number per $\mathrm{mm}^{2}$ ) - & 19.816 & 2.05 & 10.35 & $19.14-20.49$ & -24 & 38 & 10 \\
\hline Mesozooecia (number per $\mathrm{mm}^{2}$ ) - _____ & 3.9118 & 2.6671 & 68.18 & $2.98-4.84$ & -11 & 34 & 10 \\
\hline Diaphragms (number per $\mathrm{mm}$ ) - & 12.824 & 3.0795 & 24.01 & $11.75-13.90$ & $8-20$ & 34 & 9 \\
\hline Style diameter in exozone ______________ & .0408 & .0153 & 37.37 & $.36-.45$ & $.02-\quad .07$ & 49 & 10 \\
\hline Style diameter in endozone - & .090 & .010 & 11.11 & $.08-.10$ & $.08-\quad .10$ & 5 & 1 \\
\hline Zoarial branch diameter & 8.540 & 3.045 & 35.66 & $7.11-9.97$ & $4.20-16.10$ & 20 & 9 \\
\hline Endozone width __ _ & 5.020 & 2.5059 & 49.92 & $3.85-6.19$ & $2.40-13.20$ & 20 & 10 \\
\hline 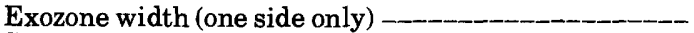 & 1.7795 & .8259 & 46.45 & $1.51-2.05$ & $.70-5.0$ & 39 & 10 \\
\hline Styles (number per $\mathrm{mm}^{2}$ ) - & 11.639 & 7.407 & 6.36 & $9.13-14.14$ & $3-39$ & 36 & 10 \\
\hline
\end{tabular}

Ferry Formation, Shermanian Stage (USGS colln. 7458-CO); Point Pleasant Tongue of the Clays Ferry Formation, Shermanian Stage (USGS colln. 6928-CO); Kope Formation, Edenian Stage (USGS collns. 6933-CO, 6934-CO, 6939-CO).

Ulrich and Bassler (1904, p. 28) found $H$. foliacea in their "Lexington Limestone of the Trenton," near Lexington, Ky. Nickles $(1905$, p. 48) reported $H$. foerstei (assigned herein to $H$. foliacea) from his "Eden" Group, Upper Ordovician, at Rogers Gap in Kentucky. McFarlan (1931, p. 98) reported Dekayella milleri (assigned herein to $H$. foliacea) from his "Greendale Member of the Cynthiana" strata near Lexington.

Studied material.-Dekayella foliacea Ulrich and Bassler, 1904, holotype USNM 43187 from the primary type suite USNM 43187 "Lexington Limestone" of Ulrich and Bassler (1904), Middle Ordovician, near Lexington, Ky. Heterotrypa foerstei Nickles, 1905, syntype USNM 96569 from the type suite USNM 96569, the "Eden Group" of Nickles, 1905, Upper Ordovician, Rogers Gap, Ky.

Hypotypes USNM 308594, 308595 from the "Eden Group," Upper Ordovician, Rogers Gap, Ky.

Hypotypes USNM 308596 (USGS colln. D1121-CO), 308597 (USGS colln. D1127-CO), 308598 (USGS colln. D1130-CO), 308599 (USGS colln. D1131-CO), 308600 (USGS colln. D1157-CO), 308601 (USGS colln. D1160-CO), 308602 (USGS colln. D1161-CO), 308603 (USGS colln. D1162-CO), 308604 (USGS colln. D1164-CO), 308605 (USGS colln. D1170-CO), 308606 (USGS colln. D1172-CO), 308607 (USGS colln. D1177-CO), 308608 (USGS colln. D1182-CO), 308609 (USGS colln. D1187-CO), 308610 (USGS colln. D1189-CO), 308611 (USGS colln. D1190-CO), 308612 (USGS colln. D1191-CO), 308613 (USGS colln. D1208-CO), 308614 (USGS colln. D1211-CO), 308615 (USGS colln. D1213-CO), 308616 (USGS colln.
D1311-CO), 308617 (USGS colln. D1311-CO), 308618 (USGS colln. 4855-CO), 308619 (USGS colln. 4858-CO), 308620 (USGS colln. 4888-CO), 308621308624 (USGS colln. 4890-CO), 308625 (USGS colln. 4891-CO), 308626 (USGS colln. 4892-CO), 308627308634 (USGS colln. 4893-CO), 308635-308638(USGS colln. 4894-CO), 308639-308641 (USGS colln. 4895-CO), 308642, 308643 (USGS colln. 4896-CO), 308644 (USGS colln. 4898-CO), 308645 (USGS colln. 4899-CO), 308646, 308647 (USGS colln. 4920-CO), 308648 (USGS colln. 4922-CO), 308649 (USGS colln. 4979-CO), 308650 (USGS colln. 4981-CO), 308651 (USGS colln. 4982-CO), 308652 (USGS colln. 4983-CO), 308653 (USGS colln. 4985-CO), 308654 (USGS colln. 4987-CO), 308655 (USGS colln. 4991-CO), 308656 (USGS colln. 4992-CO), 308657 (USGS colln. 4993-CO), 308658 (USGS colln. 4995-CO), 308659 (USGS colln. 4997-CO), 308660 (USGS colln. 4998-CO), 308661 (USGS colln. 5025-CO), 308662 (USGS colln. 5027-CO), 308663 (USGS colln. 5028-CO), 308664 (USGS colln. 5030-CO), 308665 (USGS colln. 5031-CO), 308666 (USGS colln. 5032-CO), 308667 (USGS colln. 5034-CO), 308668 (USGS colln. 5035-CO), 308669 (USGS colln. 5842-CO), 308670 (USGS colln. 5851-CO), 308671 (USGS colln. 5867-CO), 308672 (USGS colln. 5874-CO), 308673 (USGS colln. 5883-CO), 308674 (USGS colln. 6714-CO), 308675 (USGS colln. 6717-CO), 308676 (USGS colln. 6718-CO), 308677 (USGS colln. 6719-CO), 308678 (USGS colln. 6720-CO), 308679 (USGS colln. 6721-CO), 308680 (USGS colln. D1177-CO), 308681 (USGS colln. D1182-CO), 308682 (USGS colln. 6733-CO), 308683 (USGS colln. 6735-CO), 308684 (USGS colln. 6737-CO), 308685 (USGS colln. 6738-CO), 308686 (USGS colln. 6741-CO), 308687 (USGS colln. 6742-CO), 308688 (USGS colln. 
6743-CO), 308689 (USGS colln. 6928-CO), 308690 (USGS colln. 6933-CO), 308691 (USGS colln. 6934-CO), 308692 (USGS colln. 6939-CO), 308693 (USGS colln. 7039-CO), 308694 (USGS colln. 7040-CO), 308695 (USGS colln. 7040-CO), 308696 (USGS colln. 7043-CO), 308697 (USGS colln. 7046-CO), 308698 (USGS colln. 7047-CO), 308699 (USGS colln. 7048-CO), 308700 (USGS colln. 7050-CO), 308701 (USGS colln. 7054-CO), 308702 (USGS colln. 7055-CO), 308703 (USGS colln. 7056-CO), 308704 (USGS colln. 7059-CO), 308705 (USGS colln. 7061-CO), 308706 (USGS colln. 7063-CO), 308707 (USGS colln. 7072-CO), 308708 (USGS colln. 7073-CO), 308709 (USGS colln. 7074-CO), 308710 (USGS colln. 7075-CO), 308711 (USGS colln. 7314-CO), 308712 (USGS colln. 7319-CO), 308713 (USGS colln. 7328-CO), 308714 (USGS colln. 7337-CO), 308715 (USGS colln. 7448-CO), 308716 (USGS colln. 7454-CO), 308717 (USGS colln. 7455-CO), 308718 (USGS colln. 7458-CO), 308719 (USGS colln. 7460-CO), 308720 (USGS colln. 7463-CO), 308721 (USGS colln. 7464-CO), 308722 (USGS colln. 7466-CO), 308723 (USGS colln. 7467-CO), 308724 (USGS colln. 7471-CO), 308725 (USGS colln. 7472-CO), 308726 (USGS colln. 7474-CO), 308727 (USGS colln. 5182-CO), 308728 (USGS colln. 5046-CO), 308729 (USGS colln. 5057-CO), 308730 (USGS colln. 5196-CO), 308731 (USGS colln. 5064-CO), 308732 (USGS colln. 4930-CO), 308733 (USGS colln. 4931-CO), 308734 (USGS colln. 4932-CO), 308735 (USGS colln. 4934-CO), 308736 (USGS colln. 4935-CO).

Remarks. $-H$. foliacea is related most closely to $H$. trentonensis (see also remarks under $H$. trentonensis) and to $H$. ulrichi (Nicholson). Of these three species, $H$. trentonensis is the oldest and occurs in Rocklandian, Kirkfieldian, and Shermanian stages of Middle Ordovician deposits. $H$. foliacea appears first in the Shermanian Stage of Middle Ordovician age and $H$. ulrichi in the Edenian Stage of Late Ordovician age in the tristate area of Kentucky, Ohio, and Indiana.

$H$. foliacea differs from $H$. trentonensis (pl. 20) in having autozooecia with slightly thicker walls, smaller diameters of autozooecial chambers, more basal diaphragms per unit length of autozooecia, more styles and mesozooecia in exozones, and wider exozones. Both species have dendroid zoaria, but zoarial branches in $H$. foliacea can be frondescent and in general are more flattened than those in $H$. trentonensis.

H. ulrichi (Nicholson) (Boardman and Utgaard, 1966, pl. 142; Anstey and Perry, 1973, tables 2-5, pls. 16-18) differs from $H$. foliacea in having dendroid zoaria with cylindrical branches. Autozooecia of $H$. ulrichi gener- ally have relatively straight walls and virtually no basal diaphragms and styles in endozones; autozooecia of $H$. foliacea commonly have sinuous and irregularly crenulated walls and scattered basal diaphragms and styles in endozones. $H$. ulrichi differs further from $H$. foliacea in having distinct linings in most autozooecia, slightly thicker basal diaphragms, and autozooecial chambers with slightly smaller diameters in cross section. Mesozooecia of $H$. ulrichi have thick and closely spaced diaphragms and moniloid proximal portions; those of $H$. foliacea generally have straight proximal portions.

H. foerstei Nickles (1905, p. 48, pl. 2, figs. 5, from Nickles' "Eden Group," Upper Ordovician, Rogers Gap, Ky.; illustrated herein on pl. 19, fig. 2) and $H$. milleri (McFarlan, 1931, p. 98, pl. 6, figs. 6-9; described as Dekayella milleri from McFarlan's "Greendale Member of the Cynthiana strata, Ordovician, near Lexington, Ky.") are morphologically indistinguishable from $H$. foliacea. Therefore, upon reevaluation of syntypes of $H$. foerstei Nickles, USNM 96569 (pl. 19, fig. 2), and of published figures of $H$. milleri McFarlan (1931, pl. 6, figs. 6-9), these two species are regarded herein as subjective junior synonyms of $H$. foliacea, subject to further taxonomic findings.

\section{Heterotrypa trentonensis (Ulrich, 1883) Plate 20}

Dekayia trentonensis Ulrich, 1883, p. 151, pl. 5, figs. 6, $6 \mathrm{a}$.

Dekayia trentonensis Ulrich, Ulrich, 1893, p. 274.

Dekayella trentonensis (Ulrich, 1883). Nickles, 1905, p. 42, pl. 1, fig. 3; McFarlan, 1931, p. 97; Brown, 1965, p. 991, pl. 114, figs. 1-3.

Dekayella anomala Brown, 1965, p. 989, pl. 114, figs. 4-9.

Dekayella clavata Fritz, 1957, of Brown, 1965, p. 991, pl. 113, figs. 7-10.

Heterotrypa trentonensis (Ulrich, 1883). Boardman and Utgaard, 1966, p. 1106.

Description.-Zoaria dendroid with subcylindrical to slightly flattened branches.

In endozones, autozooecia subparallel to branch axis, slightly undulatory, curve gently outward. Autozooecial walls slightly sinuous, occasionally crenulated locally. Endostyles (endacanthopores) sparse, of medium size, with distinct cores, relatively thin sheaths; more common in outer endozones and in zones of rejuvenation of autozooecia, terminating in mid-exozones or locally in endozones. Basal diaphragms sparse to absent, commonly absent from axial parts of zoaria; mostly planar, at right angles to chamber axis. Zones of rejuvenation of autozooecia common in most zoaria, occurring irregularly, commonly containing scattered endostyles and basal diaphragms in indistinct zones.

In exozones, autozooecia almost at right angles to zoarial surface in indistinct petaloid pattern or, locally, 
without preferred alignment. Autozooecia generally contiguous, subpolygonal, four- to six-sided in cross section. Autozooecial walls relatively thin, straight or slightly uneven; autozooecial boundaries generally narrowly serrated in inner exozones, mostly broadly serrated in outer exozones, with mural pustules common. Endostyles generally sparse to absent locally, common in parts of some zoaria. Exozonal styles sparse to common, having small cores, relatively thick sheaths, occurring mostly in corners of autozooecia, occasionally in autozooecial walls between corners; moderately inflecting autozooecial walls locally; locally absent in some zoaria. Basal diaphragms common throughout exozones, generally spaced evenly in early exozones, irregularly in midexozones. Basal diaphragms planar to slightly curved, commonly concave to zoarial surface, generally at right angles to chamber axis. Cystoidal diaphragms sparse to absent. Autozooecial lining thin, sparse, locally intermittent, lacking in some autozooecia of a zoarium.

Autozooecial chambers subpolygonal to subcircular in cross section.

Mesozooecia sparse to absent, polygonal to subpolygonal or irregularly shaped in cross section, with rela- tively straight walls. Mesozooecial diaphragms generally thin, planar, spaced similarly to basal diaphragms of autozooecia in exozones. Mesozooecia occurring mostly in maculae, commonly absent from intermacular areas.

Maculae common, scattered; low, generally indistinct in cross section, consisting of few mesozooecia and occasional polymorphs slightly larger than autozooecia, irregularly shaped in cross section.

Measurements.-Measurements are summarized in tables 30 and 31.

Geographic and stratigraphic distribution. $-H$. trentonensis is common in rocks of the Shermanian Stage, Middle Ordovician, in Kentucky. It has been reported from the Decorah Shale and the lower part of the Galena Dolomite (Ulrich, 1893, p. 275) of current usage in Minnesota.

Occurrence in Kentucky.-Grier Limestone Member: Kirkfieldian Stage (USGS collns. 4947-CO, 4948-CO), Shermanian Stage (USGS collns. 4954-CO, 4963-CO, 4968-CO, 4969-CO; D1221-CO, D1231-CO; D1237-CO; 4927-CO; 4680-CO, 4682-CO, 4688-CO; D1295-CO, D1299-CO, D1303-CO), of the Lexington Limestone.

TABLE 30.-Summarized measurements of specimens of Heterotrypa trentonensis (Ulrich) [Holotype USNM 43660 and paratypes USNM 308737, 308738. All measurements in millimeters unless otherwise indicated]

\begin{tabular}{|c|c|c|c|c|c|c|c|}
\hline & $\begin{array}{c}\text { Arithmetic } \\
\text { mean }\end{array}$ & $\begin{array}{c}\text { Standard } \\
\text { deviation } \\
\text { of mean }\end{array}$ & $\begin{array}{c}\text { Coefficient } \\
\text { of } \\
\text { variation }\end{array}$ & $\begin{array}{l}\text { 95-percent } \\
\text { confidence } \\
\text { interval } \\
\text { of mean }\end{array}$ & Range & $\begin{array}{c}\begin{array}{c}\text { Number } \\
\text { of } \\
\text { measurements }\end{array} \\
\end{array}$ & $\begin{array}{c}\text { Number } \\
\text { of } \\
\text { zoaria } \\
\text { measured }\end{array}$ \\
\hline Autozooecial chamber maximum diameter _-______- & 0.1977 & 0.0135 & 6.82 & $0.19-0.20$ & $0.18-0.22$ & 17 & 3 \\
\hline Autozooecial chamber minimum diameter _-____- & .1589 & .0183 & 11.54 & $.15-\quad .17$ & $.13-\quad .19$ & 17 & 3 \\
\hline Autozooecial wall thickness, exozone - & .0425 & .0068 & 16.07 & $.04-\quad .05$ & $.03-$ & 16 & 3 \\
\hline Macular polymorph chamber maximum diameter _-_ & .2746 & .0129 & 4.71 & $.27-\quad .28$ & $.25-$ & 11 & 3 \\
\hline Macular polymorph chamber minimum diameter & .1973 & .0374 & 18.98 & $.17-.22$ & $.13-$ & $\hat{11}$ & 3 \\
\hline Mesozooecial chamber maximum diameter & .1010 & .0277 & 27.40 & $.08-\quad .12$ & $.05-\quad .13$ & 10 & 3 \\
\hline Autozooecia (number per $2 \mathrm{~mm}$ ) - & 8.7273 & .4671 & 5.35 & $8.41-9.04$ & $8-9$ & 11 & 3 \\
\hline Autozooecia (number per $\mathrm{mm}^{2}$ ) & 19.70 & 1.4181 & 7.20 & $18.69-20.71$ & -23 & 10 & 3 \\
\hline Diaphragms (number per mm) - & 6.875 & 1.5864 & 23.08 & $6.03-7.7$ & $5-10$ & 16 & 3 \\
\hline Style, diameter in exozone & .0563 & .0141 & 25.03 & $.04-\quad .07$ & $.03-\quad .07$ & 8 & 2 \\
\hline Zoarial branch diameter -_________________ & 8.7333 & 2.5153 & 28.80 & $6.10-11.37$ & $5.20-12.0$ & 6 & 3 \\
\hline 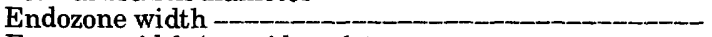 & 5.6714 & 2.4012 & 42.34 & $3.45-7.89$ & $3.40-9.0$ & 7 & 3 \\
\hline Exozone width (one side only) & 1.3154 & .2154 & 16.38 & $1.19-1.45$ & $.90-1.70$ & 13 & 3 \\
\hline
\end{tabular}

TABLE 31.-Summarized measurements of specimens of Heterotrypa trentonensis (Ulrich) [Hypotypes USNM 308754, 308756-308759 (USGS colln. 4680-CO), 308760 (USGS colln. 4682-CO), 308765 (USGS colln. 4689-CO). All measurements in millimeters unless otherwise indicated

\begin{tabular}{|c|c|c|c|c|c|c|c|}
\hline & $\begin{array}{c}\text { Arithmetic } \\
\text { mean }\end{array}$ & $\begin{array}{c}\text { Standard } \\
\text { deviation } \\
\text { of mean }\end{array}$ & $\begin{array}{c}\text { Coefficient } \\
\text { of } \\
\text { variation }\end{array}$ & $\begin{array}{c}\text { 95-percent } \\
\text { confidence } \\
\text { interval } \\
\text { of mean }\end{array}$ & Range & $\begin{array}{c}\begin{array}{c}\text { Number } \\
\text { of } \\
\text { measurements }\end{array} \\
\end{array}$ & $\begin{array}{c}\text { Number } \\
\text { of } \\
\text { zoaria } \\
\text { measured }\end{array}$ \\
\hline Autozooecial chamber maximum diameter _-____ & 0.2050 & 0.0176 & 8.57 & $0.20-0.21$ & $0.18-0.24$ & 30 & 6 \\
\hline Autozooecial chamber minimum diameter _-_ & .1607 & .0212 & 13.17 & $.15-.17$ & $.13-.20$ & 30 & 6 \\
\hline Autozooecial wall thickness, exozone & .0404 & .0114 & 28.11 & .04 & $.02-$ & 25 & 5 \\
\hline Macular polymorph chamber maximum diameter - & .3170 & .0353 & 11.13 & .29 & $.26-$ & 10 & 5 \\
\hline Macular polymorph chamber minimum diameter & .2230 & .0258 & 11.16 & .20 & $.17-$ & 10 & 5 \\
\hline Mesozooecial chamber maximum diameter & .0720 & .0249 & 34.52 & $.05-.10$ & $.04-.13$ & 10 & 5 \\
\hline Autozooecia (number per $2 \mathrm{~mm}$ ) - & 8.60 & .6325 & 7.35 & $8.25-8.95$ & $8-10$ & 15 & 6 \\
\hline Autozooecia (number per $\mathrm{mm}^{2}$ ) & 20.60 & 1.2649 & 6.14 & $19.70-21.51$ & -22 & 10 & 6 \\
\hline Diaphragms (number per $\mathrm{mm}$ ) & 6.0625 & .9979 & 16.46 & $5.53-6.59$ & $5-8$ & 16 & 5 \\
\hline Style, diameter in exozone & .05 & .0150 & 29.90 & $.04-\quad .06$ & $.03-\quad .08$ & 18 & 6 \\
\hline Zoarial branch diameter - & 5.9143 & 1.8078 & 30.57 & $4.24-7.59$ & $4.5-9.0$ & 7 & 4 \\
\hline Endozone width & 3.880 & 1.1429 & 29.46 & $3.06-4.70$ & $2.80-5.70$ & 10 & 6 \\
\hline Exozone width (one side only) & 1.1769 & .0228 & 19.36 & $1.04-1.31$ & $.80-1.50$ & 13 & 4 \\
\hline
\end{tabular}


Ulrich $(1883$, p. 152$)$ reported $H$. trentonensis from his "upper part of the Trenton Group," Middle Ordovician, at Burgin. Nickles (1905, p. 42) found it in his "Lexington Group" at Frankfort, and McFarlan (1931, p. 98) reported it from his "Jessamine" strata of the Lexington Limestone. Brown (1965, p. 991) reported $H$. trentonensis (as Dekayella trentonensis) from his undivided "Logana-Jessamine Limestone Members" of the Lexington Limestone (the Logana and Grier Limestone Members of the Lexington Limestone of current usage) at several localities in the Blue Grass region of Kentucky.

Dekayella anomala Brown, 1965; holotype IU 8232-3 and paratype IU 8242-3 from the undivided "LoganaJessamine Limestone Members" of the Lexington Limestone (the Logana and Grier Limestone Members, respectively, of the Lexington Limestone of current usage), Middle Ordovician, Jessamine, Woodford, and Franklin counties, Ky.

Studied material.-Dekayia trentonensis Ulrich, 1883, holotype USNM 43660 and paratypes USNM 308737,308738 from the primary type suite USNM 43660, "Wilmore of the Trenton Group," Middle Ordovician, near Burgin, Ky. Hypotypes USNM 308739308742 from the "Trenton beds" near Frankfort, Ky. Hypotypes USNM 308743, 308744 from the "Trenton beds" near Berry, Ky.; 308745 from Ordovician strata near Burgin, Ky.; and 308746 from Ordovician strata near Danville, Ky.

Hypotypes USNM 308747 (USGS colln. D1221-CO), 308748 (USGS colln. D1231-CO), 308749 (USGS colln. D1237-CO), 308750 (USGS colln. D1295-CO), 308751 (USGS colln. D1299-CO), 308752, 308753 (USGS colln. D1303-CO), 308754-308759 (USGS colln. 4680-CO), 308760-308762 (USGS colln. 4682-CO), 308763, 308764 (USGS colln. 4688-CO), 308765 (USGS colln. 4689-CO), 308766 (USGS colln. 4927-CO), 308767 (USGS colln. 4974-CO), 308768 (USGS colln. 4948-CO), 308769 (USGS colln. 4954-CO), 308770 (USGS colln. 4963-CO), 308771 (USGS colln. 4968-CO), 308772 (USGS colln. 4969-CO), 308773 (USGS colln. 4969-CO).

Remarks. $-H$. trentonensis is related most closely to $H$. foliacea (Ulrich and Bassler), differing from it in few morphological characteristics. Geographically, both species occur in the same general area in Kentucky and $H$. foliacea is known only from Kentucky. Stratigraphically, $H$. trentonensis occurs in Rocklandian, Kirkfieldian, and Shermanian Stages of Middle Ordovician deposits and $H$. foliacea in the upper Shermanian Stage of Middle Ordovician strata and in the Edenian Stage of the Upper Ordovician. H. trentonensis reportedly occurs (Ulrich, 1893, p. 274, as Dekayia trentonensis) in the upper part of the Decorah Shale and the lower part of the Galena Dolomite, Rocklandian and Kirkfieldian Stages respectively, in Minnesota. The close morphological similarity and geographic and stratigraphic proximity of the two species suggest that $H$. trentonensis may be an ancestor of $H$. foliacea.

$H$. trentonensis typically has zoaria with subcylindrical branches and autozooecia with relatively thin cortices and linings, relatively few endostyles (endoacanthopores of authors) or exozonal styles, and virtually no basal diaphragms in axial portions of endozones, except for autozooecial zones of rejuvenation. Basal diaphragms are common in exozones of $H$. trentonensis, but are less regularly spaced and generally occur farther apart than in $H$. foliacea (pl. 19, figs. $1 a, 3 b$ ). Mesozooecia in $H$. trentonensis occur mostly in maculae and are only sparingly present in intermacular areas. Mesozooecial walls of $H$. trentonensis are generally straight and do not have the moniloid appearance that commonly characterizes proximal parts of mesozooecia of other Heterotrypa species.

The combination of morphological characters that typifies $H$. trentonensis is also present in Dekayella anomala Brown (1965, pl. 114, figs. 4-9) and in specimens assigned to D. clavata Fritz (Brown, 1965, pl. 113, figs. 7-10), which Brown (1965, p. 989-991) described from his undivided "Logana-Jessamine Members" of the Lexington Limestone (the Logana and Grier Limestone Members, respectively, of the Lexington Limestone of current usage) at several localities in central Kentucky.

These taxa are morphologically indistinguishable; therefore $D$. anomala, upon reevaluation of its primary material, and $D$. clavata, upon reevaluation of specimens found by Brown in Kentucky, are regarded herein as subjective junior synonyms of $H$. trentonensis (Ulrich, 1883).

Boardman and Utgaard (1966, p. 1103-1106) reevaluated the generic concepts of Heterotrypa Nicholson, Dekayella Ulrich, and Dekayia Milne-Edwards and Haime, a reevaluation that resulted in the retaining of Heterotrypa and Dekayia as separate and distinct genera and the reassignment of Dekayella to the synonomy of Heterotrypa. Boardman and Utgaard's revised classification (1966) on the generic level has been generally accepted in subsequently published works (Bork and Perry, 1968a; McKinney, 1971; Anstey and Perry, 1973; Astrova, 1978, among others) and is followed herein.

In accordance with emended definitions of Heterotrypa and Dekayia, Boardman and Utgaard (1966) reassigned a number of species to these genera, and included Dekayia trentonensis Ulrich and Dekayella foliacea Ulrich and Bassler (see H. foliacea) in Heterotrypa. H. trentonensis (Ulrich) and Dekayella clavata 
Fritz are closely related, as noted by Brown (1965, p. 992), and D. clavata Fritz (1957, p. 13) is consistent with the emended definition of Heterotrypa. $H$. clavata (Fritz), however, differs from $H$. trentonensis in having club-shaped zoaria in which autozooecia are thicker walled and have monilaelike swellings, abundant and conspicuous exozonal styles (acanthopores of Fritz), less regularly developed basal diaphragms in exozones, and prominent maculae.

Specimens of Heterotrypa that Ulrich (1893, p. 274) reported as Dekayia trentonensis from his "upper third of the Trenton Shales and Galena Shales," Middle Ordovician, in Minnesota, differ from those of $H$. trentonensis reported from Kentucky in having smaller zoaria in which autozooecia have thick walls, conspicuous and numerous exozonal styles, abundant basal diaphragms in endozones and exozones, and relatively thick autozooecial linings. These specimens are retained in $H$. trentonensis until additional thin-sectioned material becomes available for evaluation.

\section{Genus STIGMATELLA Ulrich and Bassler, 1904}

Type species.-Stigmatella crenulata Ulrich and Bassler, 1904, p. 33; by original designation, Richmondian Stage, Late Ordovician.

Remarks.-The original definition by Ulrich and Bassler (1904, p. 33) for the genus Stigmatella is followed here. They characterized Stigmatella as having zoaria with irregular and various growth habits, polygonal to subrounded autozooecial shapes in cross section, relatively few basal diaphragms, and numerous but irregularly distributed styles (acanthopores of Ulrich and Bassler). Mesozooecia (mesopores of Ulrich and Bassler) were characterized as sparse or irregularly variable in abundance.

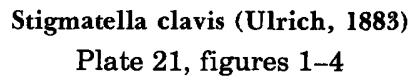

Leptotrypa clavis Ulrich, 1883, p. 161, pl. 6, figs. 3, 3a.

Stigmatella clavis (Ulrich). Ulrich and Bassler, 1904, p. 34, pl. 10, fig. 4; Cumings, 1908, p. 881, pl. 24, figs. 2, 2a; pl. 25, fig. 3. Armstrong, 1945, p. 151. Anstey and Perry, 1973, p. 22, fig. 6, pl. 22, figs. 2-6.

Description.-Zoaria small, subdomal or irregular in shape, encrusting, commonly having conspecific overgrowth. Basal layers exceedingly thin, indistinctly laminate, imperforate.
Endozones narrow, poorly defined. In endozones autozooecia recumbent for very short distances, extending distally slightly obliquely to basal layers of zoaria. Styles and basal diaphragms absent.

In exozones, intercalate budding sparse; autozooecia contiguous, irregularly polygonal, four- to six-sided in cross section, without preferred alignment. Autozooecial walls thin, approximately $0.01-0.02 \mathrm{~mm}$ thick on the average, only slightly thicker than in endozones, straight to slightly sinuous, occasionally slightly crenulated, locally thickened by styles approximately $0.02-0.03 \mathrm{~mm}$ thick. Autozooecial boundaries narrowly serrated, commonly obscured. Styles abundant, generally small, with distinct cores and thin sheaths, occasionally thickened locally. Core boundaries generally distinct. Styles in corners of autozooecia and along walls between corners, slightly inflecting autozooecial walls locally, occasionally projecting into autozooecial chambers. Basal diaphragms sparse, planar to slightly curved, generally absent in many autozooecia. Autozooecial linings absent.

Autozooecial chambers polygonal, four- to six-sided in cross section.

Mesozooecia sparse, generally absent; polygonal to subpolygonal in cross section, slightly moniloid locally. Mesozooecial diaphragms sparse, poorly defined. Maculae common, indistinct in cross section, consisting of polymorphs slightly larger than autozooecia and of occasional mesozooecia. Polymorphs in centers of maculae commonly subcircular, subpolygonal to polygonal along macular margins.

Measurements.-Measurements are summarized in tables 32 and 33.

Geographic and stratigraphic distribution.-S. clavis occurs commonly in rocks of Edenian and Maysvillian stages, Upper Ordovician, in the tristate area of Kentucky, Ohio, and Indiana. Foerste $(1916$, p. 86) reportedly found $S$. clavis (as identified by $\mathrm{E}$. O. Ulrich and J. M. Nickles) in rocks of Late Ordovician age on Manitoulin Island in Ontario. Verification of this find will considerably increase the geographic range of $S$. clavis in deposits of the Upper Ordovician of eastern North America.

Occurrence in Kentucky.-Sulphur Well Member, Shermanian Stage (USGS colln. D1164-CO), of the Lexington Limestone; Clays Ferry Formation: Sher-

TABLE 32.-Summarized measurements of a specimen of Stigmatella clavis (Ulrich) [Hypotype USNM 308775. All measurements in millimeters unless otherwise indicated]

\begin{tabular}{|c|c|c|c|c|c|c|c|}
\hline & $\begin{array}{c}\text { Arithmetic } \\
\text { mean }\end{array}$ & $\begin{array}{l}\text { Standard } \\
\text { deviation } \\
\text { of mean }\end{array}$ & $\begin{array}{l}\text { Coefficient } \\
\text { of } \\
\text { variation }\end{array}$ & $\begin{array}{l}\text { 95-percent } \\
\text { confidence } \\
\text { interval } \\
\text { of mean }\end{array}$ & Range & $\begin{array}{c}\text { Number } \\
\text { of } \\
\text { measurements }\end{array}$ & $\begin{array}{c}\text { Number } \\
\text { of } \\
\text { zoaria } \\
\text { measured }\end{array}$ \\
\hline $\begin{array}{l}\text { Autozooecial chamber maximum diameter } \\
\text { Autozooecial chamber minimum diameter } \\
\text { Styles in autozooecium (number) }\end{array}$ & $\begin{array}{l}0.2060 \\
.170 \\
5.0\end{array}$ & $\begin{array}{r}0.0219 \\
.0255 \\
.7071\end{array}$ & $\begin{array}{l}10.64 \\
15.0 \\
14.14\end{array}$ & $\begin{array}{r}0.18-0.23 \\
.14-.20 \\
4.12-5.88\end{array}$ & $\begin{array}{l}0.18-0.24 \\
.13-.20 \\
4^{.2}-6\end{array}$ & $\begin{array}{l}5 \\
5 \\
5\end{array}$ & $\begin{array}{l}1 \\
1 \\
1\end{array}$ \\
\hline
\end{tabular}


TABLE 33.-Summarized measurements of specimens of Stigmatella clavis (Ulrich) [Hypotypes USNM 308777 (USGS colln. D1164-CO) and 308778 (USGS colln. 6714-CO). All measurements in millimeters unless otherwise indicated]

\begin{tabular}{|c|c|c|c|c|c|c|c|}
\hline & $\begin{array}{c}\text { Arithmetic } \\
\text { mean }\end{array}$ & $\begin{array}{l}\text { Standard } \\
\text { deviation } \\
\text { of mean }\end{array}$ & $\begin{array}{c}\text { Coefficient } \\
\text { of } \\
\text { variation }\end{array}$ & $\begin{array}{l}\text { 95-percent } \\
\text { confidence } \\
\text { interval } \\
\text { of mean } \\
\end{array}$ & Range & $\begin{array}{c}\begin{array}{c}\text { Number } \\
\text { of } \\
\text { measurements }\end{array}\end{array}$ & $\begin{array}{c}\text { Number } \\
\text { of } \\
\text { zoaria } \\
\text { measured }\end{array}$ \\
\hline Autozooecial chamber maximum diameter _-____ & 0.1978 & 0.0211 & 10.66 & $0.18-0.21$ & $0.17-0.23$ & 9 & 2 \\
\hline Autozooecial chamber minimum diameter & .1744 & .2603 & 14.92 & $.15-\quad .19$ & $.14-.22$ & 9 & 2 \\
\hline Macular polymorph chamber maximum diameter -- & .2633 & .0314 & 11.93 & $.23-$ & $.22-$ & 6 & 2 \\
\hline Macular polymorph chamber minimum diameter-- & .1983 & .0248 & 12.52 & $.17-$ & $.17-$ & 6 & 2 \\
\hline Mesozooecial chamber maximum diameter & .0971 & .0390 & 4.02 & $.06-\quad .13$ & $.05-.17$ & 7 & 2 \\
\hline Autozooecia (number per $2 \mathrm{~mm}$ ) - & 9.60 & .6992 & 7.18 & $9.10-10.10$ & $9^{\cdot-11}$ & 10 & 2 \\
\hline Autozooecia (number per $\mathrm{mm}^{2}$ ) & 21.20 & 3.0332 & 14.31 & $17.43-24.97$ & -25 & 5 & 1 \\
\hline Mesozooecia (number per $\mathrm{mm}^{2}$ ) & 3.0 & 2.0 & 66.66 & $(-1.97-7.97)$ & -5 & 3 & 1 \\
\hline Styles in autozooecium (number) & 4.80 & 1.62 & 33.74 & $3.64-5.96$ & -7 & 10 & 2 \\
\hline
\end{tabular}

manian Stage (USGS colln. 6714-CO, 6716-CO, 6717-CO), Edenian Stage (USGS collns. 6721-CO, 6725-CO, 6733-CO).

Anstey and Perry (1973, p. 34, fig. 8) established that $S$. clavis ranged from near the base almost to the top of their Eden Shale (the Kope Formation of current usage). They named $S$. clavis to be the index species of a bryozoan zone comprising strata approximately $10 \mathrm{~m}$ thick from about $8 \mathrm{~m}$ to $18 \mathrm{~m}$ above the base of the Kope Formation.

In addition, Anstey and Perry (1973, p. 32, fig. 8) noted that $S$. clavis seemed to be all but absent from the middle part of the Kope Formation in their study area. They ascribed this absence to a change in sedimentation in the depositional basin of the Kope Formation. Anstey and Perry (1973) suggested that S. clavis probably thrived better in the limier zones of the lower and upper parts of their Eden Shale (the Kope Formation of current usage) than in the muddier zone in the middle part of the Kope Formation.

Occurrence outside Kentucky.-Ulrich (1883, p. 162) reported S. clavis (as Leptotrypa) from his "lower $200 \mathrm{ft}$ of strata" at Cincinnati, Ohio. Cumings (1908, p. 881) and Cumings and Galloway $(1913$, p. 52) found $S$. clavis in their "Eden" and "lower Maysville" strata at Tanners Creek in Indiana.

Studied material.-Leptotrypa clavis Ulrich, 1883, lectotype USNM 43718 from the syntype suite USNM 43718, "lower beds of the Eden Shales" (the lower Kope Formation of current usage), Covington, Ky.

Hypotypes USNM 308774, "Eden" strata, near Cincinnati; 308775, "Cincinnati Group," Covington, Ky.

Hypotypes USNM 308776, 308777 USGS colln. D1164-CO), 308778 (USGS colln. 6714-CO), 308779308781 (USGS colln. 6716-CO), 308782, 308783 (USGS colln. 6717-CO), 308784 (USGS colln. 6721-CO), 308785 (USGS colln. 6725-CO), 308786 (USGS colln. 6733-CO).

Remarks. $-S$. clavis is characterized by small subglobular and encrusting zoaria having relatively straight and thin-walled autozooecia and virtually no basal diaphragms but abundant styles throughout exo- zones. The combination of these morphological features in zoaria distinguishes $S$. clavis from other species of Stigmatella.

$$
\begin{gathered}
\text { Stigmatella multispinosa Brown, } 1965 \\
\text { Plate } 18 \text {, figures } 4,5
\end{gathered}
$$

Stigmatella multispinosa Brown, 1965, p. 996, pl. 115, figs. 9-11.

Description.-Zoaria subconical, unbranched. Basal layers of zoaria irregularly sinuous, thin, indistinctly laminate, imperforate.

Endozones narrow, indistinctly defined. In endozones, autozooecia recumbent for short distances, extending distally approximately at right angles to basal layer of zoaria. Basal diaphragms sparse, occurring singly in some autozooecia, lacking in others.

In exozones, autozooecia generally contiguous, sparingly intercalated, straight or slightly curving outward, generally without preferred alignment, polygonal to subpolygonal in cross section, occasionally partly separated by mesozooecia. Autozooecial walls straight, thin, only slightly thicker than in endozones, approximately $0.01-0.2 \mathrm{~mm}$ thick on the average, slightly thickened by styles. Autozooecial boundaries narrowly serrated, generally indistinct. Styles small and abundant with thin cores and sheaths, arising throughout exozones, locally terminating within exozones, occurring in corners of autozooecia and along walls between corners, inflecting autozooecial walls locally, extending occasionally into autozooecial chambers, locally occurring at similar growth stages of zoarium.

Basal diaphragms abundant, planar to slightly curved, at right angles or oblique to chamber axis, evenly spaced, generally more closely spaced in late exozones, occurring locally in indistinct zones at similar growth stages. Autozooecial linings absent.

Autozooecial chambers polygonal in cross section, four- to six-sided in inner exozones, polygonal to subpolygonal, generally six-sided in outer exozones.

Mesozooecia sparse, with slightly moniloid proximal parts, polygonal in cross section; chambers slightly constricted at junctions of mesozooecial walls and diaphragms. Mesozooecial diaphragms twice as closely 
spaced as basal diaphragms in autozooecia.

Maculae common, generally indistinct in cross section, consisting of polymorphs slightly larger than autozooecia, subpolygonal to subcircular in cross section, with scattered styles and occasional mesozooecia in various combinations.

Measurements.-Measurements are summarized in table 34.

Geographic and stratigraphic distribution.-S. multispinosa is known only from Kentucky, where it occurs in the Grier Limestone Member, Shermanian Stage (USGS collns. D1299-CO, D1302-CO; 4694-CO), and the Tanglewood Limestone Member, Shermanian Stage (USGS collns. 4992-CO, 4993-CO; D1305-CO), Middle Ordovician, of the Lexington Limestone.

Brown (1965, p. 997) reported $S$. multispinosa from his undivided "Logana-Jessamine Limestone Members" of the Lexington Limestone in Fayette County.

Studied material.-Holotype IU 8241-2, undivided "Logana-Jessamine Limestone Members" of the Lexington Limestone of Brown (1965), Fayette County, Ky.

Hypotypes USNM 308787 (USGS colln. D1320-CO), 308788 (USGS colln. D1305-CO), 308789, 308790 (4694-CO), 308791 (USGS colln. 4992-CO), 308792 (USGS colln. 4993-CO).

Remarks.-S. multispinosa characteristically has autozooecia with thin, straight walls, abundant and relatively evenly spaced basal diaphragms, abundant small styles (acanthopores of Brown, 1965) and few mesozooecia (mesopores of Brown, 1965). Maculae of $S$. multispinosa are approximately $2-3 \mathrm{~mm}$ apart (Brown, 1965, p. 996).

S. multispinosa is more closely related to $S$. sessilis Cumings and Galloway (1913, "Fairmount" strata of Cumings and Galloway, Upper Ordovician, Tanner's Creek, Ind.) than to any other species of Stigmatella, having erect autozooecia with numerous basal diaphragms. S. multispinosa, however, differs from $S$. sessilis (Cumings and Galloway, 1913, pl. 20, fig. 2a; Brown, 1965, p. 997) in having more abundant but smaller styles, thinner autozooecial walls, and fewer mesozooecia. Proximal parts of mesozooecia in $S$. multispinosa are only slightly moniloid, those in $S$. sessilis distinctly so.

\section{Stigmatella sp. \\ Plate 21, figure 5}

Description.-Zoarium subdomal, layered, and encrusting, consisting of autozooecia in two or more superimposed layers. Basal layer of zoarium and of superimposed autozooecial layers indistinctly laminate.

Endozones narrow. In endozones, autozooecia recumbent for short distances, extending distally at approximately right angles to basal layers. Basal diaphragms absent.

In exozones, intercalated budding sparse to absent; autozooecia contiguous, irregularly polygonal, four- to six-sided in cross section, without preferred alignment. Autozooecial walls relatively straight, slightly crenulated locally, generally thin, locally thickened slightly by styles; autozooecial boundaries narrowly serrated, mostly obscured. Styles small, generally sparse, with small cores and relatively thick sheaths; core boundaries smooth. Styles arising and commonly terminating within exozones, occurring singly in corners of some autozooecia and along walls, lacking in others, occasionally slightly inflecting walls of some autozooecia and projecting locally into autozooecial chambers. Basal diaphragms common, planar to slightly curved, approximately at right angles to chamber axis, evenly spaced locally, occasionally occurring in indistinct zones. Cystoidal diaphragms sparse, generally absent. Autozooecial linings absent.

Autozooecial chambers irregularly polygonal in cross section.

Mesozooecia sparse, generally lacking in intermacular areas. Maculae common, indistinct in cross section, occurring regularly, consisting of polymorphs slightly larger than autozooecia and occasionally of mesozooecia.

TABLE 34.-Summarized measurements of specimens of Stigmatella multispinosa Brown [Hypotypes USNM 308789, 308790 (USGS colln. 4694-CO), 308787 (USGS colln. D1302-CO), 308788 (USGS colln. D1305-CO). All measurements in millimeters unless otherwise indicated]

\begin{tabular}{|c|c|c|c|c|c|c|c|}
\hline & $\begin{array}{c}\text { Arithmetic } \\
\text { mean }\end{array}$ & $\begin{array}{c}\text { Standard } \\
\text { deviation } \\
\text { of mean }\end{array}$ & $\begin{array}{c}\text { Coefficient } \\
\text { of } \\
\text { variation }\end{array}$ & $\begin{array}{c}\text { 95-percent } \\
\text { confidence } \\
\text { interval } \\
\text { of mean }\end{array}$ & Range & $\begin{array}{c}\begin{array}{c}\text { Number } \\
\text { of } \\
\text { measurements }\end{array} \\
\end{array}$ & $\begin{array}{c}\text { Number } \\
\text { of } \\
\text { zoaria } \\
\text { measured }\end{array}$ \\
\hline Autozooecial chamber maximum diameter & 0.2095 & 0.0123 & 5.89 & $0.20-0.22$ & $0 . \overline{18}-0 . \overline{23}$ & 20 & 4 \\
\hline Autozooecial chamber minimum diameter _-_ & .1745 & .0289 & 11.97 & $.16-.18$ & $.14-.21$ & 20 & 4 \\
\hline Macular polymorph chamber maximum diameter & .2646 & .0338 & 12.69 & $.24-$ & $.22-$ & 11 & 3 \\
\hline Macular polymorph chamber minimum diameter & .2282 & .0286 & 12.52 & $.21-$ & $.20-$ & 11 & 3 \\
\hline Mesozooecial chamber maximum diameter & .0878 & .0682 & 30.56 & $.07-.11$ & $.04-\quad .12$ & 9 & 3 \\
\hline Autozooecia (number per $2 \mathrm{~mm}$ ) & 9.1176 & .6966 & 7.64 & $8.76-9.48$ & $8-10$ & 17 & 4 \\
\hline Autozooecia (number per $\mathrm{mm}^{2}$ ) & 20.909 & 2.4271 & 11.61 & $19.28-22.54$ & -25 & 11 & 4 \\
\hline Mesozooecia (number per $\mathrm{mm}^{2}$ ) & 5.0 & 2.1213 & 42.43 & $2.37-7.63$ & -8 & 5 & 3 \\
\hline Diaphragms (number per mm) & 6.3333 & 1.2344 & 19.49 & $5.65-7.02$ & $4-8$ & 15 & 3 \\
\hline Zoarial branch diameter & 3.60 & .9849 & 27.36 & $1.15-6.05$ & $2.5-4.4$ & 3 & 1 \\
\hline Styles in autozooecium (number) & 4.80 & 1.196 & 24.92 & $4.24-5.36$ & $2-7$ & 20 & 4 \\
\hline
\end{tabular}


Measurements.-Measurements are summarized in table 35.

Geographic and stratigraphic distribution.-Stigmatella sp. occurs in the Tanglewood Limestone Member, Shermanian Stage (USGS colln. 4886-CO), Middle Ordovician, of the Lexington Limestone.

Studied material.-Hypotype USNM 308793 (USGS colln. 4886-CO); $S$. conica Brown, 1965, holotype IU 8235-3, undivided "Logana-Jessamine Limestone Members" of the Lexington Limestone, Middle Ordovician, Garrard County, Lexington, Ky. (Brown, 1965, p. 996).

Remarks.-The single specimen is included tentatively in Stigmatella sp. It is similar to generalized Stigmatella in having autozooecia with polygonal cross sectional shapes, thin autozooecial walls, sparseness of mesozooecia in intermacular and macular areas, and small styles. It differs from typical Stigmatella in having straight autozooecial walls and numerous basal diaphragms.

Stigmatella sp. appears to be similar to $S$. conica Brown (1965, p. 995, pl. 116, figs. 1-7, from undivided "Logana-Jessamine Limestone Members" of Brown in the Lexington Limestone at several localities in central Kentucky). Specimens of Stigmatella sp. and $S$. conica both have multilayered zoaria in which autozooecia have poorly defined endozones, are aligned approximately at right angles to zoarial basal layers, and have basal diaphragms and styles in exozones.

$S$. sp., however, differs from $S$. conica in several morphological characteristics. Basal diaphragms in $S$. sp. are relatively abundant (table 35 ) in unit distance; those in $S$. conica are sparse throughout zoarium (Brown, 1965, pl. 116, figs. 1-3). Styles in S. sp. are generally less than $0.02 \mathrm{~mm}$ in diameter and smaller than those in $S$. conica. Styles in $S$. conica are approximately $0.05 \mathrm{~mm}$ in diameter and are conspicuous in some specimens (Brown, 1965, pl. 116, fig. 6; table 13). $S$. $s p$. differs further from $S$. conica in number of autozooecia in unit length. $S$. sp. has about 8 autozooecia in $2 \mathrm{~mm}$ (table 35 ); $S$. conica has approximately 10
(Brown, 1965, table 13). Furthermore, $S$. sp. lacks the conspicuous maculae that characterize $S$. conica.

Because of these morphological differences, $S$. sp. is not assigned to $S$. conica at present. The taxonomic position of this specimen thus remains uncertain until additional material becomes available for study.

\section{Family AMPLEXOPORIDAE \\ Genus AMPLEXOPORA Ulrich, 1882}

Type species.-Atactopora septosa Ulrich, 1879, subsequent designation by Boardman (1960b, p. 16); Fairview Formation, Maysvillian Stage, Upper Ordovician.

Remarks.-Boardman (1960b, p. 16) emended the definition for the genus Amplexopora Ulrich, and that emended definition is followed here.

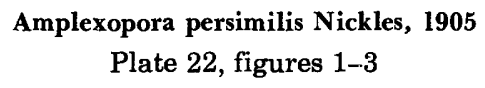

Amplexopora persimilis Nickles, 1905, p. 47, pl. 2, figs. 2, 3; Ruedemann, 1925, p. 98, pl. 9, fig. 2; Boardman, 1960b, p. 18.

Description.-Zoaria dendroid, branching irregularly, occasionally encrusting; branches subcylindrical to flattened, irregularly variable in size.

In endozones, autozooecia irregularly polygonal in cross section, curving gradually outward. Autozooecial walls nearly straight, slightly crenulated locally. Basal diaphragms common; locally straight to slightly curved, generally at right angles to chamber axis, unevenly spaced; closely spaced in indistinct zones in late endozones. Zones of rejuvenation of autozooecia locally common, extending across zoaria.

In exozones, autozooecia approximately at right angles to zoarial surface, irregularly polygonal, generally five- to six-sided in cross section, without preferred alignment; partly contiguous, separated by mesozooecia. Autozooecial walls generally thin, irregularly crenulated locally in early exozones. Autozooecial boundaries distinct, narrowly serrated.

Styles small, common to abundant, with distinct cores and thin sheaths; occurring generally along autozooecial boundaries, locally slightly offset from but

TABLE 35.-Summarized measurements from a specimen of Stigmatella $s p$.

[Hypotype USNM 308793 (USGS colln. 4886-CO). All measurements in millimeters unless otherwise indicated]

\begin{tabular}{|c|c|c|c|c|c|c|c|}
\hline & $\begin{array}{c}\text { Arithmetic } \\
\text { mean }\end{array}$ & $\begin{array}{c}\text { Standard } \\
\text { deviation } \\
\text { of mean }\end{array}$ & $\begin{array}{c}\text { Coefficient } \\
\text { of } \\
\text { variation }\end{array}$ & $\begin{array}{l}\text { 95-percent } \\
\text { confidence } \\
\text { interval } \\
\text { of mean }\end{array}$ & Range & $\begin{array}{c}\begin{array}{c}\text { Number } \\
\text { of } \\
\text { measurements }\end{array} \\
\end{array}$ & $\begin{array}{c}\text { Number } \\
\text { of } \\
\text { zoaria } \\
\text { measured }\end{array}$ \\
\hline $\begin{array}{l}\text { Autozooecial chamber maximum diameter } \\
\text { Autozoecial chamber minimum diameter } \\
\text { Macular polymorph chamber maximum diameter } \\
\text { Macular polymorph chamber minimum diameter-- } \\
\text { Mesozooecial chamber maximum diameter } \\
\text { Autozooecia (number per } 2 \mathrm{~mm}^{2} \text { ) } \\
\text { Autozooecia (number per } \mathrm{mm}^{2} \text { ) } \\
\text { Mesozooecia (number per } \mathrm{mm}^{2} \text { ) } \\
\text { Diaphragms (number per } \mathrm{mm} \text { ) } \\
\text { Zoarial thickness }\end{array}$ & $\begin{array}{c}0.220 \\
.1940 \\
.3380 \\
.2760 \\
.1167 \\
8 \\
16.80 \\
1.6667 \\
5 \\
3.2667\end{array}$ & $\begin{array}{r}0.0037 \\
.0152 \\
.0179 \\
.0270 \\
.0473 \\
7.0711 \\
1.7889 \\
.5774 \\
1.2247 \\
.6110\end{array}$ & $\begin{array}{r}3.77 \\
7.82 \\
5.29 \\
9.79 \\
40.51 \\
8.84 \\
10.65 \\
34.64 \\
24.50 \\
18.70\end{array}$ & 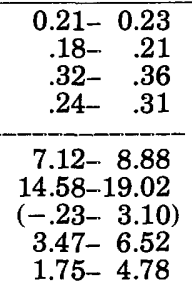 & $\begin{aligned} & 0.21-0.23 \\
& .17- .21 \\
& .32- .36 \\
& .25- .32 \\
& .08-.17 \\
& 7 \quad-9 \\
& 15 \quad-19 \\
& 1-2 \\
& 4=7 \\
& 2.60-3.80\end{aligned}$ & $\begin{array}{l}5 \\
5 \\
5 \\
5 \\
3 \\
5 \\
5 \\
3 \\
5 \\
3\end{array}$ & $\begin{array}{l}1 \\
1 \\
1 \\
1 \\
1 \\
1 \\
1 \\
1 \\
1 \\
1\end{array}$ \\
\hline
\end{tabular}


commonly inflecting autozooecial walls. Basal diaphragms abundant, slightly curved, commonly concave in relation to zoarial surface; generally evenly spaced, locally scattered, commonly oblique to chamber axis. Cystoidal diaphragms sparse in exozones. Autozooecial linings generally absent.

Autozooecial chambers subpolygonal in cross section. Mesozooecia common, irregularly polygonal in cross section, occurring mostly in corners of autozooecia. Mesozooecial walls similar in thickness to those of autozooecia, occasionally slightly moniloid proximally. Mesozooecial diaphragms abundant, generally closely and more evenly spaced than basal diaphragms in autozooecia, commonly terminating in late exozones.

Maculae common, occurring in indistinct rhombic pattern, generally evenly spaced; consisting of polymorphs larger than autozooecia, irregularly polygonal in cross section, and scattered mesozooecia.

Measurements.-Measurements are summarized in table 36.

Geographic and stratigraphic distribution.-A. persimilis ranges from the late Shermanian Stage, Middle Ordovician, into the Edenian Stage, Late Ordovician, in Kentucky. It occurs in the Millersburg Member, Shermanian Stage (USGS colln. 7052-CO), of the Lexington Limestone; the Clays Ferry Formation, Edenian Stage (USGS colln. 5003-CO, 6738-CO); and the Kope Formation, Edenian Stage (USGS colln. 6934-CO).

Occurrence outside Kentucky.-Nickles (1905, p. 47) reported A. persimilis from his "lower two-thirds of the Eden Group" (the Kope Formation of current usage), at Cincinnati, Ohio. A. persimilis has been reported as occurring in the upper part of the "Whetstone Gulf Formation," Upper Ordovician, in the northern part of New York State (Ruedemann, 1925, p. 98, as identified by O. E. Ulrich) and the lower part of Upper Ordovician deposits on Manitoulin Island, western Ontario. (Foerste, p. 84, 86, 88, 91, as identified by O. E. Ulrich, R. S. Bassler, and J. M. Nickles). These reported occurrences, however, need to be verified in order to estab- lish geographic and stratigraphic limits of $A$. persimilis outside Kentucky.

Studied material.-Lectotype USNM 96566, designated herein from primary type suite USNM 96566, from the "lower beds of the Eden Shales," Upper Ordovician, West Covington, Ky. Hypotype USNM 308794 from the "lower beds of the Eden Shales," Covington, Ky., and hypotype USNM 308795 from the "lower beds of the Eden Shales" at Cincinnati.

Hypotypes, USNM 308796 (USGS colln. 5003-CO), 308797 (USGS colln. 6738-CO), 308798 (USGS colln. 6934-CO), 308799 (USGS colln. 7052-CO).

Remarks. $A$. persimilis is characterized by autozooecia having relatively large chambers and thin walls and a few small styles in exozones, and by basal diaphragms in endozones.

A. persimilis is similar to A. septosa (Ulrich) (Boardman, 1960 b, p. 20 , pl. 5, figs. $1-2$; pl. 6, figs. $1-3$ ) in shape in cross section of autozooecia and approximate size and appearance of styles (acanthopores of Boardman). A. persimilis differs from A. septosa, however, in having autozooecia with thinner walls and slightly larger chambers in exozones, numerous basal diaphragms in endozones, and mesozooecia in early exozones. Styles are small and numerous in both species, but they strongly inflect and are commonly offset from autozooecial walls in A. septosa. In A. persimilis, styles only slightly inflect autozooecial walls and generally are only slightly offset from autozooecial walls.

\section{Amplexopora aff. A. winchelli Ulrich, 1886 Plate 23}

Description.-Zoaria dendroid, branching irregularly; branches subcylindrical, irregularly variable in thickness.

In endozones, autozooecia four- to six-sided in cross section, curving broadly outward. Autozooecial walls straight to slightly sinuous, in some zoaria occasionally crenulated locally. Basal diaphragms common to sparse, planar, mostly at right angles to chamber

TABLE 36.-Summarized measurements of specimens of Amplexopora persimilis Nickles [Lectotype USNM 96566 and hypotypes USNM 308797 (USGS colln. 6738-CO), 308799 (USGS colln. 7052-CO). All measurements in millimeters unless otherwise indicated]

\begin{tabular}{|c|c|c|c|c|c|c|c|}
\hline & $\begin{array}{c}\text { Arithmetic } \\
\text { mean }\end{array}$ & $\begin{array}{l}\text { Standard } \\
\text { deviation } \\
\text { of mean }\end{array}$ & $\begin{array}{c}\text { Coefficient } \\
\text { of } \\
\text { variation }\end{array}$ & $\begin{array}{l}\text { 95-percent } \\
\text { confidence } \\
\text { interval } \\
\text { of mean }\end{array}$ & Range & $\begin{array}{c}\begin{array}{c}\text { Number } \\
\text { of } \\
\text { measurements }\end{array} \\
\text { mas }\end{array}$ & $\begin{array}{c}\text { Number } \\
\text { of } \\
\text { zoaria } \\
\text { measured }\end{array}$ \\
\hline Autozooecial chamber maximum diameter & 0.2350 & 0.0246 & 10.47 & $0.2174-0.2526$ & $0.20-0.27$ & 10 & 2 \\
\hline Autozooecial chamber minimum diameter & .2080 & .0161 & 7.79 & $.1964-\quad 2196$ & $.19-\quad .24$ & 10 & $\overline{2}$ \\
\hline $\begin{array}{l}\text { Autozooecial wall thickness between chambers -- } \\
\text { Macular polymorph chamber maximum }\end{array}$ & .0210 & .0074 & 35.14 & $.0157-\quad .0263$ & $.01-.03$ & 10 & 2 \\
\hline diameter-_. & .3625 & .0275 & 7.60 & $.3187-$ & $.33-$ & 4 & 2 \\
\hline $\begin{array}{l}\text { Macular polymorph chamber minimum } \\
\text { diameter- }\end{array}$ & & & 1108 & 3398 & 24 & 4 & $?$ \\
\hline Mesozooecial chamber maximum diameter - & .1110 & .0378 & 34.09 & .0839 & $.07-\quad .17$ & 10 & 2 \\
\hline Autozooecia (number per $\mathrm{mm}^{2}$ ) & 14.00 & .866 & 6.19 & $13.333-14.666$ & $13-15$ & 9 & 2 \\
\hline Diaphragms (number per $\mathrm{mm}$ ) & 7.50 & 1.1785 & 15.71 & $6.657-8.3430$ & $\begin{array}{ll}6 & -10 \\
\end{array}$ & 10 & 2 \\
\hline Zoarial br & 10.50 & 2.1213 & 20.20 & $-8.5590-29.559$ & $9.00-12.00$ & 2 & 1 \\
\hline
\end{tabular}


axis, evenly spaced locally in some zoaria, scattered or absent in others; occurring more commonly in outer endozones and locally in autozooecial zones of rejuvenation. Zones of rejuvenation of autozooecia sparse, limited in lateral extent.

In exozones, autozooecia at approximately right angles to zoarial surface, contiguous, irregularly polygonal in cross section, four- to six-sided, generally without preferred alignment. Autozooecial walls moderately thick, slightly variable in thickness locally.

Autozooecial boundaries narrowly serrated, generally distinct, occasionally obscured locally. Styles common to absent, small, with poorly defined small cores, indistinct sheaths; occurring in corners of autozooecia and occasionally along boundaries; locally absent from some zoaria. Basal diaphragms abundant, locally variable in thickness, planar to slightly curved, commonly concave distally, at right angles or oblique to chamber axis; basal diaphragms generally closely spaced, commonly unevenly spaced locally. Thick diaphragms locally in some autozooecia of zoaria. Cystoidal and compound diaphragms sparse to absent, occurring irregularly in zoaria. Autozooecial linings generally thin, indistinct, locally discontinuous, commonly absent.

Autozooecial chambers subcircular to subpolygonal in cross section.

Mesozooecia sparse to absent, subpolygonal in cross section, occasionally with indistinctly moniloid proximal parts. Mesozooecial walls similar in thickness to those of autozooecia; mesozooecial diaphragms common, irregular in thickness and spacing.

Maculae indistinct in cross section, consisting of mesozooecia in centers of maculae and of polymorphs larger than autozooecia in various combinations.

Measurements.-Measurements are summarized in table 37.

Geographic and stratigraphic distribution.-A. aff. A. winchelli is present in rocks of Shermanian Stage, Mid- dle Ordovician, in Kentucky. It occurs in the Grier Limestone Member, Shermanian Stage (USGS colln. 4963-CO, 4968-CO, 4969-CO, 4971-CO-4973-CO); the Millersburg Member, Shermanian Stage (USGS colln. 4857-CO, 7052-CO); and the Tanglewood Limestone Member, Shermanian Stage (USGS colln. 4886-CO, 5016-CO), of the Lexington Limestone.

Studied material.-Hypotypes USNM 308800 (USGS colln. 4857-CO), 308801 (USGS colln. 4857-CO), 308802-308804 (USGS colln. 4886-CO), 308805 (USGS colln. 4963-CO), 308806 (USGS colln. 4968-CO), 308807, 308809 (USGS colln. 4969-CO), 308810, 308811 (USGS colln. 4971-CO), 308812, 308813 (USGS colln. 4972-CO), 308814, 308815 (USGS colln. 4973-CO), 308816 (USGS colln. 5016-CO), 308817 (USGS colln. 7052-CO).

Remarks.-Specimens assigned herein to A. aff. A. winchelli Ulrich are characterized by thin autozooecial walls in exozones, with the exception of a few zoaria (pl. 23, fig. 1); exceedingly small and generally indistinct styles; sparse mesozooecia; and commonly few or no basal diaphragms in endozones. Persistent association of these characters in $A$. aff. A. winchelli distinguishes it from $A$. winchelli as described by Ulrich (1893, p. 295, as Batostoma, especially pl. 26, figs. 36 , 37, and pl. 27, figs. 1-6, from the Decorah Shale, Middle Ordovician, Minnesota), Brown (1965, p. 1002, from undivided "Logana-Jessamine Limestone Members" of Lexington Limestone, Middle Ordovician, Kentucky), Bork and Perry (1967, p. 1374, pl. 173, fig. 9, from "Guttenberg," "Ion," and "Quimbys Mill" formations, Middle Ordovician, Iowa and Wisconsin), Ross (1969, p. 265, pl. 37, figs. 2-4, from "Denmark" and "Cobourg" formations, Ordovician, New York), and McKinney (1971, p. 250, pl. 54, figs. 1, 7; pl. 55, figs. 1, 3, from the "Lower Chickamauga Group," Middle Ordovician, Alabama). In addition, $A$. winchelli differs from $A$. aff. $A$. winchelli in having larger autozooecial chambers (table 38), abundant basal diaphragms

TABLE 37.-Summarized measurements of specimens of Amplexopora aff. A. winchelli Ulrich

[Hypotypes USNM 308805 (USGS colln. 4963-CO), 308807, 308808 (USGS colln. 4969-CO), 308810, 308811 (USGS colln. 4971-CO), 308812, 308813 (USGS colln. 4972-CO), 308814, 308815 (USGS colln. 4973-CO). All measurements in millimeters unless otherwise indicated

\begin{tabular}{|c|c|c|c|c|c|c|c|}
\hline & $\begin{array}{l}\text { Arithmetic } \\
\text { mean }\end{array}$ & $\begin{array}{c}\text { Standard } \\
\text { deviation } \\
\text { of mean }\end{array}$ & $\begin{array}{c}\text { Coefficient } \\
\text { of } \\
\text { variation }\end{array}$ & $\begin{array}{l}\text { 95-percent } \\
\text { confidence } \\
\text { interval } \\
\text { of mean }\end{array}$ & Range & $\begin{array}{c}\begin{array}{c}\text { Number } \\
\text { of } \\
\text { measurements }\end{array} \\
\end{array}$ & $\begin{array}{c}\text { Number } \\
\text { of } \\
\text { zoaria } \\
\text { measured }\end{array}$ \\
\hline Autozooecial chamber maximum diameter & 0.2078 & 0.0207 & 9.94 & $0.2016-0.2140$ & $0.14-0.24$ & 45 & 9 \\
\hline Autozooecial chamber minimun & .1733 & .0228 & 13.13 & $.1665-.1802$ & $.10-.22$ & 45 & 9 \\
\hline Autozooecial wall thickness between chambers- & .0367 & .0117 & 31.85 & .0332 & $.02-\quad .07$ & 45 & 9 \\
\hline Macular polymorph chamber maximum & & & & & & & \\
\hline $\begin{array}{l}\text { diameter } \\
\text { Macular polymorph chamber minimum }\end{array}$ & & & 8.03 & & .34 & 7 & 2 \\
\hline diameter - & .2657 & .0382 & 14.39 & $.2304-\quad .3011$ & .20 & 7 & 2 \\
\hline Mesozooecial chamber maximum diameter - & .0790 & .0346 & 42.37 & $.0651-\quad .0915$ & $.03-.14$ & 30 & 9 \\
\hline $\begin{array}{l}\text { Autozooecia (number per } \mathrm{mm}^{2} \text { ) } \\
\text { Diaphragms (number per } \mathrm{mm} \text { ) }\end{array}$ & 16.40 & 2.4581 & 14.99 & $15.250-17.550$ & $12.00-21.00$ & 20 & 8 \\
\hline $\begin{array}{l}\text { Diaphragms (number per } \mathrm{mm} \text { ) } \\
\text { Zoarial branch diameter }\end{array}$ & $\begin{array}{c}11.895 \\
8.7560\end{array}$ & $\begin{array}{l}3.6039 \\
28561\end{array}$ & $\begin{array}{l}30.30 \\
32.62\end{array}$ & $\begin{array}{r}10.158-13.632 \\
5.2103-12.302\end{array}$ & $6-18$ & $\begin{array}{r}19 \\
5\end{array}$ & $\begin{array}{l}4 \\
3\end{array}$ \\
\hline Endozone width - & 4.1400 & 2.1663 & 52.32 & $1.4506-6.8294$ & $3.00-8.00$ & 5 & 3 \\
\hline Exozone width (one side only) & 1.7000 & .4598 & 27.05 & $1.3155-2.0846$ & $1.00-2.60$ & 8 & 3 \\
\hline
\end{tabular}


throughout zoaria, generally thicker autozooecial walls in exozones (table 38 ), and relatively numerous styles and mesozooecia. A. winchelli, which occurs in the Trenton Group, Middle Ordovician, in New York State (Ross, 1969 , p. 265), appears to be similar to $A$. aff. A. winchelli in sparseness of mesozooecia, size of styles in cross section, and thickness of autozooecial walls. However, specimens from New York have more numerous basal diaphragms throughout zoaria and more abundant styles than $A$. aff. $A$. winchelli. Quantitative differences between specimens of $A$. winchelli from the various localities and $A$. aff. A. winchelli from Kentucky are summarized in table 38 .

Because of these quantitative and qualitative differences, $A$. aff. $A$. winchelli is herein regarded tentatively as an autonomous taxon until primary material of $A$. winchelli is redescribed.

\section{Family BATOSTOMELLIDAE Genus ERIDOTRYPA Ulrich, 1893}

Type species.-Eridotrypa mutabilis Ulrich, 1893, p. 264; by original designation. "Galena Shales" of Ulrich (1893, p. 266) (approximate stratigraphical equivalent of the "Cummingsville Member" of the Galena Dolomite of current usage), Middle Ordovician, Minnesota.

Remarks.-Ross (1967b, p. 635) emended the concept for Eridotrypa; her diagnosis of the genus is followed here.

\section{Eridotrypa mutabilis Ulrich, 1893 Plates 24, 25}

Eridotrypa mutabilis Ulrich, 1893, pl. 265, p. 26, figs. 22-28, 31, 32; Sardeson, 1901, p. 13, pl. A, fig. 11, text fig. 1h; Bassler, 1953, text figs. 63, 5a-e; Ross, 1967b, p. 637, pl. 69, figs. 1, 5, 6, 9, 11; pl. 71, figs. 1-10. Anstey and Perry, 1973, p. 21, fig. 6, 8, pl. 11, pl. 12, figs. 1-4. McKinney, 1975, pl. 1, fig. 5; 1976, pl. 5, figs. 2, 3.
Eridotrypa aedilis (Eichwald). Bassler, 1911, p. 242, in part, text-fig. 138;

Eridotrypa aedilis (Eichwald). Wilson and Mather, 1916, p. 55; McFarlan 1931, p. 103, pl. 2, figs. 13, 15, pl. 8, fig. 13; Sardeson, 1936, p. 188, pl. 15, fig. 7; Twenhofel, 1938, p. 43; Fritz, 1957, p. 16, pl. 6, fig. 4 , pl. 7, figs. 4,5 .

Description.-Zoaria dendroid with cylindrical branches, slightly variable in thickness, occasionally with conspecific overgrowth.

In axial parts of endozones, autozooecia larger than in endozone peripheries, approximately parallel to branch axis for some distance, gradually curving outward. In endozone peripheries, autozooecia regularly intercalated, curving gently outward, locally slightly constricted or expanded. Autozooecia irregularly polygonal in cross section, walls straight to slightly sinuous, occasionally crenulated locally. Basal diaphragms in axial parts of endozones sparse, occasionally common, commonly absent locally in some zoaria, evenly spaced in other zoaria and in zones of rejuvenation of autozooecia. Basal diaphragms regular, evenly spaced, in endozone peripheries. Zones of rejuvenation of autozooecia sparse.

Exozones wide; autozooecia oblique or almost at right angles to zoarial surface, generally contiguous, mostly without preferred alignment, polygonal to subpolygonal in cross section, locally partly separated by mesozooecia. Autozooecial walls slightly irregular in thickness locally in early exozones, generally of uniform thickness in outer exozones. Autozooecial wall laminae distinct. Autozooecial boundaries well defined, narrowly serrated, straight to slightly sinuous, locally crenulated. Pustules sparse, occurring mostly along autozooecial boundaries. Styles small, short, sparse to absent, with indistinct cores and sheaths, occurring

TABLE 38.-Differences between arithmetic means from Amplexopora winchelli Ulrich and confidence intervals of means from A. aff. A. winchelli [All measurements in millimeters unless otherwise noted]

\begin{tabular}{|c|c|c|c|c|c|}
\hline Statistic & \multicolumn{4}{|c|}{$\begin{array}{l}\text { Amplexopora winchelli Ulich } \\
\text { Arithmetic means } \\
\text { (except as noted below) }\end{array}$} & \multirow{2}{*}{ 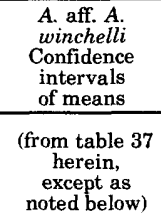 } \\
\hline Reference & $\begin{array}{l}\text { Brown, } 1965 \\
\quad \text { table } 19\end{array}$ & $\begin{array}{l}\text { Bork and Perry, } \\
1967 \text {, table 5 }\end{array}$ & $\begin{array}{l}\text { Ross, } 1969, \\
\text { table } 3\end{array}$ & $\begin{array}{c}\text { McKinney, 1971, } \\
\text { table } 24\end{array}$ & \\
\hline $\begin{array}{l}\text { Autozooecial chamber maximum diameter } \\
\text { Autozooecial chamber minimum diameter } \\
\text { Wall thickness between chambers } \\
\text { Macular polymorph maximum diameter } \\
\text { Maeular polymorph minimum diameter } \\
\text { Mesozooecial chamber diameter } \\
\text { Style diameter } \\
\text { Autozooecia (number per mm) } \\
\text { Diaphragms in exozone (number per } \mathrm{mm} \text { ) } \\
\text { Zoarial branch diameter }\end{array}$ & $\begin{array}{l}0.241 \\
.057 \\
-\overline{-} \\
\overline{-} \\
.048 \\
= \\
-\end{array}$ & $\begin{array}{l}0.276 \\
\overline{.049} \\
-\overline{-} \\
\overline{-} \\
.003 \\
9.25 \\
-\overline{-}\end{array}$ & $\begin{array}{c}0.31 \\
.29 \\
.01-.03 \\
-- \\
\overline{.06} \\
.01-.02 \\
19 \\
\overline{4.3}\end{array}$ & $\begin{array}{r}0.262 \\
.207 \\
.056 \\
.362 \\
.286 \\
.125 \\
.043 \\
12.6 \\
8.5 \\
-1\end{array}$ & $\begin{array}{c}0.20-0.21 \\
.17-\quad .18 \\
.03-\quad .04 \\
.29-\quad .33 \\
.23-\quad .30 \\
.07-.10 \\
15.2-17.01 \\
10.16-13.63 \\
5.21-12.30\end{array}$ \\
\hline
\end{tabular}


mostly in autozooecial boundaries in corners between autozooecia. Basal diaphragms common to absent, planar to slightly curved, generally at right angles to chamber axis; occurring commonly, evenly spaced, in inner exozones, scattered or absent in outer exozones. Compound diaphragms and cystiphragms sparse, occurring occasionally in outer exozones of some autozooecia.

Autozooecial chambers generally subelliptical, locally subcircular in cross section.

Mesozooecia sparse to common, subpolygonal to subcircular in cross section, with slightly moniloid proximal portions locally. Mesozooecial diaphragms irregular in thickness and spacing, slightly curved, locally coalescent. Mesozooecia commonly arising in inner and middle exozones in corners of autozooecia, commonly terminated in outer exozones by zooecial deposits, appearing as indistinct depressions in cross section.

Maculae sparse, low, generally indistinct in cross section, commonly consisting of clusters of polymorphs with thicker walls and smaller chambers than those of autozooecia.

Measurements.-Measurements are summarized in tables 39-41.
Geographic and stratigraphic distribution.-E. mutabilis is geographically widespread in rocks of late Middle Ordovician and early Late Ordovician age in North America. In Kentucky, E. mutabilis is one of the more abundant species, ranging from the upper part of the Grier Limestone Member (Shermanian Stage), Middle Ordovician, of the Lexington Limestone into the Clays Ferry Formation of the Edenian Stage, Upper Ordovician. $E$. mutabilis has been reported by Sardeson (1936, p. 188, as E. aedilis) and Twenhofel (1938, p. 43) as occurring in rocks of Blackriveran Age, Middle Ordovician, in Minnesota and Quebec, respectively. However, these occurrences need to be verified to establish the stratigraphic horizon for the oldest occurrence of $E$. mutabilis in North America.

Occurrence in Kentucky.-Lexington Limestone: Grier Limestone Member, Shermanian Stage (USGS colln. 4693-CO; 4972-CO; 4927-CO; 4957-CO, 4878-CO, 4882-CO; 4850-CO); Perryville Limestone Member, Shermanian Stage (USGS colln. 5016-CO); Brannon Member, Shermanian Stage (USGS colln. D1202-CO; 4974-CO; 5838-CO); Sulphur Well Member, Shermanian Stage (USGS collns. 4939-CO, 4932-CO-4934-CO, 4887-CO, 4888-CO, 4890-CO,

TABLE 39.-Summarized measurements of specimens of Eridotrypa mutabilis Ulrich

[Hypotypes USNM 308864-308866 (USGS colln. 4877-CO), 308867-308870 (USGS colln. 4878-CO), 308871-308873 (USGS colln. 4882-CO), 308874 (USGS colln. 4885-CO), 308875 (USGS colln. 4887-CO), 308877, 308878 (USGS colln. 4888-CO), 308879, 308880 (USGS colln. 4890-CO), 308882-308884 (USGS colln. 4894-CO), 308885-308888 (USGS colln. (U)5-CO), 308891 (USGS colln. 4898-CO), 308892-308895 (USGS colln. 4899-CO), 308890, 309534 (USGS colln. 4896-CO), 308898, 308899 (USGS colln. 4902-CO), 308900-308902 (USGS colln. 4907-CO), 308903 (USGS colln. 4909-CO), 308904 (USGS colln. 4901-CO). All measurements in millimeters unless otherwise indicated]

\begin{tabular}{|c|c|c|c|c|c|c|c|}
\hline & $\begin{array}{c}\text { Arithmetic } \\
\text { mean }\end{array}$ & $\begin{array}{c}\text { Standard } \\
\text { deviation } \\
\text { of mean }\end{array}$ & $\begin{array}{c}\text { Coefficient } \\
\text { of } \\
\text { variation }\end{array}$ & $\begin{array}{c}\text { 95-percent } \\
\text { confidence } \\
\text { interval } \\
\text { of mean }\end{array}$ & Range & $\begin{array}{c}\begin{array}{c}\text { Number } \\
\text { of } \\
\text { measurements }\end{array} \\
\end{array}$ & $\begin{array}{c}\text { Number } \\
\text { of } \\
\text { zoaria } \\
\text { measured }\end{array}$ \\
\hline Autozooecial chamber maximum diameter _- & 0.1888 & 0.0348 & 18.45 & $0.18-0.19$ & $0.09-0.32$ & 165 & 33 \\
\hline Autozooecial wall thickness, exozone - & .0961 & .0307 & 32.00 & $.09-\quad .10$ & $.03-\quad .19$ & 165 & 33 \\
\hline Mesozooecial chamber maximum diameter _-_ _-_ & .0692 & .0276 & 39.94 & $.06-\quad .07$ & $.02-\quad .18$ & 110 & 22 \\
\hline Autozooecia (number per $2 \mathrm{~mm}$ ) - & 7.5046 & .8347 & 11.12 & $7.35-7.66$ & $6-10$ & 109 & 22 \\
\hline Autozooecia (number per $\mathrm{mm}^{2}$ ) - & 13.655 & .2916 & 21.36 & $13.17-14.14$ & -21 & 139 & 28 \\
\hline Mesozooecia (number per $\mathrm{mm}^{2}$ ) & 1.8750 & 1.4660 & 78.18 & $1.59-2.16$ & -8 & 104 & 21 \\
\hline Autozooecial angle at surface $a$ (in degrees) & 55.98 & 12.46 & 22.25 & $54.15-57.81$ & $30-80$ & 180 & 36 \\
\hline Zoarial branch diameter - & 5.0009 & 1.4639 & 29.27 & $4.27-5.28$ & $2.50-10.80$ & 109 & 22 \\
\hline Endozone width _- & 3.2361 & .9504 & 29.37 & $3.05-3.42$ & $1.60-7.30$ & 108 & 22 \\
\hline Exozone width (one side only) & .9370 & .4070 & 43.42 & $.88-1.00$ & $.30-2.50$ & 181 & 37 \\
\hline Styles (number per $\mathrm{mm}^{2}$ ) & 7.30 & 4.16 & 57.05 & $4.32-10.28$ & $2-13$ & 10 & 2 \\
\hline Style diameter - & .0130 & .0048 & 37.16 & $.01-\quad .02$ & $.01-\quad .02$ & 10 & 2 \\
\hline
\end{tabular}

a Definition of autozooecial angle in table 4.

TABLE 40.-Summarized measurements of specimens of Eridotrypa mutabilis Ulrich [Hypotypes USNM 308851 (USGS colln. 4927-CO, 308852, 308853 (USGS colln. 4939-CO), 308854-308857 (USGS colln. 4932-CO), 308861 (USGS colln. 4938-CO), 308859, 308860 (USGS colln. 4934-CO). All measurements in millimeters unless otherwise indicated]

\begin{tabular}{|c|c|c|c|c|c|c|c|}
\hline & $\begin{array}{c}\text { Arithmetic } \\
\text { mean }\end{array}$ & $\begin{array}{l}\text { Standard } \\
\text { deviation } \\
\text { of mean }\end{array}$ & $\begin{array}{c}\text { Coefficient } \\
\text { of } \\
\text { variation }\end{array}$ & $\begin{array}{c}\text { 95-percent } \\
\text { confidence } \\
\text { interval } \\
\text { of mean }\end{array}$ & Range & $\begin{array}{c}\text { Number } \\
\text { of } \\
\text { measurements }\end{array}$ & $\begin{array}{c}\text { Number } \\
\text { of } \\
\text { zoaria } \\
\text { measured }\end{array}$ \\
\hline Autozooecial chamber maximum diameter -_____-_ & 0.1728 & 0.0287 & 16.62 & $0.16-0.18$ & $0.12-0.25$ & 50 & 10 \\
\hline Autozooecial wall thickness, exozone - & .1108 & .0229 & 20.70 & $.10-\quad .12$ & $.04-\quad .16$ & 50 & 10 \\
\hline Mesozooecial chamber maximum diameter - & .6083 & .0287 & 42.0 & $.06-\quad .08$ & $.03-\quad .14$ & 29 & 6 \\
\hline Autozooecia (number per $2 \mathrm{~mm}$ ) - & 7.5434 & .8085 & 10.72 & $7.30-7.78$ & $6-9$ & 46 & 10 \\
\hline Autozooecia (number per $\mathrm{mm}^{2}$ ) & 14.42 & 2.49 & 17.28 & $13.71-15.13$ & -19 & 50 & 10 \\
\hline Mesozooecia (number per $\mathrm{mm}^{2}$ ) & 1.7714 & 1.0595 & 59.81 & $1.41-2.13$ & -5 & 35 & 7 \\
\hline Autozooecial angle at surface ${ }^{a}$ (in degrees) & 57.265 & 9.1418 & 15.96 & $54.64-59.89$ & $40 \quad-75$ & 49 & 10 \\
\hline Zoarial branch diameter & 4.9384 & 1.6025 & 32.45 & $4.29-5.59$ & $2.40-8.00$ & 26 & 6 \\
\hline Endozone width & 3.2384 & 1.2930 & 39.93 & $2.72-3.76$ & $.90-6.00$ & 26 & 6 \\
\hline Exozone width (one side only) ___ & .8633 & .3193 & 36.99 & $.77-.96$ & $.30-1.50$ & 49 & 10 \\
\hline
\end{tabular}

a Definition of autozooecial angle in table 4. 
TABLE 41.-Summarized measurements of specimens of Eridotrypa mutabilis

[Hypotypes USNM 308927, 308928 (USGS colln. 5047-CO), 308931 (USGS colln. 5049-CO), 308934, 308935 (USGS colln. 5053-CO), 308940, 308941 (USGS colln. 5190-CO). All measurements in millimeters unless otherwise indicated]

\begin{tabular}{|c|c|c|c|c|c|c|c|}
\hline & $\begin{array}{c}\text { Arithmetic } \\
\text { mean }\end{array}$ & $\begin{array}{c}\text { Standard } \\
\text { deviation } \\
\text { of mean }\end{array}$ & $\begin{array}{c}\text { Coefficient } \\
\text { of } \\
\text { variation }\end{array}$ & $\begin{array}{c}\text { 95-percent } \\
\text { confidence } \\
\text { interval } \\
\text { of mean } \\
\end{array}$ & Range & $\begin{array}{c}\begin{array}{c}\text { Number } \\
\text { of } \\
\text { measurements }\end{array} \\
\end{array}$ & $\begin{array}{c}\text { Number } \\
\text { of } \\
\text { zoaria } \\
\text { measured }\end{array}$ \\
\hline Autozooecial chamber maximum diameter _-__-_ & 0.1925 & 0.0301 & 15.64 & $0.18-0.20$ & $0.12-0.24$ & 40 & 8 \\
\hline Autozooecial wall thickness, exozone - & .0820 & .0288 & 35.17 & $.07-.09$ & $.04-.16$ & 40 & 7 \\
\hline Mesozooecial chamber maximum diameter & .80 & .0229 & 28.57 & $.07-.09$ & $.03-\quad .12$ & 37 & 7 \\
\hline Autozooecia (number per $2 \mathrm{~mm}$ ) & 7.8378 & .7643 & 9.75 & $7.58-8.09$ & $6-9$ & 37 & 7 \\
\hline Autozooecia (number per $\mathrm{mm}^{2}$ ) & 12.263 & 2.5114 & 20.48 & 11.44-13.09 & -19 & 38 & 7 \\
\hline Mesozooecia (number per $\mathrm{mm}^{2}$ ) & 2.1470 & 1.4798 & 68.92 & $1.63-2.66$ & -7 & 34 & 6 \\
\hline Autozooecial angle at surface ${ }^{a}$ (in degrees) & 63.349 & 17.114 & 27.02 & $57.88-68.82$ & $27 \quad-90$ & 40 & 8 \\
\hline Zoarial branch diameter & 5.8799 & 1.7092 & 29.07 & $5.08-6.68$ & $3.90-9.10$ & 20 & 4 \\
\hline 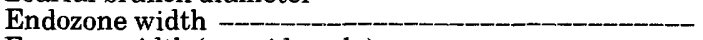 & 3.8449 & 1.5118 & 39.32 & $3.14-4.55$ & $1.90-6.40$ & 20 & 4 \\
\hline Exozone width (one side only) & 1.0249 & .3152 & 30.75 & $.92-1.13$ & $.50-1.70$ & 40 & 8 \\
\hline
\end{tabular}

a Definition of autozooecial angle in table 4.

4962-CO); Tanglewood Limestone Member, Shermanian Stage (USGS collns. 4701-CO; D1210-CO; 4996-CO; D1133-CO; 4885-CO; 5851-CO; 7448-CO; 4855-CO; 7463-CO-7466-CO, 5047-CO, 5049-CO); Nicolas Bed of the Tanglewood Limestone: Shermanian Stage (USGS colln. 5860-CO; 5031-CO) and Edenian Stage (USGS colln. 5034-CO, 5190-CO, 7473-CO); Millersburg Member, Shermanian Stage (USGS colln. D1209-CO; 4857-CO; 7039-CO-7041-CO, 7048-CO, 7061-CO, 7074-CO, 7075-CO; 7334-CO; 7456-CO; 5025-CO, 5027-CO). Clays Ferry Formation: Shermanian Stage (USGS collns. 7467-CO, 7469-CO, 5053-CO; 4999-CO, 5001-CO, 4893-CO-4896-CO, 4898-CO, 4899-CO, 4901-CO, 4902-CO; D1171-CO, 6716-CO, D1175-CO), Edenian Stage (USGS collns. 7474-CO, 5054-CO; D1211-CO; D1134-CO; 4907-CO, 4909-CO; 6721-CO, D1178-CO, 6723-CO-6725-CO, D1179-CO, 6727-CO; 6731-CO). Point Pleasant Tongue, Shermanian Stage (USGS collns. 6921-CO, 6926-CO-6928-CO), of the Clays Ferry Formation. Kope Formation, Edenian Stage (USGS colln. 6932-CO).

Ulrich (1893, p. 266) found E. mutabilis in the shaly portions of his "Trenton Group," Middle Ordovician, in central Kentucky. McFarlan (1931, p. 103) and McFarlan and Freeman (1935, p. 2001) reported $E$. mutabilis (as $E$. aedilis) from their "Rogers Gap" and "Fulton" strata, Middle or Upper Ordovician, at several localities in central Kentucky.

Anstey and Perry (1973, p. 34, text fig. 8) established that $E$. mutabilis ranged through strata approximately $8 \mathrm{~m}$ thick at the base of their Eden Shale (Kope Formation of current usage) in Gallatin County, northern Kentucky.

Occurrence outside Kentucky.-Ulrich (1893, p. 266) reported E. mutabilis from his "Galena Shales" (approximate stratigraphic equivalent of the "Cummingsville Member" of the Galena Dolomite of current usage), Middle Ordovician, in Minnesota, Iowa, and Wisconsin, and from rocks of Middle Ordovician age near Nashville, Tenn., and Ottawa, Ontario. Ross (1967b, p. 638, text-fig. 2) established that the range of E. mutabilis was from the base of the Rockland Formation, Rocklandian Stage, Middle Ordovician, to the lower part of the "Cobourg Formation," Edenian Stage, Upper Ordovician, of the Trenton Group of Ross in New York State. Wilson and Mather (1916, p. 53, 55) have reported $E$. mutabilis (as $E$. aedilis) from the lower part of their "Trenton Limestone," Middle Ordovician, in the Kingston area of Ontario.

Studied material.-Lectotype USNM 43536, designated by Ross, $1967 \mathrm{~b}$, p. 637 , figured by Ulrich, 1893 , pl. 26, fig. 28; and paralectotypes USNM 158314, $158315,308818-308832$, from syntype suite USNM 43536, "Galena Shales" of Ulrich, 1893 (approximate stratigraphic equivalent of the "Cummingsville Member" of the Galena Dolomite of current usage), Middle Ordovician, near Cannon Falls, Minn.

Hypotypes USNM 308833 (USGS colln. 4693-CO), 308834 (USGS colln. 4701-CO), 308835 (USGS colln. D1202-CO), 308836 (USGS colln. D1202-CO), 308837 (USGS colln. D1209-CO), 308838 (USGS colln. D1210-CO), 308839-308841 (USGS colln. D1211-CO), 308842 (USGS colln. D1211-CO), 308843 (USGS colln. 4972-CO), 308844 (USGS colln. 4794-CO), 308845 (USGS colln. 4996-CO), 308846 (USGS colln. 4999-CO), 308847 (USGS colln. 5001-CO), 308848 (USGS colln. D1133-CO), 308849 (USGS colln. D1134-CO), 308850 (USGS colln. 4957-CO), 308851 (USGS colln. 4927-CO), 308852, 308853 (USGS colln. 4939-CO), 308854-308857 (USGS colln. 4932-CO), 308858 (USGS colln. 4933-CO), 308859, 308860 (USGS colln. 4934-CO), 308861 (USGS colln. 4938-CO), 308862 (USGS colln. 4962-CO), 308863 (USGS colln. 5016-CO), 308864-308866 (USGS colln. 4877-CO), 308867-308870 (USGS colln. 4878-CO), 308871308873 (USGS colln. 4882-CO), 308874 (USGS colln. 4885-CO), 308875, 308876 (USGS colln. 4887-CO), 308877, 308878 (USGS colln. 4888-CO), 308879, 308880 (USGS colln. 4890-CO), 308881 (USGS colln. 
4893-CO), 308882-308884 (USGS colln. 4894-CO), 308885-308889 (USGS colln. 4895-CO), 308890 (USGS colln. 4896-CO), 309534 (USGS colln. 4896-CO), 309535 (USGS colln. 4896-CO), 308891 (USGS colln. 4898-CO), 308892-308895 (USGS colln. 4899-CO), 308896, 308897 (USGS colln. 4901-CO), 308898 , 308899 (USGS collnl 4902-CO), 308900308902 (USGS colln. 4907-CO), 308903, 308904 (USGS colln. 4909-CO), 308905 (USGS colln. D1171-CO), 308906 (USGS colln. 6717-CO), 308907 (USGS colln. D1175-CO), 308908 (USGS colln. 6721-CO), 308909 (USGS colln. D1178-CO), 308910 (USGS colln. 6723-CO), 308911 (USGS colln. 6724-CO), 308912 (USGS colln. 6725-CO), 308913 (USGS colln. D1179-CO), 308914 (USGS colln. 6727-CO), 308915 (USGS colln. 6731-CO), 308916 (USGS colln. 5838-CO), 308917 (USGS colln. 5851-CO), 308918 (USGS colln. 5860-CO), 308919 (USGS colln. 5867-CO), 308920 (USGS colln. 4850-CO), 308921 (USGS colln. 4855-CO), 308922 (USGS colln. 4857-CO), 308923 (USGS colln. 7448-CO), 308924 (USGS colln. 7456-CO), 308925 (USGS colln. 7463-CO), 308926 (USGS colln. 7464-CO), 308927, 308928 (USGS colln. 5047-CO), 308929 (USGS colln. 7465-CO), 308930 (USGS colln. 7466-CO), 308931 (USGS colln. 5049-CO), 308932 (USGS colln. 7467-CO), 308933 (USGS colln. 7469-CO), 308934308936 (USGS colln. 5053-CO), 308937 (USGS colln. 7473-CO), 308938 (USGS colln. 7474-CO), 308939 (USGS colln. 5054-CO), 308940, 308941 (USGS colln. 5190-CO), 308942 (USGS colln. 7039-CO), 308943 (USGS colln. 7040-CO), 308944 (USGS colln. 7041-CO), 308945, 308946 (USGS colln. 7048-CO), 308947 (USGS colln. 7061-CO), 308948 (USGS colln. 7047-CO), 308949 (USGS colln. 7075-CO), 308950 (USGS colln. 7334-CO), 308951 (USGS colln. 5025-CO), 308952 (USGS colln. 5027-CO), 308953 (USGS colln. 5031-CO), 308954 (USGS colln. 5034-CO), 308955 (USGS colln. 6921-CO), 308956 (USGS colln. 6927-CO), 308957 (USGS colln. 6928-CO), 308958 (USGS colln. 6932-CO), 308959 (USGS colln. 6926-CO).

Remarks. $-E$. mutabilis characteristically has relatively large dendroid zoaria with wide endozones and exozones. Autozooecia in early exozones have typical gentle curvatures (pl. 24, fig. 1b). In middle and outer exozones, autozooecia in $E$. mutabilis are characterized by their shapes in cross section (pl. 24, figs. 1a,2a) and profile (pl. 24, fig. 1b). Mesozooecia and styles in $E$. mutabilis are relatively sparse and characteristically undistinctive.

$E$. mutabilis is most closely related to $E$. trentonensis (Nicholson), subject to redescription of Nicholson's type material elsewhere. Both species are similar in auto- zooecial budding pattern, cross sectional shapes of autozooecia, and relative sparseness of mesozooecia and styles. The great morphological similarity between the two species makes it difficult to differentiate between zoaria of $E$. mutabilis and $E$. trentonensis in early ontogenetic growth stages. The species, however, differ in later ontogenetic stages in zoarial size and in other morphological characters (See remarks under $E$. trentonensis and table 45).

The taxonomic position of $E$. mutabilis, which Ulrich (1893, p. 264) designated to be the type species of Eridotrypa, has been somewhat indeterminate until recently (Ross, 1967b). Bassler (1911) considered $E$. mutabilis to be conspecific with Cladopora aedilis Eichwald, 1855, from the Middle and Upper Ordovician deposits in Estonia, USSR. Thus E. mutabilis became junior synonym of $E$. aedilis (Eichwald). Because of Bassler's decision (1911), many paleontologists since 1911 have described $E$. mutabilis as $E$. aedilis in their reports (for bibliography see Bassler, 1915, and McKinney, 1974).

Ross (1967b) emended the definition of the genus Eridotrypa, designating a lectotype for E. mutabilis and reconfirming that $E$. mutabilis, not $E$. aedilis (Eichwald), was the valid type species of Eridotrypa until $E$. aedilis should be redescribed.

Although primary types of $E$. aedilis have not been described, the examples that illustrate the nearest possible concept are the figured specimens by Dybowski (1877, pl. 3, figs. 5, $5 a$, as Monticulipora aedilis; reduced figures by Bassler, 1911, pl. 4, figs. 5, 5a) and hypotypes of $E$. aedilis on file at the U.S. National Museum of Natural History (pl. 26, figs. 1, 2).

Morphological differences between $E$. aedilis (pl. 26, figs. 1, 2) and E. mutabilis (pls. 24, 25) are subtle but recognizable. Autozooecial budding patterns are approximately the same in zoaria of both species. Autozooecia in $E$. mutabilis bud by longitudinally partitioning the large autozooecia in axial portions of endozones (pl. 24, figs. $1 b, 3 b$ ) into smaller autozooecia toward the peripheries, in intrazooecial budding pattern B1 of McKinney, (1977, p. 316-319). This pattern appears to be slightly modified in $E$. aedilis, resulting in a longitudinal alignment of autozooecia (pl. 26, fig. 1c, 2a) in exozones in the general direction of growth of its zoarial branches. Autozooecia in exozones of $E$. mutabilis, however, are generally without preferred longitudinal alignment (pl. 24, fig. 1a).

In addition, the species differ in shape of autozooecia in cross section, distribution of basal diaphragms, and, possibly, in thickness of autozooecial wall laminae. Autozooecia in $E$. mutabilis are generally subpolygonal in cross section (pl. 24, fig. $1 a, 2 a$ ) but in $E$. aedilis are subelliptical (pl. 26, fig. 1b, 1c). Basal diaphragms 
occur throughout zoaria of $E$. aedilis (pl. 26, fig. $2 b$ ), but are generally sparse in endozones (pl. 24 , fig. $1 b$ ) and late exozones in $E$. mutabilis. Autozooecial wall laminae appear to be thicker in E. mutabilis (pl. 25, fig. 5) than in E. aedilis (pl. 26, fig. 1d).

These morphological differences indicate that $E$. mutabilis and $E$. aedilis are two autonomous species. Therefore, E. mutabilis apparently does not occur in the Middle Ordovician strata of Estonia, and thus is known only from Middle and Upper Ordovician deposits in North America.

Eridotrypa trentonensis (Nicholson, 1881)

Plate 26, figure 3; plate 27

Monticulipora (Heterotrypa) trentonensis Nicholson, 1881, p. 149. fig. 28.

Monotrypella trentonensis (Nicholson). Foord, 1883, p. 15; Ulrich, 1883 , p. 83.

Eridotrypa trentonensis (Nicholson). Nickles and Bassler, 1900, p. 238; Anstey and Perry, 1973, p. 21, fig. 6.

Eridotrypa aedilis (Eichwald) of Brown, 1965, p. 997, pl. 117, figs. 3-6.

Eridotrypa aedilis minor (Ulrich) of Brown, 1965, p. 998, pl. 117, figs. $1,2$.

Description.-Zoaria dendroid, generally small, with subcylindrical to cylindrical branches, commonly with conspecific overgrowths.

Autozooecia larger in diameter in axial portion of endozones than in endozone peripheries, approximately parallel to branch axis for some distance, gradually curving outward. In endozone peripheries, autozooecia regularly intercalated. Autozooecial walls generally straight, occasionally crenulated locally, irregularly polygonal in cross section. Basal diaphragms common to absent, commonly absent from axial portions, locally evenly spaced in endozone peripheries, sparse in zones of rejuvenation of autozooecia. Zones of rejuvenation sparse.

Exozones generally narrow, having autozooecia almost at right angles to zoarial surface, generally contiguous, polygonal to subpolygonal in cross section, locally occurring in indistinct longitudinal alignment. Autozooecial walls irregularly variable in thickness locally. Autozooecial boundaries generally straight, occasionally crenulated locally.

Pustules scattered, occurring mostly along autozooecial boundaries. Styles common to absent, generally scattered, with small indistinct cores and thin sheaths, occurring mostly in corners at autozooecial boundaries. Basal diaphragms common, sparse, evenly spaced locally in early exozones, commonly lacking in late exozones. Basal diaphragms planar to slightly curved, generally at right angles to chamber axis. Cystoidal diaphragms rare to absent in zoaria.
Autozooecial chambers subelliptical to subcircular in cross section.

Mesozooecia common, scattered, lacking locally, subcircular or irregularly shaped in cross section, occurring mostly in corners between autozooecia, commonly terminated by zooecial deposits in late exozones. Mesozooecial diaphragms irregular in thickness, unevenly spaced. Maculae sparse to absent, indistinct in cross section, lacking in some zoaria, consisting mostly of polymorphs with thicker walls and smaller chambers than those of autozooecia.

Measurements.-Measurements are summarized in tables 42-44.

Geographic and stratigraphic distribution.-E. trentonensis (Nicholson), subject to evaluation of its taxonomic position as based on specimens in the collection of $\mathrm{H}$. A. Nicholson, appears to be widely distributed geographically in strata that are the approximate stratigraphic equivalents of the rocks of the Trenton Group (or Limestone), Middle and Upper Ordovician, in North America.

In Kentucky, E. trentonensis ranges from the Kirkfieldian Stage, Middle Ordovician, into the early part of the Edenian Stage, Late Ordovician.

Occurrence in Kentucky.-Grier Limestone Member: Kirkfieldian Stage (USGS collns. 4944-CO, 4947-CO, 4948-CO; D1235-CO-D1237-CO) and Shermanian Stage (USGS collns. 4680-CO-4683-CO, 4686-CO4688-CO, 4693-CO, 4698-CO; 4950-CO, 4954-CO, 4957-CO; 4863-CO, 4867-CO, 4868-CO, 4870-CO, 4872-CO, 4875-CO, 4881-CO, D1222-CO); Brannon Member, Shermanian Stage (USGS colln. D1159-CO); Sulphur Well Member, Shermanian Stage (USGS colln. D1165-CO); Tanglewood Limestone Member, Shermanian Stage (USGS collns. D1158-CO, D1305-CO, D1304-CO, 7063-CO); Millersburg Member, Shermanian Stage (USGS collns. D1129-CO; 7455-CO; 7039-CO, 7040-CO, 7041-CO, 7060-CO, 7061-CO; D1311-CO, D1312-CO) and Edenian Stage (USGS collns. 7070-CO, 7072-CO, 7075-CO) of the Lexington Limestone.

Clays Ferry Formation: Shermanian Stage (USGS collns. 7047-CO; 5001-CO-5003-CO; 6713-CO, 6715-CO; 7346-CO) and Edenian Stage (USGS collns. 5004-CO, 8130-CO); Point Pleasant Tongue, Shermanian Stage (USGS collns. 6921-CO, 6927-CO) of the Clays Ferry Formation.

Bassler (1915, p. 497) indicated that $E$. trentonensis occurred in strata of his "Trenton" in Mercer County, Ky. Brown $(1965$, p. 998, 999) reported this species as $E$. aedilis and $E$. aedilis minor from his undivided "Logana-Jessamine Limestone Members" of the Lexington Limestone at several localities in central Kentucky. 
TABLE 42.-Summarized measurements of specimens of Eridotrypa trentonensis (Nicholson) [Hypotypes USNM 308996-308999 (USGS colln. 4867-CO), 309000 (USGS colln. 4868-CO), 309001-309006 (USGS colln. 4870-CO), 309007-309010 (USGS colln. 4872-CO), 309011,
309012, 309014-309017 (USGS colln. 4875-CO), 309018, 309020-309022 (USGS colln. 4881-CO), 309536 (USGS colln. 4882-CO). All measurements in millimeters unless otherwise indicated]

\begin{tabular}{|c|c|c|c|c|c|c|c|}
\hline & $\begin{array}{l}\text { Arithmetic } \\
\text { mean }\end{array}$ & $\begin{array}{l}\text { Standard } \\
\text { deviation } \\
\text { of mean }\end{array}$ & $\begin{array}{c}\text { Coefficient } \\
\text { of } \\
\text { variation }\end{array}$ & $\begin{array}{l}\text { 95-percent } \\
\text { confidence } \\
\text { interval } \\
\text { of mean }\end{array}$ & Range & $\begin{array}{c}\begin{array}{c}\text { Number } \\
\text { of } \\
\text { measurements }\end{array} \\
\end{array}$ & $\begin{array}{c}\text { Number } \\
\text { of } \\
\text { zoaria } \\
\text { measured }\end{array}$ \\
\hline Autozooecial chamber maximum diameter & 0.1945 & 0.0315 & 16.21 & $0.19-0.20$ & $0.11-0.28$ & 125 & 25 \\
\hline xozone - _ _ _ _ _ & .1006 & .0166 & & $.09-.11$ & $.04-.21$ & 12 & 25 \\
\hline Mesozooecial chamber maximum diameter & .0686 & .0316 & 46.15 & $.06-\quad .07$ & $.01-.21$ & 91 & 21 \\
\hline Autozooecia (number per $2 \mathrm{~mm}$ ) & 7.1831 & 1.0044 & 13.98 & $6.95-7.42$ & $5-10$ & 71 & 23 \\
\hline Autozooecia (number per $\mathrm{mm}^{2}$ ) & 11.753 & 2.4522 & 20.86 & $11.21-12.30$ & -17 & 81 & 23 \\
\hline Mesozooecia (number per $\mathrm{mm}^{2}$ ) & 2.4583 & 1.4817 & 60. & $2.11-2.81$ & -7 & 72 & 24 \\
\hline al angle at surface ${ }^{a}$ (in degrees) & 70.893 & 14.778 & 20.8 & $68.34-73.45$ & $30-90$ & $13 \overline{1}$ & 27 \\
\hline Zoarial branch diameter & 4.0035 & .6771 & 16. & $3.86-4.15$ & $2.5-5.8$ & 85 & 27 \\
\hline Pats & 2.360 & .29 & & $2.26-2.45$ & $1.50-3.60$ & 85 & 27 \\
\hline Exozone width (one side only) _-_._._. & .8310 & .2954 & 35.55 & $.78-\quad .88$ & $.20-1.70$ & 129 & 27 \\
\hline
\end{tabular}

${ }^{a}$ Definition of autozooecial angle in table 4.

TABLE 43.-Summarized measurements of specimens of Eridotrypa trentonensis (Nicholson)

(Hypotypes USNM 308963 (USGS colln. 4680-CO), 308964-308966 (USGS colln. 4681-CO), 308967-308968 (USGS colln. 4682-CO), 308969 (USGS colln. 4683-CO), 308970-308972 (USGS colln. 4686-CO), 308973 (USGS colln. 4687-CO), 308974 (USGS colln. 4687-CO), 308975 (USGS colln. 4688-CO), 308977 (USGS colln. 4673-CO). All measurements in millimeters unless otherwise indicated

\begin{tabular}{|c|c|c|c|c|c|c|c|}
\hline & $\begin{array}{l}\text { Arithmetic } \\
\text { mean }\end{array}$ & $\begin{array}{l}\text { Standard } \\
\text { deviation } \\
\text { of mean }\end{array}$ & $\begin{array}{c}\text { Coefficient } \\
\text { of } \\
\text { variation }\end{array}$ & $\begin{array}{l}\text { 95-percent } \\
\text { confidence } \\
\text { interval } \\
\text { of mean }\end{array}$ & Range & $\begin{array}{c}\begin{array}{c}\text { Number } \\
\text { of } \\
\text { measurements }\end{array} \\
\end{array}$ & $\begin{array}{c}\text { Number } \\
\text { of } \\
\text { zoaria } \\
\text { measured }\end{array}$ \\
\hline Autozooecial chamber maximum diameter & 0.2024 & 0.0319 & 15.80 & $0.19-0.21$ & $0.13-0.28$ & 50 & 10 \\
\hline xozone - - _ _ & .0710 & .0228 & 32.10 & $.06-.08$ & $.03-.15$ & 50 & 10 \\
\hline Mesozooecial chamb & .0719 & .0307 & 42.72 & $.06-\quad .08$ & $.03-.15$ & 26 & 7 \\
\hline Autozooecia (number per $2 \mathrm{~mm}$ ) & 6.4545 & .8004 & 12.40 & $6.10-6.80$ & $5-8$ & 22 & 8 \\
\hline Autozooecia (number per $\mathrm{mm}^{2}$ ) & 11.559 & 2.9459 & 25.49 & $10.53-12.59$ & -19 & 34 & 8 \\
\hline Mesozooecia (number per $\mathrm{mm}^{2}$ ) - & 3.7917 & 1.7932 & 47.29 & $3.03-4.55$ & $1-9$ & 24 & 7 \\
\hline Zooecial angle at surface ${ }^{a}$ (in degrees) & 67.870 & 13.739 & 20.24 & $64.57-71.17$ & $36.0-90.0$ & 6 & 14 \\
\hline ch diameter - & 4.3931 & 1.2942 & 29.46 & $4.03-4.76$ & $1.90-6.90$ & 5 & 14 \\
\hline Endozone & 2.6706 & .8526 & 31.92 & $2.43-2.91$ & $.80-4.60$ & 51 & 14 \\
\hline Exozone width (one side on & .7747 & .4429 & 57.17 & $.68-.88$ & $.20-2.10$ & 67 & 14 \\
\hline
\end{tabular}

${ }^{a}$ Definition of autozooecial angle in table 4.

TABLE 44.-Summarized measurements of specimens of Eridotrypa trentonensis (Nicholson) [Hypotypes USNM 308960, 308961. All measurements in millimeters unless otherwise indicated]

\begin{tabular}{|c|c|c|c|c|c|c|c|}
\hline & $\begin{array}{c}\text { Arithmetic } \\
\text { mean }\end{array}$ & $\begin{array}{l}\text { Standard } \\
\text { deviation } \\
\text { of mean }\end{array}$ & $\begin{array}{c}\text { Coefficient } \\
\text { of } \\
\text { variation }\end{array}$ & $\begin{array}{c}\text { 95-percent } \\
\text { confidence } \\
\text { interval } \\
\text { of mean }\end{array}$ & Range & $\begin{array}{c}\begin{array}{c}\text { Number } \\
\text { of } \\
\text { measurements }\end{array} \\
\end{array}$ & $\begin{array}{c}\text { Number } \\
\text { of } \\
\text { zoaria } \\
\text { measured }\end{array}$ \\
\hline Autozooecial chamber maximum diameter & 0.1850 & 0.0227 & 12.29 & $0.17-0.20$ & $0.16-0.22$ & 10 & 2 \\
\hline Autozooecial chamber minimum diameter & .1240 & .0190 & & $.11-.13$ & $.10-\quad .16$ & 10 & 2 \\
\hline Autozooecial wall thickness, exozone & .099 & .0154 & 15.39 & $.09-$ & $.08-$ & 10 & 2 \\
\hline Axial autozooecial chamber maximum diameter-_._. & .4267 & .0252 & 5.90 & $.36-$ & .40 & 3 & 1 \\
\hline Axial autozooecial chamber minimum diameter - & 260 & .020 & 7.69 & $.21-$ & $.24-$ & 3 & 1 \\
\hline Mesozooecial chamber maximum diameter & .070 & .0224 & 31.94 & $.04-$ & $.04-$ & 5 & 1 \\
\hline Autozooecia (number per $\mathrm{mm}^{2}$ ) & 14.556 & 2.6977 & 18.53 & $12.48-16.62$ & $\begin{array}{ll}9 & -17\end{array}$ & 9 & 2 \\
\hline Zoarial branch diameter & 3.450 & 1.1121 & 32.23 & $1.68-5.22$ & $2.40-5.00$ & 4 & 2 \\
\hline zone width & 2.1750 & 1.0905 & 50.14 & $.44-3.90$ & $1.50-3.80$ & 4 & 2 \\
\hline one width (one side only) & .6375 & .1685 & 26.43 & $.49-.78$ & $.40-1.00$ & 8 & 2 \\
\hline
\end{tabular}

Occurrence outside Kentucky.-Nicholson (1881, p. 149 ) found $E$. trentonensis (as Monticulipora) in his "Trenton" limestones in Peterboro, Ontario, and Foord (1883, p. 154, as Monotrypella) in his "Trenton Formation" near Ottawa.

Studied material.-Hypotypes USNM 308960, 308961, from hypotype type suite USNM 44822 and 308962, "Trenton Group," near Frankfort, Ky.

Hypotypes USNM 308963 (USGS colln. 4680-CO), 308964-308966 (USGS colln. 4681-CO), 308967, 398068 (USGS colln. 4682-CO), 308969 (USGS colln. 4683-CO), 308970-308972 (USGS colln. 4686-CO), 308973 (USGS colln. 4687-CO), 308974 (USGS colln.
4687-CO), 308975, 308976 (USGS colln. 4688-CO), 308977 (USGS colln. 4673-CO), 308978 (USGS colln. 4698-CO), 308979 (USGS colln. 5001-CO), 308980 (USGS colln. 5002-CO), 308981 (USGS colln. 5003-CO), 308982 (USGS colln. 5004-CO), 308983 (USGS colln. D1304-CO), 308984 (USGS colln. D1305-CO), 308985 (USGS colln. 7455-CO), 308986 (USGS colln. 7466-CO), 308987 (USGS colln. 8130-CO), 308988 (USGS colln. 4944-CO), 308989 (USGS colln. 4947-CO), 308990 (USGS colln. 4948-CO), 308991 (USGS colln. 4950-CO), 308992 (USGS colln. 4954-CO), 308993 (USGS colln 4957-CO), 308994 (USGS colln. D1129-CO), 308995 
(USGS colln. 4863-CO), 308996-308999 (USGS colln. 4867-CO), 309000 (USGS colln. 4868-CO), 309001309006 (USGS colln. 4870-CO), 309007-309010 (USGS colln. 4872-CO), 309011-309017 (USGS colln. 4875-CO), 309018-309022 (USGS colln. 4881-CO), 309536 (USGS colln. 4882-CO), 309023 (USGS colln. D1158-CO), 309024 (USGS colln. D1159-CO), 309025 (USGS colln. D1165-CO), 309026 (USGS colln. 6713-CO), 309027 (USGS colln. 6715-CO), 309028 (USGS colln. D1235-CO), 309029 (USGS colln. D1236-CO), 309030 (USGS colln. D1237-CO), 309031 (USGS colln. 7039-CO), 309032 (USGS colln. 7040-CO), 309033 (USGS colln. 7041-CO), 309034 (USGS colln. 7047-CO), 309035 (USGS colln. 7060-CO), 309036 (USGS colln. 7061-CO), 309037 (USGS colln. 7063-CO), 309038 (USGS colln. 7070-CO), 309039 (USGS colln. 7072-CO), 309040 (USGS colln. 7075-CO), 309041 (USGS colln. 7075-CO), 309042 (USGS colln. 7346-CO), 309043 (USGS colln. 6921-CO), 309044 (USGS colln. 6927-CO).

Eridotrypa aedilis (Eichwald) of Brown, 1965, hypotypes IU 8233-5 and IU 8233-6 from undivided "Logana-Jessamine Limestone Members" of Brown, 1965, of the Lexington Limestone Jessamine County, $\mathrm{Ky}$.

Remarks. $-E$. trentonensis is most closely related to E. mutabilis, but persistently differs from it in zoarial size. The characteristic quantitative differences between the two species are summarized in table 45 .
E. trentonensis in general has smaller zoaria whose endozones and exozones are narrower and autozooecial walls narrower than those of $E$. mutabilis. Confidence intervals of means show little or no overlap among these morphological characters in $E$. trentonensis and E. mutabilis (table 45). In addition, E. trentonensis (pl. 26 , fig. 3, and pl. 27) differs from E. mutabilis in having autozooecia almost at right angles to zoarial surfaces (pl. 26, fig. 3c; pl. 27, fig. 3) and autozooecial chambers mostly subelliptical in cross sectional in exozones (pl. 26, fig. 3b; pl. 27, fig. 7).

Although $E$. trentonensis is regarded as an autonomous species, its taxonomic status is unclear because the primary types of $E$. trentonensis have not been located. The examples most closely embodying a possible concept for $E$. trentonensis are the specimens in the type collection of $H$. A. Nicholson, which are being evaluated elsewhere (Anstey and Perry, 1973, p. 21; Perry and Horowitz, 1973; Horowitz, 1978, oral commun.). Until the authenticity of Nicholson's specimens is evaluated, $E$. trentonensis is retained herein as a species. Hypotype specimens of $E$. trentonensis (pl. 26, fig. 3) deposited by E. O. Ulrich at the USNM in 1906 conform with specimens in recent collections from Kentucky.

Brown (1965, p. 997-999, pl. 117, figs. 1-6) reportedly found $E$. aedilis (Eichwald) in his undivided "LoganaJessamine Limestone Members" of the Lexington Limestone in central Kentucky. These specimens are morphologically indistinguishable from those included

TABLE 45.-Differences in 95-percent confidence interval of means for the characters in Eridotrypa mutabilis, E. trentonensis, and $\mathrm{E}$. sadievillensis

[All measurements in millimeters]

\begin{tabular}{|c|c|c|c|}
\hline $\begin{array}{ll}\text { Character } & \text { Species } \\
\end{array}$ & Eridotrypa mutabilis Ulrich & E. trentonensis (Nicholson) & E. sadievillensis n. sp. \\
\hline Autozooecial wall thickness & $\begin{array}{l}0.09-0.10 \\
\text { (Valley View) } \\
0.10-0.12 \\
\text { (Salvisa) } \\
0.07-0.09 \\
\text { (Sadieville) }\end{array}$ & $\begin{array}{l}0.09-0.11 \\
\text { (Valley View) } \\
0.06-0.08 \\
\text { (Frankfort East) } \\
0.09-0.11 \\
\text { (hypotype USNM) }\end{array}$ & $\begin{array}{l}0.05-0.06 \\
\quad \text { (Sadieville) }\end{array}$ \\
\hline Zoarial width & $\begin{array}{l}4.27-5.28 \\
\text { (Valley View) } \\
4.29-5.59 \\
\text { (Salvisa) } \\
5.08-6.68 \\
\text { (Sadieville) }\end{array}$ & $\begin{array}{l}3.86-4.15 \\
\text { (Valley View) } \\
4.03-4.76 \\
\text { (Frankfort East) } \\
1.68-4.18 \\
\text { (hypotype USNM) }\end{array}$ & $\begin{array}{c}2.76-3.25 \\
\text { (Sadieville) }\end{array}$ \\
\hline Endozone width & $\begin{array}{l}3.05-3.42 \\
\text { (Valley View) } \\
2.72-3.76 \\
\text { (Salvisa) } \\
3.14-4.55 \\
\text { (Sadieville) }\end{array}$ & $\begin{array}{l}2.26-2.45 \\
\text { (Valley View) } \\
2.43-2.91 \\
\text { (Frankfort East) } \\
1.25-2.01 \\
\text { (hypotype USNM) }\end{array}$ & $\begin{array}{l}1.78-2.19 \\
\text { (Sadieville) }\end{array}$ \\
\hline Exozone width & $\begin{array}{l}0.88-1.00 \\
\text { (Valley View) } \\
0.77-0.96 \\
\text { (Salvisa) } \\
0.92-1.13 \\
\text { (Sadieville) } \\
\end{array}$ & $\begin{array}{l}0.78-0.88 \\
\text { (Valley View) } \\
0.68-0.88 \\
\text { (Frankfort East) } \\
0.48-0.81 \\
\text { (hypotype USNM) }\end{array}$ & $\begin{array}{l}0.49-0.57 \\
\text { (Sadieville) }\end{array}$ \\
\hline
\end{tabular}


in $E$. trentonensis in this study, and therefore are reassigned herein to $E$. trentonensis. The taxonomic position of $E$. aedilis (pl. 26, figs. 1,2) is briefly noted in the remarks under $E$. mutabilis.

\section{Eridotrypa sadievillensis n. sp. \\ Plate 28}

Etymology.-The trivial name of $E$. sadievillensis n. sp. is derived from the name of the quadrangle, the Sadieville, where the specimens commonly occur.

Description.-Zoaria dendroid, small, with subcylindrical to cylindrical branches, generally without conspecific overgrowth.

Endozones relatively wide. In axial part of endozones, autozooecia parallel to branch axis, irregularly polygonal in cross section, with straight walls, larger in diameter than those in endozone peripheries, curving gradually outward after extending distally for some distance. In endozone peripheries, autozooecia with distinctly flattened, irregularly polygonal cross sections.

Basal diaphragms sparse to absent in axial part, locally common in endozone peripheries and in zones of rejuvenation of autozooecia. Zones of rejuvenation of autozooecia sparse to absent.

Exozones narrow; autozooecia mostly oblique to zoarial surface, subpolygonal to polygonal in cross section, contiguous, generally without preferred longitudinal alignment. Autozooecia walls thin, irregularly variable in thickness in some zoaria. Autozooecial boundaries narrowly serrated, well defined, generally straight. Pustules mostly absent from zooecial walls. Styles sparse to absent, exceedingly small, with indistinct cores and sheaths, occurring mostly in autozooecial boundaries, and corners, occasionally in autozooecial walls between corners. Basal diaphragms sparse to absent, planar, generally at right angles to chamber axis, occurring mostly in inner exozones, commonly lacking in outer exozones. Cystoidal diaphragms sparse to absent.
Autozooecial chambers subelliptical to subcircular in cross section. Mesozooecia sparse to absent, subcircular in cross section, occurring in corners between some autozooecia, in many zoaria entirely lacking.

Maculae absent.

Measurements.-Measurements are summarized in table 46.

Geographic and stratigraphic distribution.-In Kentucky $E$. sadievillensis occurs in rocks of upper Shermanian Stage and lower Edenian Stage. It is present in the Tanglewood Limestone Member, Shermanian Stage (USGS colln. 7448-CO) and the Millersburg Member, Shermanian Stage (USGS collns. 7453-CO, 7455-CO; D1312-CO), of the Lexington Limestone. Clays Ferry Formation: Shermanian Stage (USGS collns. 7449-CO; 7468-CO) and Edenian Stage (USGS colln. 7474-CO); Point Pleasant Tongue, Shermanian Stage (USGS colln. 6922-CO, 6923-CO), of the Clays Ferry Formation.

Studied material.-Holotype USNM 309045 (USGS colln. 7448-CO). Paratypes USNM 309046-309052 (USGS colln. 7448-CO), 309053-309060 (USGS colln. 7449-CO), 309061-309063 (USGS colln. 7453-CO), 309064, 309065 (USGS colln. 7455-CO), 309066, 309067 (USGS colln. 7468-CO), 309068 (USGS colln. 7474-CO), 309069 (USGS colln. 6922-CO), 309070 (USGS colln. 6923-CO), 309071, 309072 (USGS colln. D1312-CO).

Remarks. $-E$. sadievillensis is assigned to Eridotrypa because its budding pattern is typical of Eridotrypa (budding pattern B-1 of McKinney, 1977), its autozooecia are subpolygonal to polygonal in cross section, its autozooecial boundaries are well defined, and its laminae in profile are V-shaped. Furthermore, $E$. sadievillensis has sparse mesozooecia and indistinct and small styles like those of $E$. mutabilis, the type species of Eridotrypa.

$E$. sadievillensis characteristically has small zoaria whose thin branches have relatively wide endozones and narrow exozones. Autozooecia of $E$. sadievillensis

TABLE 46.-Summarized measurements of specimens of Eridotrypa sadievillensis $n$. sp.

[Holotype USNM 309045 (USGS colln. 7448-CO), and paratypes USNM 309046-309051 (USGS colln. 7448-CO), 309053-309059 (USGS colln. 7449-CO), 309061, 309062 (USGS colln. $7453-\mathrm{CO}$ ), 309064 (USGS colln. 7455-CO), 309066 (USGS colln. 7468-CO). All measurements in millimeters unless otherwise indicated)

\begin{tabular}{|c|c|c|c|c|c|c|c|}
\hline & $\begin{array}{l}\text { Arithmetic } \\
\text { mean }\end{array}$ & $\begin{array}{c}\text { Standard } \\
\text { deviation } \\
\text { of mean }\end{array}$ & $\begin{array}{c}\text { Coefficient } \\
\text { of } \\
\text { variation }\end{array}$ & $\begin{array}{c}\text { 95-percent } \\
\text { confidence } \\
\text { interval } \\
\text { of mean }\end{array}$ & Range & $\begin{array}{c}\begin{array}{c}\text { Number } \\
\text { of } \\
\text { measurements }\end{array} \\
\end{array}$ & $\begin{array}{c}\text { Number } \\
\text { of } \\
\text { zoaria } \\
\text { measured }\end{array}$ \\
\hline Autozooecial chamber maximum diameter & 0.2179 & 0.0281 & 12.89 & $0.21-0.22$ & $0.15-0.31$ & 65 & 14 \\
\hline Autozooecial chamber minimum diameter & .1646 & .0332 & 20.15 & $.16-.17$ & $.10-.24$ & 65 & 14 \\
\hline Autozooecial wall thickness, exozone - & .0535 & .0186 & 34.69 & $.05-$ & $.20-$ & 65 & 14 \\
\hline Axial autozooecial chamber maximum diameter & .3056 & .0256 & 8.36 & .29 & $.27-$ & 9 & 2 \\
\hline Axial autozooecial chamber minimum diameter & .2144 & .0265 & 12.36 & .19 & .19 & 9 & 2 \\
\hline Mesozooecial chamber maximum diameter & .0793 & .0293 & 36.74 & $.07-\quad .09$ & $.04-.16$ & 37 & $1 \overline{1}$ \\
\hline Autozooecia (number per $\mathrm{mm}^{2}$ ) - & 13.250 & .9574 & 7.23 & $11.73-14.77$ & $12-14$ & 4 & 1 \\
\hline Zoarial branch diameter & 3.0065 & .6698 & 22.28 & $2.76-3.25$ & $2.10-4.30$ & 31 & 18 \\
\hline Endozone width - & 1.9867 & 5538 & 27.87 & $1.78-2.19$ & $1.10-3.30$ & 30 & 18 \\
\hline Exozone width (one side only) & .5290 & .1712 & 32.36 & $.49-\quad .57$ & $.30-1.0$ & 62 & 18 \\
\hline
\end{tabular}


have virtually no basal diaphragms in axial parts of endozones and mostly thin walls in exozones (table 46 ). Conspecific overgrowths are generally lacking and maculae absent. The combination of these characteristics in E. sadievillensis distinguishes it from other species of Eridotrypa. In confidence intervals of means of zoarial size, wall thickness, and width of endozones and exozones (table 45), there is no overlap between $E$. mutabilis on the one hand and E. trentonensis and $E$. sadievillensis on the other.

\section{Family CALOPORIDAE \\ Genus PARVOHALLOPORA Singh, 1979}

Type species.-Monticulipora ramosa d'Orbigny, 1850, p. 25; from "Blue Lime, Silurian A," Cincinnati, Ohio, locality 59 of d'Orbigny; designated by Singh, 1979, p. 226.

Singh (1979, p. 226) erected Parvohallopora, of which $M$. ramosa d'Orbigny is the type species, and characterized it as having ramose zoria with polygonal autozooecia in endozones and polygonal to circular autozooecia in cross section in exozones. Basal diaphragms of autozooecia are common in endozones and can be sparse or lacking in exozones. Autozooecial wall laminae in Parvohallopora are broadly U- or V-shaped (Singh, 1979, pl. 43, fig. 1c, and pl. 38, fig. 1f, respectively). Parvohallopora is further characterized by maculae in zoaria of some species and numerous mesozooecia (mesopores of Singh) between autozooecia in most species. Parvohallopora is differentiated (Singh, 1979 , p. 227) from Calopora elegantula (Hallopora of Singh, 1979, but see also Ross, 1969, 1970b), the type species of Calopora, by the smaller cross-sectional sizes of its autozooecia and mesozooecia and by the shape of its endozonal autozooecia in cross section, which are polygonal, instead of circular as they are in $C$. elegantula (Cornelliussen and Perry, 1973, text-fig. 22; McKinney, 1979, pl. 2, figs. 2, 3b). Singh also noted that Parvohallopora lacks the accessory autozooecial wall structures, such as spines and cysts, that are common in C. elegantula. P. ramosa has been regarded as a species of Calopora since Ulrich's assignment (1882, p. 252).

The two species of Parvohallopora described herein are consistent with the definition proposed for the genus by Singh (1979), and his concept is followed here.

\footnotetext{
Parvohallopora nodulosa (Nicholson, 1874)
}

Plate 29; plate 30, figures 1, 4-6

Chaetetes? nodulosus Nicholson, 1874, p. 506, pl. 29, figs. 9, 9a; 1875 , p. 200 , pl. 21 , figs. $10,10 \mathrm{a} ; 1876$, p. 87 , pl. 5 , fig. 3 .

Monticulipora (Heterotrypa) nodulosa (Nicholson). Nicholson, 1881, p. 116 , pl. 1, figs. $4-4$ d.

Monticulipora nodulosa (Nicholson). James and James, 1888, p. 182; James, 1894, p. 206.
Callopora nodulosa (Nicholson). Ulrich, 1882, p. 252; 1883, p. 83. Nickles, 1905, p. 50, pl. 2, figs. 8, 9; Cumings, 1908, p. 786, pl. 9, figs. 2-2c; pl. 27, fig. 8.

Hallopora nodulosa (Nicholson). Cumings and Galloway, 1913, p. 50; Anstey and Perry, 1973, p. 22, fig. 6, pl. 12, fig. 7, pls. 13-15.

Description.-Zoaria dendroid, occasionally encrusting; zoarial branches cylindrical, anastomosing, showing conspecific overgrowth. Basal layers of encrusting zoarial segments laminated, imperforate.

Endozones generally wide. In endozones of erect zoaria, autozooecia subparallel to branch axis, budding at irregular, relatively short intervals, curving gradually outward. In encrusting segments of zoaria, endozones generally narrow, autozooecia recumbent for short distances, becoming erect in outer endozones. Autozooecia polygonal, generally three- to six-sided in cross section, with straight to slightly sinuous, occasionally crenulated walls locally. Basal diaphragms sparse to absent, locally common, evenly spaced in proximal tips and late endozones of some autozooecia; planar, occurring at right angles to chamber axis.

Zones of rejuvenation of autozooecia common to sparse, scattered.

In exozones, autozooecia almost at right angles to zoarial surface, locally aligned indistinctly in approximate growth direction of branch, subelliptical to subcircular in cross section, partly contiguous, separated by mesozooecia. Autozooecial walls moderately thick, relatively straight. Autozooecial boundaries broadly serrated, distinct, relatively wide; laminae of adjacent autozooecia form indistinct junctions locally within autozooecial boundaries. Pustules common; scattered in boundaries of many autozooecia. Basal diaphragms common to sparse, planar to slightly curved, regularly occurring, commonly evenly spaced in inner exozones of some autozooecia, scattered in others. Cystoidal and compound diaphragms common to sparse, scattered in exozones. Autozooecial linings indistinct, exceedingly thin locally, commonly absent in many autozooecia.

Autozooecial chambers subelliptical to subcircular in cross section.

Mesozooecia abundant to common, generally elongate, subpolygonal to subcircular in cross section, partly separating, or locally almost completely separating, autozooecia. Mesozooecial diaphragms abundant, moderately thick, closely and evenly spaced, occasionally filling mesozooecia in outer exozones.

Maculae generally abundant, low, subrounded to slightly elongate laterally, relatively evenly spaced, consisting of mesozooecia and of polymorphs slightly larger than autozooecia in various combinations; lacking in some zoaria. Macular zooecia subcircular to irregularly shaped in cross section; macular mesozoo- 
ecia generally larger in diameter than intermacular ones.

Measurements.-Measurements are summarized in table 47.

Geographic and stratigraphic distribution. $-P$. nodulosa (Nicholson) is common and widespread in rocks of the upper Shermanian Stage, Middle Ordovician, in Kentucky, and the Edenian Stage and lower Maysvillian Stage in the tristate area of Kentucky, Ohio, and Indiana.

Occurrence in Kentucky.-Lexington Limestone: Brannon Member, Shermanian Stage (USGS collns. D1157-CO, D1160-CO, D1161-CO, 4974-CO, 4975-CO); Tanglewood Limestone Member, Shermanian Stage (USGS collns. 4976-CO, 4990-CO, 4996-CO; D1210-CO, D1130-CO, D1131-CO; 5842-CO, 5846-CO; 7465-CO, 5049-CO); Nicolas Bed, Edenian Stage (USGS collns. 5032-CO, 5034-CO, 5035-CO; 7473-CO), of the Tanglewood Limestone Member; Sulphur Well Member, Shermanian Stage (USGS collns. D1163-CO, D1162-CO, D1164-CO, D1165-CO; 4962-CO; 4932-CO, 4933-CO, 4935-CO), Faulconer Bed, Shermanian Stage (USGS colln. 5013-CO), of Perryville Limestone Member; and Millersburg Member, Shermanian Stage (USGS collns. D1311-CO, D1312-CO). Clays Ferry Formation: Shermanian Stage (USGS collns. 5000-CO, 5002-CO, 4894-CO, 4896-CO, 4897-CO, 6713-CO, 6720-CO, 6725-CO; 7468-CO, 7469-CO) and Edenian Stage (USGS collns. 5003-CO; D1213-CO; D1134-CO; 4908-CO, 4911-CO, 4912-CO, 4913-CO, 4914-CO, 4921-CO, 4922-CO, 4924-CO, 4925-CO; 6726-CO, 6728-CO, 6729-CO, 6730-CO, D1182-CO, 6732-CO, 6734-CO-6736-CO, 6738-CO, 6742-CO, 6744-CO; 5862-CO-5864-CO, 5874-CO, 5883-CO; 5193-CO, 5055-CO, 5056-CO, 5193-CO, 5195-CO, 7476-CO-
7478-CO, 5197-CO, 5060-CO, 5061-CO, 5062-CO5065-CO; 7471-CO-7474-CO); Point Pleasant Tongue, Shermanian Stage (USGS colln. 6925-CO), of Clays Ferry Formation. Kope Formation, Edenian Stage (USGS collns. 6931-CO, 6933-CO, 6934-CO, 6936-CO-6939-CO).

Nickles $(1905$, p. 50) reportedly found $P$. nodulosa (as Hallopora) in the upper part of his Eden strata (the Kope Formation of current usage) and his Mount Hope beds of the Maysville Group in northern Kentucky and Ohio. Anstey and Perry (1973, fig. 8) established that P. nodulosa (as Hallopora) occurred throughout their Eden Shale (the Kope Formation of current usage) in Kentucky, Indiana, and Ohio.

Occurrence outside Kentucky.-Nicholson (1874, p. 506) described $P$. nodulosa (as Chaetetes?) for the first time from his "Cincinnati Group" near Cincinnati and subsequently from his "Cincinnati Group" (Nicholson, 1875, p. 200) in Clermont County, Ohio.

James and James (1888, p. 183) and J. F. James (1894, p. 206) reportedly found P. nodulosa (as Monticulipora) in their "Lower Silurian" deposits near Loveland in Ohio. Cumings (1908, p. 786) and Cumings and Galloway (1913, p. 50, as Hallopora) indicated that $P$. nodulosa ranged from their McMicken strata of the Eden Shale into their Mt. Hope and Fairmount strata of their "Maysville" Group in Tanners Creek, Ind. These stratigraphic occurrences need to be verified.

Studied material.-Calopora nodulosa, hypotype USNM 96572, 309665, from the "McMicken beds" of the "Eden" strata (Kope Formation of current usage) near Cincinnati. Specimen figured by Nickles, 1905, plate 2 , figure 8 .

Hypotypes USNM 309073 (USGS colln. 4962-CO), 309074 (USGS colln. 4932-CO), 309075 (USGS colln. 4933-CO), 309076 (USGS colln. 4935-CO), 309077

TABLE 47.-Summarized measurements of specimens of Parvohallopora nodulosa (Nicholson)

[Hypotypes USNM 309101-309104 (USGS colln. 4911-CO), 309106 (USGS collln. 4912-CO), 309107, 309108 (USGS colln. 4913-CO), 309110, 309111 (USGS colln. 4914-CO), 309112 (USGS colln. 4921-CO), 309113-309117 (USGS colln. 4922-CO), 309119 (USGS colln. 4925-CO), 309141-309143 (USGS 5862-CO), 309145-309146 (USGS colln. 5863-CO), 309154, 30915 (USGS colln. 5864-CO), 309158 (USGS colln. 5883-CO), 309166, 309167 (USGS colln. 5049-CO), 309175-309179 (USGS colln. 5055-CO), 309182 (USGS 5193-CO), 309183, 309184 (USGS colln. 5195-CO), 309188 (USGS colln. 5197-CO), 309189, 309190 (USGS colln. 5060-CO), 309192 (USGS colln. 5061-CO), 309194 (USGS colln. 5062-CO), 309195 (USGS colln. 5063-CO), 309196 (USGS colln. 5064-CO), 309197 (USGS colln. 5065-CO). All measurements in millimeters urless otherwise indicated]

\begin{tabular}{|c|c|c|c|c|c|c|c|}
\hline & $\begin{array}{c}\text { Arithmetic } \\
\text { mean }\end{array}$ & $\begin{array}{c}\text { Standard } \\
\text { deviation } \\
\text { of mean }\end{array}$ & $\begin{array}{c}\text { Coefficient } \\
\text { of } \\
\text { variation }\end{array}$ & $\begin{array}{c}\text { 95-percent } \\
\text { confidence } \\
\text { interval } \\
\text { of mean } \\
\end{array}$ & Range & $\begin{array}{c}\begin{array}{c}\text { Number } \\
\text { of } \\
\text { measurements }\end{array} \\
\end{array}$ & $\begin{array}{c}\text { Number } \\
\text { of } \\
\text { zoaria } \\
\text { measured } \\
\end{array}$ \\
\hline Autozooecial chamber maximum diameter & 0.2296 & 0.0282 & 12.29 & $0.225-0.234$ & $0.14-0.31$ & 170 & 34 \\
\hline $\begin{array}{l}\text { Autozooecial wall thickness, exozone } \\
\text { Monticular polymorph chamber maximum }\end{array}$ & .0718 & .0253 & 36.0 & $.066-\quad .074$ & $.03-\quad .17$ & 170 & 34 \\
\hline diameter & .3261 & .0328 & 10.06 & $.32-$ & $.25-$ & 107 & 23 \\
\hline Mesozooecial chamber maximum diameter & .0739 & .0291 & 39.35 & $.07-.08$ & $.02-.21$ & 170 & 34 \\
\hline Autozooecia (number per $2 \mathrm{~mm}$ ) & 6.4967 & .7844 & 12.07 & $6.37-6.62$ & $5-9$ & 155 & 32 \\
\hline Autozooecia (number per $\mathrm{mm}^{2}$ ) & 10.802 & 1.5485 & 14.33 & $10.55-11.05$ & -15 & 15 & 34 \\
\hline Mesozooecia (number per $\mathrm{mm}^{2}$ ) & 12.708 & 4.4893 & 35.33 & $11.99-13.43$ & -27 & 151 & 34 \\
\hline Diaphragms (number per $\mathrm{mm}$ ) in exozone- & 2.8730 & 1.8733 & 65.20 & $2.61-3.14$ & $1-8$ & 197 & 42 \\
\hline Zoarial branch diameter - & 4.3742 & 1.0165 & 23.24 & $4.18-4.57$ & $1.70-7.20$ & 105 & 42 \\
\hline Endozone width - & 2.8638 & .8539 & 29.82 & $2.70-3.03$ & $.90-5.40$ & 10 & 42 \\
\hline Exozone width (one side only) - & .7529 & .2459 & 32.66 & $.72-.79$ & $.30-1.50$ & 208 & 42 \\
\hline Autozooecial angle ${ }^{a}$ & 73.414 & 10.465 & 14.26 & $71.99-74.84$ & $33-90$ & 210 & 42 \\
\hline
\end{tabular}

${ }^{a}$ Definition of autozooecial angle in table 4. 
(USGS colln. 4974-CO), 309078 (USGS colln. 4975-CO), 309079 (USGS colln. 4976-CO), 309080 (USGS colln. 4990-CO), 309081 (USGS colln. 4996-CO), 309082 (USGS colln. 5000-CO), 309083 (USGS colln. 5002-CO), 309084 (USGS colln. 5003-CO), 309085 (USGS colln. D1210-CO), 309086 (USGS colln. D1213-CO), 309087 (USGS colln. D1127-CO), 309088 (USGS colln. D1130-CO), 309089 (USGS colln. D1131-CO), 309090 (USGS colln. D1134-CO), 309091 (USGS colln. D1311-CO), 309092 (USGS colln. D1312-CO), 309093 (USGS colln. 5013-CO), 309094-309096 (USGS colln. 4894-CO), 309097 (USGS colln. 4896-CO), 309098, 309099 (USGS colln. 4897-CO), 309100 (USGS colln. 4908-CO), 309106 (USGS colln. 4912-CO), 309107-309109 (USGS colln. 4913-CO), 309110, 309111 (USGS colln. 4914-CO), 309112 (USGS colln. 4921-CO), 309113309117 (USGS colln. 4922-CO), 309118 (USGS colln. 4924-CO), 309119 (USGS colln. 4925-CO), 309120 (USGS colln. D1157-CO), 309121 (USGS colln. 6713-CO), 309122 (USGS colln. 6720-CO), 309123 (USGS colln. 6725-CO), 309124 (USGS colln. 6726-CO), 309125 (USGS colln. 6728-CO), 309126 (USGS colln. 6729-CO), 309127 (USGS colln. 6730-CO), 309128 (USGS colln. D1182-CO), 309129, 309130 (USGS colln. 6732-CO), 309131 (USGS colln. 6734-CO), 309132 (USGS colln. 6735-CO), 309133 (USGS colln. 6736-CO), 309134 (USGS colln. 6738-CO), 309135 (USGS colln. 6739-CO), 309136 (USGS colln. 6742-CO), 309137 (USGS colln. 6744-CO), 309138 (USGS colln. 6745-CO), 309139 (USGS colln. 5842-CO), 309140 (USGS colln. 5846-CO), 309141-309144 (USGS colln. 5862-CO), 309145-309147 (USGS colln. 5863-CO), 309148 (USGS colln. D1160-CO), 309149 (USGS colln. D1161-CO), 309150 (USGS colln. D1163-CO), 309151 (USGS colln. D1162-CO), 309152 (USGS colln. D1164-CO), 309153 (USGS colln. D1165-CO), 309154309156 (USGS colln. 5864-CO), 309157 (USGS colln. 5874-CO), 309158, 309159 (USGS colln. 5883-CO), 309160 (USGS colln. 5032-CO), 309161 (USGS colln. 5034-CO), 309162 (USGS colln. 5035-CO), 309163 (USGS colln. 7453-CO), 309164 (USGS colln. 7458-CO), 309165 (USGS colln. 7465-CO), 309166, 309167 (USGS colln. 5049-CO), 309168 (USGS colln. 7468-CO), 309169, 309666 (USGS colln. 7469-CO), 309170 (USGS colln. 7471-CO), 309171 (USGS colln. 7472-CO), 309172 (USGS colln. 7473-CO), 309173, 309174 (USGS colln. 7474-CO), 309175-309180 (USGS colln. 5055-CO), 309181 (USGS colln. 5056-CO), 309182 (USGS colln. 5193-CO), 309183, 309184 (USGS colln. 5195-CO), 309185 (USGS colln. 7476-CO), 309186 (USGS colln. 7477-CO), 309187 (USGS colln. 7478-CO), 309188 (USGS colln.
5197-CO), 309189-309191 (USGS colln. 5060-CO), 309192, 309193 (USGS colln. 5061-CO), 309194 (USGS colln. 5062-CO), 309195 (USGS colln. 5063-CO), 309196 (USGS colln. 5064-CO), 309197 (USGS colln. 5065-CO), 309198 (USGS colln. 6925-CO), 309199 (USGS colln. 6931-CO), 309200 (USGS colln. 6933-CO), 309201 (USGS colln. 6934-CO), 309202 (USGS colln. 6936-CO), 309203 (USGS colln. 6937-CO), 309204 (USGS colln. 6938-CO), 309205 (USGS colln. 6939-CO).

Remarks.-Specimens that are assigned herein to $P$. nodulosa have zoaria with relatively thick cylindrical branches, abundant maculae, and autozooecia with scattered and evenly spaced basal diaphragms in endozones and indistinct linings in exozones. Specimens with these characteristics are consistent with Hallopora nodulosa (Nicholson) sensu stricto now Parvohallopora Singh, 1979, that Anstey and Perry (1973) redescribed as Hallopora from the Kope Formation and the collection of $\mathrm{H}$. A. Nicholson. Although the nomenclature status of specimens of $P$. nodulosa in the collection of $\mathrm{H}$. A. Nicholson has not been evaluated (Anstey and Perry, 1973, p. 78), these specimens are regarded as the nearest examples of a possible concept for $P$. nodulosa.

$P$. nodulosa is closely related to $P$. onealli, but differs from it in having zooaria with thicker branches and in distribution of basal diaphragms in endozones of autozooecia (see remarks under $P$. onealli).

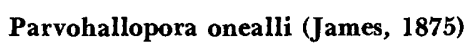

Chaetetes? O'Nealli James, 1875, p. 2.

(?)Monticulipora o'nealli (James). James and James, 1888, p. 175; James, 1894, p. 194.

Callopora onealli (James). Miller, 1889, p. 296; Bassler, 1906, p. 23, pl. 6, figs. 1, 2; Cumings, 1908, p. 786, pl. 9, fig. 3 (not 3a, 3b); pl. 27, figs. 9, 10.

Hallopora onealli (James). Ruedemann, 1912, p. 51; 1925, p. 99; Cumings and Galloway, 1913, p. 50; Foerste, 1916, p. 90; Parks, 1925, p. 35, pl. 4, fig. 7 (after Bassler, 1906, pl. 6, fig. 1); McFarlan, 1931, p. 107, pl. 9, figs. 10-12; Anstey and Perry, 1973, p. 22.

Calopora onealli (James). Ross, 1969, p. 271, pl. 43, figs. 1, 6; pl. 44, fig. 1; pl. 45, figs. 1-3, 5 .

Description.-Zoaria dendroid, having cylindrical, slender, occasionally anatomosing branches, generally without conspecific overgrowth.

Endozones relatively wide. In endozones autozooecia approximately parallel to branch axis, intercalated regularly at relatively long intervals, curving gradually outward, polygonal, generally three- to six-sided in cross section. Autozooecial walls straight to slightly sinuous locally. Basal diaphragms generally absent in endozones of many zoaria, locally sparse in some autozooecia. 
Exozones generally narrow. Autozooecia in exozones approximately at right angles to zoarial surface, subelliptical to elliptical in cross section, aligned longitudinally. Autozooecia partly contiguous, separated by mesozooecia. Autozooecial walls relatively thin, straight, generally of uniform thickness throughout exozones.

Autozooecial boundaries broadly serrated, distinct in profile, locally having indistinct pustules. Basal diaphragms common to sparse, planar to slightly curved, commonly slightly oblique to chamber axis, evenly spaced in early exozones of some autozooecia, scattered or locally absent in other autozooecia. Cystoidal diaphragms common, scattered throughout exozones; compound diaphragms sparse. Autozooecial linings sparse to absent; indistinct where present, extending for short distances distal to diaphragms, merging with laminae of cortex.

Autozooecial chambers subelliptical, occasionally subcircular in cross section.

Mesozooecia common, subelliptical to subcircular in cross section, partly separating autozooecia, commonly terminating in late exozones. Mesozooecial diaphragms irregular in thickness, relatively thick locally, closely and evenly spaced, commonly coalescing, and filling mesozooecia in late exozones. Maculae common to sparse, scattered, flat or slightly raised above zoarial surface, generally indistinct in cross section, consisting of clusters of mesozooecia and of one or two polymorphs larger than autozooecia.

Measurements.-Measurements are summarized in tables 48-50.

Geographic and stratigraphic distribution. $-P$. onealli (James) appears to be widespread geographically in rocks of the upper Shermanian Stage, Middle Ordovician, and Edenian Stage, Upper Ordovician, in eastern North America, subject to verification of occurrences that have been listed in several reports (noted further on in the section on occurrences outside Kentucky).

Occurrence in Kentucky.-Lexington Limestone: Tanglewood Limestone Member, Shermanian Stage (USGS collns. 4992-CO, 4998-CO, 4997-CO; 7448-CO, 7462-CO, 7466-CO), Faulconer Bed, Shermanian Stage (USGS colln. 5013-CO), of the Perryville Limestone Member; Millersburg Member: Shermanian Stage (USGS colln. 5857-CO; D1127-CO; 7040-CO, 7042-CO, 7043-CO, 7068-CO; 7453-CO, 7455-CO)

TABLE 48.-Summarized measurements of specimens of Parvohallopora onealli (James) [Lectotype UC 230-C and paralectotypes UC 230-1, UC 230-2, UC 230-3. All measurements in millimeters unless otherwise indicated]

\begin{tabular}{|c|c|c|c|c|c|c|c|}
\hline & $\begin{array}{c}\text { Arithmetic } \\
\text { mean }\end{array}$ & $\begin{array}{c}\text { Standard } \\
\text { deviation } \\
\text { of mean }\end{array}$ & $\begin{array}{c}\text { Coefficient } \\
\text { of } \\
\text { variation }\end{array}$ & $\begin{array}{l}\text { 95-percent } \\
\text { confidence } \\
\text { interval } \\
\text { of mean }\end{array}$ & Range & $\begin{array}{c}\begin{array}{c}\text { Number } \\
\text { of } \\
\text { measurements }\end{array} \\
\end{array}$ & $\begin{array}{c}\text { Number } \\
\text { of } \\
\text { zoaria } \\
\text { measured }\end{array}$ \\
\hline Autozooecial chamber maximum diameter ______- & 0.2295 & 0.0191 & 8.32 & $0.22-0.24$ & $0.20-0.26$ & 21 & 4 \\
\hline Autozooecial chamber minimum diameter _- & .151 & .0383 & 25.39 & $.13-.17$ & $.10-.24$ & 21 & 4 \\
\hline Autozooecial wall thickness, exozone - & .0635 & .0135 & 21.24 & $.05-$ & .04 & 20 & 4 \\
\hline Macular polymorph chamber maximum diameter _-_. & .344 & .0598 & 17.39 & $.27-$ & $.27-$ & 5 & 2 \\
\hline Macular polymorph chamber minimum diameter - & .2520 & .0409 & 16.22 & $.20-$ & $.21-$ & 5 & $\overline{2}$ \\
\hline Mesozooecial chamber maximum diameter & .0850 & .0355 & 41.73 & $.07-\quad .10$ & $.03-.16$ & 20 & $\overline{4}$ \\
\hline Mesozooecia (number per $\mathrm{mm}^{2}$ ) & 11.625 & 2.825 & 24.30 & $9.26-13.99$ & $7-15$ & 8 & $\overline{3}$ \\
\hline Diaphragms (number per $0.2 \mathrm{~mm}$ ) in mesozooecia - & 4.8182 & .7508 & 15.58 & $4.31-5.32$ & $4-6$ & 11 & 3 \\
\hline Zoarial branch diameter & 2.6667 & .6928 & 25.98 & $2.13-3.20$ & $1.70-3.40$ & 9 & 4 \\
\hline Endozone width & 1.7889 & .7149 & 39.96 & $1.24-2.34$ & $.09-2.70$ & 9 & 4 \\
\hline Exozone width (one side only) & .4667 & .0767 & 16.44 & $.43-\quad .50$ & $.40-\quad .60$ & 18 & 4 \\
\hline
\end{tabular}

TABLE 49.-Summarized measurements of specimens of Parvohallopora onealli (James)

[Hypotypes USNM 309225, 309648 (USGS colln. 7453-CO), 309226 (USGS 7455-CO), 309227, 309638 (USGS 7458-CO), 309228, 309639 (USGS colln. 7459-CO), 309641 (USGS colln. 7460-CO), 309642, 309643 (USGS colln. 7462-CO), 309231 (USGS colln. 7466-CO), 309232 (ÚSGS colln. 5185-CO), 309644 (USGS colln. 7472-CO), 309645 (USGS colln. 6924-CO), 309256, 309646 (USGS colln. 6936-CO). All measurements in millimeters unless otherwise indicated

\begin{tabular}{|c|c|c|c|c|c|c|c|}
\hline & $\begin{array}{c}\text { Arithmetic } \\
\text { mean }\end{array}$ & $\begin{array}{c}\text { Standard } \\
\text { deviation } \\
\text { of mean }\end{array}$ & $\begin{array}{c}\text { Coefficient } \\
\text { of } \\
\text { variation }\end{array}$ & $\begin{array}{l}\text { 95-percent } \\
\text { confidence } \\
\text { interval } \\
\text { of mean }\end{array}$ & Range & $\begin{array}{c}\begin{array}{c}\text { Number } \\
\text { of } \\
\text { measurements }\end{array} \\
\end{array}$ & $\begin{array}{c}\text { Number } \\
\text { of } \\
\text { zoaria } \\
\text { measured }\end{array}$ \\
\hline Autozooecial chamber maximum diameter __ & 0.2057 & 0.0180 & 8.77 & $0.20-0.21$ & $0.17-0.24$ & 35 & 9 \\
\hline Autozooecial chamber minimum diameter & .1325 & .0215 & 16.19 & $.13-.14$ & $.10-.20$ & 35 & 9 \\
\hline Autozooecial wall thickness, exozone - & .5114 & .0169 & 33.12 & $.05-\quad .06$ & $.02-$ & 35 & 9 \\
\hline Macular polymorph chamber maximum diameter & .2711 & .0271 & 10.0 & $.25-\quad .29$ & $.23-$ & 9 & 4 \\
\hline Macular polymorph chamber minimum diameter & .1978 & .0299 & 15.12 & $.17-$ & $.13-$ & 9 & 4 \\
\hline Mesozooecial chamber maximum diameter & .0986 & .0250 & 27.53 & .08 & $.05-$ & 35 & 9 \\
\hline Autozooecia (number per $2 \mathrm{~mm}$ ) & & & & & & 2 & 2 \\
\hline Diaphragms (number per $0.5 \mathrm{~mm}$ ) in proximal & & & & & & & \\
\hline tips, endozone - & 3.80 & .4472 & 11.77 & $3.24-4.36$ & -4 & 5 & 3 \\
\hline Diaphragms (number per $0.2 \mathrm{~mm}$ ) in mesozooecia & 6.037 & .7061 & 11.70 & $5.76-6.32$ & & 27 & 13 \\
\hline Zoarial branch diameter & 1.6412 & .3043 & 18.54 & $1.48-1.80$ & $1.20-2.20$ & 17 & 14 \\
\hline Endozone width & .9813 & .2428 & 24.75 & $.85-1.11$ & $.7-1.70$ & 16 & 14 \\
\hline Exozone width (one side only) & .3625 & .0984 & 27.13 & $.33-\quad .40$ & $.20-\quad .60$ & 32 & 14 \\
\hline Autozooecial surface angle ${ }^{a}$ (in degrees) & 78.75 & 12.44 & 15.80 & $73.92-83.58$ & $50-90$ & 28 & 13 \\
\hline
\end{tabular}

${ }^{a}$ Definition of autozooecial angle in table 4 
TABLE 50.-Summarized measurements of specimens of Parvohallopora onealli (James) [Hypotypes USNM 309206, 309208. All measurements in millimeters unless otherwise indicated]

\begin{tabular}{|c|c|c|c|c|c|c|c|}
\hline & $\begin{array}{c}\text { Arithmetic } \\
\text { mean }\end{array}$ & $\begin{array}{c}\text { Standard } \\
\text { deviation } \\
\text { of mean } \\
\end{array}$ & $\begin{array}{c}\text { Coefficient } \\
\text { of } \\
\text { variation }\end{array}$ & $\begin{array}{c}\text { 95-percent } \\
\text { confidence } \\
\text { interval } \\
\text { of mean }\end{array}$ & Range & $\begin{array}{c}\begin{array}{c}\text { Number } \\
\text { of } \\
\text { measurements }\end{array} \\
\end{array}$ & $\begin{array}{c}\text { Number } \\
\text { of } \\
\text { zoaria } \\
\text { measured }\end{array}$ \\
\hline Autozooecial chamber maximum diameter -_-_-_- & 0.1960 & 0.0327 & 16.70 & $0.17-0.22$ & $0.14-0.24$ & 10 & 2 \\
\hline Autozooecial chamber minimum diameter _-___- & .1140 & .0184 & 16.22 & $.10-\quad .13$ & $.10-1.15$ & 10 & 2 \\
\hline Autozooecial wall thickness, exozone -_-___-_ & .0630 & .0189 & 29.98 & $.05-$ & $.04-\quad .09$ & 10 & 2 \\
\hline Mesozooecial chamber maximum diameter -_-_-_- & .0710 & .0173 & 24.35 & $.06-\quad .08$ & $.04-\quad .10$ & 10 & 2 \\
\hline Autozooecia (number per $2 \mathrm{~mm}$ ) & 6.3333 & .5774 & 9.12 & $4.9-7.8$ & $6-7$ & 3 & 2 \\
\hline Diaphragms (number per $0.2 \mathrm{~mm}$ ) in mesozooecia - & & .8165 & 16.33 & $3.70-6.3$ & $4-6$ & 4 & 2 \\
\hline Zoarial branch diameter - & 1.950 & .495 & 25.38 & $(-2.50-6.40)$ & $1.60-2.30$ & 2 & 2 \\
\hline Endozone width -_- & .90 & .2828 & 31.43 & $(-1.64-3.44)$ & $.70-1.10$ & 2 & 2 \\
\hline Exozone width (one side only) - & .5125 & .0539 & 16.662 & $.38-.65$ & $.40-.60$ & 4 & \\
\hline Autozooecial angle at surface ${ }^{a}$ (in degrees) & 76.75 & - & ---- & & $65-90$ & 4 & \\
\hline
\end{tabular}

a Definition of autozooecial angle in table 4.

and Edenian Stage (USGS collns. 7070-CO, 7073-CO); and Strodes Creek Member, Edenian Stage (USGS colln. 7328-CO).

Clays Ferry Formation: Shermanian Stage (USGS collns. 5185-CO; 5001-CO; 7044-CO; 7452-CO, 7458-CO, 7459-CO; 6713-CO, D1170-CO), and Edenian Stage (USGS collns. 7471-CO, 7472-CO; $7477-\mathrm{CO}$; 6722-CO, 6723-CO, 6725-CO, 6728-CO, 6730-CO, 6736-CO, 6741-CO, 6744-CO; 4925-CO; 8130-CO); Point Pleasant Tongue, Shermanian Stage (USGS collns. 6924-CO, 6925-CO, 6929-CO).

Kope Formation, Edenian Stage (USGS collns. 6930-CO-6932-CO, 6934-CO, 6936-CO, 6938-CO).

Occurrence outside Kentucky.-James (1875, p. 2), James and James (1888, p. 175) and James (1894, p. 194 ) reported $P$. onealli (as Callopora onealli) from their "Lower Silurian" strata (the Upper Ordovician of current usage) in Ohio. Bassler (1906, p. 23, pl. 6, figs. 1,2 ) redescribed the type material of $C$. onealli (now Parvohallopora) and reported that it occurred abundantly in the "Economy Member of the Eden Shale" (the Kope Formation of current usage) of Bassler near Cincinnati. Cumings (1908, p. 787) and Cumings and Galloway (1913, p. 50) found P. onealli (as Callopora onealli) in their "Southgate" and "McMicken" strata of their Eden Shale (the Kope Formation of current usage) of Cumings at Tanners Creek in Indiana.

Subsequently, Ruedemann (1912, p. 51) reportedly found $P$. onealli (as $H$. onealli) in his "lower Siluric shales" (Upper Ordovician of current usage), and later (Ruedemann, 1925, p. 99, 100) found it in his "Utica" and "Lorraine" Formations (the Upper Ordovician of current usage) in New York. Foerste (1916, p. 90) reported $P$. onealli (as $H$. onealli) from his "Upper Ordovician" strata on Manitoulin Island, Ontario, and Parks (1925, p. 35 , as $H$. onealli) reported it from his Humber Member of the Dundas Formation, Upper Ordovician, in Ontario.

McFarlan (1931, p. 107) thought he recognized $P$. onealli (as $\mathrm{H}$. onealli) in his "Economy Member" and at higher stratigraphic horizons in his Eden Shale (the
Kope Formation of current usage) near Cincinnati. Ross (1969, p. 273) reported P. onealli (as Calopora onealli) from her "Shoreham Formation," Shermanian Stage, Middle Ordovician, in New York State.

Studied material.-Parvohallopora onealli, lectotype Field Museum of Natural History, James Collection, Callopora onealli UC 230-C; paralectotypes Field Museum of Natural History, James Collection, Callopora onealli, UC $230-1$, UC $230-2$, UC $230-3$; UC 230-A, UC 230-B, UC 230-E, UC 230-G from the "Eden Shale of the Cincinnatian." Hypotypes USNM 309206-309208, from strata "approximately $110 \mathrm{ft}$ above low water mark of the Ohio River" in the "lower third of the Eden Shale" of Bassler, 1906, p. 8; USNM 309209 from hypotype suite USNM 44527, "base of the Economy Member of the Eden strata," River Quarries, near Ludlow, Ky.

Hypotypes USNM 309210 (USGS colln. 8130-CO), 309211 (USGS colln. 4857-CO), 309212 (USGS colln. 4992-CO), 309213 (USGS colln. 4997-CO), 309214 (USGS colln. 5001-CO), 309215 (USGS colln. 7040-CO), 309216 (USGS colln. 7042-CO), 309217 (USGS colln. 7043-CO), 309218 (USGS colln. 7044-CO), 309219 (USGS colln. 7068-CO), 309220 (USGS colln. 7070-CO), 309221 (USGS colln. 7073-CO), 309222, 309533 (USGS colln. 7328-CO), 309223 (USGS colln. 7448-CO), 309224 (USGS colln. 7452-CO), 309225, 309647, 309648 (USGS colln. 7453-CO), 309226 (USGS colln. 7455-CO), 309227, 309637, 309638 (USGS colln. 7458-CO), 309228, 309639, 309640 (USGS colln. 7459-CO), 309229, 309641 (USGS colln. 7460-CO), 309230, 309642, 309643 (USGS colln. 7462-CO), 309231 (USGS colln. 7466-CO), 309232 (USGS colln. 5185-CO), 309233 (USGS colln. 7471-CO), 309234, 309644 (USGS colln. 7472-CO), 309235 (USGS colln. 7477-CO), 309236 (USGS colln. 6713-CO), 309237 (USGS colln. D1170-CO), 309238 (USGS colln. 6725-CO), 309239 (USGS colln. 6722-CO), 309240 (USGS colln. 6723-CO), 309241 (USGS colln. 6728-CO), 309242 (USGS colln. 6730-CO), 309243 (USGS colln. 
6736-CO), 309244 (USGS colln. 6741-CO), 309245 (USGS colln. 6744-CO), 309246 (USGS colln. 4925-CO), 309247 (USGS colln. 5013-CO), 309248 (USGS colln. 7017-CO), 309249, 309645 (USGS colln. 6924-CO), 309250 (USGS colln. 6925-CO), 309251, 309667 (USGS colln. 6929-CO), 309252 (USGS colln. 6930-CO), 309253 (USGS colln. 6931-CO), 309254 (USGS colln. 6932-CO), 309255 (USGS colln. 6934-CO), 309256, 309646 (USGS colln. 6936-CO), 309257 (USGS colln. 6938-CO), 309668 (USGS colln. D1127-CO).

Remarks. $-P$. onealli is characterized by zoaria in which autozooecia bud at relatively long intervals (pl. 31 , fig. 2e) and generally lack basal diaphragms in endozones. Branches of zoaria are typically thin, approximately $1.6 \mathrm{~mm}$ in diameter on the average. Exozones are generally narrow; mesozooecia commonly terminate within outer exozones.

$P$. onealli is closely related to $P$. nodulosa (Nicholson). Anstey and Perry $(1973$, p. 22) informally regarded $P$. onealli as a junior subjective synonym of $P$. nodulosa.

$P$. onealli differs from $P$. nodulosa, however, in having thinner zoarial branches, autozooecia with chambers smaller in diameter (tables 48-50), and relatively narrower exozones; it also lacks basal diaphragms in endozones of most zoaria. Autozooecia with mesozooeciumlike proximal tips ("interstitial tubes" of Ulrich, 1882 , p. 252; mesozooeciumlike tubes of McKinney, 1977 , p. 308), which characteristically occur in $P$. ramosa, the type species of Parvohallopora, are sparse or entirely lacking in endozones of $P$. onealli.

The persistent occurrence of a combination of these characters in zoaria of $P$. onealli differentiated it from $P$. nodulosa, and $P$. onealli is therefore regarded herein as an autonomous species until complete zoaria of both species become available for further study.

Tarphophragma n. gen.

Type species.-Monotrypella multitabulata Ulrich, 1886, p. 100; "Trenton Shales" of Ulrich (Decorah Shale of current usage), Middle Ordovician, Minnesota; designated here.

Etymology.-The name Tarphophragma is derived from tarphys, the Greek adjective for close, and phragma, the noun for partition.

Description.-Zoaria dendroid, occasionally having conspecific overgrowth and anastomosing.

In endozones, autozooecia contiguous, budding regularly from junctions of walls of preceding autozooecia, gradually expanding distally, curving outward. Autozooecia polygonal to subpolygonal in cross section, with abundant basal diaphragms occurring regularly throughout zoaria. Zones of rejuvenation of autozooecia locally present.
In exozones, autozooecia polygonal to subcircular in cross section, occasionally with preferred alignment locally, contiguous or partly separated by mesozooecia. Laminae in zooecial walls V-shaped in profile, exceedingly thin. Autozooecial boundaries narrowly serrated, well defined throughout exozones. Styles absent. Basal diaphragms generally evenly spaced; compound and cystoidal diaphragms common. Laminae of diaphragms form indistinct autozooecial linings locally, extend into cortex of autozooecial walls at low angles to chamber proximal to laminae of succeeding diaphragms. Boundaries between autozooecial linings and cortex indistinct.

Autozooecial chambers subpolygonal to subcircular in cross section.

Mesozooecia sparse to common, arising in outer endozones and inner exozones, occasionally changing to autozooecia in outer exozones. Mesozooecia subpolygonal to subcircular in cross section, having slightly thinner walls than those of autozooecia. Mesozooecial diaphragms abundant; linings absent.

Maculae common, flat or slightly raised, consisting of mesozooecia and a few polymorphs slightly larger than autozooecia in intermacular areas. Maculae relatively evenly spaced.

Remarks.-Tarphophragma $\mathrm{n}$. gen. is characterized by its autozooecial budding pattern, the regular occurrence of abundant basal diaphragms throughout zoaria, the microstructure of its zooecial walls, the presence of mesozooecia in exozones, and by a general lack of styles and accessory autozooecial wall structures (mural spines, cysts) in exozones.

The development of autozooecia in the endozones of Tarphophragma is similar to a kind of zoarial growth pattern that McKinney (1977, p. 307) described as an "apparently disordered interzooecial budding pattern" (budding patterns A1 and A2 of McKinney, 1977) in a number of trepostome genera. Autozooecia in zoaria showing McKinney's A1 budding pattern bud from junctions of three or four previous autozooecia, have planar walls in cross section, and gradually expand distally as the preceding autozooecia curve outward from axial parts of branch endozones. Autozooecia in zoaria showing the A2 budding pattern bud initially as mesozooeciumlike polymorphs, have curved walls in cross section, and then change to autozooecia later in endozones.

The interzooecial budding pattern of Tarphophragma is similar to the McKinney's A1 budding pattern (1977, text-fig. 2B) in having autozooecia with planar walls in endozones (pl. 32, fig. 4b; pl. 33, fig. 2), but differs from it in having regularly developed basal diaphragms throughout endozones (pl. 32, fig. 4b; pl. 33, fig. 1a). The interzooecial budding pattern of Tarphophragma differs from McKinney's pattern A2 (1977, pl. 2, figs. 2, 
3 ) in having autozooecia with planar walls in cross section and lacking mesozooeciumlike polymorphs in inner endozones.

Mesozooecia in Tarphophragma arise generally in inner exozones and occasionally in outer endozones. Mesozooecia in middle and outer exozones of the species can change locally into autozooecia.

Zooecial walls of Tarphophragma characteristically have thin skeletal laminae aligned in a typical inverted $\mathrm{V}$-shape, a chevron pattern, in profile (pl. 32, fig. 1b). Zooecial boundaries in Tarphophragma are narrowly serrated and generally distinct throughout exozones. They are formed by intertonguing and abutting of skeletal laminae of adjacent zooecia.

The regular interzooecial budding pattern of autozooecia with planar walls and abundant basal diaphragms throughout zoaria, combined with the shape of skeletal laminae in exozones, presence of distinct autozooecial boundaries, and absence of styles in zoaria differentiates Tarphophragma from other trepostome genera.

The designated type species for Tarphophragma, Monotrypella multitabulata Ulrich (1886, p. 100), has been regarded as a species of Calopora by most paleontologists since Ulrich (1893, p. 280) reassigned it from Monotrypella Ulrich to Calopora Hall. (For the taxonomic history of T. multitabulata, see remarks under T. multitabulata.)

Ross (1969, p. 270, 271) and Corneliussen and Perry (1973, p. 191) redescribed C. elegantula Hall, which is the type species of Calopora Hall, and McKinney (1977, p. 308) discussed the autozooecial budding pattern in C. elegantula. These reports show that $C$. elegantula is distinctly different from $C$. multitabulata (Ulrich) and therefore C. multitabulata cannot be regarded as a species of Calopora.

Comparative morphologies of $C$. elegantula and Tarphophragma multitabulata indicate that these species are similar in general appearance, approximate size of zoaria, and absence of styles, but are different in autozooecial budding pattern, cross-sectional shape of autozooecia in endozones and exozones, distribution of basal diaphragms in autozooecia, microstructure of zooecial walls, abundance and distribution of mesozooecia, and appearance and alignment ofmaculae (monticules of Corneliussen and Perry, 1973).

C. elegantula is characterized by an interzooecial budding pattern in which autozooecia bud initially as mesozooeciumlike polymorphs and then change to autozooecia later in endozones (A2 budding pattern of McKinney, 1977). Autozooecia in C. elegantula have generally subcircular cross-sectional shapes in endozones and exozones and are separated partly or almost completely by abundant mesozooecia in exozones (Ross,
1969, pl. 43, figs. 5, 8; McKinney, 1977, pl. 2, figs. 2, 3, 5).

Autozooecia in T. multitabulata bud according to A1 interzooecial budding pattern of McKinney (1977), but have regularly occurring basal diaphragms throughout the endozone and have polygonal to subpolygonal crosssectional shapes in endozones and exozones (pl. 32, figs. 1a, 4b; pl. 33, fig. 2). In these zoaria autozooecia are only partly separated by mesozooecia locally (pl. 32 , fig. $4 \mathrm{a} ;$ pl. 33 , fig. $3 \mathrm{~b}$ ).

Zooecial wall laminae in $C$. elegantula are broadly $\mathrm{V}$-shaped in profile and have broadly serrated, commonly indistinct zooecial boundaries (Ross, 1969, pl. 43, figs. 3, 7, 8; Corneliussen and Perry, 1973, text-figs. 18, 19). Zooecial wall laminae in T. multitabulata form a $V$-shaped chevron pattern in profile and have distinct, narrowly serrated zooecial boundaries throughout exozones (pl. 32, figs. 1b, 2b, 4a, 4c). Mural spines, cysts, and occasional cystiphragms are characteristic of C. elegantula (Ross, 1969, p. 271; Corneliussen and Perry, 1973, p. 195, 196, text-fig. 18); these structures are absent in T. multitabulata. Maculae (monticules of Corneliussen and Perry, 1973) in C. elegantula occur in transversely oriented bands (Cornelliussen and Perry, 1973, p. 192); in T. multitabulata they occur as small, slightly elevated areas of only a few polymorphs in an alternating pattern (pl. 33, fig. 1c).

On the basis of examination of thin sections from syntypes and hypotypes on file at the U.S. National Museum of Natural History, figured specimens in publications, and comparison with the primary and secondary material from $T$. multitabulata, the type species of Tarphophragma n. gen., I conclude that the following species have morphological characters consistent with those of Tarphophragma and assign them herein to that species.

Callopora ampla (Ulrich, 1893, p. 281), middle and upper part of the Decorah Shale and lower part of the Galena Dolomite, Middle Ordovician; Goodhue and Fillmore Counties, Minn., and Decorah, Iowa.

C. angularis (Ulrich, 1893, p. 277), lower part of the Decorah Shale, Middle Ordovician; Minneapolis, Chatfield, and Fountain, Minn.

C. goodhuensis (Ulrich, 1893, p. 282), lower part of the Galena Dolomite, Middle Ordovician; St. Paul and Cannon Falls, Minn. C. goodhuensis (pl. 33, fig. 1) is herein considered to be a subjective junior synonym of Tarphophragma multitabulata (see the remarks under T. multitabulata).

Geographic and stratigraphic distribution.-Tarphophragma n. gen. occurs in the eastern United States, Canada, and Estonia, U.S.S.R. The known range of Tarphophragma is Middle Ordovician in the United 
States and Middle Ordovician (D3) and Upper Ordovician (E) in Estonia.

\section{Tarphophragma multitabulata (Ulrich, 1886) \\ Plates 32, 33}

Monotrypella multitabulata Ulrich, 1886, p. 100. Astrova, 1978, p. 108,

Callopora multitabulata (Ulrich). Ulrich, 1893, p. 280, pl. 23, figs. 11, $12,16,17,24-26,30,31 ; 1896$, p. 274, fig. 456C, D. Sardeson, 1901 , p. 9, pl. A, figs. 5-6d. Ruedemann, 1901, p. 13; 1904, p. 13. Nickles, 1905, p. 42, pl. 1, fig. 2. Bassler, 1906, p. 22, pl. 1, figs. 5-7. Grabau and Shimer, 1909, p. 139, figs. 188n, 190n.

Hallopora multitabulata (Ulrich). Bassler, 1911, in part, p. 326, fig. 202; 1913, p. 337, figs. 491C, D, H. McFarlan, 1931, p. 106, pl. 1, figs. 5, 6. Sardeson, 1936, p. 98, 101-103, 111, 112, pl. 6, fig. 1 . Fritz, 1957, p. 19, pl. 11, figs. 1-4. Brown, 1965, p. 1003, pl. 18, figs. 5-7. Astrova, 1978, p. 70.

Monticulipora kentuckensis James, 1883, p. 57, pl. 2, fig. 1. James and James, 1888, p. 180, pl. 2, fig. 6, James, 1894, p. 203. Nomen oblitum (see Remarks).

Callopora goodhuensis Ulrich, 1893, p. 282, pl. 23, figs. 9, 10, 21, 29.

Hallopora goodhuensis (Ulrich). Bassler [parts], 1911, p. 327, text-fig. 203; not text-fig. 204.

Description.-Zoaria irregularly dendroid, having cylindrical to subcylindrical occasionally anastomosing branches, conspecific overgrowth locally.

In endozones, autozooecia subparallel to branch axis, three- to six-sided in cross section with straight walls. Basal diaphragms planar, at right angles to chamber axis, locally more closely spaced in proximal than in distal portions of some autozooecia. Zones of rejuvenation of autozooecia sparse.

In exozones, autozooecia occurring at an angle of $70^{\circ}$ and $90^{\circ}$ with zoarial surface, locally in indistinct alignment longitudinally, elongated and subpolygonal in cross section, generally contiguous, separated partly by mesozooecia in corners of junctions of autozooecia. Autozooecial boundaries straight to slightly crenulated locally. Basal diaphragms planar to slightly curved, generally oblique to chamber axis, occurring locally at similar growth stages of several adjacent autozooecia. Basal diaphragms occasionally more closely spaced in late than early exozones. Compound and cystoidal diaphragms occurring intermittently, locally more common in late than early exozones.

Autozooecial chambers elongated, subpolygonal to subcircular in cross section.

Mesozooecia common, one to two per autozooecium on average, elongated, polygonal to subcircular in cross section. Mesozooecial diaphragms abundant, spaced similarly to or slightly closer than basal diaphragms in autozooecia. Mesozooecia locally absent or terminating in exozones, occasionally changing to autozooecia in outer exozones.

Maculae slightly raised, occurring regularly in alternating pattern, centers approximately $2-2.5 \mathrm{~mm}$ apart. Maculae consisting of one or two polymorphs slightly larger than autozooecia and of mesozooecia singly or in groups.

Measurements.-Measurements are summarized in tables 51-53.

Geographic and stratigraphic distribution.-T. multitabulata occurs commonly in eastern North American strata of Middle Ordovician age. Specimens occurring in the Middle Ordovician strata in Estonia, U.S.S.R., that Bassler (1911) assigned to Hallopora multitabulata (Ulrich) and $H$. goodhuensis Ulrich, now Tarphophragma, are excluded from $T$. multitabulata on morphological grounds (see remarks on T. multitabulata).

Occurrence in Kentucky.-Curdsville Limestone Member, Kirkfieldian Stage (USGS colln. 6751-CO); Grier Limestone Member, Shermanian Stage (USGS collns. 4681-CO, 4682-CO, 4687-CO, 4691-CO, 4693-CO, 4697-CO, 4963-CO, 4967-CO, 4968-CO, 4972-CO, D1115-CO, 4944-CO, 4945-CO, 4947-CO, 4949-CO, 4952-CO, 4863-CO, 4867-CO, 4873-CO,

TABLE 51.-Summarized measurements of specimens of Tarphophragma multitabulata (Ulrich)

[Lectotype USNM 43522; paralectotype USNM 309305, 309308; hypotypes USNM 309649, 309307, 309306, 309315, 309316. All measurements in millimeters unless otherwise noted]

\begin{tabular}{|c|c|c|c|c|c|c|c|}
\hline & $\begin{array}{l}\text { Arithmetic } \\
\text { mean }\end{array}$ & $\begin{array}{c}\text { Standard } \\
\text { deviation } \\
\text { of mean }\end{array}$ & $\begin{array}{c}\text { Coefficient } \\
\text { of } \\
\text { variation }\end{array}$ & $\begin{array}{l}\text { 95-percent } \\
\text { confidence } \\
\text { interval } \\
\text { of mean }\end{array}$ & Range & $\begin{array}{c}\begin{array}{c}\text { Number } \\
\text { of } \\
\text { measurements }\end{array} \\
\end{array}$ & $\begin{array}{c}\text { Number } \\
\text { of } \\
\text { zoaria } \\
\text { measured }\end{array}$ \\
\hline Autozooecial chamber maximum diameter - _. & 0.2460 & 0.0238 & 9.67 & $0.24-0.25$ & \multirow{14}{*}{$\begin{array}{rr}0.18- & 0.30 \\
.12- & .23 \\
.04- & .07 \\
.30- & .43 \\
.20- & .30 \\
.03- & .17 \\
4 & -8 \\
40 & -14 \\
2 & -10 \\
3 & -6 \\
3 & -4.7 \\
5 & -7 \\
5.0 & -5.60 \\
3.7 & -4.3 \\
.40- & 1.10\end{array}$} & 35 & 7 \\
\hline eter _-_._._._- & .193 & .0256 & 12.98 & $.18-.20$ & & & 7 \\
\hline utozooecial wall thickness, exozone & .0526 & .010 & 19.21 & $.05-$ & & 35 & 7 \\
\hline Macular polymorph chamber maximum diameter & .3567 & .0337 & 9.44 & $.34-$ & & 12 & 3 \\
\hline$\ldots$ & .2483 & .028 & 11. & $.23-$ & & 12 & 3 \\
\hline$\ldots$ & .0889 & .0332 & 37.50 & $.07-.10$ & & 3 & 7 \\
\hline (1) & 6.150 & .9333 & 15.18 & $5.71-6.59$ & & 20 & 6 \\
\hline 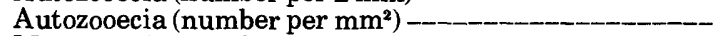 & 11.833 & 1.24 & & $11.21-12.45$ & & 18 & 7 \\
\hline zooecia (number per $\mathrm{mm}^{2}$ ) & 5.82 & 2.6513 & 45.53 & $4.46-7.19$ & & 17 & 6 \\
\hline Iragms (number per $\mathrm{mm}$ ) in endozone & 4.6970 & .8472 & & & & 33 & 7 \\
\hline Diaphragms (number per $0.2 \mathrm{~m}$ & 4.25 & .7746 & & -4.7 & & 16 & 4 \\
\hline Diaphragms (number per $0.2 \mathrm{~mm}$ ) in mesozooecia & 5.8571 & .8997 & 15.36 & $5.03-6.69$ & & 7 & \\
\hline Endozone width & & & & & & & 2 \\
\hline $\begin{array}{l}\text { Endozone width - } \\
\text { Exozone width (one side only) }\end{array}$ & .650 & $\begin{array}{l}.3055 \\
.3317\end{array}$ & $\begin{array}{r}7.57 \\
51.03\end{array}$ & $\begin{array}{r}3.27-4.79 \\
.12-1.18\end{array}$ & & $\begin{array}{l}3 \\
4\end{array}$ & $\begin{array}{l}3 \\
2\end{array}$ \\
\hline
\end{tabular}


TABLE 52.-Summarized measurements of specimens of Tarphophragma multitabulata (Ulrich) [Callopora goodhuensis (Ulrich) syntypes USNM 43524, 309311, 309312. All measurements in millimeters unless otherwise indicated]

\begin{tabular}{|c|c|c|c|c|c|c|c|}
\hline & $\begin{array}{l}\text { Arithmetic } \\
\text { mean }\end{array}$ & $\begin{array}{c}\text { Standard } \\
\text { deviation } \\
\text { of mean }\end{array}$ & $\begin{array}{c}\text { Coefficient } \\
\text { of } \\
\text { variation }\end{array}$ & $\begin{array}{l}\text { 95-percent } \\
\text { confidence } \\
\text { interval } \\
\text { of mean }\end{array}$ & Range & $\begin{array}{c}\begin{array}{c}\text { Number } \\
\text { of } \\
\text { measurements }\end{array} \\
\text {. }\end{array}$ & $\begin{array}{c}\text { Number } \\
\text { of } \\
\text { zoaria } \\
\text { measured }\end{array}$ \\
\hline Autozooecial chamber maximum diameter ___ & 0.2410 & 0.0267 & 11.09 & $0.23-0.25$ & $0.22-0.31$ & 20 & 4 \\
\hline Autozooecial chamber minimum diameter & .1605 & .2328 & 14.50 & $.15-.17$ & $.11-.20$ & 20 & 4 \\
\hline Autozooecial wall thickness, exozone - & .0520 & .0152 & 29.26 & $.04-$ & $.03-$ & 15 & 3 \\
\hline Macular polymorph chamber maximum diameter _-_- & .320 & .0163 & 5.10 & $.29-$ & .30 & 4 & 2 \\
\hline Macular polymorph chamber minimum diameter & .220 & .0115 & 5.25 & $.20-$ & $.21-$ & 4 & 2 \\
\hline Mesozooecial chamber maximum diameter & .0970 & .0269 & 27.80 & $.08-.11$ & $.04-.14$ & 20 & 4 \\
\hline Autozooecia (number per $2 \mathrm{~mm}$ ) & 6.416 & .6686 & 10.42 & $6^{.00}-7^{.11}$ & $5^{.01}-7^{.01}$ & 12 & 4 \\
\hline Autozooecia (number per $\mathrm{mm}^{2}$ ) & 12.182 & 1.8878 & 15.50 & $10.91-13.45$ & -15 & 11 & 4 \\
\hline Mesozooecia (number per $\mathrm{mm}^{2}$ ) & 7.27 & 2.149 & 29.55 & $5.83-8.72$ & -11 & 11 & 4 \\
\hline Diaphragms (number per $\mathrm{mm}$ ) in endozone & 5.840 & 1.0279 & 17.60 & $5.41-6.26$ & -8 & 25 & 5 \\
\hline Diaphragms (number per $0.2 \mathrm{~mm}$ ) in exozone & $\begin{array}{l}3.040 \\
3.80\end{array}$ & .9189 & 24.18 & $3.14-4.46$ & -5 & 10 & 3 \\
\hline Diaphragms (number per $0.2 \mathrm{~mm}$ ) in mesozooecia & 4.5455 & .6876 & 15.13 & $4.08-5.0$ & $4-6$ & 11 & 3 \\
\hline Zoarial branch diameter & 3.3750 & .4992 & 14.79 & $2.58-4.17$ & $2.90-3.90$ & 4 & 2 \\
\hline Endozone width - & 2.250 & .6245 & 27.76 & $1.26-3.24$ & $1.50-2.90$ & 4 & 2 \\
\hline Exozone width (one side only) & .5875 & .1126 & 19.17 & $.49-\quad .68$ & $.50-\quad .80$ & 8 & 2 \\
\hline
\end{tabular}

TABLE 53.-Summarized measurements of specimens of Tarphophragma multitabulata (Ulrich)

[Hypotypes USNM 309321, 309650, 309651 (USGS colln. 4681-CO), 309322, 309652 (USGS colln. 4682-CO), 309325 (USGS colln. 4693-CO), 309326, 309653, 309654 (USGS colln. 4697-CO), 309344 (USGS colln. 4863-CO), 309345, 309655 (USGS colln. 4867-CO), 309656-309659 (USGS colln. 4873-CO), 309347, 309660 (USGS colln. 4875-CO), 309348 (USGS colln. 4882-CO). All measurements in millimeters unless otherwise indicated]

\begin{tabular}{|c|c|c|c|c|c|c|c|}
\hline & $\begin{array}{c}\text { Arithmetic } \\
\text { mean }\end{array}$ & $\begin{array}{c}\text { Standard } \\
\text { deviation } \\
\text { of mean }\end{array}$ & $\begin{array}{c}\text { Coefficient } \\
\text { of } \\
\text { variation }\end{array}$ & $\begin{array}{c}\text { 95-percent } \\
\text { confidence } \\
\text { interval } \\
\text { of mean } \\
\end{array}$ & Range & $\begin{array}{c}\text { Number } \\
\text { of } \\
\text { measurements }\end{array}$ & $\begin{array}{c}\text { Number } \\
\text { of } \\
\text { zoaria } \\
\text { measured }\end{array}$ \\
\hline Autozooecial chamber maximum diameter _____- & 0.2552 & 0.0286 & 11.19 & $0.25-0.26$ & $0.20-0.35$ & 90 & 18 \\
\hline Autozooecial wall thickness, exozone - & .0470 & .0134 & 28.43 & $.04-.05$ & $.02-\quad .08$ & 90 & 18 \\
\hline Macular polymorph chamber maximum diameter & .3579 & .0461 & 12.88 & .35 & $.27-$ & 80 & 16 \\
\hline Mesozooecial chamber maximum diameter - & .080 & .0299 & 37.30 & $.07-.09$ & $.03-\quad .17$ & 86 & 18 \\
\hline Autozooecia (number per $2 \mathrm{~mm}$ ) & 6.7121 & .9886 & 14.73 & $6-7^{.00}$ & $4^{0}-8$ & 66 & 15 \\
\hline Autozooecia (number per $\mathrm{mm}^{2}$ ) & 10.83 & 1.870 & 17.27 & $10.4-11.26$ & -16 & 75 & 18 \\
\hline Mesozooecia (number per $\mathrm{mm}^{2}$ ) & 2.2258 & 1.093 & 49.09 & $1.95-2.50$ & -6 & 62 & 18 \\
\hline Diaphragms (number per $\mathrm{mm}$ ) in exozone-_______ & 12.177 & 1.5852 & 13.08 & $11.70-12.65$ & -15 & 45 & 12 \\
\hline Diaphragms (number per $\mathrm{mm}$ ) in endozone & 4.0097 & .9851 & 24.57 & $3.82-4.20$ & -7 & 103 & 21 \\
\hline Zoarial branch diameter & 4.7418 & 1.0788 & 22.75 & $4.41-5.07$ & $3.0-6.80$ & 43 & 17 \\
\hline Endozone width __________________________ & 3.3232 & .8791 & 26.45 & $3.05-3.59$ & $1.50-5.10$ & 43 & 17 \\
\hline Exozone width (one side only) & .7188 & .262 & 36.46 & $.66-\quad .78$ & $.30-1.40$ & 85 & 18 \\
\hline Autozooecial angle at surface ${ }^{a}$ (in degrees) & 71.555 & 10.00 & 13.98 & $69.45-73.65$ & $53-90$ & 90 & 18 \\
\hline
\end{tabular}

aefinition of autozooecial angle in table 4.

4875-CO, 4882-CO, 4884, D1151-CO, D1231-CO, D1235-CO-D1237-CO, D1222-CO, D1302-COD1304-CO); and Brannon Member, Shermanian Stage (USGS colln. 4973-CO, D1156-CO), of the Lexington Limestone.

Ulrich $(1886$, p. $101 ; 1893$, p. 281$)$ reported T. multitabulata from his "Trenton" strata, Middle Ordovician, in central Kentucky. Nickles (1905, p. 42) found this species (as Callopora) in the deposits of his "Lexington Group" near Frankfort and at other localities in Kentucky. Bassler $(1906$, p. 23) indicated that T. multitabulata (as Callopora) occurred in his "Lexington Limestone of the Trenton" at several localities in Kentucky.

James (1883, p. 57) and James and James (1888, p. 181) reportedly found T. multitabulata (as Monticulipora kentuckensis) in the Ordovician strata near Paris, Ky. (Bassler, 1906, p. 23). McFarlan (1931, p. 106) found that T. multitabulata (as Hallopora) occurs abundantly in his Jessamine Limestone, Middle Ordovician, and extended into his "Woodburn" strata in
Kentucky. Brown (1965, p. 1004) reported T. multitabulata (as Hallopora) from his undivided "LoganaJessamine Members of the Lexington Limestone (the Logana and Grier Limestone Members, respectively, of the Lexington Limestone of current usage), Middle Ordovician, at several localities in central Kentucky.

Occurrence outside Kentucky.-Ulrich (1893, p. 281) reported T. multitabulata (as Callopora) from his "Middle and Upper third of the Trenton shales" (approximate stratigraphic equivalents of the Stictopora mutabilis and Stictopora minima zones, respectively, of Karklins, 1969, p. 33); the Decorah Shale, Middle Ordovician, Minnesota; his "Galena Shales," Middle Ordovician, Minnesota and Iowa; and his Middle Ordovician strata in Tennessee.

Ruedemann (1901, p. 13; 1904, p. 13) reportedly found T. multitabulata (as Callopora) in his "Trenton conglomerates" at two locations in New York.

Sardeson (1936, p. 98) noted that T. multitabulata (as Hallopora) ranged from his Plateville Limestone into his "Galena Limestone," Middle Ordovician, in Minne- 
sota, and in the "Galena Limestone" in Iowa. Fritz (1957) indicated that T. multitabulata (as Hallopora) ranged through most beds of her Ottawa Formation, Middle Ordovician, in the Ottawa-St. Lawrence lowland region, Ontario.

Studied material.-Callopora multitabulata (Ulrich, 1886), type species of Tarphophragma n. gen., herein designated lectotype USNM 43522 and paralectotypes USNM 309303, 309304, 309305 from the syntype suite USNM 43522, Decorah Shale ("Phylloporina Bed" of Ulrich), Middle Ordovician, St. Paul, Minn.; USNM 309306 marked "type section," Decorah Shale ("Phylloporina Bed" of Ulrich), figured by Ulrich (1893, pl. 23, fig. 24); 309307, marked "type section," figured by Ulrich (1893, pl. 23, fig. 17); 309649 and 309308 from the Galena Dolomite ("Clitambonites Bed" of Ulrich) from syntype suite USNM 43523, Cannon Falls, Minn.

Hypotypes USNM 309309, 309310, Decorah Shale (Phylloporina bed), St. Paul, Minn.

"Hallopora multitabulata" (Ulrich), hypotype USNM 57459 from hypotype suite USNM 57459, "Wassalem Beds," D3, Ordovician, Uxnorm, Estonia, U.S.S.R.

Callopora goodhuensis Ulrich (1893), syntype USNM 43524, marked "type section," illustrated by Ulrich (1893, pl. 23, fig. 21) from his "Trenton Group," Middle Ordovician, Cannon Falls, Minn.; syntype USNM 309311, 309312 from syntype suite USNM 43524, Galena Dolomite ("Prosser," "Clitambonites Bed" of the "lower Galena shales" of Ulrich), Middle Ordovician, Cannon Falls, Minn. Hypotypes USNM 309313 and 309314, syntype suite USNM 34951/44508, from the "Trenton Group" of Ulrich, Middle Ordovician, St. Paul, Minn.

"Callopora goodhuensis," hypotype USNM 57460, thin section figured by Bassler (1911, text-fig. 204), from hypotype suite USNM 57460, "Wassalem Beds," D3, Ordovician, Uxnorm, Estonia, U.S.S.R. Hypotypes USNM 309315 and USNM 309316 from the Decorah Shale ("Trenton Shales" of Ulrich), Minneapolis, Minn.

USNM 309317 and USNM 309318 from the "Trenton Group" of Ulrich, Burgin, Ky.; USNM 309319 "Trenton Group" of Ulrich, near Claysville, $\mathrm{Ky}$.

Hypotypes USNM 309320 (USGS colln. 6751-CO), 309344 (USGS colln. 4863-CO), 309321, 309650, 309651 (USGS colln. 4681-CO), 309345, 309655 (USGS colln. 4867-CO), 309322, 309652 (USGS colln. 4682-CO), 309346, 309656-309659 (USGS colln. 4873-CO), 309323, 309669 (USGS colln. 4687-CO), 309347,309660 (USGS colln. 4875-CO), 309324 (USGS colln. 4691-CO), 309348 (USGS colln. 4882-CO), 309325 (USGS colln. 4693-CO), 309349 (USGS colln. 4884-CO), 309326, 309653, 309654 (USGS colln.
4697-CO), 309350 (USGS colln. D1151-CO), 309327 (USGS colln. 4963-CO), 309351 (USGS colln. D1156-CO), 309328 (USGS colln. 4967-CO), 309352 (USGS colln. D1231-CO), 309329 (USGS colln. 4968-CO), 309353 (USGS colln. D1235-CO), 309330 (USGS colln. 4972-CO), 309354 (USGS colln. D1236-CO), 309331 (USGS colln. 4973-CO), 309355 (USGS colln. D1237-CO), 309332 (USGS colln. D1115-CO), 309356 (USGS colln. D1222-CO), 309333 (USGS colln. D1117-CO), 309334 (USGS colln. D1302-CO), 309335 (USGS colln. D1303-CO), 309336 (USGS colln. D1304-CO), 309337 (USGS colln. 4944-CO), 309338 (USGS colln. 4945-CO), 309339 (USGS colln. 4947-CO), 309340 (USGS colln. 4949-CO), 309341 (USGS colln.. 4952-CO), 309342 (USGS colln. 4952-CO), 309343 (USGS colln. 4862-CO).

Remarks.-T. multitabulata is characterized by autozooecia having elongated subpolygonal cross-sectional shapes in exozones and relatively closely and evenly spaced basal diaphragms throughout zoaria. Mesozooecia in T. multitabulata are common, but are irregularly distributed in exozones. They occur mostly between distal and proximal junctions of autozooecia, but may be lacking locally in parts of a zoarium.

Ulrich (1893, p. 282) erected Callopora goodhuensis from his "Galena Shales," Middle Ordovician, at St. Paul and Cannon Falls, Minn. Examination of thin sections from the syntypes of $C$. goodhuensis (pl. 33, fig. 1) on file at the U.S. National Museum of Natural History indicates that the species is morphologically consistent with T. multitabulata and therefore is herein regarded as a subjective junior synonym of $T$. multitabulata (Ulrich).

Bassler (1911, p. 326, 327) reportedly found T. multitabulata (as Hallopora) in the Wassalem Beds (D3), Middle Ordovician, and C. goodhuensis (as Hallopora) in the Wassalem (D3) strata, Middle Ordovician, and Wesenberg Limestone (E), Upper Ordovician, in Estonia, U.S.S.R. On the basis of examinations of thin sections on file at the U.S. National Museum of Natural History, these specimens are deemed consistent with the concept for Tarphophragma n. gen., but differ from T. multitabulata in a number of morphological characters and thus are excluded from it.

Specimens (pl. 33, fig. 4) from Estonia, U.S.S.R., that are included in Tarphophragma n. gen. differ from $T$. multitabulata in having autozooecia with subcircular shapes in cross section, narrowly V-shaped laminae in autozooecial walls, and broadly serrated autozooecial boundaries in exozones (pl. 33, fig. 4). In addition, autozooecia in the Estonian specimens have abundant cystoidal diaphragms and more closely spaced basal diaphragms throughout zoaria (pl. 33 , fig. 4 b) than do 
specimens of $T$. multitabulata. Furthermore, mesozooecia appear to be more abundant in the Estonian specimens than in T. multitabulata specimens.

The morphological differences between specimens of Tarphophragma from the Ordovician strata in Estonia, U.S.S.R. and those from North America indicate that the specimens from Estonia belong to an undescribed species of Tarphophragma.

Taxonomic history.-Ulrich (1886, p. 100) erected $T$. multitabulata on the basis of specimens from his "Trenton Group," Middle Ordovician, in Kentucky and Minnesota and assigned these specimens to Monotrypella Ulrich, 1882 . In a subsequent major work on the Ordovician bryozoans from Minnesota, Ulrich (1893, p. 280) redescribed T. multitabulata, illustrated it for the first time, and reassigned it to Calopora Hall (his Callopora). Ulrich (1893, p. 277) noted, however, that T. multitabulata differed from "ordinary Callopora" in having abundant diaphragms and relatively few mesozooecia (his mesopores). As to morphological differences between Monotrypella and T. multitabulata, Ulrich $(1893$, p. 277) further noted that autozooecia have subequal instead of equal (polygonal) crosssectional shapes in axial portions of endozones in Monotrypella.

Recently sectioned primary type material of $M$. aequalis Ulrich (syntype suite USNM 43684, on file at the U.S. National Museum of Natural History), which is the type species of Monotrypella, indicates other differences, such as configuration of autozooecial wall laminae, autozooecial boundaries, and presence of styles in Monotrypella.

Most paleontologists in subsequent investigations (Bassler, 1915, p. 581; McKinney, 1974, p. 67) have followed Ulrich's 1893 taxonomic assignment of T. multitabulata as a species of Calopora (or Hallopora).

Bassler (1906, p. 22), in his restudy of the James types of Ordovician and Silurian bryozoans, determined that T. multitabulata (as Hallopora) was conspecific with Monticulipora kentuckensis James, 1883. Although $M$. kentuckensis James had a priority over the name of Callopora multitabulata (Ulrich) at that time, Bassler placed $M$. kentuckensis in synonomy with C. multitabulata because he considered James' description (1883) and illustrations of $M$. kentuckensis inadequate for its recognition as an autonomous species.

Subsequently prepared thin sections by J. R. P. Ross from the primary types (UC 2315) of M. kentuckensis on file at the Field Museum of Natural History indicate that $M$. kentuckensis is conspecific with $T$. multitabulata.

The name Monticulipora kentuckensis, however, has not been used during the more than 50 years since Bassler's (1906) report and therefore is considered to be nomen oblitum, according to the "International Code of Zoological Nomenclature," 1964 (article 23b).

Family TREMATOPORIDAE

Genus BALTICOPORA Vinassa de Regny, 1921

Type species.-Hemiphragma tenuimurale Ulrich, 1893, p. 301; "Galena Shales of the Trenton Group" of Ulrich, Middle Ordovician, Minnesota.

Remarks.-Vinassa de Regny (1921, p. 219) erected the genus Balticopora to include species of Hemiphragma Ulrich (1893) that have autozooecia with polygonal shapes in cross section and thin exozonal walls. Vinassa de Regny (1921) placed $H$. tenuimurale Ulrich, 1893, and $H$. subsphaericum Bassler (1911, p. 292) in Balticopora and designated $H$. tenuimurale as the type species of Balticopora.

Bassler (1935, p. 123; 1953, p. G114), however, placed Balticopora in synonomy with Hemiphragma.

Examination of primary type material of $\mathrm{Hemi}$ phragma irrasum Ulrich $(1893$, p. 299 , pl. 24, figs. 5-19), which is type species of Hemiphragma (on file at the U.S. National Museum of Natural History), and of recently described material from the "Gutenberg" and "Ion" Formations, Middle Ordovician, in Iowa (Bork and Perry, 1968a, p. 342, pl. 44, figs. 1-3, 5) indicates that $H$. tenuimurale, the designated type species of Balticopora, differs from $H$. irrasum not only in crosssectional shape and thickness of autozooecia in exozones, but also in configuration of autozooecial wall laminae and appearance and distribution of styles.

Autozooecial walls of $B$. tenuimurale are, on the average, between 0.03 and $0.04 \mathrm{~mm}$ thick (tables 54-56) and can attain a thickness of approximately $0.07 \mathrm{~mm}$ (Ross, 1970a, table 6). Autozooecial walls of $H$. irrasum range from 0.07 to $0.13 \mathrm{~mm}$ (Bork and Perry, 1968a, table 5) in thickness. Autozooecial wall laminae of Balticopora, as in $B$. tenuimurale, are generally $\checkmark$-shaped in profile and form distinct and narrowly serrated autozooecial boundaries (pl. 32, fig. 1c, 1d, 2b; Ulrich, 1893, pl. 24, fig. 20). Hemiphragma, as in $H$. irrasum, have autozooecia in which laminae have $\mathrm{U}$-shaped configuration in profile and form broadly serrated autozooecial boundaries that are commonly indistinct (Ulrich, 1893, pl. 24, figs. 8, 9; Bork and Perry, 1968a, figs. 2, 5). Styles in Hemiphragma are large in diameter and abundant (Ulrich, 1893, pl. 24, figs. 6, 9: Bork and Perry, 1968a, pl. 44, figs. 2, 3, table 5), but in Balticopora, as in $H$. tenuimurale, styles are small, approximately $0.01-0.02 \mathrm{~mm}$ in diameter throughout exozones (pl. 32, figs. 1a, 1d, 2a; Ross, 1970a, pl. 69, fig. 1).

The morphological differences between Hemiphragma, as observed in $H$. irrasum, and Balticopora, as observed in $H$. tenuimurale, indicate that de Regny's 
concept for Balticopora is valid; it is therefore used herein.

Balticopora tenuimurale (Ulrich, 1893)

Plate 34; plate 35, figure 1

Hemiphragma tenuimurale Ulrich, 1893, p. 301, pl. 24, figs. 20-23; Bassler, 1911, text-fig. 171; Fritz, 1957, p. 21, pl. 13, figs. 3, 5; Brown, 1965, p. 1004, pl. 117, figs. 7-9; Ross, 1970a, p. 370, pl. 69, figs. $1,3,5,6,8,9 ;$ pl. 70 , figs. 1,5 .

?Hemiphragma tenuimurale Ulrich. Wilson, 1921, pl. 2, figs. 13, 14; Premik, 1924, p. 186, pl. 7, fig. 15. Not Hemiphragma tenuimurale Ulrich. Bassler, 1911, p. 282, text-fig. 170.

Description.-Zoaria irregularly dendroid, having subcylindrical branches, variable in size, and, commonly, conspecific overgrowth locally.

Endozones relatively wide. In endozones, autozooecia subparallel in axial portions of endozones, irregularly polygonal, generally five- to six-sided in cross section, curving gradually, slightly irregularly, outward. Autozooecial walls sinuous, occasionally crenulated in areas of autozooecial budding and in outer endozones. Hemiphragms, perhaps some basal diaphragms, sparse to absent, planar to slightly curved, occurring locally in indistinct zones in areas of autozooecial budding and outer endozones, generally lacking in axial portions of endozones and between areas of autozooecial budding. Zones of rejuvenation of autozooecia sparse, locally having few hemiphragms.

Exozones relatively narrow. In exozones, autozooecia approximately at right angles to zoarial surface, generally contiguous, subpolygonal to subelliptical in cross section, without preferred alignment. Autozooecial walls generally thin, slightly sinuous, occasionally crenulated, irregular in thickness locally. Autozooecial boundaries generally distinct, narrowly serrated, occasionally not visible locally. Autozooecial wall laminae generally V-shaped in profile. Styles sparse to absent, commonly showing indistinct small cores, exceedingly thin sheaths. Styles generally centered on autozooecial boundaries in corners of autozooecia; lacking in many autozooecia. Hemiphragms, perhaps some basal diaphragms, common, planar to irregularly curved, terminal tips commonly bulbous, proximally curved. Hemiphragms evenly spaced in many autozooecia, scattered in others, projecting alternately or at similar growth stages of autozooecia from opposite sides of autozooecial walls; occasionally merging to form irregularly curved partitions (basal diaphragms) across autozooecial chambers. Autozooecial linings locally common, extending for short distances distally of hemiphragms, continuing obliquely into autozooecial cortex.

Autozooecial chambers subpolygonal to subelliptical in cross section, sinuous in profile locally.

Mesozooecia sparse to absent, subpolygonal to subcircular in cross section, occasionally with moniloid proximal portions. Mesozooecial walls approximately similar in thickness to those of autozooecia. Mesozooecial diaphragms unevenly spaced. Maculae common, scattered, generally low, consisting of polymorphs slightly larger than autozooecia and scattered mesozooecia in various combinations.

Measurements.-Measurements are summarized in tables 54-56.

Geographic and stratigraphic distribution. - B. tenuimurale occurs in rocks of the upper Champlainian Provincial Series, Middle Ordovician, and lower Edenian Stage, Upper Ordovician, in North America. Premik (1924, pl. 7, fig. 15) reported B. tenuimurale (as Hemiphragma) from rocks of Middle Ordovician age in Podolia, Poland, now part of the U.S.S.R. However, published figures of these specimens are inadequate for taxonomic comparisons, and therefore this stratigraphic occurrence needs to be verified.

B. tenuimurale does not appear to be present in rocks of Middle Ordovician age in Estonia, U.S.S.R., as reported by Bassler (1911, p. 282, as Hemiphragma) (see remarks in this section).

Occurrence in Kentucky.-Grier Limestone Member,

TABLE 54.-Summarized measurements of specimens of Balticopora tenuimurale (Ulrich) [Lectotype USNM 43563 and paratype USNM 309269. All measurements in millimeters unless otherwise indicated]

\begin{tabular}{|c|c|c|c|c|c|c|c|}
\hline & $\begin{array}{c}\text { Arithmetic } \\
\text { mean }\end{array}$ & $\begin{array}{l}\text { Standard } \\
\text { deviation } \\
\text { of mean }\end{array}$ & $\begin{array}{c}\text { Coefficient } \\
\text { of } \\
\text { variation }\end{array}$ & $\begin{array}{c}\text { 95-percent } \\
\text { confidence } \\
\text { interval } \\
\text { of mean }\end{array}$ & Range & $\begin{array}{c}\begin{array}{c}\text { Number } \\
\text { of } \\
\text { measurements }\end{array} \\
\end{array}$ & $\begin{array}{c}\text { Number } \\
\text { of } \\
\text { zoaria } \\
\text { measured }\end{array}$ \\
\hline Autozooecial chamber maximum diameter - & 0.2665 & 0.0322 & 12.08 & $0.25-0.28$ & $0.20-0.32$ & 17 & 2 \\
\hline Autozooecial chamber minimum diameter & .2253 & .0429 & 19.03 & $.20-.25$ & $.16-\quad .30$ & 17 & $\overline{2}$ \\
\hline Autozooecial wall thickness, exozone & .0429 & .0172 & 40.14 & $.03-$ & $.02-$ & 17 & $\overline{2}$ \\
\hline Macular polymorph chamber maximum diameter & .3360 & .0499 & 11.20 & $.32-$ & $.30-$ & 5 & $\overline{2}$ \\
\hline Macular polymorph chamber minimum diameter & .2660 & .0241 & 9.05 & $.24-$ & $.24-$ & 5 & 2 \\
\hline Mesozooecial chamber maximum diameter - & .1047 & .0339 & 32.40 & $.09-\quad .12$ & $.06-\quad .18$ & 17 & 2 \\
\hline Autozooecia (number per $2 \mathrm{~mm}$ ) & 6.3333 & .8165 & 12.89 & $5.48-7.19$ & $5.00-7.00$ & 6 & 2 \\
\hline Autozooecia (number per $\mathrm{mm}^{2}$ ) & 9.20 & 1.3038 & 14.17 & $7.58-10.81$ & $8-11$ & $\mathbf{5}$ & 2 \\
\hline Mesozooecia (number per $\mathrm{mm}^{2}$ ) & 3.20 & 1.4832 & 46.35 & $1.36-5.04$ & -5 & 5 & 2 \\
\hline Diaphragms (number per $\mathrm{mm}$ ) - & 6.3750 & .7440 & 11.67 & $5.76-7.0$ & $5-7$ & 8 & 2 \\
\hline Zoarial branch diameter & 8.3333 & 1.1547 & 13.86 & $5.46-11.20$ & $7.00-9.00$ & 3 & 2 \\
\hline Endozone width & 4.560 & 1.1127 & 24.40 & $3.18-5.94$ & $3.50-6.00$ & 5 & 2 \\
\hline Exozone width (one side only) & 1.30 & .245 & 18.84 & $1.11-1.49$ & $1.00-1.80$ & 9 & 2 \\
\hline
\end{tabular}


TABLE 55.-Summarized measurements of specimens of Balticopora tenuimurale (Ulrich)

[Hypotypes USNM 309287 (USGS colln. 4863-CO), 309288-309294 (USGS colln. 4866-CO), 309295-309298 (USGS colln. 4870-CO). All measurements in millimeters unless otherwise indicated]

\begin{tabular}{|c|c|c|c|c|c|c|c|}
\hline & $\begin{array}{c}\text { Arithmetic } \\
\text { mean }\end{array}$ & $\begin{array}{c}\text { Standard } \\
\text { deviation } \\
\text { of mean }\end{array}$ & $\begin{array}{c}\text { Coefficient } \\
\text { of } \\
\text { variation }\end{array}$ & $\begin{array}{l}\text { 95-percent } \\
\text { confidence } \\
\text { interval } \\
\text { of mean }\end{array}$ & Range & $\begin{array}{c}\text { Number } \\
\text { of } \\
\text { measurements }\end{array}$ & $\begin{array}{c}\text { Number } \\
\text { of } \\
\text { zoaria } \\
\text { measured }\end{array}$ \\
\hline Autozooecial chamber maximum diameter & 0.2470 & 0.0257 & 10.42 & $0.2397-0.2543$ & $0.19-0.29$ & 50 & 10 \\
\hline Autozooecial wall thickness, exozone - & .0392 & .0194 & 49.39 & $.0337-\quad .0447$ & $.02-\quad .10$ & 50 & 10 \\
\hline \multicolumn{8}{|l|}{ Macular polymorph chamber maximum } \\
\hline diameter _- & .3428 & .0327 & 9.55 & $.3293-$ & $.30-$ & 25 & 5 \\
\hline Mesozooecial chamber maximum diameter -_- & .0976 & .0322 & 33.05 & $.0829-$ & $.04-$ & 49 & 10 \\
\hline Autozooecia (number per $2 \mathrm{~mm}$ ) - & 6.7441 & .7589 & 11.25 & $6.5105-6.9777$ & $5-8$ & 43 & 9 \\
\hline Autozooecia (number per $\mathrm{mm}^{2}$ ) & 10.57 & 1.60 & 15.15 & $10.089-11.040$ & -14 & 46 & 10 \\
\hline Mesozooecia (number per $\mathrm{mm}^{2}$ ) & 3.1714 & 2.0071 & 63.29 & $2.4817-3.8610$ & $0-11$ & 35 & 7 \\
\hline Zoarial branch diameter -_- & 5.5045 & .6565 & 11.92 & $5.2134-5.7956$ & $4.20-6.40$ & 22 & 9 \\
\hline Endozone width & 4.2608 & .4590 & 10.77 & $4.0623-4.4593$ & $3.10-5.10$ & 23 & 9 \\
\hline Exozone width (one side only) _-_ & .6320 & .2065 & 32.67 & $.5733-\quad .6907$ & $.30-1.20$ & 50 & 10 \\
\hline
\end{tabular}

TABLE 56.-Summarized measurements of specimens of Balticopora tenuimurale (Ulrich) [Hypotype USNM 309277-309279 (USGS colln. D1200-CO), 309285, 309286 (USGS colln. 4700-CO). All measurements in millimeters unless otherwise indicated]

\begin{tabular}{|c|c|c|c|c|c|c|c|}
\hline & $\begin{array}{c}\text { Arithmetic } \\
\text { mean }\end{array}$ & $\begin{array}{c}\text { Standard } \\
\text { deviation } \\
\text { of mean }\end{array}$ & $\begin{array}{c}\text { Coefficient } \\
\text { of } \\
\text { variation }\end{array}$ & $\begin{array}{l}\text { 95-percent } \\
\text { confidence } \\
\text { interval } \\
\text { of mean }\end{array}$ & Range & $\begin{array}{c}\begin{array}{c}\text { Number } \\
\text { of } \\
\text { measurements }\end{array} \\
\end{array}$ & $\begin{array}{c}\text { Number } \\
\text { of } \\
\text { zoaria } \\
\text { measured }\end{array}$ \\
\hline Autozooecial chamber maximum diameter ___ & 0.2730 & 0.0380 & 13.92 & $0.2552-0.2908$ & $0.18-0.32$ & 20 & 4 \\
\hline Autozooecial wall thickness, exozone - & .0365 & .0131 & 35.86 & $.0304-.0426$ & $.02-\quad .07$ & 20 & 4 \\
\hline Macular polymorph chamber maximum diameter -_- & .3608 & .0454 & 12.57 & $.3334-.3882$ & $.31-$ & 25 & 5 \\
\hline Mesozooecial chamber maximum diameter & .0919 & .0462 & 50.31 & $.0673-.1165$ & $.03-.17$ & 16 & 4 \\
\hline Autozooecia (number per $2 \mathrm{~mm}$ ) & 6.8124 & .9106 & 13.37 & $6.3273-7.2976$ & $5^{.00}-8^{.14}$ & 16 & 4 \\
\hline Autozooecia (number per $\mathrm{mm}^{2}$ ) & 8.8571 & 1.7032 & 19.23 & $7.8738-9.8404$ & -12 & 14 & 4 \\
\hline Mesozooecia (number per $\mathrm{mm}^{2}$ ) & 1.9166 & .6686 & 34.88 & $1.4918-2.3414$ & $0-3$ & 12 & 4 \\
\hline Zoarial branch diameter & 5.9199 & 1.0443 & 17.64 & $5.1729-6.6670$ & $4.30-7.70$ & 10 & 5 \\
\hline Endozone width & 3.4899 & .8647 & 24.78 & $2.8714-4.1085$ & $2.50-5.20$ & 10 & 5 \\
\hline Exozone width (one side only) & 1.2239 & .2278 & 17.64 & $1.130-1.3180$ & $.80-1.60$ & 25 & 5 \\
\hline
\end{tabular}

Shermanian Stage (USGS collns. D1110-CO; 4863-CO, 4866-CO, 4870-CO; 4972-CO); Brannon Member, Shermanian Stage (USGS collns. 4973-CO, 4974-CO); and Tanglewood Limestone Member, Shermanian Stage (USGS colln. 4700-CO, D1200-CO; 4976-CO, 4991-CO), of the Lexington Limestone. Clays Ferry Formation, Shermanian Stage (USGS colln. 4898-CO).

Brown (1965, p. 1005) found B. tenuimurale (as Hemiphragma) in his undivided "Logana-Jessamine Limestone Members" of the Lexington Limestone, Middle Ordovician, in several localities in central Kentucky.

Occurrence outside Kentucky.-Ulrich (1893, p. 301) described B. tenuimurale (as Hemiphragma) from his "Galena Shales," Middle Ordovician, in Goodhue County, Minn. Ulrich's specimens probably were from strata that appear to be the stratigraphic equivalents of the Cummingsville Member of the Galena Formation in lithostratigraphic nomenclature of Weiss (1957, p. 1029) and Webers (1972, p. 477, text-fig. V1-25).

Ross (1970a, p. 371, text-fig. 8) established that $B$. tenuimurale (as Hemiphragma) ranged throughout her Trenton Group in New York. The Trenton Group of Ross (1970a) comprises, in ascending order, the Rockland, Kirkfield, Shoreham, and Denmark formations, Middle Ordovician, and the Cobourg Formation, Edenian Stage, Upper Ordovician.

B. tenuimurale reportedly occurs in the Middle Ordo- vician strata of Canada. Wilson (1921, p. 31, pl. 2, figs. 13,14 ) reported $B$. tenuimurale (as Hemiphragma) from the "Trenton" strata near Rockland, Ont. This occurrence may need to be verified because the published figures (Wilson, 1921, pl. 2, figs. 13, 14) are inadequate for taxonomic comparison. Fritz (1957, p. 21) found $B$. tenuimurale (as Hemiphragma) in the Hull, Sherman Fall, and Cobourg beds of her Ottawa Formation, Middle Ordovician, in the Ottawa-St. Lawrence Lowland area of Ontario.

Studied material.-Lectotype USNM 43563 and paratypes USNM 309258 (E. O. Ulrich's thin section), 309259-309275 from the syntype suite USNM 43563, "Trenton Group" of Ulrich, near Cannon Falls, Goodhue County, Minn.

Hypotypes USNM 309276 (USGS colln. D1110-CO), 309277-309279 (USGS colln. D1200-CO), 309280 (USGS colln. 4972-CO), 309281 (USGS colln. 4973-CO), 309282 (USGS colln. 4974-CO), 309283 (USGS colln. 4976-CO), 309284 (USGS colln. 4991-CO), 309285, 309286 (USGS colln. 4700-CO), 309287 (USGS colln. 4863-CO), 309288-309294 (USGS colln. 4866-CO), 309295-309298 (USGS colln. 4870-CO), 309299 (USGS colln. 4898-CO).

Remarks. - B. tenuimurale (Ulrich) characteristically possesses autozooecia having thin, occasionally crenulated walls, relatively well-defined autozooecial bound- 
aries, small and sparse styles, and sparse maculae. $B$. tenuimurale has virtually no hemiphragms in axial portions of endozones.

Bassler (1911, p. 282, text-fig. 170) reportedly found B. tenuimurale (as Hemiphragma) in the Middle Ordovician strata (Wassalem beds, his D3) of Estonia, U.S.S.R. Examination of Bassler's Estonian material (1911) indicates that autozooecia in these zoaria have generally more angular shapes in cross section (Bassler, 1911 , p. 282, text-fig. 170b) than those in North American Middle Ordovician deposits, and that they lack styles (Bassler, 1911, p. 282, text-fig. 170b). Because of these differences, specimens of Balticopora from the Middle Ordovician deposits of Estonia, U.S.S.R., cannot be included in $B$. tenuimurale; they probably belong to another species of Balticopora.

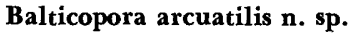

Etymology.-The trivial name is from the Latin, arcuatilis, and means "shaped like a bow"; it refers to the general appearance of the hemiphragms.

Description.-Zoaria subglobular to subdomal, unbranched; occasionally having conspecific overgrowth locally.

Autozooecia erect, approximately parallel to vertical growth direction of zoaria, slightly curved locally. Endozones and exozones indistinctly differentiated.

In endozones, autozooecia polygonal, generally fiveto six-sided in cross section, sparingly intercalated, having $U$-shaped proximal portions at points of budding. Autozooecial walls generally straight, exceedingly thin. Styles sparse to absent, showing indistinct cores and thin, indistinct sheaths; locally occurring at points of autozooecial budding, projecting occasionally into proximal portions of autozooecial chambers. Hemiphragms, perhaps basal diaphragms, common to absent, planar, occurring commonly in areas of intercalation of autozooecia, scattered or lacking locally throughout endozones.

In exozones, autozooecia generally contiguous, irregularly polygonal, five- to six-sided, occasionally foursided, in cross section. Autozooecial walls generally straight, slightly thicker than in endozones, indistinctly crenulated locally, having narrowly $U$-shaped laminae in profile. Autozooecial boundaries broadly serrated, commonly not visible. Styles exceedingly small, sparse to absent, having indistinct cores and sheaths, occurring locally in corners of autozooecia. Hemiphragms, perhaps basal diaphragms, common, planar, thin, commonly slightly curved proximally, at right angles or slightly oblique to chamber axis. Hemiphragms projecting irregularly and alternately from opposite sides of autozooecial walls, occasionally merg- ing, forming irregularly curved partitions (basal diaphragms) locally. Hemiphragms evenly spaced or scattered locally; locally more closely spaced, in indistinct zones. Autozooecial linings generally absent.

Autozooecial chambers polygonal to subpolygonal in cross section, locally sinuous in profile.

Mesozooecia sparse to absent, polygonal in cross section, with scattered hemiphragms or diaphragms. Mesozooecial walls similar in thickness to those of autozooecia. Mesozooecia common in maculae, sparse in intermacular areas, commonly terminating within exozones.

Maculae common to sparse, consisting of clusters of mesozooecia in macular centers and polymorphs slightly larger than autozooecia along macular margins; occurrence irregular throughout exozones.

Measurements.-Measurements are summarized in tables 57 and 58.

Geographic and stratigraphic distribution.-B. arcuatilis $\mathrm{n}$. sp. is known only from Kentucky, where it occurs in the Grier Limestone Member, Shermanian Stage (USGS colln. D1303-CO), and the Brannon Member, Shermanian Stage (USGS colln. D1156-CO), of the Lexington Limestone.

Studied material.-Holotype USNM 309300 (USGS colln. D1156-CO) and paratype USNM 309301 (USGS colln. D1303-CO).

Remarks. - B. arcuatilis $\mathbf{n}$. sp. is characterized by subglobular zoaria in which autozooecia are generally erect distally, have thin walls that consist of narrowly U-shaped laminae, and have numerous hemiphragms throughout zoaria.

Specimens included in $B$. arcuatilis $\mathbf{n}$. sp. are similar to those of B. tenuimurale, the type species of Balticopora, in having autozooecia with polygonal shapes in cross section, small styles, and numerous hemiphragms in exozones.

However, B. arcuatilis n. sp. differs from B. tenuimurale in having subglobular zoaria in which endozones and exozones are indistinctly delineated, autozooecial walls with $U$-shaped configurations of wall laminae, broadly serrated autozooecial boundaries (pl. 36 , fig. $1 \mathrm{~b}$ ), and no autozooecial linings. Wall laminae in autozooecia of $B$. tenuimurale are generally $V$-shaped in profile and autozooecia are delineated by well-defined, narrowly serrated boundaries (pl. 34, figs. $1 c, d)$.

\section{Genus BATOSTOMA Ulrich, 1882}

Type species.-Monticulipora (Heterotrypa) implicatum Nicholson, 1881, p. 147, by monotypy; "Cincinnati Group, Ohio" of Nicholson, 1881.

Remarks.-Boardman (1960b, p. 5) emended the defi- 
TABLE 57.-Summarized measurements of a specimen of Balticopora arcuatilis $n$. $s p$.

[Holotype USNM 309300 (USGS colln. D1156-CO). All measurements in millimeters unless otherwise indicated]

\begin{tabular}{|c|c|c|c|c|c|c|c|}
\hline & $\begin{array}{c}\text { Arithmetic } \\
\text { mean }\end{array}$ & $\begin{array}{c}\text { Standard } \\
\text { deviation } \\
\text { of mean }\end{array}$ & $\begin{array}{c}\text { Coefficient } \\
\text { of } \\
\text { variation }\end{array}$ & $\begin{array}{l}\text { 95-percent } \\
\text { confidence } \\
\text { interval } \\
\text { of mean } \\
\end{array}$ & Range & $\begin{array}{c}\begin{array}{c}\text { Number } \\
\text { of } \\
\text { measurements }\end{array} \\
\end{array}$ & $\begin{array}{c}\text { Number } \\
\text { of } \\
\text { zoaria } \\
\text { measured } \\
\end{array}$ \\
\hline Autozooecial chamber maximum diameter _-___- & 0.2720 & 0.0286 & 10.51 & $0.25-0.29$ & $0.21-0.30$ & 10 & 1 \\
\hline Autozooecial chamber minimum diameter & .220 & .0279 & 12.68 & $.20-\quad .24$ & $.16-\quad .25$ & 10 & 1 \\
\hline Macular polymorph chamber maximum diameter & .3957 & .0305 & 7.70 & $.37-$ & .16 & 7 & 1 \\
\hline Macular polymorph chamber minimum diameter & 3171 & .0403 & 12.71 & $.28-\quad .35$ & $.25-$ & 7 & 1 \\
\hline Mesozooecial chamber maximum diameter - & .1230 & .0275 & 22.36 & $.10-.14$ & $.08-\quad .16$ & 10 & 1 \\
\hline Autozooecia (number per $2 \mathrm{~mm}$ ) & 6.50 & .5345 & 8.22 & $6.05-6.95$ & $6-7^{.00}$ & 8 & 1 \\
\hline Autozooecia (number per $\mathrm{mm}^{2}$ ) & 11.38 & 2.0659 & 18.16 & $9.65-13.10$ & -14 & 8 & 1 \\
\hline Mesozooecia (number per $\mathrm{mm}^{2}$ ) & 3.00 & 2.1602 & 72.0 & $(-.45-6.44)$ & -6 & 4 & 1 \\
\hline Diaphragms (number per $\mathrm{mm}$ ) & 6.625 & .5176 & 7.81 & $6.19-7.05$ & -7 & 8 & $\overline{1}$ \\
\hline
\end{tabular}

TABLE 58.-Summarized measurements of a specimen of Balticopora arcuatilis $n$. $s p$. [Paratype USNM 309301 (USGS colln. D1303-CO). All measurements in millimeters unless otherwise indicated]

\begin{tabular}{|c|c|c|c|c|c|c|c|}
\hline & $\begin{array}{c}\text { Arithmetic } \\
\text { mean }\end{array}$ & $\begin{array}{c}\text { Standard } \\
\text { deviation } \\
\text { of mean }\end{array}$ & $\begin{array}{c}\text { Coefficient } \\
\text { of } \\
\text { variation }\end{array}$ & $\begin{array}{c}\text { 95-percent } \\
\text { confidence } \\
\text { interval } \\
\text { of mean }\end{array}$ & Range & $\begin{array}{c}\begin{array}{c}\text { Number } \\
\text { of } \\
\text { measurements }\end{array} \\
\end{array}$ & $\begin{array}{c}\text { Number } \\
\text { of } \\
\text { zoaria } \\
\text { measured } \\
\end{array}$ \\
\hline Autozooecial chamber maximum diameter ___ & 0.2760 & 0.0275 & 9.99 & $0.26-0.30$ & $0.23-0.33$ & 10 & 1 \\
\hline Autozooecial chamber minimum diameter & .2230 & .0148 & 6.36 & $.21-.23$ & $.20-\quad .24$ & 10 & 1 \\
\hline Macular polymorph chamber maximum diameter & .40 & .4321 & 10.80 & $.33-$ & $.34-$ & 4 & $\overline{1}$ \\
\hline Macular polymorph chamber minimum diameter & .32 & .01 & 3.17 & $.30-$ & .30 & 4 & $\overline{1}$ \\
\hline Mesozooecial chamber maximum diameter & .105 & .0258 & 21.51 & $.08-.13$ & $.08-\quad .14$ & 6 & 1 \\
\hline Autozooecia (number per $2 \mathrm{~mm}$ ) & 6.4286 & .5345 & 8.31 & $5.93-6.92$ & $6-7$ & 7 & $\overline{1}$ \\
\hline Autozooecia (number per $\mathrm{mm}^{2}$ ) & 11.333 & 1.5275 & 13.48 & $7.54-15.13$ & $10-13$ & 3 & 1 \\
\hline Diaphragms (number per $\mathrm{mm}$ ) - & 4.80 & 1.7889 & 37.27 & $2.58-7.02$ & $3.0-7.0$ & 5 & 1 \\
\hline
\end{tabular}

nition for the genus Batostoma; his emendation is followed here.

\author{
Batostoma cf. B. jamesi (Nicholson, 1874) \\ Plate 22, figure 4
}

Description.-Zoarium of the single specimen available irregularly dendroid, with subcylindrical branches variable in size; conspecific overgrowths common locally, consisting of one or more layers of zooecia.

In endozones, autozooecia gradually curving outward, locally irregular in growth direction. Basal diaphragms sparse to absent, occurring mostly in late endozones. Zones of rejuvenation of autozooecia sparse to absent.

In exozones, autozooecia almost at right angles to zoarial surface, subpolygonal to subcircular, occasionally elongated, locally slightly petaloid in cross section, in diameter approximately $0.28-0.34 \mathrm{~mm}$ long by $0.20-0.24 \mathrm{~mm}$ wide on the average. Autozooecia partly continguous or almost completely separated by mesozooecia. Autozooecial walls approximately $0.11-0.16 \mathrm{~mm}$ thick, consisting of poorly defined, indistinct laminae. Autozooecial boundaries exceedingly narrow, well defined.

Styles common, approximately four to six per autozooecium, $0.02-0.04 \mathrm{~mm}$ in diameter. Style cores distinct, slightly notched or spinose locally, with exceedingly thin sheaths. Styles generally occurring on autozooecial boundaries or slightly outside them, occasionally slightly inflecting autozooecial walls. Basal diaphragms sparse to absent, thin, commonly concave distally, absent in some autozooecia. Single basal diaphragms commonly proximal to base of overgrowths. Autozooecial linings absent.

Autozooecial chambers subelliptical to subcircular, occasionally slightly petaloid in cross section.

Mesozooecia abundant, irregularly polygonal in cross section, locally having moniloid proximal parts, variable in size. Mesozooecial diaphragms common, irregularly spaced, slightly curved, much thicker distally than proximally, occasionally filling mesozooecia in outer exozones, locally forming cystose structures in inner exozones.

Maculae common, scattered, indistinct in cross section, consisting of polymorphs slightly larger than autozooecia and mesozooecia in various combinations. Mesozooecia in maculae commonly filled by thickened diaphragms.

Geographic and stratigraphic distribution.-The single specimen of $B$. cf. $B$. jamesi, hypotype USNM 309302, occurs in the upper part of the Clays Ferry Formation, Edenian Stage (USGS colln. D1188-CO), in central Kentucky.

Remarks.-The specimen described is similar to $B$. jamesi (Nicholson), as illustrated by Anstey and Perry (1973, p. 22, pl. 6, figs. 4-6; pl. 7; pl. 8, figs. 1-3), in cross-sectional shape of autozooecia and mesozooecia, abundance and distribution of mesozooecia, general appearance and size of styles, and presence of conspecific overgrowth. B. jamesi, however, possesses autozooecia 
with distinct linings (the cingula of Anstey and Perry) and relatively numerous basal diaphragms in exozones, characters that appear to be lacking or are not preserved in the available specimen of Batostoma.

Because of these differences, poor preservation, and lack of additional material, the single specimen of Batostoma is herein assigned to $B$. cf. B. jamesi until additional adequately preserved material can be found for further consideration.

Anstey and Perry (1973, p. 22, fig. 8) established that B. jamesi ranged through the upper $25 \mathrm{~m}$ of their Eden Shale (Kope Formation of current usage) in Kentucky and Indiana and occurred in the middle part of their Eden Shale in their area of investigation in Ohio, and made $B$. jamesi a zonal index species.

The occurrence of $B$. cf. B. jamesi in the Clays Ferry Formation may indicate, subject to finding of additional material, that the $B$. jamesi assemblage of Anstey and Perry may have extended into the lower part of the Upper Ordovician strata in central Kentucky.

\section{Order CYSTOPORATA Family CERAMOPORIDAE Genus ACANTHOCERAMOPORELLA Utgaard, 1968}

Type species.-Ceramoporella granulosa Ulrich, 1890 , p. 466; designated by Utgaard, 1968 b, p. 1451; Richmondian Stage, Late Ordovician, Illinois.

Remarks.-Utgaard (1968b, p. 1451) established the genus Acanthoceramoporella and his definition of it is followed here.

\section{Acanthoceramoporella valliensis n. sp. Plate 37, figure 3}

Etymology.-The trivial name valliensis is derived from the first word of the quadrangle, Valley View, in which the specimen occurred.

Description.-Zoaria subglobular to irregularly shaped, consisting of one or more superimposed layers of autozooecia. Basal zoarial layers and superimposed autozooecial layers exceedingly thin, imperforate.
Endozones narrow; autozooecia in endozones contiguous, recumbent for short distances, becoming erect at base of exozones.

In exozones, autozooecia slightly oblique to basal layers, indistinctly aligned in general growth direction, locally in indistinct radial pattern near maculae, elliptical to subelliptical in cross section, partly contiguous, separated by mesozooecia. Autozooecial walls thin, relatively straight; autozooecial boundaries narrowly serrated, commonly obscured; wall laminae exceedingly thin, indistinct. Communication pores few, generally absent in many zooecia. Styles few to common, having distinct cores, thin sheaths; generally sparse in intermacular regions, common in maculae.

Basal diaphragms sparse, lacking entirely in most autozooecia. Lunaria indistinct, thin, locally thicker in outer exozones, without cores. Autozooecial linings absent.

Autozooecial chambers subelliptical to elliptical in cross section.

Mesozooecia abundant, subcircular to subelliptical in cross section; walls similar in thickness to those of autozooecia, generally without diaphragms, occasionally having communication pores, commonly having styles in maculae, partly to almost completely separating autozooecia locally.

Maculae common, low, indistinct in cross section, consisting of clusters of irregularly shaped mesozooecia in their centers and occasional polymorphs, slightly larger than autozooecia, along margins of maculae.

Measurements.-Measurements are summarized in table 59.

Geographic and stratigraphic distribution.-A. valliensis is known only from Kentucky, where it occurs in the Sulphur Wells Member, Shermanian Stage (USGS colln. 4890-CO), and Millersburg Member, Shermanian Stage (USGS colln. 5030-CO), of the Lexington Limestone.

Studied material.-Holotype USNM 309357 (USGS colln. 4890-CO) and paratype USNM 309358 (USGS colln. 5030-CO).

TABLE 59.-Summarized measurements of a specimen of Acanthoceramoporella valliensis n. sp. [Holotype USNM 309357 (USGS colln. 4890-CO). All measurements in millimeters unless otherwise indicated]

\begin{tabular}{|c|c|c|c|c|c|c|c|}
\hline & $\begin{array}{c}\text { Arithmetic } \\
\text { mean }\end{array}$ & $\begin{array}{c}\text { Standard } \\
\text { deviation } \\
\text { of mean }\end{array}$ & $\begin{array}{c}\text { Coefficient } \\
\text { of } \\
\text { variation }\end{array}$ & $\begin{array}{c}95 \text {-percent } \\
\text { confidence } \\
\text { interval } \\
\text { of mean } \\
\end{array}$ & Range & $\begin{array}{c}\begin{array}{c}\text { Number } \\
\text { of } \\
\text { measurements }\end{array} \\
\end{array}$ & $\begin{array}{c}\text { Number } \\
\text { of } \\
\text { zoaria } \\
\text { measured }\end{array}$ \\
\hline Autozooecial chamber maximum diameter ______-_-_ & 0.230 & 0.0160 & 9.39 & $0.21-0.25$ & $0.20-0.26$ & 7 & 1 \\
\hline Autozooecial chamber minimum diameter & .1286 & .009 & 7.0 & $.12-.14$ & $.12-.14$ & 7 & 1 \\
\hline Autozooecial wall thickness, exozone & .0288 & .0083 & 29.02 & $.02-.04$ & $.02-.04$ & 8 & 1 \\
\hline Exilazooecial chamber maximum diameter & .0918 & .0289 & 31.5 & $.07-.11$ & $.04-.14$ & 11 & 1 \\
\hline Lunarial width & .1467 & .0231 & 15.75 & $.09-.20$ & $.12-.16$ & 3 & 1 \\
\hline Lunarial radius _-__________________ & .1267 & .0058 & 4.56 & $.11-.14$ & $.12-.13$ & 3 & 1 \\
\hline Endozone width ___ & .0920 & .0084 & 9.09 & $.08-.10$ & $.08-.10$ & 5 & 1 \\
\hline Exozone width (one side only) & 1.050 & .2345 & 22.34 & $.80-1.30$ & $.60-.20$ & 6 & 1 \\
\hline Thickness of single layer & 1.5333 & .326 & 21.3 & $1.20-1.88$ & $1.20-2.00$ & 6 & 1 \\
\hline
\end{tabular}


Remarks.-A. valliensis $\mathrm{n}$. sp. is assigned to Acanthoceramoporella Utgaard, 1968b, on the basis of similarities in shape of autozooecia in cross section, polymorphism, presence of styles (acanthopores of Utgaard), and skeletal structure of zooecial walls. Zooecial walls in both are thinly laminated and autozooecia have relatively distinct lunaria. The zooecial walls of $A$. valliensis, however, lack the beadlike swellings and cores in lunaria that occur typically in $A$. granulosa (Ulrich), which is the type species of Acanthoceramoporella (Utgaard, 1968b, p. 1451, pl., 183, fig. 1a).

Utgaard (1968b, p. 1451) erected Acanthoceramoporella as a result of his revision of North American ceramoporoid bryozoans and assigned to it $A$. granulosa (Ulrich, 1890, previously regarded as Ceramoporella from the Upper Ordovician deposits in Illinois), $A$. triloba (Cumings and Galloway, 1913, previously regarded as Ceramoporella from the Eden Formation of Utgaard, Upper Ordovician, in Indiana), and $A$. crassimurale (Bassler, 1911, previously regarded as Coeloclema from the Middle Ordovician of Estonia, U.S.S.R.). These species, however, have not been redescribed. Therefore, comparative morphologies of $A$. valliensis n. sp. and the other three species of Acanthoceramoporella may need to be reevaluated when additional material becomes available.

A. valliensis appears to be the earliest among species of Acanthoceramoporella occurring in North American Middle Ordovician deposits and is more closely related to A. triloba than to A. granulosa or A. crassimurale.

A. valliensis is characterized by zoaria consisting of superimposed layers of autozooecia with uniformly thin walls that generally lack communication pores and basal diaphragms. Styles occur mostly in polymorphs of maculae; the calcitic spherical bodies present in A. granulosa apparently are not present in autozooecial walls of $A$. valliensis.

A. valliensis is similar to $A$. triloba in having encrusting zoaria that consist of superimposed layers of autozooecia whose thin walls generally have neither communication pores nor calcitic spherical bodies (mural pores and granules, respectively, of Cumings and Galloway, 1913, p. 74, pl. 6, figs. 1, 1b). A. triloba, however, has prominent lunaria with cores, larger autozooecia and mesozooecia with irregular shapes in cross section, a few basal diaphragms, and numerous styles.

A. granulosa (Utgaard, 1968b, pl. 183, fig. 1) differs from $A$. valliensis in having autozooecia with abundant basal diaphragms, relatively thick autozooecial walls with distinct communication pores, calcitic spherical bodies, beadlike swellings, and abundant styles throughout exozones.

A. crassimurale (Bassler, 1911, p. 84, text fig. 24, pl. 7, fig. 12) differs from $A$. valliensis in having erect hollow dendroid zoaria in which autozooecia and mesozooecia have thick and distinctly laminated walls with abundant communication pores and numerous styles. Mesozooecia of $A$. crassimurale appear to have abundant diaphragms locally. Mesozooecial diaphragms are generally lacking in $A$. valliensis.

\section{Genus CERAMOPHYLLA Ulrich, 1893}

Type species.-Ceramophylla frondosa Ulrich, 1893, p. 331, by original designation; "upper third of Trenton Shales" of Ulrich, 1893; (the upper part of the Decorah Shale of current usage), Middle Ordovician.

Remarks.-Utgaard $(1968 \mathrm{~b}$, p. $1452 ; 1983 \mathrm{~b})$ redescribed the genus Ceramophylla and emended its definition. That emended definition is followed herein.

$$
\begin{gathered}
\text { Ceramophylla alternatum (James, 1878) } \\
\text { Plate } 37 \text {, figures 1, 2; plate } 38 \text {, figures } 2,3
\end{gathered}
$$

Ceramopora alternata James, 1878 , p. 5.

Monticulipora (Fistulipora) alternata James, U. P., 1888, p. 34, pl. 1, figs. $5,5 \mathrm{a}, 5 \mathrm{~b}$.

Diamesopora vaupeli Ulrich, 1890 , p. 468, pl. 39, figs. 3, 3b; pl. 41, figs. 4, 4c. Nickles and Bassler, 1900, p. 24, 212; Bassler, 1953, p. G82.

Diamesopora trentonensis Ulrich, 1893, p. 330, pl. 28, fig. 14.

Coeloclema alternatum (James). Nickles and Bassler, 1900, p. 212; Bassler, 1906, p. 33; 1953, p. G82, text-fig. 46, 1; Ross, 1969, p. 278, pl. 46, figs. 2, 4, 7-9; pl. 47, figs. 1-8; pl. 48, figs. 1-13, 15. Coeloclema vaupeli (Ulrich). Elias, 1954, p. 54.

Ceramophylla vaupeli (Ulrich). Utgaard, 1968b, p. 1453, pl. 183, fig. 4 ; pl. 184, figs. 34; 1973, figs. 34-36.

Description.-Zoaria dendroid; branches subcylindrical with hollow axial portions, occasionally with conspecific overgrowth.

Basal layers moderately thick, imperforate, nonlaminated, indistinctly laminated locally, slightly sinuous.

In endozones, autozooecia contiguous, elongated and subrhombic in cross section with slightly curved walls, obscured autozooecial boundaries.

In exozones, autozooecia at angles slightly less than $90^{\circ}$ to zoarial surface, subelliptical in cross section, partly contiguous, separated by exilazooecia. Autozooecial walls conspicuously thickened at base of exozones, increasing gradually in thickness ontogenetically.

Autozooecial wall laminae distinct, relatively thick, abutting or locally intertonguing with lunarial deposits. Autozooecial boundaries generally broadly serrated, locally obscured, occasionally narrowly serrated. Stylelike structures with indistinct cores, exceedingly short, occurring locally in outer exozones of some zoaria, sparse to absent elsewhere. Communication pores very sparse, lacking in most zoaria.

Lunarial deposits thin in inner endozones, thickening conspicuously in late endozones, generally of uniform thickness in exozones, commonly distinct at 
zoarial surfaces, locally with poorly defined cores. Basal diaphragms absent.

Autozooecial chambers elliptical to subcircular in cross section. Exilazooecia common, subcircular to elliptical in cross section, commonly elongated at right angles to zoarial surface, subparallel to autozooecia. Occasionally indistinct mesozooecial chamber linings, chambers slightly enlarged at points of origin in early exozones, narrowing ontogenetically, locally terminating at zoarial surface.

Maculae common, slightly raised or on level with zoarial surface, generally consisting of indistinctly elongated clusters of mesozooecia; mesozooecia sub- elliptical to irregularly shaped in cross section, occasionally filled with zooecial skeletal material.

Measurements.-Measurements are summarized in tables 60-62.

Geographic and stratigraphic distribution.-C. alternatum (James) is widely distributed in eastern North America, where it ranges from rocks of the Blackriveran Stage, Middle Ordovician, into rocks of the Edenian Stage, Upper Ordovician.

Occurrence in Kentucky.-Grier Limestone Member, Shermanian Stage (USGS colln. 4694-CO); Brannon Member, Shermanian Stage (USGS collns. D1157-CO, D1159-CO); Cornishville Bed, Shermanian Stage

TABLE 60.-Summarized measurements of specimens of Ceramophylla alternatum (James)

[Lectotype USNM 159720 and paralectotypes of Diamesopora vaupeli Ulrich, USNM 159718, 159719, 312606. All measurements in millimeters unless otherwise indicated]

\begin{tabular}{|c|c|c|c|c|c|c|c|}
\hline & $\begin{array}{l}\text { Arithmetic } \\
\text { mean }\end{array}$ & $\begin{array}{l}\text { Standard } \\
\text { deviation } \\
\text { of mean }\end{array}$ & $\begin{array}{c}\text { Coefficient } \\
\text { of } \\
\text { variation }\end{array}$ & $\begin{array}{l}\text { 95-percent } \\
\text { confidence } \\
\text { interval } \\
\text { of mean }\end{array}$ & Range & $\begin{array}{c}\begin{array}{c}\text { Number } \\
\text { of } \\
\text { measurements }\end{array}\end{array}$ & $\begin{array}{c}\text { Number } \\
\text { of } \\
\text { zoaria } \\
\text { measured }\end{array}$ \\
\hline Autozooecial chamber maximum diameter - & 0.2133 & 0.0266 & 12.49 & $0.19-0.23$ & $0.17-0.27$ & 15 & 3 \\
\hline Autozooecial chamber minimum diameter _-___._. & .1287 & .0177 & 13.74 & $.12-\quad .14$ & $.11-\quad .16$ & 15 & 3 \\
\hline Autozooecial wall thickness, exozone & .0940 & .0351 & 33.35 & $.08-$ & $.04-$ & 15 & 3 \\
\hline Exilazooecial chamber maximum diameter & .0667 & .0277 & 41.53 & $.05-\quad .08$ & $.02-\quad .11$ & 15 & 3 \\
\hline Autozooecia (number per $\mathrm{mm}^{2}$ ) & 10.167 & .9839 & 9.67 & $9.13-11.20$ & $9.0-12.0$ & 6 & 3 \\
\hline Lunarial width-_- & .1139 & .009 & 7.64 & $.11-.12$ & $.10-.13$ & 13 & 3 \\
\hline Lunarial radius _-___________ & .0654 & .0145 & 22.18 & $.06-$ & $.04-$ & 13 & 3 \\
\hline Zoarial branch diameter _-_______ & 3.4250 & .5702 & 16.65 & $3.02-3.83$ & $2.60-4.60$ & 10 & 4 \\
\hline Endozone width ___ & .1500 & .0236 & 15.71 & $.13-\quad .17$ & $.10-\quad .20$ & 10 & 4 \\
\hline Exozone width (one side only) _-__ & .50 & .0782 & 15.63 & $.44-\quad .56$ & $.40-\quad .60$ & 10 & 4 \\
\hline Axial hollow diameter - & 2.1150 & .6192 & 29.27 & $1.67-2.56$ & $1.30-3.50$ & 10 & 4 \\
\hline
\end{tabular}

TABLE 61.-Summarized measurements of specimens of Ceramophylla alternatum (James)

[Hypotypos USNM 309361-309363 (USGS colln. 4694-CO), 309364-309366 (USGS colln. 5016-CO). All measurements in millimeters unless otherwise indicated]

\begin{tabular}{|c|c|c|c|c|c|c|c|}
\hline & $\begin{array}{l}\text { Arithmetic } \\
\text { mean }\end{array}$ & $\begin{array}{c}\text { Standard } \\
\text { deviation } \\
\text { of mean }\end{array}$ & $\begin{array}{c}\text { Coefficient } \\
\text { of } \\
\text { variation }\end{array}$ & $\begin{array}{c}\text { 95-percent } \\
\text { confidence } \\
\text { interval } \\
\text { of mean }\end{array}$ & Range & $\begin{array}{c}\begin{array}{c}\text { Number } \\
\text { of } \\
\text { measurements }\end{array}\end{array}$ & $\begin{array}{c}\text { Number } \\
\text { of } \\
\text { zoaria } \\
\text { measured }\end{array}$ \\
\hline Autozooecial chamber maximum diameter _-_ & 0.2252 & 0.0212 & 9.43 & $0.22-0.23$ & $0.19-0.26$ & 25 & 5 \\
\hline Autozooecial chamber minimum diameter & .1420 & .0293 & 20.63 & $.13-.15$ & $.10-\quad .22$ & 25 & 5 \\
\hline Autozooecial wall thickness, exozone & .070 & .0260 & 37.12 & .05 & $.04-$ & 25 & 5 \\
\hline Exilazooecial chamber maximum diameter & .080 & .0263 & 29.86 & $.08-\quad .10$ & $.04-\quad .14$ & 20 & 4 \\
\hline Autozooecia (number per $\mathrm{mm}^{2}$ ) & 11.75 & 2.3146 & 19.70 & $9.81-13.69$ & $9^{\cdot 0 x}-16^{\cdot 1 x}$ & 8 & 4 \\
\hline Lunarial width-..._. & .1308 & .0202 & 15.44 & $.12-.14$ & $.10-.16$ & 13 & 3 \\
\hline Lunarial radius ______________ & .0969 & .035 & 34.58 & $.08-\quad .12$ & $.06-.15$ & 13 & 3 \\
\hline Zoarial branch diameter & 2.7778 & .2949 & 10.62 & $2.55-3.00$ & $2.30-3.20$ & 9 & 3 \\
\hline Endozone width & .30 & .10 & 33.33 & $.21-.39$ & $.20-\quad .40$ & 7 & 3 \\
\hline Exozone width (one side only) & .9257 & .2843 & 30.71 & $.76-1.09$ & $.50-1.50$ & 14 & 4 \\
\hline Axial hollow diameter & .7167 & .1683 & 23.49 & $.61-\quad .82$ & $.45-1.00$ & 12 & 3 \\
\hline
\end{tabular}

TABLE 62.-Summarized measurements of specimens of Ceramophylla alternatum (James)

[Hypotypos USNM 309368-309370 (USGS colln. 5057-CO), 309373 (USGS colln. 7476-CO), 309375-309377 (USGS colln. 7477-CO), 309371 (USGS colln. 7466-CO). All measurements in millimeters unless otherwise indicated]

\begin{tabular}{|c|c|c|c|c|c|c|c|}
\hline & $\begin{array}{c}\text { Arithmetic } \\
\text { mean }\end{array}$ & $\begin{array}{c}\text { Standard } \\
\text { deviation } \\
\text { of mean }\end{array}$ & $\begin{array}{c}\text { Coefficient } \\
\text { of } \\
\text { variation }\end{array}$ & $\begin{array}{c}\text { 95-percent } \\
\text { confidence } \\
\text { interval } \\
\text { of mean } \\
\end{array}$ & Range & $\begin{array}{c}\begin{array}{c}\text { Number } \\
\text { of } \\
\text { measurements }\end{array} \\
\end{array}$ & $\begin{array}{c}\text { Number } \\
\text { of } \\
\text { zoaria } \\
\text { measured }\end{array}$ \\
\hline Autozooecial chamber maximum diameter _-_.__. & 0.2210 & 0.0210 & 9.50 & $0.21-0.23$ & $19.00-0.26$ & 20 & 4 \\
\hline Autozooecial chamber minimum diameter _- & .1610 & .0269 & 16.73 & $.15-.17$ & $.12-\quad .20$ & 20 & 4 \\
\hline Autozooecial wall thickness, exozone - & .080 & .0297 & 33.71 & $.07-$ & $.04-$ & 20 & 4 \\
\hline Exilazooecial chamber maximum diameter-- & .0750 & .2351 & 31.34 & $.06-\quad .09$ & $.03-\quad .12$ & 20 & 4 \\
\hline Autozooecia (number per $\mathrm{mm}^{2}$ ) - & 10.0 & .7071 & 7.07 & $9.12-10.88$ & $9.0-11.0$ & 5 & 4 \\
\hline Lunarial width-____ & .1425 & .0117 & 8.18 & $.13-\quad .15$ & $.12-.16$ & 8 & 2 \\
\hline Lunarial radius _-________ & .0713 & .0083 & 11.71 & $.06-\quad .08$ & $.06-.08$ & 8 & $\overrightarrow{2}$ \\
\hline Zoarial branch diameter _-_____ & 3.3778 & 1.3526 & 40.00 & $2.34-4.42$ & $1.70-5.10$ & 9 & $\overline{6}$ \\
\hline Endozone width & .1833 & .0537 & 29.27 & $.15-\quad .22$ & $.10-\quad .30$ & 12 & 5 \\
\hline Exozone width (one side only) & .6083 & .0734 & 12.06 & $.56-\quad .65$ & $.50-\quad .70$ & 12 & 5 \\
\hline Axial hollow diameter & 2.353 & .9492 & 40.33 & $1.78-2.93$ & $.30-3.50$ & $\overline{13}$ & 2 \\
\hline
\end{tabular}


(USGS colln. 5016-CO), of the Perryville and Tanglewood limestone members, Shermanian Stage (USGS colln. 7466-CO), of the Lexington Limestone. Clays Ferry Formation, Edenian Stage (USGS collns. 5054-CO, 5057-CO, 7474-CO, 7476-CO, 7477-CO).

Occurrence outside Kentucky.-James $(1878$, p. 5) and Ulrich $(1888$, p. $34 ; 1890$, p. 468) reportedly found $C$. alternatum (James) in their "Cincinnati Group" near Cincinnati. Bassler (1906, p. 33) and Cumings and Galloway $(1913$, p. 49) reported C. alternatum from their "Southgate" and "McMicken" members of their Eden Formation in Ohio and Indiana, respectively. Ulrich (1893, p. 331) reported this species (as Diamesopora trentonensis Ulrich) from his "upper third of the Trenton Shales" and "Galena Shale" in Minnesota and noted its presence in the Ordovician deposits of New York and Ontario. Ulrich's "upper third of the Trenton Shales" in Minnesota is the approximate stratigraphic equivalent of the Stictopora minima zone of the Decorah Shale of Karklins (1969, fig. 10).

Ross (1969, p. 280) established that $C$. alternatum James (as Coeloclema alternatum) occurred in her "Chaumont," "Rockland," "Shoreham," and "Denmark" formations, Middle Ordovician, and the "Rust Member of the Cobourg Formation," Edenian Stage, Upper Ordovician, in New York State.

Studied material.-Lectotype USNM 159720 and paralectotypes USNM 159718, 159719, 245041-245046, and 312606 of Diamesopora vaupeli Ulrich from the USNM syntype suite 43292, from the "Eden Group" ("Utica Group") (the Kope Formation of current usage), Upper Ordovician, Cincinnati. Syntype USNM 43294 of $D$. trentonensis Ulrich, from the syntype suite USNM 43294, "Galena Shales," Middle Ordovician, near Cannon Falls, Minn.

Hypotypes USNM 309359 (USGS colln. D1157-CO), 309360 (USGS colln. D1159-CO), 309361-390363 (USGS colln. 4694-CO), 309364-309366 (USGS colln. 5016-CO), 309367 (USGS colln. 5054-CO), 309368309370 (USGS colln. 5057-CO), 309371 (USGS colln. 7466-CO), 309372 (USGS colln. 7474-CO), 309373, 309374 (USGS colln. 7476-CO), 309375-309377 (USGS colln. 7477-CO).

Remarks.-Ceramopora alternata James, 1878, herein is regarded as a species of Ceramophylla Ulrich, 1893. This assignment on the generic level is considered to be valid morphologically and is in accordance with the taxonomic interpretations proposed by Utgaard (1968b, p. 1453) in his revision of North American ceramoporoid genera.

Ceramophylla alternatum (James) and C. frondosa Ulrich, 1893, the type species of the genus Ceramophylla (Utgaard 1968b, p. 1452), are similar in structure of basal and median layers of zoaria, configuration of zooecial wall laminae, cross sectional shapes of zooecia in exozones, and polymorphism.

C. frondosa differs from C. alternatum in having bifoliate zoarial growth habit, autozooecia with elongated and relatively narrow recumbent endozonal portions, and narrowly serrated autozooecial boundaries in exozones (Utgaard, 1968b, pl. 184, figs. 1a, 2).

C. alternatum (James) characteristically possesses hollow dendroid zoaria. Autozooecia have broadly serrated boundaries in exozones (pl. 37, fig. 1b; Ross, 1969, pl. 47 , figs. 7,8 ) and relatively short recumbent portions of autozooecia in endozones (pl. 37, fig. 1b).

Autozooecia of specimens of $C$. alternatum from Ordovician deposits in Kentucky appear to have slightly larger diameters than those from the Middle Ordovician deposits in New York (tables 60-62; Ross, 1969, table 12). Autozooecial boundaries in some specimens from New York Ordovician deposits appear to be narrowly serrated (Ross, 1969, pl. 46, figs. 2, 7). In other measured characters (tables 60-62) and zoarial appearance specimens occurring in Kentucky are in general agreement with those from New York (Ross, 1969, table 12).

The taxonomic status of C. alternatum (James) is somewhat confused because its subjective junior synonym Diamesopora vaupeli Ulrich, 1890 , is widely but erroneously regarded as the type species of the genus Coeloclema Ulrich, 1882 (Utgaard, 1968b, p. 1453).

Nickles and Bassler (1900, p. 24, 211) designated Diamesopora vaupeli Ulrich, 1890 (Ceramopora alternata James, 1878) as the type species of Coeloclema Ulrich, and regarded Ceramopora alternata James as the senior synonym of $D$. vaupeli Ulrich (Nickles and Bassler, 1900, p. 212; Bassler, 1906, p. 33).

Utgaard (1968b, p. 1454, pl. 183, fig. 4; pl. 184, figs. 3, 4) illustrated the primary type specimens of $D$. vaupeli Ulrich, designated the lectotype for $D$. vaupeli, and regarded this species as being consistent with the emended definition of the genus Ceramophylla Ulrich.

Utgaard (1968b, p. 1453) and Ross (1969, p. 277) reviewed in detail the taxonomic status of Coeloclema Ulrich, 1882. Both agree that Ulrich is the author (see the discussion that follows) of the genus Coeloclema but differ in opinion on the correct designation of the type species.

When Ulrich proposed Coeloclema in 1882, it was an indication because Ulrich did not define it, nor did he assign any species to it. In subsequent works Ulrich $(1890,1893)$ indicated in the synonym of the genus Diamesopora Hall, 1852, that Coeloclema was a junior synonym of Diamesopora, but did not discuss this assignment (Ross, 1969, p. 277).

Nickles and Bassler (1900, p. 24, 211), however, considered Coeloclema as a distinct genus. They based its 
concept on the species which Ulrich $(1890,1893)$ had included in Diamesopora Hall and therefore designated $D$. vaupeli Ulrich as the type species of $C$. Ulrich. Bassler (1953, p. g 82) described Coeloclema Ulrich, 1882, and cited D. vaupeli Ulrich, 1890 (Ceramopora alternata James, 1878) as its type species.

Later Elias (1954, p. 53) assigned the authorship of Coeloclema to Nickles and Bassler, 1900, because he considered Coeloclema to be nomen nudum in 1882 and until Nickles and Bassler made it available with the designation of the type species in 1900 (Utgaard, 1968b, p. 1453).

According to Utgaard (1968b, p. 1453) Nickles and Bassler $(1900$, p. 24,211$)$ erred in designating $D$. vaupeli Ulrich 1890 (Ceramopora alternata James 1878) as the type species of Coeloclema because this species was not one of the species originally included by Ulrich in Coeloclema.

Ross (1969, p. 278) reevaluated the primary types of Ceramopora alternata James and Diamesopora vaupeli Ulrich, designated the lectotype for Ceramopora alternata James (Ross, 1969, pl. 47, fig. 1; pl. 48, figs. 11, 15 ), and concurred with Nickles and Bassler (1900) and Bassler (1906) that $D$. vaupeli is the subjective junior synonym of Ceramopora alternata James and is the type species of Coeloclema Ulrich.

Utgaard (1968b, p. 1454) established further that Ulrich did not describe Coeloclema nor assign any species to it in 1882 and that therefore it was nomen nudum, as noted by Elias (1954). However, the name became available in 1883 when Ulrich assigned the available species Trematopora osculum, $T$. infrequens, and T. subimbricata to Coeloclema. Consequently, Coeloclema Ulrich, 1883, must have as its type species one of these species. Therefore the designation of Diamesopora vaupeli Ulrich (Ceramopora alternata James) as the type species of Coeloclema by Nickles and Bassler in 1900 is erroneous and does not constitute a new genus (Utgaard, 1968b, p. 1454).

Utgaard (1968b, p. 1454) designated Trematopora osculum Hall, 1876, as the type species of Coeloclema Ulrich, 1883, and, subsequently, considered (Utgaard, 1983b) Coeloclema Ulrich to be a subjective junior synonym of the fistuliporoid genus Diamesopora Hall, 1852 , from the Silurian period.

\section{Genus GERAMOPORELLA Ulrich, 1882}

Type species. $-C$. distincta Ulrich, 1890 , p. 380 ; by subsequent designation by Ulrich, 1890 , p. 380 : "Cincinnati Group" of Ulrich, 1890, Upper Ordovician, Cincinnati. Utgaard $(1968 \mathrm{~b}$, p. $1450 ; 1983 \mathrm{~b})$ emended the definition for the genus Ceremoporella; this definition is followed here.
Ceramoporella distincta Ulrich 1890

Plate 38, figures 1,4

Ceramoporella distincta Ulrich, 1890 , p. 464, pl. 39, figs. 6, 6a; Grabau and Shimer, 1909, p. 122; Cumings, 1908, p. 799, pl. 10, fig. 7, pl. 11, figs. 2, 2a; Bassler, 1953, p. G81, text-figs. 44, 2a, 2b (not 2c); Utgaard, 1968b, p. 1450, pl. 181, fig. 4, pl. 182, figs. 1-3; 1973, figs. 16, 23.

Not $C$. distincta Ulrich. Ulrich, 1893, p. 328, pl. 28, fig. 13; 1896, fig. 435; Simpson, 1897, p. 565, fig. 130; Bassler, 1913, fig. 462: 1953, text-figs. 44, 2c (Ceramoporella sp.).

Description.-Zoaria encrusting, explanate, consisting of several superimposed layers of autozooecia; individual layers of autozooecia relatively thin, approximately $0.5 \mathrm{~mm}$ thick on the average.

Basal layers of zoaria and of superimposed layers of autozooecia thin, indistinctly laminate, granular locally, imperforate.

Endozones narrow; endozonal autozooecia recumbent for moderately long distances, contiguous, subelliptical in cross section, generally elongated in approximate growth direction of zoaria. Autozooecial walls relatively straight; basal diaphragms sparse, generally absent.

In exozones, autozooecia between approximately $50^{\circ}$ and $80^{\circ}$ to zoarial surface on the average, subelliptical to subcircular in cross section, generally separated by exilazooecia throughout exozones, partly contiguous locally. Autozooecial walls thin, indistinctly laminated; wall laminae slightly irregular in microstructure locally. Autozooecial boundaries narrowly serrated, commonly obscured locally. Styles absent.

Lunarial deposits slightly thickened in outer endozones of autozooecia, generally of uniform thickness throughout exozones. Cores in lunaria indistinct, locally lacking. Lateral margins of lunaria commonly projecting into autozooecial chambers.

Basal diaphragms of autozooecia indistinctly laminated, planar to slightly curved, convex distally, locally curving proximally at junctions with autozooecial walls, sparse to absent in many autozooecia.

Autozooecial linings exceedingly thin, indistinct, occur locally, commonly lacking. Communication pores mostly absent.

Autozooecial chambers subelliptical to subcircular in cross section.

Exilazooecia abundant, subpolygonal to subcircular in cross section, irregularly variable in size, locally aligned in indistinct series, generally separating autozooecia throughout exozones.

Maculae common, occasionally lacking locally, generally on level with zoarial surface, locally slightly raised, consisting of exilazooecia, irregularly shaped in cross section, variable in size; mesozooecia occurring in circular or indistinctly elongated clusters. 
Measurements.-Measurements are summarized in tables 63 and 64 .

Geographic and stratigraphic distribution.-C. distincta is known from rocks of the Shermanian Stage, Middle Ordovician, in Kentucky and from rocks of Late Ordovician age in Indiana and Ohio.

Occurrence in Kentucky.-Brannon Member, Shermanian Stage (USGS colln. 4939-CO); Millersburg Member, Shermanian Stage (USGS colln. 7319-CO), of the Lexington Limestone.

Occurrence outside Kentucky.-Ulrich (1890, p. 465) described $C$. distincta from his "Cincinnati Group," Upper Ordovician, at Cincinnati. Cumings (1908, p. $799)$ and Cumings and Galloway (1913, p. 49) reported C. distincta as ranging from their "Eden Formation" into their "Waynesville Formation," Upper Ordovician, at Tanners Creek, Ind.

Studied material.-Lectotype USNM 159710 and paralectotypes USNM 159709, 159711, 159712, and 245033-245039 from the syntype suite USNM 43225, the "McMicken strata of the Eden Formation," Upper Ordovician, Cincinnati.

Hypotypes USNM 309378, 309379 (USGS colln. 4939-CO), 309380, 309381 (USGS colln. 7319-CO).

Remarks. C. distincta is characterized by zoaria that are commonly multilayered. Individual layers of zoaria are thin (tables 63,64 ) and consist of autozooecia having thin walls throughout zoaria, sparse basal diaphragms, and distinct lunaria near zoarial surfaces. Autozooecia in exozones of each zoarial layer are generally surrounded by exilazooecia (pl. 38, fig. 1).

Primary type specimens of $C$. distincta (pl. 38, fig. 1, table 67; Utgaard, 1968b, pl. 181, fig. 4, pl. 182, figs. $1-3$;) appear to have zooecia with slightly larger diameters in cross section than hypotypes from the Lexington Limestone in Kentucky but are similar in budding pattern of exilazooecia, zooecial wall thickness, microstructure and appearance of lunaria, and thickness of individual layers of zooecia constituting zoaria (pl. 38, fig. 4).

Ulrich (1893, p. 328) reportedly found $C$. distincta in his "lower third of the Trenton shales" (the approximate stratigraphic equivalent of the Stictoporella angularis zone, Decorah Shale, of Karklins, 1969, fig. 10) at Minneapolis, Minn. This specimen (Ulrich, 1893, pl. 28, fig. 13) differs from the primary type material of C. distincta and from the other material in Kentucky in having an encrusting zoarium that is much smaller and consists of a single layer. Autozooecia of this zoarium appear to be smaller and are aligned in a more distinct pattern than those of the primary type specimens of $C$. distincta.

TABLE 63.-Summarized measurements of specimens of Ceramoporella distincta Ulrich [Lectotype USNM 159710 and paratypes USNM 159711, 245033, 245035. All measurements in millimeters unless otherwise indicated]

\begin{tabular}{|c|c|c|c|c|c|c|c|}
\hline & $\begin{array}{c}\text { Arithmetic } \\
\text { mean }\end{array}$ & $\begin{array}{l}\text { Standard } \\
\text { deviation } \\
\text { of mean }\end{array}$ & $\begin{array}{c}\text { Coefficient } \\
\text { of } \\
\text { variation }\end{array}$ & $\begin{array}{c}\text { 95-percent } \\
\text { confidence } \\
\text { interval } \\
\text { of mean } \\
\end{array}$ & Range & $\begin{array}{c}\begin{array}{c}\text { Number } \\
\text { of } \\
\text { measurements }\end{array} \\
\end{array}$ & $\begin{array}{c}\text { Number } \\
\text { of } \\
\text { zoaria } \\
\text { measured }\end{array}$ \\
\hline Autozooecial chamber maximum diameter & 0.2915 & 0.0333 & 11.42 & $0.28-0.31$ & $0.24-0.35$ & 20 & 4 \\
\hline Autozooecial chamber minimum diameter & .2245 & .0256 & 11.42 & $.21-.23$ & $.20-.28$ & 20 & 4 \\
\hline Autozooecial wall thickness between chambers & .026 & .0075 & 28.0 & $.02-.03$ & $.02-.04$ & 20 & 4 \\
\hline Exilazooecial chamber maximum diameter - & .1305 & .0358 & 27.40 & $.11-.15$ & $.05-.18$ & 20 & 4 \\
\hline Autozooecia (number pe & & & & & $6-8$ & 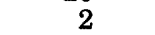 & 2 \\
\hline ial width-_ & .1550 & .0212 & 13.65 & $.15-.16$ & $.11-.19$ & 20 & 4 \\
\hline ial radius & .1235 & .0274 & & $.11-.14$ & $.08-.17$ & 20 & 4 \\
\hline ial thickness - & .0365 & .0109 & 29.85 & $.03-.04$ & $.02-.07$ & 20 & 4 \\
\hline 1 thickness - & 2.0333 & 1.4816 & 72.86 & $.89-3.17$ & $.40-4.50$ & $\mathbf{9}$ & 3 \\
\hline Wutdth & .0875 & .0190 & 21.81 & $.07-.10$ & $.05-.11$ & 8 & 2 \\
\hline e cidenoly) & .3963 & .1351 & 34.10 & $.28-.51$ & $.17-.60$ & 8 & 2 \\
\hline Thickness of single la & .5300 & .1252 & 23.62 & $.44-.62$ & $.40-.70$ & 10 & 3 \\
\hline
\end{tabular}

TABLE 64.-Summarized measurements of specimens of Ceramoporella distincta Ulrich [Hypotypes USNM 309380, 309381 (USGS colln. 7319-CO). All measurements in millimeters unless otherwise indicated]

\begin{tabular}{|c|c|c|c|c|c|c|c|}
\hline & $\begin{array}{c}\text { Arithmetic } \\
\text { mean }\end{array}$ & $\begin{array}{l}\text { Standard } \\
\text { deviation } \\
\text { of mean }\end{array}$ & $\begin{array}{c}\text { Coefficient } \\
\text { of } \\
\text { variation }\end{array}$ & $\begin{array}{c}\text { 95-percent } \\
\text { confidence } \\
\text { interval } \\
\text { of mean } \\
\end{array}$ & Range & $\begin{array}{c}\begin{array}{c}\text { Number } \\
\text { of } \\
\text { measurements }\end{array} \\
\end{array}$ & $\begin{array}{c}\text { Number } \\
\text { of } \\
\text { zoaria } \\
\text { measured }\end{array}$ \\
\hline Autozooecial chamber maximum diameter & 0.2240 & 0.0227 & 10.14 & $0.21-0.24$ & $0.20-0.26$ & 10 & 2 \\
\hline Autozooecial chamber minimum diameter & .1540 & .0212 & 13.76 & $.14-\quad .17$ & $.12-.20$ & 10 & 2 \\
\hline Autozooecial wall thickness between chambers- & .030 & .0082 & 24.95 & $.03-$ & $.02-$ & 10 & 2 \\
\hline Exilazooecial chamber maximum diameter & .150 & .0443 & 38.51 & $.08-.15$ & $.04-.18$ & 10 & 2 \\
\hline Autozooecia (number per $\mathrm{mm}^{2}$ ) & 9.0 & 1.00 & 11.11 & $6.52-11.48$ & $8.0-10.0$ & 3 & 1 \\
\hline Lunarial width & .1540 & .0266 & 13.41 & $.14-.17$ & $.13-.20$ & 10 & $\overline{2}$ \\
\hline Lunarial radius -_____ & .1170 & .0236 & 20.17 & .10 & .07 & 10 & 2 \\
\hline 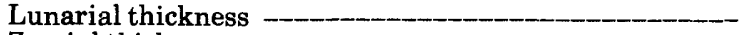 & .0430 & .0106 & 24.64 & $.04-.06$ & $.03-.06$ & 10 & 2 \\
\hline Zoarial thickness -_-__- & 3.1389 & 2.4858 & 79.19 & $1.23-5.05$ & $.58-6.5$ & 9 & 2 \\
\hline Endozone width - & .1112 & .0436 & 39.16 & $.07-.15$ & $.06-.20$ & 8 & 2 \\
\hline Exozone width (one side only) ___ & .5588 & .130 & 23.27 & $.45-$ & $.40-$ & 8 & 2 \\
\hline Thickness of single layer of zoarium-- & .5767 & .1940 & 33.65 & $.43-$ & .20 & $\mathbf{9}$ & 2 \\
\hline
\end{tabular}


One specimen from the Decorah Shale is illustrated erroneously (Bassler, 1953, text fig. 44-2c) as being the external view of a primary type specimen from the "Eden" strata in Ohio (Bassler, 1953, text-fig. 44-2ab). Until additional material becomes available for further evaluation, Ulrich's (1893) material from the Decorah Shale in Minnesota is regarded a Ceramoporella sp. other than $C$. distincta; $C$. distincta apparently does not occur in the lower part of the Decorah Shale at Minneapolis.

\section{Genus CREPIPORA Ulrich, 1882}

Type species.-Chaetetes venustus Ulrich, 1878, p. 93; by subsequent monotypy by Spjeldnaes, 1963 , p. 64; "Economy Member of the Eden Formation" of Bassler, 1906, Upper Ordovician, West Covington, Ky.

Remarks.-Utgaard (1968b, p. 1448; 1983b) emended the definition for the genus Crepipora Ulrich; his definition of Crepipora is followed here.

\section{Crepipora venusta (Ulrich, 1878)}

Plate 38 , figure 5 ; plate 39 , figures $1-4$

Chaetetes venustus Ulrich, 1878 , p. 93, pl. 4, figs. 7, 7a.

Crepipora venusta (Ulrich). Ulrich, 1882, p. 257; Nickles, 1905, p. 49 pl. 2, fig. 7; Foerste, 1914, p. 126; Spjeldnaes, 1963, p. 64, pls. 9, 10; Utgaard, 1968b, p. 1448, pl. 181, figs. 1-3; 1973, fig. 46.

Monticulipora (Fistulipora) venusta James and James, 1888, p. 33.

Description.-Zoaria dendroid with subcylindrical solid or hollow encrusting branches irregularly variable in size, commonly with conspecific overgrowth in one or more layers. Basal layers of encrusting part of zoaria and of overgrowths imperforate, indistinctly granular proximally, laminated distally.

Endozones variable in width locally. Autozooecia in endozones with relatively long recumbent parts contiguous, subrhombic in cross section with slightly curved walls, occasionally having thin, slightly curved, scattered basal diaphragms. Communications pores sparse to absent.

In exozones, autozooecia slightly oblique to zoarial surface, generally contiguous, subpolygonal to subcir- cular in cross section, elongated in zoarial growth direction. Autozooecial walls moderately thick in some zoaria, variable in thickness or relatively thin in others; laminae broadly curved, locally irregular in microstructure; autozooecial boundaries broadly serrated, occasionally crenulated locally.

Styles sparse, with exceedingly small cores and thin sheaths, occurring mostly in walls of exilazooecia in maculae, generally lacking in intermacular areas. Basal diaphragms thin to moderately thick, planar to curved, concave distally, commonly thickened at junctions with zooecial walls, occurring slightly oblique or at right angles to chamber axis, sparse to common, scattered in some autozooecia, absent in others. Autozooecial lining thin, indistinct, absent locally in some autozooecia, occurring mostly distally of basal diaphragms. Communication pores sparse to common, slightly variable in size, occurring in autozooecial walls at right angles or slightly oblique to zooecial chambers, sparse in exilazooecial walls.

Lunarial deposits occur throughout autozooecia, originating locally at basal layer of zoaria, constituting partly endozonal autozooecial walls, thickening slightly in exozones.

Cores in lunaria indistinct, scattered, lacking in lunaria of some autozooecia. Lunarial deposits form straight to jagged boundaries with laminated cortex of autozooecial walls; margins of lunaria projecting commonly into zooecial chambers.

Autozooecial chambers subelliptical to subcircular, locally irregularly shaped in cross section.

Exilazooecia sparse to common, subelliptical to subcircular in cross section, occurring mostly in maculae, sparingly in intermonticular areas.

Maculae common, slightly depressed to elevated at zoarial surfaces, consisting of abundant exilazooecia having small scattered styles. Maculae generally occurring in regular rhombic pattern.

Measurements.-Measurements are summarized in table 65.

TABLE 65.-Summarized measurements of specimens of Crepipora venusta (Ulrich)

[Hypotypes USNM 309388 (USGS colln. 5004-CO), 309383 (USGS colln. 4932-CO), 309395-309397 (USGS colln. 8130-CO). All measurements in millimeters unless otherwise indicated]

\begin{tabular}{|c|c|c|c|c|c|c|c|}
\hline & $\begin{array}{c}\text { Arithmetic } \\
\text { mean }\end{array}$ & $\begin{array}{c}\text { Standard } \\
\text { deviation } \\
\text { of mean }\end{array}$ & $\begin{array}{c}\text { Coefficient } \\
\text { of } \\
\text { variation }\end{array}$ & $\begin{array}{c}\text { 95-percent } \\
\text { confidence } \\
\text { interval } \\
\text { of mean }\end{array}$ & Range & $\begin{array}{c}\begin{array}{c}\text { Number } \\
\text { of } \\
\text { measurements }\end{array} \\
\end{array}$ & $\begin{array}{c}\text { Number } \\
\text { of } \\
\text { zoaria } \\
\text { measured }\end{array}$ \\
\hline Autozooecial chamber maximum diameter-_- & 0.2530 & 0.0290 & 11.46 & $0.24-0.27$ & $0.21-0.32$ & 23 & 5 \\
\hline Autozooecial chamber minimum diameter - & .19609 & .0292 & 14.89 & $.18-.21$ & $.15-.26$ & 23 & 5 \\
\hline Autozooecial wall thickness between chambers & .0452 & .0120 & 26.56 & $.04-$ & $.03-$ & 23 & 5 \\
\hline Exilazooecial chamber maximum diameter & .0917 & .0343 & 37.42 & $.05-.13$ & $.05-.13$ & 6 & 2 \\
\hline Autozooecia (number per $\mathrm{mm}^{2}$ ) & 12.375 & 2.3261 & 18.80 & $10.43-14.32$ & $9-16$ & 8 & 4 \\
\hline Lunarial width & .1300 & .0212 & 16.32 & $.12-\quad .14$ & $.10-.17$ & 13 & 3 \\
\hline Lunarial radius & .0862 & .0243 & 28.25 & $.07-.10$ & $.05-.12$ & 13 & 3 \\
\hline Zoarial branch diameter - & 3.400 & .6164 & 18.13 & $2.41-4.38$ & $2.90-4.30$ & 4 & 3 \\
\hline Endozone width & .1243 & .0359 & 27.03 & $.09-.15$ & $.07-.15$ & 7 & 2 \\
\hline Zoarial width (one side only) & .700 & .1803 & 25.75 & $.56-\quad .83$ & $.50-1.00$ & $\dot{9}$ & 4 \\
\hline Axial hollow diamete & 1.880 & .7662 & 40.75 & $.93-2.83$ & $1.20-3.20$ & 5 & 3 \\
\hline
\end{tabular}


Geographic and stratigraphic distribution.-C. venusta is known to occur in rocks of Shermanian Stage, Middle Ordovician, and Edenian Stage, Upper Ordovician, in Kentucky, and in rocks of Edenian Stage, Upper Ordovician, in Ohio.

Occurrence in Kentucky.-Grier Limestone, Shermanian Stage (USGS colln. D1299-CO; 4971-CO), Tanglewood Limestone, Shermanian Stage (USGS colln. 4997-CO; 4934-CO), and Sulphur Well members, Shermanian Stage (USGS colln. 4932-CO), of the Lexington Limestone. In the Clays. Ferry Formation, Shermanian Stage (USGS colln. 5003-CO) and Edenian Stage (USGS collns. 5004-CO; 6731-CO, 8130-CO).

Ulrich (1878, p. 94) reported C. venusta (as Chaetetes) from his stratigraphical interval between what was then the low-water mark of the Ohio River and $100 \mathrm{ft}$ above that level in his "Cincinnati Group." According to Bassler (1906, p. 8), this interval of strata included the "uppermost Trenton" strata and lower part of the "Eden Formation" of Bassler in the general area of Cincinnati.

In a more recent classification of Middle and Upper Ordovician lithic units in Kentucky, Ulrich's 100 -ftthick stratigraphical interval (1878) above the then low-water level of the Ohio River probably roughly approximates the uppermost part of the Point Pleasant Tongue of the Clays Ferry Formation of current usage of Luft (1971).

James and James (1888, p. 33) have found C. venusta in their "Trenton Group" at Frankfort and their "Cincinnati Group" at Covington, Ky., and near Cincinnati in Ohio. Nickles (1905, p. 49) reported C. venusta from the lower part of his "Eden" strata, Upper Ordovician, near Covington, and Foerste (1914, p. 126) reportedly found it in his "Rogers Gap" strata in Kentucky.

Studied material.--Lectotype USNM 159706 and paralectotypes USNM 159707, 159708, and 213292213294 , from the syntype suite USNM 43236, "Economy Member of the Eden Group," Upper Ordovician, West Covington, $\mathrm{Ky}$.

Hypotypes USNM 309382 (USGS colln. D1299-CO), 309383, 309384 (USGS colln. 4932-CO), 309385 (USGS colln. 4791-CO), 309386 (USGS colln. 4997-CO), 309387 (USGS colln. 5003-CO), 309388, 309389 (USGS colln. 5004-CO), 309390 (USGS colln. 6770-CO), 309391 (USGS colln. 6731-CO), 309392 (USGS colln. 7017-CO), 309393-309398 (USGS colln. 8130-CO).

Remarks.-Specimens of Crepipora venusta from the Lexington Limestone and the Clays Ferry Formation in Kentucky are consistent with primary types of $C$. venusta on file at the U.S. National Museum of Natural History, and are illustrated by Utgaard (1968b, pl. 181, figs. 1-3). The hypotype material from Kentucky differs from the primary type specimens in having some- what smaller zoaria in which autozooecia have thinner walls and fewer basal diaphragms and communication pores than in the type specimens.

Hypotype specimens from the Grier Limestone Member of the Lexington Limestone are questionably assigned to $C$. venusta because they are inadequately preserved.

Specimens from the Grier Limestone Member and Sulphur Well Member of the Lexington Limestone in Kentucky are the earliest known representatives of $C$. venusta in the North American Ordovician deposits.

\section{Genus PAPILLALUNARIA Utgaard, 1969}

Type species.-Crepipora spatiosa Ulrich, 1893, p. 323 , "top of the Trenton" strata of Ulrich, Middle Ordovician, near Harrodsburg, Ky.; designated by Utgaard, 1969, p. 290.

Remarks.-Utgaard (1969, p. 29) established the genus Papillalunaria; his concept is followed here.

Papillalunaria spatiosa (Ulrich, 1893) Plate 39, figures 5, 6

Crepipora spatiosa Ulrich, 1893, p. 323.

Papillalunaria spatiosa (Ulrich), Utgaard, 1969, pl. 51, figs. 1-3.

Description.-Zoaria subdomal to discoidal and irregularly shaped, commonly having conspecific overgrowth locally; generally massive with convoluted base. Basal layers exceedingly thin, indistinctly laminated and imperforate.

Endozones indistinct; in endozones, autozooecia recumbent for exceedingly short distances, curving slightly from basal layers at almost right angles to basal layers, contiguous, with sparse basal diaphragms.

In exozones, autozooecia approximately at right angles to basal layers, occasionally intercalated, slightly curved, generally contiguous, subpolygonal, mostly five- to six-sided, occasionally subcircular, in cross section. Autozooecial walls generally thin, straight to slightly sinuous, or crenulated, with monilaelike swellings locally. Autozooecial boundaries narrowly serrated, commonly obscured.

Lunarial deposits indistinct, commonly lacking in endozones, thin throughout exozones, relatively small, with short radii in cross section. Cores in lunaria generally absent or obscured; proximal protuberances of lunaria exceedingly small, occurring mostly in lunaria of polymorphs of maculae or in lunaria of adjacent autozooecia.

Basal diaphragms sparse to common, thin, with poorly defined microstructure, planar to slightly curved, at right angles to chamber axis, occasionally evenly spaced at same ontogenetic stage of several autozooecia. Autozooecial linings and communication pores generally absent. 
Autozooecial chambers subpolygonal to subcircular, occasionally irregularly shaped in cross section.

Exilazooecia exceedingly sparse to absent, subcircular to subpolygonal in cross section, occasionally terminating within exozones of zoaria.

Maculae common, consisting of large polymorphs subpolygonal in cross section and occasional exilazooecia irregularly shaped in cross section.

Measurements.-Measurements are summarized in table 66.

Geographic and stratigraphic distribution. $-P$. spatiosa is found only in Kentucky, where it occurs in the Brannon Member, Shermanian Stage (USGS colln. D1159-CO), of the Lexington Limestone.

Ulrich (1893, p. 323) reported this species as Crepipora spatiosa from his "top of the Trenton" strata, Middle Ordovician, near Harrodsburg, Ky.

Studied material.-Lectotype USNM 159723 and paralectotypes USNM 159724, 159725, 245028-245032 (designated by Utgaard, 1969, p. 290, pl. 51) from syntype suite USNM 43228, from "top of the Trenton" strata near Harrodsburg, Ky.

Hypotype USNM 309399 (USGS colln. D1159-CO).

Remarks.-Papillalunaria spatiosa (Ulrich) characteristically has relatively large autozooecia (pl. 39, figs. 5, 6a) and macular polymorphs (table 66) with thin walls having monilaelike swellings, poorly defined endozones (Utgaard, 1969, pl. 51, figs. 1-3), and very few exilazooecia. Zoaria are generally massive and have exceedingly thin basal layers.

\section{Family CONSTELLARIIDAE Genus CONSTEllaRIA Dana, 1846}

Type species.-Constellaria florida Ulrich, 1882, p. 257; subsequent designation by Ulrich, 1883, p. 266. "Cincinnati Group" of Ulrich, Upper Ordovician, Ohio.

Remarks.-Ross (1963, p. 51) emended the definition for the genus Constellaria and subsequently (Ross, 1969 , p. 274) published a diagnosis for Constellaria that is followed here.

Cutler (1973) discussed the morphology and development of acanthorods (the "acanthopores" of authors; termed herein styles) and related nonlaminate skeletal deposits ("yellow tissue" of authors) in the genus Constellaria. McKinney (1977, p. 323-326) discussed the development of zoaria in several species of Constellaria, including the type species $C$. florida, and showed that Constellaria characteristically manifests a budding pattern in which autozooecia bud into three-sided conein-cone groups.

Constellaria fischeri Ulrich, 1883

Plate 35, figures 2-4; plate 40 , figure 4

Constellaria fischeri Ulrich, 1883, p. 270, pl. 14, figs. 6-6c; McFarlan, 1931, p. 101, pl. 6, fig. 1; Utgaard, 1973, fig. 54.

Description.-Zoaria dendroid, commonly having flattened, irregularly convoluted branches and occasional subcylindrical branches; conspecific overgrowth scattered locally.

In endozones, autozooecia subparallel to branch axis, polygonal, generally three- to six-sided in cross section, curving abruptly, locally gradually, outward in outer endozones or inner exozones. Autozooecial walls slightly sinuous. Basal diaphragms generally sparse to absent, planar, occurring at right angles or slightly oblique to chamber axis. Basal diaphragms occasionally common in endozones of some zoaria. Zones of rejuvenation of autozooecia sparse.

In exozones, autozooecia generally at right angles to zoarial surface. Autozooecia in interstellar macular areas without preferred alignment, subcircular to circular, occasionally subpolygonal in cross section, partly contiguous to almost completely separated by vesicular deposits.

Stellate maculae abundant, low, generally indistinct, occurring regularly or irregularly across zoarial surface. Stellate maculae consisting of small, irregularly shaped areas of vesicular deposits in centers and of autozooecia clustered in approximately five to six rays. Ray clusters of autozooecia indistinctly defined, generally slightly longer than wide, separated by irregular strips of vesicular deposits, merging with autozooecia of interstellate macular areas and occasionally with adjacent rays. Ray clusters consisting of approximately

TABLE 66.-Summarized measurements of specimens of Papillalunaria spatiosa (Ulrich) [Lectotype USNM 159723 and paralectotypes USNM 159724, 159725, 245028. All measurements in millimeters unless otherwise indicated]

\begin{tabular}{|c|c|c|c|c|c|c|c|}
\hline & $\begin{array}{c}\text { Arithmetic } \\
\text { mean }\end{array}$ & $\begin{array}{c}\text { Standard } \\
\text { deviation } \\
\text { of mean }\end{array}$ & $\begin{array}{c}\begin{array}{c}\text { Coefficient } \\
\text { of } \\
\text { variation }\end{array} \\
\end{array}$ & $\begin{array}{c}\text { 95-percent } \\
\text { confidence } \\
\text { interval } \\
\text { of mean }\end{array}$ & Range & $\begin{array}{c}\text { Number } \\
\text { of } \\
\text { measurements }\end{array}$ & $\begin{array}{c}\text { Number } \\
\text { of } \\
\text { zoaria } \\
\text { measured }\end{array}$ \\
\hline Autozooecial chamber maximum diameter _-_ & 0.3880 & 0.0349 & 8.99 & $0.37-0.40$ & $0.32-0.44$ & 20 & 4 \\
\hline Autozooecial chamber minimum diameter & .3305 & .040 & 12.12 & $.31-.35$ & $.25-.42$ & 20 & 4 \\
\hline Autozooecial wall thickness, exozone & .0290 & .0085 & 29.39 & $.025-.032$ & $.02-.04$ & 20 & 4 \\
\hline Macular polymorph chamber maximum diameter & .5773 & .0825 & 14.29 & $.52-.63$ & $.51-.74$ & 11 & 4 \\
\hline Macular polymorph chamber minimum diameter & .4191 & .0647 & 15.44 & $.38-.46$ & $.33-.57$ & 11 & 4 \\
\hline Mesozooecial chamber maximum diameter ___ & .160 & .0344 & 21.52 & $.14-.17$ & $.11-.23$ & 15 & 4 \\
\hline Autozooecia (number per $2 \mathrm{~mm}$ ) & 4.3889 & .6077 & 13.85 & $4.09-4.69$ & $4^{2+1}-6$ & 18 & 4 \\
\hline 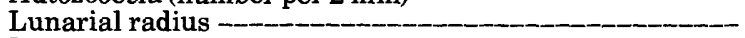 & .0788 & .0295 & 29.15 & $.06-.10$ & $.06-.13$ & 8 & 2 \\
\hline 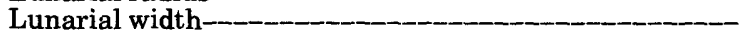 & .1513 & .0337 & 22.19 & $.12-.18$ & $.10-.20$ & 8 & $\overline{2}$ \\
\hline
\end{tabular}


2 to 8 , in rare instances up to 15 , autozooecia. Ray clusters commonly subdivided longitudinally by indistinct partitions; midray partitions locally discontinuous or indistinctly bifurcating.

Autozooecial walls straight to slightly sinuous, irregular in thickness locally. Autozooecial boundaries distinct. Basal diaphragms generally sparse to absent, planar to slightly curved, commonly concave distally, occurring at right angles or slightly oblique to chamber axis. Basal diaphragms locally common and evenly spaced in autozooecia of some zoaria.

Autozooecial chambers circular to subcircular in cross section.

Vesicular skeletal deposits abundant in centers of stellate maculae, occurring in narrow strips, irregular in width, between rays of maculae and commonly in interstellar macular areas. Vesicles small, polygonal in cross section, rectangular in profile, with thin walls. Chambers of vesicles partly filled by laminate skeletal deposits occasionally.

Styles abundant to common throughout exozones, slightly variable in shape and size, occasionally expanding into irregular patches. Styles occurring mostly in walls of vesicles, in centers of stellate maculae, occasionally projecting into chambers of vesicles, commonly occurring in autozooecial walls.

Nonlaminate skeletal deposits (yellow tissue of authors) abundant, occurring irregularly throughout exozones as styles, as midray partitions between autozooecia clustered in rays, as cylindrical deposits in autozooecial walls locally, and as scattered irregularly shaped skeletal patches.

Measurements.-Measurements are summarized in table 67.

Geographic and stratigraphic distribution.-C. fischeri is known only from Kentucky, where it occurs in the Nicholas Bed of the Tanglewood Limestone Member, Shermanian Stage (USGS colln. 5031-CO), and the Millersburg Member, Shermanian Stage (USGS colln. 4859-CO), of the Lexington Limestone, and the Clays
Ferry Formation, Shermanian Stage (USGS colln. 7043-CO, 7046-CO).

In addition, Ulrich (1883, p. 272) reported $C$. fischeri from his "Cincinnati Group," near Mt. Sterling in Kentucky. McFarlan (1931, p. 102) found it in his "Greendale Division of the Cynthiana" strata, near Lexington. Cutler (1968, p. 146) reported C. fischeri from his "Cynthiana Formation" in the Lexington West and Austerlitz Quadrangles, Kentucky.

Studied material.-Lectotype USNM 44068, from syntype suite USNM 44068, from the "Upper Trenton (Cynthiana)" strata, Middle Ordovician, near Winchester, Ky. Hypotypes USNM 390400-309402 (USGS colln. 4859-CO), 309403 (USGS colln. 5031-CO), 309404 (USGS colln. 7043-CO), 309405 (USGS colln. 7046-CO).

Remarks.-C. fischeri characteristically possesses zoaria having flattened branches and inconspicuous, irregularly shaped stellate maculae and relatively small vesicles, mostly rectangular in profile, that are only occasionally partly filled by laminate skeletal deposits. C. fischeri generally has abundant styles and, commonly, large patches of nonlaminate skeletal deposits (yellow tissue of authors) throughout exozones.

C. fischeri is closely related to $C$. teres in the approximately similar number of rays in stellate maculae, the thickness of zoarial branches, and the abundance of basal diaphragms and styles throughout exozones (Cutler, 1968, p. 158, 159).

C. fischeri differs from C. teres, however, in its flattened zoarial branches (pl. 40, fig. 4c) and their inconspicuous and irregularly shaped stellate maculae, its autozooecia chambers of slightly larger diameter, and its narrower zoarial endozones (table 67). Autozooecia in interstellar macular areas in C. fischeri are without preferred alignment; those in $C$. teres are commonly clustered in indistinct groups (Cutler, 1968, p. 158, 159). C. fischeri differs further from $C$. teres in having smaller vesicles, more abundant styles (pl. 35 , figs. $3 \mathrm{~b}$, 3c; pl. 40, fig. 4a), and nonlaminate deposits in auto-

TABLE 67.-Summarized measurements of specimens of Constellaria fischeri Ulrich

[Hypotypes USNM 309402 (USGS colln. 4859-CO), 309404 (USGS colln. 7043-CO), 309403 (USGS colln. 5031-CO). All measurements in millimeters unless otherwise indicated]

\begin{tabular}{|c|c|c|c|c|c|c|c|}
\hline & $\begin{array}{c}\text { Arithmetic } \\
\text { mean }\end{array}$ & $\begin{array}{c}\text { Standard } \\
\text { deviation } \\
\text { of mean }\end{array}$ & $\begin{array}{c}\text { Coefficient } \\
\text { of } \\
\text { variation }\end{array}$ & $\begin{array}{l}\text { 95-percent } \\
\text { confidence } \\
\text { interval } \\
\text { of mean }\end{array}$ & Range & $\begin{array}{c}\begin{array}{c}\text { Number } \\
\text { of } \\
\text { measurements }\end{array} \\
\end{array}$ & $\begin{array}{c}\text { Number } \\
\text { of } \\
\text { zoaria } \\
\text { measured }\end{array}$ \\
\hline $\begin{array}{l}\text { Interstellar autozooecial chamber maximum } \\
\text { diameter }\end{array}$ & \multirow{2}{*}{0.13750} & \multirow{2}{*}{0.0133} & 9.69 & $0.13-0.14$ & $0.11-0.16$ & 20 & 4 \\
\hline $\begin{array}{l}\text { Interstellar autozooecial chamber minimum } \\
\text { diameter- }\end{array}$ & & & 0.00 & o. & & & \\
\hline Stellar polymorph chamber maximum diameter & .1330 & .0122 & 9.16 & $.13-\quad .14$ & $.11-$ & 20 & 4 \\
\hline Stellar polymorph chamber minimum diameter & .1160 & .0088 & 7.61 & $.11-\quad .12$ & $.10-.14$ & 20 & 4 \\
\hline Vesicles (number per $\mathrm{mm}$ ) - & 20.750 & 2.9861 & 14.39 & $16.0-25.50$ & $17.0-24.0$ & 4 & 2 \\
\hline Zoarial branch diameter - & 6.50 & 4.79 & 73.77 & $(-5.41-18.41)$ & $3.20-12.0$ & 3 & 3 \\
\hline Endozone width - & 1.9333 & .6807 & 35.21 & $(.24-3.62)$ & $1.40-2.70$ & 3 & 3 \\
\hline Exozone width (one side only) & 2.2167 & 1.9854 & 89.57 & $(.13-4.30)$ & $.80-5.2$ & 6 & 3 \\
\hline
\end{tabular}


zooecia in interstellar macular areas (pl. 35, fig. 3b) (Cutler, 1968, p. 158, 159).

\section{Constellaria teres Hayes and Ulrich, 1903}

Plate 40, figures 1-3; plate 41

Constellaria teres Hayes and Ulrich, 1903, fig. 31.

Constellaria teres Ulrich and Bassler, 1904, pl. 37; McFarlan, 1931, p. 100 , pl. 4, fig. 12 .

?Constellaria teres Hayes and Ulrich, Wilson, 1949, pl. 13, fig. 3, 4.

Description.-Zoaria dendroid, having cylindrical to subcylindrical, occasionally flattened, commonly anastomosing branches and conspecific overgrowth. Zoaria rarely encrusting.

In endozones, autozooecia subparallel to branch axis, polygonal, generally three- to five-sided in cross section, curving abruptly, occasionally gradually, outward in late endozones or early exozones. Autozooecial walls straight to slightly sinuous. Basal diaphragms common to absent, planar to slightly curved, occurring at right or slightly oblique angles to chamber axis; commonly evenly spaced, occasionally occurring irregularly or lacking altogether in endozones of some zoaria. Zones of rejuvenation of autozooecia common, occurring irregularly.

In exozones, autozooecia almost at right angles to zoarial surface, subcircular to circular in cross section, with straight to slightly sinuous walls. Autozooecial boundaries generally distinct, locally not visible in autozooecia near centers of stellate maculae. Basal diaphragms generally common throughout exozones, planar to slightly curved, slightly oblique or at right angles to chamber axis. Basal diaphragms evenly spaced in some autozooecia, occurring irregularly or absent altogether in others.

In interstellar macular areas, autozooecia occurring without preferred alignment, separated almost completely by vesicular deposits, usually in clusters of three to four. Clustered autozooecia partly contiguous, separated partly by vesicular deposits. Stellate maculae abundant, relatively small, generally regular in shape, low or slightly raised, occurring irregularly over zoarial surface, coalescing locally. Stellate maculae made up of autozooecia clustered in an average of five to seven rays and small areas of vesicular deposits in centers of maculae. Ray clusters of autozooecia generally well defined, slightly wider outward from centers of maculae, separated by strips of narrow vesicular deposits. Ray clusters formed of approximately 8-25 autozooecia, rarely more than 30 . Autozooecia in ray clusters contiguous to partly contiguous, separated by vesicular deposits.

Ray clusters commonly subdivided by indistinct partitions longitudinally; midray partitions lacking in rays of some maculae.
Autozooecial chambers subcircular to circular in cross section.

Vesicular deposits abundant, occurring in centers of stellate maculae, between rays of maculae in narrow strips, locally irregular in width; partly separating autozooecia in ray clusters of maculae and in interstellar macular areas. Vesicles generally of medium size, irregularly polygonal in cross section, generally rectangular in profile or having curved walls; walls of vesicles commonly thickened in late exozones; chambers of vesicles partly or almost completely filled by laminate skeletal deposits in late exozones of many zoaria.

Styles abundant in exozones of many zoaria, sparse to absent in others. Styles generally irregular in size and shape, occasionally extending into patches of irregular shape. Styles generally occurring in walls of autozooecia in interstellar macular areas, sparingly or not at all in autozooecia in ray clusters. Styles common in walls of vesicles in centers of maculae, projecting occasionally into vesicles.

Nonlaminate skeletal deposits (yellow tissue of authors) abundant, irregularly occurring throughout exozones as styles and stylelike deposits, forming indistinct midray partitions and locally surrounding autozooecia clustered in rays; occurring irregularly in autozooecial walls in interstellar macular areas.

Measurements.-Measurements are summarized in tables 68 and 69.

Geographic and stratigraphic distribution.-C. teres is abundantly present in the Catheys Formation, Middle Ordovician part, in central Tennessee. It is the most abundant species in rocks of the upper Shermanian Stage and occurs in those of the lower Edenian Stage, Upper Ordovician, in Kentucky. C. teres is not known to occur outside the depositional basin of Tennessee-Kentucky.

Occurrence in Kentucky.-Grier Limestone Member, Shermanian Stage (USGS colln. D1117-CO); Tanglewood Limestone Member, Shermanian Stage (USGS collns. D1305-CO-D1307-CO; D1120-CO; D1202-CO; 7065-CO, 7067-CO; D1130-COD1132-CO; D1206-CO; 4855-CO; 7460-CO; 5180-CO, 5181-CO, 7462-CO, 7464-CO, 7465-CO, 7466-CO; 7337-CO; 4980-CO-4983-CO, 4985-CO-4988-CO, 4992-CO-4996-CO; 5842-CO, 5845-CO, 5850-CO, 5855-CO; 4886-CO); Nicholas Bed: Shermanian Stage (USGS collns. 5031-CO; 5860-CO) and Edenian Stage (USGS collns. 5032-CO-5035-CO), of the Tanglewood Limestone Member; Millersburg Member: Shermanian Stage (USGS collns. D1127-CO-D1129-CO; 4858-CO; D1208-CO, D1209-CO; 5857-CO; 7039-CO-7042-CO, 7048-CO, 7050-CO, 7052-CO, 7054-CO, 7056-CO; 7059-CO, 7060-CO; 7068-CO, 7070-CO-7073-CO; 
TABLE 68.-Summarized measurements of specimens of Constellaria teres Hayes and Ulrich

[Hypotypes USNM 309501 (USGS colln. 7314-CO), 309503 (USGS colln. 7319-CO), 309507 (USGS colln. 7321-CO), 309509 (USGS colln. 7310-CO), 309512 (USGS colln. 7337-CO), 309514 (USGS colln. 7336-CO), 309515 (USGS colln. 7334-CO), 309518, 309519 (USGS colln. 7330-CO). All measurements in millimeters unless otherwise indicated]

\begin{tabular}{|c|c|c|c|c|c|c|c|}
\hline & $\begin{array}{c}\text { Arithmetic } \\
\text { mean }\end{array}$ & $\begin{array}{l}\text { Standard } \\
\text { deviation } \\
\text { of mean }\end{array}$ & $\begin{array}{c}\text { Coefficient } \\
\text { of } \\
\text { variation }\end{array}$ & $\begin{array}{c}\text { 95-percent } \\
\text { confidence } \\
\text { interval } \\
\text { of mean }\end{array}$ & Range & $\begin{array}{c}\text { Number } \\
\text { of } \\
\text { measurements }\end{array}$ & $\begin{array}{c}\text { Number } \\
\text { of } \\
\text { zoaria } \\
\text { measured }\end{array}$ \\
\hline \multicolumn{8}{|l|}{ Interstellar autozooecial chamber maximum } \\
\hline diameter _-_ _ & 0.1198 & 0.0103 & 8.68 & $0.12-0.12$ & $0.10-0.14$ & 50 & 10 \\
\hline \multicolumn{8}{|l|}{ Interstellar autozooecial chamber minimum } \\
\hline diameter _-_ & .1054 & .0079 & 7.48 & $.10-$ & $.08-$ & 50 & 10 \\
\hline Stellar polymorph chamber maximum diameter-_-_- & .110 & .0127 & 11.40 & $.11-$ & $.07-$ & 50 & 10 \\
\hline Stellar polymorph chamber minimum diameter & .0926 & .0137 & 14.44 & $.09-.10$ & $.04-.11$ & 50 & 10 \\
\hline Endozone diaphragms (number per $\mathrm{mm}$ ) - & 2.1667 & .7528 & 34.74 & $1.38-2.96$ & $1-3$ & 6 & 2 \\
\hline Exozone diaphragms (number per $\mathrm{mm}$ ) & 7.17 & 1.6021 & 22.36 & $5.49-8.85$ & -9 & 6 & 2 \\
\hline Vesicles (number per $\mathrm{mm}$ ) & 16.79 & 2.39 & 14.26 & $15.86-17.71$ & $11-21$ & 28 & 8 \\
\hline Zoarial branch diameter & 8.2857 & 4.3954 & 53.05 & $5.75-10.82$ & $3.00-21.0$ & 14 & 10 \\
\hline Endozone width & 4.2867 & 2.3197 & 54.12 & $3.00-5.57$ & $1.40-11.0$ & 15 & 20 \\
\hline Exozone width (one side only) & 1.8333 & 1.0364 & 56.53 & $1.45-2.22$ & $.80-5.80$ & 30 & 10 \\
\hline
\end{tabular}

TABLE 69.-Summarized measurements of specimens of Constellaria teres Hayes and Ulrich

[Hypotypes USNM 309421 (USGS colln. D1202-CO), 309422-309425 (USGS colln. D1206-CO), 309426, 309427 (USGS colln. D1208-CO), 309428, 309429 (USGS colln. D1209-CO). All measurements in millimeters unless otherwise indicated

\begin{tabular}{|c|c|c|c|c|c|c|c|}
\hline & $\begin{array}{c}\text { Arithmetic } \\
\text { mean }\end{array}$ & $\begin{array}{c}\text { Standard } \\
\text { deviation } \\
\text { of mean }\end{array}$ & $\begin{array}{c}\text { Coefficient } \\
\text { of } \\
\text { variation }\end{array}$ & $\begin{array}{c}\text { 95-percent } \\
\text { confidence } \\
\text { interval } \\
\text { of mean }\end{array}$ & Range & $\begin{array}{c}\begin{array}{c}\text { Number } \\
\text { of } \\
\text { measurements }\end{array} \\
\end{array}$ & $\begin{array}{c}\text { Number } \\
\text { of } \\
\text { zoaria } \\
\text { measured }\end{array}$ \\
\hline Interstellar autozooecial chamber maximum & \multirow{3}{*}{0.1115} & \multirow{3}{*}{0.0120} & \multirow{3}{*}{10.76} & \multirow[b]{2}{*}{$0.10-0.12$} & \multirow[b]{2}{*}{$0.08-0.14$} & \multirow{3}{*}{27} & \multirow{3}{*}{$\mathbf{5}$} \\
\hline diameter - & & & & & & & \\
\hline Interstellar autozooecial chamber minimum & & & & & & & \\
\hline diameter - & .0967 & .0104 & 10.74 & .09 & $.08-$ & 27 & 5 \\
\hline Interstellar autozooecial wall thicknes: & .0175 & .0064 & 36.50 & $.01-$ & $.01-$ & 20 & 4 \\
\hline Stellar polymorph chamber maximum & .1060 & .0109 & 10.28 & $.10-$ & $.08-$ & 35 & 7 \\
\hline Stellar polymorph chamber minimu & .080 & .0149 & 16.95 & $.08-$ & $.04-$ & 35 & 7 \\
\hline Stellar-zooecial wall thickness-_- & .0148 & .0050 & 34.45 & $.01-\quad .02$ & $.01-\quad .02$ & 25 & 5 \\
\hline Endozone diaphragms (number per $\mathrm{mm}$ ) _ & 2.50 & .7141 & 28.34 & $2.23-2.81$ & $1-4$ & 25 & 6 \\
\hline Exozone diaphragms (number per $\mathrm{mm}$ ) & 9.6667 & 1.5275 & 15.80 & $5.87-13.46$ & -11 & 3 & 1 \\
\hline Vesicles (number per $\mathrm{mm}$ ) & 14.647 & 2.23 & 15.26 & $13.50-15.80$ & $11-18$ & 17 & 6 \\
\hline Zoarial branch diameter & 8.4125 & 4.27 & 50.80 & $4.83-11.99$ & $4.20-15.0$ & 8 & 7 \\
\hline Endozone width - & 3.80 & 1.8469 & 48.60 & $2.48-5.12$ & $1.50-7.20$ & 10 & 7 \\
\hline Exozone width (one side only) & 2.20 & 1.3178 & 59.90 & $1.40-3.0$ & $.60-4.80$ & 13 & 7 \\
\hline
\end{tabular}

7334-CO, 7336-CO; 7456-CO; 5025-CO, 5030-CO), and Edenian Stage (USGS collns. 7314-CO, 7319-CO7321-CO, 7330-CO); Sulphur Well Member, Shermanian Stage (USGS collns. D1161-CO-D1165-CO), and Strodes Creek Member, Edenian Stage (USGS colln. 7310-CO, 7324-CO, 7328-CO) of the Lexington Limestone. Clays Ferry Formation: Shermanian Stage (USGS collns. 4938-CO; 5856-CO; 5863-CO; 4898-CO; 6714-CO, D1170-CO, 6715-CO, 6718-CO, 6719-CO; 7346-CO, 7333-CO) and Edenian Stage (USGS collns. 6722-CO, 6731-CO, 6740-CO, 6741-CO).

McFarlan (1931, p. 100) reported C. teres from the "Woodburn" and "Greendale" Members of his "Cynthiana" strata near Frankfort. Cutler (1968, p. 151) found C. teres in his "Cynthiana Formation," Lexington Limestone, and in the lower part of the Clays Ferry Formation, in central and northern Kentucky.

Occurrence outside Kentucky.-Hayes and Ulrich (1903) and Ulrich and Bassler (1904, p. 37) reported C. teres from shales at the top of their Bigby Limestone and from their Catheys Limestone in Tennessee. Wilson (1949, pl. 13, fig. 1) reportedly found C. teres in Middle Ordovician strata at several localities in central Ten- nessee. Cutler (1968, p. 152) reported C. teres from his "Bigby-Cannon" Formations, Middle Ordovician, at one locality and from his Catheys Formation, Middle Ordovician, at 20 localities in central Tennessee.

Studied material.-Lectotype USNM 43205 and paralectotypes USNM 309406, 390407, from syntype suite USNM 43205, Bigby Limestone, "Trenton" strata, near Columbia, Tenn.

Hypotypes USNM 309408 (USGS colln. D1117-CO), 309436 (USGS colln. D1305-CO), 309409 (USGS colln. D1120-CO), 309437 (USGS colln. D1306-CO), 309410 (USGS colln. D1127-CO), 309438 (USGS colln. D1307-CO), 309411 (USGS colln. D1128-CO), 309439 (USGS colln. D1170-CO), 309412 (USGS colln. D1129-CO), 309440 (USGS colln. 4980-CO), 309413 (USGS colln. D1130-CO), 309441 (USGS colln. 4981-CO), 309414 (USGS colln. D1131-CO), 309442 (USGS colln. 4982-CO), 309415 (USGS colln. D1132-CO), 309443 (USGS colln. 4983-CO), 309416 (USGS colln. D1161-CO), 309444 (USGS colln. 4985-CO), 309417 (USGS colln. D1163-CO), 309445 (USGS colln. 4988-CO), 309418 (USGS colln. D1162-CO), 309446 (USGS colln. 4986-CO), 309419 (USGS colln. D1164-CO), 309420 (USGS colln. 
D1165-CO), 309421 (USGS colln. D1202-CO), 309422309425 (USGS colln. D1206-CO), 309426-309427 (USGS colln. D1208-CO), 309428-309430 (USGS colln. D1209-CO), 309431 (USGS colln. 4886-CO), 309432 (USGS colln. 4898-CO), 309433-309434 (USGS colln. 4855-CO), 309435 (USGS colln. 4858-CO), 309447 (USGS colln. 4987-CO), 309460 (USGS colln. 5842-CO), 309448 (USGS colln. 4992-CO), 309461 (USGS colln. 5845-CO), 390449 (USGS colln. 4993-CO), 309462 (USGS colln. 5850-CO), 305450 (USGS colln. 4994-CO), 309463 (USGS colln. 5854-CO), 309451 (USGS colln. 4995-CO), 390464 (USGS colln. 5855-CO), 309452 (USGS colln. 4996-CO), 309465 (USGS colln. 5856-CO), 309453 (USGS colln. 4938-CO), 309466 (USGS colln. 5857-CO), 309454 (USGS colln. 5025-CO), 309467 (USGS colln. 5860-CO), 309455 (USGS colln. 5030-CO), 309468 (USGS colln. 5863-CO), 309456 (USGS colln. 5031-CO), 309457 (USGS colln. 5032-CO), 309469 (USGS colln. 6714-CO), 309458 (USGS colln. 5033-CO), 309470 (USGS colln. 6715-CO), 309459 (USGS colln. 5034-CO), 309471 (USGS colln. 6718-CO), 309472 (USGS colln. 6719-CO), 309473 (USGS colln. 6722-CO), 309474 (USGS colln. 6740-CO), 309475 (USGS colln. 6731-CO), 309476 (USGS colln. 6741-CO), 309477 (USGS colln. 7039-CO), 309479 (USGS colln. 7041-CO), 309478 (USGS colln. 7040-CO), 409480 (USGS colln. 7042-CO), 309481 (USGS colln. 7043-CO), 309482 (USGS colln. 7044-CO), 309483 (USGS colln. 7046-CO), 309512, 309513 (USGS colln. 7337-CO), 309484 (USGS colln. 7047-CO), 309514 (USGS colln. 7336-CO), 309485 (USGS colln. 7048-CO), 309515, 309516 (USGS colln. 7334-CO), 309486 (USGS colln. 7050-CO), 309517 (USGS colln. 7333-CO), 309487 (USGS colln. 7052-CO), 309518309520 (USGS colln. 7330-CO), 309488 (USGS colln. 7054-CO), 309521 (USGS colln. 7324-CO), 309489 (USGS colln. 7056-CO), 309522 (USGS colln. 7328-CO), 309490 (USGS colln. 7059-CO), 309523, 309524 (USGS colln. 7456-CO), 309491 (USGS colln. 7060-CO), 309525 (USGS colln. 7458-CO), 309492 (USGS colln. 7062-CO), 309526 (USGS colln. 7460-CO), 309493 (USGS colln. 7065-CO), 309527 (USGS colln. 7462-CO), 309494 (USGS colln. 7067-CO), 309528 (USGS colln. 7464-CO), 309529 (USGS colln. 5180-CO), 309495 (USGS colln. 7068-CO), 309530 (USGS colln. 7465-CO), 309496 (USGS colln. 7070-CO), 309531 (USGS colln. 5181-CO), 309497 (USGS colln. 7071-CO), 309532 (USGS colln. 7466-CO), 309498 (USGS colln. 7072-CO), 309499 (USGS colln. 7073-CO), 309500 (USGS colln. 7346-CO), 309501, 309502 (USGS colln. 7314-CO), 309503 (USGS colln. 7319-CO), 309504
(USGS colln. 7320-CO), 309507, 309508 (USGS colln. 7321-CO), 309509, 309510 (USGS colln. 7310-CO), 309511 (USGS colln. 7322-CO).

Remarks. -C. teres is characterized by zoaria having cylindrical branches and small but generally conspicuous and symmetrical maculae (pl. 40, fig. 3; pl. 41, figs. $5,7 \mathrm{~b})$.

C. teres is closely related to $C$. fischeri (see Remarks under $C$. fischeri) and to $C$. florida Ulrich, which is the type species of Constellaria.

C. teres appears to be ancestral to C. florida (Cutler, 1968, p. 174). The two species (Ulrich, 1883, pl. 14, figs. 2-4) have similar diameters of autozooecial chambers in exozones, cross sectional shapes of autozooecia in endozones (pl. 40, fig. 2; McKinney, 1977, pl. 9, figs. 1, 2), and budding patterns resulting in three-sided cone-incone autozooecial groups in endozones (McKinney, 1977 , p. 322,323$)$. C. teres, however, differs from $C$. florida (Ulrich, 1883, pl. 14, figs. 2, 2a, 2b) in having zoarial branches that are more cylindrical than flattened and generally have smaller stellate maculae. $C$. teres differs further from $C$. florida in having smaller vesicles, indistinctly developed midray partitions, and styles in vesicles. Styles in C. florida do not appear to project into vesicle chambers (Cutler, 1968, p. 175).

\section{REFERENCES CITED}

Anstey, R. L., and Fowler, M. L., 1969, Lithostratigraphy and depositional environment of the Eden Shale (Ordovician) in tri-state area of Indiana, Kentucky, and Ohio: Journal of Geology, v. 77, p. 668-682.

Anstey, R. L., and Perry, T. G., 1969, Redescription of cotypes of Peronopora vera Ulrich, a Cincinnatian (Late Ordovician) ectoproct species: Journal of Paleontology, v. 43, no. 2, p. 245-251, pls. 31, 32 .

1973, Eden Shale bryozoans: a numerical study (Ordovician, Ohio Valley): Michigan State University Public Museum Paleontological ser., v. 1, no. 1, 80 p., 22 pls. 15 figs.

Armstrong, H. S., 1945, Stigmatella in the Ordovician of the central Ontario Basin: Journal of Paleontology, v. 19, no. 2, p. 149-157.

Astrova, G. G., 1964, O novum otryade Palezoyskikh mshanok: Paleontologicheskiy Zhurnal, no. 2, p. 22-31. 1965, Morfologiya, istoriya razvitiya i sistema ordovikskikh i siluriyskikh mshanok: Akademiya Nauk SSSR, Paleontologicheskiy Institut Trudy, v. 106, 432 p. (Morphology, evolutionary history and systematics of Ordovician and Silurian bryozoans.)

1978, Istoriya razvitiya, sistema i filogeniya mshanok: Akademiya Nauk SSSR, Paleontologicheskiy Institut Trudy, v. 169, 240 p., 46 pls. (Historical development, systematics and phylogeny of Bryozoa.)

Bassler, R. S., 1903, The structural features of the bryozoan genus Homotrypa, with descriptions of species from the Cincinnatian Group: U.S. National Museum Proceedings, v. 26 , no. 1323 , p. $565-591$, pls. $20-25$. 
1906, A study of the James types of Ordovician and Silurian Bryozoa: U.S. National Museum Proceedings, v. 30 , no. 1442 , p. $1-66$, pls. $1-7$.

1911, The early Paleozoic Bryozoa of the Baltic provinces: Smithsonian Institution, U.S. National Museum Bulletin 77, 382, p., 13 pls.

1913, Bryozoa: In Eastman, C. R., ed., v. 1 of Zittel's Text-book of Paleontology 2d ed.: London, Macmillan, p. 314-355.

1915, Bibliographic index of American Ordovician and Silurian fossils: U.S. National Museum Bulletin 92, v. 1, 2, 1521 p.

1932, The stratigraphy of the central basin of Tennessee: Tennessee Department of Education, Division of Geology, Bulletin 38, 268 p., 49 pls., 4 figs.

1953, Bryozoa, pt. G of Moore, R. C., ed., Treatise on invertebrate paleontology: Geological Society of America and University of Kansas Press, 253 p.

Bergström, S. M., and Sweet, W. C., 1966, Conodonts from the Lexington Limestone (Middle Ordovician) of Kentucky and its lateral equivalents in Ohio and Indiana: Bulletin of American Paleontology, v. 50, no. 299, p. 267-441, pls. 28-35.

Black, D. F. B., Cressman, E. R., and MacQuown, W. C., Jr., 1965, The Lexington Limestone (Middle Ordovician) of central Kentucky: U.S. GeologicaI Survey Bulletin 1224-C, $29 \mathrm{p}$.

Black, D. F. B., and Cuppels, N. P., 1973, Strodes Creek Member (Upper Ordovician)-A new Map Unit in the Lexington Limestone of north-central Kentucky: U.S. Geological Survey Bulletin 1372-C, 16 p.

Boardman, R. S., 1959, A revision of the Silurian bryozoan genus Trematopora: Smithsonian Miscellaneous Collections, v. 139 , no. 6,14 p., 2 pls.

1960a, Trepostomatous Bryozoa of the Hamilton Group of New York State: U.S. Geological Survey Professional Paper 340, 87 p., 22 pls.

$1960 \mathrm{~b}, \mathrm{~A}$ revision of the Ordovician bryozoan genera Batostoma, Anaphragma, and Amplexopora: Smithsonian Miscellaneous Collections, v. 140, no. 5, 28 p., 7 pIs.

1971, Mode of growth and functional morphology of autozooids in some Recent and Paleozoic tubular Bryozoa: Smithsonian Contributions to Paleobiology, no. 8, 51 p., 11 pls.

Boardman, R. S., and Cheetham, A. H., 1969, Skeletal growth, intracolony variation, and evolution in Bryozoa: A review: JournaI of Paleontology, v. 43, no. 2, p. 205-233, pls. 27-30.

1973. Degrees of colony dominance in stenolaemate and gymnolaemate Bryozoa, in Boardman, R. S., Cheetham, A. H., and Oliver, W., eds., Animal colonies: Stroudsburg, Pa., Dowden, Hutchinson and Ross, p. 121-220.

1983, Glossary of morphological terms: Bryozoa, pt. G (revised vol. 1) of Robison, R. A., ed., Treatise on invertebrate paleontology: GeologicaI Society of America and University of Kansas Press, p. 304-320.

Boardman, R. S., and McKinney, F. K., 1976, Skeletal architecture and preserved organs of four-sided zooids in convergent genera of Paleozoic Trepostomata (Bryozoa): Journal of Paleontology, v. 50, no. 1, p. 25-78, 16 pIs.

Boardman, R. S., and Utgaard, John, 1964, Modifications of study methods for Paleozoic Bryozoa: Journal of Paleontology, v. 38 , no. 4 , p. 768-770.

1966, A revision of the Ordovician bryozoan genera Monticulipora, Peronopora, Heterotrypa, and Dekayia:
Journal of Paleontology, v. 40, no. 5, p. 1082-1108, pls. 133-142.

Borella, P. E., and Osborne, R. H., 1978, Late Middle and early Late Ordovician history of the Cincinnati arch province, central Kentucky to centraI Tennessee: Geological Society of America Bulletin, v. 89, p. 1559-1573.

Bork, K. B., and Perry, T. G., 1967, Bryozoa (Ectoprocta) of Champlainian age (Middle Ordovician) from northwestern Illinois and adjacent parts of Iowa and Wisconsin: Journal of Paleontology, v. 41, no. 6, p. 1365-1392, pls. 173-177.

1968a, Bythotrypa Diplotrypa Hemiphragma, Heterotrypa, Stigmatella, Eridotrypa, and Nicholsonella, pt. 2 of Bryozoa (Ectoprocta) of Champlainian age (Middle Ordovician) from northwestern IIlinois and adjacent parts of Iowa and Wisconsin: Journal of Paleontology, v. 42, no. 2, p. $337-355$, pls. $44-48$.

1968b, Homotrypa, Orbignyella, Prasopora, Monticulipora and Cyphotrypa, pt. 3 of Bryozoa (Ectoprocta) of Champlainian age (Middle Ordovician) from northwestern Illinois and adjacent parts of Iowa and Wisconsin: Journal of Paleontology, v. 42, no. 4, p. 1042-1065, pls. 133-138.

Brown, G. D., Jr., 1965, Trepostomatous Bryozoa from the Logana and Jessamine Limestone (Middle Ordovician) of the Kentucky Bluegrass region: Journal of Paleontology, v. 39, no. 5, p. 974-1006, pls. 111-118.

Brown, G. D., Jr., and Lineback, J. A., 1966, Lithostratigraphy of Cincinnatian Series (Upper Ordovician) in southeastern Indiana: American Association of Petroleum Geologists Bulletin, v. 50, p. 1018-1032.

Caley, J. F., 1936, The Ordovician of Manitoulin Island, Ontario, pt. 2 of Contributions to the study of the Ordovician of Ontario and Quebec: Canada, GeologicaI Survey Memoir 202, Publication 2427, p. 21-91, 6 pls.

Corneliussen, E. F., and Perry, T. G., 1973, Monotrypa, Hallopora, Amplexopora, and Hennigopora (Ectoprocta) from the Brownsport Formation (Niagaran), Western Tennessee: Journal of PaIeontology, v. 47, no. 2, p. 151-220, 10 pls.

CoryelI, H. N., 1921, Bryozoan faunas of the Stones River Group of central Tennessee: Indiana Academy Sciences, Proceedings for 1919, p. 261-340, 14 pls.

Cressman, E. R., 1973, Lithostratigraphy an depositionaI environments of the Lexington Limestone (Ordovician) of centraI Kentucky: U.S. GeologicaI Survey Professional Paper 768, 61 p., 11 pIs. [1974].

Cressman, E. R., and KarkIins, O. L., 1970, Lithostratigraphy and fauna of the Lexington Limestone (Ordovician) of central Kentucky, Field Trip No. 2 in guidebook for Field Trips 18th Annual Meeting Southeastern Section Geological Society of America: Lexington; Kentucky Geological Survey, p. 17-28.

Cumings, E. R., 1902, A revision of the bryozoan genera Dekayia, Dekayella and Heterotrypa of the Cincinnati Group: American Geologist, v. 29, p. 197-217, pIs. 9-12.

1908, The stratigraphy and paleontology of the Cincinnati Series of Indiana: Indiana, Department of Geology and Natural Resources, Annual Report 32, p. 605-1189, 55 pIs.

1912, Development and systematic position of the Monticuliporoids: GeoIogical Society of America Bulletin, v. 23 , p. $357-370$, pIs. 19-22.

Cumings, E. R., and Galloway, J. J., 1913, The stratigraphy and paIeontology of the Tanner's Creek section of the Cin- 
cinnati Series of Indiana: Indiana Department of Geology and Natural Resources, Annual Report 37, p. 353-479, 20 pls.

1915, Studies of the morphology and histology of the Trepostomata or monticuliporoids: Geological Society of America Bulletin, v. 26, p. 349-374, pls. 10-15.

Cutler, J. F., 1968, Morphology, taxonomy, and evolution of the bryozoan Constellaria from the Cincinnati Arch: New York, Columbia University, unpublished $\mathrm{Ph}$. D. dissertation, $297 \mathrm{p}$.

1973, Nature of "acanthopores" and related structures in the Ordovician bryozoan Constellaria: in Larwood, G. P., ed., Living and fossil Bryozoa: London, Academic, p. 257-260.

Dana, J. D., 1846, Zoophytes: in U.S. Exploring Expedition under command of C. Wilkes, U.S.N., Text of v. 7: Philadelphia, C. Sherman, Printer, 741 p. (With a folio of 61 plates, published in 1849).

Dybowski, Wladislaw, 1877, Die Chaetetiden der Ostbaltischen Silur-Formation: St. Petersburg, Verhandlungen Russisch-KaiserIichen Mineralogischen Gesselschaft, 134 p., 4 pls. (separate, 1877; complete volume, 1879).

Eichwald, Eduard, 1855, Beitrag zur geographischen Verbreitung der fossilen Thiere Russlands: Bulletin Society Imperiale Nature Moscou, v. 28, p. 433-466.

Elias, M. K., 1954, Cambroporella and Coeloclema, Lower Cambrian and Ordovician bryozoans: Journal of Paleontology, v. 28 , no. 1 , p. 52-58, pls. 9, 10.

Foerste, A. F., 1905, The classification of the Ordovician rocks of Ohio and Indiana: Science, new ser., v. 22, no. 553 , p. 149-152.

1909, Preliminary notes on Cincinnatian and Lexington fossils: Denison University Science Laboratory Bulletin, v. 14, p. 289-334, pls. 7-11.

1910, Preliminary notes on Cincinnatian and Lexington fossils of Ohio, Indiana, Kentucky, and Tennessee: Denison University Science Laboratory Bulletin, v. 16, p. 17-100, pls. 1-6.

1912, Strophomena and other fossils from Cincinnatian and Mohawkian horizons, chiefly in Ohio, Indiana and Kentucky: Denison University Science Laboratory, Bulletin 17, p. 17-22.

1913, The identification of Trenton and lower geological horizons: Kentucky Geological Survey Report, ser. 4, v. 1 , pt. 1 , p. $365-376$.

1914, The Rogers Gap fauna of central Kentucky: Cincinnatian Society Natural History Journal, v. 21, no. 4, p. $109-156$, pls. $1-4$.

1916, Upper Ordovician Formations in Ontario and Quebec: Canada Department of Mines, Geology Survey, Memoir 83, p. i-iv, 271 p.

Foord, A. H., 1883, Contributions to the micro-palaeontology of the Cambro-Silurian rocks of Canada: Canada, Geological and Natural History Survey, 26 p., 7 pls.

Ford, J. P., 1968, Upper Ordovician stratigraphic relations between Covington and Clays Ferry, Kentucky: American Association of Petroleum Geologists, Bulletin 52, p. 1779-1791.

Fritz, M. A., 1957, Bryozoa (mainly Trepostomata) from the Ottawa Formation (Middle Ordovician) of the Ottawa-St. Lawrence Lowland: Canada Geological Survey, Bulletin 42,75 p., 30 pls.

1970, Redescription of type specimens of the bryozoan Hallopora from the Upper Ordovician of Toronto Region,
Ontario: Geological Association of Canada, Proceedings, v. 21 , p. $15-23,3$ pIs.

1976, Redescription of type specimens of species of the bryozoan genera Monticulipora, Mesotrypa, Peronopora from the Upper Ordovician rocks of Toronto and vicinity, Ontario, Canada: Life Science Contribution, Royal Ontario Museum, no. 107, 24 p.

Gibbons, A. B., 1972, Geologic map of parts of the Burlington and Addyston Quadrangles, Boone County, Kentucky: U.S. Geological Survey, Geologic Quadrangle Map GQ-1025, 1:24000.

Grabau, A. W., and Shimer, H. W., 1909, North American Index fossils, v. 1: New York, A. G. Seiler, 853 p.

Hall, James, 1851, New genera of fossil corals from the Report by James Hall on Paleontology of New York: American Journal of Science and Arts, 2nd ser. 11, p. $398-401$.

1852, Paleontology of New York, 11: Containing descriptions of the organic remains of the lower middle divisions of the New York System: Albany, C. V. Benthuysen, 362 p., 84 pls.

Hayes, C. W., and Ulrich, E. O., 1903, Columbia Folio, Tennessee: U.S. Geological Survey, Geologic Atlas of the United States, no. 95, 6 p., 1 pl.

Healy, N. D., and Utgaard, John, 1979, Ultrastructure of the skeleton of the cystoporate bryozoans: in Larwood, G. P., and Abbott, M. B., eds., Advances in bryozoology, special v. 13: London and New York, Systematics Association, Academic, p. 179-194, 2 pls.

I.C.Z.N. [International Commission on Zoological Nomenclature], 1968, Opinion 838, Designation under the Plenary Powers of the type species in harmony with accustomed usage for the genera Heterotrypa Nicholson, 1879, and Peronopora Nicholson, 1881 (Class Bryozoa) (Ordovician). Opinions and Declarations rendered by the International Commission on Zoological Nomenclature, v. 24, pt. 6, p. 835-841.

Jacobson, J. R., 1979, Acritarchs as paleoenvironmental indicators in Middle and Upper Ordovician rocks from Kentucky, Ohio, and New York: Journal of Paleontology, v. 53 , no. 5, p. 1197-1212.

James, J. F., 1894, Manual of the Paleontology of the Cincinnati Group, pt. 5: Cincinnati Society of Natural History Journal, v. 16, p. 179-208.

1896, Manual of the Paleontology of the Cincinnati Group, v. 28: Cincinnati Society of Natural History Journal, p. 115-140.

James, U. P., 1871, Catalogue of Lower Silurian Fossils, Cincinnati Group: Cincinnati, U. P. James.

1875, Catalogue of Lower Silurian Fossils of the Cincinnati Group, with descriptions of some new species of corals and Polyzoa, Cincinnati, U. P. James.

1878, Descriptions of newly discovered species of fossils from the Lower Silurian Formation, Cincinnati Group: The Paleontologist, no. 1, p. 1-8.

1883, Descriptions of new species of fossils from the Cincinnati Group, Ohio and Kentucky: The Paleontologist, no. 7, p. 57-59, 2 pls.

1884, Descriptions of three species of fossils: Cincinnati Society of Natural History Journal, v. 7, p. 21-24.

James, U. P., and James, J. F., 1888, On the Monticuliporoid corals of the Cincinnati Group, with a critical revision of the species: Cincinnati Society of Natural History Journal, v. 10, p. 158-184.

Karklins, O. L., 1969, The cryptostome Bryozoa from the Mid- 
dle Ordovician Decorah Shale, Minnesota: Minnesota Geological Survey Special Publication Series, SP-6, 121 p.

1983, Ptilodyctyoid Cryptostomata Bryozoa from the Middle and Upper Ordovician rocks of Central Kentucky: Paleontological Society Memoir 14 (Journal of Paleontology, v. 57, no. 1, suppl.), 31 p.

Kay, G. M., 1968, Ordovician formations in northwestern New York: Naturaliste Canadien, v. 95, p. 1373-1378.

Kentucky Geological Survey, 1979, Generalized geologic map of Kentucky: University of Kentucky, Lexington.

Liberty, B. A., 1969, Palaeozoic geology of the Lake Simcoe area, Ontario: Canada Geological Survey Memoir 355, 201 p., 30 pls.

Luft, S. J., 1971, Geologic map of part of the Covington quadrangle northern Kentucky: U.S. Geological Survey, Geologic Quadrangle Map. GQ-955.

Marintsch, E. J., 1981, Taxonomic reevaluation of Prasopora simulatrix Ulrich (Bryozoa: Trepostomata): Journal of Paleontology, v. 55, no. 5, p. 957-961.

Männil, R. M., 1961, K morfologii polusfericheskikh mshanok otriada Trepostomata [On the morphology of the hemispherical Bryozoa of the order Trepostomata]: Eesti NSV Teaduste Akadeemia Geoloogia Instituudi Uurimused, v. 6, p. 113-140.

McFarlan, A. C., 1931, The Ordovician fauna of Kentucky, in Jillson, W. R., ed., Paleontology of Kentucky: Kentucky Geological Survey Report, ser. 6, v. 36, p. 47-165, 15 pls. 1938, Stratigraphic relationships of the Lexington, Perryville, and Cynthiana (Trenton) rocks of Central Kentucky: Geological Society of America Bulletin, v. 49, p. 989-996.

1943, Geology of Kentucky: Lexington, Kentucky, University of Kentucky, $531 \mathrm{p}$.

McFarlan, A. C., and Freeman, L. B., 1935, Rogers Gap and Fulton Formations in central Kentucky: Geological Society of America Bulletin, v. 46, p. 1975-2006, pls. 183-185.

McFarlan, A. C., and White, W. H., 1948, Trenton and preTrenton of Kentucky: American Association of Petroleum Geologists Bulletin, v. 32, no. 8, p. 1627-1646, 8 figs.

McKinney, F. K., 1969, Bibliography and list (1900-1965) of the families Constellariidae and Dianulitidae (Ectoprocta, Order Cystoporata), Southeastern Geology, v. 10, no. 3 , p. 175-184.

1971, Trepostomatous Ectoprocta (Bryozoa) from the lower Chickamauga Group (Middle Ordovician), Wills Valley, Alabama: Bulletins of American Paleontology, v. 60 , no. 267 , p. $193-337$, pls. $46-68$.

1974, Bibliography and catalogue (1900-1969) of the Trepostomata (phylum Ectoprocta): Southeastern Geology, Special Publication, no. 4, 147 p.

1975, Autozooecial budding patterns in dendroid stenolaemate bryozoans, "Bryozoa 1974" Documents, pt. 1 Laboratoires Geologie Faculte des Sciences Lyons-H.S. 3, p. $65-76,4$ pls.

1977, Autozooecial budding patterns in dendroid Paleozoic bryozoans: Journal of Paleontology, v. 51, no. 2, p. $303-329,9$ pls.

Miller, A. M., 1925, Geology of Woodford County: Kentucky Geological Survey Reports, Series 6, v. 21, p. 119-144.

Miller, S. A., 1889, North American Geology and Paleontology: Cincinnati, $664 \mathrm{p}$.

Milne-Edwards, Henry, and Haime, Jules, 1851, Monographie des polypiers fossiles des terrains Palaéozoïques, précédée d'un tableau general de la classification des polypes:
Paris, Archives du Muséum d'Histoire Naturelle, v. 5, 504 p., 20 pls.

Nicholson, H. A., 1874, 38. Descriptions of species of Chaetetes from the Lower Silurian rocks of North America: Quarterly Journal of Geological Society of London, v. 30, p. 499-515.

1875, Description of the corals of the Silurian and Devonian systems: Ohio Geological Survey report, v. 2, Geology and Paleontology, part 2, Paleontology, p. 181-268, pls. 20-25.

1876, Notes on the Palaeozoic corals of the State of Ohio: Annual Magazine Natural History, ser. 4, v. 18, p. 85-95, pl. 5 .

1879 , On the structure and affinities of the "tabulate corals" of the Paleozoic period: with critical descriptions of illustrative species: Edinburgh, William Blackwood, 342 p., 15 pls.

1881 , On the structure and affinities of the genus Monticulipora and its sub-genera: Edinburgh, William Blackwood, 240 p., 6 pls.

Nicholson, H. A., and Etheridge, R., Jr., 1877, On Prasopora grayae, a new genus and species of Silurian corals: Annual Magazine Natural History, ser. 4, v. 20, p. 388-392.

Nickles, J. M., 1902, The Geology of Cincinnati: Cincinnati Society of Natural History Journal, v. 20, no. 2, p. 49-100, $1 \mathrm{pl}$.

1905, The Upper Ordovician rocks of Kentucky and their Bryozoa: Kentucky Geological Survey Bulletin 5, 64 pages, 3 pls.

Nickles, J. M., and Bassler, R. S., 1900, A synopsis of American fossil Bryozoa, including bibliography and synonymy: U.S. Geological Survey Bulletin 173, 663 p.

Nye, O. B., Jr., Dean, D. A., and Hinds, R. W., 1972, Improved thin section techniques for fossil and recent organisms: Journal of Paleontology, v. 46, no. 2, p. 271-275, 1 pl.

d'Orbigny, Alcide, 1850, Prodrome de paléontologie stratigraphique universelle, v. 1: Paris, Victor Masson, p. i-lx, $394 \mathrm{p}$.

Parks, W. A., 1925, Stratigraphy and correlation of the Dunda Formation, in Stratigraphy, pt. 6 of The stratigraphy and paleontology of Toronto and vicinity: Ontario Department of Mines 32nd Annual Report for 1923, v. 32, p. 7 .

1925, The stratigraphy and paleontology of Toronto and vicinity; pts. 1-4, Addenda et corrigenda: Ontario Department of Mines Annual Report for 1923, v. 32, pt. 7, p. $35-46$, pl. 4 .

Parks, W. A., and Dyer, W. S., 1922, The stratigraphy and paleontology of Toronto and vicinity; Part 2, The Molluscoidea: Ontario Department of Mines 13th Annual Report for 1921 , v. 30 , pt 7, 43 p., 6 pls.

Perry, T. G., and Horowitz, A. S., 1973, Restudy of some Nicholson's types of Palaezoic bryozoans; in Larwood, G. P., ed., Living and fossil Bryozoa, Academic, London, p. $429-436$.

Pojeta, John, Jr., 1979, The Ordovician paleontology of Kentucky and nearby states-Introduction, in Pojeta, John, Jr., ed., Contributions to the Ordovician paleontology of Kentucky and nearby states: U.S. Geological Survey Professional Paper 1066-A, p. A1-A48.

Premik, I., 1924, O Bryozoach sylurskich Podola polskiego: Service Geological de Pologne Travaux, v. 1, p. 157-197, pls. 6,7 .

Rominger, Carl, 1866, Observations on Chaetetes and some related genera, in regard to their systematic position: Pro- 
ceedings of Academy of Natural Sciences of Philadelphia, p. 113-123.

Ross, J. R. P., 1963a, Constellaria from the Chazyan (Ordovician), Isle La Motte, Vermont: Journal of Paleontology, v. 37 , no. 1 , p. $51-56$, pls. 5-6.

1963b, New Ordovician species of Chazyan trepostome and cryptostome Bryozoa: Journal of Paleontology, v. 37, no. 1 , p. $57-63$, pls. 7,8 .

$1963 \mathrm{c}$, The bryozoan trepostome Batostoma in Chazyan (Ordovician) Strata: Journal of Paleontology, v. 37, no. 4, p. 857-866, pls. 106-109.

1964, Morphology and phylogeny of early Ectoprocta (Bryozoa): Geological Society of America Bulletin, v. 75, p. 927-948.

1966, Early Ordovician ectoproct from Oklahoma:

Oklahoma Geology Notes, v. 26, no. 8, p. 218-224.

1967a, Evolution of ectoproct genus Prasopora in Trentonian time (Middle Ordovician) in northern and central United States: Journal of Paleontology, v. 41, no. 2, p. 403-416, pls. $46-50$.

1967b, Champlainian Ectoprocta (Bryozoa), New York State: Journal of Paleontology, v. 41, no. 3, p. 632-648, pls. 67-74.

1969, Champlainian (Ordovician) Ectoprocta (Bryozoa), New York State, pt. II: Journal of Paleontology, v. 43, no. 2 , p. 257-284, pls. $35-49$.

1970a, Distribution, paleoecology and correlation of Champlainian Ectoprocta (Bryozoa), New York State, pt. 111: Journal of Paleontology, v. 44, no. 2, p. 346-382, pls. 67-74.

$1970 \mathrm{~b}$, Discussion of "On the validity of the name Hallopora for a genus of trepostome bryozoan" by R. J. Singh: Journal of Paleontology, v. 44, no. 4, p. 785.

Ruedemann, Rudolf, 1901, Trenton Conglomerate of Rysedorph Hill, Rensselaer Co., N.Y., and its fauna: New York State Museum, Museum Bulletin, v. 49, 226 p., 11 pls.

1912, The Lower Siluric shales of the Mohawk Valley: New York State Museum, Museum Bulletin, v. 162, 151 p., 10 pls.

1925, The Utica and Lorraine formations of New York; pt. 2, Systematic Paleontology; no. 1, Plants, sponges, corals, graptolites, crinoids, worms, bryozoans, brachiopods: New York State and Science Service, Bulletin 262, 171 p., 13 pls.

Ryland, J. S., 1970, Bryozoans: London, Hutchinson University Library, $175 \mathrm{p}$.

Sardeson, F. W., 1901, Problem of the Monticuliporoidea, 1: Journal of Geology, v. 9, p. 1-27, pl. A.

1936, Early bryozoans: Monotrypa, Eridotrypa: The Pan-American Geologist, v. 66, no. 3, p. 179-190.

Simpson, G. B., 1897, A handbook of the genera of the North American Paleozoic Bryozoa: with an introduction upon the structure of living species: State Geologist of New York, 14th Annual Report, p. 407-608, pls. A-E.

Singh, R. J., 1970, On the validity of the name Hallopora for a genus of trepostome bryozoan: Journal of Paleontology, v. 44 , no. 4 , p. 784,785 .

1979, Trepostomatous bryozoan fauna from the Bellevue Limestone, Upper Ordovician, in the tri-state area of Ohio, Indiana and Kentucky: Bulletins of American Paleontology, v. 76, no. 307, p. 159-288, 33 pls.

Spjeldnaes, Nils, 1963, A redescription of the type species of the bryozoan genus Crepipora: Journal of Paleontology, v. 37 , p. 64-68, pls. $9,10$.
Swadley, W. C., 1974, Geologic map of the Glencoe quadrangle, north-central Kentucky: U.S. Geological Survey Geologic Quadrangle Map GQ-1154, 1:24000.

Swadley, W. C., Luft, S. J., and Gibbons, A. B., 1975, The Point Pleasant tongue of the Clays Ferry Formation, northern Kentucky: U.S. Geological Survey Bulletin 1405-A, p. 30-31.

Sweet, W. C. 1979, Conodonts and conodont biostratigraphy of post-Tyrone Ordovician rocks of the Cincinnati region: U.S. Geological Survey Professional Paper 1066-G, 25 p.

Sweet, W. C., and Bergström, S. M., 1971, The American Upper Ordovician Standard, xiii, A revised time-stratigraphic classification of North American upper Middle and Upper Ordovician rocks: Geological Society of America Bulletin, v. 82, p. 613-628.

1976, Conodont biostratigraphy of the Middle and Upper Ordovician of the United States mid-continent, in Bassett, M. G., ed., The Ordovician system: Proceedings of a Palaeontological Association symposium, Birmingham, September 1974; Cardiff, University of Wales Press and National Museum of Wales, p. 121-151.

Tavener-Smith, Roland, 1969, Wall structure and acanthopores in the bryozoan Leioclema asperum Lethaia, v. 2, p. 89-97.

Tavener-Smith, Roland, and Williams, Alwyn, 1972, The secretion and structure of the skeleton of living and fossil Bryozoa: Royal Society of London, Philosophical Transactions, Series B, Biological Sciences, v. 264, p. 97-159, pls. 6-30.

Twenhofel, W. H., 1938, Geology and paleontology of the Mingan Islands, Quebec: Geological Society of America Special Paper 11, 132 p., 24 pls.

Ulrich, E. O., 1878, Descriptions of some new species of fossils, from the Cincinnati Group: Cincinnati Society of Natural History Journal, v. 1, p. 92-100, pl. iv.

1879, Descriptions of a new genus and some new species of Bryozoa from the Cincinnati Group: Cincinnati Society of Natural History Journal, v. 2, p. 119-131, pl. xii.

1882, American Paleozoic Bryozoa: Cincinnati Society of Natural History Journal, v. 5, p. 121-175, pls. vi-viii; p. 232-257, pls. x, xi.

1883, American Paleozoic Bryozoa: Cincinnati Society of Natural History Journal, v. 6, p. 82-92, pl. i; p. 148-168, pls. vi, vii; p. 245-279, pls. xii-xiv.

1884, American Paleozoic Bryozoa: Cincinnati Society of Natural History Journal, v. 7, p. 24-51, pls. i-iii.

1886, Report on the Lower Silurian Bryozoa with preliminary descriptions of some of the new species: Minnesota Geological and Natural History Survey, Annual Report 14, p. 57-103.

1888, A correlation of the Lower Silurian horizons of Tennessee and of the Ohio and Mississippi valleys with those of New York and Canada: American Geologist, v. 2, p. $39-44$.

1890, Paleozoic Bryozoa: Illinois Geological Survey, v. 8, p. $285-688$, pls. xxix-lxxviii.

1893, On Lower Silurian Bryozoa of Minnesota: Minnesota Geological and Natural History Survey, Final Report, v. 3, pt. 1, p. 96-332, 13 figs. 28 pls. (Author's separate, 1893; volume published 1895).

Ulrich, E. O., and Bassler, R. S., 1904, A revision of the Paleozoic Bryozoa, pt. 2, On genera and species of Trepostomata: Smithsonian Miscellaneous Collections, v. 47, no. 1470 , p. $15-55$, pls. $6-14$. 
Utgaard, John, 1968a, A revision of North American genera of ceramoporoid bryozoans (Ectoprocta), pt. 1, Anolotichiidae: Journal of Paleontology, v. 42, no. 4, p. 1033-1041, pls. 129-132.

$1968 \mathrm{~b}$, A revision of North American genera of ceramoporoid bryozoans (Ectoprocta), pt. 2, Crepipora, Ceramoporella, Acanthoceramoporella, and Ceramophylla: Journal of Paleontology, v. 42, no. 6, p. 1444-1455, pls. 181-184.

1969, A revision of North American genera of ceramoporoid Bryozoans (Ectoprocta), pt. 3, The ceramoporoid genera Ceramopora, Papillalunaria Favositella and Haplotrypa: Journal of Paleontology: v. 43, no. 2, p. 289-297, pls. 51-54.

1973, Mode of colony growth, autozooids, and polymorphism in the bryozoan order Cystoporata, in Boardman, R. S., Cheetham, A. H., and Oliver, W. A., Jr., eds., Animal colonies: Stroudsburg, Pa., Dowden, Hutchinson and Ross, p. 317-360.

1983a, Paleobiology and taxonomy of the order Cystoporata: Bryozoa, pt. G (revised vol. 1) of Robison, R. A., ed., Treatise on invertebrate paleontology: Geological Society of America and University of Kansas Press, p. 327-357.

1983b, Systematic descriptions for the order Cystoporata: Bryozoa, pt. G (revised, vol. 1) of Robison, R. A., ed., Treatise on invertebrate paleontology: Geological Society of America and University of Kansas Press, p. $358-439$.

Utgaard, John, and Boardman, R. S., 1965, Heterotrypa Nicholson, 1879, and Peronopora Nicholson, 1881 (Bryozoa, Trepostomata): Proposed designation of a type-species in conformity with generally accepted usage: Bulletin of
Zoological Nomenclature, v. 22, pt. 2, p. 112-118.

Utgaard, John, and Perry, T. G., 1964, Trepostomatous bryozoan fauna of the upper part of the Whitewater Formation (Cincinnatian) of eastern Indiana and western Ohio: Indiana Departament of Conservation Geological Survey Bulletin 33, 111 p., 23 pls.

Vinassa de Regny, P. E., 1921, Sulla classificazione dei treptostomidi: Societa Italiana di Scienze Naturali Atti, v. 59 , for 1920 , p. 212-231.

Webers, G. F., 1972, Paleoecology of the Cambrian and Ordovician strata of Minnesota: p. 474-484, in Sims, P. K., and Morey, G. B., eds., Geology of Minnesota: a Centennial volume, Minnesota Geological Survey, $632 \mathrm{p}$.

Weir, G. W., and Greene, R. C., 1965, Clays Ferry Formation (Ordovician)-A new map unit in south-central Kentucky: U.S. Geological Survey Bulletin 1224-B, 18 p.

Weiss, M. P., 1957, Upper Middle Ordovician stratigraphy of Fillmore County, Minnesota: Geological Society of America Bulletin, v. 68, no. 8, p. 1027-1062.

Weiss, M. P., and Sweet, W. C., 1964, Kope Formation (Upper Ordovician): Ohio and Kentucky: Science, v. 145, p. 1296-1302.

Wilson, A. E., 1921, The range of certain Lower Ordovician faunas of the Ottawa Valley with descriptions of some new species: Department of Mines, Canada Geological Survey Bulletin 33, p. 19-57, pls. 2-4.

Wilson, A. E., and Mather, K. F., 1916, Synopsis of the common fossils of the Kingston area: Ontario Department of Mines Annual Report, v. 25, pt. 3, app. 2, p. 45-67, 3 pls.

Wilson, C. W., Jr., 1949, Pre-Chattanooga stratigraphy in central Tennessee: Tennessee Department of Conservation, Division of Geology, Bulletin 56, 407 p., 28 pls. 


\section{INDEX}

[Major references are in italics]

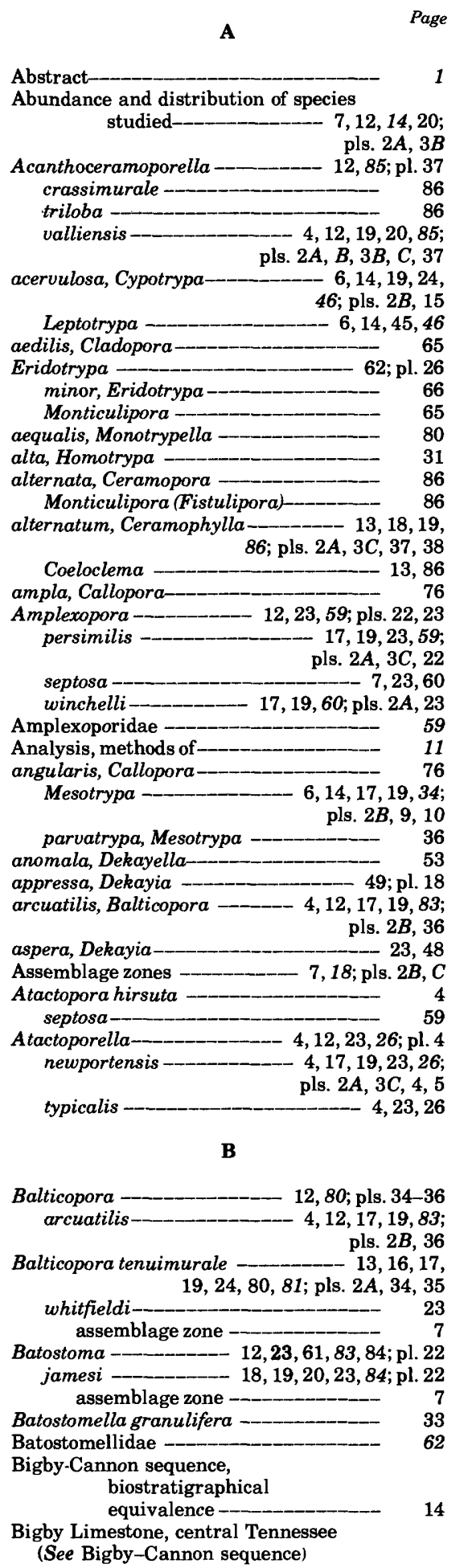

Page

Biostratigraphical comparisons _-___ 20,25;

pl. $2 C$

Blackriveran strata, first occurrences of species studied

Blue Grass region, Kentucky-_-_- $14,18,20$

Brannon Member, Lexington Limestone-

- $4,18,21 ;$ pl. $2 B$

$\mathbf{C}$

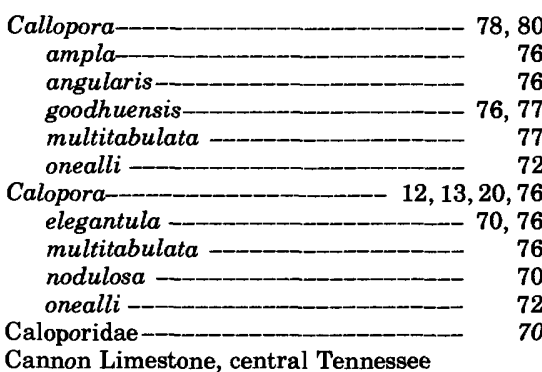

(See Bigby-Cannon sequence)

$\begin{array}{lr}\text { Central Tennessee region - } & 13 \\ \text { Ceramophylla } & 12,86 \text {; pls. } 37,38\end{array}$

alternatum -_-_____-_ $13,18,19,86$ pls. $2 A, 3 C, 37,38$

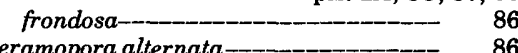

Ceramopora alternata-__-___ 86

Cramoporella - 12,86,89; pl. 38 distincta -___- $18,19,22,89$; pls. $3 C, 38$ granulosa _-___________ 85

Ceramoporidae ______ 25, 85

Chaetetes -______________________

decipiens -

granuliferus _-_______________ 32

nodulosa -

O'Nealli__________________________

venustus______________ 4, 4

Champlainian Provincial Series ____ 20,24,

Chaumont Formation, Trenton pl. $2 C$

$\begin{array}{lr}\text { Group-- } & 13 \\ \text { Cincinnati region - } & 2,20 \\ \text { Cincinnatian Provincial Series } & 20 \\ \text { Cladopora aedilis - } & 65 \\ \text { clavata, Dekayella- } & 53 \\ \text { clavis, Leptotrypa - } & 56 \\ \text { Stigmatella } & \text { pls. } 2 A, 3 C, 21\end{array}$

Clays Ferry Formation_____ 2, 14, 18, 19, 21;

pl. $1 B$

dominant species_-________-_ 15

Point Pleasant Tongue -_-______ 4

Coeloclema -_-___-_ 86

alternatum-________________ 13, 86

vaupeli-_____________ 86

compacta, Prasopora_-_______________ $\quad 45$

Cobourg Formation, Trenton Group_-_ 13, 20,24

Composition of species studied _-_____ $\quad 12$

conica, Stigmatella -___________ $\quad 59$

Constellaria - ________ 12,93; pl. 35

abundance and geographic restrictions

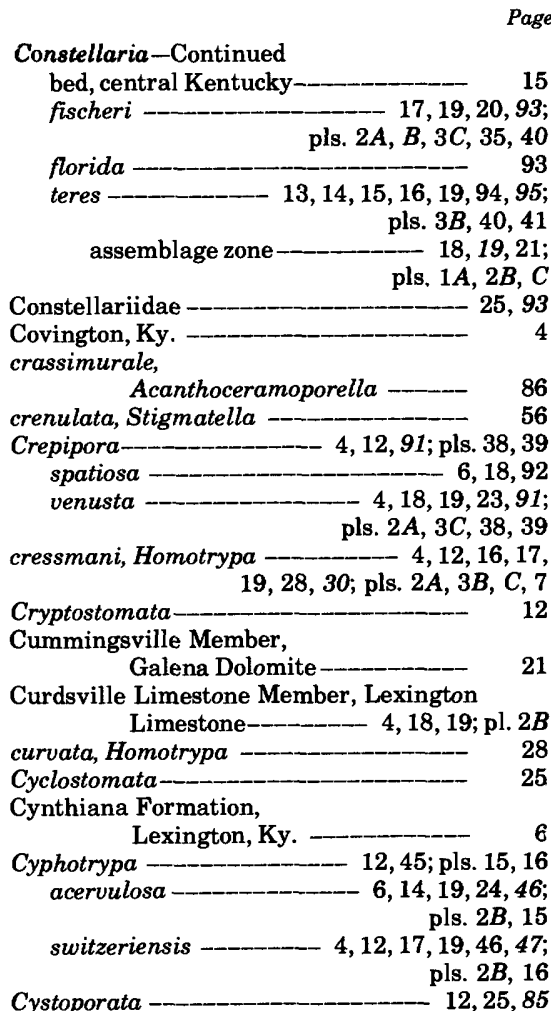

D

decipiens, Chaetetes -________- 38

Peronopora _-___________ $\quad 39$

Decorah Shale, Minnesota _-____ 13, 21

correlation with Trenton Group,

$\begin{array}{cc}\text { New York } & 13 \\ \text { Dekayella-_- } & 55 \\ \text { anomala_- } & 53\end{array}$

$\begin{array}{ll}\text { anomala-___ } & 53 \\ \text { clavata-__- } & 53\end{array}$

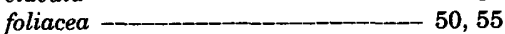

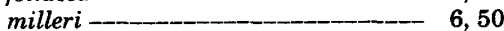

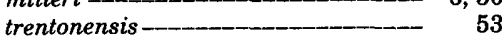

ulrichi-____________________ 6

Dekayia -_____ 12, 14, 48; pls. 17-20

appressa -_______ $49 ; \mathrm{pl} .18$

aspera -_____________ 23,48

assemblage zone -__________ 7

epetrima ___ $4,12,17,19,48$; pls. $2 A, 17$

sugarensis _-____ 50 trentonensis_____________________ 63 sp. - $17,19,20,49$; pls. $2 A, B, 3 C, 18$

Denmark Formation

Trenton Group-_-_-_-_ 24

Depositional environments in study area -

Devils Hollow Member, Lexington Limestone -_-_-_ 15

Diamesopora- 88,89

trentonensis___________________ 86

vaupeli_________________ 86

Dianulitidae - 


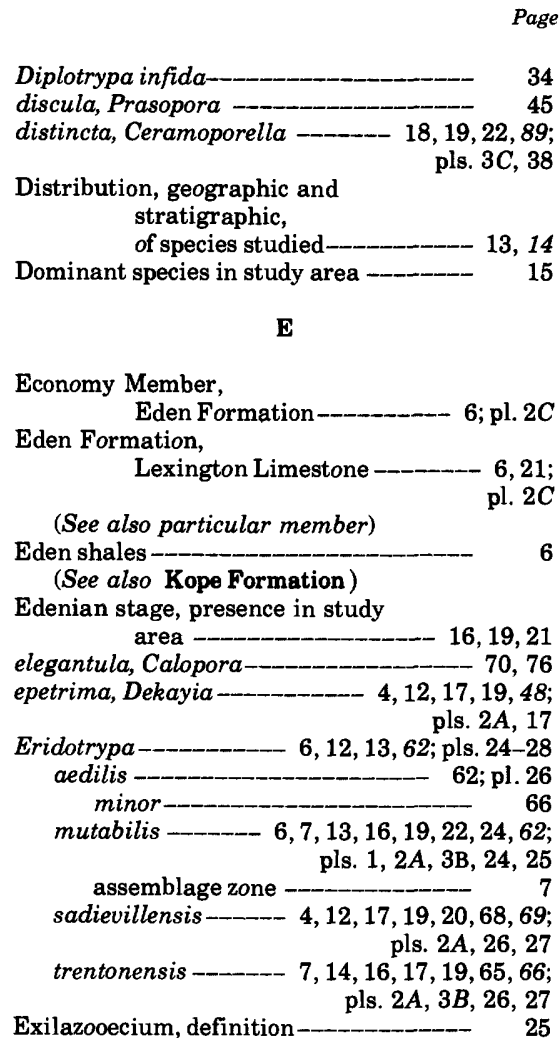

$\mathbf{F}$

falesi, Monticulipora-______ $4,42,43$ Prasopora -_ 4, 16, 17, 19, 42;

First occurrences of species pls. $1 A, 2 B, 3 B, 13,14$ studied -

$13,14,19 ; \mathrm{pl} .2 \mathrm{C}$

fischeri, Constellaria _-____ $17,19,20,93$;

(Fistulipora) alternata, Monticulipora - $\quad 86$ granulifera, Monticulipora_________ 33 venusta, Monticulipora_______ 91

Fistuliporidae -

florida, Constellaria _-__________ 93

foerstei, Heterotrypa_________ $50 ; \mathrm{pl} .19$

foliacea, Dekayella -_____ 50,55 Heterotrypa -_- 6, 15, 16, 19, 20, 23, 50; frondosa, Ceramophylla___ pls. $3 B, 15,16,19$ Monticulipora-_- 50

G

Galena Dolomite, Minnesota _______ 14, 21 Garrard Siltstone ________ 2,19

Geographic distribution of species studied-_-_- 13

goodhuensis, Callopora________ 76, 77 granulifera, Batostomella-______-_ 33

Monticulipora (Fistulipora)_____-_- $\quad 33$ granuliferus, Chaetetes-_-_-_- 32 granulosa, Ceramoporella _-____-_ 85 grayae, Prasopora--_-_-_-_-_-_ 42 Grier Limestone Member, Lexington Limestone - $-4,7,17,18,19$; pls. $2 A, B, 3 B$

depositional environment______ $\quad 15$

\section{H}

Halloporamultitabulata

$4,13,70,78$ 7, $77 ;$ pl. 33

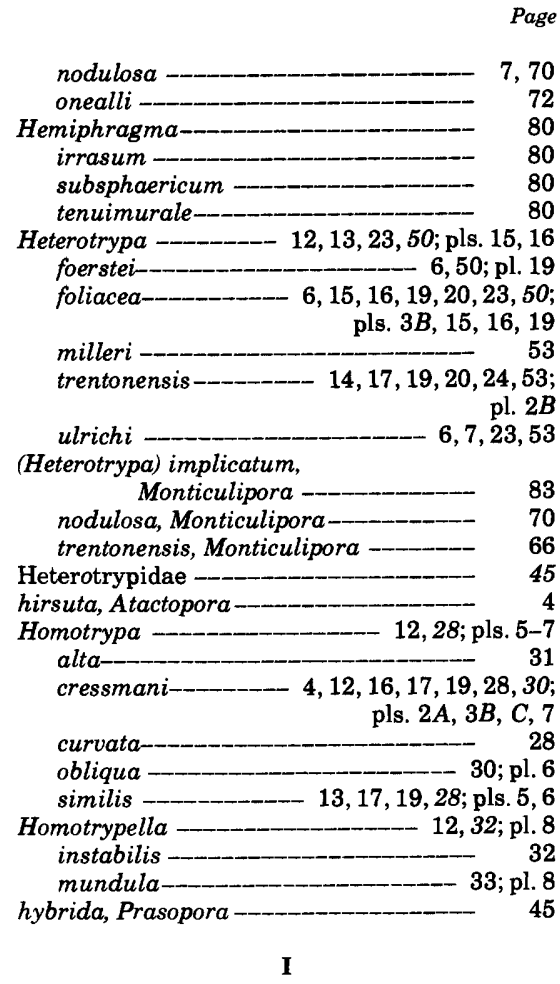

Immigrant species, biostratigraphic comparisons and provenance --

implicatum, Monticulipora (Heterotrypa)

Indigenous species in study area -_- 14; pls. $2 A, C$ infida, Diplotrypa --_-_-_- 34 infrequens, Trematopora _-_____-_-_ 89 instabilis, Homotrypella -_-_-_-_-_ Introduction irrasum, Hemiphragma-_-_-_-- 80 J

jamesi, Batostoma_______ 18, 19, 20, 23, 84;

$\mathbf{K}$

kentuckensis, Monticulipora-______ 4,77 Kentucky-Ohio-Indiana, tristate area of study --

Kirkfield Formation, Trenton Kope Formation-_- 24 depositional environment______- 6

\section{$\mathbf{L}$}

Leptotrypa acervulosa - 6,14,45 clavis Lexington Limestone-____-_ 2, 6, 14, 18, 21 biographical significance of fauna -

dominant species-_-_- 15

(See also particular member)

Lexington, $\mathbf{K y}$.

Limestone content of rocks, and

abundance of species-_-_-_ 15

Localities - $5 f, 8,9 f$, pls. $1,3 A$

Logana Member, Lexington Limestone - 7, 18
Page

$\mathbf{M}$

Macula, definition-___-_ 26

Materials and methods of study -____ $\quad 11$ McMicken Member, Eden

Formation -

Mesotrypa - 12, 34; pls. 9, 10 angularis__ $6,14,17,19,34$; pls. $2 B, 9,10$

parvatrypa-____ 34 pl. 36 spinosa-_ $34 ;$ pl. 10
sp. $18,19,20,36 ;$ pls. $1 C, 10$ Mesozooecium, definition _-_______ 25 milleri, Dekayella __________ 6,50

Heterotrypa - 53

Peronopora - 6, 16, 17, 19, 20,38; pls. $2 A, 3 B, C, 10,11$

Millersburg Member, Lexington Limestone

minima, Stictopora -___-_-_-_-_

Minnesota-Iowa region _-_____ 2,13

minor, Eridotrypa aedilis __________ 66

Monotrypella_-_ $\quad 76$

aequalis_-____________________ 80

multitabulata ________ 6,75

trentonensis_-____________________ 66

Monticulipora aedilis______________ 65

falesi -_____ 4, 42

(Fistulipora) alternata_________ $\quad 86$ granulifera -__________ 33 venusta _-____________ 91

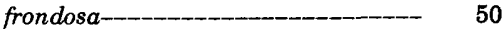

(Heterotrypa) implicatum -_-__-_- 83 nodulosa-_- 70 trentonensis_-_______-_ $\quad 66$

kentuckensis ______________ $\quad 77$

kentuckiensis_-___________ 4

newportensis -_-_________ 26

nodulosa -_ 70, 71

o'nealli______________________ 72

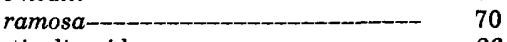

Monticuliporidae -__________ 26

multispinosa, Stigmatella_____ 17, 19,57;

multitabulata, Callopora $\quad$ pls. 2A, 18

Calopora -_-_ $\quad 76$

Hallopora -___ 7, 77; pl. 33

Monotrypella______________ 6, 75

Tarphophragma____ 4, 7, 13, 16, 19,

$24,76,77$; pls. $1 A, B, 2 A, B, 3 B, C, 32,33$

mundula, Homotrypella________ $33 ; \mathrm{pl} .8$

mutabilis, Eridotrypa_____ 6, 7, 13, 16, 22, 24,62 ; pls. $1,2 A, 3 B, 24,25$

Stictopora

78

\section{$\mathbf{N}$}

New taxa, proposed New York-Ontario region _-______ 13 New York State area________________ 2, 20

(See also Trenton Group, New York State)

newportensis, Atactoporella______ 4, 17, 19, 23,26 ; pls. $2 A, 3 C, 4,5$

Monticulipora - _ 26 Monticulipora-C
nodosa, Prasoporanodulosa, Calopora -_____-_ $\quad 70$

Chaetetes -____________ $\quad 70$

Hallopora _-_ 7, 70

Monticulipora - $\quad 70$ (Heterotrypa) - 70

Parvohallopora pls. $1 B, 2 A, 3 B, C, 29,30$

North American standard section, subdivisions-
(1)

.

12
3
0

5
5
5
0
70
0
0
0
70
30


Page

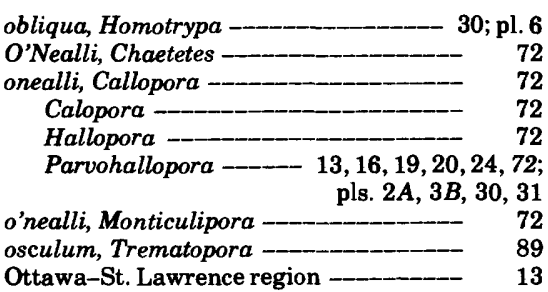

Ottawa-St. Lawrence region

Pamelia beds, Ottawa-St. Lawrence region, first occurrences of species studied-.

Papillalunaria spatiosa_- $18,19,20,92 ;$ pls. $1 B, 39$ Papillaunaria spatiosa -____ 92 parvatrypa, Mesotrypa angularis _-___ $\quad 36$ Parvohallopora -_ 7, 13, 70; pls. 29-31 nodulosa pls. $1 B, 2 A, 3 B, C, 29,30$ onealli ___ 13,16,19, 20, 24, 72 pls. $2 A, 3 B, 30,31$ ramosa-____ 70,75

Peronopora _______ 12, 13, 38; pls. 11, 12 decipiens _________ 39 milleri-__________ $6,16,38$; pls. $2 A, 3 B, C, 10,11$

Peronopora vera _-__ $7,16,19,20,22,40$;

Perryville Limestone Member, pl. 12 Lexington Limestone

$17,19,23,59$ pls. $2 A, 3 C, 22$

Point Pleasant Tongue, Clays Ferry

Prasopora Formation -_- 4,12,42; pls. 13, 14 compacta______________________ 45 discula-______ $4,16,17,19,45$ falesi pls. $1 A, 2 B, 3 B, 13,14$

grayae hybrida -

richmondensis---7simulatrix - 42

\section{$\mathbf{R}$}

ramosa, Monticulipora -________ $\quad 70$ Parvohallopora - 70, 75 Ranges of species_________ 18; pls. 2A-C References cited _-____ 97

Regionalism of species studied -____ $\quad 12$

Relative abundances _______ $7,12,14$; pls. $2 A, 3 B$ patterns of fluctuation _-_____ 20,22 richmondensis, Prasopora _-_____ $\quad 45$ Rockland Formation, Trenton

$$
\text { Group }
$$

correlation with Decorah Shale,

$$
\text { Minn. }
$$

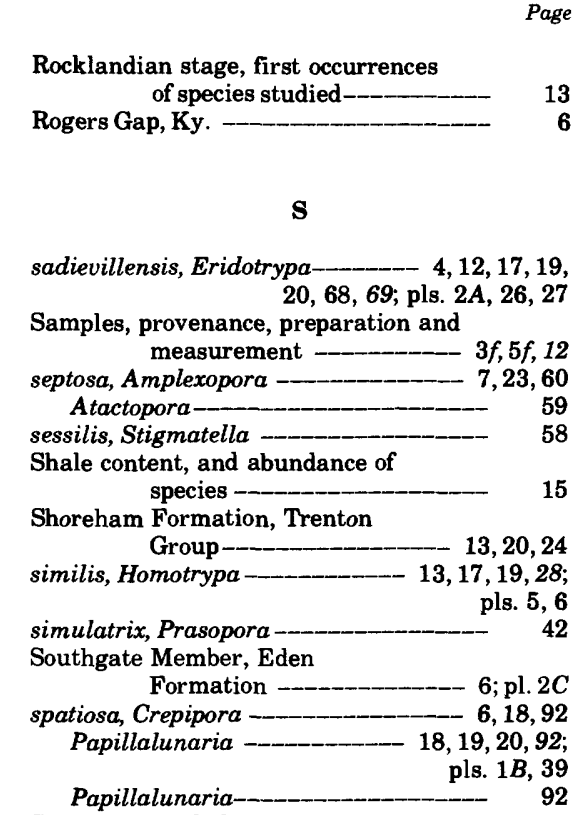

Species studied, dominant

$$
\text { genera -_________ 13, } 15
$$

spinosa, Mesotrypa_________ 34; pl. 10

Stictopora minima

assemblage zone, Decorah Shale

Minnesota -_____ 88

Stigmatella 12, 56; pls. 18,21

clavis____ $16,17,19,20,22,56$;

$\begin{array}{r}\text { pls. } 2 A, 3 C, 21 \\ \hline\end{array}$

\begin{tabular}{rr} 
assemblage zone - $\quad 7$ \\
\hline
\end{tabular}

crenulata-_____ 56

multispinosa_— $17,19,57$; pls. $2 A, 18$

sessilis-_- 58

sp. - $18,19,58$; pl

studied -

Style, definition-

26

subimbricata, Trematopora -_______ 89

subsphaericum, Hemiphragma _-____ 80

sugarensis, Dekayia _- $\quad 50$

Sulphur Well Member, Lexington

Limestone _-_ 4,16 ; pls. $1 A, B$

switzeriensis, Cyphotrypa____ $4,12,17,19$, 46,47 ; pls. $2 B, 16$

Systematic paleontology____

\section{$\mathbf{T}$}

Tanglewood Limestone Member, Lexington Limestone phophragma —_ 4, 12, 75; pls. 32,33 multitabulata _.__ $4,7,13,16,19,24$

76,77 ; pls. $1 A, B, 2 A, B, 3 B, C, 32,33$ assemblage zone-_ $18,19,21$;
Page

tenuimurale, Balticopora -______ 13,16,17, $19,24,80,81$; pls. $2 A, 34,35$

Hemiphragma- 80 teres, Constellaria_____ 14, 15, 16, 19, 94, 95 ; pls. $3 B, 40,41$

Trematopora infrequens -____ 89 osculum____________________ 89 subimbricata_________________ $\quad 89$

Trematoporidae -- $\quad 80$

Trenton Group, New York State_____ $\quad 24$ correlation with Lexington Limestone --_-_

(See also particular member)

trentonensis, Dekayella -_________ $\quad 53$

Dekayia_-________________ 53

Diamesopora-______ 86

Eridotrypa-____ 14, 16, 17, 19,65, 66; pls. $2 A, 26,27$

Heterotrypa -_- 14, 17, 19, 20, 24, 53; pl. $2 B$

Monotrypella____________ $\quad 66$

Monticulipora (Heterotrypa) _____ $\quad 66$

Trepostomata - 12, 25

triloba, Acanthoceramoporella_-_____ 86

typicalis, Atactoporella -_____ 4, 23, 26

Tyrone Limestone, central Kentucky

$2,6,18$

$\mathbf{U}$

\begin{tabular}{lr}
$\begin{array}{l}\text { ulrichi, Dekayella- } \\
\text { Heterotrypa - }\end{array}$ & 6 \\
$\begin{array}{l}\text { Upper Mississippi Valley } \\
\text { region }\end{array}$ & $7,23,53$ \\
Utica shales- & $14 ; \mathrm{pl} .2 C$ \\
\hline
\end{tabular}

(See also Kope Formation)

$\mathbf{v}$

valliensis, Acanthoceramoporella_____ 4, 12 , $17,19,20,26,85$; pls. $2 A, B, 3 B, C, 37$ vaupeli, Ceramopora____________ 86 Coeloclema - 86 Diamesopora _________ 86 venusta, Crepipora _-____ 4, 18, 19, 23, 91; pls. $2 A, 3 C, 38,39$

Monticulipora (Fistulipora)_-_-_ 91 venustus, Chaetetes vera, Peronopora -__ 7, 16, 19, 20, 22, 39, 40; pl. 12

\section{$\mathbf{w}$}

whitfieldi, Balticoporella _-_______ 23 winchelli, Amplexopora - 17, 19,60;

Winchester Group, Lexington pls. $2 A, 23$ Limestone

(See also Lexington Limestone and Clays Ferry Formation) 



\section{PLATES 4-41}

Contact photographs of the plates in this report are available, at cost, from U.S.

Geological Survey Library, Federal Center, Denver, CO 80225. 


\section{PLATE 4}

FIGURES 1, 2. Atactoporella newportensis Ulrich (p. I26).

"Economy Member of Eden strata" (lower Kope Formation of current usage) (Edenian Stage), Newport, Ky.

1. Lectotype USNM 40193; $1 a$, cross-sectional shape of autozooecia in early exozone, styles in autozooecial walls, mesozooecia almost completely separate autozooecia, segment of overgrown part of zoarium in center of figure, tangential section, $\times 30 ; 1 b$, cross-sectional shape of autozooecia in late and early exozone, numerous small styles inflect autozooecial chambers, tangential section, $\times 30 ; 1 c$, cross sectional shape of contiguous autozooecia in endozone, conspecific overgrowth of zoarium (upper left of figure), transverse section, $\times 30 ; 1 d$, encrusting segment of zoarium consisting of two layers of conspecific overgrowth, longitudinal section, $\times 30 ; 1 e$, microstructure of autozooecial and mesozooecial walls and of styles, coalescing mesozooecia, terminal diaphragms of autozooecia, imperforate basal layer and early endozone of conspecific overgrowth, top of figure, transverse section, $\times 100 ; 1$, crosssectional shape of autozooecial chambers, poorly defined autozooecial boundaries, styles in zooecial walls inflect some chambers, tangential section, $\times 30$.

2. Paralectotype USNM 308305; $2 a$, primary branch of zoarium, distribution and shape of monticules, external view, $\times 3 ; 2 b$, autozooecia curve gently outward in endozone, scattered basal diaphragms in autozooecia, longitudinal section, $\times 30$. 


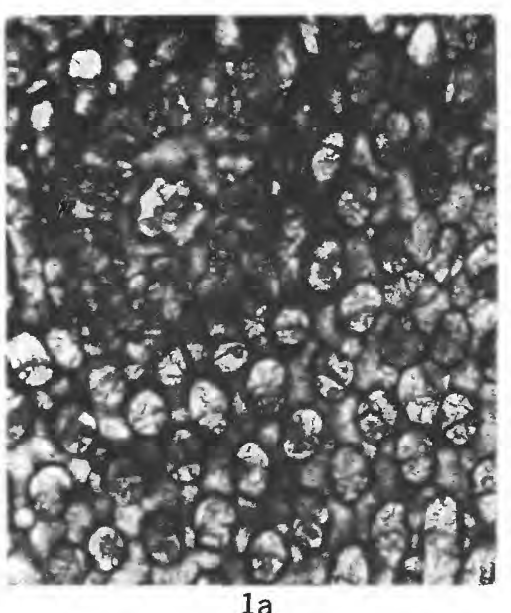

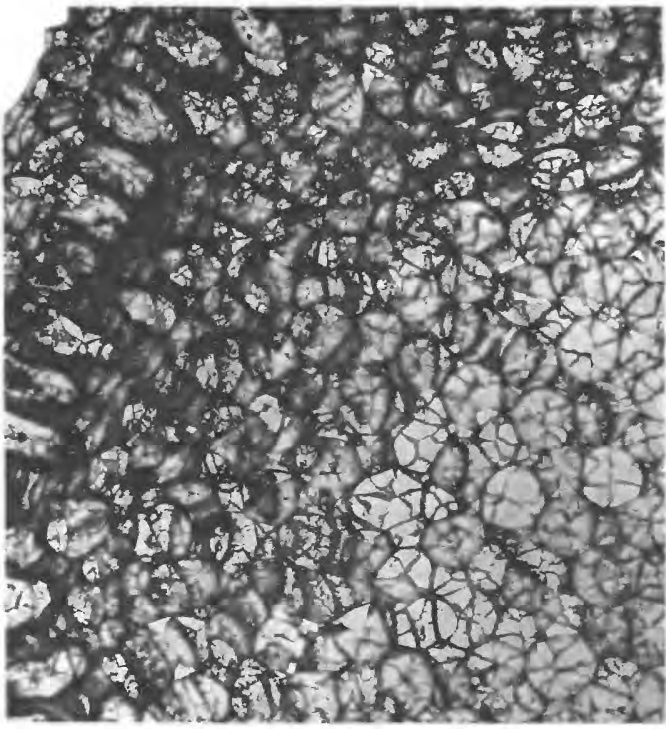

$1 \mathrm{c}$

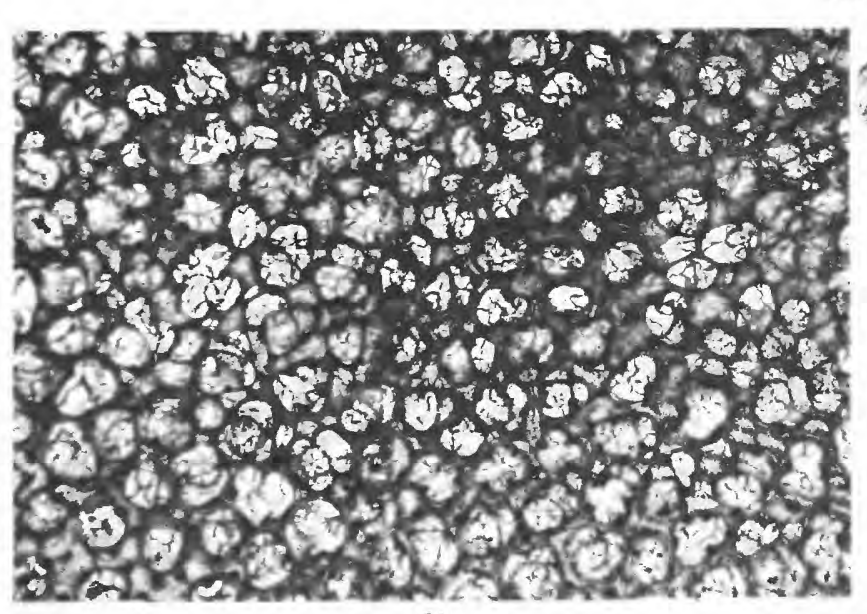

$1 \mathrm{~b}$

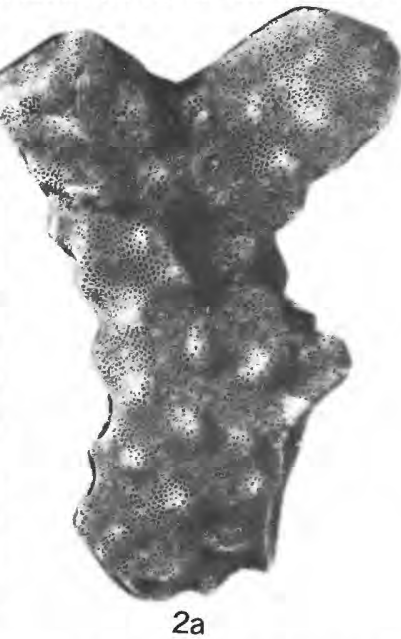

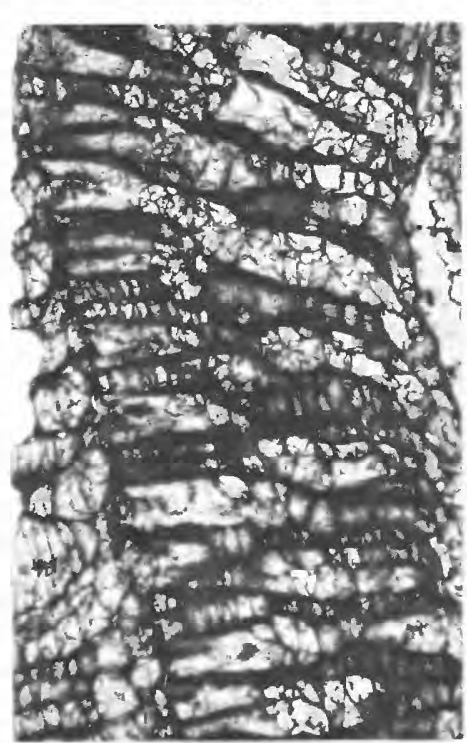

$1 d$

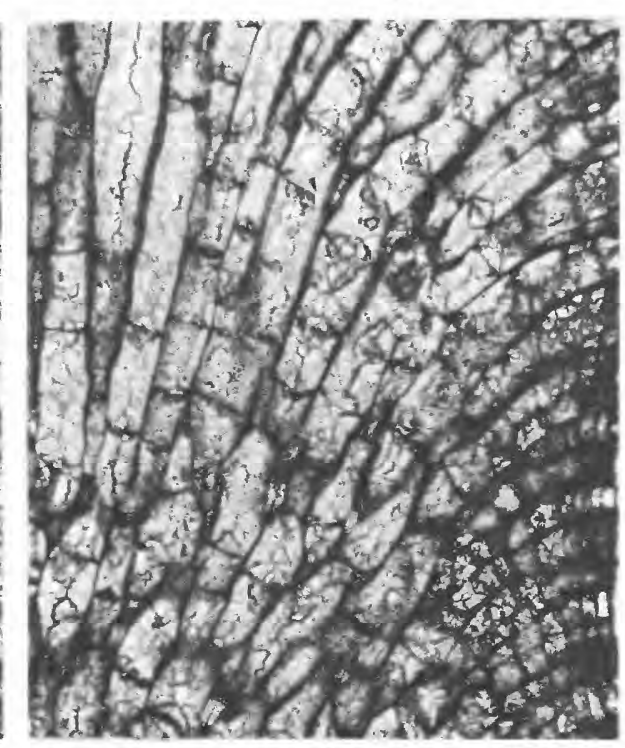

$2 \mathrm{~b}$
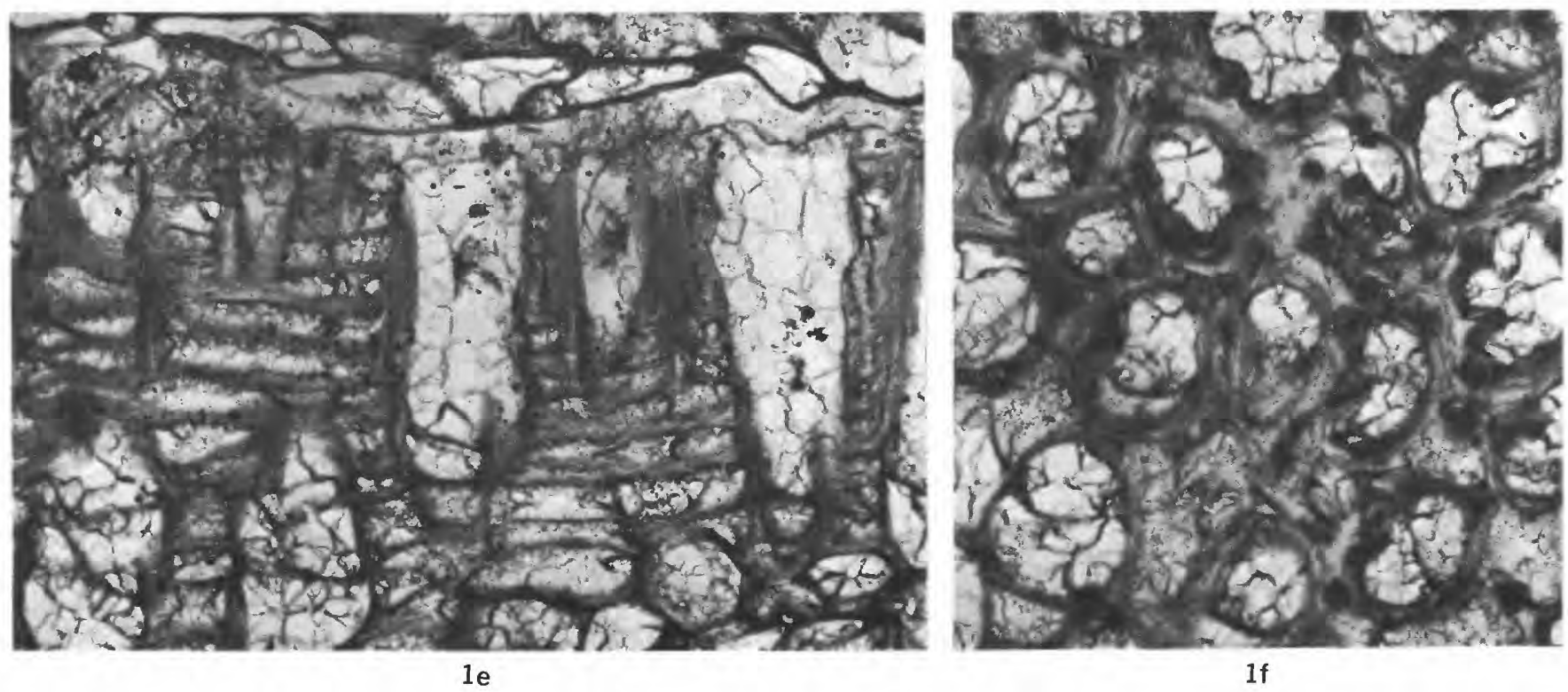

If

ATACTOPORELLA 


\section{PLATE 5}

FiguRES 1, 4. Atactoporella newportensis Ulrich (p. I26).

Hypotypes, Lexington Limestone, Moorefield Quadrangle, Kentucky.

1. USNM 308314, Nicholas Bed, Shermanian Stage (USGS colln. 5031-CO), of Tanglewood Limestone Member; $1 a$, cystiphragms in early exozone, narrow autozooecial boundaries, mesozooecial diaphragms, styles in zooecial walls, longitudinal section, $\times 100 ; 1 b$, zones of rejuvenation with few basal diaphragms, slightly crenulated autozooecial walls in endozone, cystiphragms in exozone, longitudinal section, $\times 30$.

4. USNM 308312, Millersburg Member, Shermanian Stage (USGS colln. 5030-CO); 4a, styles diverge from indistinct autozooecial boundaries, microstructure of zooecial walls, sparse mesozooecia, tangential section, $\times 100 ; 4 b$, numerous styles in a segment of zoarium, tangential section, $\times 30$.

2. Homotrypa similis (Foord) (p. I28).

Hypotype, USNM 309661, "Trenton" strata, Middle Ordovician, Ottawa, Canada; 2a, cross-sectional shape of autozooecia and their chambers, styles poorly defined or absent, maculae (right half of figure) with slightly larger polymorphs and thicker skeletal deposits, tangential section, $\times 50 ; 2 b$, evenly spaced basal diaphragms in endozone, relatively large cystiphragms in early exozone or late endozone, well-defined, narrowly serrated autozooecial boundaries in exozone, longitudinal section, $\times 30$.

3. "Homotrypa similis" of Bassler, 1911 (p. I29).

Hypotype USNM 308342, "Wassalem Beds," D3, Middle Ordovician, Uxnorm, Estonia, U.S.S.R. 3a, cross-sectional shape of autozooecia, small styles with well-defined cores inflect walls of some autozooecia, microstructure of zooecial walls, tangential section, $\times 30 ; 3 b$, cystiphragms in well-defined series in late endozone decreasing in size ontogenetically, cystiphragms in overlapping series in exozone (upper left of figure), broadly serrated autozooecial boundaries in exozone, longitudinal section, $\times 30$. 
GEOLOGICAL SURVEY

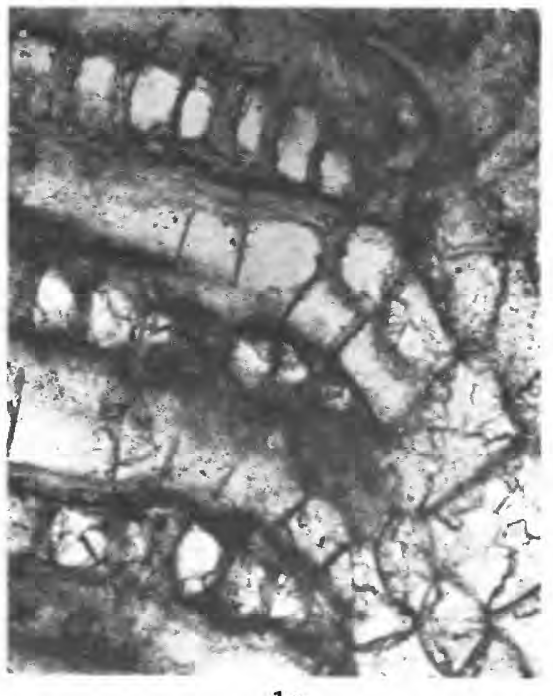

$1 \mathrm{a}$

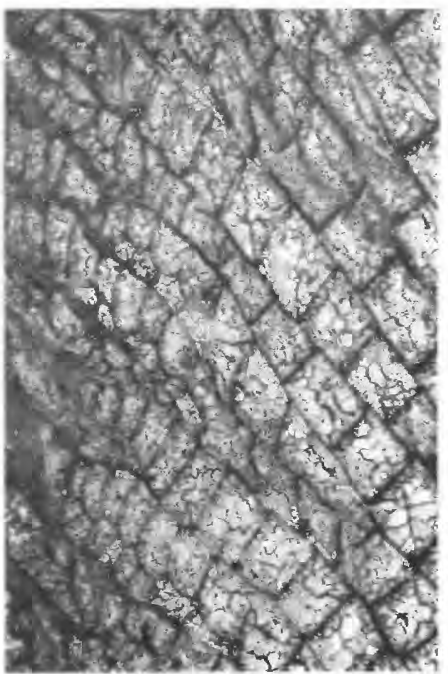

$2 b$

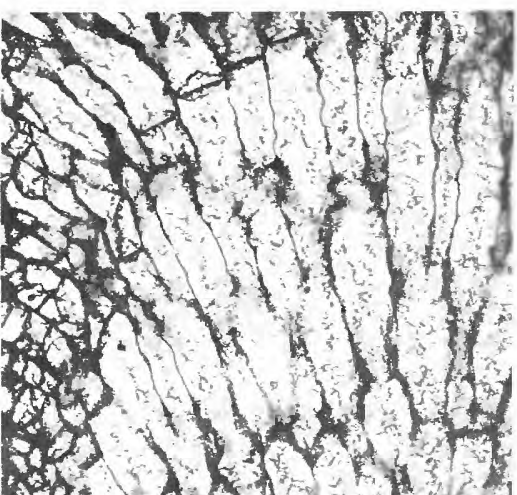
a, $2 x+1$ - 12131

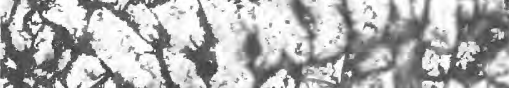
1. 1. a

$1 b$

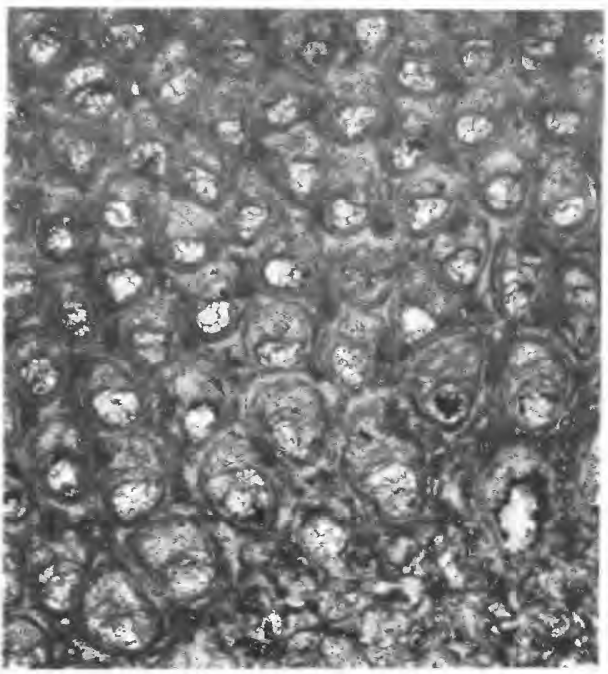

$3 a$

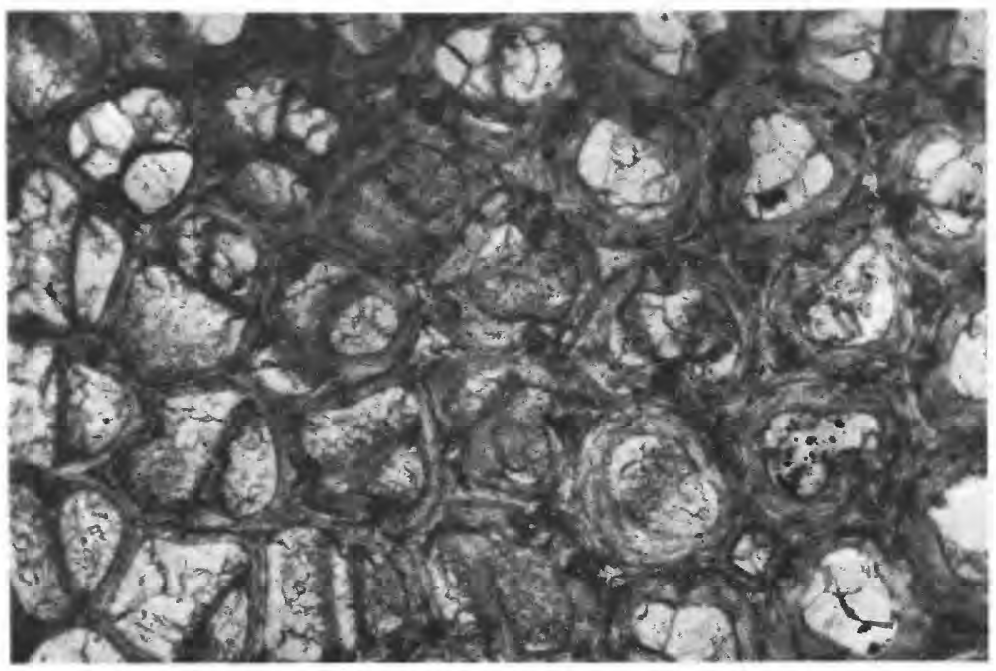

$4 a$
PROFESSIONAL PAPER 1066-I PLATE 5

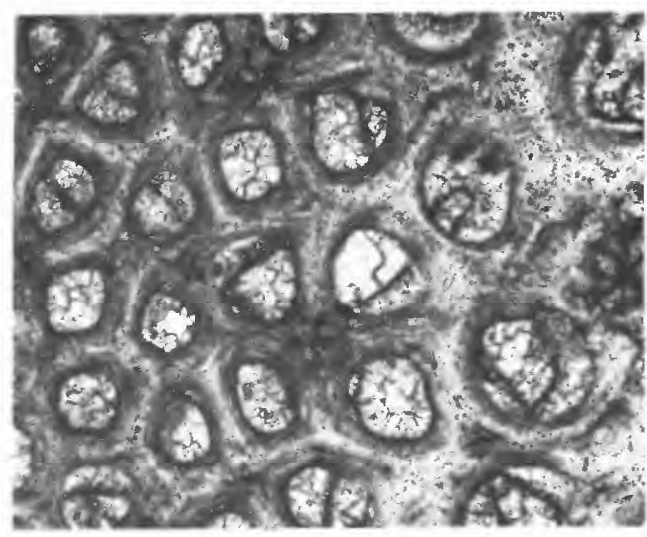

$2 a$

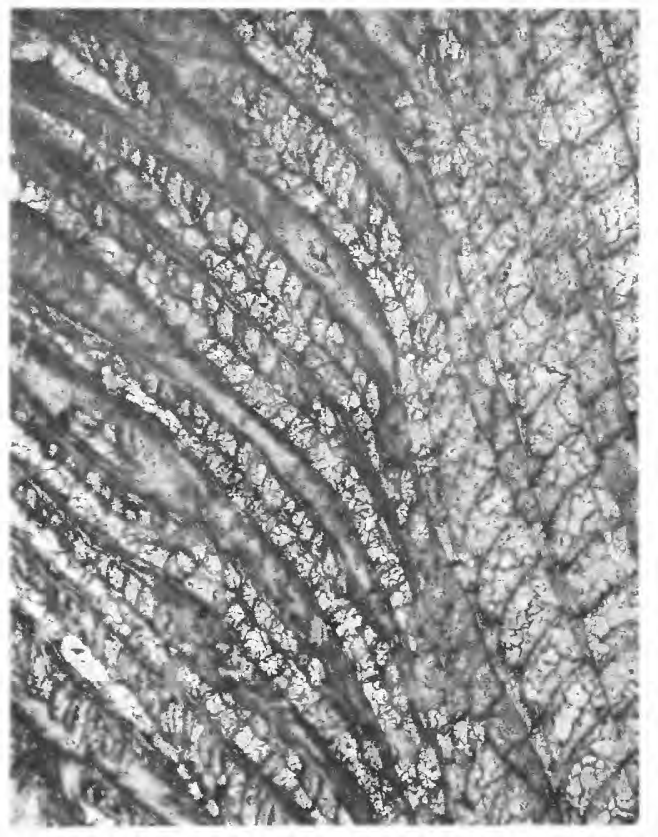

$3 b$

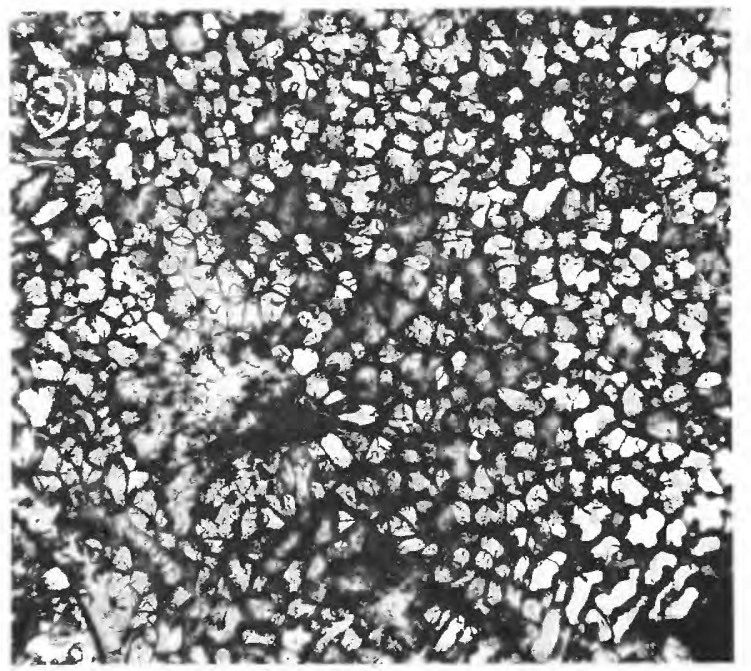

$4 b$

ATACTOPORELLA, HOMOTRYPA 


\section{PLATE 6}

FiguRes 1, 4-6. Homotrypa similis (Foord) (p. I28).

1. Hypotype suite USNM 43995, from the "Trenton" strata, Middle Ordovician, Ottawa, Canada; USNM 30835, "type section" of Ulrich (1893, pl. 20, fig. 30). Cross-sectional shape of autozooecia and their chambers, sparse and poorly defined styles, microstructure of zooecial walls, tangential section, $\times 50$.

4-6. Grier Limestone Member of the Lexington Limestone, Kentucky.

4. Hypotype USNM 308350, Shermanian Stage (USGS colln. 4971-CO), Frankfort West Quadrangle; 4a, relatively well defined autozooecial boundaries in exozone, cross-sectional shape of autozooecial chambers as outlined by cystiphragms and laminated walls, tangential section, $\times 50 ; 4 b$, well-defined and narrowly serrated, somewhat jagged autozooecial boundaries, slightly irregularly shaped overlapping cystiphragms, microstructure of zooecial walls, sparse basal diaphragms, thick exozone, longitudinal section, $\times 50$.

5, 6. Lexington Limestone, type section, Frankfort East Quadrangle.

5. Hypotype USNM 308345, Shermanian Stage (USGS colln. 4697-CO), polygonal autozooecia in cross section in exozone, styles virtually absent, tangential section, $\times 50$.

6. Hypotype USNM 308347, Shermanian Stage (USGS colln. 4697-CO); basal diaphragms evenly spaced in endozone, cystiphragms in late endozone and in exozone, longitudinal section, $\times 30$.

2, 3. Homotrypa obliqua Ulrich, hypotype suite USNM 41736 from the "Lorraine Group (Cincinnati Group)," Upper Ordovician (Maysvillian), Cincinnati, Ohio.

2. Hypotypes USNM 308396 (thin section probably figured by Ulrich, 1882, pl. 10, fig. 6b). $2 a$, Microstructure of autozooecial walls in exozone, styles poorly defined or absent, tangential section $\times 50 ; 2 b$, shape and arrangement of autozooecia in exozone, tangential section, $\times 30$.

3. Hypotype USNM 308396 (thin section figured by Bassler, 1903, pl. 23, fig. 12), autozooecia subparallel to branch axis, autozooecial walls slightly crenulated locally, basal diaphragms lacking in midendozone, occur sparingly in late endozone, cystiphragms in well-defined series in exozone of many autozooecia, longitudinal section, $\times 30$. 


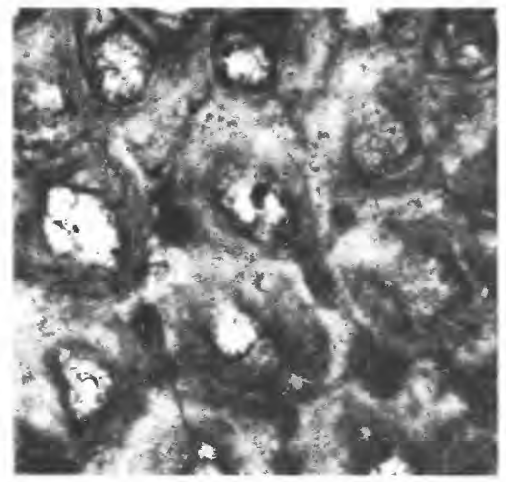

1

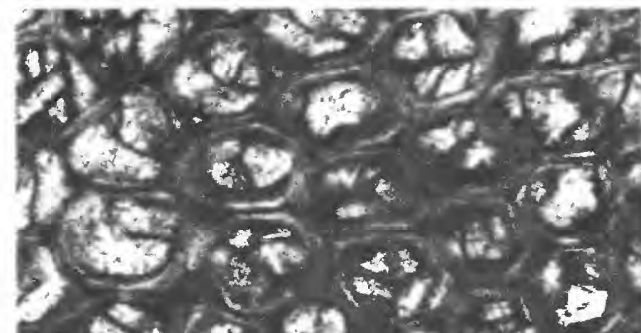

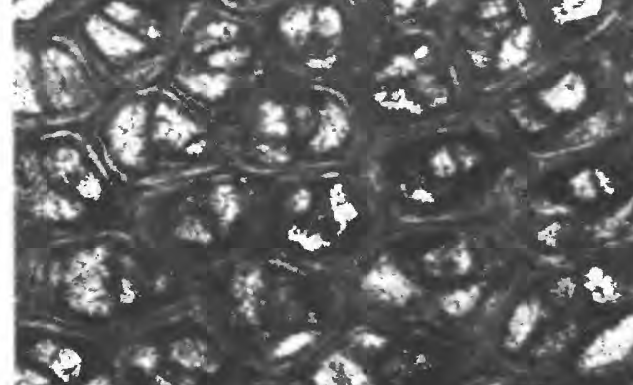

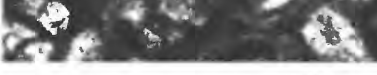

$4 a$

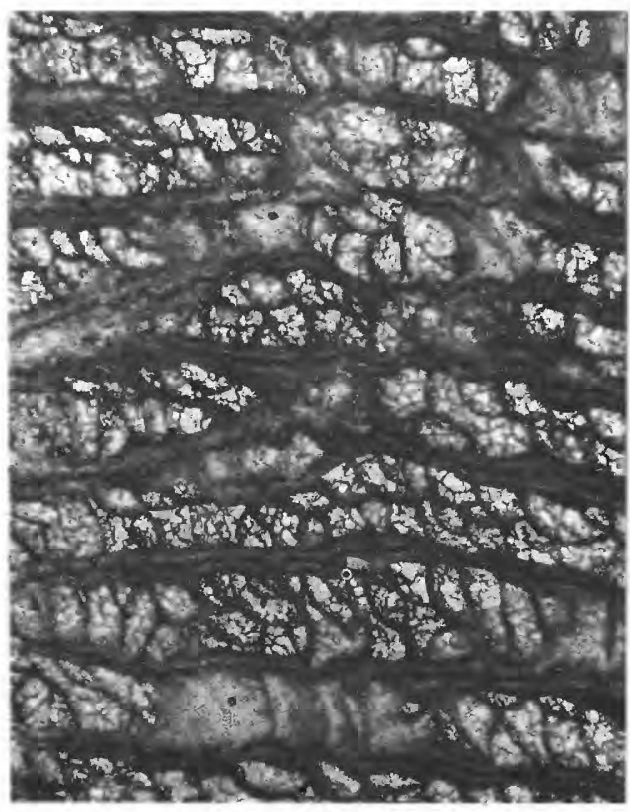

$4 \mathrm{~b}$

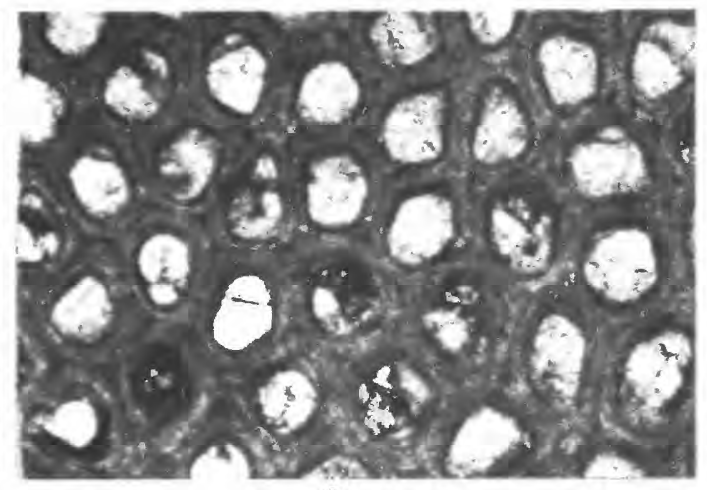

$2 \mathrm{a}$
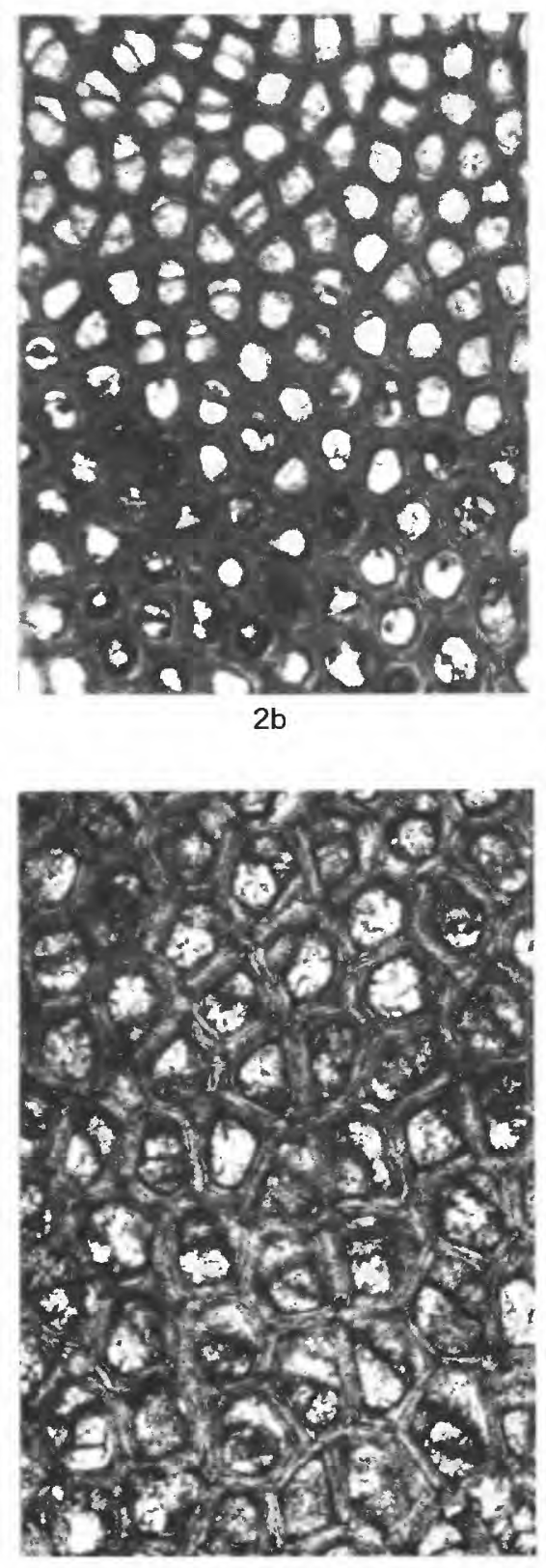

5

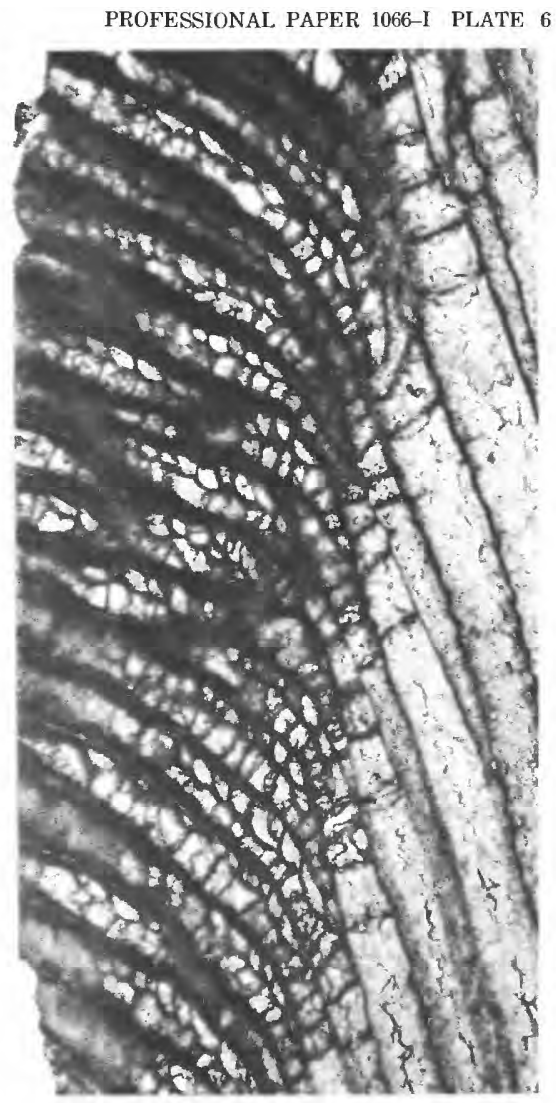

3

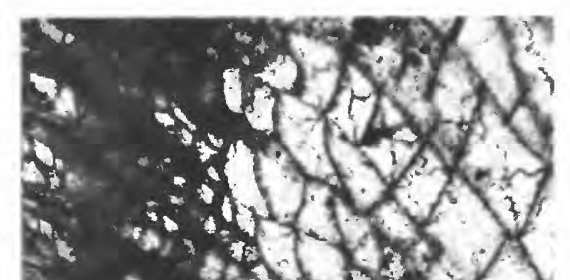
3.0 .1 ant

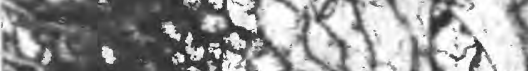

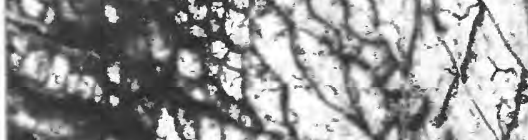

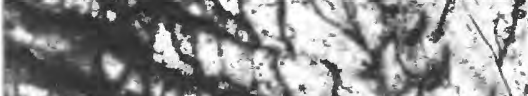

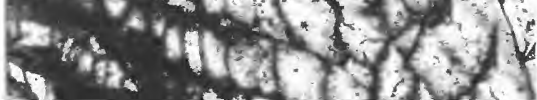

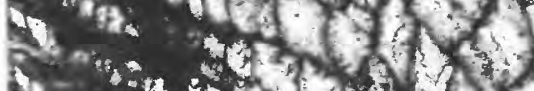

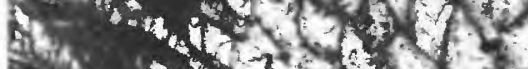

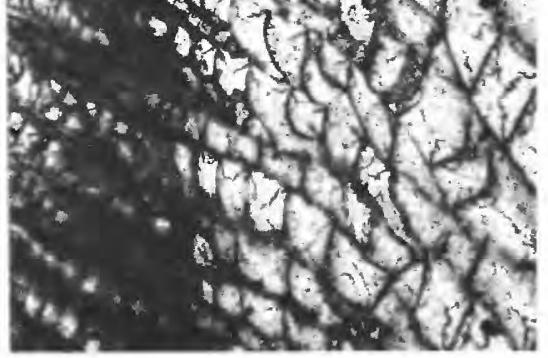

6

HOMOTRYPA 


\section{PLATE 7}

Figures 1-5. Homotrypa cressmani, n. sp. (p. I30).

Lexington Limestone, Kentucky.

1. Holotype USNM 308352, Tanglewood Limestone Member, Shermanian Stage (USGS colln. 4981-CO), Frankfort West Quadrangle. 1a, well-defined, few small styles, few mesozooecia, tangential section, $\times 50 ; 1 b$, distinct cores of styles, scattered basal diaphragms and cystiphragms in exozones, longitudinal section, $\times 50$.

2. Hypotype USNM 308392, tongue of Tanglewood Limestone Member, Edenian Stage (USGS colln. 7070-CO), in Millersburg Member, Winchester Quadrangle; scattered single cystiphragms, autozooecial walls uneven in thickness in exozone, longitudinal section, $\times 30$.

3. Hypotype USNM 308395, tongue of Clays Ferry Formation, Shermanian Stage (USGS colln. 7333-CO), in Millersburg Member, Austerlitz Quadrangle; $3 a$, shape of autozooecia in exozone, maculae with skeletal deposits in its center (lower right of figure), tangential section, $\times 50 ; 3 b$, autozooecia in indistinct alignment in exozone in direction of branch growth, styles in corners of junctions of autozooecia, narrow autozooecial boundaries with indistinct pustules, tangential section, $\times 50$; $3 c$, distribution of basal diaphragms and cystiphragms in exozone, scattered basal diaphragms in endozone, longitudinal section, $\times 30$.

4. Hypotype USNM 308382, Tanglewood Limestone Member, Edenian Stage (USGS colln. 5031-CO), Moorefield Quadrangle; $4 a$, slightly sinuous autozooecial walls in endozone, well-defined, narrowly serrated autozooecial boundaries in exozones, cystiphragms in series in some autozooecia in exozone, longitudinal section, $\times 30$; $4 b$, cross-sectional shape of autozooecial chambers, distribution to well-defined styles, tangential section, $\times 30$.

5. Paratype, USNM 308355, Tanglewood Limestone Member, Shermanian Stage (USGS colln. 4981-CO), Frankfort West Quadrangle, basal diaphragms in exozone, cystiphragms generally absent in this segment of exozone, longitudinal section, $\times 50$. 


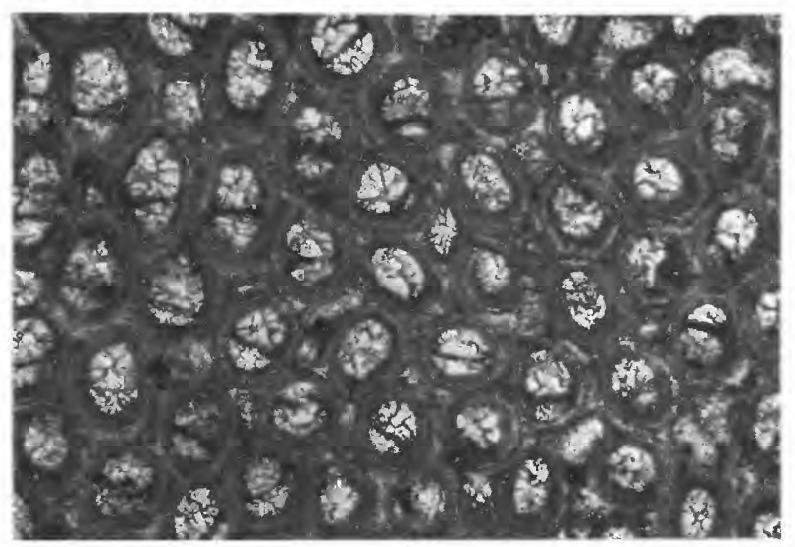

$1 a$

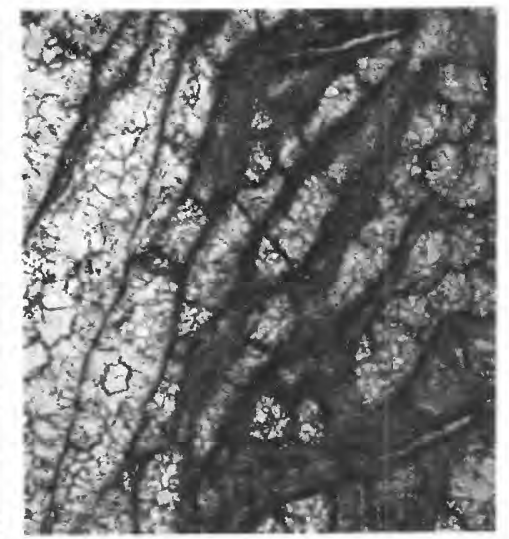

$1 \mathrm{~b}$

PROFESSIONAL PAPER 1066-I PLATE 7

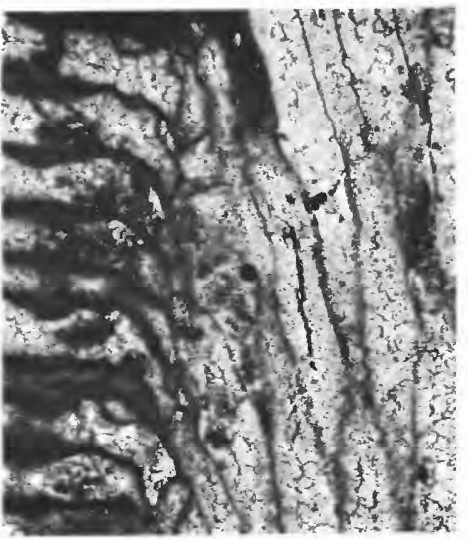

2

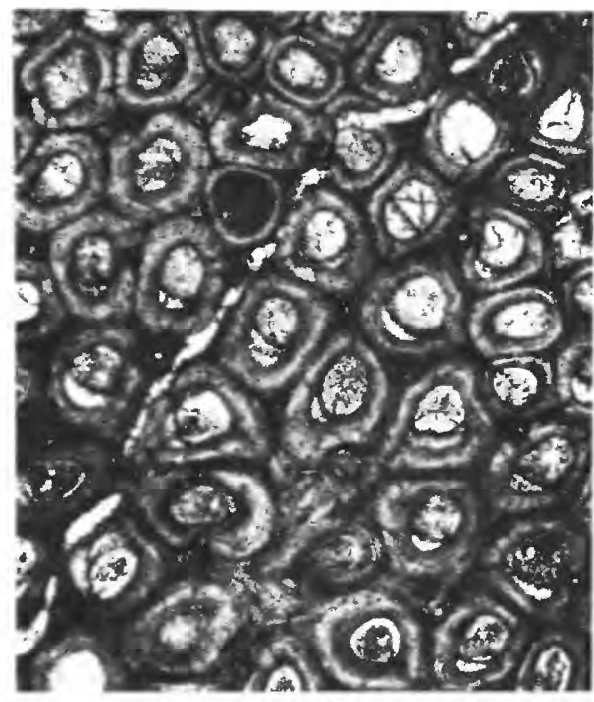

$3 a$

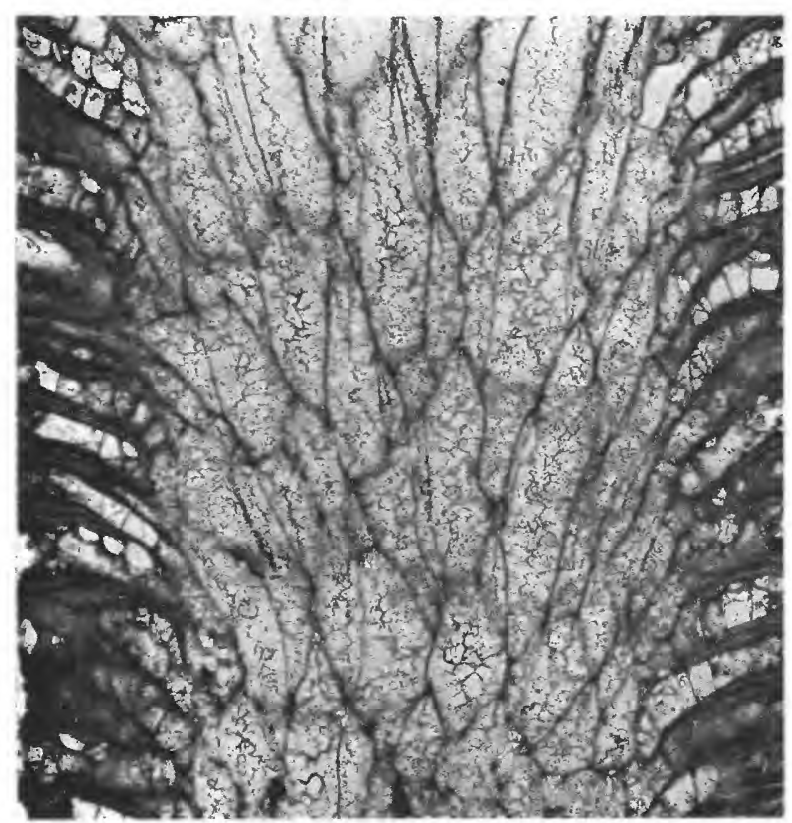

$4 a$

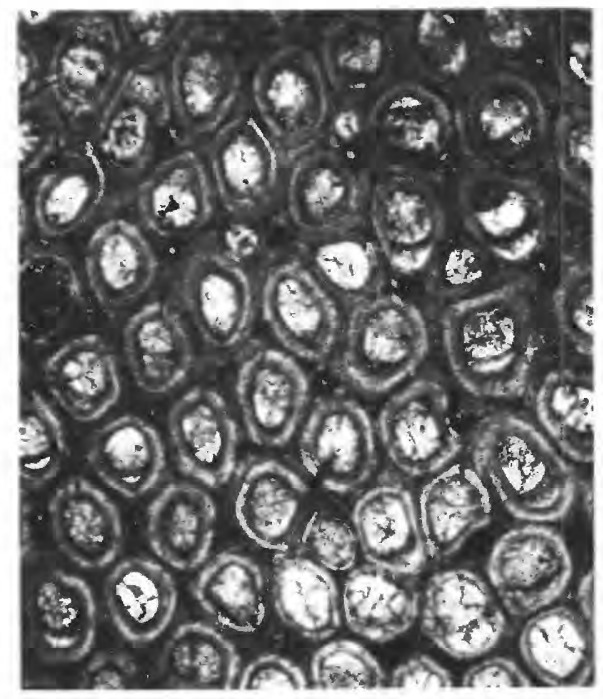

$3 b$

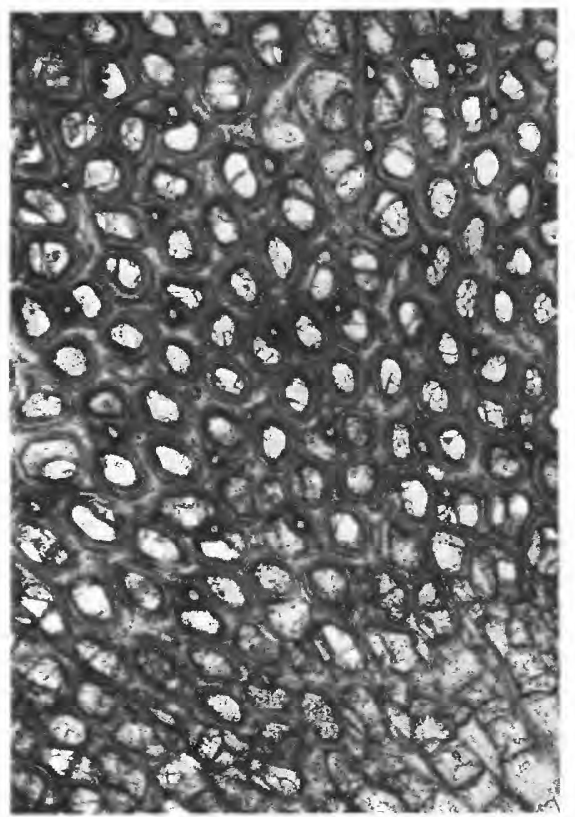

$4 b$

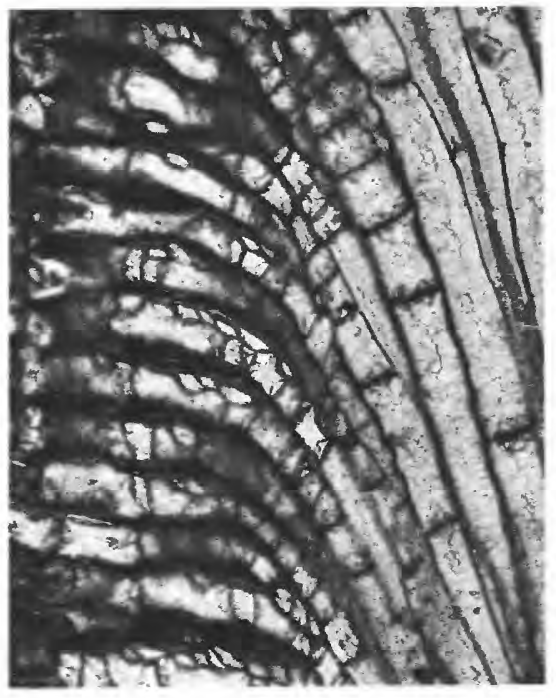

3c

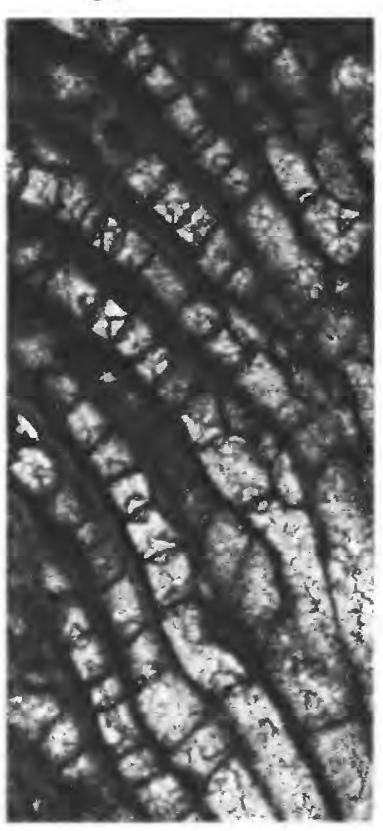

5 


\section{PLATE 8}

Figures 1, 2, 4. Homotrypella granulifera (Ulrich) (p. I32).

Grier Limestone Member of the Lexington Limestone, Kentucky.

1. Hypotype USNM 308402, Shermanian Stage (USGS colln. 4945-CO), Salvisa Quadrangle; shape of autozooecia in exozone, reversal of growth direction along zone of rejuvenation of autozooecia in endozone, longitudinal section, $\times 30$.

2. Hypotype USNM 308399, Shermanian Stage (USGS 4681-CO), type section of Lexington Limestone, Frankfort East Quadrangle; $2 a$, basal diaphragms in early exozone, scattered cystiphragms in exozone, conspecific overgrowth along left side of figure, longitudinal section, $\times 30 ; 2 b$, macula with closed mesozooecia in its center, slightly larger polymorphs in margin of macula, tangential section, $\times 50$.

4. Hypotype USNM 308398, Shermanian Stage (USGS colln. 4681-CO), type section of Lexington Limestone, Frankfort East Quadrangle; $4 a$, autozooecial boundaries in early exozone, small styles inflect autozooecial walls, irregularly shaped mesozooecia partly separate autozooecia, tangential section, $\times 50 ; 4 b$, slightly crenulated and sinuous autozooecial walls in endozone, cystiphragms in endozone and early exozone, small styles in endozone (lower left of figure), longitudinal section, $\times 30 ; 4 c$, cross-sectional shape of autozooecia and their chambers, part of macula in lower left of figure, tangential section, $\times 30 ; 4 d$, microstructure of autozooecial and mesozooecial walls in exozone, thick mesozooecial diaphragms, well-defined styles with thin cores, part of zoarial overgrowth (center of figure), irregularly shaped cystiphragms in early exozone, longitudinal section, $\times 50$.

3. Homotrypella mundula Ulrich, primary type suite USNM 43560 from the "Trenton Group," Middle Ordovician, Decorah, Iowa; holotype USNM 43560, "type section" probably figured by Ulrich, 1893, p. 232, fig. text-fig. 12.; $3 a$, relatively straight walls in endozone, autozooecial walls of uniform thickness in exozone, cystiphragms, in series or singly, occur in most autozooecia, longitudinal section, $\times 30 ; 3 b$, cross-sectional shape of autozooecia, relatively large and abundant styles in exozone, tangential section, $\times 30$. 


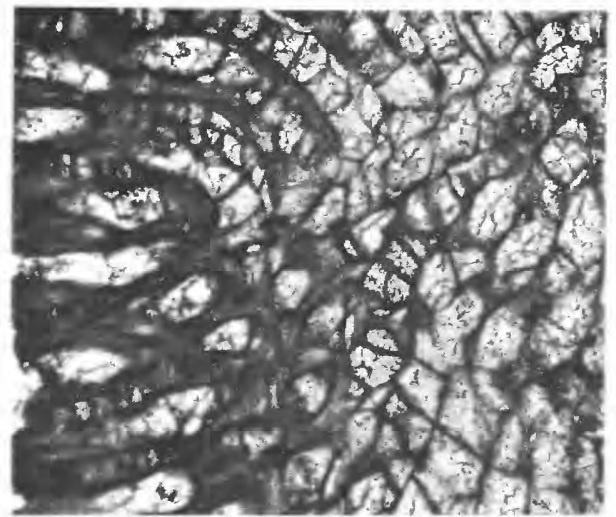

1

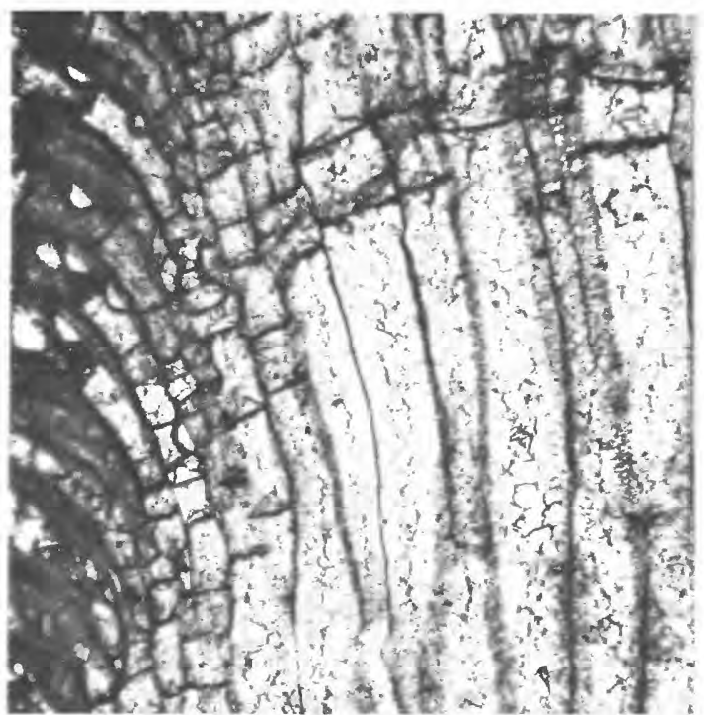

$3 a$

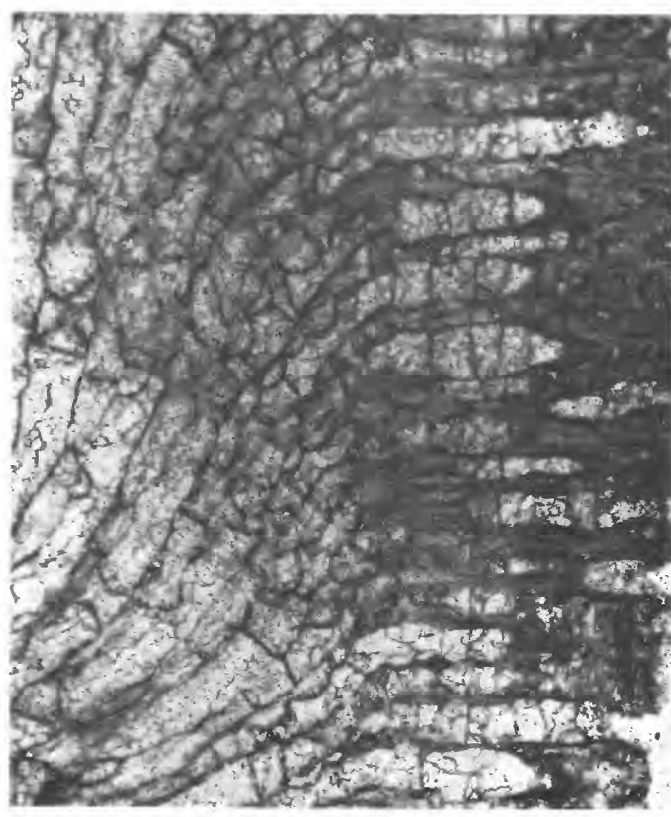

$4 \mathrm{~b}$

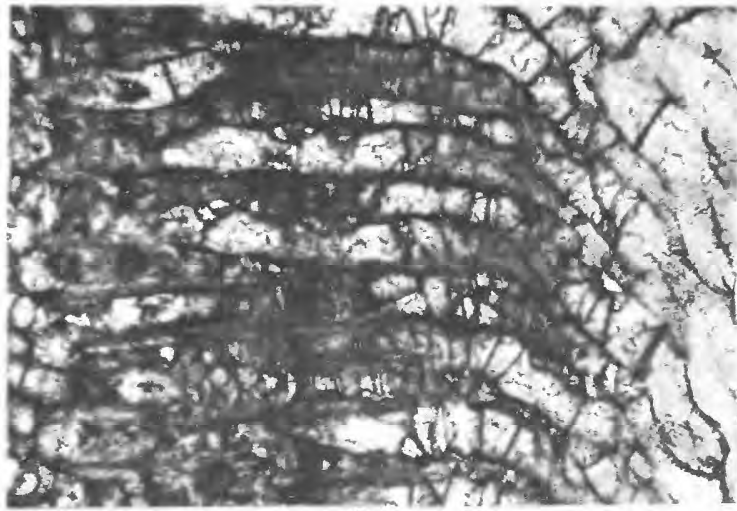

$2 a$

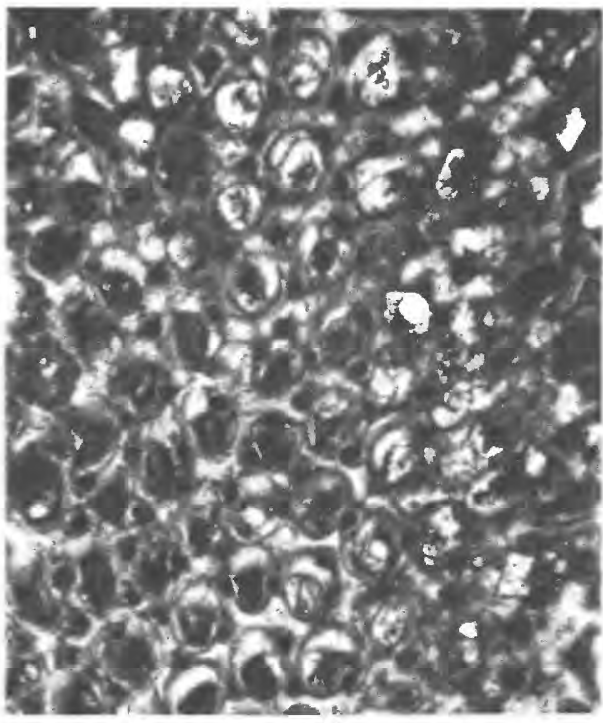

$3 b$

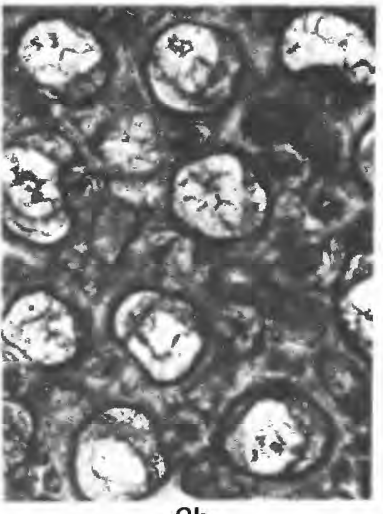

$2 b$

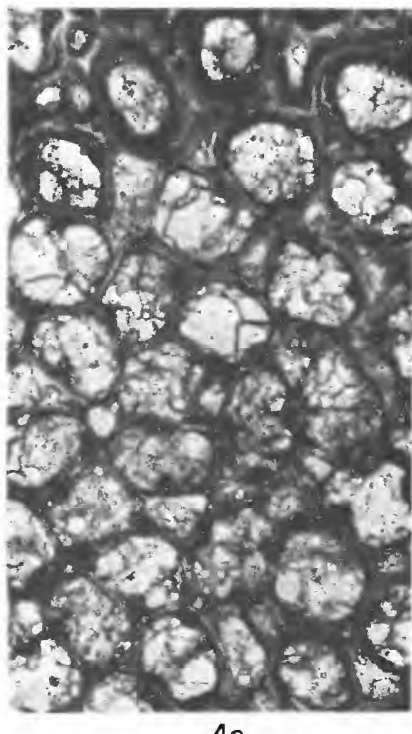

$4 a$

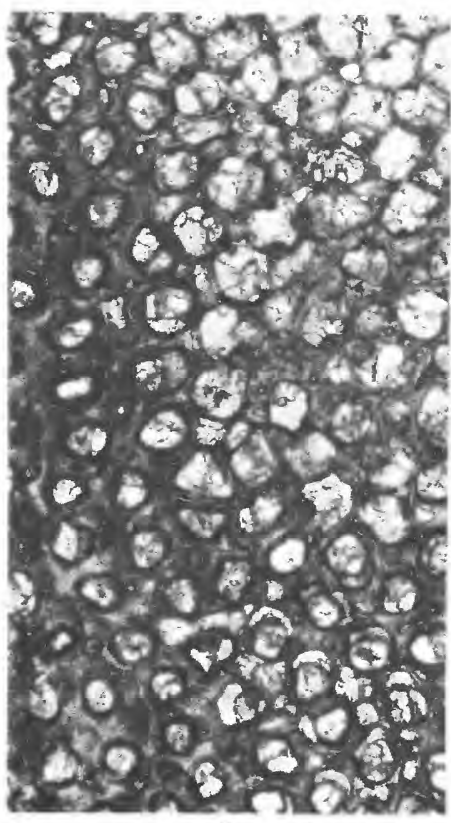

$4 \mathrm{c}$

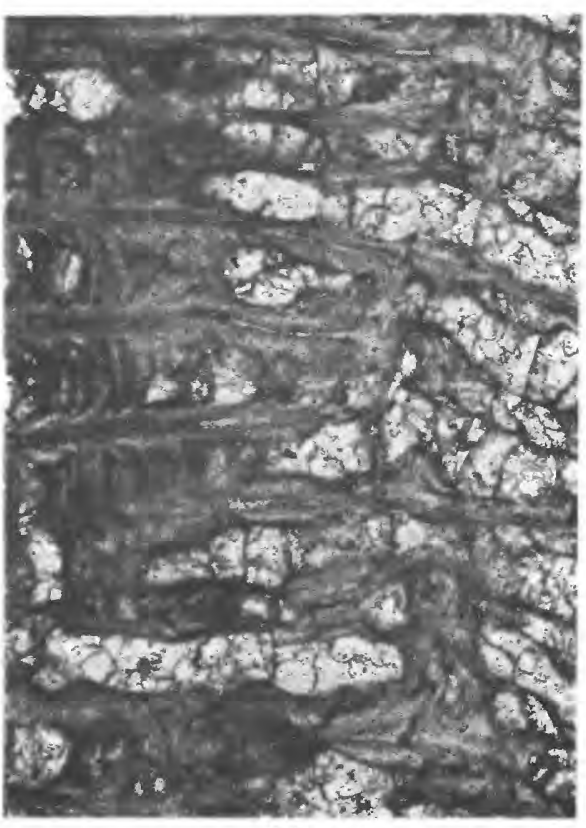

$4 d$

HOMOTRYPELLA 


\section{PLATE 9}

Figures 1-3. Mesotrypa angularis (Ulrich and Bassler, 1904) (p. I34).

1, 2. "Trenton strata" of Ulrich and Bassler, Middle Ordovician, near Frankfort, Ky.

1. Paratype USNM 308406; $1 a$, basal diaphragms slightly curved, evenly spaced, aligned in zones in exozone, longitudinal section, $\times 30 ; 1 b$, subpolygonal autozooecia, styles in autozooecial corners; exozone, tangential section, $\times 30$.

2. Holotype USNM 43182, "type section" of Ulrich and Bassler, 1904; $2 a$, polymorphs of macula (center of figure) gradational in size with autozooecia of intermacular areas, few mesozooecia in macula, walls of zooecia slightly curved, tangential section, $\times 30 ; 2 b$, styles thicken autozooecial walls, zone of evenly spaced basal diaphragms, few mesozooecia with closely spaced diaphragms; exozone, longitudinal section, $\times 30$.

3. Hypotype USNM 308408, Grier Limestone Member of the Lexington Limestone, Shermanian Stage (USGS colln. 4875-CO), Valley View Quadrangle, Kentucky; Grier Limestone Member of the Lexington Limestone; 3a, imperforate basal layer of zoarium adnate to substrate (near base of figure), autozooecia arise from basal layer, crosssectional shape of autozooecia at basal layer, transverse section, $\times 100 ; 3 b$, basal diaphragms oblique or at right angle to chamber axis, scattered; mesozooecial diaphragms concave to zoarial surface, scattered styles in exozone, narrow endozone, longitudinal section, $\times 30 ; 3 c$, styles with small, well-defined cores, subcircular to subpolygonal autozooecial chambers, curved zooecial walls in exozone, oblique basal diaphragms or scattered cystiphragms, tangential section, $\times 30$. 

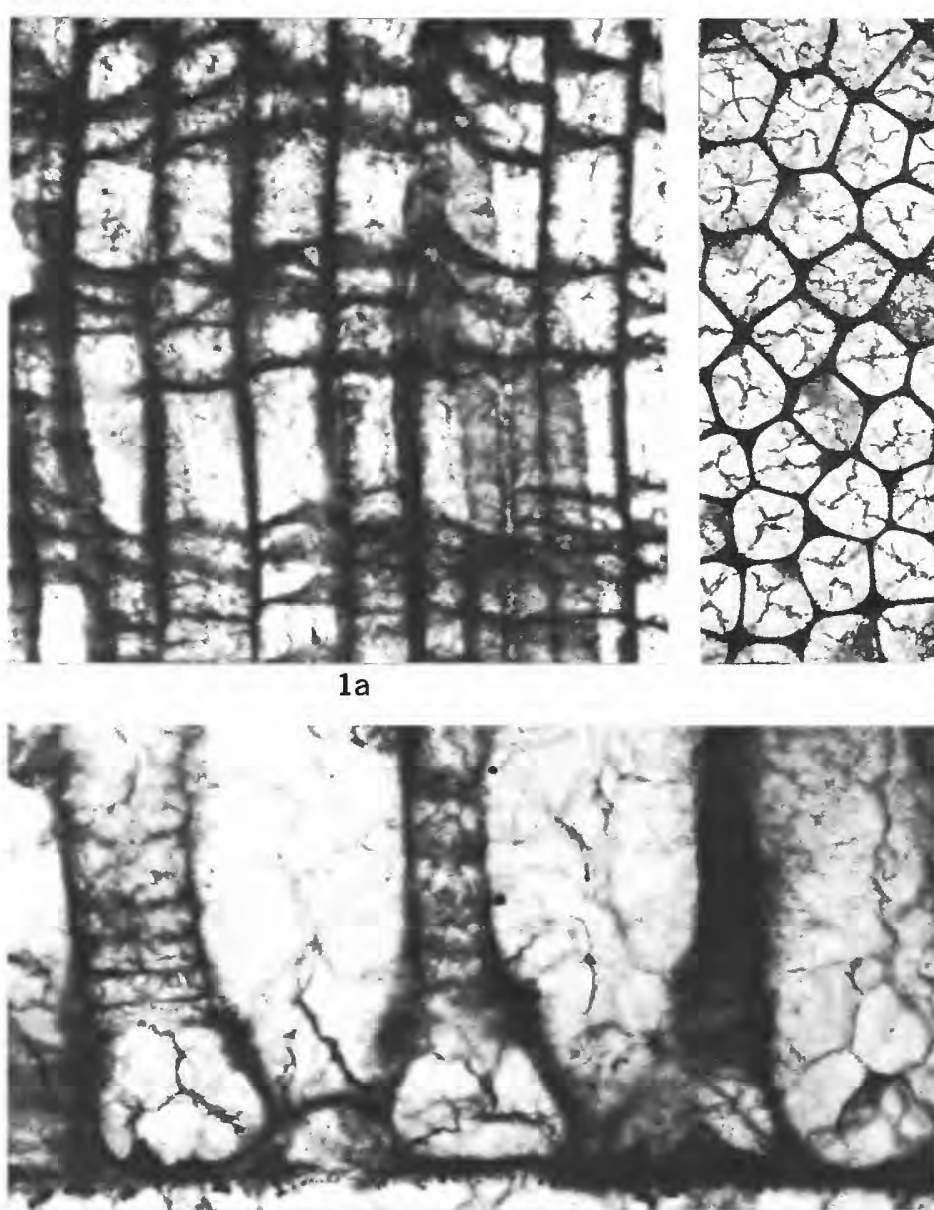

$3 a$

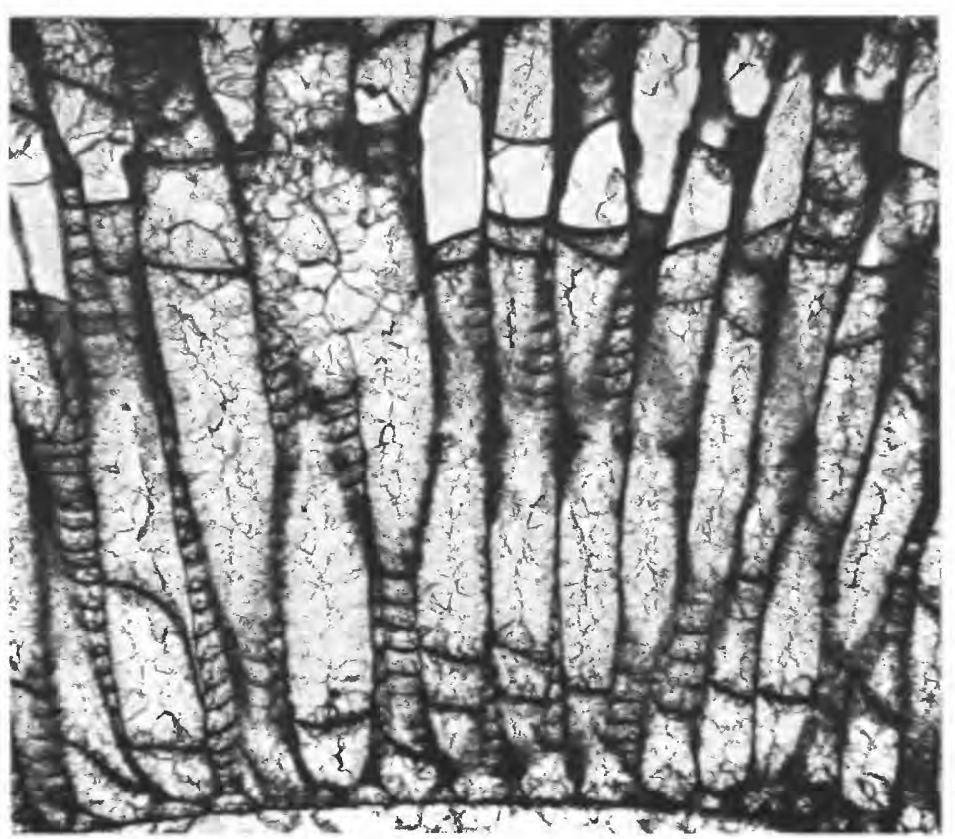

$3 \mathrm{~b}$

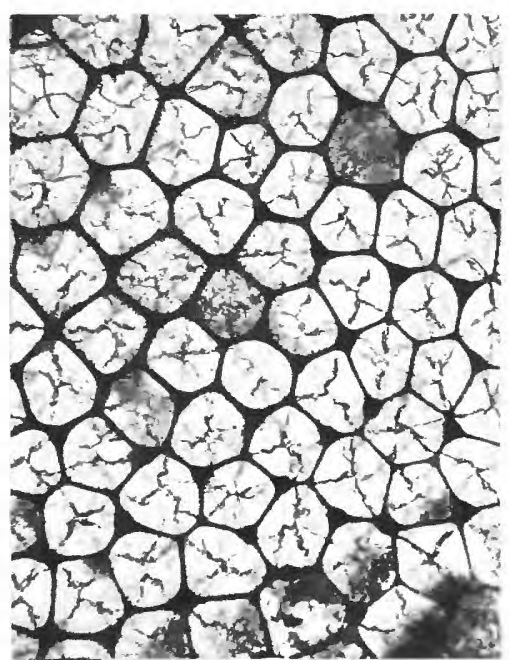

$1 b$

\section{} (1) $2 b$

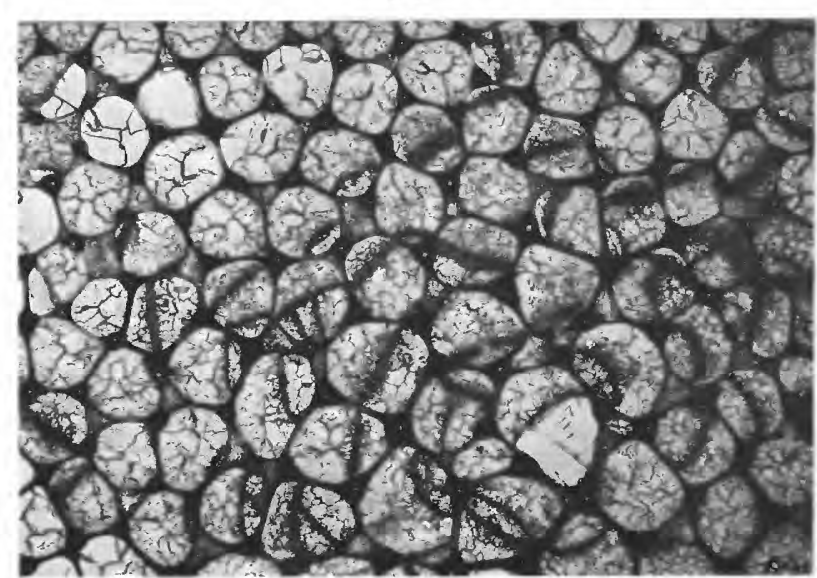

3c 
PLATE 10

1. Mesotrypa sp. (p. I36).

USNM 308410, Millersburg Member, Shermanian Stage (USGS colln. 5027-CO), of Lexington Limestone, Moorefield Quadrangle, Kentucky; $1 a$, autozooecial walls with distinct cortex, narrow, broadly serrated autozooecial boundaries, thin autozooecial lining locally present, basal diaphragms slightly curved, concave distally, imperforate basal layer poorly preserved, longitudinal section, $\times 30 ; 1 b$, cross-sectional shape of autozooecia and mesozooecia, styles with relatively thick sheaths, exozone, tangential section, $\times 50$.

2. Mesotrypa spinosa Ulrich, lectotype USNM 43546 (probably figured by Ulrich, 1893, pl. 17, figs. 10-12), from syntype suite USNM 43546, Decorah Shale, Middle Ordovician, Minneapolis and St. Paul, Minn.; 2a, autozooecia with regularly arranged cystiphragms and some basal diaphragms, abundant mesozooecia, a few styles, longitudinal section, $\times 30 ; 2 b$, cross-sectional shape of autozooecia and their chambers, numerous styles, mesozooecia partly separate autozooecia, tangential section, $\times 30$.

3. Peronopora milleri (Nickles) (p. I38).

Hypotype USNM 308413, from "Trenton Group," Middle Ordovician, near Frankfort, Ky.; thin mesotheca, well-defined, narrowly serrated autozooecial boundaries, style with thin sheath (lower left of figure), scattered basal diaphragms, cystiphragms in series, longitudinal section, $\times 50$.

4. Mesotrypa angularis (Ulrich and Bassler) (p. I34).

Hypotype USNM 308409, Grier Limestone Member, Shermanian Stage (USGS colln. 6132-CO), of the Lexington Limestone, Danville Quadrangle, Kentucky. Autozooecia recumbent for short distance along basal layer, become erect at base of exozone, narrow endozone, scattered basal diaphragms in exozone, cystiphragms generally lacking, longitudinal section, $\times 30$. 
GEOLOGICAL SURVEY

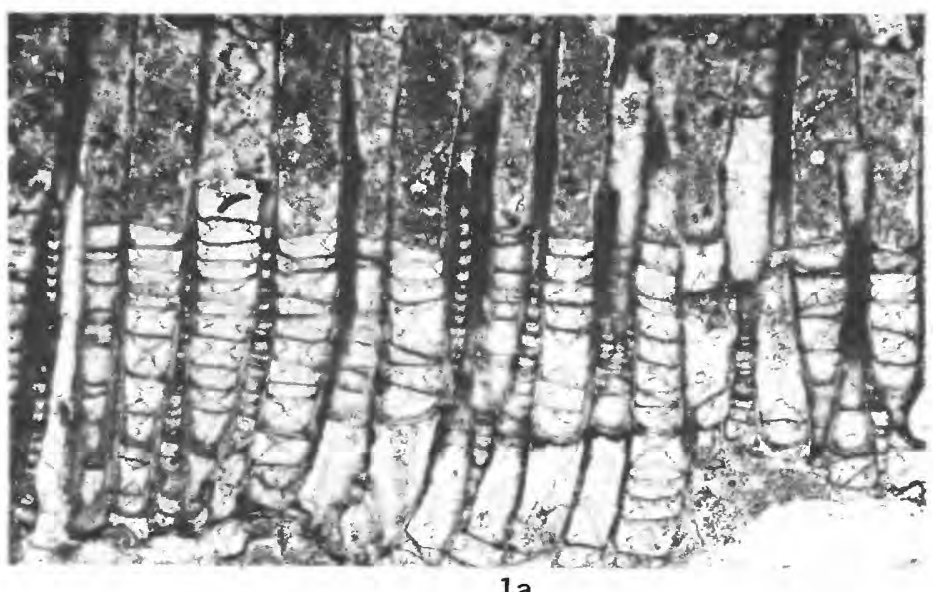

$1 a$

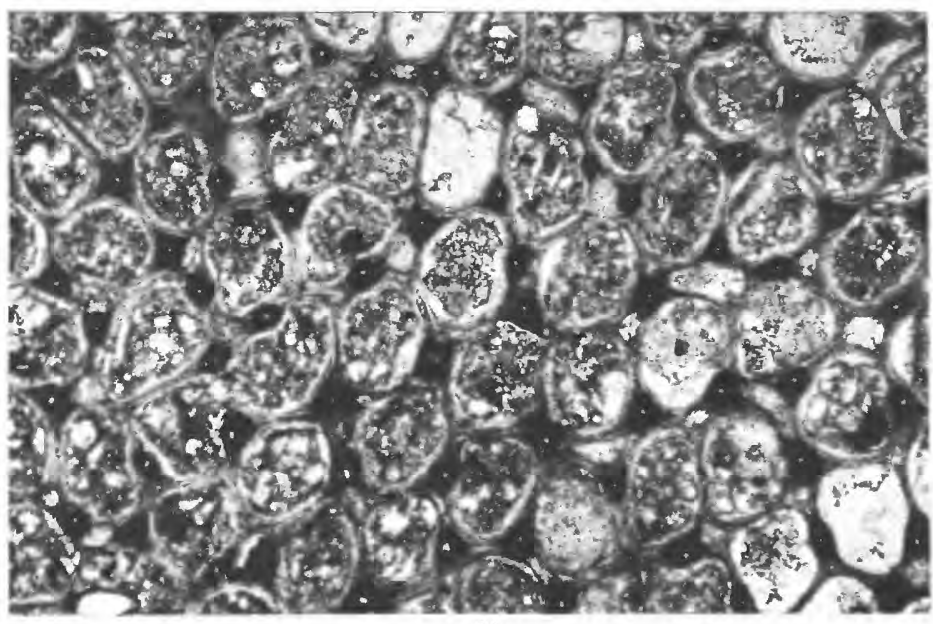
1b

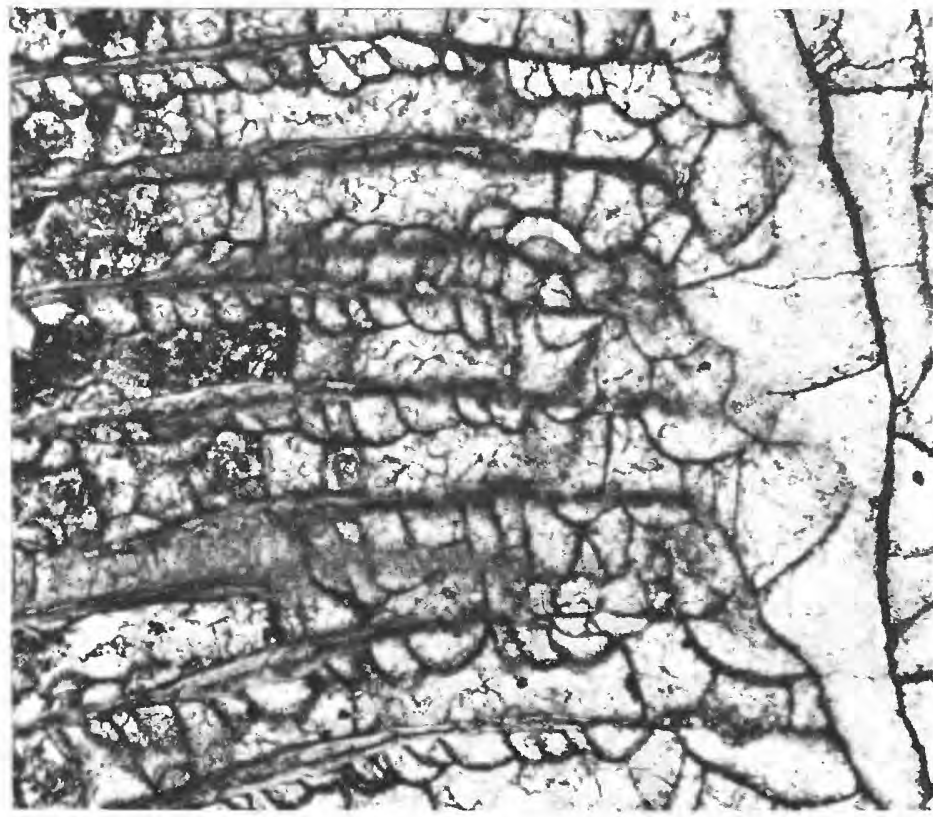
3

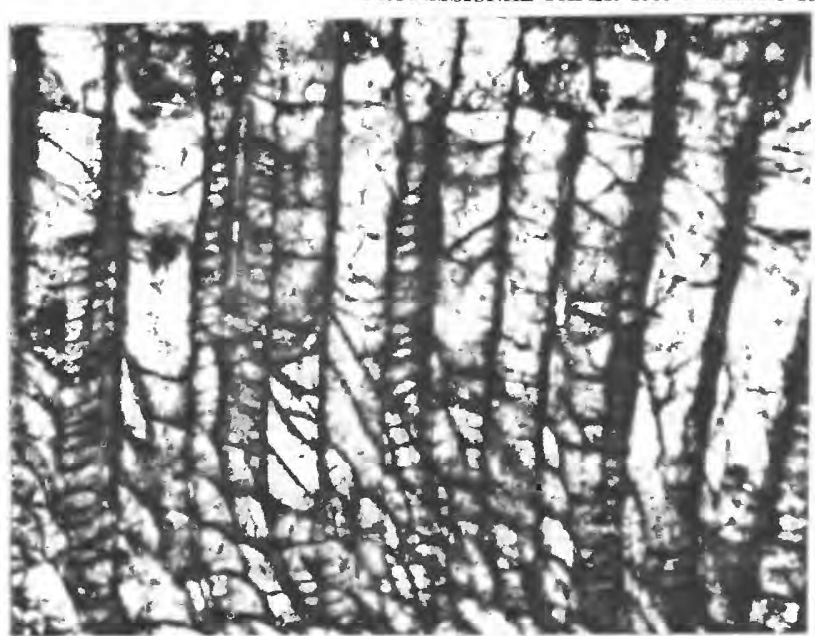

$2 a$
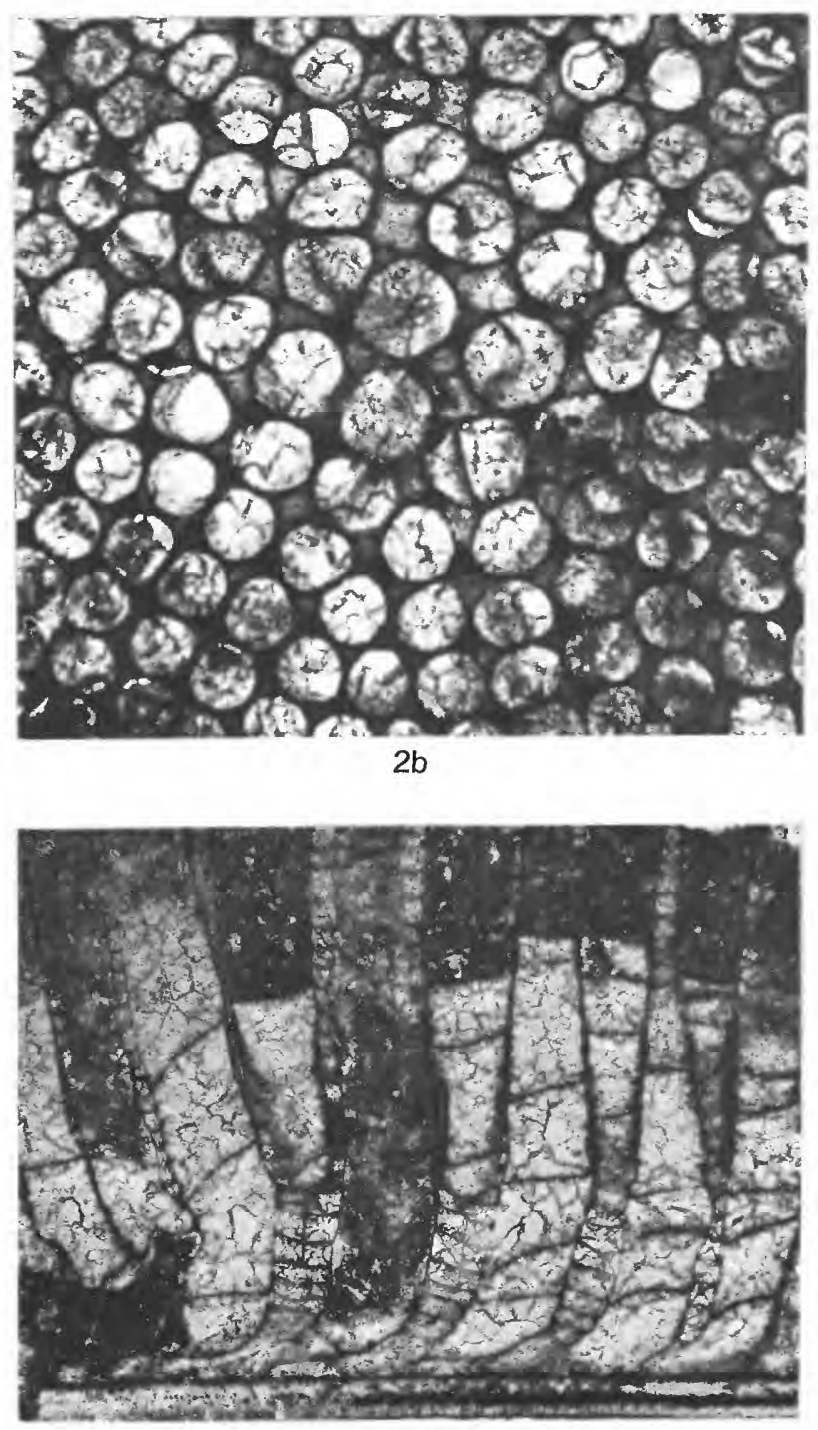


\section{PLATE 11}

Figures 1-4. Peronopora milleri (Nickles) (p. I38).

1. Hypotype USNM 308412, "Trenton Group," Middle Ordovician, near Frankfort, Ky.; 1a, subrectangular autozooecia aligned in longitudinal ranges in endozones at mesotheca, microstructure of mesotheca (thin section in plane of mesotheca in center of figure), deep tangential section, $\times 30 ; 1 b$, cross-sectional shape of autozooecia and their chambers in exozone, small styles with distinct cores and thin sheaths in autozooecial boundaries, a few mesozooecia closed by skeletal deposits, tangential section, $\times 30$.

2. Hypotype USNM 308429, Sulphur Well Member, Shermanian Stage (USGS colln. 4931-CO), of the Lexington Limestone, Salvisa Quadrangle, Kentucky, cross-sectional shape of autozooecia at mesotheca (near top of figure), mesozooecia with evenly spaced diaphragms in exozone, scattered basal diaphragms in autozooecia, transverse section, $\times 30$.

3. Lectotype USNM 96562 (thin section marked "holotype"), "Cynthiana" strata, Ordovician, Lair Station, Kentucky; $3 a$, cross-sectional shape of autozooecia and mesozooecia in early exozone, mesozooecia partly separate autozooecia, distinct autozooecial boundaries, cross-sectional shape of autozooecial chambers, tangential section, $\times 30$; $3 b$, discrete mesotheca locally absent in part of zoarium, thin autozooecial walls, cystiphragms in regular series, longitudinal section, $\times 30$.

4. Hypotype USNM 308421, Sulphur Well Member, Shermanian Stage (USGS colln. 4890-CO), of the Lexington Limestone, Valley View Quadrangle, Kentucky; 4a, styles exceedingly small, locally lacking, mesozooecia almost completely surround some autozooecia, macula with slightly larger polymorphs in right center of figure, tangential section, $\times 30 ; 4 b$, shape of autozooecia in endozone, cystiphragms in endozone and exozones, mesozooecia with overlapping diaphragms, characteristic appearance of autozooecia in exozone, longitudinal section, $\times 30$. 


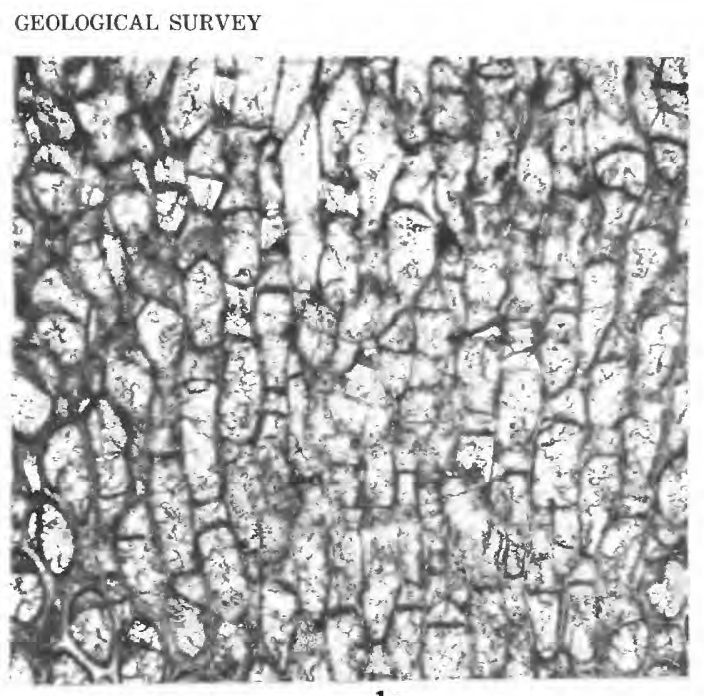

1a

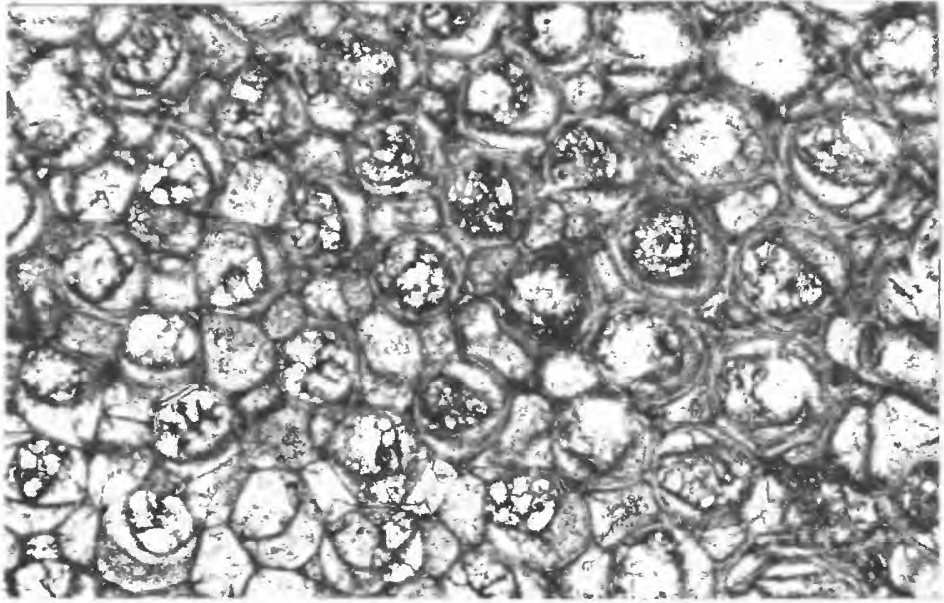

$3 a$

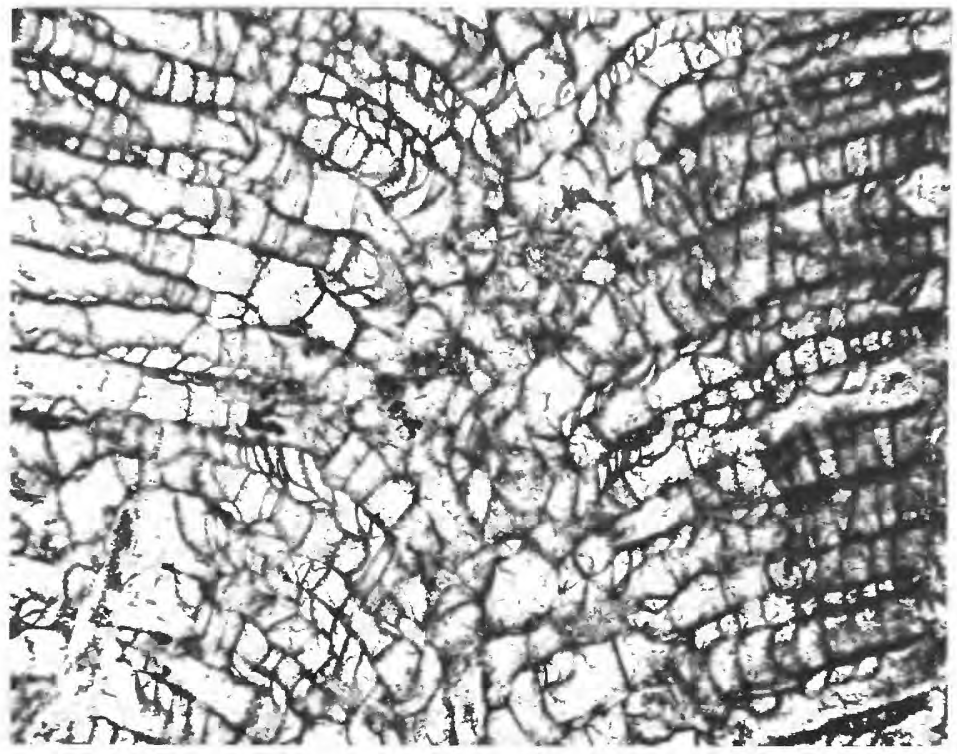

$3 b$

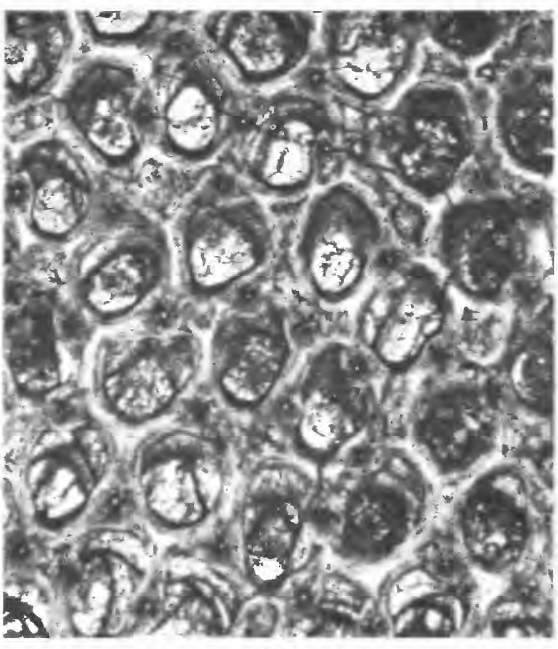

$1 \mathrm{~b}$

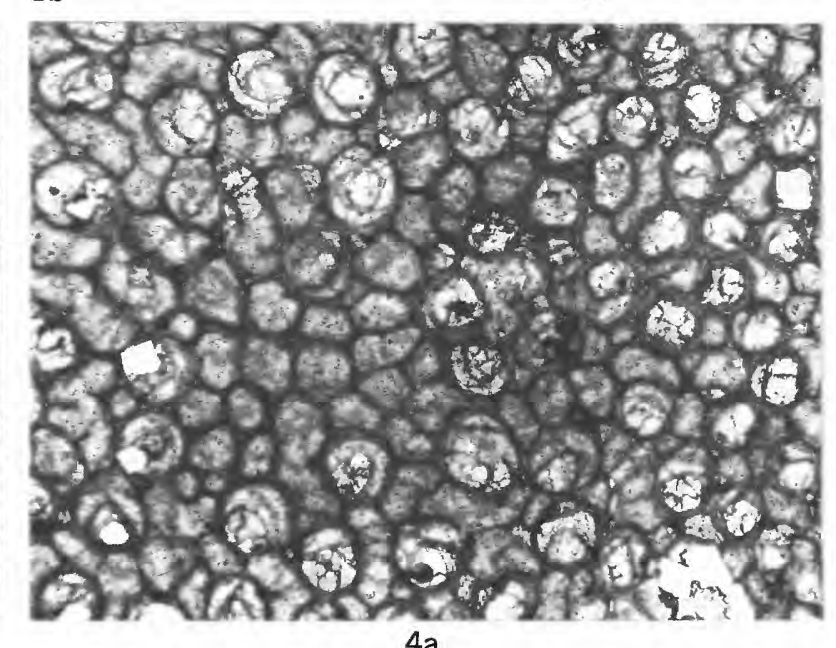

$4 a$

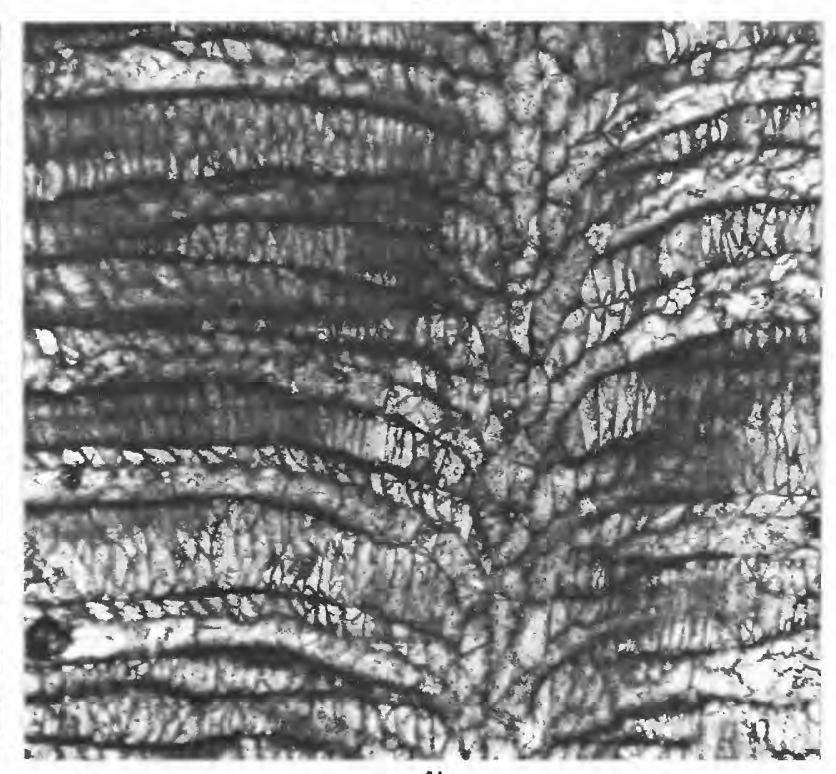
$4 b$

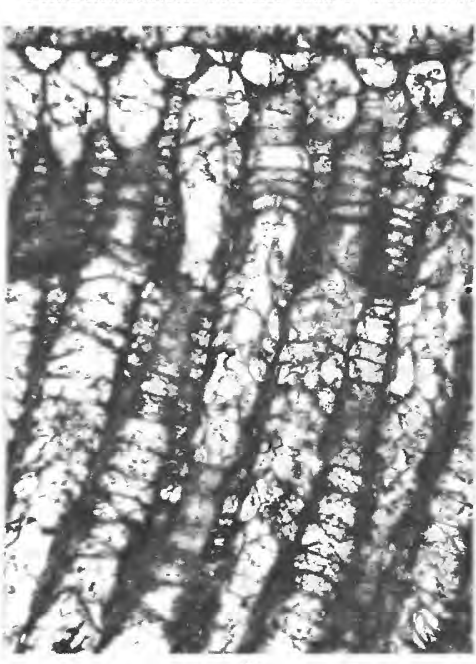

2

PERONOPORA 


\section{PLATE 12}

Figures 1-6. Peronopora vera (Ulrich) (p. I40).

1. Hypotype USNM 308453, Millersburg Member, Shermanian Stage (USGS colln. 5066-CO), of Lexington Limestone, Winchester Quadrangle, Kentucky; 1a, encrusting portion of zoarium, mesotheca constitutes basal layer adnate to substrate, shape of recumbent autozooecia with basal diaphragms in endozone, small styles in early exozone, longitudinal section, $\times 50 ; 1 b$, encrusting portion with mesotheca as basal layer and erect portion of zoarium with discontinuous mesotheca (center of figure), numerous mesozooecia with evenly spaced diaphragms, oblique longitudinal section, $\times 30$.

2. Hypotype USNM 308486, Millerburg Member, Edenian Stage (USGS colln. 7320-CO), of Lexington Limestone, Winchester Quadrangle, Kentucky; $2 a$, autozooecial walls variable in thickness, microstructure of walls in exozone, cystoidal diaphragms in early exozone, cystiphragms in series, longitudinal section, $\times 50 ; 2 b$, macula (center of figure) with irregularly shaped polymorphs, relatively large styles with thick sheaths and cores variable in thickness, tangential section, $\times 50$.

3. Hypotype USNM 308495, type section of Clays Ferry Formation, Edenian Stage (USGS colln. 6727-CO), Ford Quadrangle, Kentucky; autozooecia rectangular in cross section at mesotheca, thin section in plane of mesotheca (center of figure), deep tangential section, $\times 30$.

4. Hypotype USNM 308449, Clays Ferry Formation, Edenian Stage (USGS colln. 4907-CO), Valley View Quadrangle, Kentucky; slightly sinuous thin mesotheca, relatively thick autozooecial walls with styles, conspecific overgrowth in reversed direction of growth (right side of figure), longitudinal section, $\times 30$.

5. Hypotype USNM 308483, Millersburg Member, Shermanian Stage (USGS colln. 7071-CO), of Lexington Limestone, Winchester Quadrangle; Kentucky; $5 a$, mesotheca structurally continuous, poorly defined and elongated brown bodies in some abandoned chambers, partly filled mesozooecia (left center of figure), longitudinal section, $\times 30 ; 5 b$, cross-sectional shape and arrangement of autozooecia and mesozooecia, styles inflecting some autozooecial walls, thin autozooecial boundaries, tangential section, $\times 30$.

6. Hypotype USNM 308459, Millersburg Member, Shermanian Stage (USGS colln. 7454_CO), of Lexington Limestone, Sadieville Quadrangle, Kentucky; autozooecia with relatively thick walls and cystiphragms slightly variable in shape and size, scattered basal diaphragms, relatively thick mesozooecial diaphragms, mesotheca as basal layer in encrusting portion of zoarium, longitudinal section, $\times 30$. 
GEOLOGICAL SURVEY

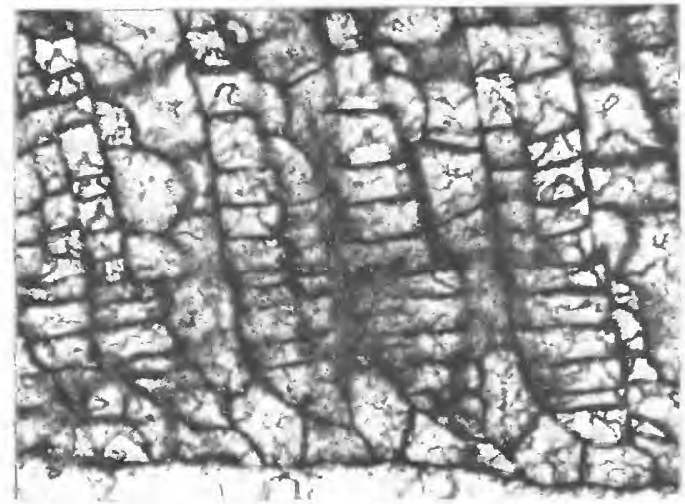

$1 a$
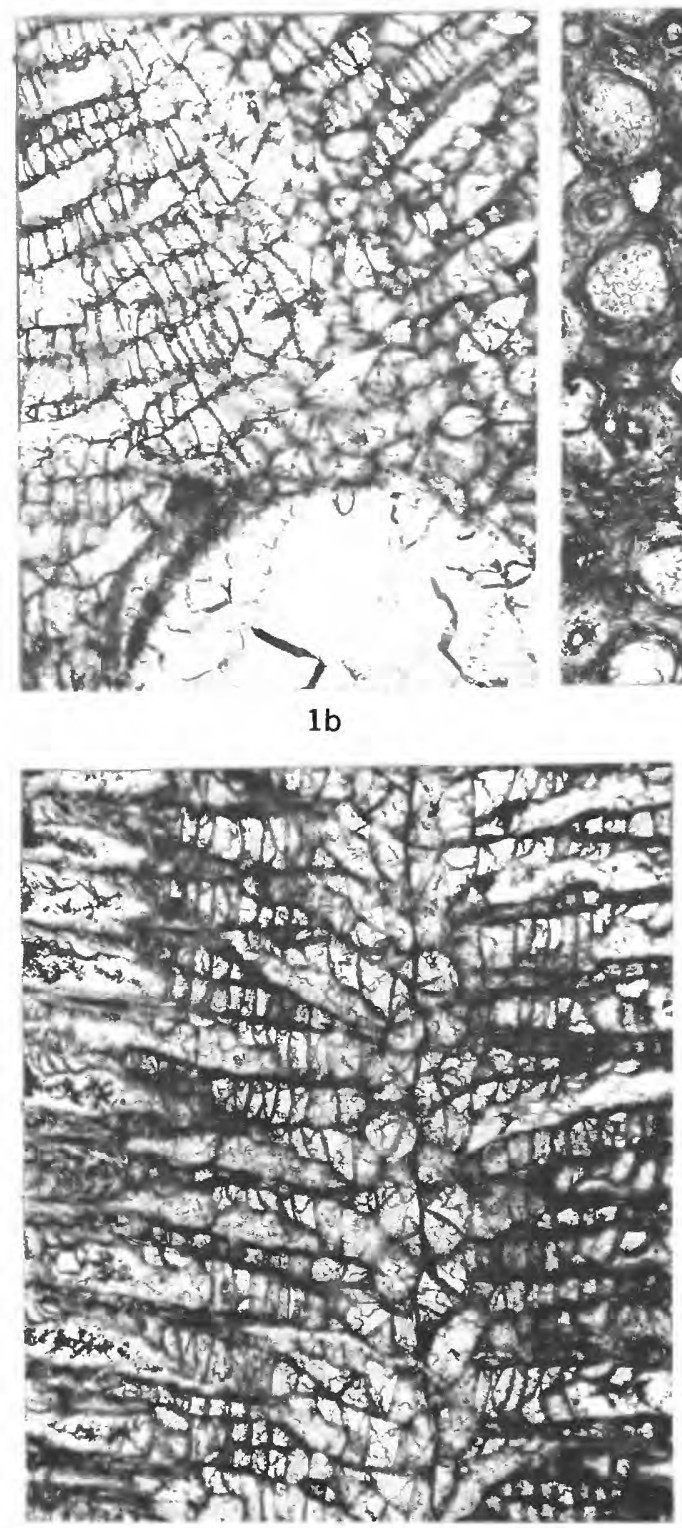

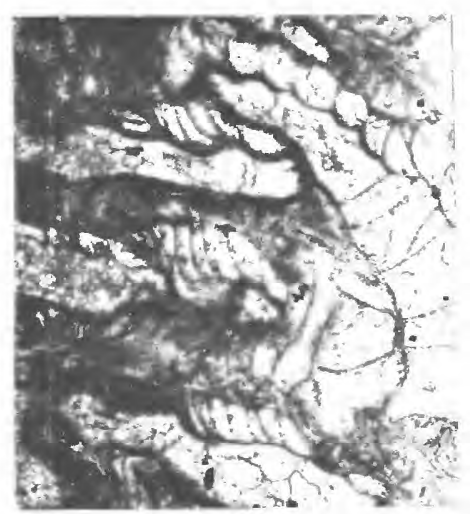

$2 a$

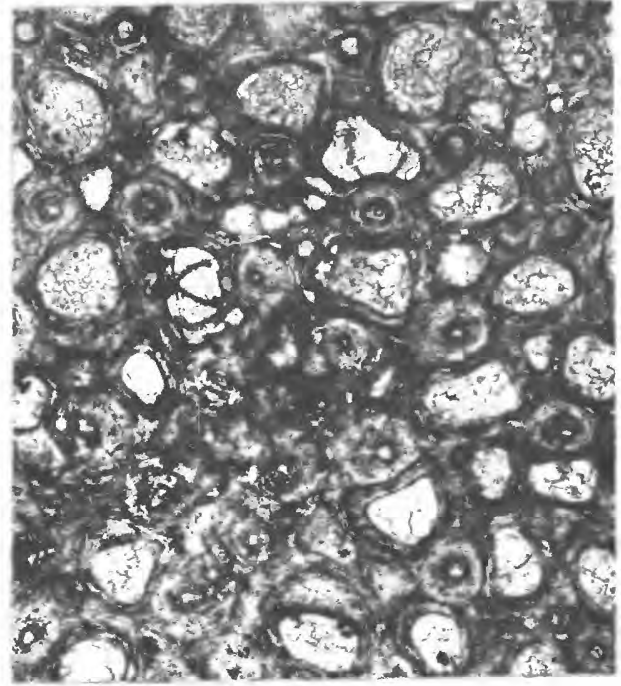

$2 b$

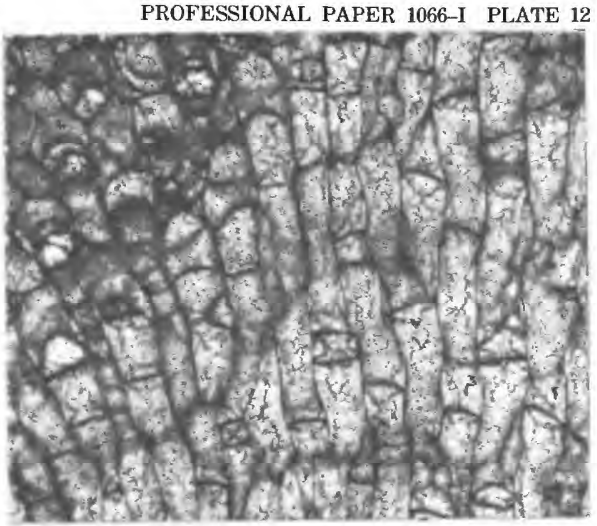

3
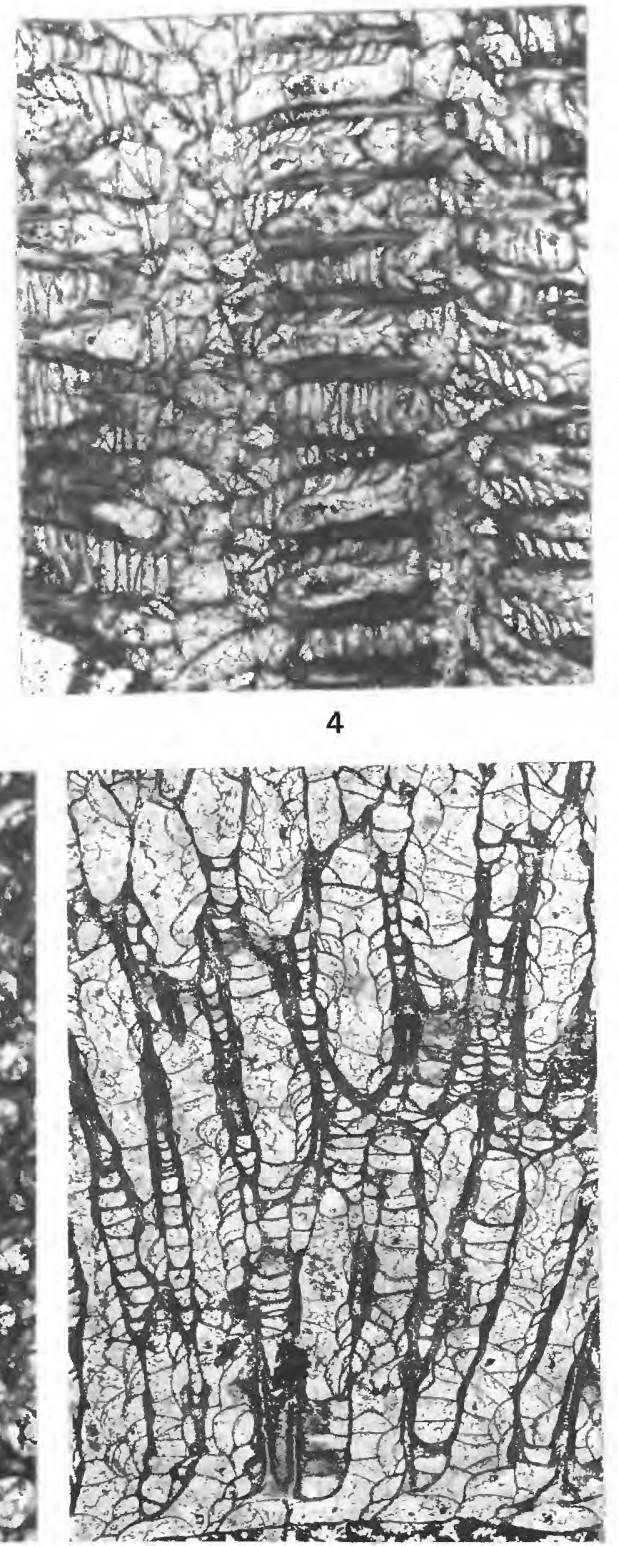

6 


\section{PLATE 13}

FIGURE 1. Prasopora falesi (James) (p. I42).

Lectotype Field Museum of Natural History 740, "Lexington Limestone," Middle Ordovician, Danville, Ky.; 1 $a$, hemispherical zoarium, shape of autozooecia and mesozooecia, external view, $\times 5$ (specimen probably illustrated by James, 1884 , pl. 7, figs. 2a-2c); $1 b$, slightly sinuous autozooecia with walls thickened by styles (center of figure), cystiphragms in longitudinal series, peel, longitudinal section, $\times 30 ; 1 c$, subpolygonal to subcircular autozooecia, subelliptical autozooecial chambers outlined by cystiphragms and laminated walls, peel, tangential section, $\times 30$.

2-4. Grier Limestone Member of the Lexington Limestone, type section, Frankfort East Quadrangle, Kentucky.

2. Hypotype USNM 308521, Shermanian Stage (USGS colln. 4691-CO), thin autozooecial walls with narrowly serrated autozooecial boundaries, style in wall between autozooecium and mesozooecium, intercalated autozooecium (upper right of figure), evenly spaced cystiphragms and diaphragms, longitudinal section, $\times 50$.

3. Hypotype USNM 308507, Shermanian Stage (USGS colln. 4680-CO); 3a, narrowly serrated autozooecial boundaries, styles with distinct cores in corners of zooecia, irregularly shaped mesozooecia separate partly autozooecia, tangential section, $\times 100 ; 3 b$, microstructure of style core, sheath, autozooecial wall, mesozooecial diaphragm and cystiphragms, longitudinal section, $\times 100$.

4. Hypotype USNM 308505, Shermanian Stage (USGS colln. 4680-CO); 4a, proximally onlapping cystiphragms in longitudinal series, evenly spaced basal diaphragms, small style (upper right of figure), longitudinal section, $\times 30 ; 4 b$, shape of autozooecia and mesozooecia, macula with cluster of mesozooecia in its center, large polymorphs in macular margins intergrade in size with autozooecia, shape of autozooecial chambers, narrow autozooecial boundaries, tangential section, $\times 30$. 
GEOLOGICAL SURVEY

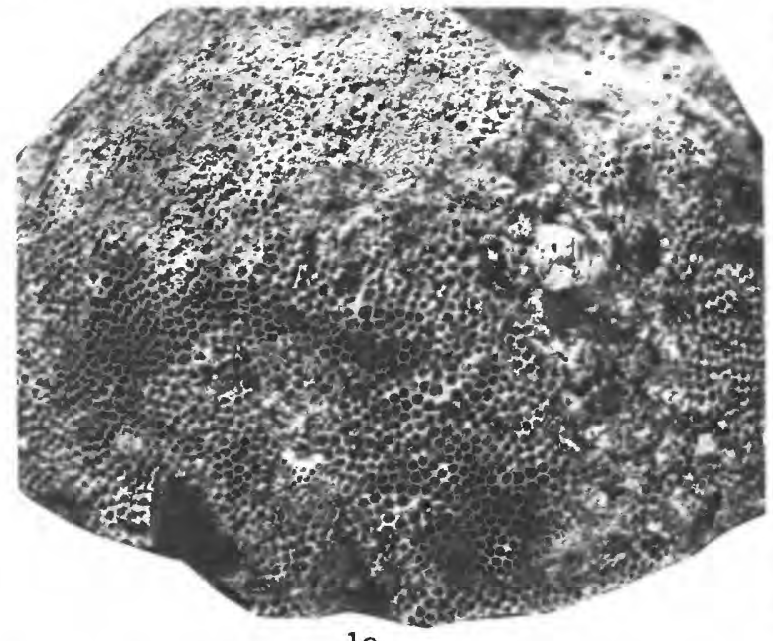

1a
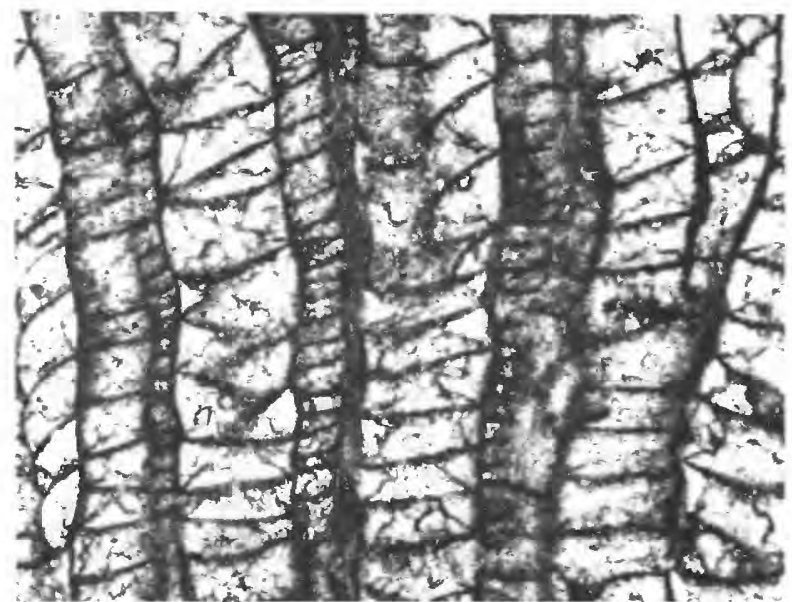

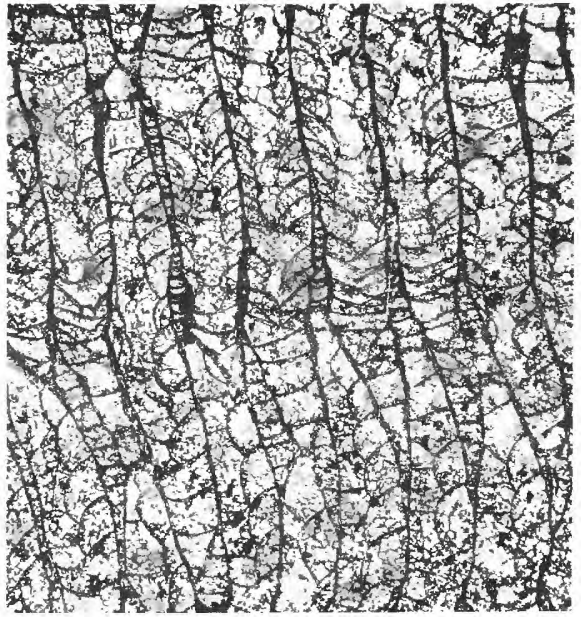

$1 b$

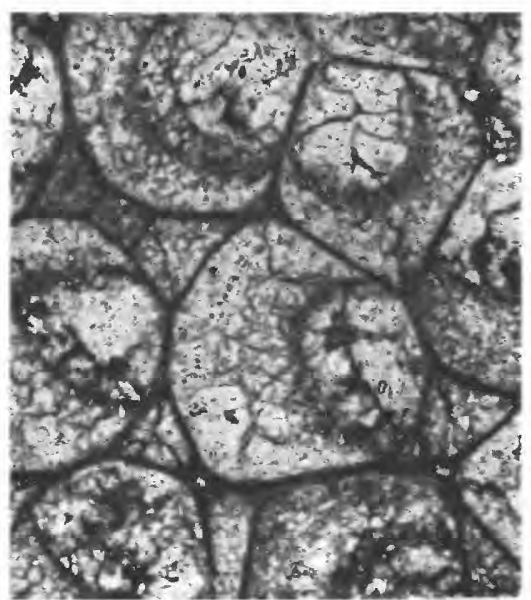

$3 a$

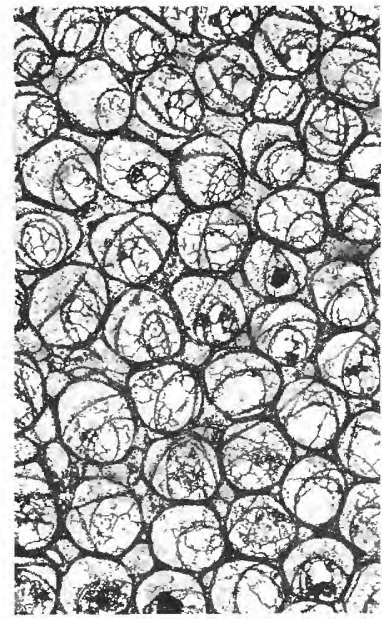

$1 \mathrm{c}$

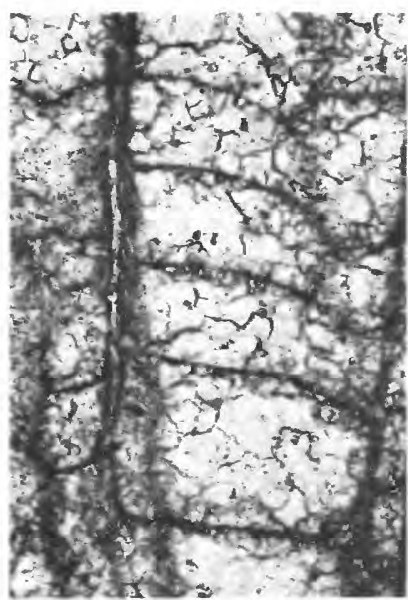

$3 \mathrm{~b}$

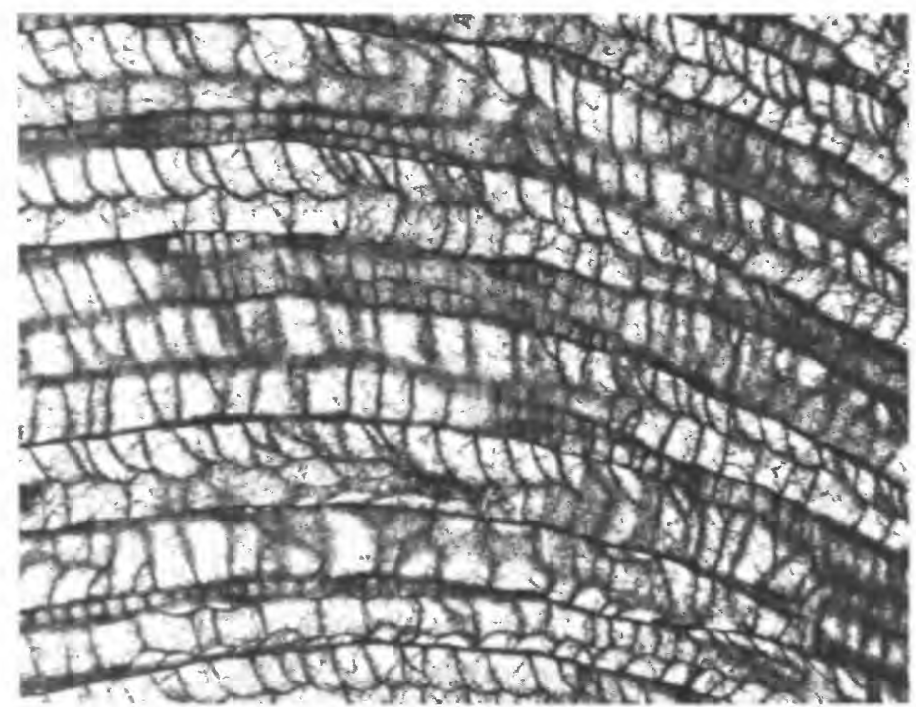

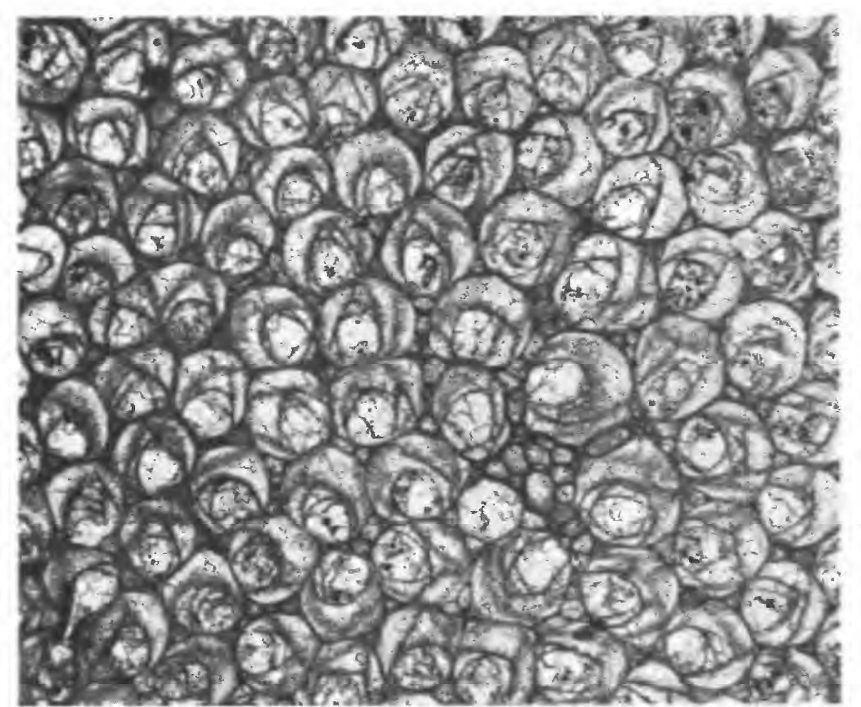

$4 b$

PRASOPORA 


\section{PLATE 14}

Figures 1-6. Prasopora falesi (James) (p. I42).

1, 2, 5, 6. Grier Limestone Member of the Lexington Limestone, Valley View Quadrangle, Kentucky.

1. Hypotype USNM 308546, Shermanian Stage (USGS colln. 4872-CO); basal layer of zoarium with thin, partly granular and laminar middle zone, indistinct endozone with recumbent autozooecia, basal diaphragms and cystiphragms abut basal layer, small styles along base of exozone (center of figure), longitudinal section, $\times 100$.

2. Hypotype USNM 308548 , Shermanian Stage (USGS colln. 4878-CO); $2 a$, autozooecium arises from mesozooecium (upper left of figure), longitudinal section, $\times 50 ; 2 b$, contiguous autozooecia with thick walls and larger chambers, few styles in late exozone, tangential section, $\times 50$.

5. Hypotype USNM 308543, Shermanian Stage (USGS colln. 4867-CO); 5a, curving autozooecia, mesozooecia with styles, basal diaphragms lack locally in some autozooecia, longitudinal section, $\times 30 ; 5 b$, microstructure of autozooecial and mesozooecial walls, and of mesozooecial diaphragms and styles having thick sheaths, sheath laminae transect cores locally, longitudinal section, $\times 100$.

6. Hypotype USNM 308537, Shermanian Stage (USGS colln. 4863-CO), cluster of mesozooecia in center of macula includes larger mesozooecia, chambers of polymorphs in macular margin oriented toward center of macula, tangential section, $\times 30$.

3. Hypotype USNM 308549, Sulphur Well Member, Shermanian Stage (USGS colln. 4893-CO) (float), of Lexington Limestone, Valley View Quadrangle, Kentucky; basal layer of zoarium forms median wall from which autozooecia bud in opposite direction (encrusted substrate to left of figure), longitudinal section, $\times 50$.

4. Hypotype USGS 308514, Grier Limestone Member, Shermanian Stage (USGS colln. 4688-CO), of Lexington Limestone, type section, Frankfort East Quadrangle, Kentucky; $4 a$, autozooecia with infundibular diaphragms (upper right of figure) and scattered brown bodies resting on basal diaphragms, cystiphragms in regular longitudinal series, longitudinal section, $\times 30 ; 4 b$, flask-shaped autozooecial chamber, inclined basal diaphragm and brown body (probable remnant of soft parts of autozooid), infundibular diaphragms form distal part of zooecial chamber, longitudinal section, $\times 100$. 


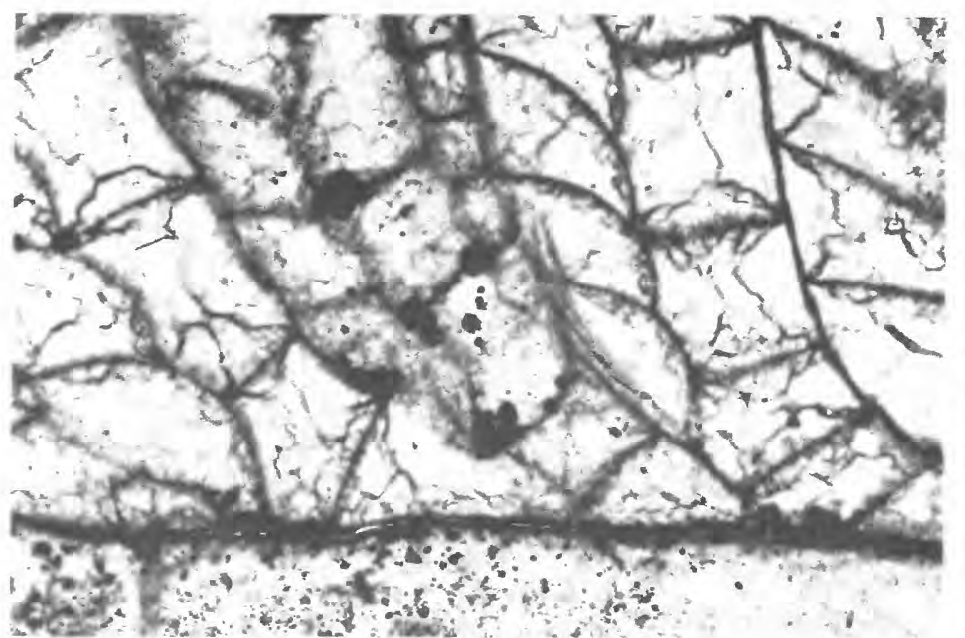

1

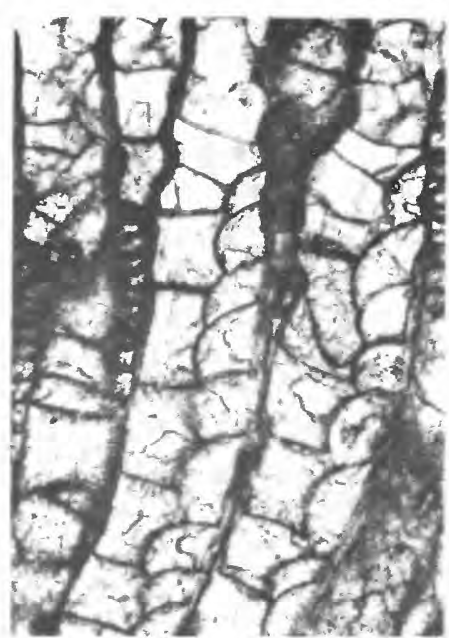

$2 a$

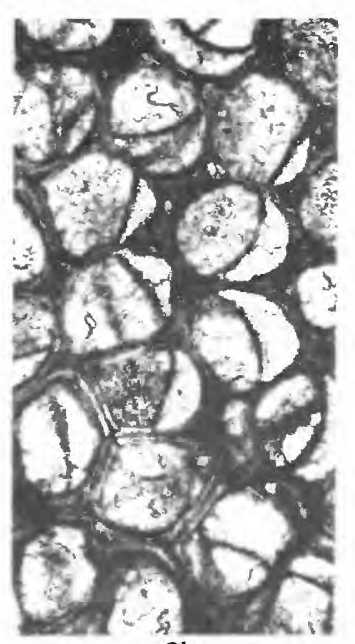

$2 b$

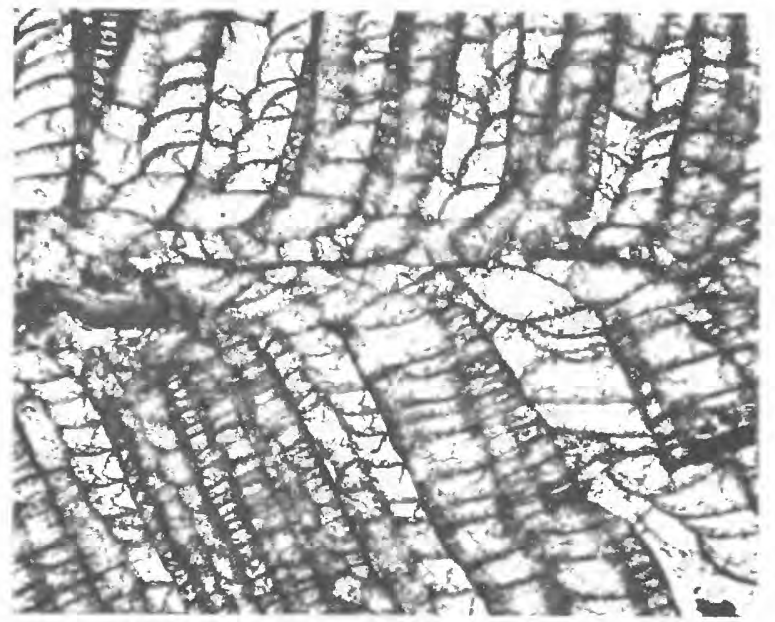

3

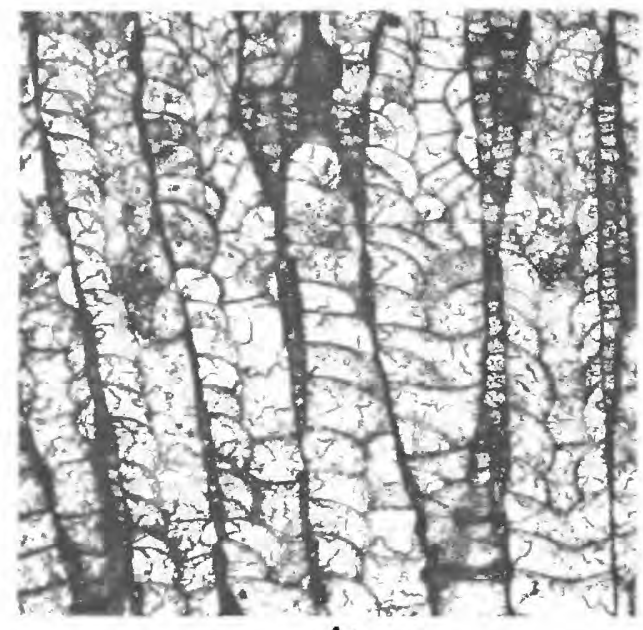

$4 a$

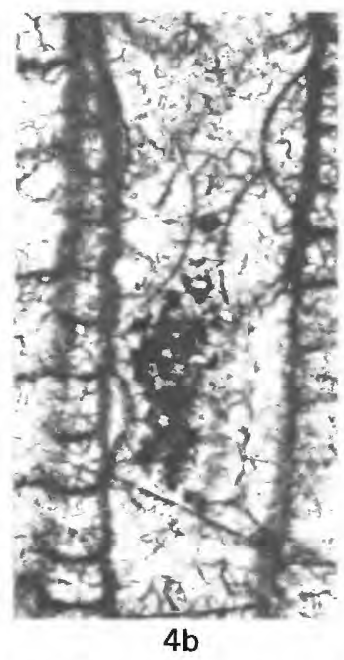

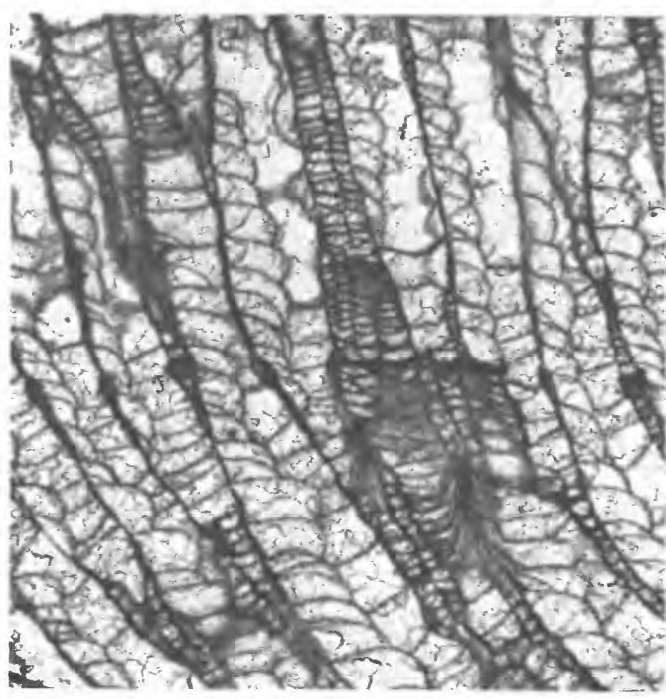

$5 a$

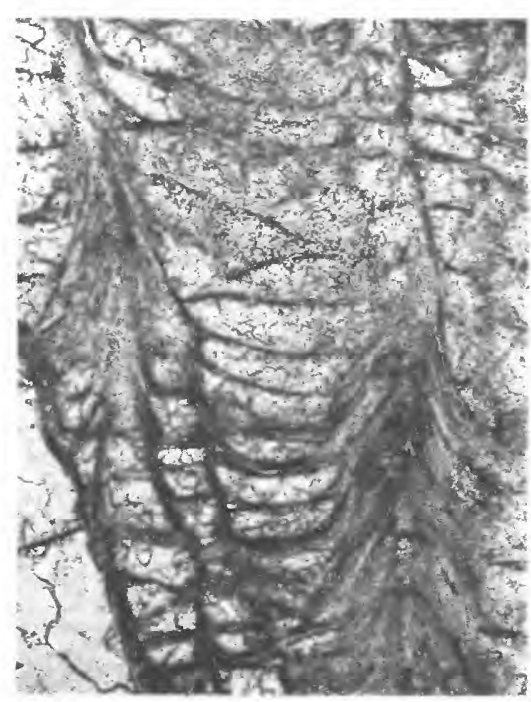

$5 b$

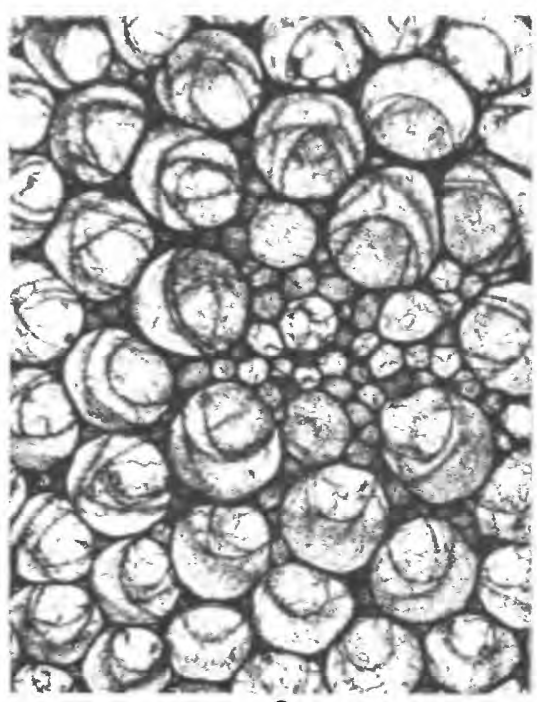

6

PRASOPORA 
PLATE 15

Figures 1, 2. Heterotrypa foliacea (Ulrich and Bassler) (p. I50).

1. Hypotype USNM 308648, Clays Ferry Formation, Edenian Stage (USGS colln. 4922-CO), Valley View Quadrangle, Kentucky; $1 a$, relatively wide exozone in encrusting portion of zoarium, basal diaphragms scattered locally, autozooecial walls exceptionally thin in this segment, few endostyles, mesozooecium with moniloid proximal portion, zone or rejuvenation of autozooecia (upper right of figure), longitudinal section, $\times 30 ; 1 b$, segment of zoarium with moderately thick autozooecial walls, small and moderately large styles, several mesozooecia, exozone, tangential section, $\times 30$.

2. Hypotype USNM 308694, Millersburg Member, Shermanian Stage (USGS colln 7040-CO), of the Lexington Limestone, Winchester Quadrangle, Kentucky; polygonal cross-sectional shape of autozooecia in endozone, basal diaphragms evenly spaced in exozone, transverse section, $\times 30$.

3-5. Cyphotrypa acervulosa (Ulrich) (p. I46).

3. Hypotype USNM 308572, Grier Limestone Member, Shermanian Stage (USGS colln. 4968-CO), of the Lexington Limestone, Frankfort West Quadrangle, Kentucky; $3 a$, autozooecia with thin walls and thin, straight to slightly curved basal diaphragms in exozone, oblique longitudinal peel, $\times 30$; $3 b$, polygonal cross-sectional shape of autozooecia, slightly larger autozooecia or polymorphs of macula (upper part of figure), tangential section, $\times 30$.

4. Hypotype USNM 308570, "Trenton Group," Middle Ordovician, Decorah, Iowa; $4 a$, contiguous autozooecia with thin walls in exozone, proximal four-sided portions of intercalated autozooecia (center of figure), tangential section, $\times 30$; $4 b$, microstructure of autozooecial walls in exozone, small styles in corners of autozooecia, tangential section, $\times 100$.

5. Hypotype USNM 308569, "Trenton Group" Middle Ordovician, Decorah, Iowa; $5 a$, autozooecia with relatively straight walls, basal diaphragms planar to slightly curved, commonly convex distally, zone of more closely spaced basal diaphragms and scattered cystoidal diaphragms, longitudinal section, $\times 30 ; 5 b$, microstructure of thin and swelled portions of autozooecial walls, basal and cystoidal diaphragms, narrowly and broadly serrated autozooecial boundaries in thin and thick walls, respectively, longitudinal section, $\times 100$. 
GEOLOGICAL SURVEY

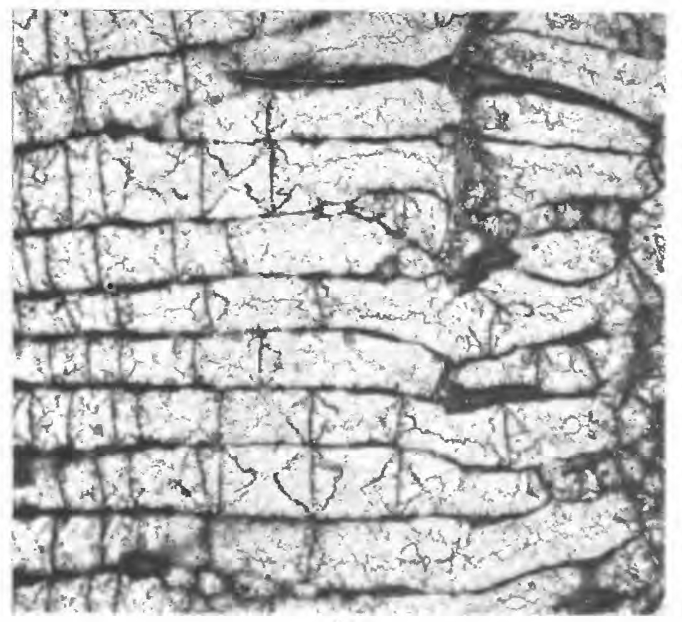

$1 \mathrm{a}$

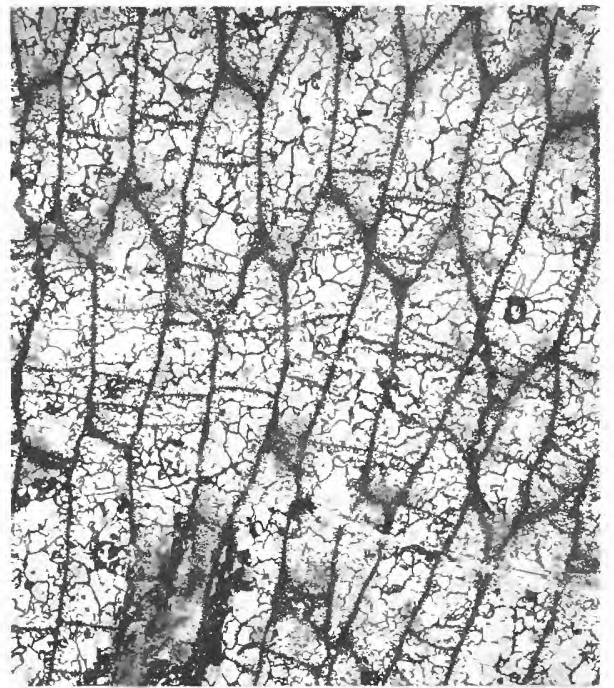

$3 a$

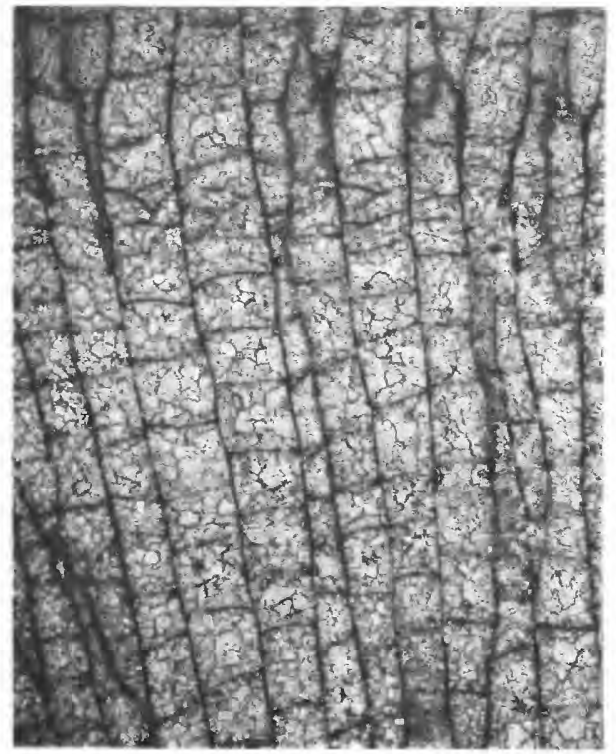

$5 a$

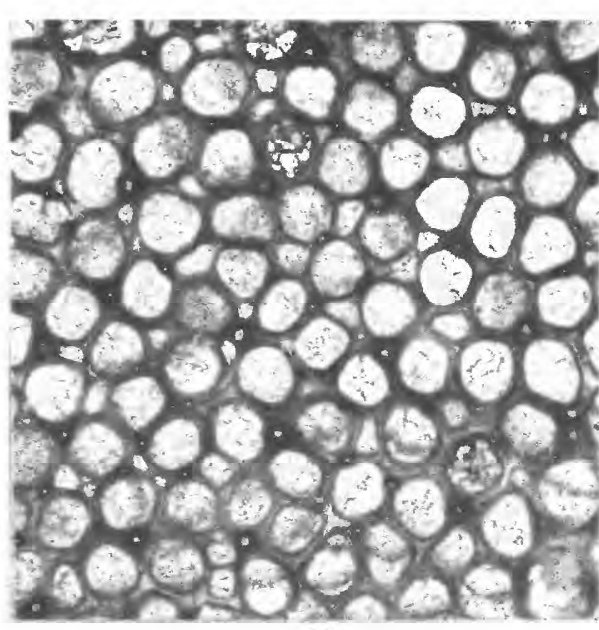

$1 b$

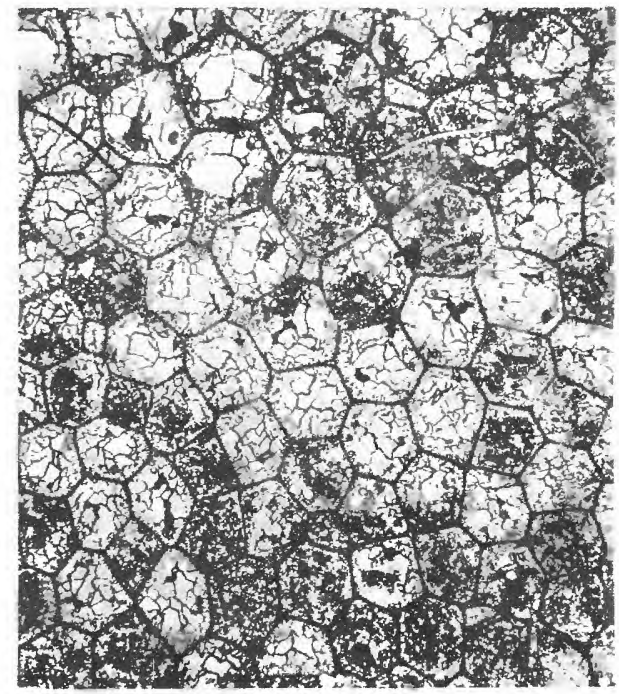

$3 \mathrm{~b}$

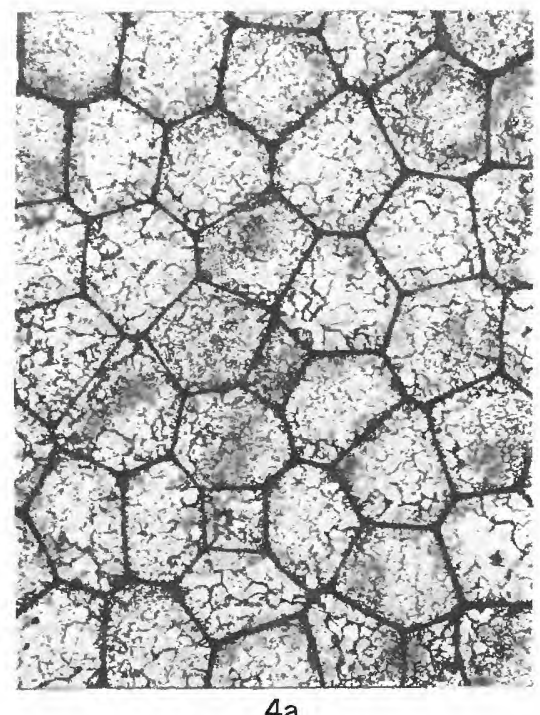

$4 a$

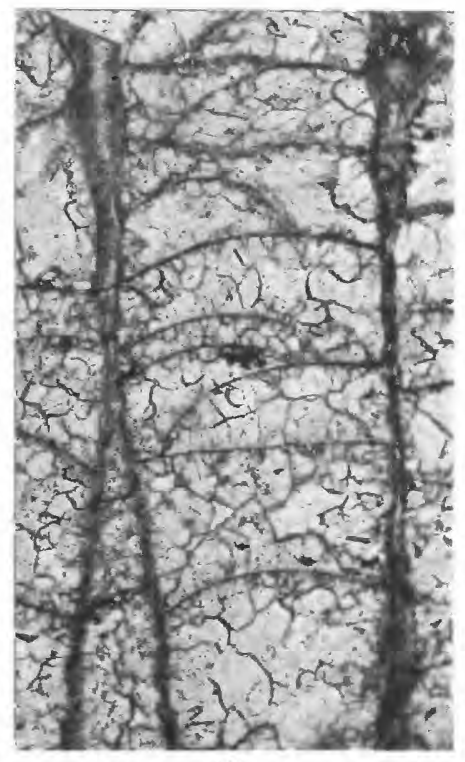

$5 b$

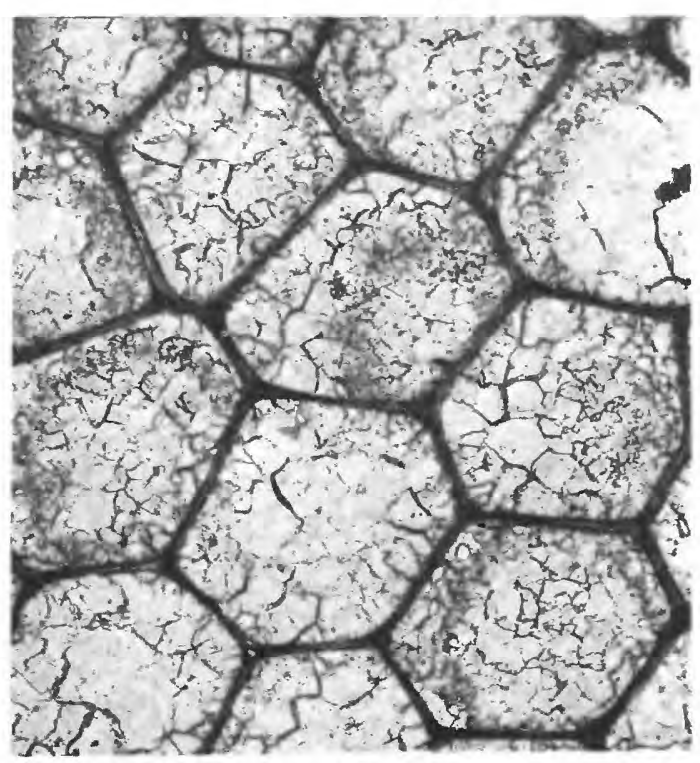

$4 \mathrm{~b}$
HETEROTRYPA, CYPHOTRYPA

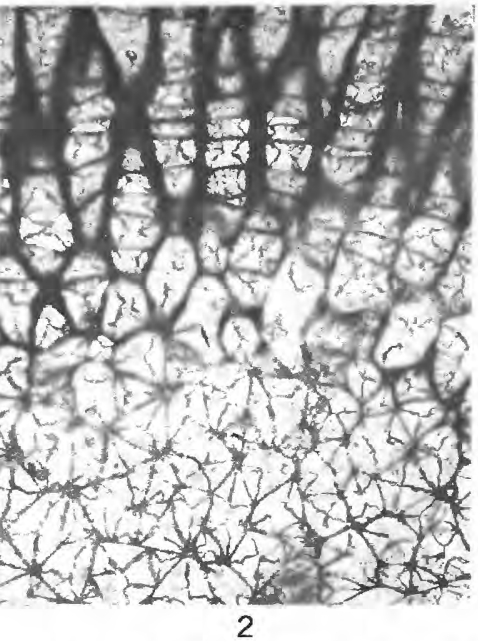




\section{PLATE 16}

Figure 1. Heterotrypa foliacea (Ulrich and Bassler) (p. I50).

Hypotype USNM 308616, Millersburg Member, Shermanian Stage (USGS colln. D1311-CO), of Lexington Limestone; Gratz Quadrangle, Kentucky; 1a, segment of zoarium with partly moniloid autozooecial walls in exozone, autozooecial boundaries narrowly serrated locally, thin basal diaphragms, sparse cystoidal diaphragms, longitudinal section, $\times 50$; $1 b$, amalgamate appearance of autozooecial walls, few mesozooecia, exceedingly small and few styles in exozone, tangential section, $\times 30$.

2, 3. Cyphotrypa switzeriensis n. sp. (p. I47); Grier Limestone Member of the Lexington Limestone, Switzer Quadrangle, Kentucky.

2. Paratype USNM 308581, Shermanian Stage (USGS colln. D1117-CO); 2a, erect and straight autozooecia with exceedingly thin walls, few basal diaphragms in a zone in late exozone, longitudinal section, $\times 30 ; 2 b$, microstructure of autozooecial walls, styles absent, tangential section, $\times 100$.

3. Holotype USNM 308578, Shermanian Stage (USGS colln. D1113-CO); 3a, microstructure of autozooecial walls, autozooecial boundaries narrowly serrated in thicker portion of autozooecial wall (center of figure), basal diaphragms exceedingly thin, longitudinal section, $\times 100 ; 3 b$, basal diaphragms sparse to lacking, autozooecia with irregularly crenulated walls locally, longitudinal section, $\times 30 ; 3 c$, microstructure of autozooecial walls in exozone, autozooecial boundaries obscured, appear to be broadly serrated locally, styles lacking, tangential section, $\times 100$; $3 d$, polygonal shape of autozooecia in cross section, general alignment of autozooecia in exozone, tangential section, $\times 30$. 


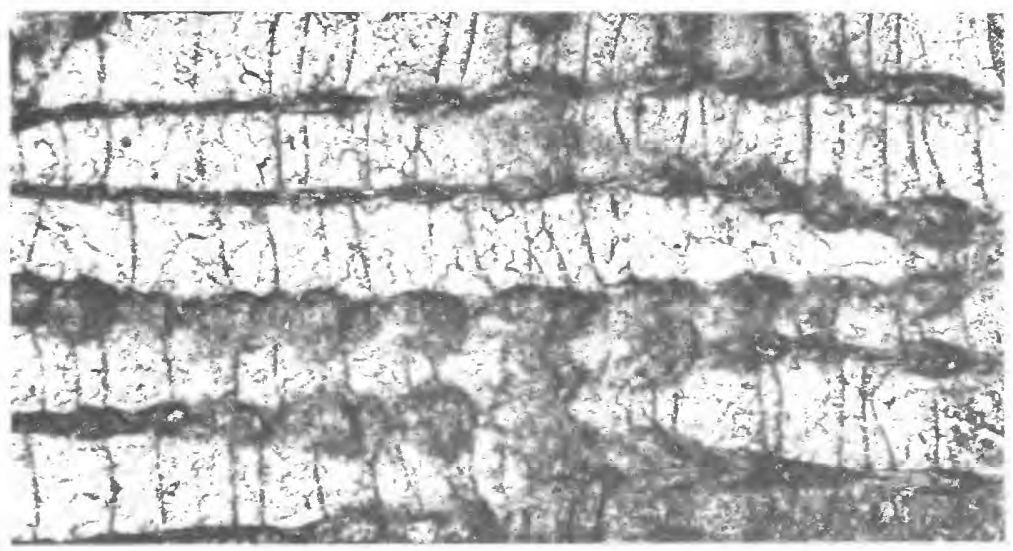

$1 \mathrm{a}$

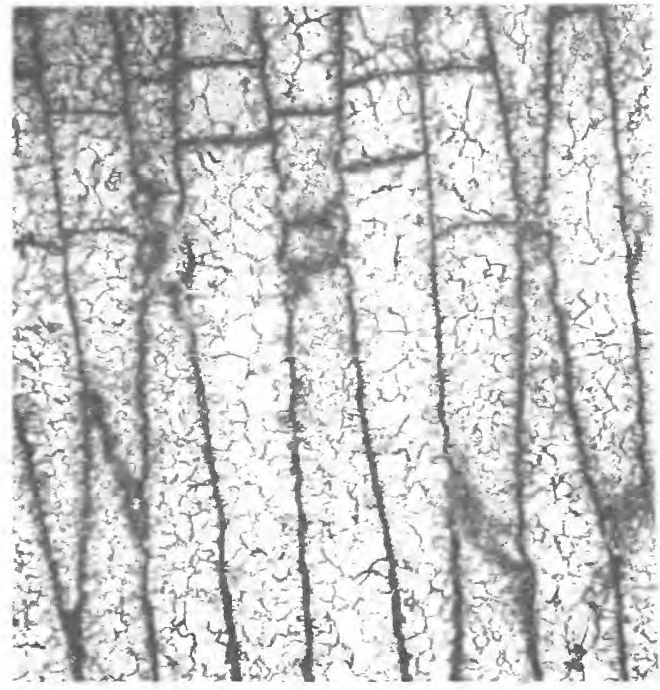

$2 a$

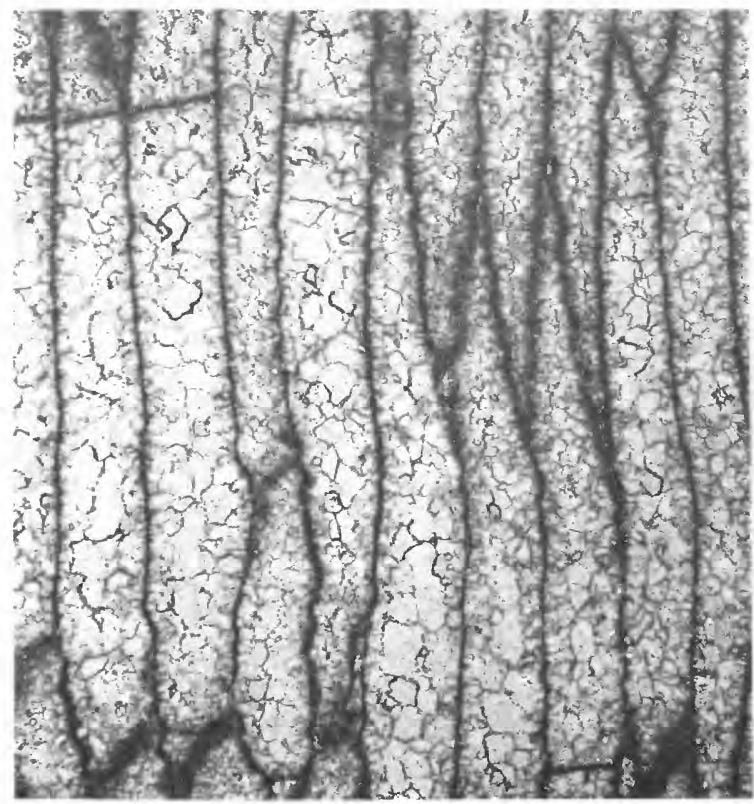

$3 b$

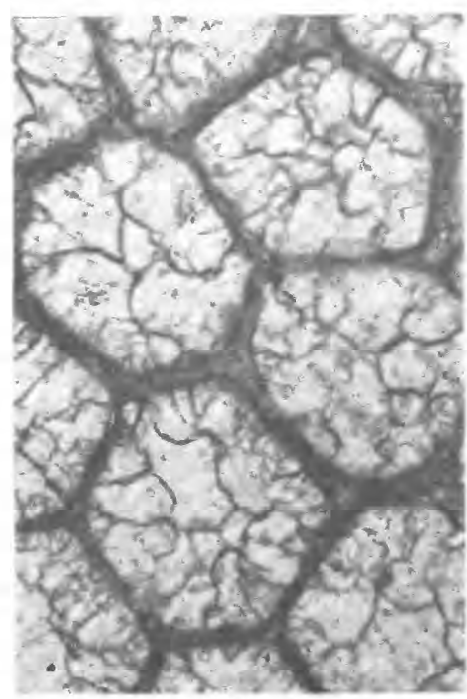

$2 b$

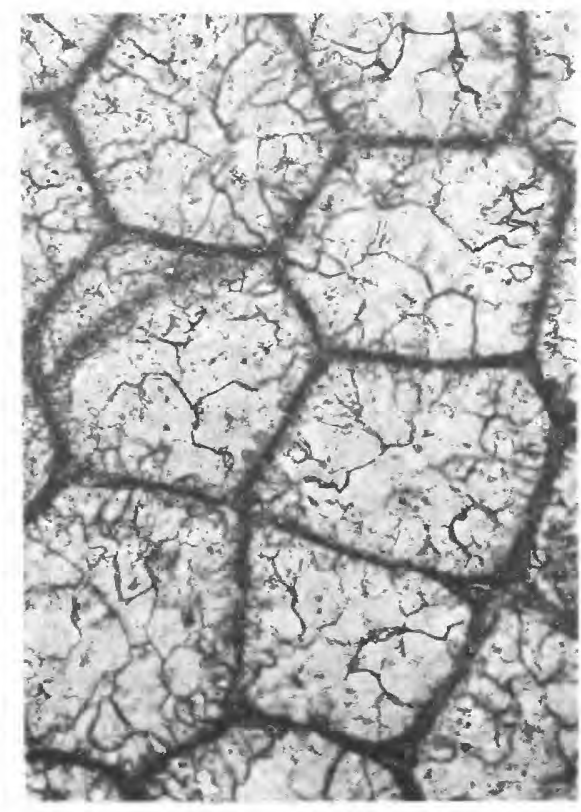

$3 c$

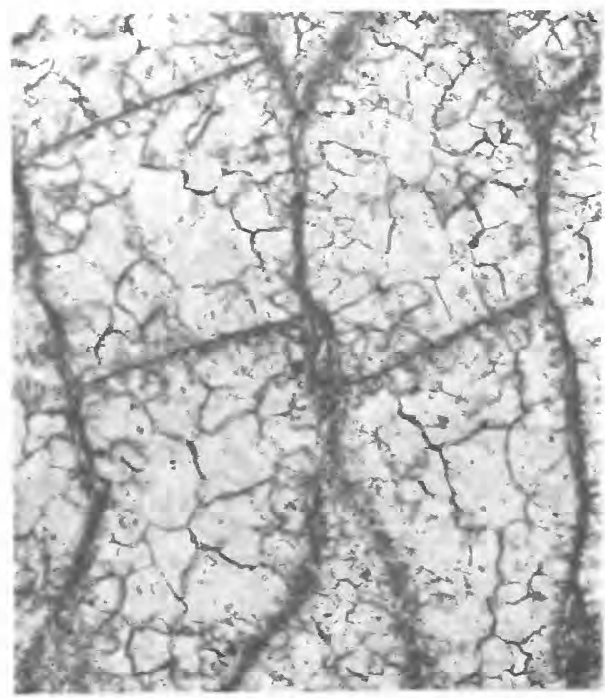

3a

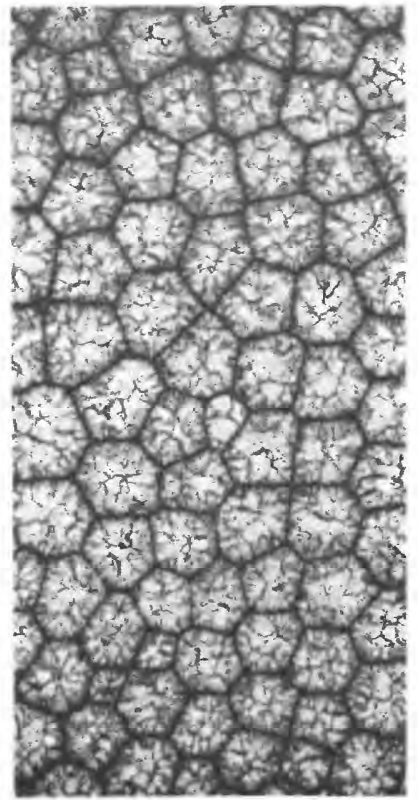

$3 d$

HETEROTRYPA, CYPHOTRYPA 


\section{PLATE 17}

Figures 1-3. Dekayia epetrima n. sp. (p. I48).

1. Paratype USNM 308585, Grier Limestone Member, Shermanian Stage (USGS colln. D1112_CO), of Lexington Limestone, Switzer Quadrangle, Kentucky; 1a, relatively large endostyles with thick sheaths distally of base of zone of rejuvenation of autozooecia in endozone, exceedingly thin autozooecial walls, longitudinal section, $\times 50 ; 1 b$, large styles with relatively small cores and thick sheaths, few small possible exozonal styles between autozooecial corners in early exozone, longitudinal section, $\times 50 ; 1 c$, general appearance of endozone and exozone, autozooecia gradually curving outward, numerous endostyles in endozone, thin autozooecial walls and numerous basal diaphragms in exozone, conspecific overgrowth in right part of figure, basal diaphragms virtually absent in endozone, longitudinal section, $\times 20 ; 1 d$, thin, slightly curved basal diaphragms in exozone, thick endostyles, thin autozooecial walls lacking styles, exozone, longitudinal section, $\times 50$.

2. Paratype USNM 308590, Millersburg Member, Shermanian Stage (USGS colln. 7453-CO), of Lexington Limestone, Sadieville Quadrangle, Kentucky; portion of encrusting portion of a zoarium, endostyles in early exozone, thin autozooecial walls distally of styles, basal diaphragms in exozone, oblique longitudinal peel, $\times 50$.

3. Holotype USNM 308584, Grier Limestone Member, Shermanian Stage (USGS colln. D1115-CO), of Lexington Limestone, Switzer Quadrangle, Kentucky; $3 a$, autozooecia aligned in petaloid clusters with endostyles in centers of clusters in exozone, tangential section, $\times 50 ; 3 b$, basal diaphragms sparse to absent in endozones, proximal portions of autozooecia locally slightly crenulated in endozone, basal diaphragms common in exozone, longitudinal section, $\times 30 ; 3 c$, autozooecial walls thin, uniform in thickness where styles are absent, incomplete infundibular diaphragms (upper part of figure), longitudinal section, $\times 50 ; 3 d$, endostyles at different growth stages in centers of petaloid clusters of autozooecia, autozooecial chambers variable in size and shape, tangential section, $\times 30$. 


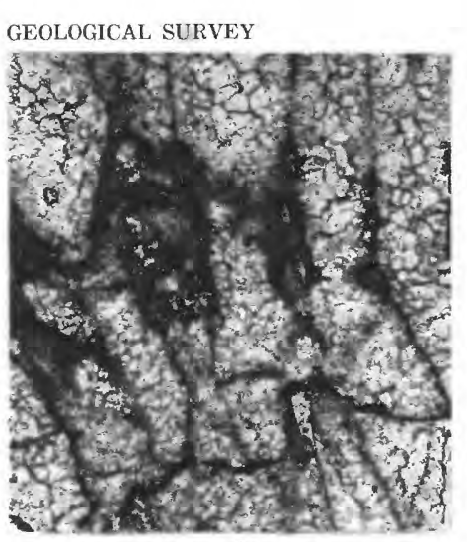

$1 a$

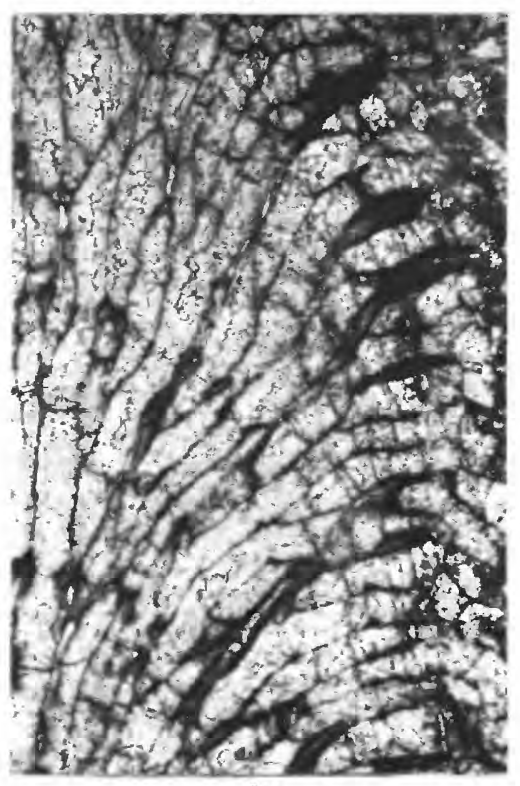
1c

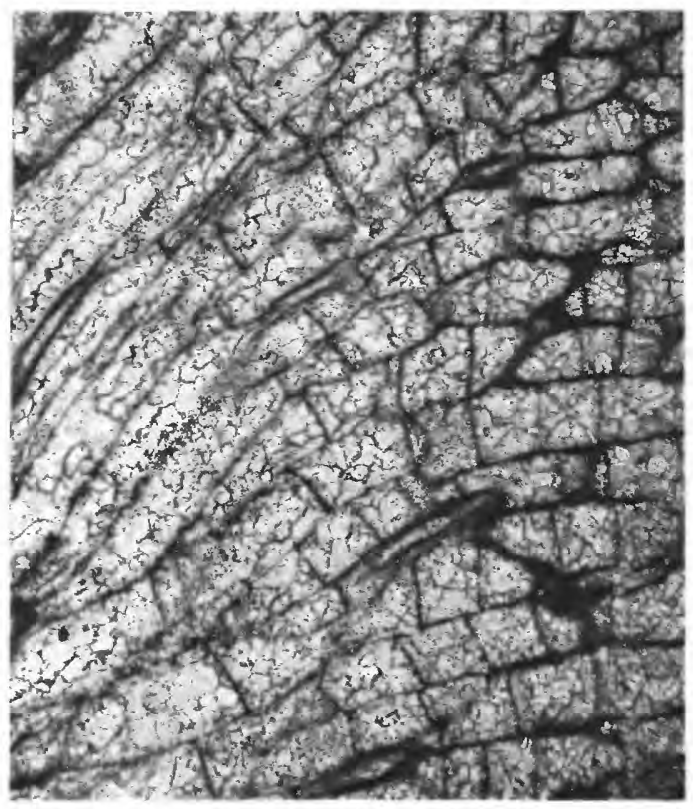

$3 b$

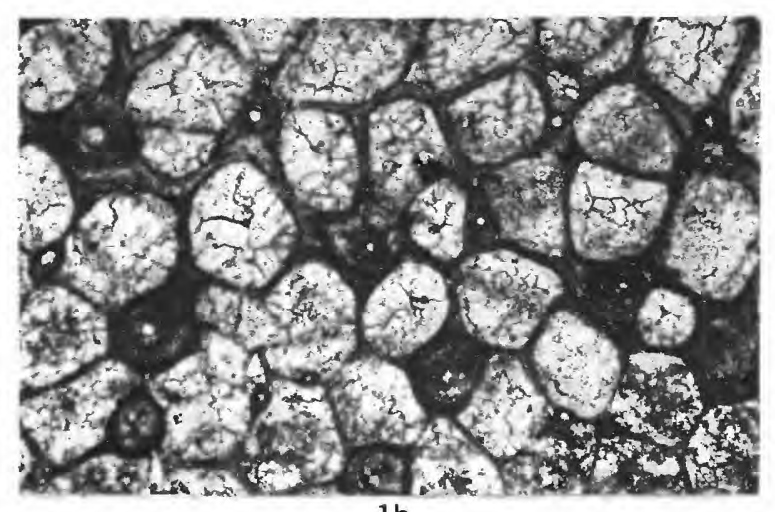

1b

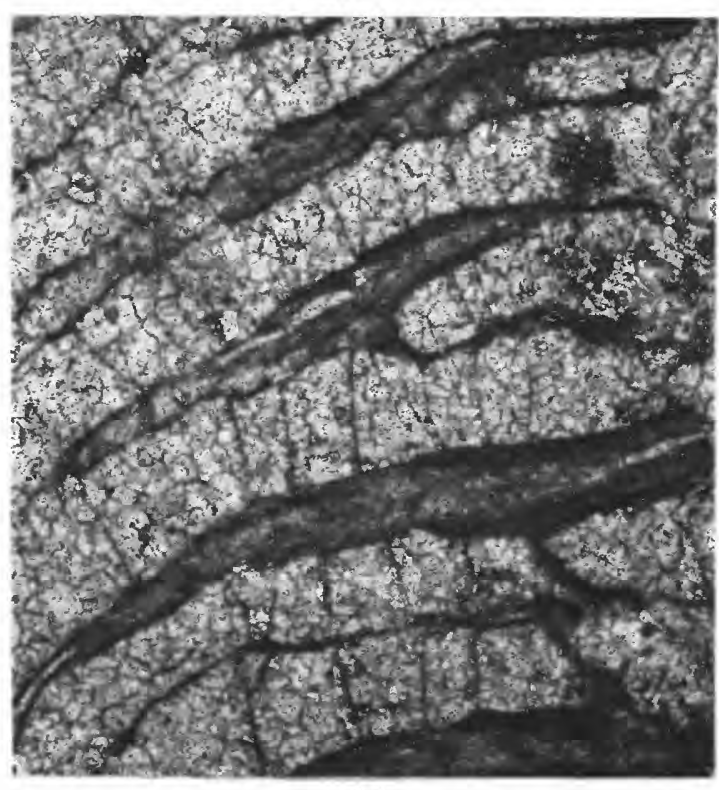

1d

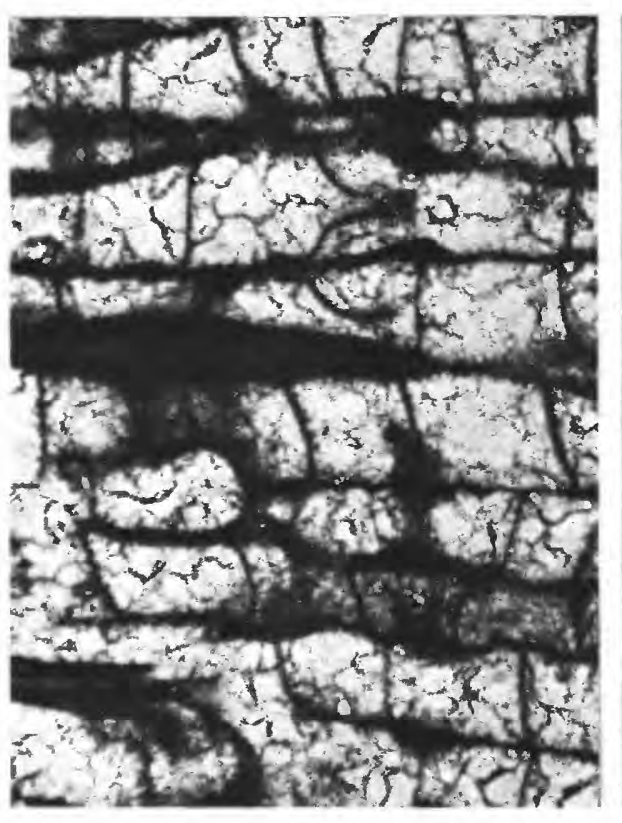

$3 c$
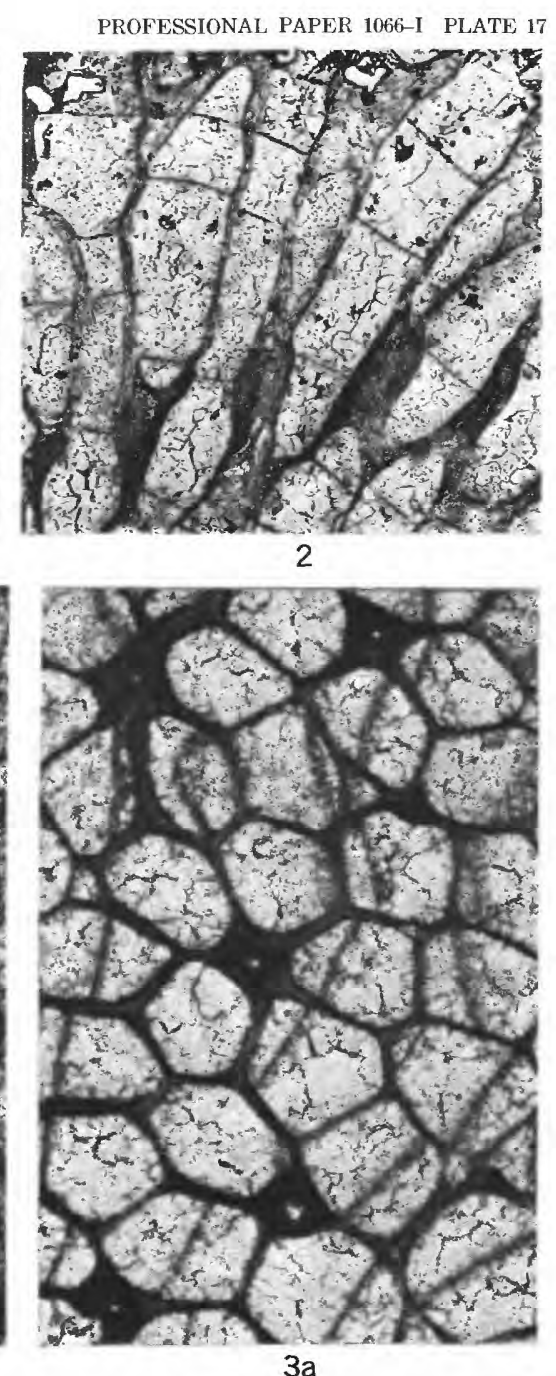

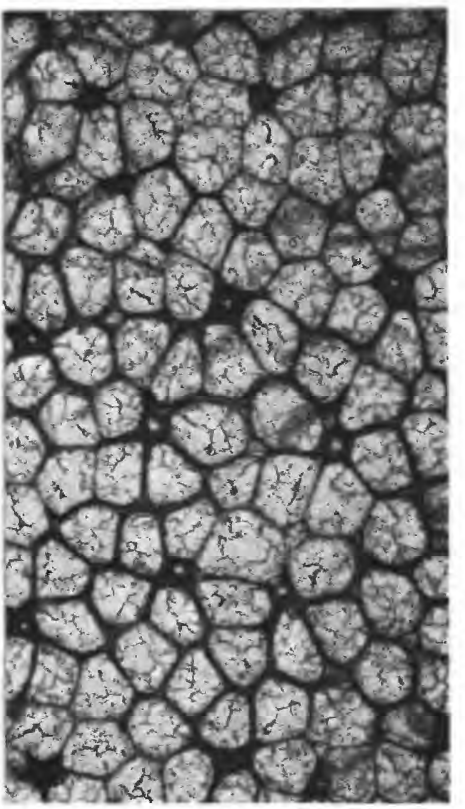

$3 d$

DEKAYIA 
PLATE 18

Figures 1, 2. Dekayia appressa Ulrich, from primary type suite USNM 43655 from the "Corryville beds, Maysvillian Stage," Upper Ordovician, Cincinnati, Ohio.

1. Paratype USNM 309662, relatively thick and distinctly crenulated autozooecial walls in exozone, moniloid portions of autozooecia in early exozone, few basal diaphragms, cross-sectional shape of autozooecia in endozone, transverse section, $\times 30$.

2. Holotype USNM 43655; $2 a$, small exozonal styles and some endostyles in autozooecial corners, autozooecia in indistinct petaloid alignment in exozone, cross-sectional shape of autozooecial chambers, tangential section, $\times 30 ; 2 b$, moniloid portions of autozooecia in late endozone and early exozone, basal diaphragms sparse in exozone, virtually lacking in endozone, broadly curved laminae in autozooecial walls, style projects into autozooecial chamber, longitudinal section, $\times 30$.

3. Dekayia sp. (p. I49), hypotype USNM 308591, Millersburg Member, Shermanian Stage (USGS colln. 7040-CO), of Lexington Limestone, Winchester Quadrangle, Kentucky; $3 a$, autozooecia irregularly polygonal in cross section in exozone, few styles, amalgamate appearance of autozooecial walls, tangential peel, $\times 50 ; 3 b$, globular zoarium envelops detrital fragment of brachiopod, basal layer bounding zoarium exceedingly thin and indistinct; cross-sectional shape of autozooecia in endozones and at basal layer, basal diaphragms generally lack in endozone, occur abundantly in exozone, closely and evenly spaced in late exozone, autozooecial walls relatively thin, straight, slightly crenulated locally, mesozooecia sparse, with moniloid proximal portions, endostyles few, with distinct cores and sheaths, transverse and oblique longitudinal peel, $\times 30$.

4, 5. Stigmatella multispinosa (Brown) (p. I57).

4. Hypotype USNM 308790, Grier Limestone Member, Shermanian Stage (USGS colln. 4694-CO), of Lexington Limestone, type section of Lexington Limestone, Frankfort East Quadrangle, Kentucky; 4a, autozooecia with exceedingly thin, straight walls in exozone, styles in thickened portions of walls (center of figure), basal diaphragms more closely spaced in late than early exozones, longitudinal section, $\times 30 ; 4 b$, cross-sectional shape of autozooecia in exozone, numerous small styles, cores of styles obscured, tangential section, $\times 50$.

5. Hypotype USNM 308787, Grier Limestone Member, Shermanian Stage (USGS colln. D1302-CO), of Lexington Limestone, Gratz Quadrangle, Kentucky; general alignment of autozooecia, cores of styles exceedingly small, autozooecia in early exozone (lower part of figure), possible mesozooecia or proximal portions of intercalated autozooecia (upper part of figure), tangential section, $\times 50$. 

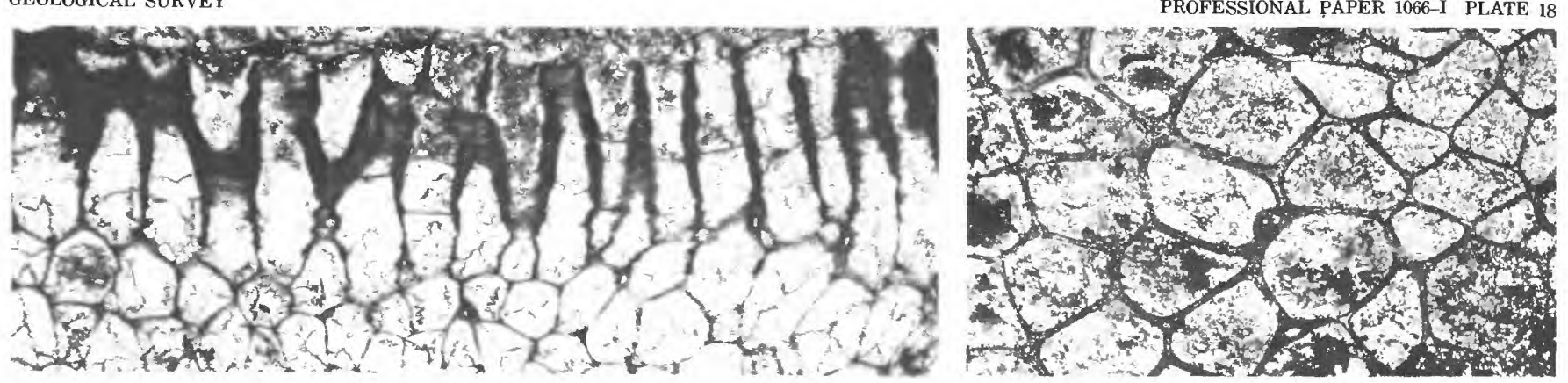

$$
1
$$

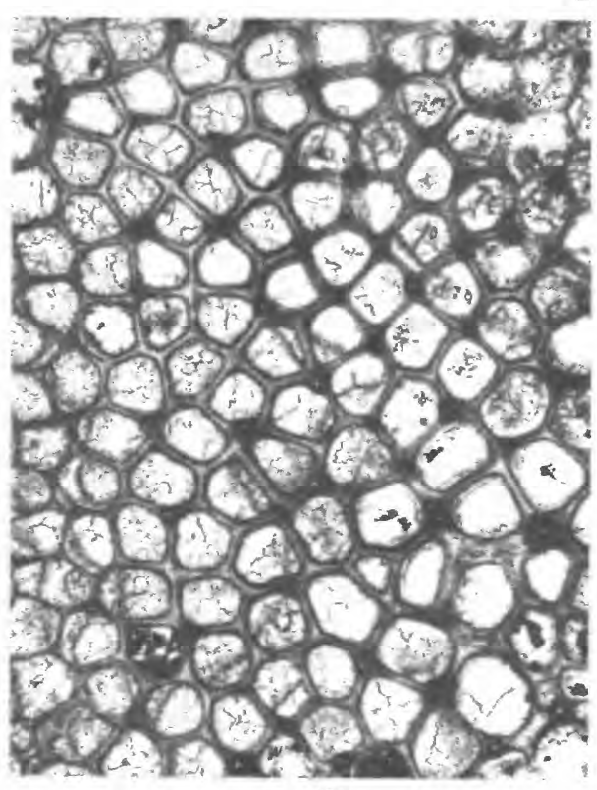

$2 a$

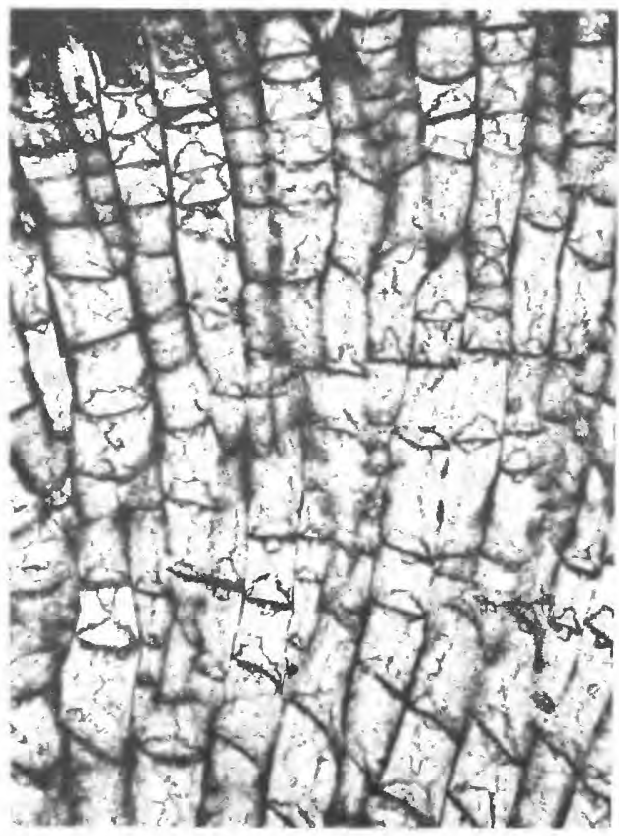

$4 a$
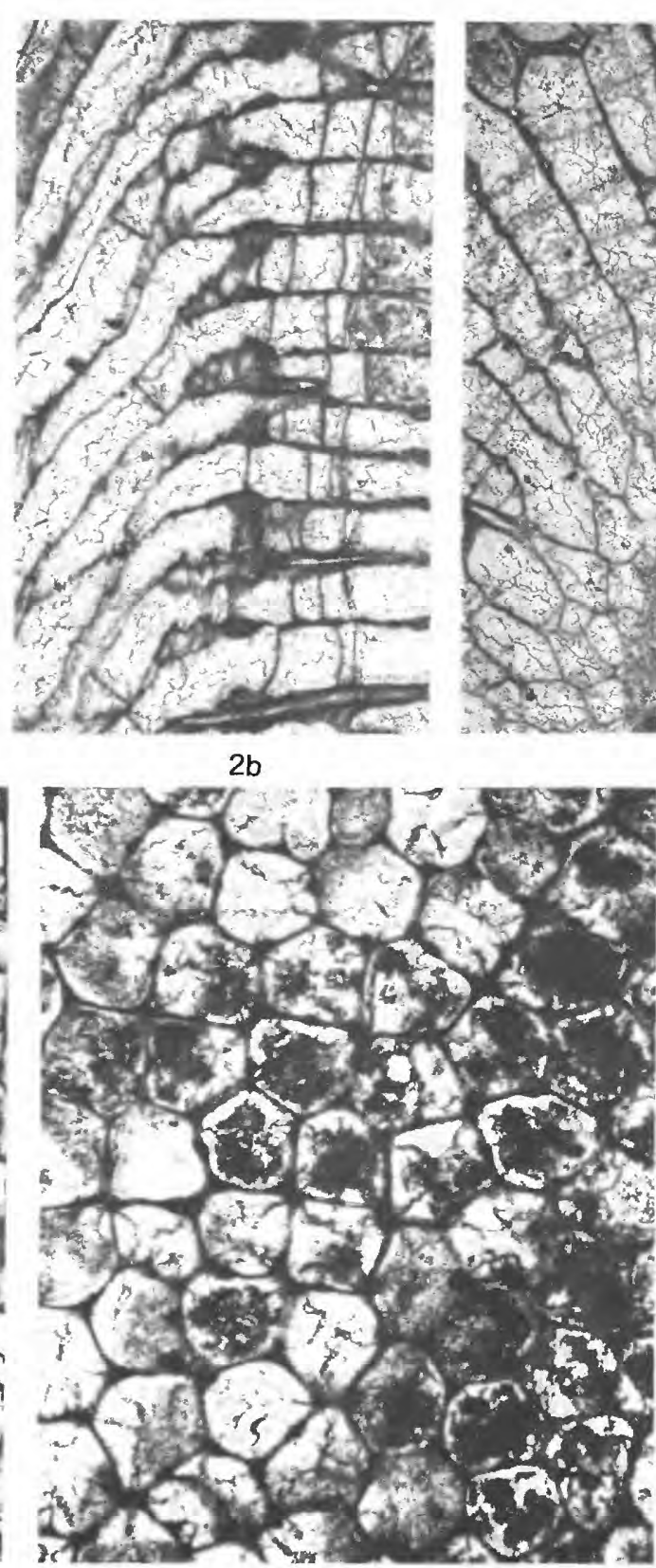

$4 b$
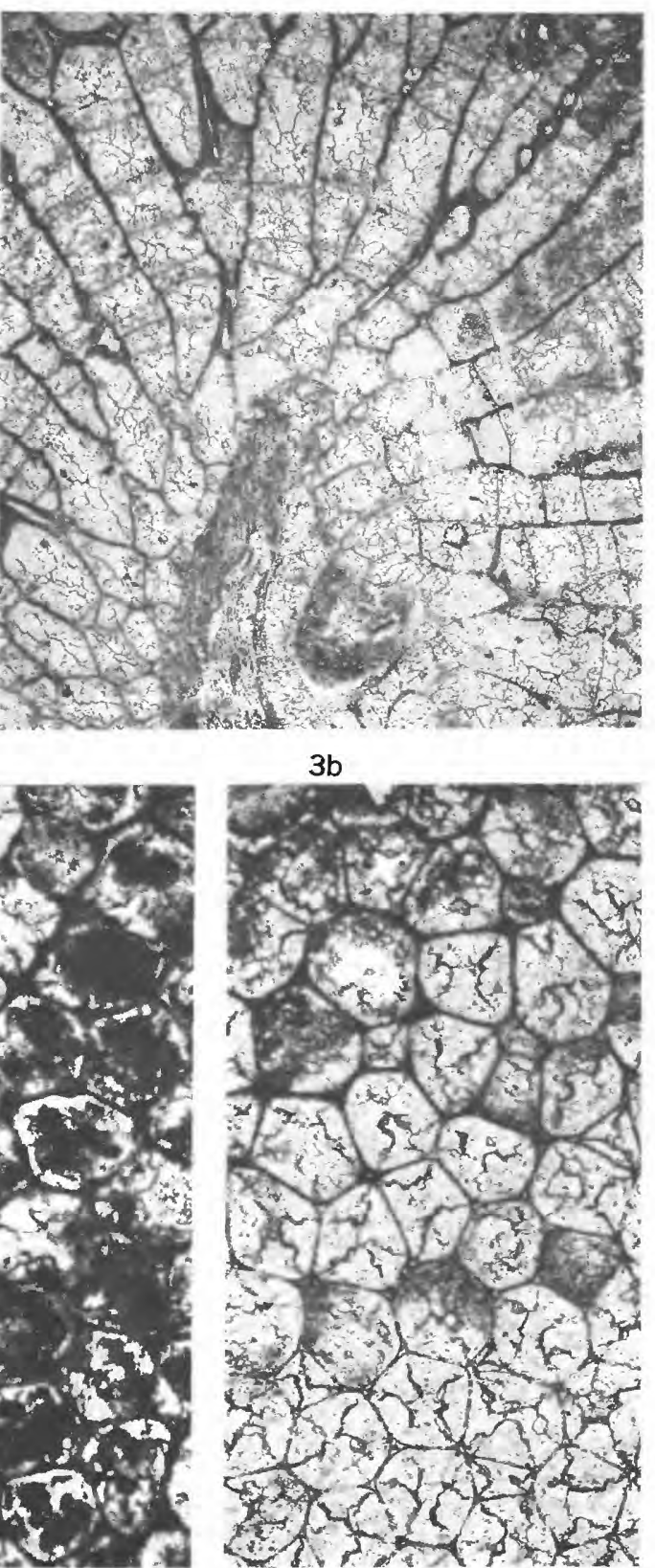

5

DEKAYIA, STIGMATELLA 


\section{PLATE 19}

Figures 1-3. Heterotrypa foliacea (Ulrich and Bassler) (p. I50).

1. Hypotype USNM 308644, Clays Ferry Formation, Shermanian Stage (USGS colln. 4898-CO), Valley View Quadrangle, Kentucky; $1 a$, wide exozone, degree of curvature of autozooecia at base of exozone, autozooecia at right angles to zoarial surface, abundant basal diaphragms evenly spaced in exozone, proximal portion of mesozooecium is almost moniloid, longitudinal section, $\times 30 ; 1 b$, exozonal styles common, relatively small in appearance, scattered mesozooecia, subcircular to subpolygonal autozooecial chambers in cross section, tangential section, $\times 30$; 1 , microstructure of autozooecial walls, styles project into autozooecial chambers, thin and planar basal diaphragms, longitudinal section, $\times 50$.

2. Syntype USNM 96569, Heterotrypa foerstei Nickles, "Eden Group," Upper Ordovician, Rogers Gap, Ky.; 2a, flattened or subfrondescent zoarial branch, general alignment of autozooecia, indistinct maculae, portion of specimen figured by Nickles, 1905 (pl. 2, fig. 5), external view, $\times 3 ; 2 b$, basal diaphragms sparse to absent in endozone, closely spaced in exozone, slightly crenulated autozooecial walls in endozone, longitudinal section, $\times 30$; $2 c$, endostyle and scattered exozonal styles, mesozooecia partly separate some autozooecia, tangential section, $\times 30$.

3. Holotype USNM 43187, Heterotrypa foliacea, "Lexington Limestone of the Trenton" of Ulrich and Bassler; thin sections probably figured by Ulrich and Bassler, 1904, pl. 7, figs. 1-12, near Lexington, Ky.; $3 a$, general alignment of autozooecia, indistinct maculae, external view, $\times 3$; $3 b$, wide exozone, autozooecia with moderately thick walls, basal diaphragms planar to slightly curved, concave distally and evenly spaced, endostyle in early exozone, few cystoidal diaphragms, longitudinal section, $\times 30 ; 3 c$,cross-sectional shape of autozooecia and mesozooecia, exozonal styles with thin cores and moderately thick sheaths slightly inflect walls of some autozooecia, tangential section, $\times 30 ; 3 d$, autozooecia in indistinct petaloid alignment, endostyles in centers in some petaloid clusters of autozooecia, scattered exozonal styles, amalgamate appearance of autozooecial walls, tangential section, $\times 30$. 


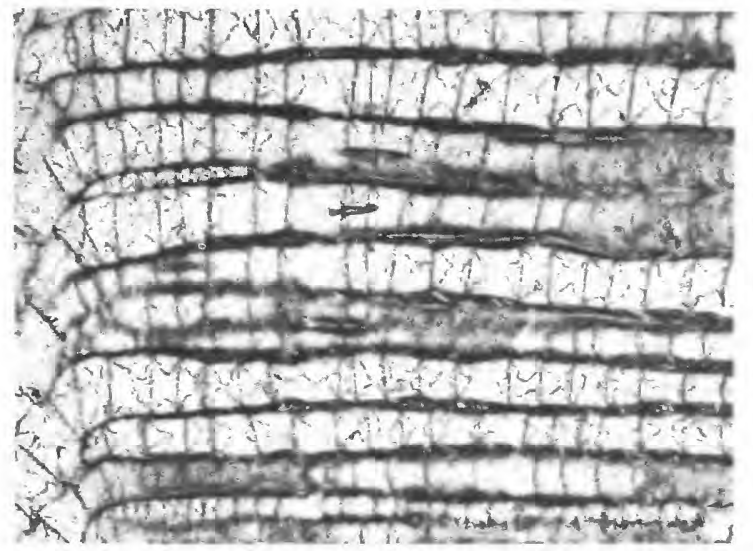
1a

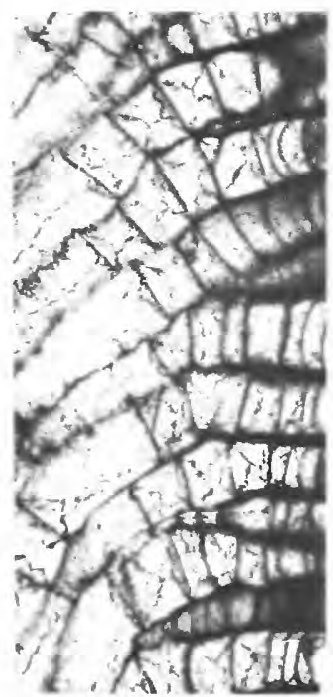

$2 b$

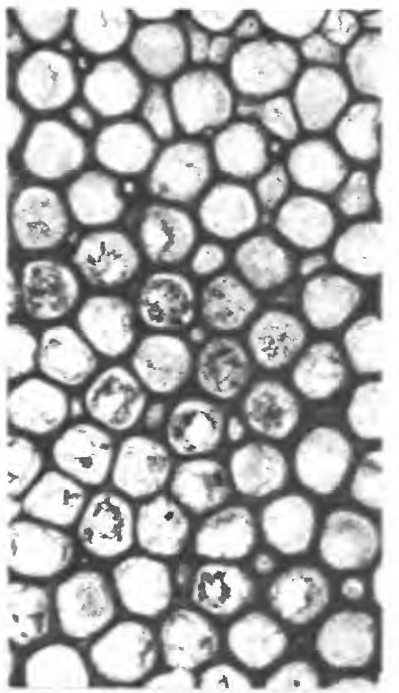

$2 \mathrm{c}$

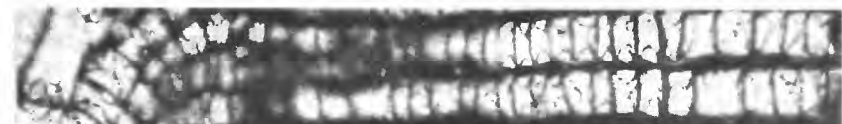

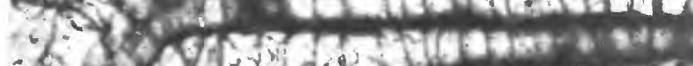

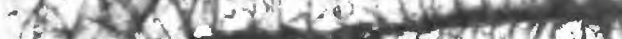

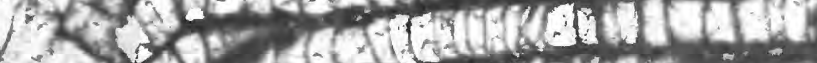

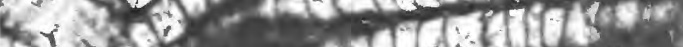

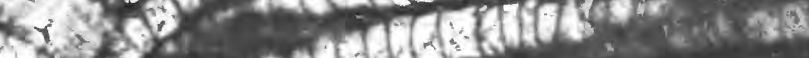

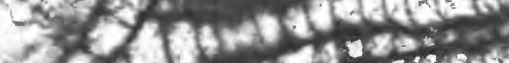

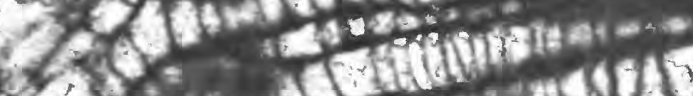

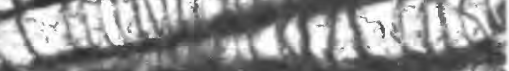

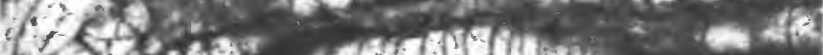

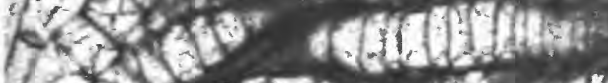

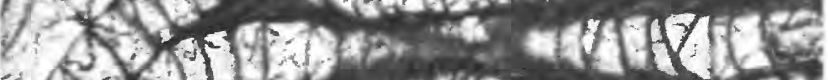

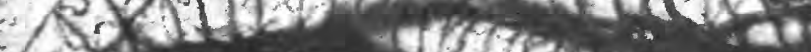

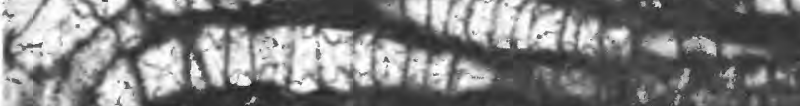

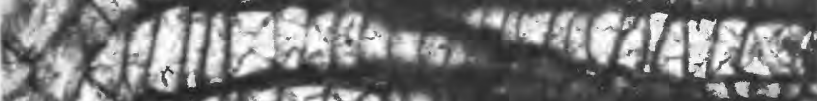

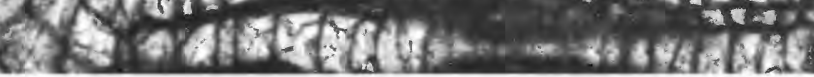

$3 b$
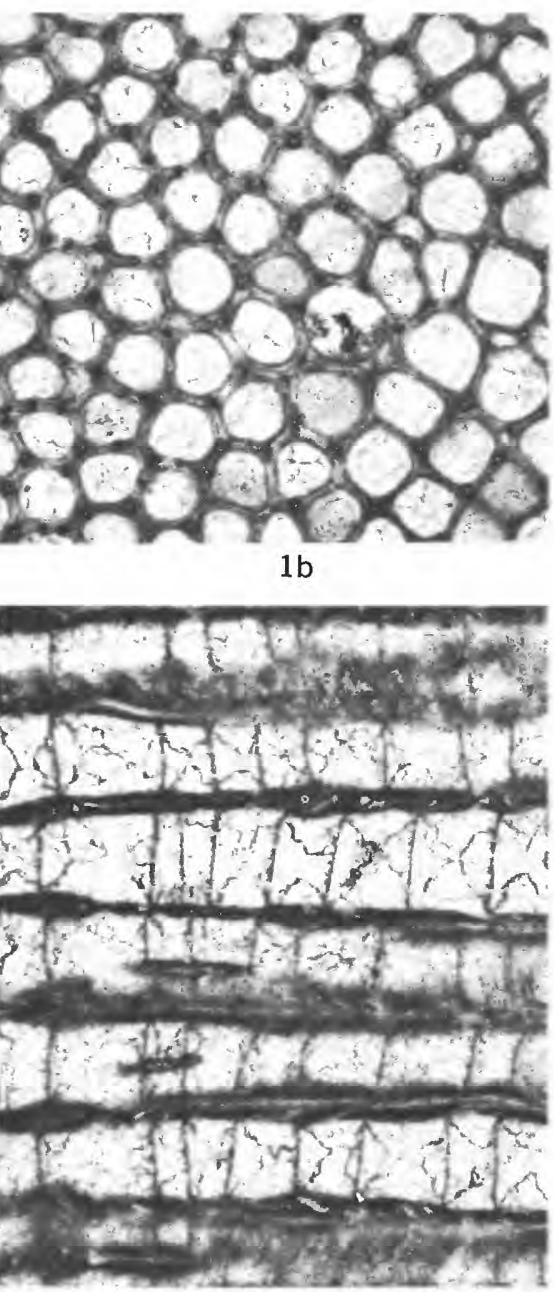

$1 \mathrm{c}$
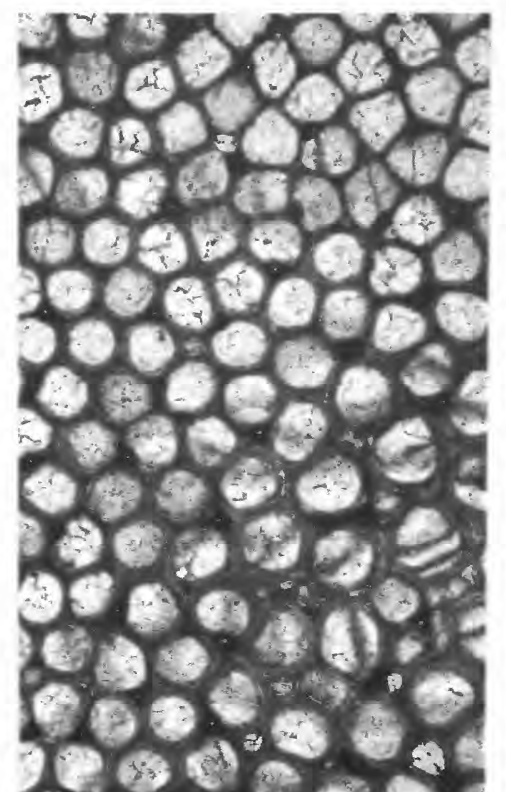

$3 c$
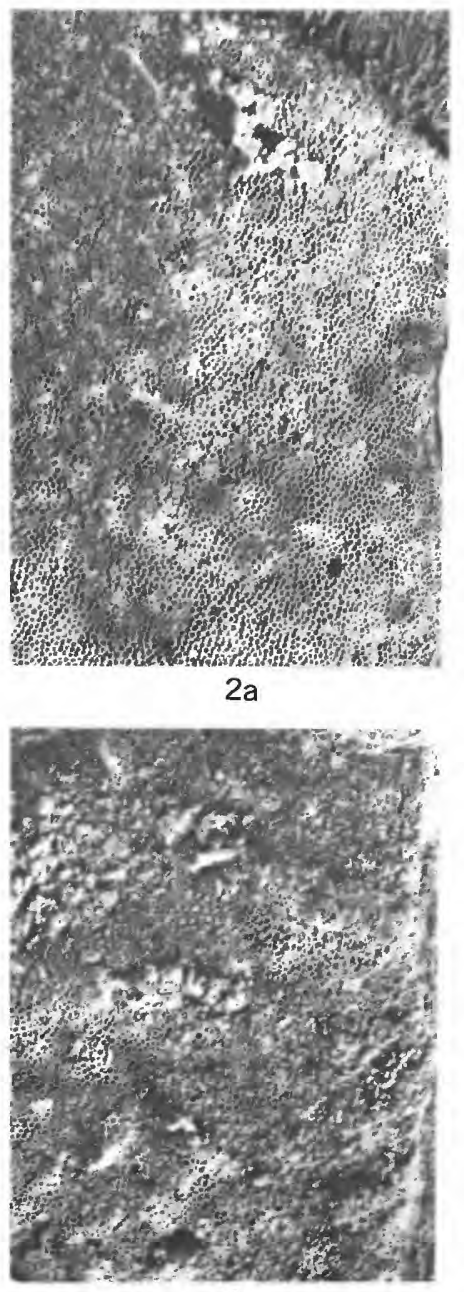

3a

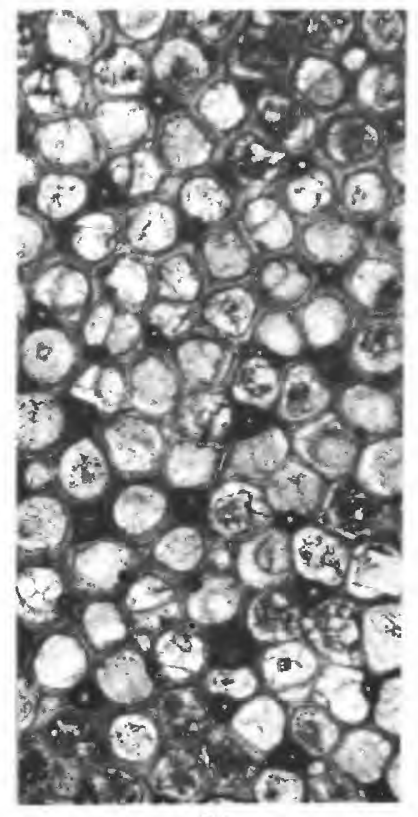

$3 d$ 


\section{PLATE 20}

Figures 1-4. Heterotrypa trentonensis (Ulrich) (p. I53),

1. Hypotype USNM 308753, Grier Limestone Member, Shermanian Stage (USGS colln. D1303-CO), of Lexington Limestone, Gratz Quadrangle, Kentucky; 1 $a$, endostyles in centers of clusters of autozooecia aligned in distinct petaloid pattern in late endozone and early exozone, tangential section, $\times 30 ; 1 b$, autozooecia with thin and slightly crenulated walls in exozone, thick endostyles in early exozone, basal diaphragms generally lack in endozones, longitudinal section, $\times 30$; $l c$, narrowly serrated autozooecial boundaries, endostyle with two distinct cores, microstructure of autozooecial walls and of sheaths of endostyles, tangential section, $\times 100$.

2. Hypotype USNM 308757, Grier Limestone Member, Shermanian Stage (USGS colln. 4680-CO), of Lexington Limestone, type section, Frankfort East Quadrangle, Kentucky; 2a, autozooecia with thin walls, exozonal styles sparse to absent in exozone, tangential section, $\times 30 ; 2 b$, autozooecia with uneven walls and somewhat irregularly spaced basal diaphragms in exozone, longitudinal section, $\times 30$.

3. Paratype USNM 308738, "Wilmore strata of the Trenton Group," Middle Ordovician, Kentucky; 3a, cross-sectional shape of autozooecia and mesozooecia in exozone, macula with mesozooecia and irregularly shaped polymorphs larger than autozooecia, amalgamate appearance of autozooecial walls, exozonal styles very small, few to absent, tangential section, $\times 30 ; 3 b$, basal diaphragms few or absent in endozones, evenly spaced in early exozone occur farther apart in late exozone, uneven autozooecial walls in exozone, autozooecial curvature from endozone to exozone, longitudinal section, $\times 30$.

4. Paratype USNM 308737, "Wilmore strata of the Trenton Group," Middle Ordovician, near Burgin, Ky.; 4a, basal diaphragms in zone of rejuvenation of autozooecia in endozone (upper center of figure), autozooecial walls partly crenulated in endozone, microstructure of autozooecial walls in exozone, longitudinal section, $\times 30 ; 4 b$, part of zoarium with numerous styles in exozone, styles inflect walls of some autozooecia, thin linings, broadly serrated autozooecial boundaries with mural pustules, cross-sectional shape of autozooecia, mesozooecia generally absent, tangential section, $\times 30$. 

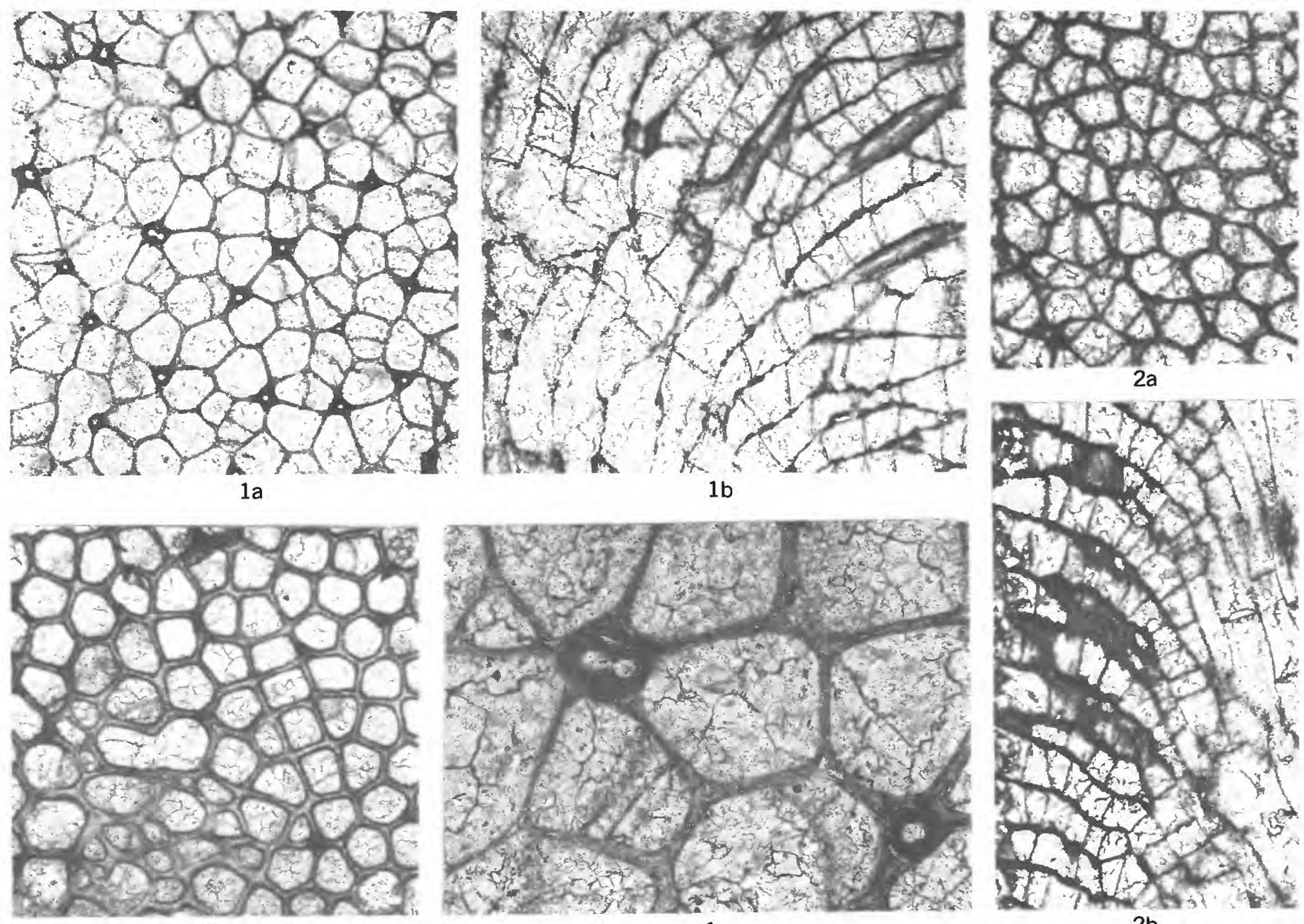

$3 a$

$1 c$

$2 \mathrm{~b}$

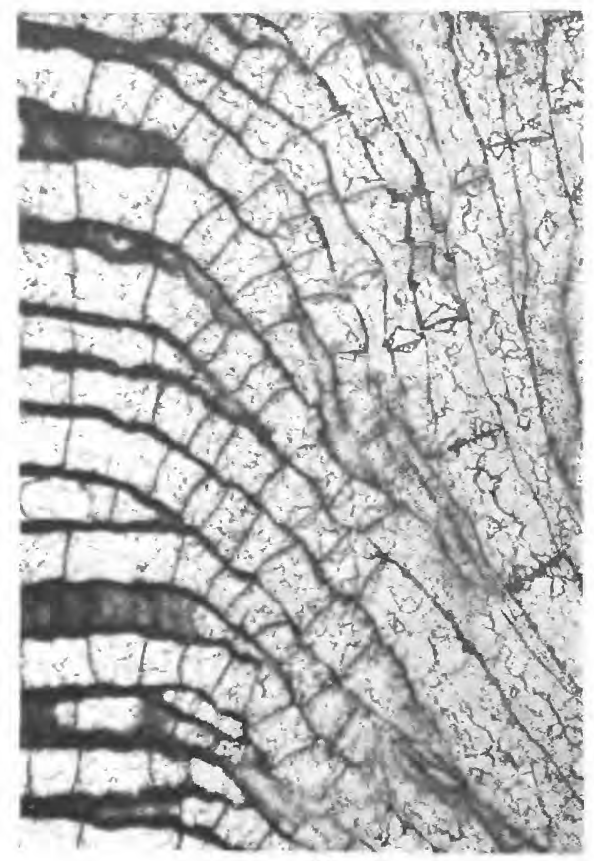

3b
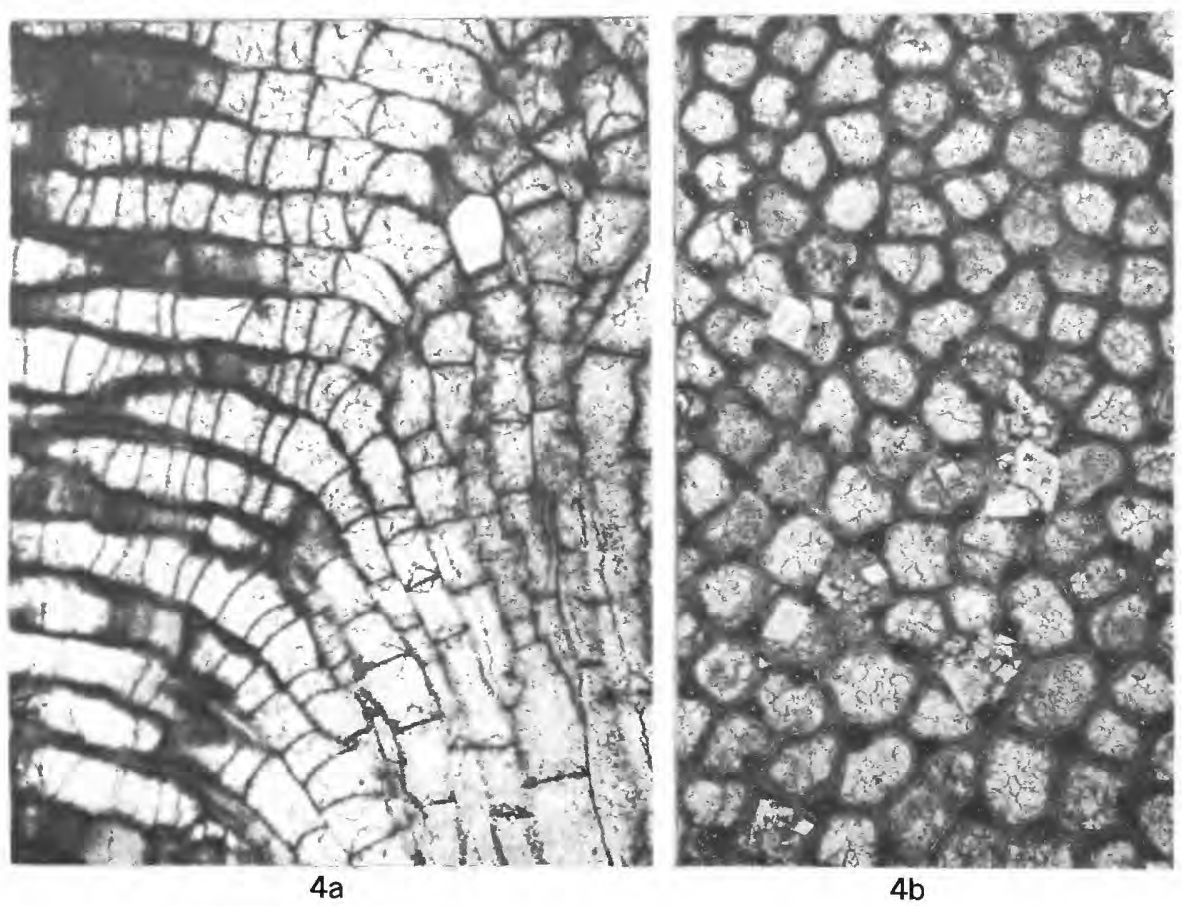

HETEROTRYPA 


\section{PLATE 21}

Figures 1-4. Stigmatella clavis (Ulrich) (p. I56).

1. Hypotype USNM 308777, Sulphur Well Member, Shermanian Stage (USGS colln. D1164-CO), of Lexington Limestone, Valley View Quadrangle, Kentucky; 1a, autozooecia with thin walls in exozone, styles with distinct cores and sheaths, basal diaphragms absent, oblique longitudinal section, $\times 30 ; 1 b$, cross-sectional shape and alignment of autozooecia in exozone, thin autozooecial walls, tangential section, $\times 50$.

2. Hypotype USNM 308782, Clays Ferry Formation, Shermanian Stage (USGS colln. 6717-CO), Ford Quadrangle, Kentucky; autozooecia recumbent for short distances at basal layer of zoarium in endozone, autozooecia in exozone slightly oblique to basal layer of zoarium, autozooecial walls locally crenulated, longitudinal section, $\times 50$.

3. Hypotype USNM 308778, Clays Ferry Formation, Shermanian Stage (USGS colln. 6714-CO), Ford Quadrangle, Kentucky; $3 a$, microstructure of autozooecial walls and of styles, moniloid mesozooecia (lower part of figure), autozooecia with sparse basal diaphragms and crenulated walls locally, longitudinal section, $\times 50$; $3 b$, styles in autozooecial corners and along walls, general alignment of autozooecia in exozone, maculae with slightly larger polymorphs than autozooecia and few mesozooecia (upper left of figure), tangential section, $\times 30$.

4. Lectotype USNM 43718 from syntype suite USNM 43718 from the "lower beds of the Eden shales" (the lower Kope Formation of current usage), Edenian Stage, Covington, Ky.; 4a, basal layer of zoarium obscured, styles throughout exozones, autozooecial walls relatively straight, part of conspecific overgrowth (upper right of figure) showing crosssectional shape of autozooecia in endozone of overgrowth, longitudinal section, $\times 50 ; 4 b$, styles with obscured cores, polygonal shape of autozooecia, slightly oblique tangential section, $\times 50$.

5. Stigmatella sp.(p.I58)

Hypotype USNM 308793, Tanglewood Limestone Member, Shermanian Stage (USGS colln. 4886-CO), of Lexington Limestone, Valley View Quadrangle, Kentucky; $5 a$, autozooecia with relatively thick walls, polygonal in cross section, styles, few and small, inflect autozooecial walls occasionally, tangential section, $\times 50 ; 5 b$, shape of autozooecia in endozone, basal layer of zoarium (bottom of figure), basal layer of superimposed autozooecial layer (near top of figure), basal diaphragms occur in indistinct zones, autozooecia with relatively straight walls, longitudinal section, $\times 30$. 

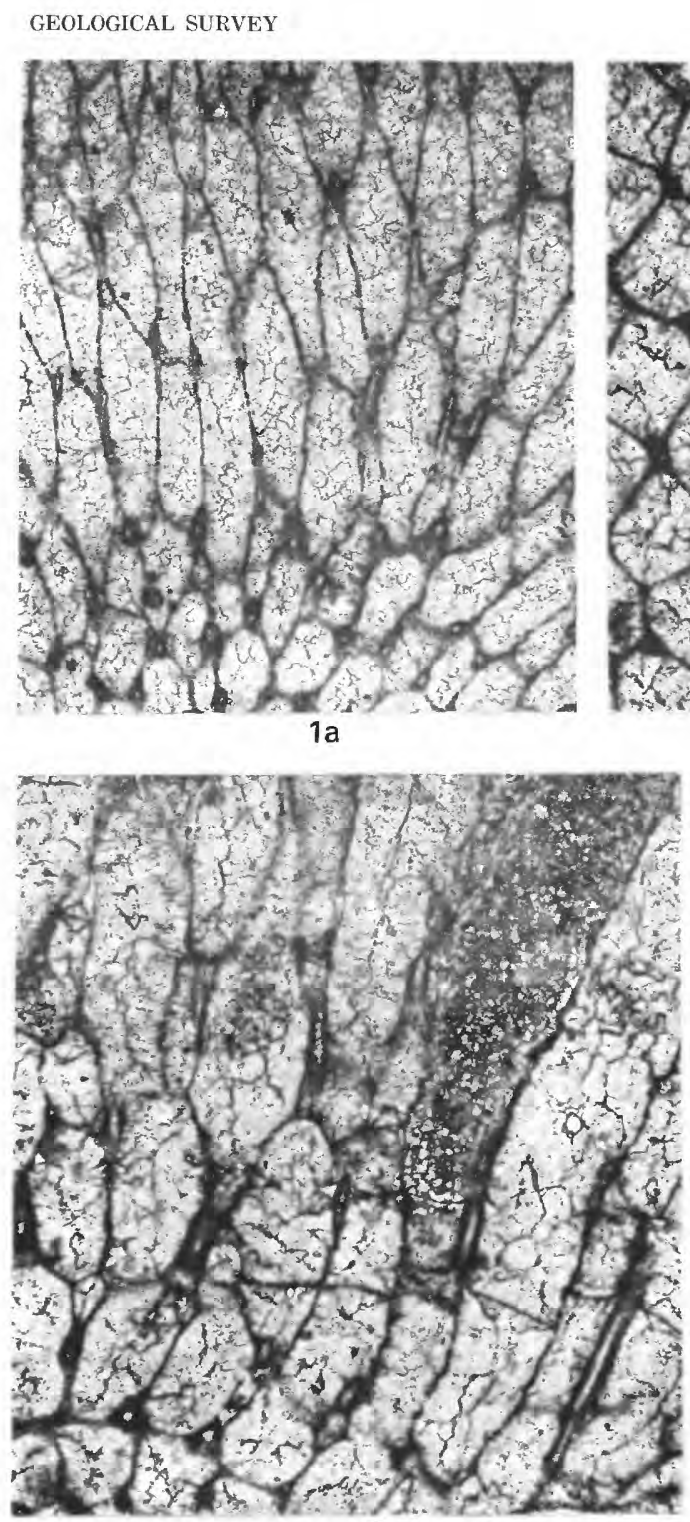

$$
3 a
$$

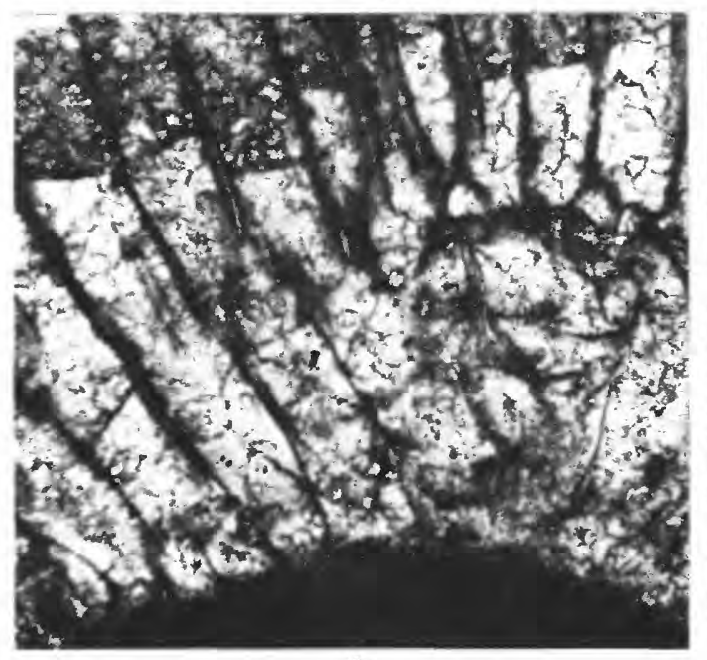

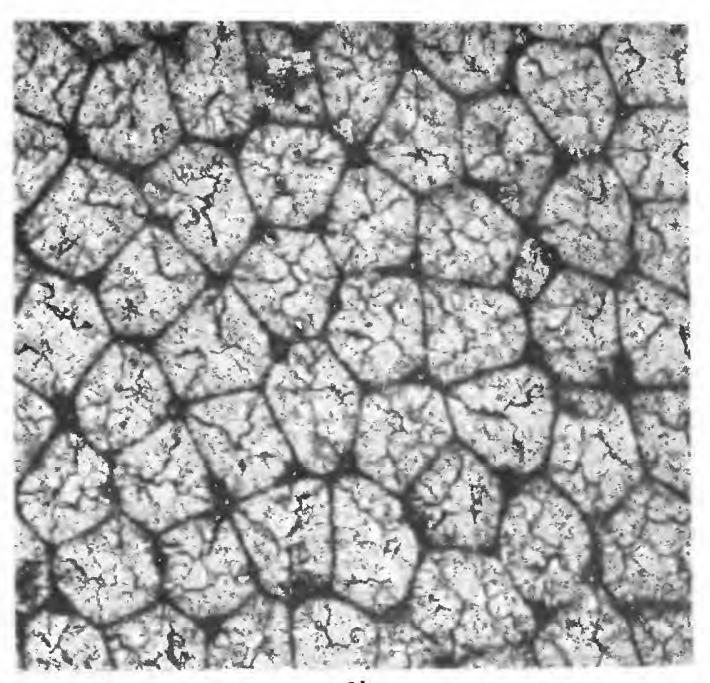

$1 \mathrm{~b}$
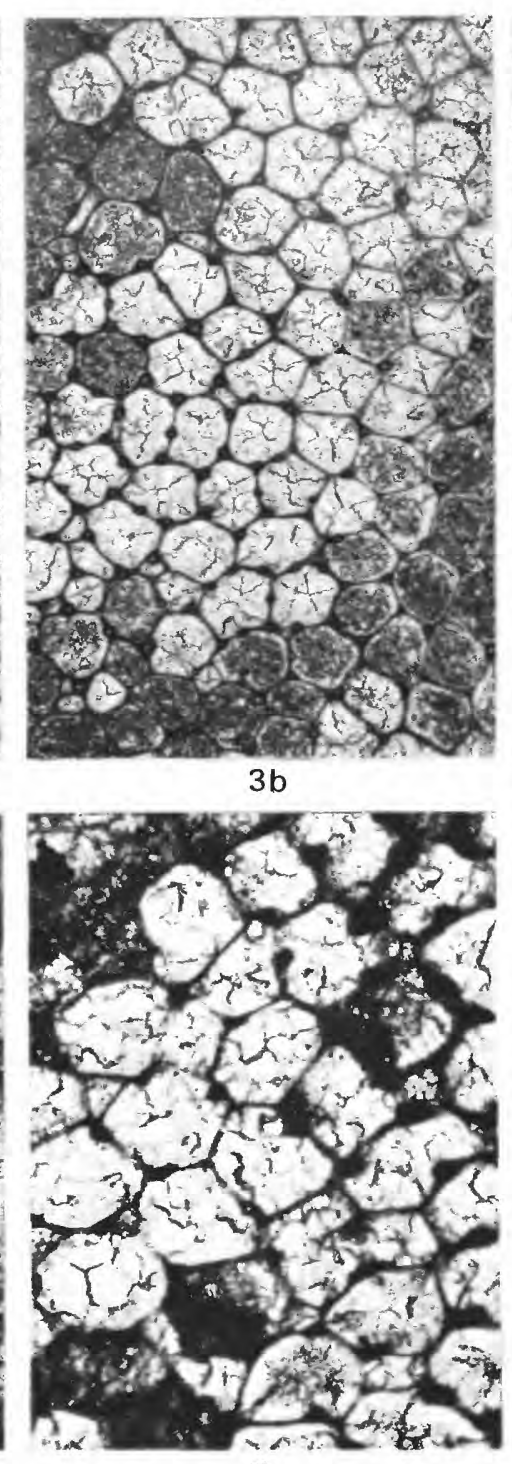

$4 b$

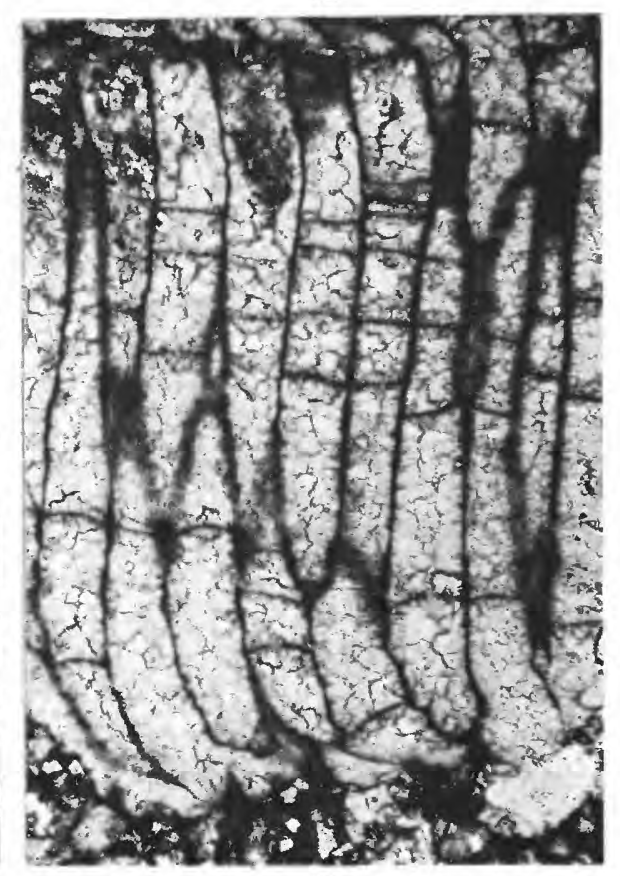

$5 b$
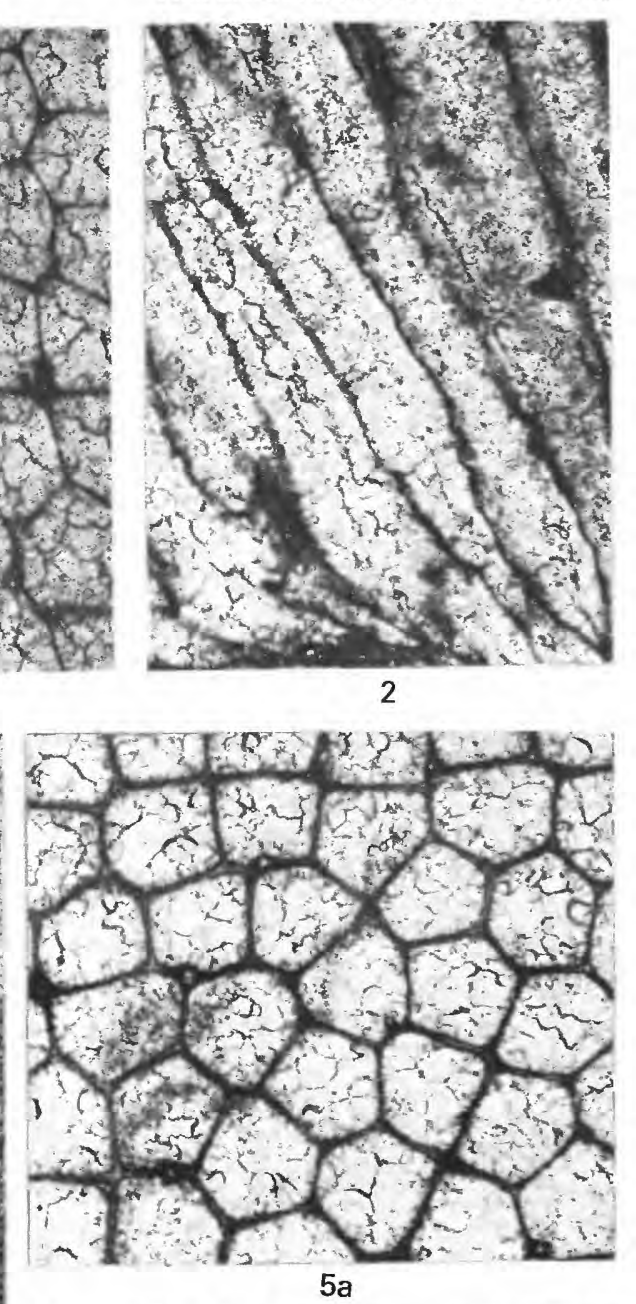

2

STIGMATELLA 
PLATE 22

Figures 1-3. Amplexopora persimilis (Nickles) (p. I59).

1. Hypotype USNM 308799, Millersburg Member, Shermanian Stage (USGS colln. 7052-CO), of Lexington Limestone, Dry Fork Road section, Winchester Quadrangle, Kentucky; thin autozooecial walls with distinct boundaries, basal diaphragms slightly oblique to chamber axis, few cystoidal diaphragms, longitudinal section, $\times 50$.

2. Hypotype USNM 308797, Clays Ferry Formation, Edenian Stage (USGS colln. 6738_CO); microstructure of autozooecial walls, small styles with distinct cores and thin sheaths along autozooecial boundaries and slightly offset from autozooecial walls, tangential section, $\times 100$.

3. Lectotypes USNM 96566, "Lower beds of Eden Shales" (lower part of Kope Formation of current usage), Edenian Stage, West Covington, Ky.; $3 a$, arrangement of autozooecia in intermacular areas, maculae slightly raised, relatively evenly distributed, larger polymorphs and mesozooecia in maculae, external view, $\times 3$ (illustrated by Nickles, 1905 , pl. 2, fig. 3); $3 b$, curvature of autozooecia, basal diaphragms common in endozone and evenly spaced in exozone, mesozooecia with thin walls, closely spaced diaphragms, autozooecial walls slightly crenulated locally, longitudinal section, $\times 30$; 3c, cross-sectional shape of autozooecia and their chambers, autozooecia partly separated by polygonal mesozooecia, styles generally centered along autozooecial boundaries, tangential section, $\times 50$; $3 d$, distinct autozooecial boundaries in exozone, autozooecial linings absent, sparse cystoidal diaphragms, longitudinal section, $\times 50$.

4. Batostoma cf. B. jamesi (Nicholson) (p. I84).

Hypotype USNM 309302, Clays Ferry Formation, Edenian Stage (USGS colln. D1188_CO), Ford Quadrangle, Kentucky; $4 a$, cross-sectional shape of autozooecia and mesozooecia, some autozooecia almost completely separated by mostly closed mesozooecia, distinct autozooecial boundaries, styles with large cores, exceedingly thin sheaths, autozooecia only slightly inflected by styles, tangential section, $\times 50 ; 4 b$, interzooecially budded autozooecia with $U$-shaped proximal portions in endozone, and slightly sinuous walls, concave basal diaphragms proximally of base of conspecific overgrowth, mesozooecia with cystose diaphragms proximally and thick diaphragms distally, notched styles poorly defined in skeletal laminae of zooecial walls, longitudinal section, $\times 50$. 
GEOLOGICAL SURVEY

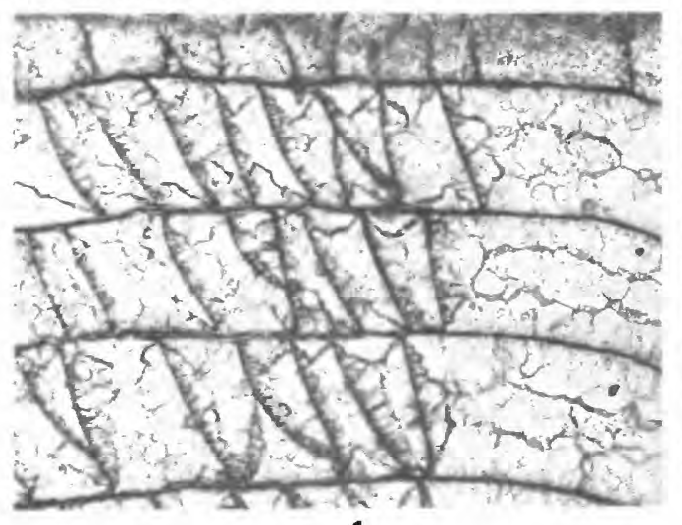

1

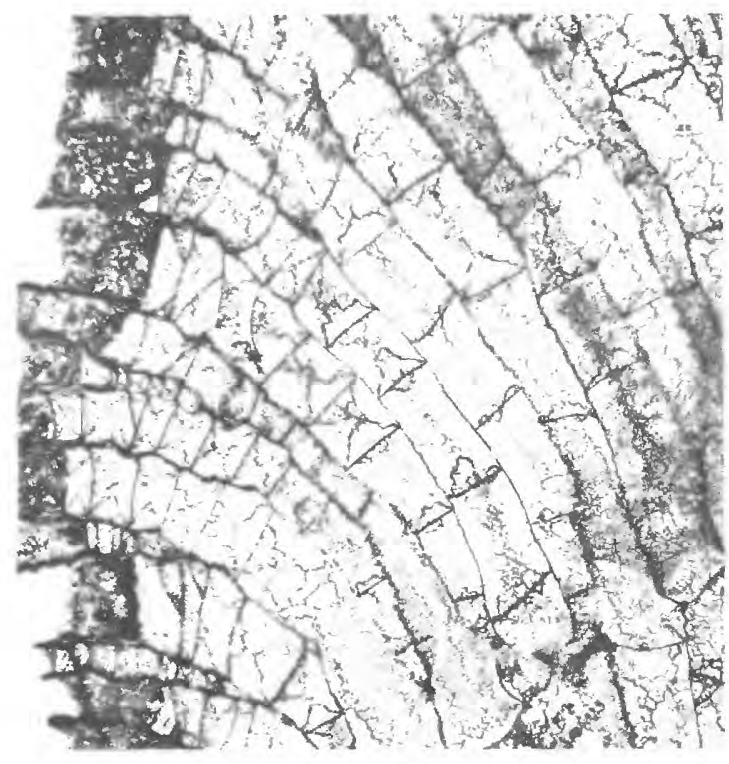

$3 b$

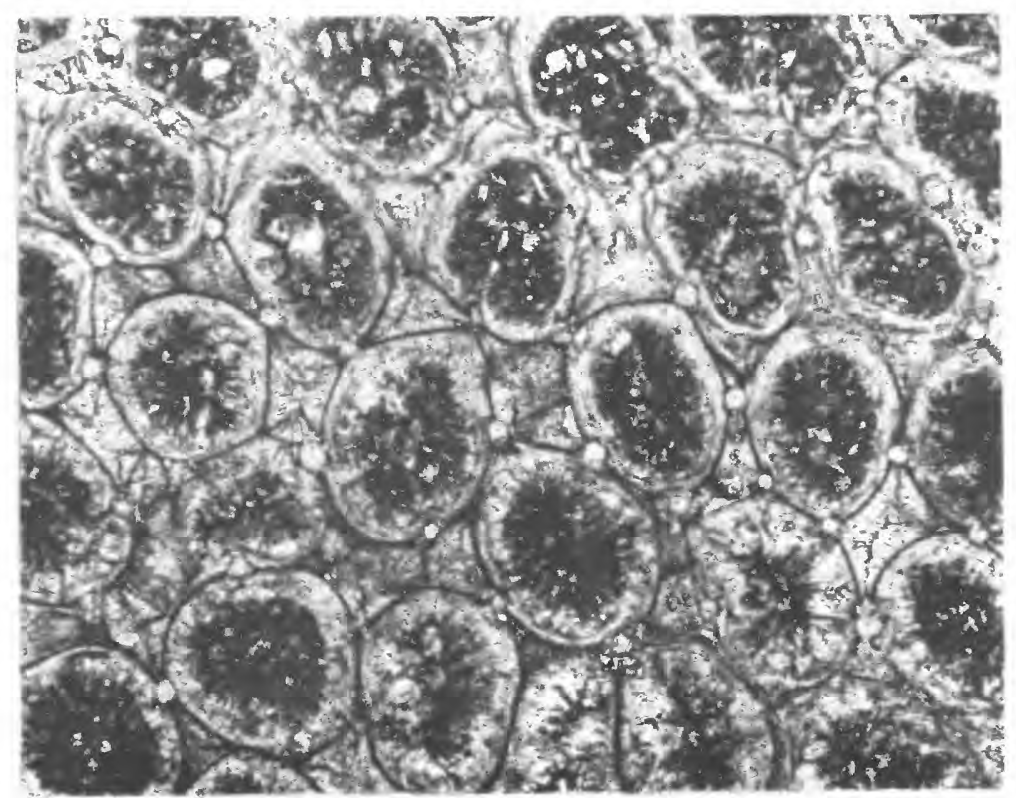

$4 a$

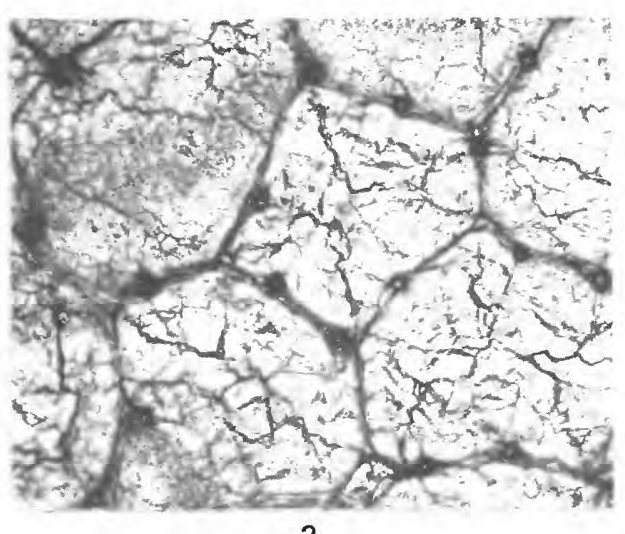

2

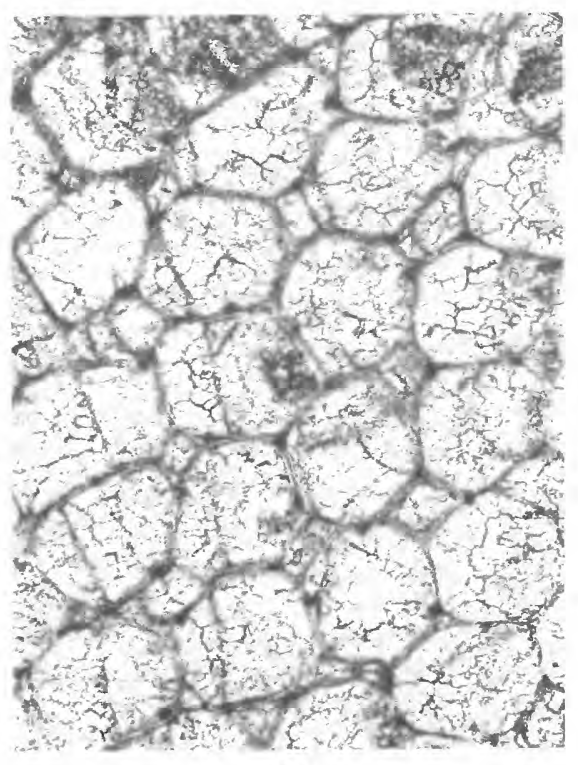

$3 c$

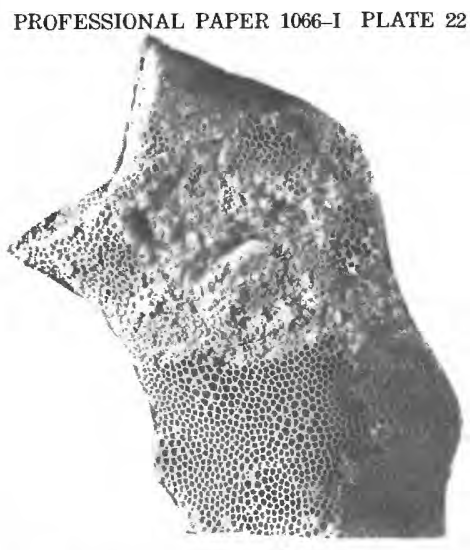

$3 a$

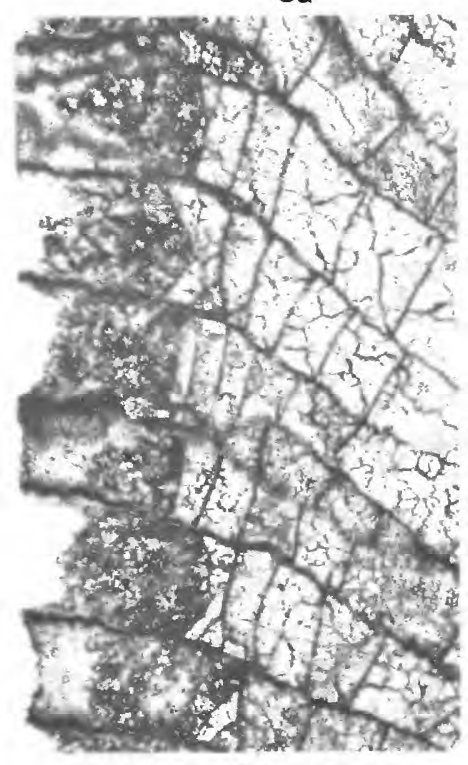

$3 d$

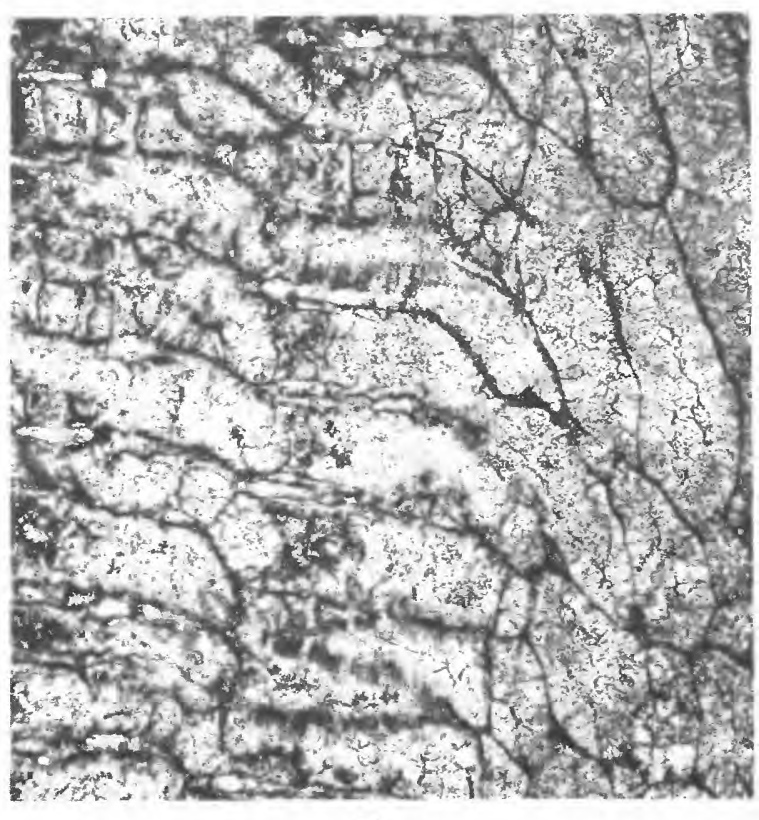

$4 b$ 


\section{PLATE 23}

Figures 1-5. Amplexopora aff. A. winchelli (Ulrich) (p. I60).

1. Hypotype USNM 308810, Grier Limestone Member, Shermanian Stage (USGS colln. 4971_CO), of Lexington Limestone, Frankfort West Quadrangle, Kentucky; 1a, microstructure of thickened and thin basal diaphragms and thin cystoidal diaphragms, thin autozooecial linings, indistinct, obscured autozooecial boundaries, longitudinal section, $\times 100 ; 1 b$, abundant basal diaphragms evenly spaced, few cystoidal diaphragms, autozooecial linings locally present, styles absent, specimen partly silicified, exozone, longitudinal section, $\times 50$; $1 \mathrm{c}$, autozooecial walls irregular in thickness in exozone, stylelike structures appear to be present, but are not observed in longitudinal sections, specimen partly silicified, tangential section, $\times 50$.

2. Hypotype USNM 308800, Millersburg Member, Shermanian Stage (USGS colln. 4857-CO), of Lexington Limestone, Georgetown Quadrangle, Kentucky; numerous slightly curved basal diaphragms in early exozone, some diaphragms are incompletely preserved, distinct autozooecial boundaries, poorly defined mesozooecium (lower part of figure), autozooecial linings absent, longitudinal section, $\times 30$.

3. Hypotype USNM 308817, Millersburg Member, Shermanian Stage (USGS colln. 7052-CO) of Lexington Limestone, Dry Fork Road section, Winchester Quadrangle, Kentucky; $3 a$, curvature of autozooecial walls, scattered basal diaphragms in endozone, longitudinal section, $\times 30 ; 3 b$, cross-sectional shape of autozooecia and their chambers, autozooecial boundaries locally obscured, mesozooecia absent, styles exceedingly small, indistinct, general arrangement of autozooecia, tangential section, $\times 30$.

4. Hypotype USNM 308802, Tanglewood Limestone Member, Shermanian Stage (USGS colln. 4886-CO), of Lexington Limestone, Valley View Quadrangle, Kentuckty; $4 a$, autozooecial walls slightly crenulated locally in endozone, basal diaphragms virtually absent in endozone, closely spaced in exozone, basal diaphragms slightly oblique to chamber axis locally, longitudinal section, $\times 30 ; 4 b$, autozooecial linings absent, boundaries of autozooecia distinct, narrowly serrated, longitudinal section, $\times 50$.

5. Hypotype USNM 308803, Tanglewood Limestone Member, Shermanian Stage (USGS colln. 4886-CO), of Lexington Limestone, Valley View Quadrangle, Kentucky; macula with polymorphs slightly larger than autozooecia, styles absent or indistinct, scattered pustules in autozooecial walls, autozooecial lining and mesozooecia absent, tangential section, $\times 50$. 

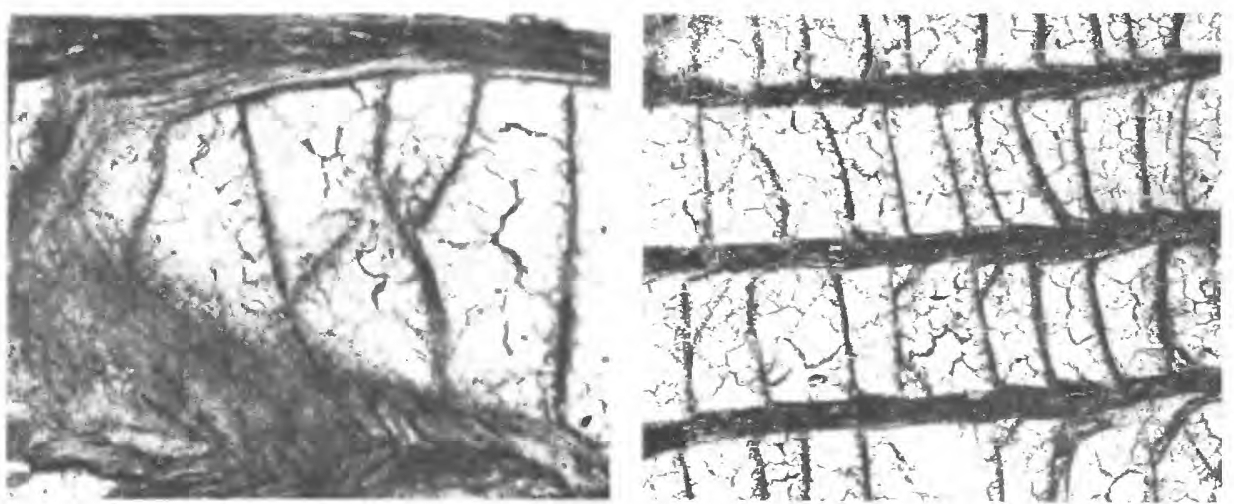

$1 b$

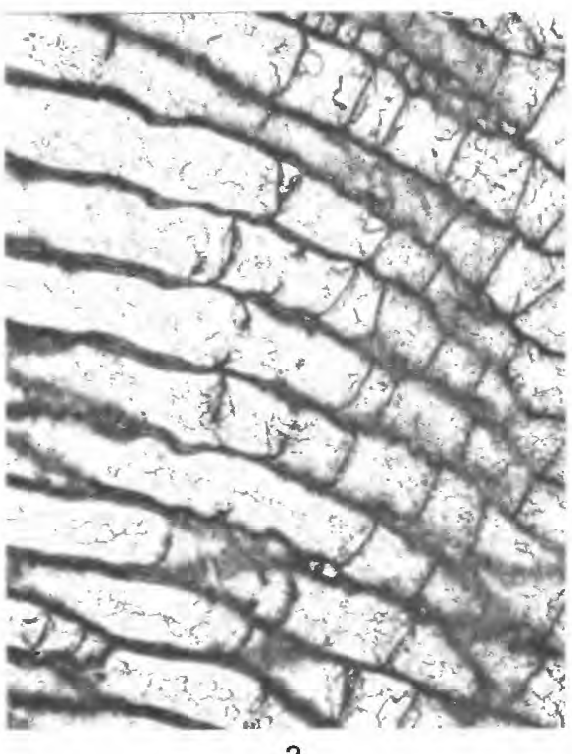

2

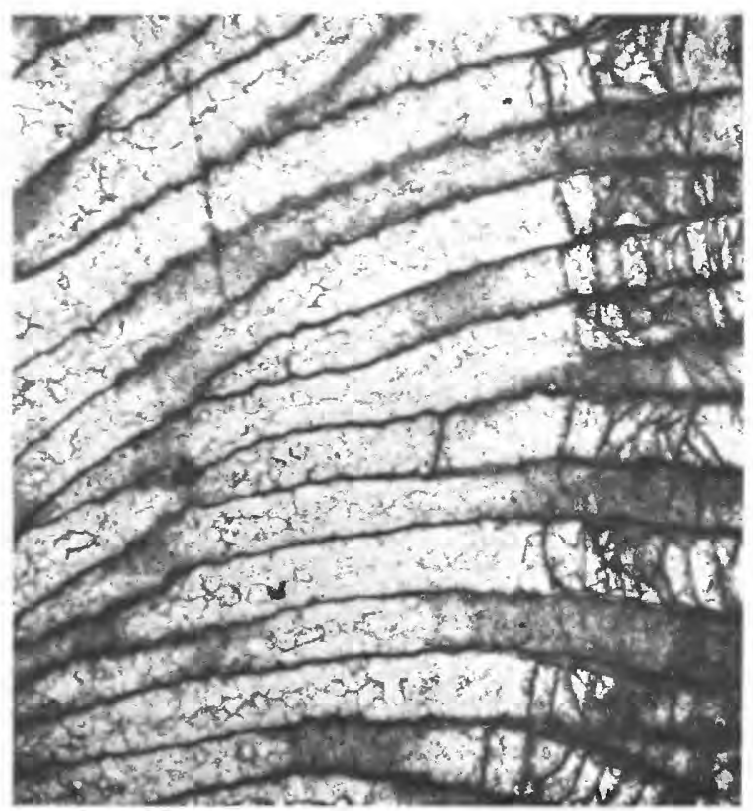

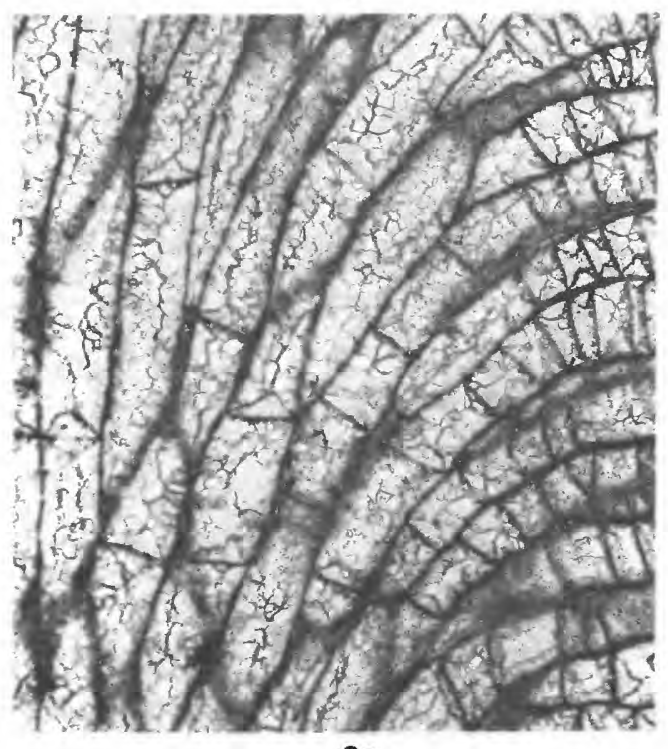

$3 a$

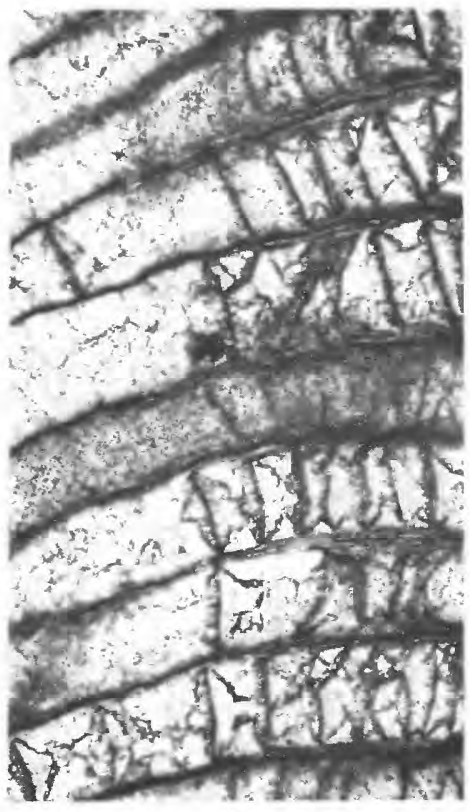

$4 \mathrm{~b}$

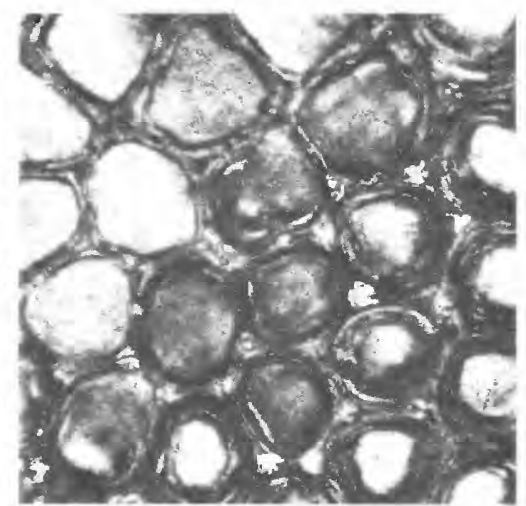

1c

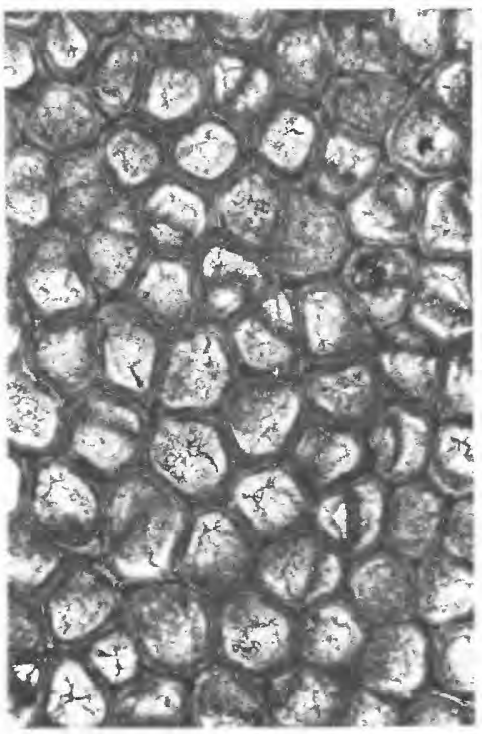

$3 b$

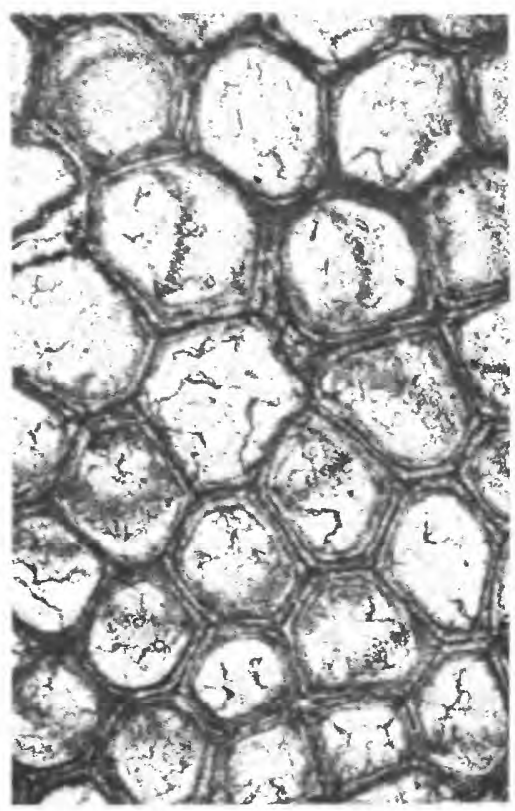

5 


\section{PLATE 24}

Figures 1-3. Eridotrypa mutabilis (Ulrich) (p. I62).

1, 2. Clays Ferry Formation, Frankfort East Quadrangle, Kentucky.

1. Hypotype USNM 308841, Edenian Stage (USGS colln. D1211-CO); 1a, subpolygonal autozooecia with subelliptical to subcircular autozooecial chambers in cross section, small styles in autozooecial boundaries, scattered open and closed mesozooecia, tangential section, $\times 30 ; 1 b$, basal diaphragms evenly spaced in late endozones and early exozones, intercalated autozooecium in midexozone, well-defined autozooecial boundaries, compound diaphragms (upper right of figure), longitudinal section, $\times 30$.

2. Hypotype USNM 308840, Edenian Stage (USGS colln. D1211-CO); 2a, exceedingly narrow autozooecial boundaries, relatively thick autozooecial walls, mesozooecia and styles indistinct or absent, tangential section, $\times 30 ; 2 b$, autozooecia gently curving outward, oblique to zoarial surface, mesozooecia indistinct or absent, basal diaphragms sparse to absent in endozones, common in wide exozone, longitudinal section, $\times 30$.

3. Hypotype USNM 308933, Clays Ferry Formation, Shermanian Stage (USGS colln. 7469-CO), Sadieville Quadrangle, Kentucky; $3 a$, shape of autozooecia in narrow exozone, basal diaphragms sparse, longitudinal section, $\times 30$; $3 b$, wide endozone, larger autozooecia in axial portion of endozone, cross-sectional shape of autozooecia in axial portion and in periphery of endozone, distinct autozooecial boundaries in exozone, transverse section, $\times 30$. 


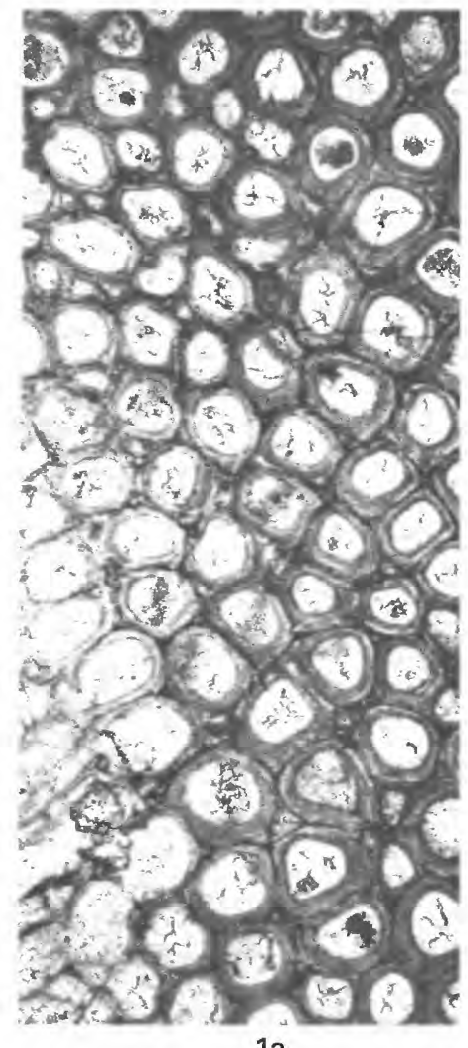

$1 \mathrm{a}$

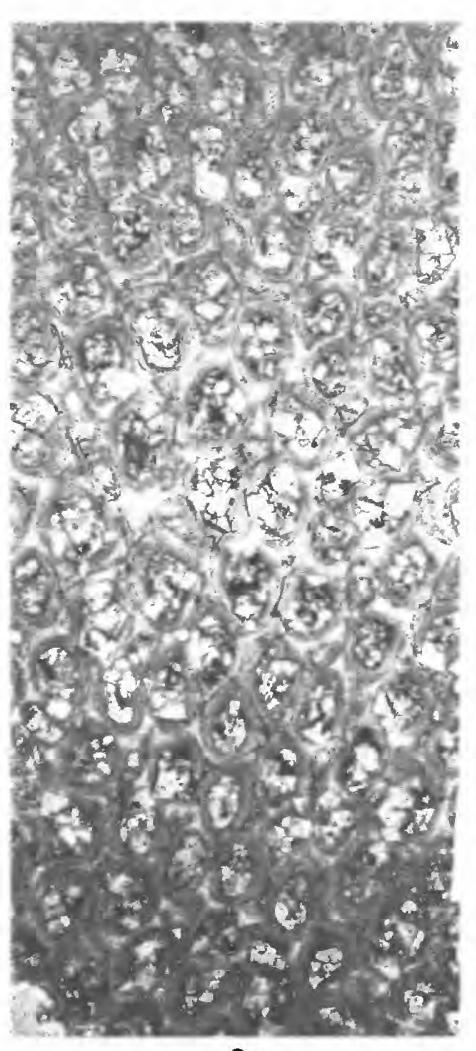

$2 a$

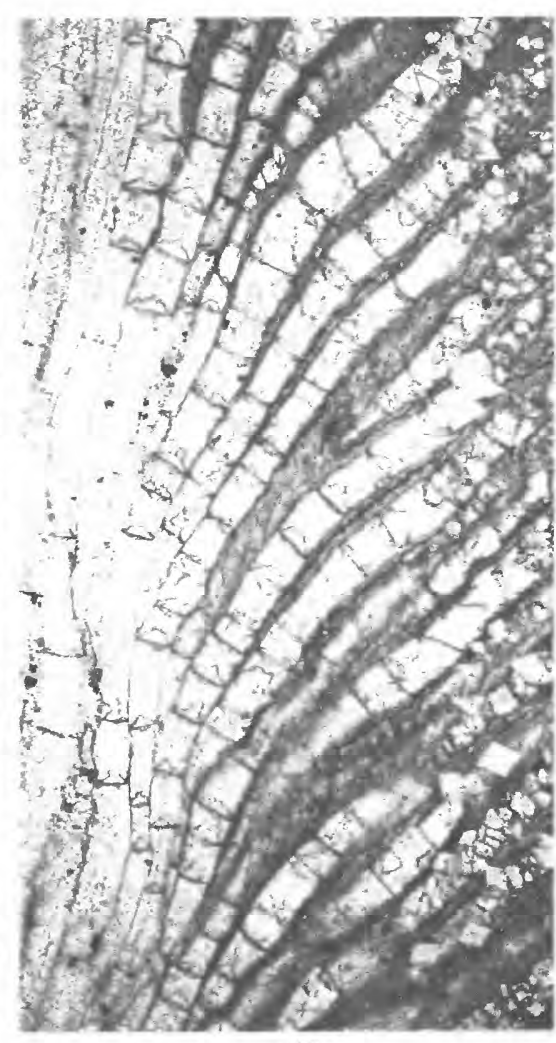

$2 b$

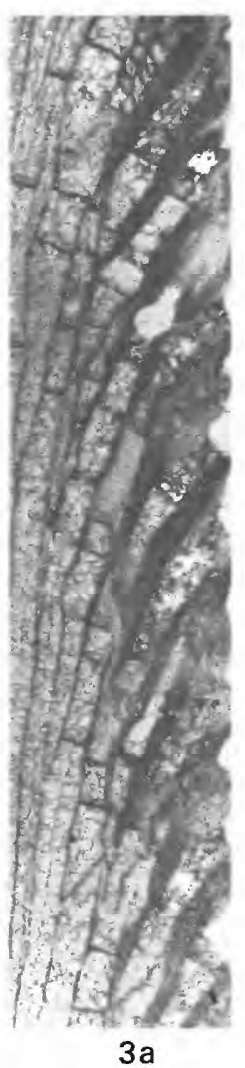

$3 a$

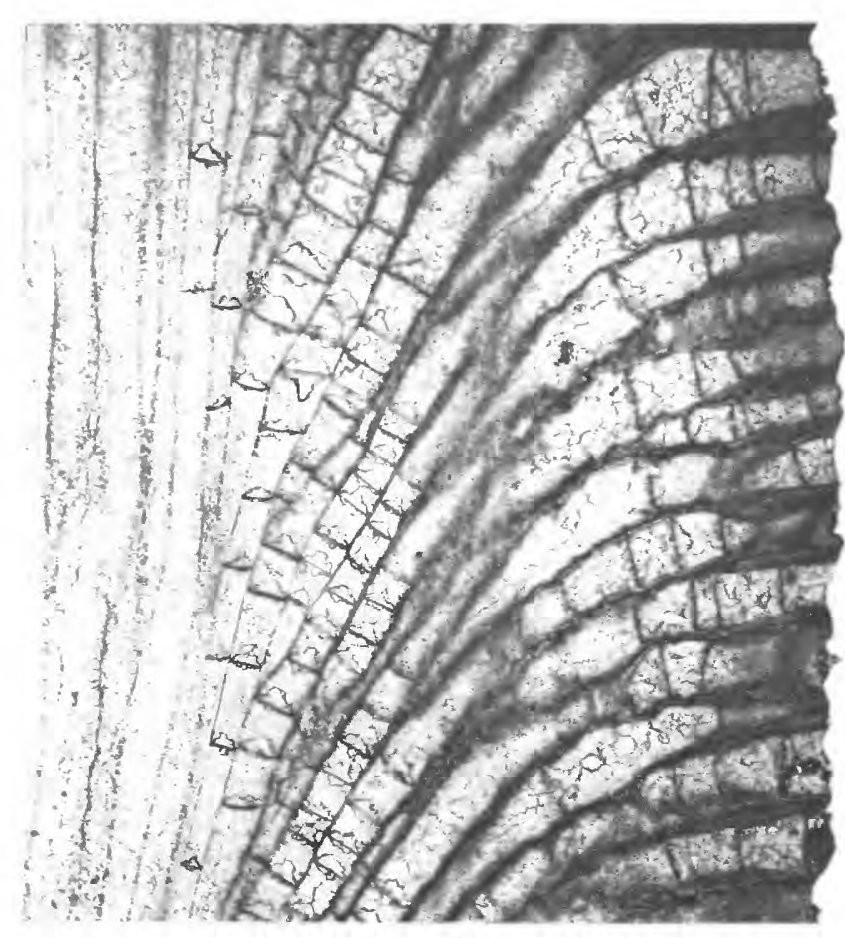

$1 b$

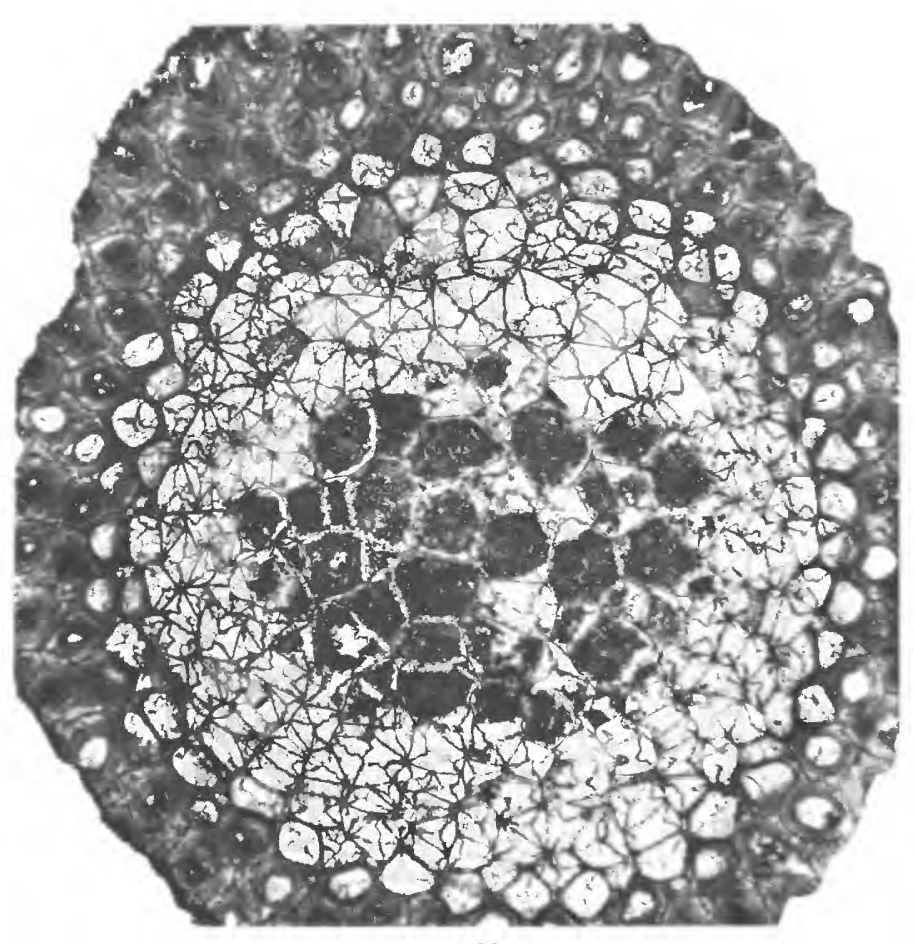

$3 b$

ERIDOTRYPA 


\section{PLATE 25}

FIGURES 1-6. Eridotrypa mutabilis (Ulrich) (p. I62).

1. Hypotype USNM 308896, Clays Ferry Formation, Shermanian Stage, (USGS colln. 4901-CO), Valley View Quadrangle, Kentucky; mesozooecium with closely spaced and variably shaped diaphragms in early exozone, styles with small cores and thin sheaths in autozooecial walls, longitudinal section, $\times 100$.

2. Hypotype USNM 308839, Clays Ferry Formation, Edenian Stage (USGS colln. D1211_CO), Frankfort East Quadrangle, Kentucky; $2 a$, intercalated autozooecium in exozone, distinct, narrowly serrated autozooecial boundaries, autozooecial walls narrowed proximally of intercalated autozooecium, thin basal diaphragms, longitudinal section, $\times 50 ; 2 b$, cluster of larger polymorphs with thicker walls and subcircular chambers in center of macula, few indistinct mesozooecia, tangential section, $\times 50$.

3. Hypotype USNM 308945, Millersburg Member, Shermanian Stage (USGS colln. 7048-CO), of Lexington Limestone, Dry Fork Road section, Winchester Quadrangle; microstructure of autozooecial walls, styles and diaphragms, longitudinal section, $\times 100$.

4. Hypotype USNM 308927, Tanglewood Limestone Member, Shermanian Stage (USGS colln. 5047-CO), of Lexington Limestone, Sadieville Quadrangle, Kentucky; narrowly serrated and distinct autozooecial boundaries with few small styles in exozone, mesozooecia mostly absent, cross-sectional shape of autozooecial chambers, alignment of autozooecia in exozone, tangential section, $\times 50$.

5. Hypotype USNM 308891, Clays Ferry Formation, Shermanian Stage (USGS colln. 4898_CO), Valley View Quadrangle, Kentucky; slightly sinuous autozooecial boundaries, arrangement of autozooecial laminae in profile, poorly defined mesozooecia with partly moniloid proximal portions, longitudinal section, $\times 50$.

6. Hypotype USNM 308892, Clays Ferry Formation, Shermanian Stage (USGS colln. 4899-CO) Valley View Quadrangle, Kentucky; irregularly shaped autozooecia in overgrowth, autozooecia of overgrowth tend to grow proximally, longitudinal section, $\times 50$. 


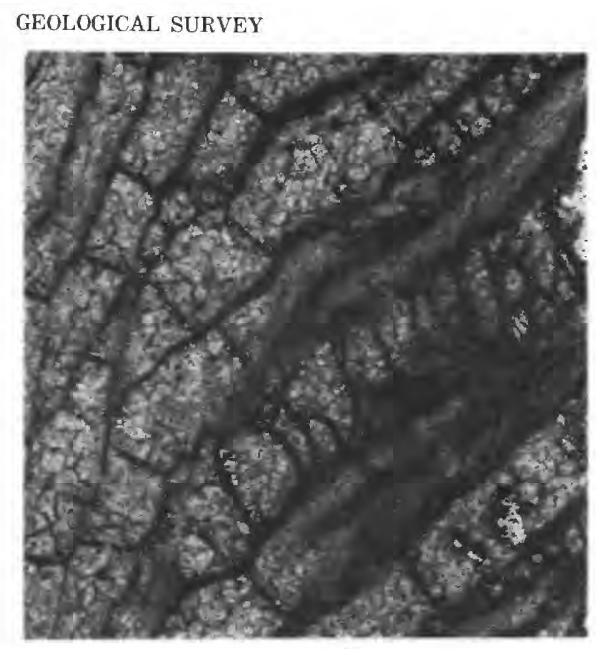

1

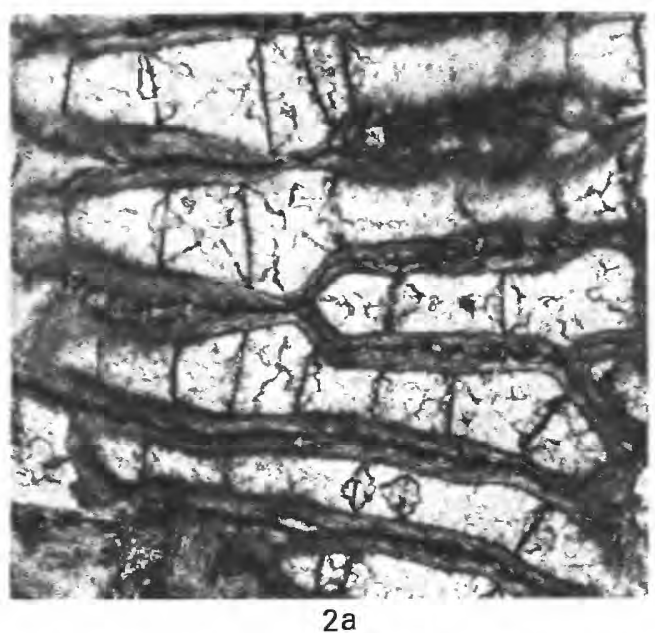

PROFESSIONAL PAPER 1066-I PLATE 25

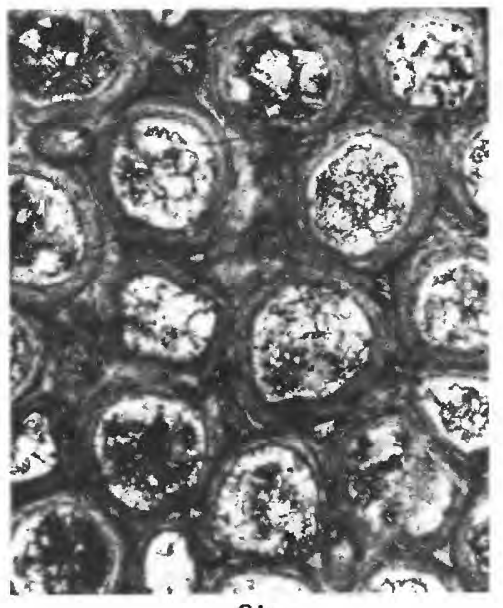

$2 b$
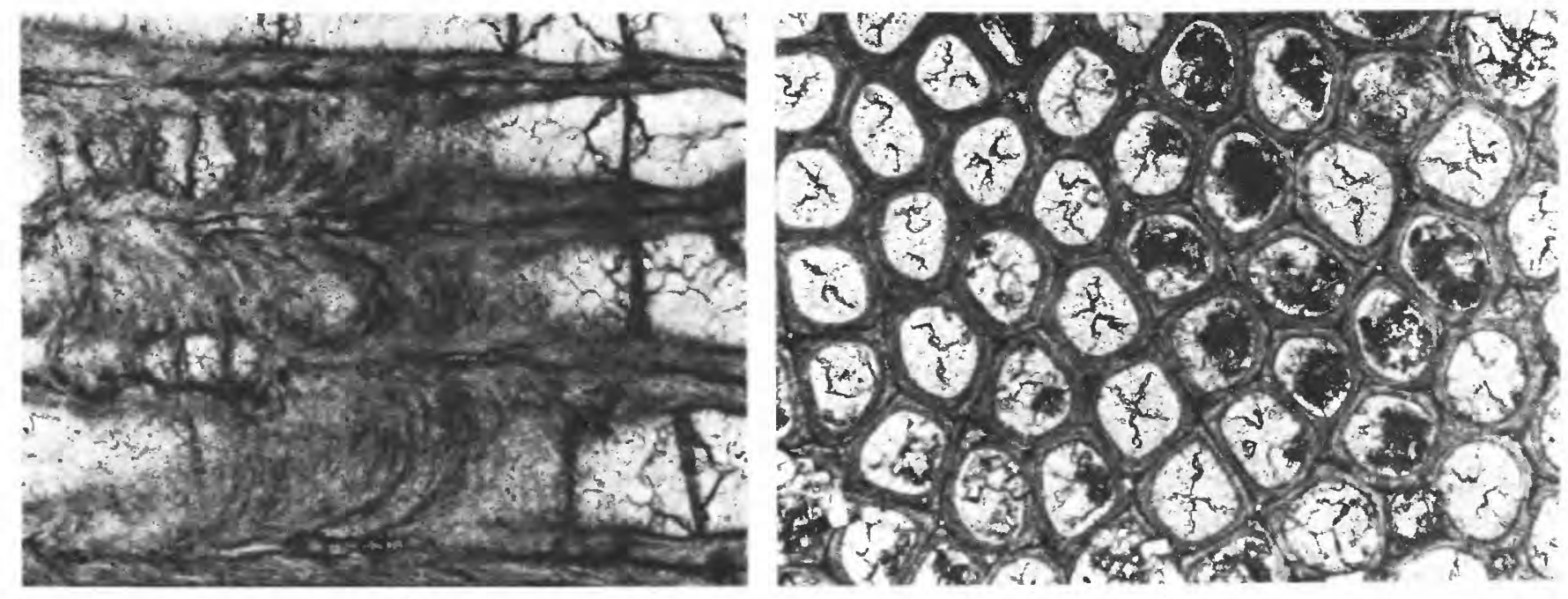

3

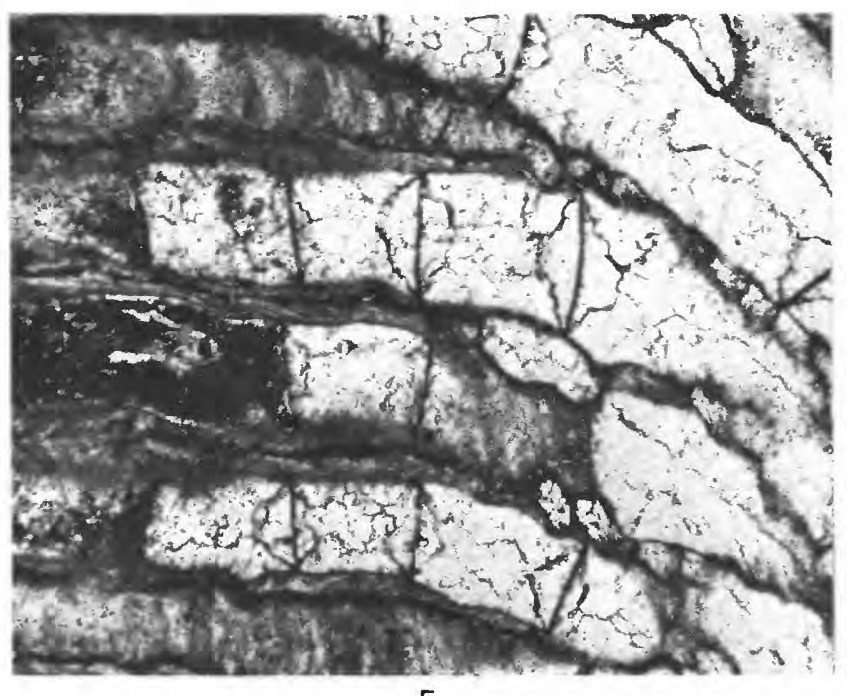

5
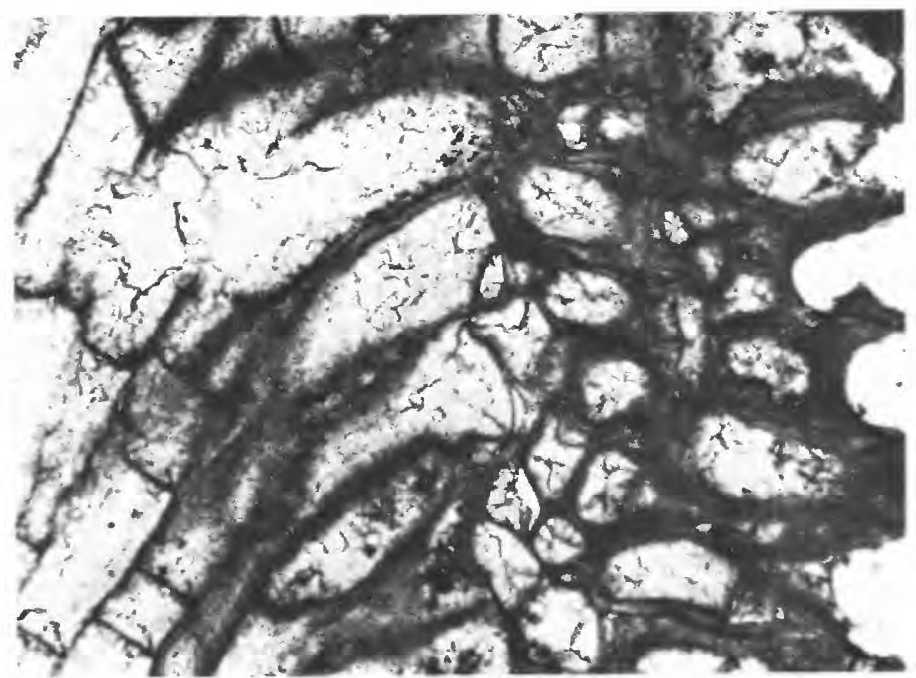

6

ERIDOTRYPA 


\section{PLATE 26}

Figures 1, 2. Eridotrypa aedilis (Eichwald) (p. I62).

1. Hypotype USNM 309663, from hypotype suite USNM 44827, Wesenberg Limestone (E. horizon) of Bassler, 1911, Upper Ordovician, Wesenberg, Estonia, U.S.S.R.; 1 $a$, shape of autozooecia in endozone and exozone (partly obscured by sediments), basal diaphragms occur regularly in endozone, mesozooecium with well-defined diaphragms (upper left of figure), longitudinal section, $\times 30 ; 1 b$, subelliptical cross-sectional shape of autozooecia and their chambers, distribution of mesozooecia, microstructure of autozooecial walls, tangential section, $\times 50 ; 1 c$, autozooecia approximately aligned parallel to branch growth direction, tangential section, $\times 30 ; 1 d$, microstructure of autozooecial walls, wall laminae exceedingly thin, microstructure of basal diaphragms in early exozone, longitudinal section, $\times 50$.

2. Hypotype USNM 309664, from hypotype suite USNM 57315 from Wassalem Beds, D3 horizon, of Bassler, 1911, Middle Ordovician, Uxnorm, Estonia, U.S.S.R.; $2 a$, general alignment of autozooecia and mesozooecia, mesozooecia partly separate autozooecia, tangential section, $\times 30 ; 2 b$, basal diaphragms evenly spaced in endozone, mesozooecia with closely and evenly spaced basal diaphragms, longitudinal section, $\times 30$.

3. Eridotrypa trentonensis (Nicholson), hypotype USNM 308960 from hypotype suite USNM 44822, "Trenton Group," Middle Ordovician, near Frankfort, $\mathrm{Ky}$; $3 a$, cross-sectional shape and size of autozooecia in axial portion and in periphery of endozones, narrow exozone, transverse section, $\times 30 ; 3 b$, microstructure of autozooecial walls in exozone, narrow autozooecial boundaries, indistinct styles in autozooecial boundaries, tangential section, $\times 50 ; 3 c$, narrow exozone, shape of autozooecial chambers in profile, few basal diaphragms in endozone and exozone, zone of rejuvenation of autozooecia in endozone, distinct autozooecial wall laminae and narrowly serrated autozooecial boundaries in exozone, longitudinal section, $\times 30$. 

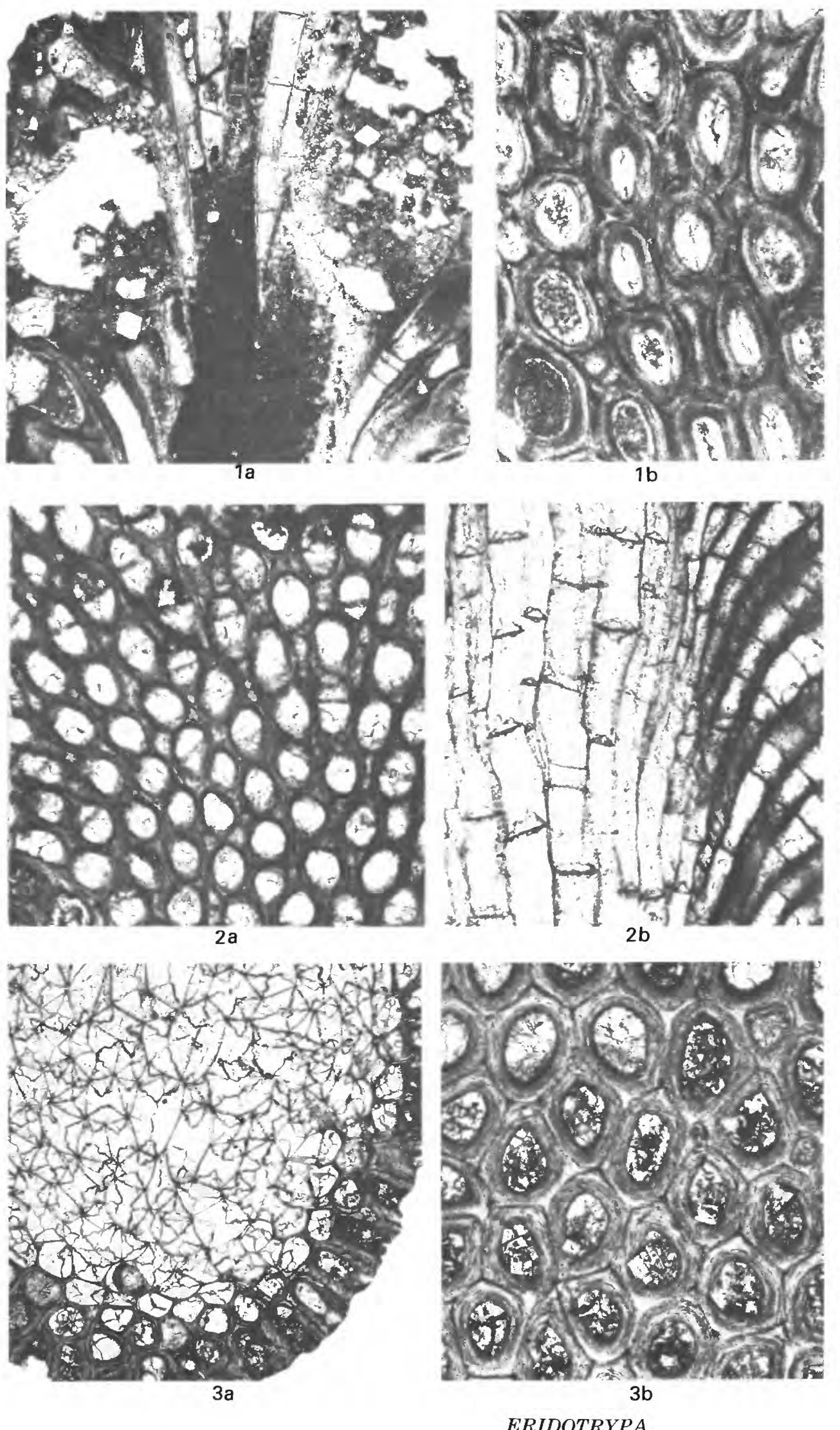
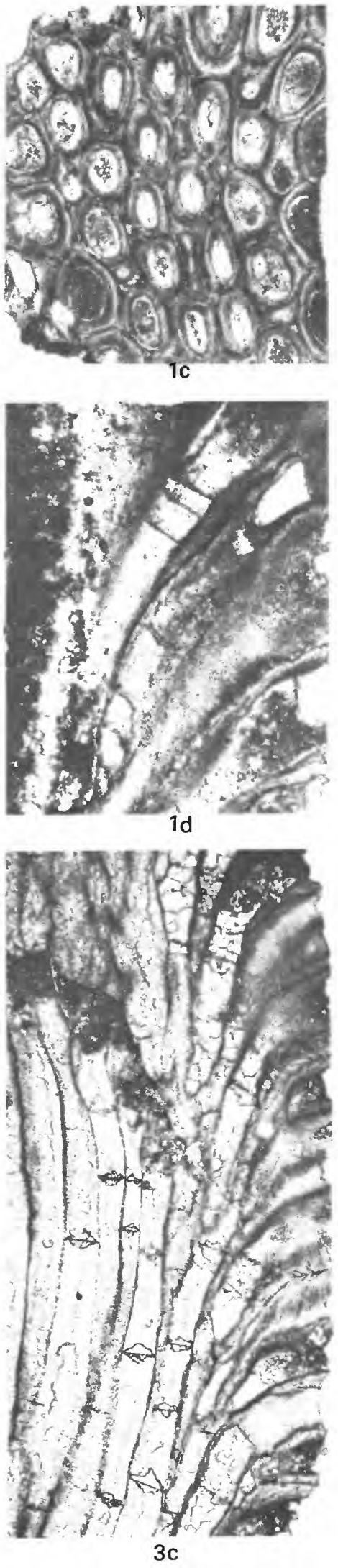


\section{PLATE 27}

FIGURES 1-7. Eridotrypa trentonensis (Nicholson) (p. I66).

Grier Limestone Member of Lexington Limestone, Kentucky.

1. Hypotype USNM 308996, Shermanian Stage (USGS colln. 4867-CO), Valley View Quadrangle; 1a, large autozooecia with relatively straight walls in axial portion of endozone, basal diaphragms few in exozone, lacking in endozone, longitudinal section, $\times 30 ; 1 b$, cross-sectional shape of autozooecia in early and late exozone, few mesozooecia in corners of autozooecia, oblique tangential section, $\times 30$.

2. Hypotype USNM 308963, Shermanian Stage (USGS colln. 4680-CO) Frankfort East Quadrangle; 2a, narrow exozone with few basal diaphragms, mesozooecia lacking, longitudinal section, $\times 30 ; 2 b$, autozooecia, subpolygonal in cross section, in indistinct longitudinal alignment in exozone, tangential section, $\times 30$.

3. Hypotype USNM 309018, Shermanian Stage (USGS colln. 4881-CO), Valley View Quadrangle, relatively numerous basal diaphragms in early exozone, indistinct zones of rejuvenation in endozone, autozooecia at right angles to zoarial surface in exozone, longitudinal section, $\times 30$.

4. Hypotype USNM 309002, Shermanian Stage (USGS colln. 4870-CO), Valley View Quadrangle; autozooecia in reversed growth direction in conspecific overgrowth of zoarium, longitudinal section, $\times 30$.

5. Hypotype USNM 308967, Shermanian Stage (USGS colln. 4682-CO), Frankfort East Quadrangle, few basal diaphragms in endozone, narrow exozone, autozooecia oriented distally in overgrowth of zoarium, longitudinal section, $\times 30$.

6. Hypotype USNM 309005, Shermanian Stage (USGS colln. 4870-CO), Valley View quadrangle, microstructure of autozooecial walls, boundaries and of basal and cystoidal diaphragms, longitudinal section, $\times 100$.

7. Hypotype USNM 308970, Shermanian Stage (USGS colln. 4686-CO), Frankfort East Quadrangle; subelliptical cross-sectional shape of autozooecial chambers in exozone, exceedingly small styles, few mesozooecia, narrowly serrated autozooecial boundaries, tangential section, $\times 30$. 


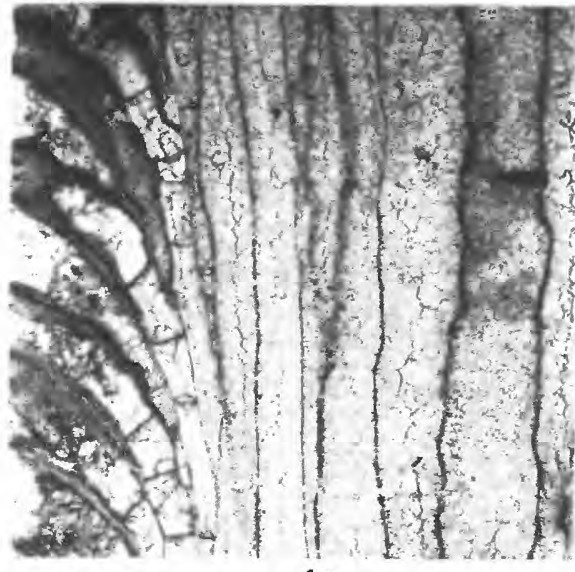

1a

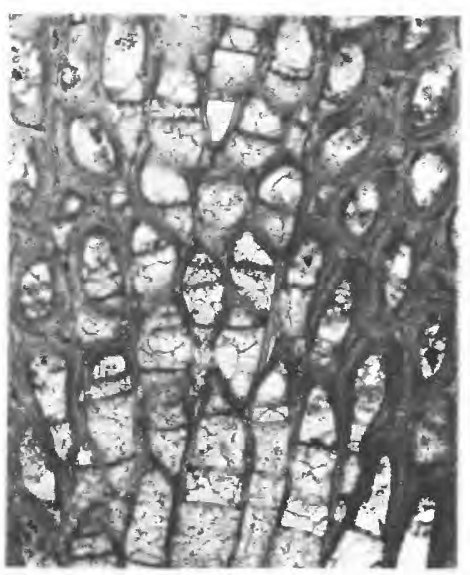

$1 b$

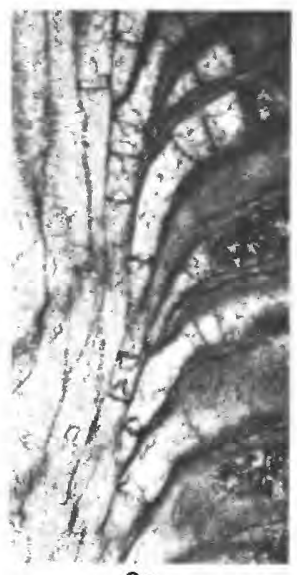

$2 a$

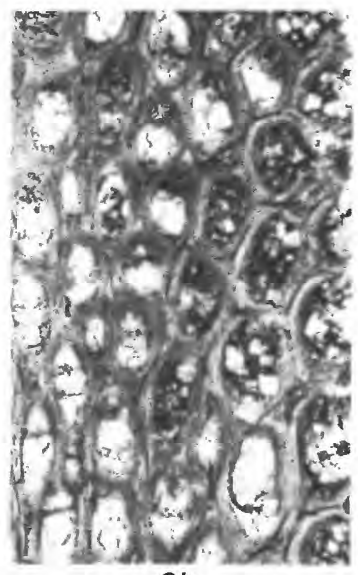

$2 b$

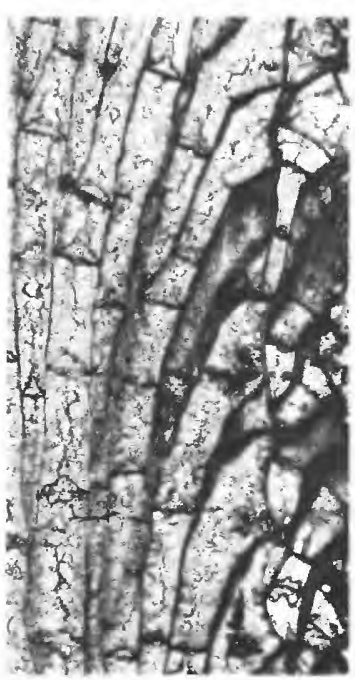

5

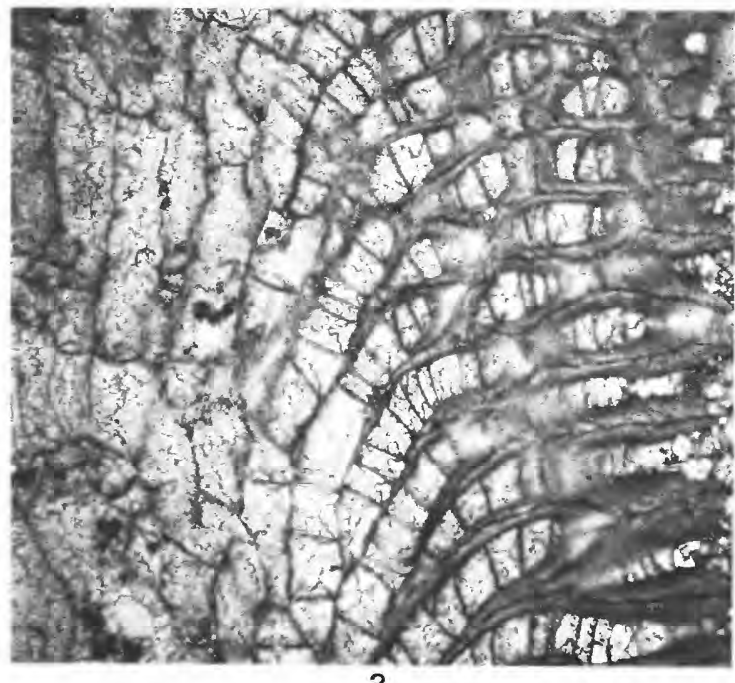

3

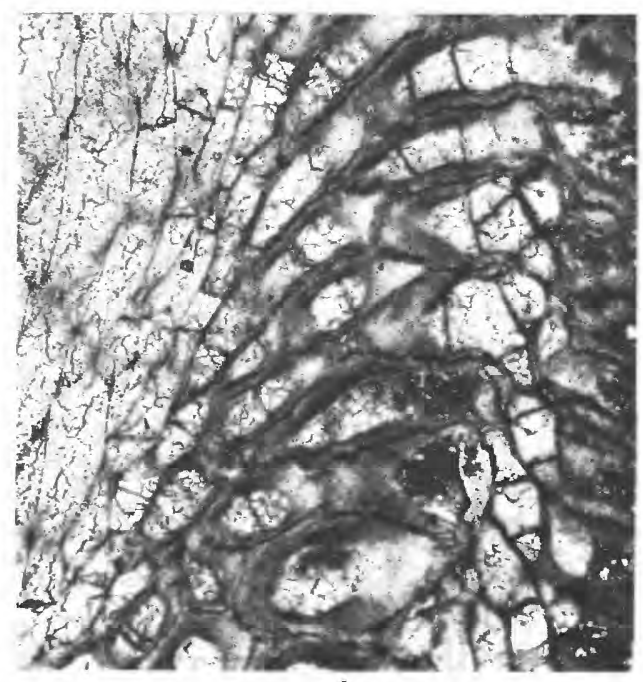

4

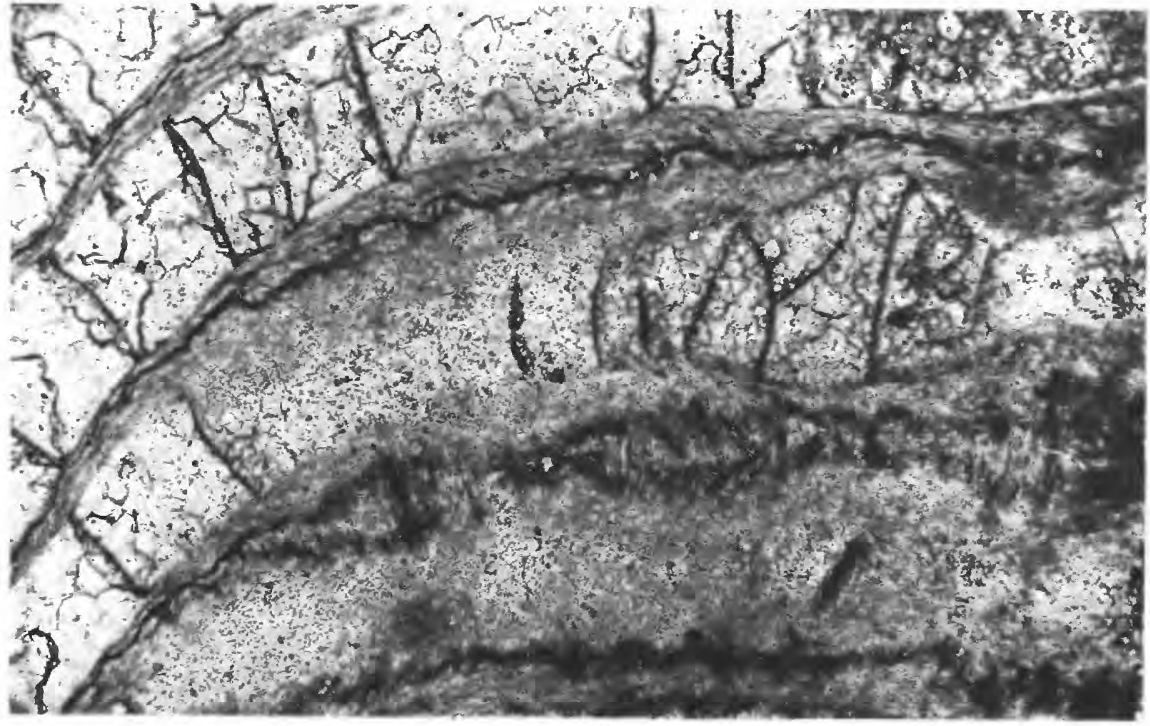

6

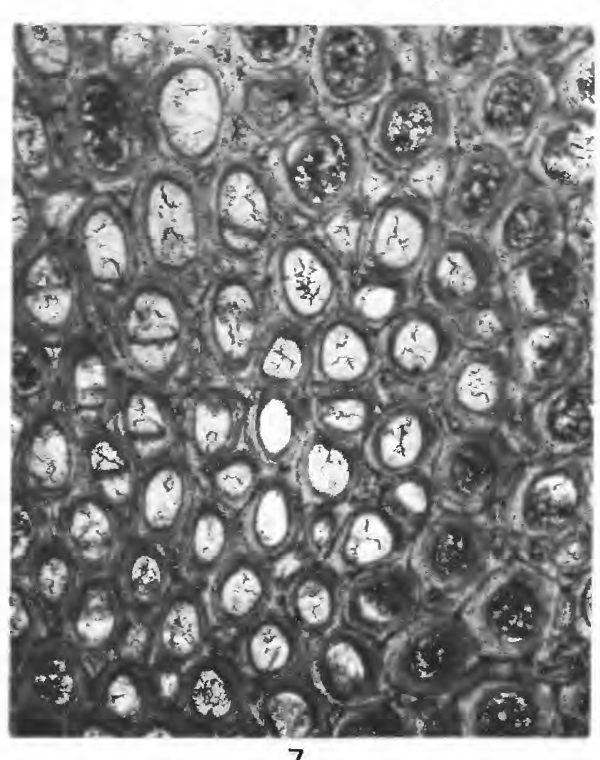

7 


\section{PLATE 28}

FIGURES 1-3. Eridotrypa sadievillensis, n. sp., (p. I69).

1. Paratype USNM 309071, Millersburg Member, Shermanian Stage (USGS colln. D1312-CO), Gratz Quadrangle, Kentucky; 1a, microstructure of autozooecial walls in exozone, distinct autozooecial boundaries without pustules and styles, tangential section, $\times 100 ; 1 b$, narrowly serrated, relatively smooth autozooecial boundaries in exozone, few basal diaphragms, longitudinal section, $\times 100$; $1 c$, large autozooecia with relatively straight walls in axial portion of endozone, basal diaphragms virtually lacking, narrow exozone with thin autozooecial walls, longitudinal section, $\times 30 ; 1 d$, cross-sectional shape of autozooecia in exozone, distinct autozooecial boundaries, mesozooecia absent, tangential section, $\times 30$.

2. Holotype USNM 309045, Tanglewood Limestone Member, Shermanian Stage (USGS colln. 7448-CO), of Lexington Limestone, Sadieville Quadrangle, Kentucky; $2 a$, wide endozones and narrow exozones with thin walls in exozones, autozooecia oriented obliquely to zoarial surface, basal diaphragms absent in axial portion of endozone, longitudinal section, $\times 50 ; 2 b$, microstructure of autozooecial walls, cross-sectional shape of autozooecia and their chambers, styles in autozooecial boundaries exceedingly small or absent, few mesozooecia, tangential section, $\times 50$; $2 c$, larger autozooecia in axial portion of endozone, intercalated autozooecia decrease in size and become flattened in cross-sectional shape from axial portion of endozone toward endozone periphery, narrow exozone, transverse section, $\times 30$.

3. Paratype USNM 309051, Tanglewood Limestone Member, Shermanian Stage (USGS colln. 7448-CO), of Lexington Limestone, Sadieville Quadrangle, Kentucky; basal diaphragms absent in axial portion of endozone, autozooecia irregular in thickness in exozone, cystoidal diaphragms present in one autozooecium (upper right of figure), longitudinal peel, $\times 30$. 
GEOLOGICAL SURVEY

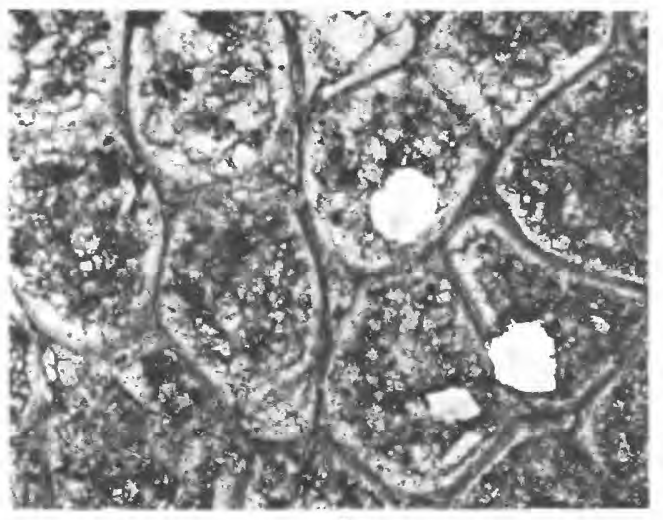

1a

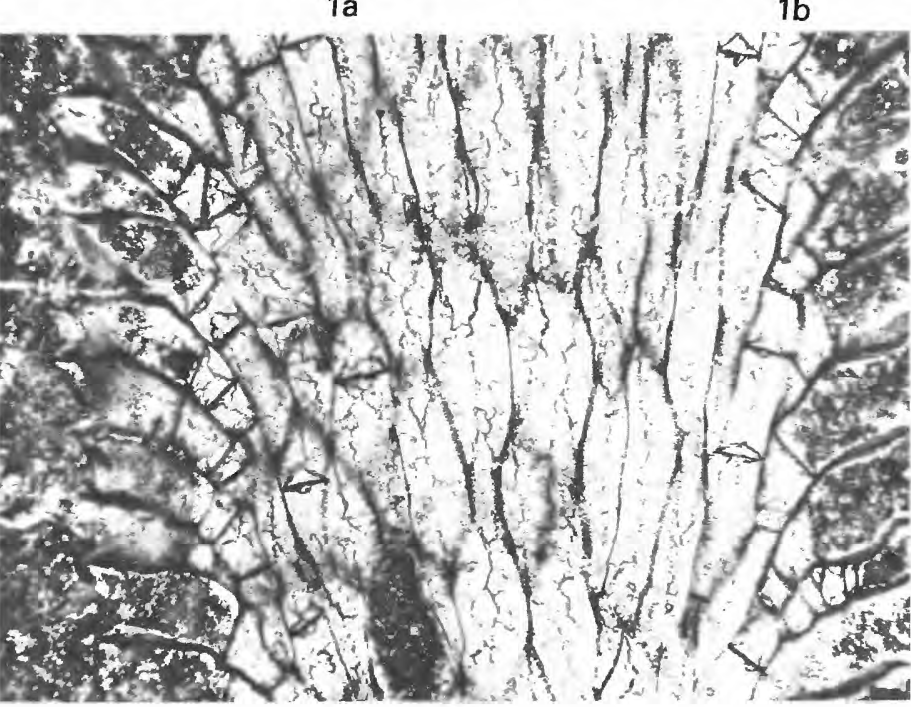

$2 \mathrm{a}$

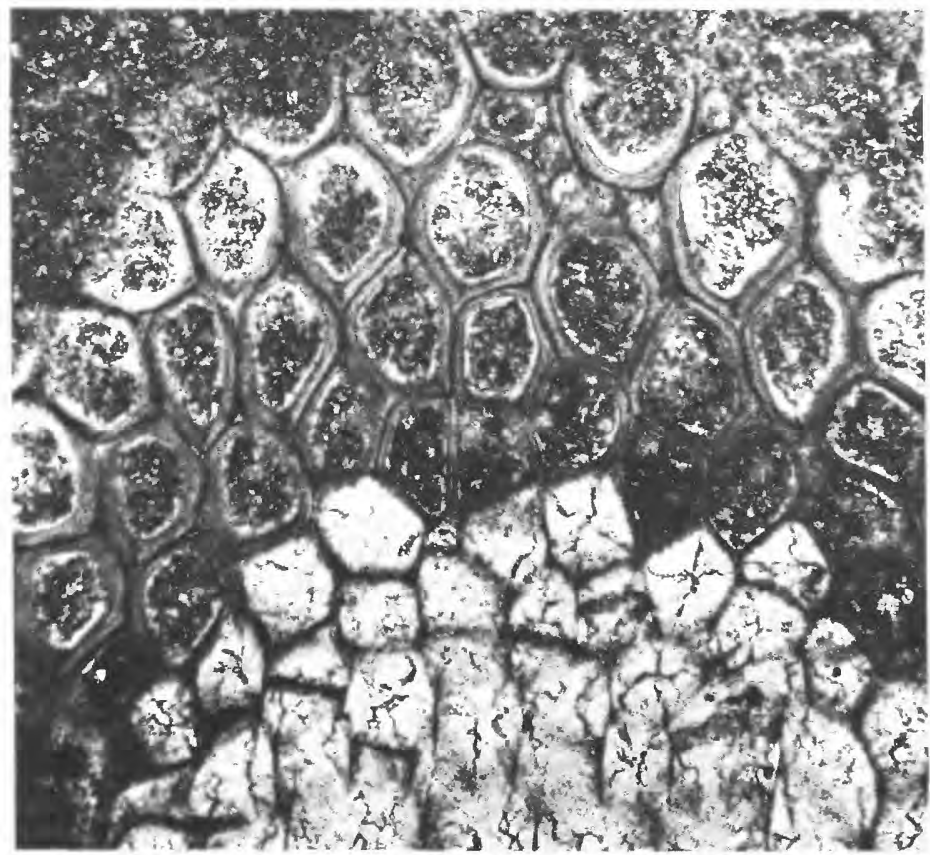

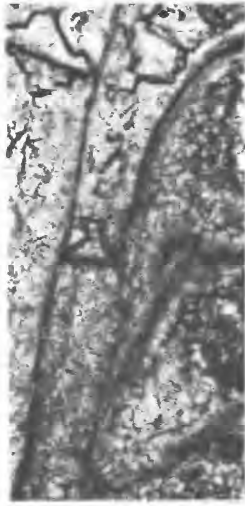

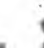

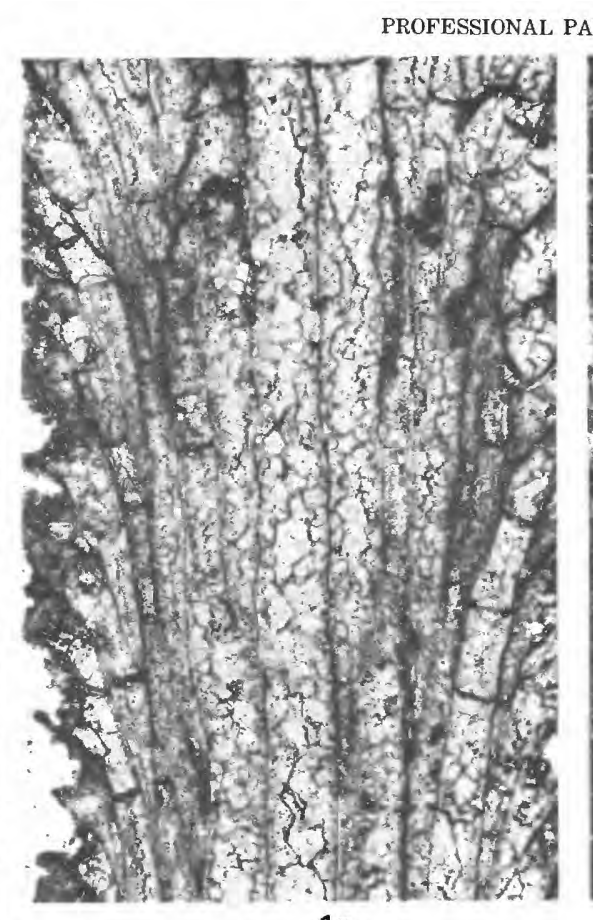

1c

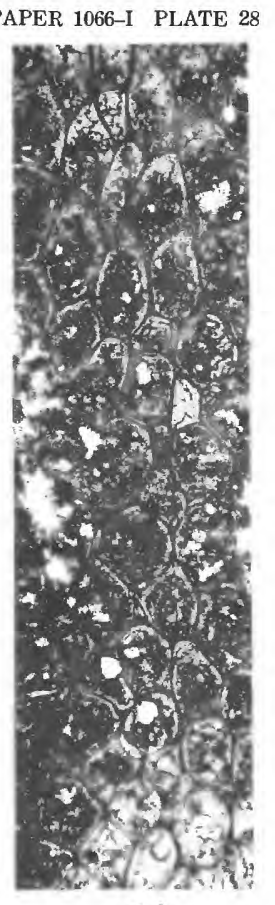

1d
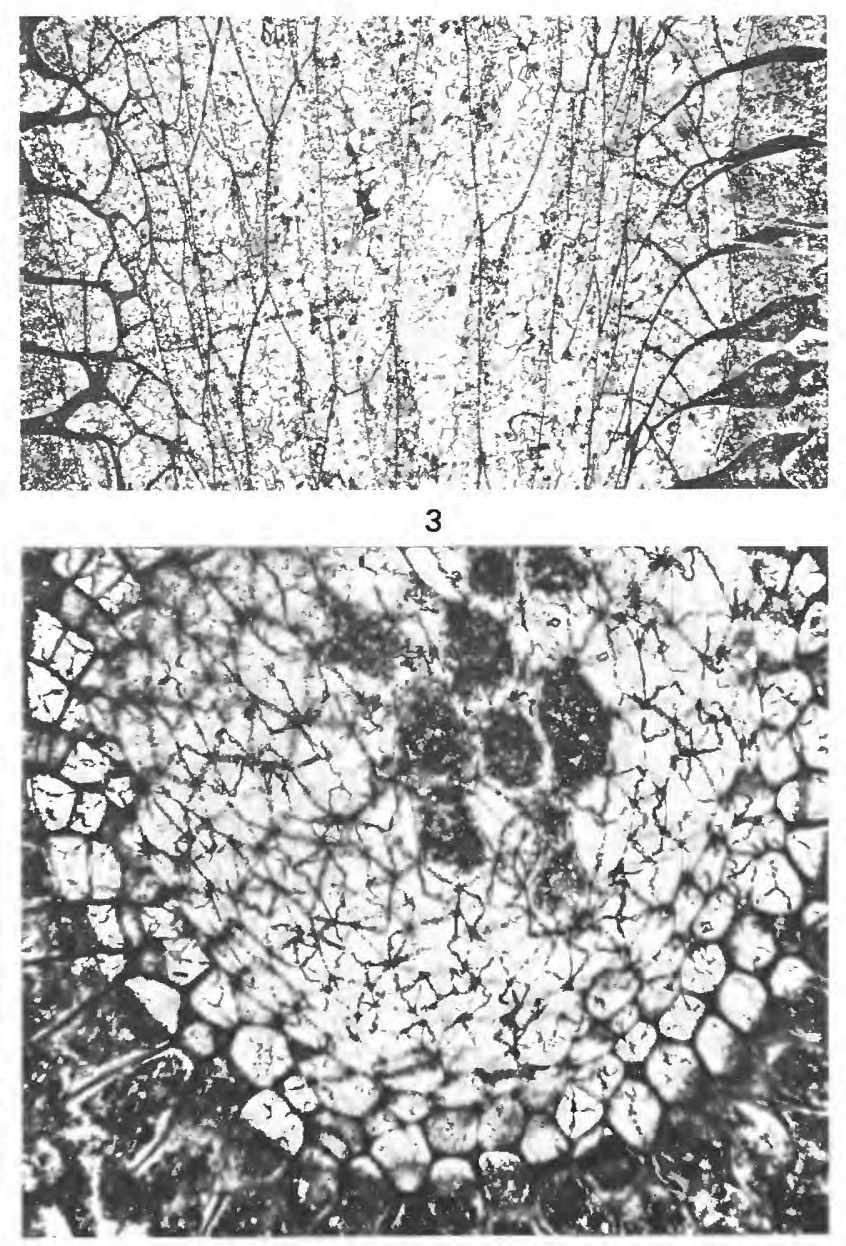

2c

ERIDOTRYPA 


\section{PLATE 29}

Figures 1-3. Parvohallopora nodulosa (Nicholson) (p. I70)

1. Hypotype USNM 309115, Clays Ferry Formation, Edenian Stage (USGS colln. 4922_CO), Valley View Quadrangle, Kentucky; $1 a$, slightly raised macula initiated in early exozone, part of polymorphs not well preserved, crenulated autozooecial walls in endozone, longitudinal section, $\times 30 ; 1 b$, macula with clustered mesozooecia and polymorphs slightly larger than autozooecia in intermacular area, exozone, tangential section, $\times 30 ; 1 c$, microstructure of autozooecial and mesozooecial walls, some mesozooecia closed by skeletal deposits, autozooecial linings absent, indistinct pustules within autozooecial walls, fissioned autozooecium (lower right of figure), tangential section, $\times 100$.

2. Hypotype USNM 309665, sections of specimen figured by Nickles, 1905, pl. 2, fig. 8, from Nickles "McMicken beds of the Eden" strata; $2 a$, macula with clustered mesozooecia of various sizes and polymorphs slightly larger than autozooecia, cross-sectional shape of autozooecia in indistinct alignment in intermacular area, mesozooecia partly closed, tangential section, $\times 30 ; 2 b$, microstructure of autozooecial walls, broadly serrated autozooecial boundaries, along median of autozooecial boundaries laminae adjoin along indistinct junctions, autozooecial linings absent, transverse section, $\times 100$; 2 c, cross-sectional shapes and sizes of autozooecia at various growth stages in endozone, autozooecia of uniform appearance in exozone, autozooecial boundaries distinct, transverse section, $\times 30 ; 2 d$, microstructure of autozooecial and mesozooecial walls and diaphragms, exceedingly thin autozooecial lining (center of figure), cystoidal diaphragms, longitudinal section, $\times 100 ; 2 e$, wide endozone with autozooecia subparallel to branch axis, some autozooecia with mesozooeciumlike proximal parts, curvature of autozooecia in early exozone, scattered basal diaphragms in exozone, longitudinal section, $\times 30$.

3. Hypotype USNM 309094, Clays Ferry Formation, Shermanian Stage (USGS colln. 4896_CO), Valley View Quadrangle, Kentucky; several autozooecia with mesozooeciumlike proximal tips in endozone, autozooecia with scattered basal diaphragms, indistinct linings in relatively wide exozone, slightly raised macula in lower right of figure, longitudinal section, $\times 30$. 


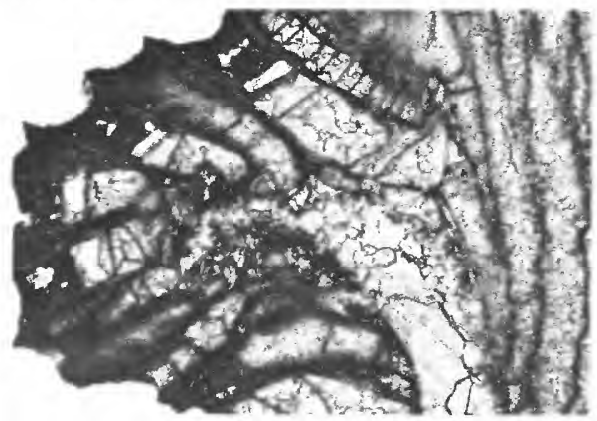

$1 \mathrm{a}$
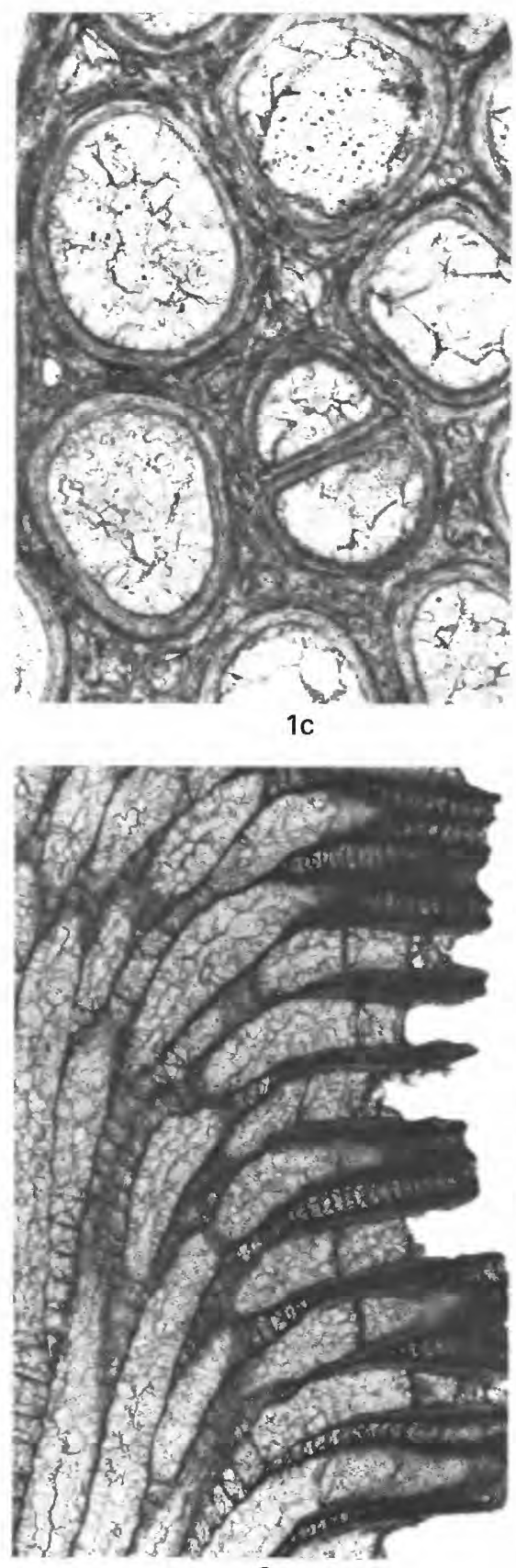

3

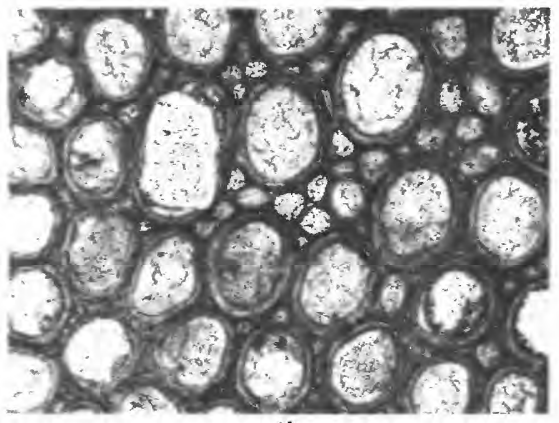

$1 \mathrm{~b}$
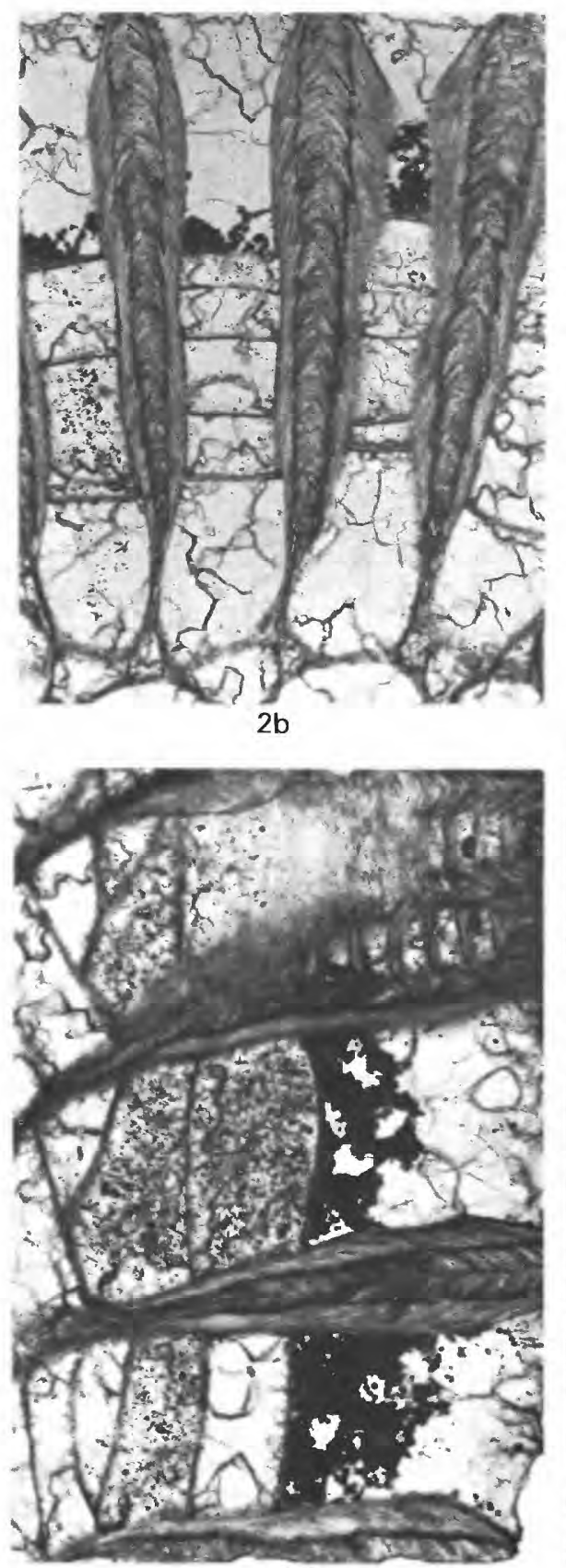

$2 \mathrm{~d}$

PARVOHALLOPORA

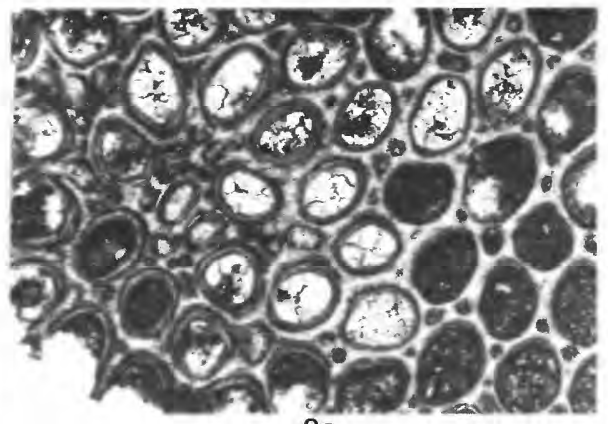

$2 a$
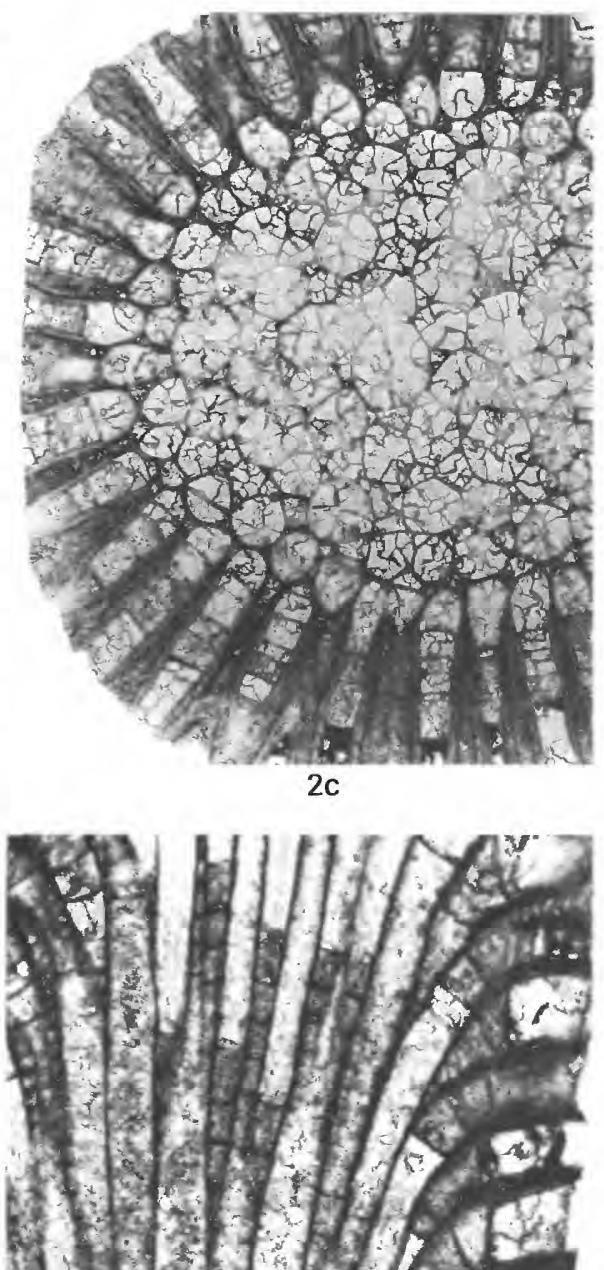

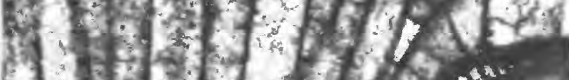

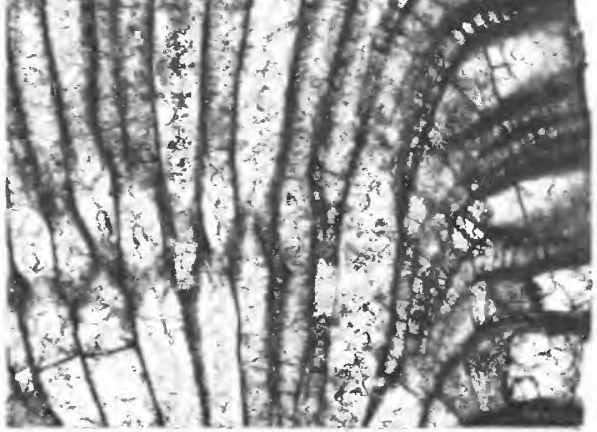

$2 e$ 


\section{PLATE 30}

Figures 1, 4-6. Parvohallopora nodulosa (Nicholson) (p. I70).

1. Hypotype USNM 309169, Clays Ferry Formation, Shermanian Stage (USGS colln. 7469_CO), Sadieville Quadrangle, Kentucky; $1 a$, polygonal cross-sectional shape of autozooecia at various growth stages in endozone, conspecific overgrowth of zoarium apparently expands from an area of the zoarial surface in upper left of figure, transverse section, $\times 20 ; 1 b$, possible point of origin of another part of overgrowth (lower center of figure), thin basal layer of overgrowth extends across preceding autozooecia (center of figure), broadly serrated autozooecial boundaries in overgrowth zoarium, evenly spaced diaphragms in mesozooecia of overgrowth, transverse section, $\times 100 ; 1 c$, cross-sectional shape of polymorphs and indistinct macula (lower right of figure) and of autozooecia in intermacular area (left side of figure), indistinct pustules in autozooecial boundaries, autozooecial linings lacking, exozone, tangential section, $\times 50$.

4. Hypotype USNM 309173, Clays Ferry Formation, Edenian Stage (USGS colln. 7474-CO), Sadieville Quadrangle, Kentucky; segment of zoarium encrusting skeletal fragment of crinoid, basal layer of encrusting zoarium exceedingly thin, laminated distally with dark zone adjacent to substrate, recumbent autozooecia in narrow exozone, mesozooecium originates at base of exozone, oblique longitudinal section, $\times 100$.

5. Hypotype USNM 309129, Clays Ferry Formation, Edenian Stage (USGS colln. 6732-CO), Ford Quadrangle, Kentucky; zoarium encrusts sedimentary particle, autozooecia recumbent in narrow endozone, become erect at base of exozone, cross-sectional shape of autozooecia in early exozone (center of figure), oblique longitudinal section, $\times 20$.

6. Hypotype USNM 309167, Tanglewood Limestone Member, Shermanian Stage (USGS colln. 5049_CO), of Lexington Limestone, Sadieville Quadrangle, Kentucky; zone of rejuvenation of autozooecia in endozone, regular autozooecia and those with mesozooeciumlike proximal tips become autozooecia at a later growth stage, longitudinal section, $\times 20$.

2, 3. Parvohallopora onealli (James) (p. I72).

2. Hypotype USNM 309222, Strodes Creek Member, Edenian Stage (USGS colln. 7328-CO) of Lexington Limestone, Austerlitz Quadrangle, Kentucky; scattered basal diaphragms in early exozone, autozooecia aligned approximately longitudinally in exozone, shallow to deep tangential section, $\times 50$.

3. Hypotype USNM 309209, from "base of the Economy Member of the Eden strata" (lower part of Kope Formation of current usage), Edenian Stage, River Quarries, near Ludlow, Kentucky; $3 a$, scattered and partly closed mesozooecia between autozooecia, autozooecial boundaries generally with pustules, autozooecial linings absent, tangential section, $\times 30 ; 3 b$, basal diaphragms exceedingly sparse in endozone, zone of rejuvenation of autozooecia in upper part of figure, curvature of autozooecia in early exozone, scattered basal diaphragms in exozone, longitudinal section, $\times 20$. 


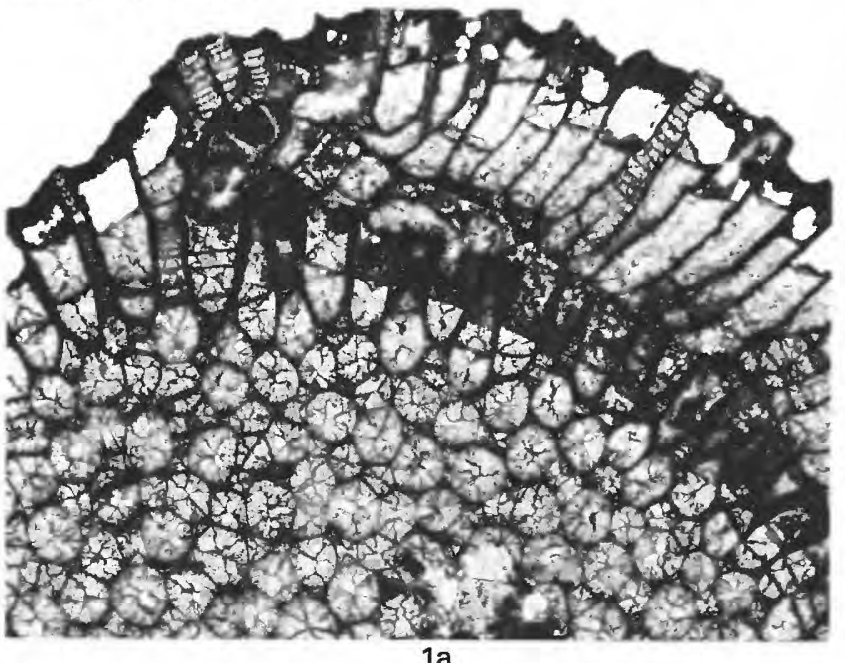
$1 a$

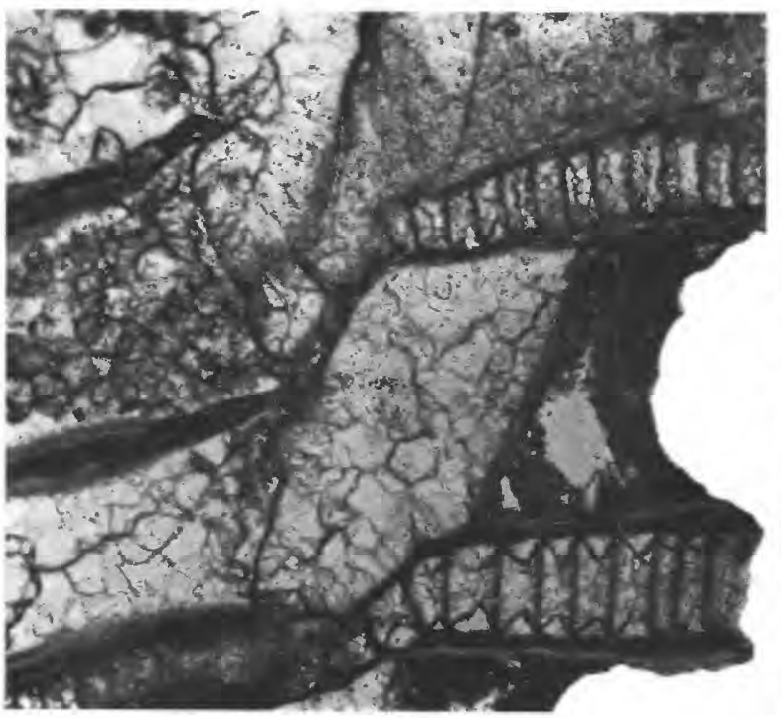

$1 \mathrm{~b}$

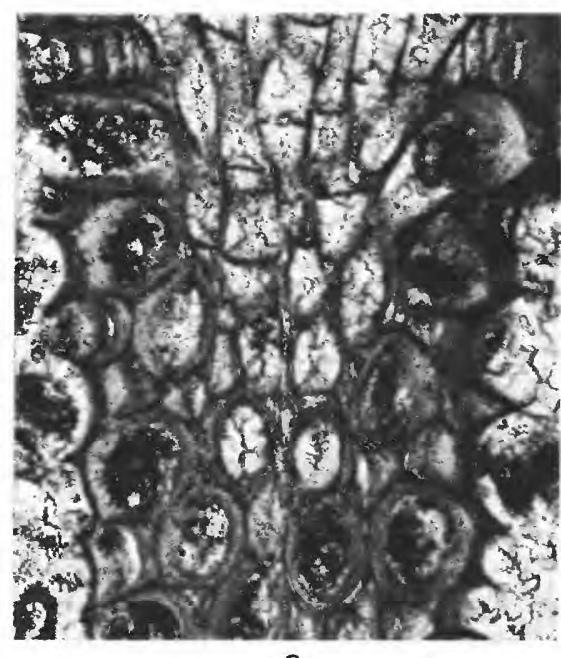

2

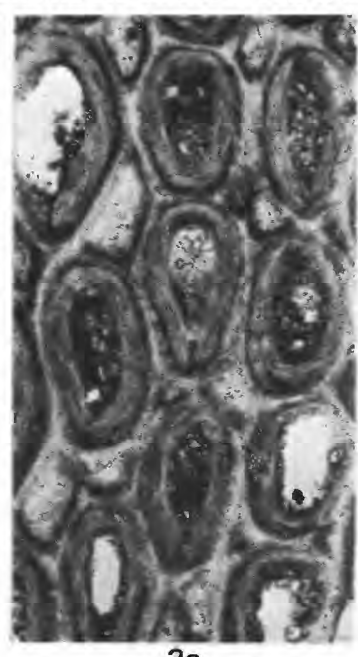

$3 a$

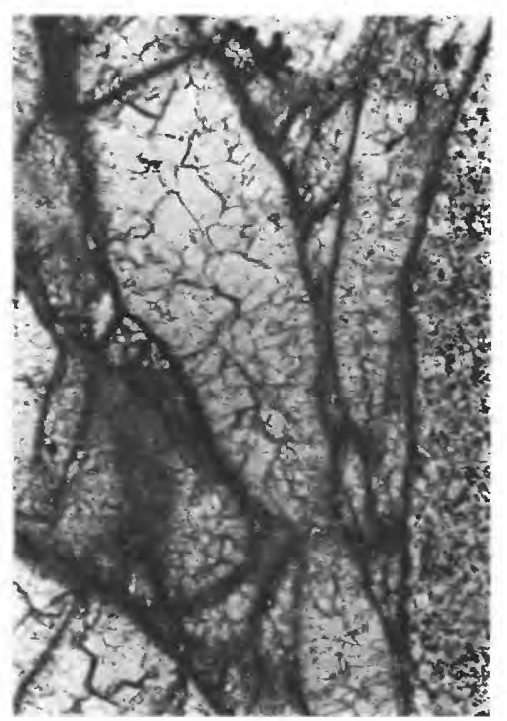

4

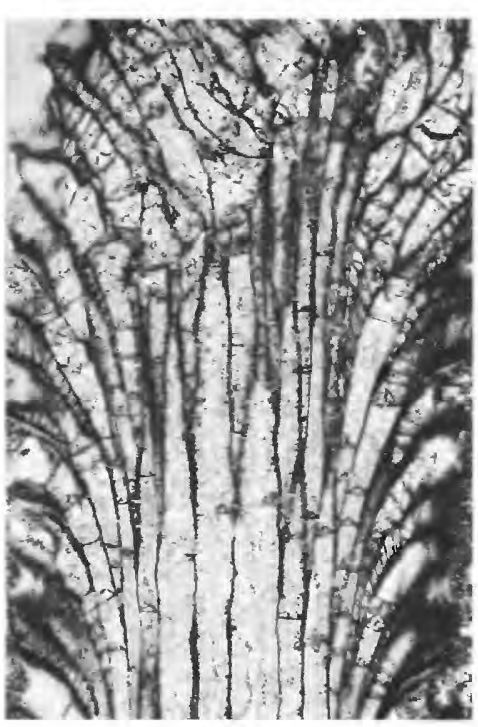

$3 b$

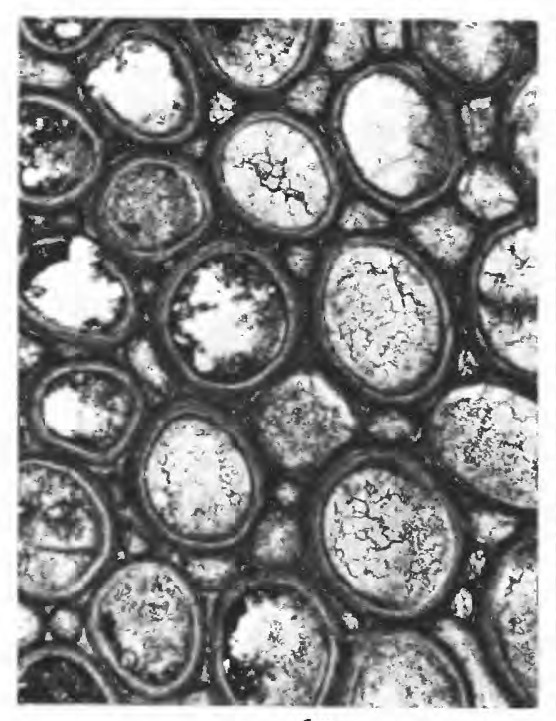

1c

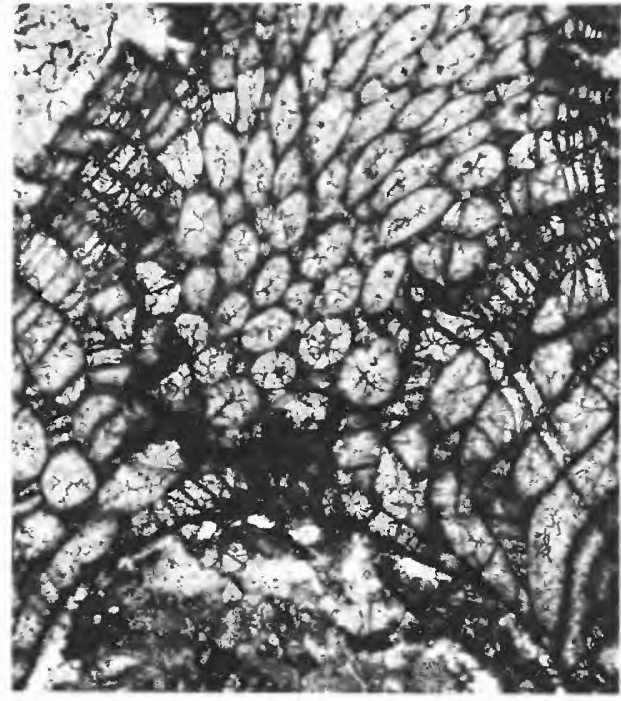

5

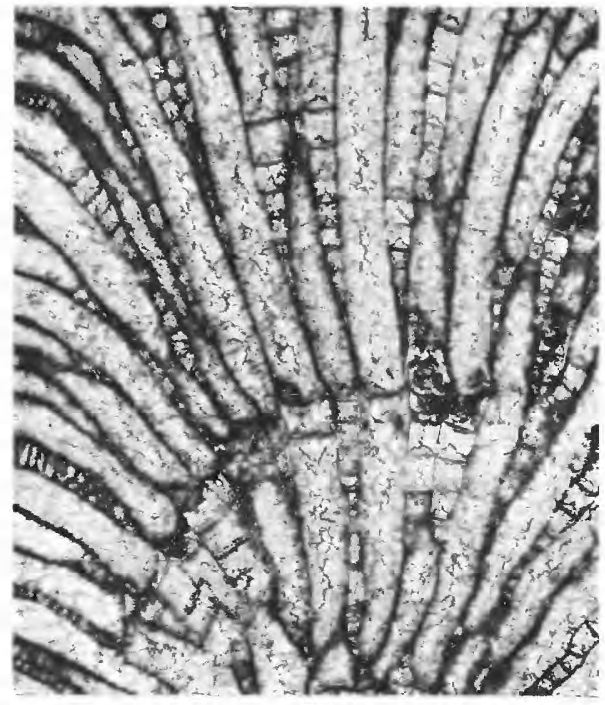

6 
Figures 1-7. Parvohallopora onealli (James) (p. I72).

\section{PLATE 31}

1. Hypotype USNM 309251, Point Pleasant Tongue, Shermanian Stage (USGS colln. 6929_CO), of Clays Ferry Formation, Falmouth Quadrangle, Kentucky; cross-sectional shape of small, partly closed mesozooecia in late exozone, scattered basal diaphragms in early exozone or late endozone, oblique tangential section, $\times 50$.

2. Lectotype Field Museum of Natural History, James Collection, UC230-C, "Eden Shale" (Kope Formation of current usage), Ohio; $2 a$, partly closed mesozooecia distally and proximally of elongate autozooecia, indistinct autozooecial boundaries, tangential section, $\times 50 ; 2 b$, longitudinal alignment of autozooecia with elliptical to subelliptical cross sections, tangential section, $\times 30 ; 2 c$, segment of branching portion of relatively large zoarium, exterior view, $\times 3$; $2 d$, polygonal cross-sectional shape of autozooecia in axial portion of endozone, relatively thick autozooecial walls in exozone, autozooecial boundaries generally visible in exozone, transverse section, $\times 50$; $2 e$, autozooecia with relatively straight walls approximately parallel to branch axis bud at relatively along intervals, basal diaphragms virtually absent in axial portion of endozone, scattered in endozone periphery and early exozone, curvature of autozooecia in late endozone, longitudinal section, $\times 30$.

3. Paralectotype Field Museum of Natural History, James Collection, UC 230-F, "Eden Shale," Cincinnati, Ohio; general branching pattern, alignment of autozooecia and distribution of mesozooecia, portion of zoarium, external view, $\times 3$.

4. Hypotype USNM 309206, "lower third of Eden Shale; approximately $110 \mathrm{ft}$ above then low-water level of the Ohio River" (Bassler, 1906, p. 8); 4a, autozooecia subelliptical to subcircular in cross section, partly separated by open or closed mesozooecia, autozooecial boundaries relatively distinct, tangential section of late and middle exozone, $\times 50$; $4 b$, polygonal autozooecia in endozones, autozooecia with distinct, broadly serrated autozooecial boundaries in exozones, portion of transverse section of cylindrical branch, $\times 50 ; 4 c$, few planar basal diaphragms in endozone, relatively thick autozooecial walls in exozone, basal and cystoidal diaphragms scattered in exozone, longitudinal section, $\times 30$.

5. Hypotype USNM 309668, Millersburg Member, Shermanian Stage (USGS colln. D1127-CO) of Lexington Limestone, Switzer Quadrangle, Kentucky; cystoidal and curved basal diaphragms in exozone, indistinct autozooecial linings merge with wall laminae of cortex distally of basal diaphragms, microstructure of zooecial walls and of autozooecial boundaries, mesozooecia with closely and evenly spaced diaphragms, longitudinal section, $\times 100$.

6. Hypotype USNM 309643, Tanglewood Limestone Member, Shermanian Stage (USGS colln. 7462-CO), of Lexington Limestone, Sadieville Quadrangle, Kentucky; relatively large autozooecium in axial portion of endozone, single basal diaphragm in proximal portions of some autozooecia, narrow exozone with thin walls of autozooecia, mesozooecia with thin, closely spaced diaphragms, longitudinal section, $\times 50$.

7. Hypotype USNM 309232, Clays Ferry Formation, Shermanian Stage (USGS colln. 5185-CO), Sadieville Quadrangle, Kentucky; autozooecia with scattered planar basal diaphragms in endozone, curvature of autozooecia in endozone periphery, thin autozooecial walls in exozone, slightly oblique longitudinal section, $\times 50$. 

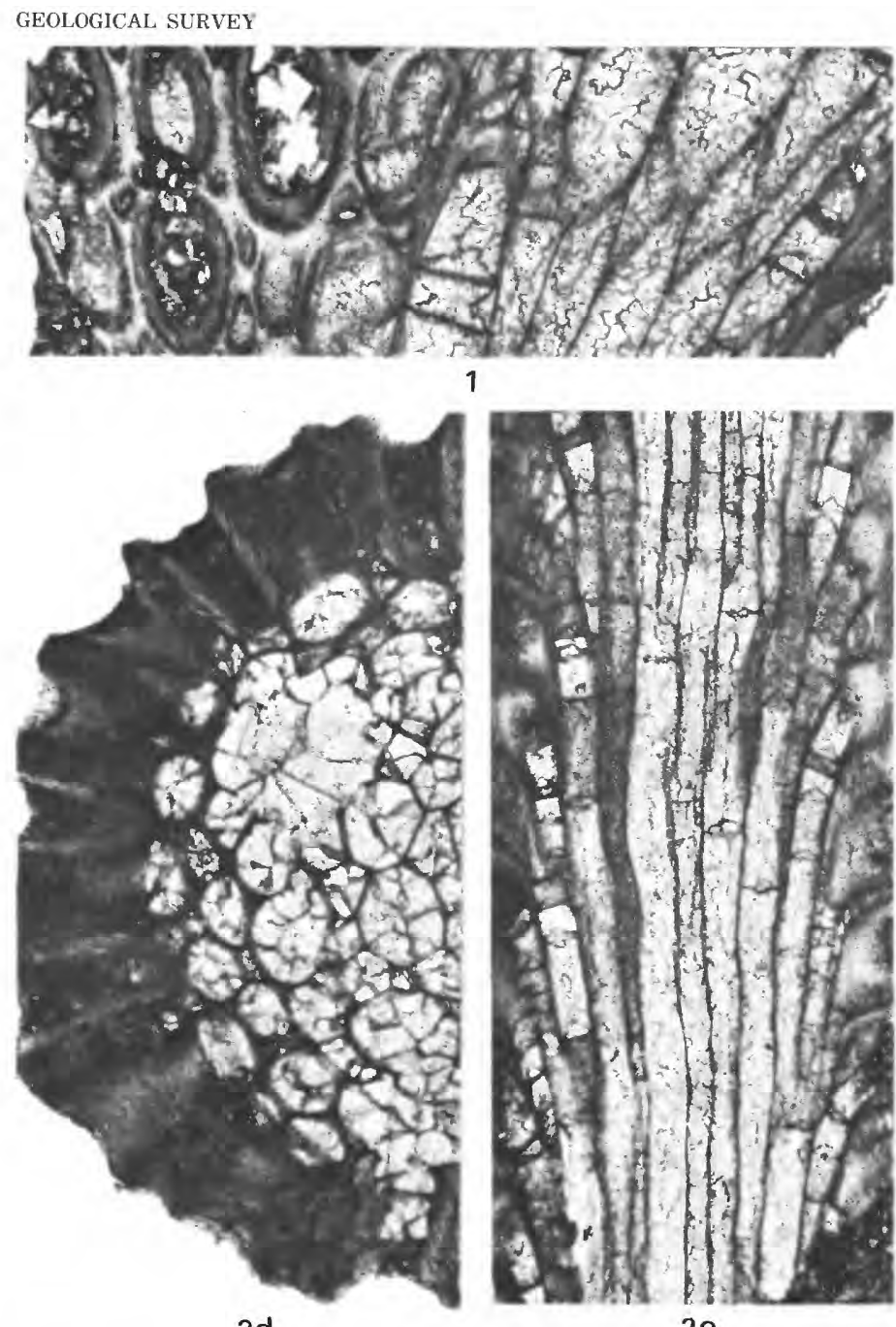

$2 d$

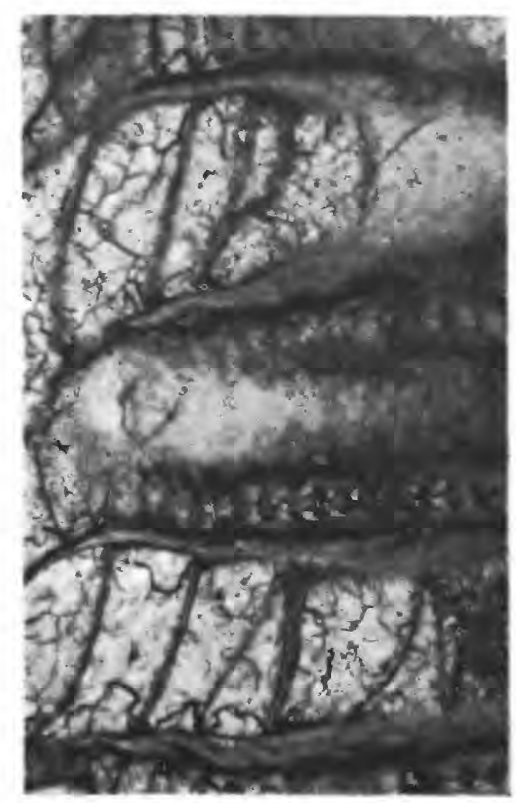

5
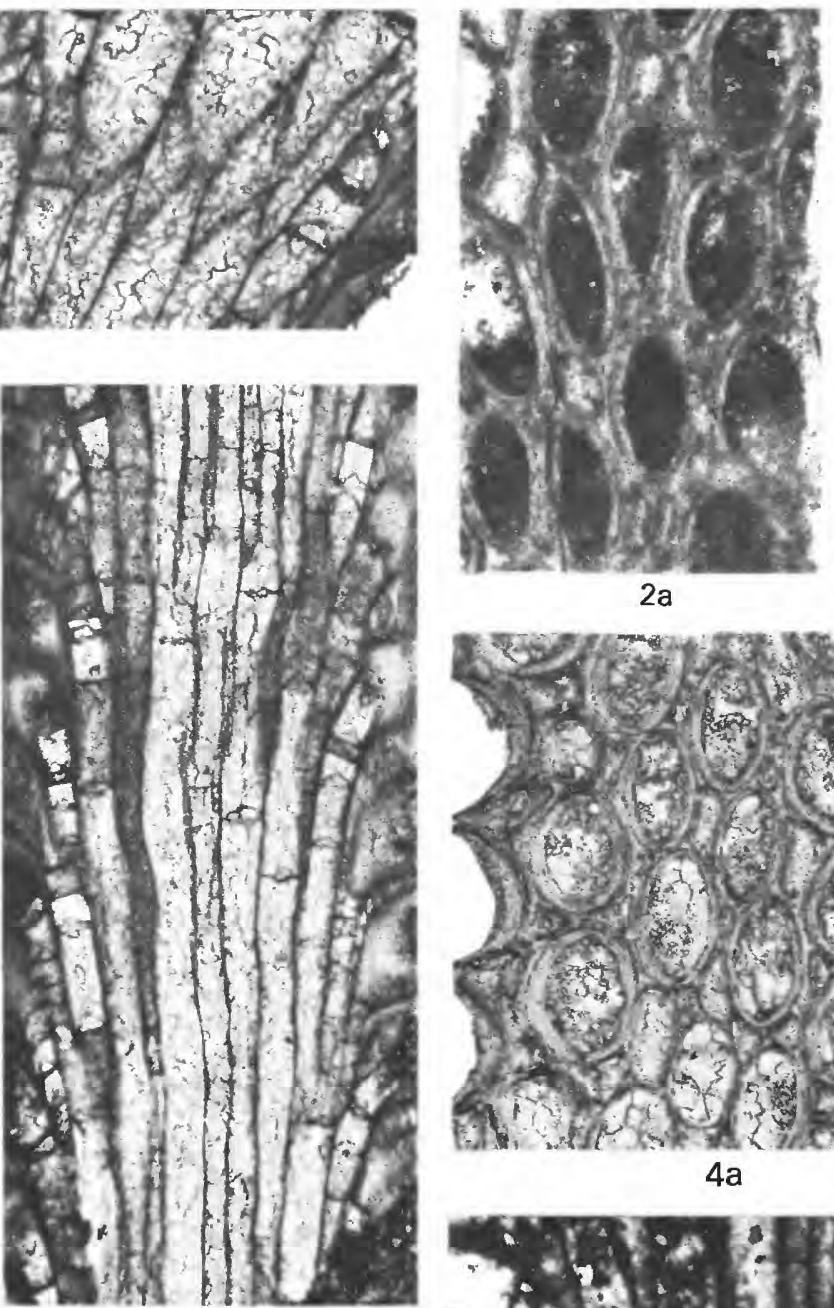

$2 \mathrm{e}$

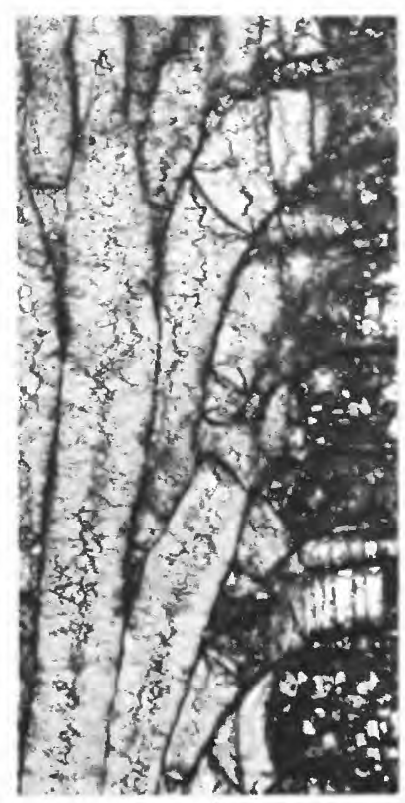

6

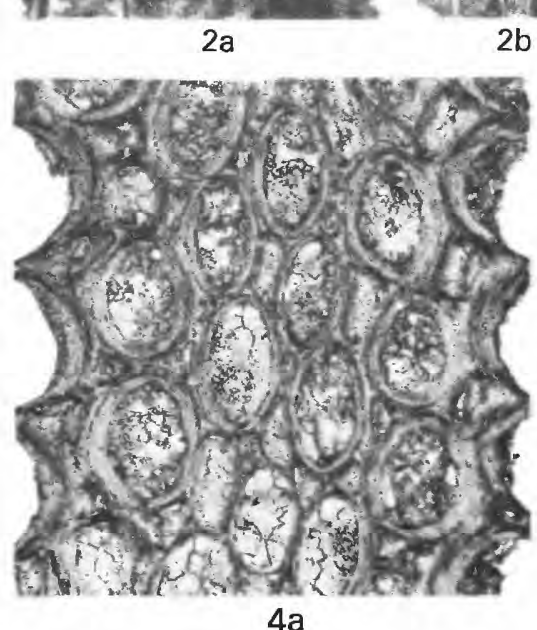

$4 a$

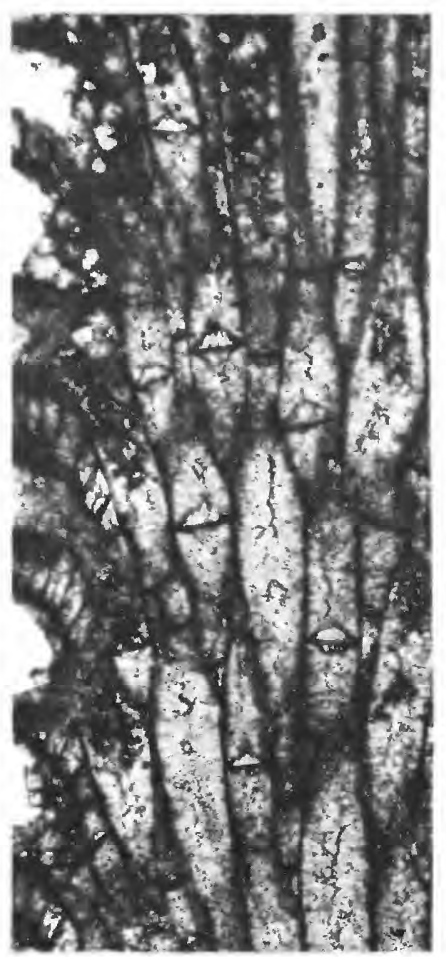

7

PROFESSIONAL PAPER 1066-I PLATE 31

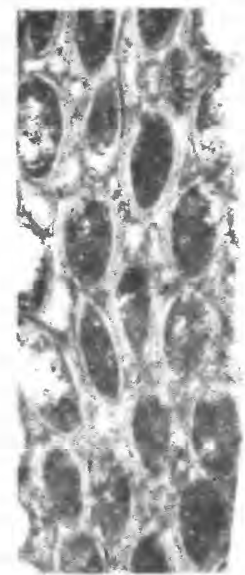

$2 \mathrm{~b}$

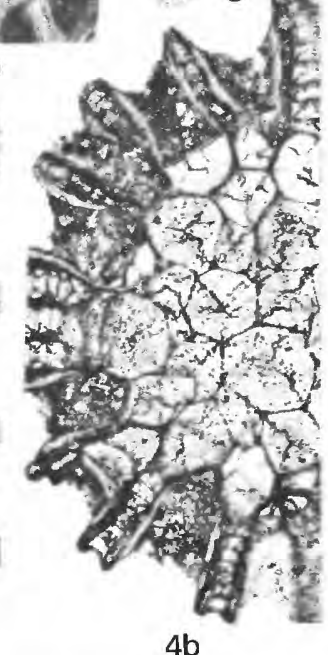

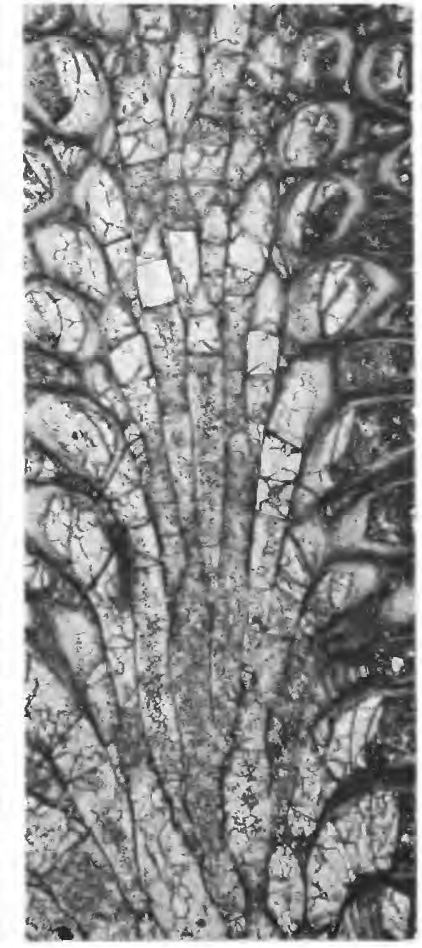

$4 \mathrm{c}$

PARVOHALLOPORA 
Figures 1-5. Tarphophragma multitabulata (Ulrich) (p. I77).

1. Hypotype USNM 309323, Grier Limestone Member, Shermanian Stage (USGS colln. 4687-CO) of Lexington Limestone, Frankfort East Quadrangle, Kentucky; 1a, part of zoarium in area of dichotomous branching, polygonal autozooecia in cross section in axial portions of endozones in diverging branches (left and right of figure), autozooecia with elongate cross sections in late endozones between two branches (center of figure), mesozooecia absent in endozones, sparse in early exozones (upper left of figure), transverse section, $\times 20 ; 1 b$, microstructure of autozooecial walls and basal diaphragms, exceedingly thin skeletal laminae aligned in V-shaped (chevron) pattern with apexes at right angles to zoarial surface, narrowly serrated distinct autozooecial boundaries, laminae of basal diaphragms merge obliquely with laminae of zooecial walls proximally of succeeding basal diaphragms, longitudinal section, $\times 100$.

2. Paralectotype USNM 309307, marked "type section," figured by Ulrich, 1893, pl. 23, fig. 24, Decorah Shale ("Phylloporina Bed"), Cannon Falls, Minn.; 2a, macula projects slightly above zoarial surface, basal diaphragms in macular polymorphs poorly preserved, basal diaphragms in endozones planar, curved and planar in exozones, scattered cystoidal diaphragms, longitudinal section, $\times 30 ; 2 b$, autozooecia with subpolygonal cross-sectional shapes, distinct autozooecial boundaries and relatively thin walls in exozones, mesozooecia occur distally and proximally to autozooecia, tanagential section, $\times 30$.

3. Paralectotype USNM 309305, Decorah Shale ("Phylloporian Bed"), St. Paul, Minn.; part of branching zoarium, general alignment of autozooecia, maculae alternate in indistinct pattern, slightly raised above zoarial surface, external view, $\times 3$.

4. Lectotype USNM 43522, Decorah Shale ("Phylloporina bed"), St. Paul, Minn.; 4a, autozooecia with elongate subpolygonal cross-sectional shapes, distinct autozooecial boundaries, scattered mesozooecia, part of macula with polymorphs slightly larger than autozooecia (upper right of figure), tangential section, $\times 30 ; 4 b$, autozooecia with planar walls expand gradually distally, basal diaphragms occur regularly through endozone, autozooecial walls of uniform thickness in exozone, longitudinal section, $\times 30 ; 4 c$, autozooecia with distinct, narrowly serrated boundaries, basal and scattered cystoidal diaphragms, proximal portion of conspecific overgrowth in skeletal continuity with underlying autozooecia (upper right of figure), longitudinal section, $\times 50$.

5. Hypotype USNM 309324, Grier Limestone Member, Shermanian Stage (USGS colln. 4691_CO), of Lexington Limestone, Frankfort East Quadrangle, Kentucky; closely spaced basal diaphragms occur locally at some growth stage of several autozooecia, spacing of diaphragms similar in some mesozooecia and autozooecia, longitudinal section, $\times 30$. 


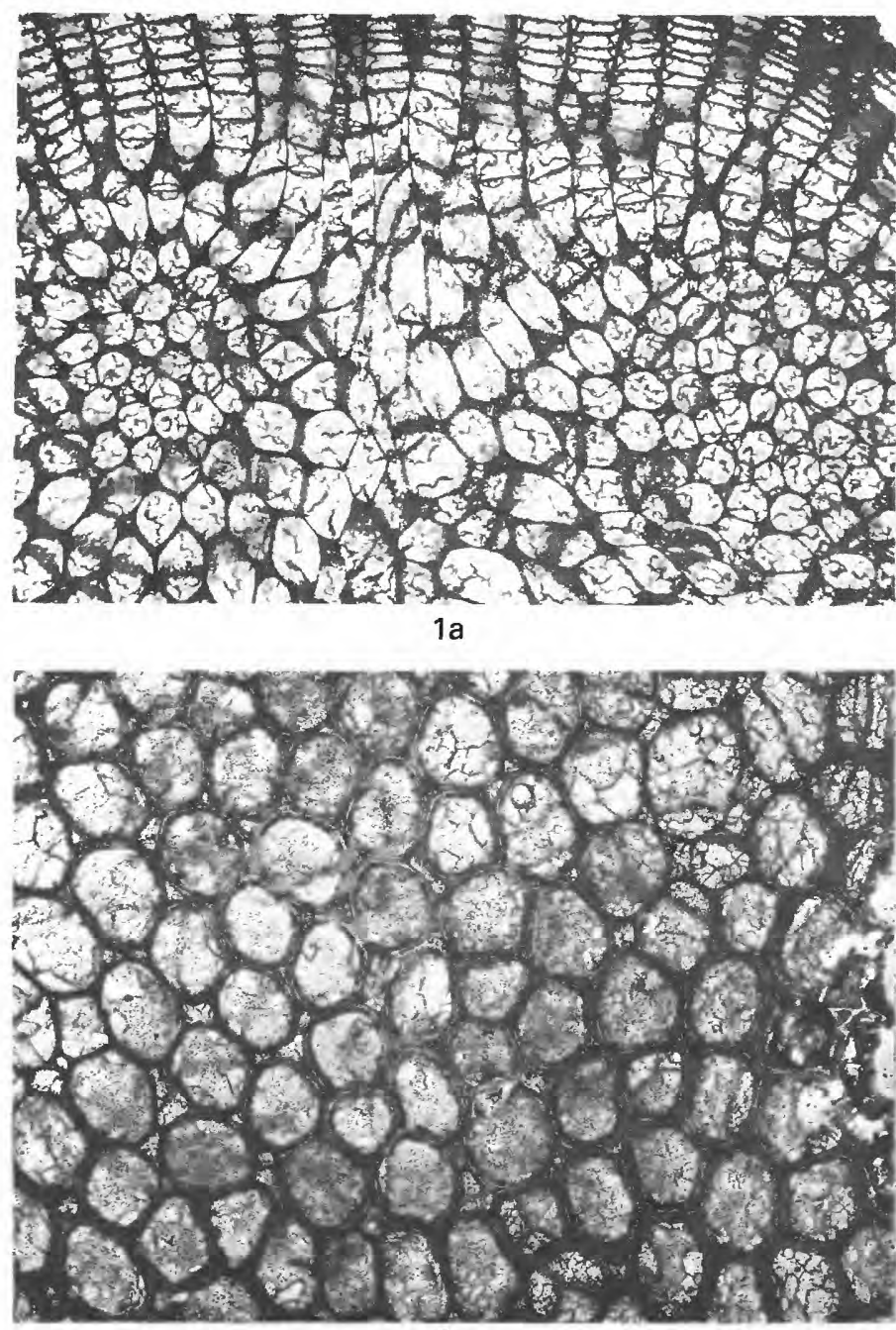

$4 a$

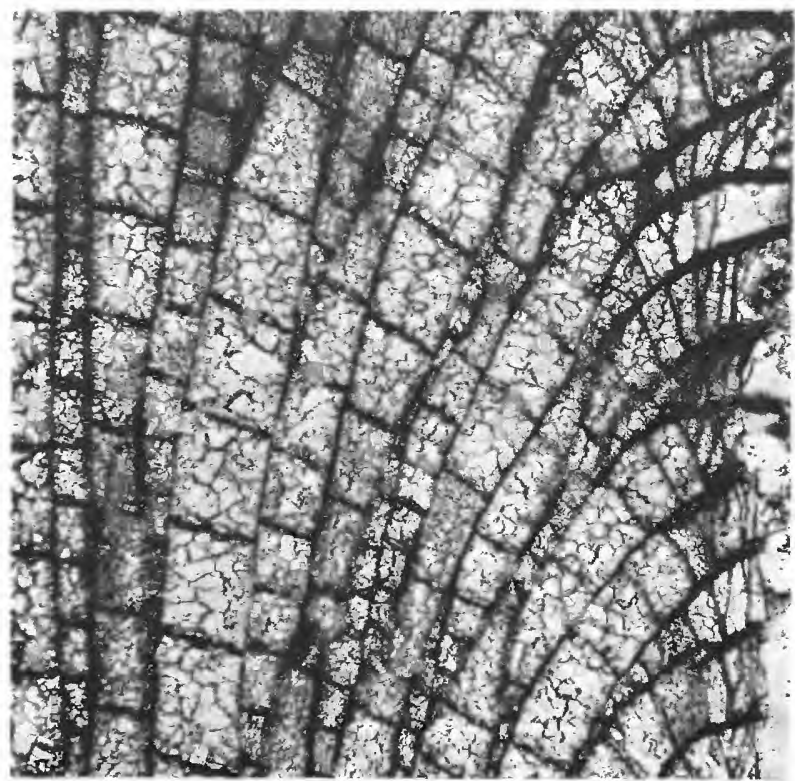

4.b
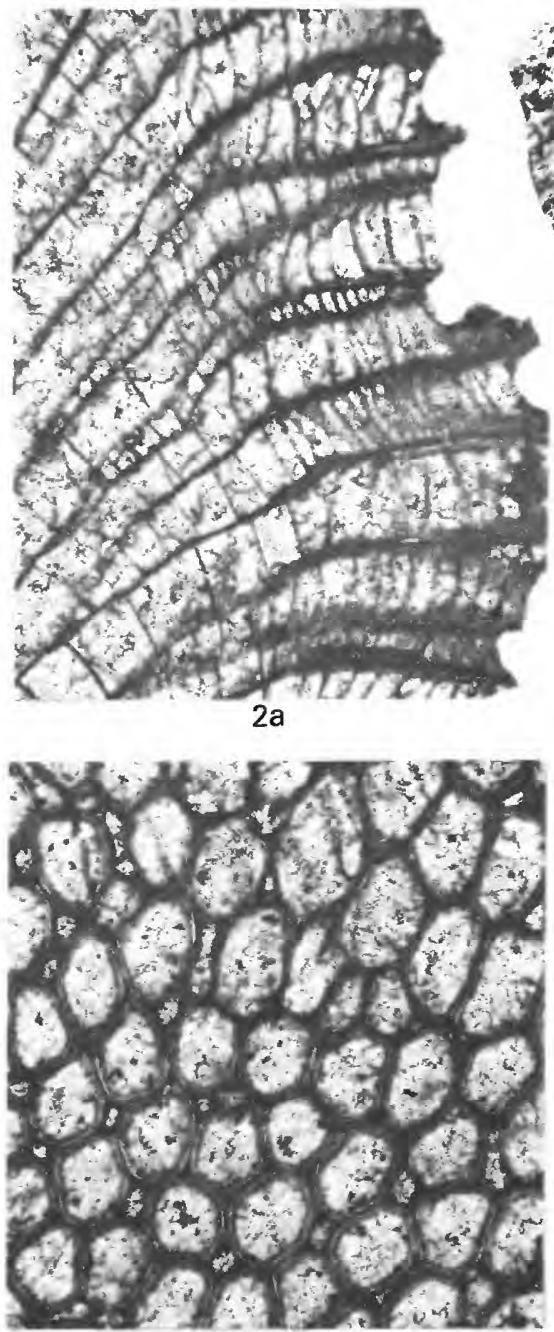

$2 b$

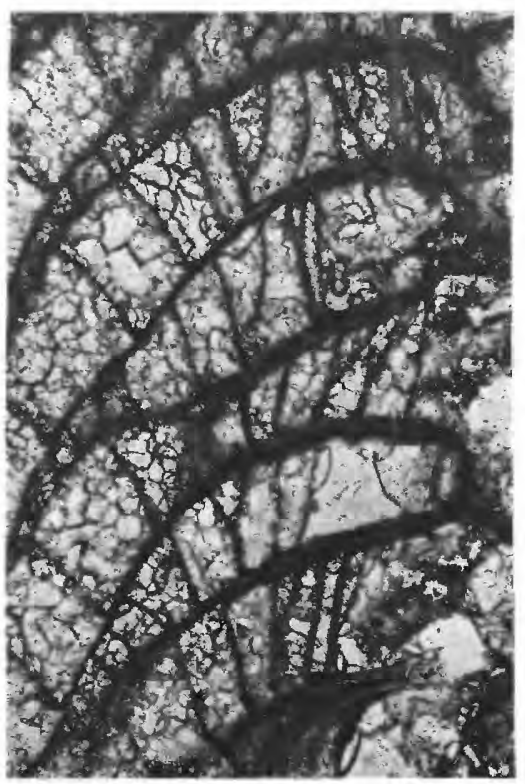

$4 c$

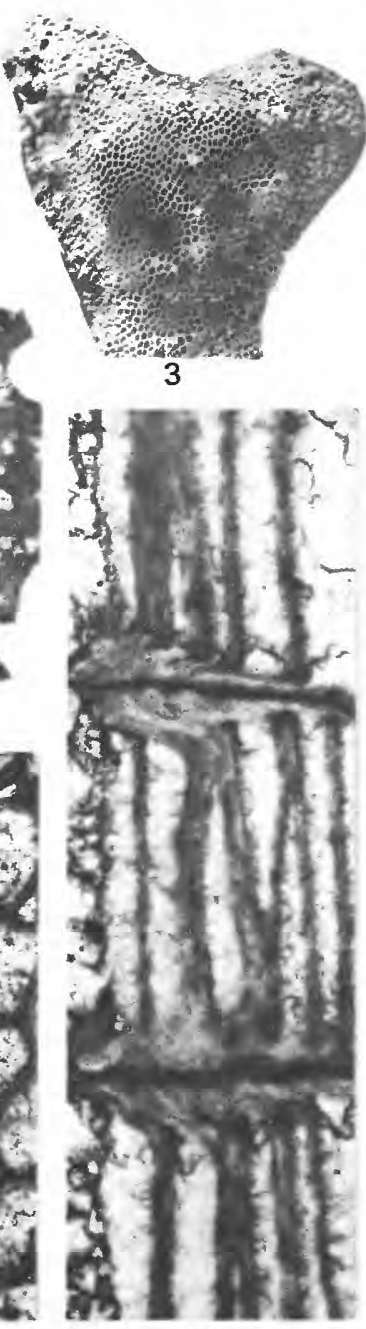

$1 \mathrm{~b}$

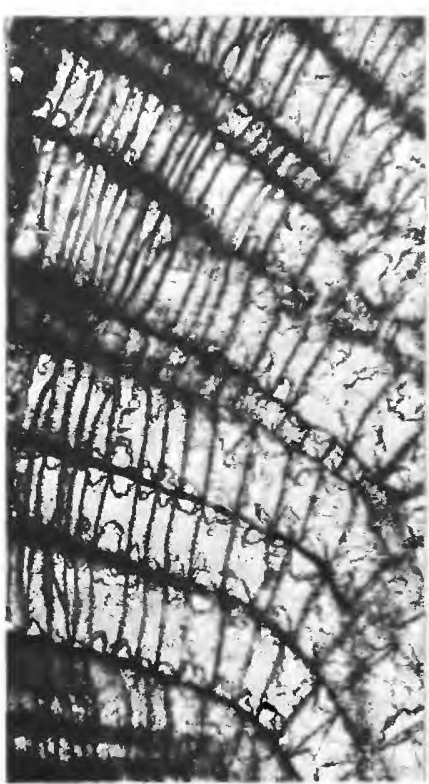

5

TARPHOPHRAGMA 


\section{PLATE 33}

Figures 1-4. Tarphophragma multitabulata (Ulrich) (p. I77).

1, 2. Hallopora goodhuensis of Ulrich, Galena Dolomite ("Clitambonites Bed"), Middle Ordovician, Cannon Falls, Minn.

1. Syntype USNM $309311,1 a$, autozooecia regularly intercalated in endozone, basal diaphragms evenly spaced, autozooecia in exozones of early growth stage, longitudinal section, $\times 30 ; 1 b$, autozooecia subpolygonal in cross section, scattered mesozooecia, distinct autozooecial boundaries in early exozone, tangential section, $\times 30 ; 1 c$, portion of branched zoarium, autozooecia in indistinct longitudinal alignment, maculae slightly raised, alternate in indistinct rhombic pattern, external view, $\times 3$.

2. Syntype USNM 43524, autozooecial budding pattern in cross section, autozooecia with planar walls, subpolygonal in cross section, proximal tips of succeeding autozooecia with smaller cross-sectional areas, mesozooecia absent in endozone, transverse section, $\times 30$.

3. Tarphophragma multitabulata, hypotype USNM 309652, Grier Limestone Member, Shermanian Stage (USGS colln. 4682-CO), of Lexington Limestone, Frankfort East Quadrangle, Kentucky; $3 a$, microstructure of autozooecial walls, basal and compound diaphragms, narrowly serrated autozooecial boundaries, proximal portion of endozone of autozooecium of conspecific overgrowth (left side of figure), longitudinal section, $\times 100 ; 3 b$, polygonal cross-sectional shape of autozooecia in exozone, relatively thin autozooecial walls with distinct boundaries, basal diaphragms in oblique view (upper part of figure), mesozooecia sparse to absent in exozone, tangential section, $\times 30$.

4. "Hallopora multitabulata" (Ulrich) of Bassler 1911, syntype USNM 57459, Wassalem Beds (D3), Uxnorm, Estonia, U.S.S.R.; $4 a$, autozooecia with subcircular to subelliptical cross-sectional shapes, relatively broad autozooecial boundaries, mesozooecia sparse to common with subcircular cross-sectional shapes, macular polymorphs variable in size (left center of figure), tangential section, $\times 30 ; 4 b$, intercalated autozooecia with planar walls expand gradually distally, basal diaphragms closely spaced in exozone, cystoidal diaphragms and scattered cystiphragms in exozone, autozooecial boundaries broadly serrated, autozooecial wall laminae relatively broadly curved in thin walls in exozone, longitudinal section, $\times 30$. 


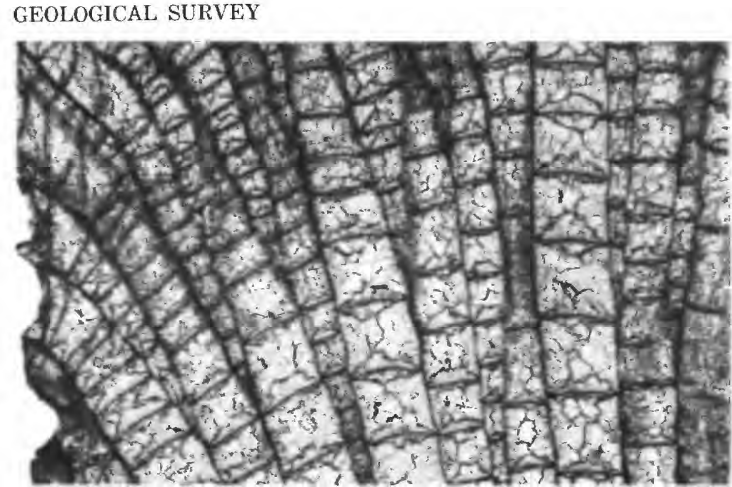

1 a

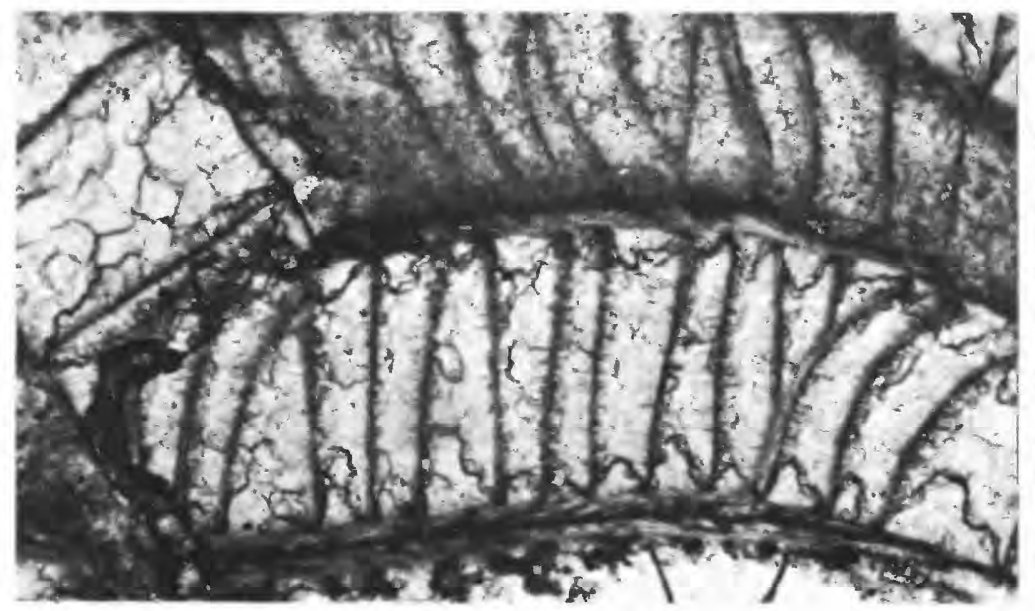

$3 a$

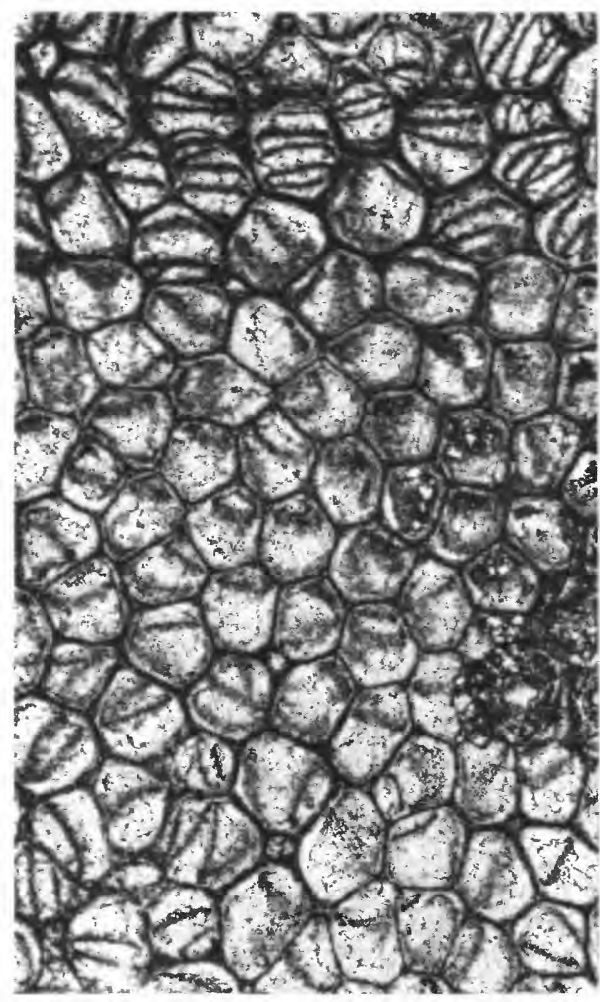

$3 b$

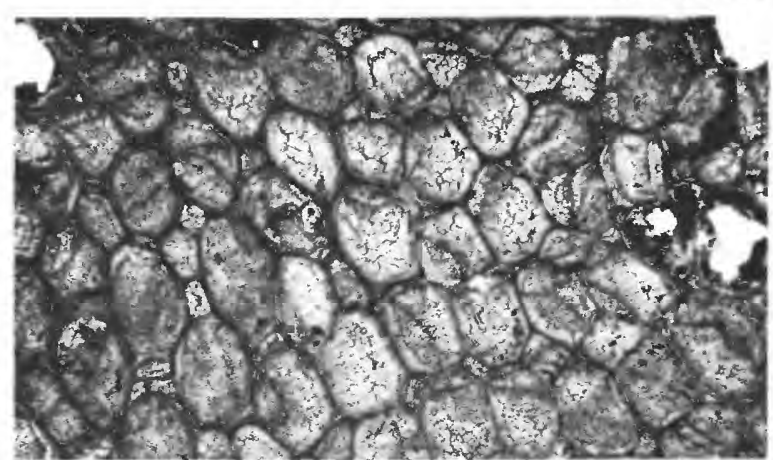

$1 \mathrm{~b}$

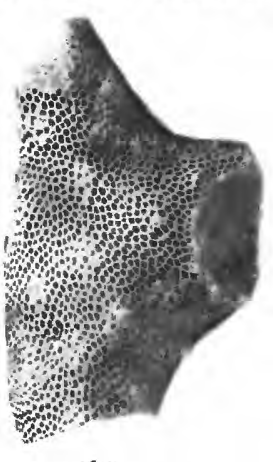

1c

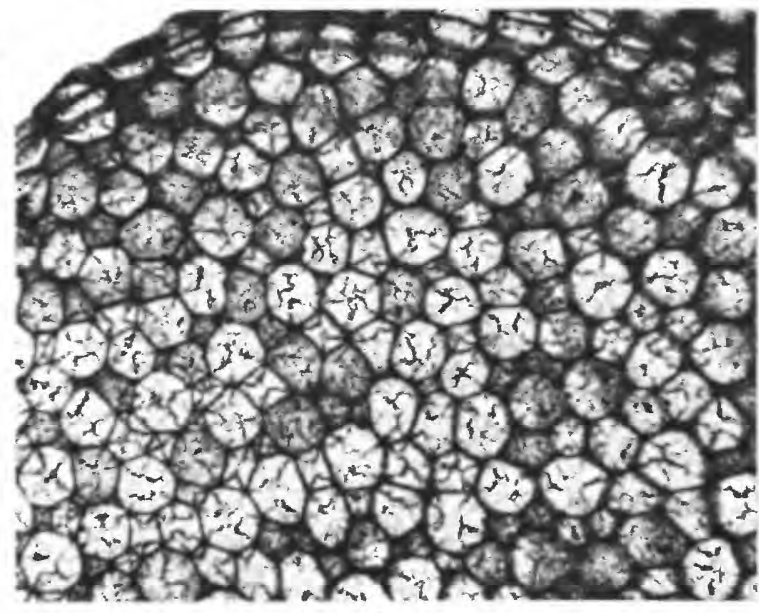

2

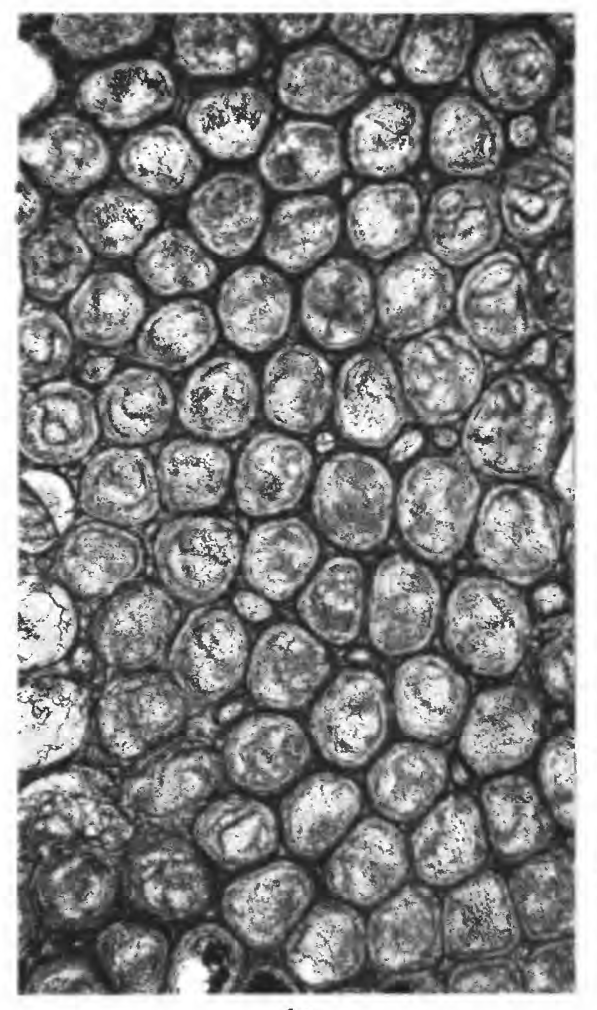

$4 a$

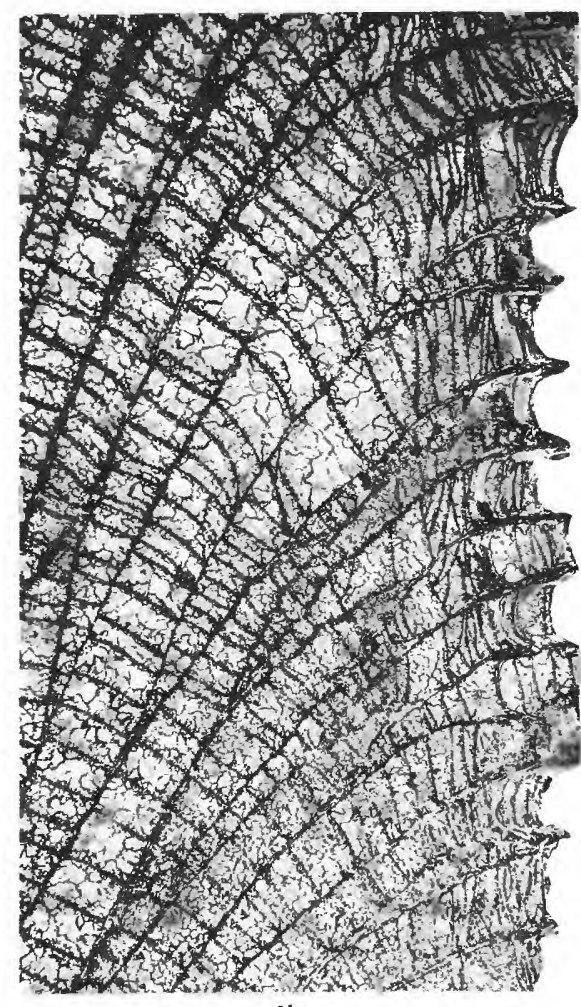

$4 b$

TARPHOPHRAGMA 


\section{PLATE 34}

FIGURES 1-3. Balticopora tenuimurale (Ulrich) (p. 181).

1. Hypotype USNM 309299, Clays Ferry Formation, Shermanian Stage (USGS colln. 4898-CO), Valley View Quadrangle, Kentucky; 1 $a$, laminae of hemiphragm form autozooecial lining, continue obliquely into autozooecial cortex, style with thin core and sheath along autozooecial boundary, longitudinal section, $\times 100$; $1 b$, narrowly serrated indistinct autozooecial boundary with small styles in autozooecial corners, hemiphragm extends partly across autozooecial chamber (lower center half of figure), tangential section, $\times 100 ; 1 c$, hemiphragms, perhaps some basal diaphragms, evenly spaced in early exozone, scattered in late exozone, $V$-shaped laminae in autozooecial walls in exozone, narrowly serrated and distinct autozooecial boundaries, part of zone of autozooecial rejuvenation of autozooecia (lower right of figure), longitudinal section, $\times 30 ; 1 d$, cross-sectional shape of autozooecia and their chambers, hemiphragms project less than halfway across chambers in some autozooecia, distinct autozooecial boundaries, styles exceedingly small, lack in many autozooecia, mesozooecia sparse, generally lacking, tangential section, $\times 30$.

2. Paralectotype USNM 309269, "Trenton Group" of Ulrich ("Galena shales"), Cannon Falls, Minn.; 2a, polygonal cross-sectional shape of autozooecia and mesozooecia, autozooecial boundaries indistinct locally, zooecial walls relatively thin, styles virtually lacking, tangential section, $\times 30 ; 2 b$, autozooecia subparallel in axial portion of endozone, slightly sinuous and locally crenulated autozooecial walls in endozone and early exozone, curvature of autozooecia, hemiphragms evenly spaced in exozone, virtually absent in endozone, longitudinal section, $\times 30$; $2 c$, hemiphragms with slightly bulbous terminal tips curved proximally, project alternately from opposite sides of autozooecia, longitudinal section, $\times 30$.

3. Hypotype USNM 309289, Grier Limestone Member Shermanian Stage (USGS colln. 4866-CO), of Lexington Limestone, Valley View Quadrangle, Kentucky; macula with polymorphs slightly larger than autozooecia and mesozooecia, thin autozooecial and mesozooecial walls in early exozone, styles virtually absent, tangential section, $\times 30$. 

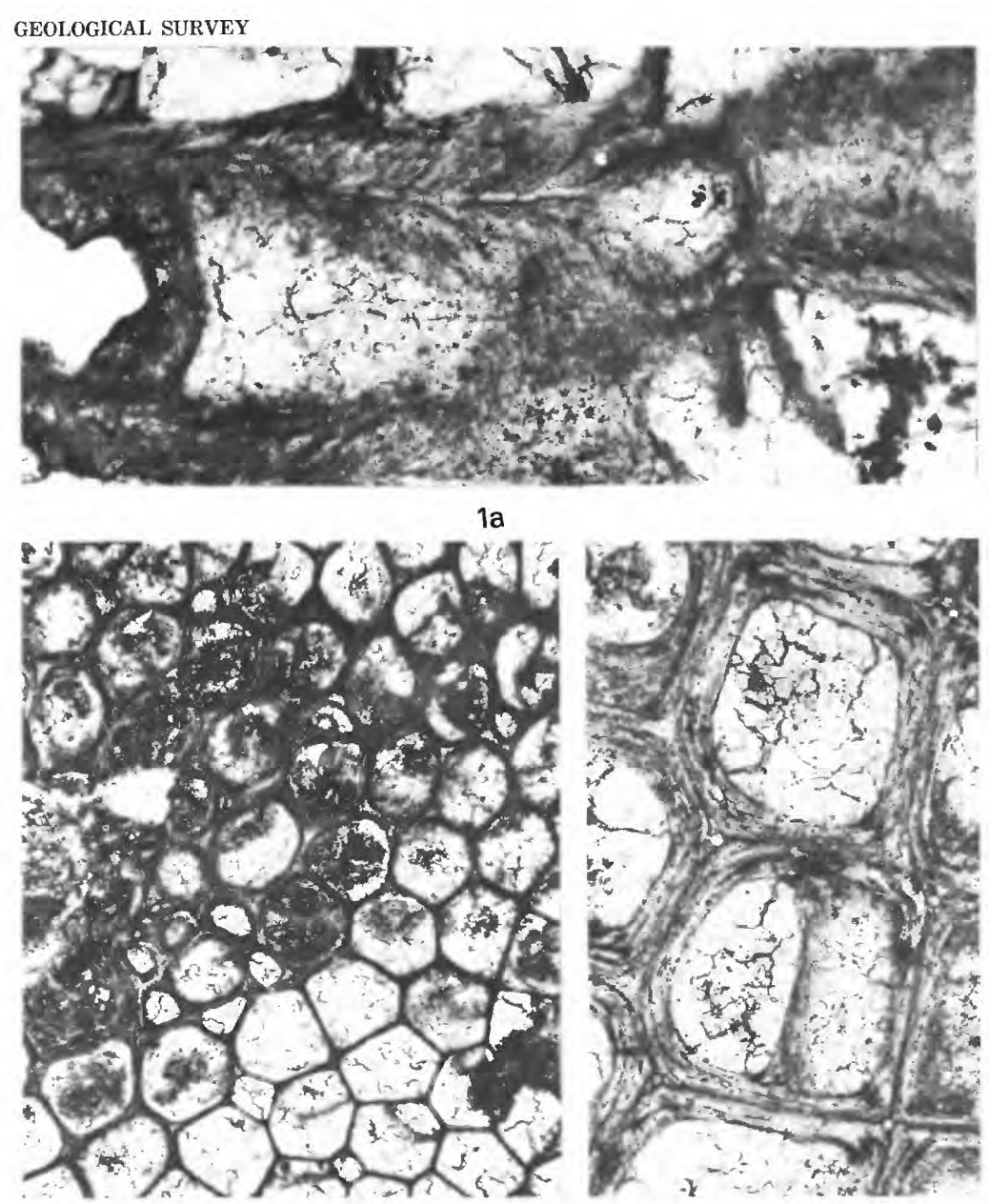

3

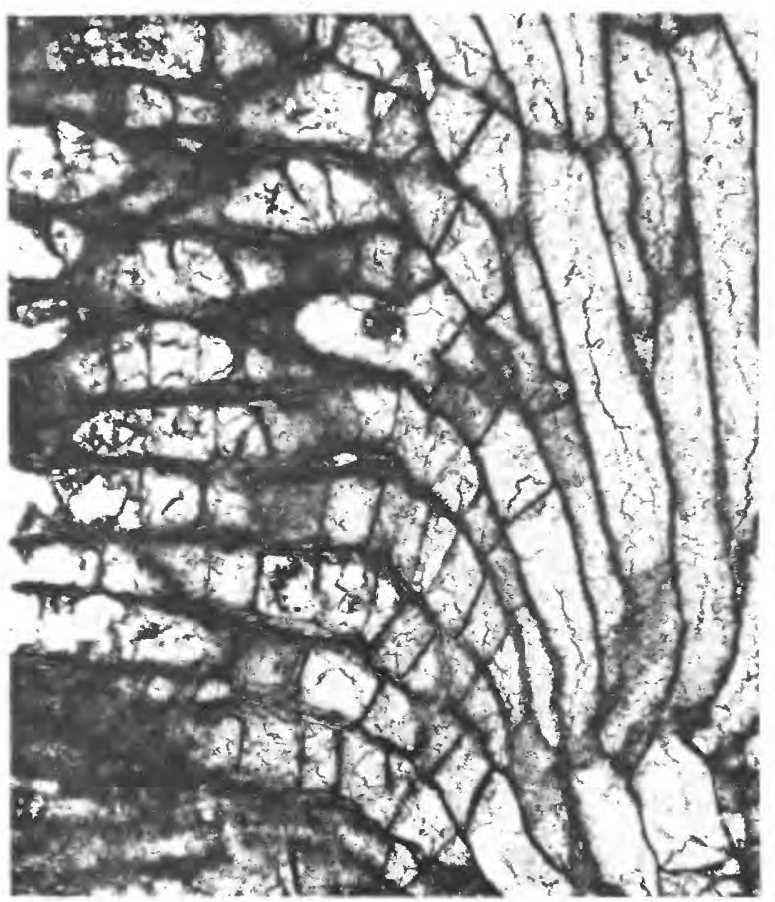

1c

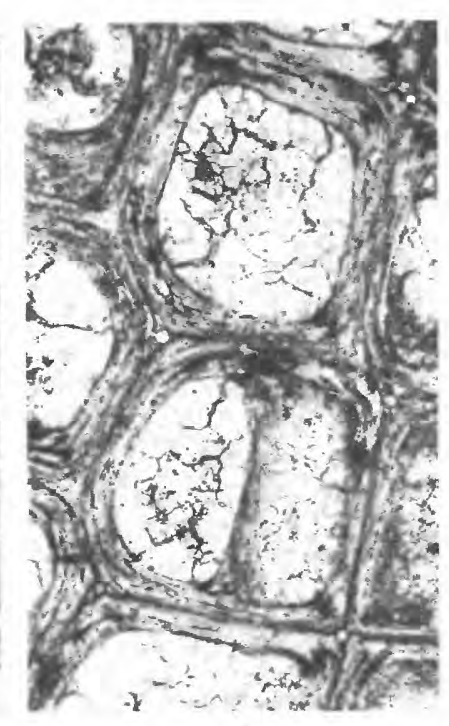

$1 b$

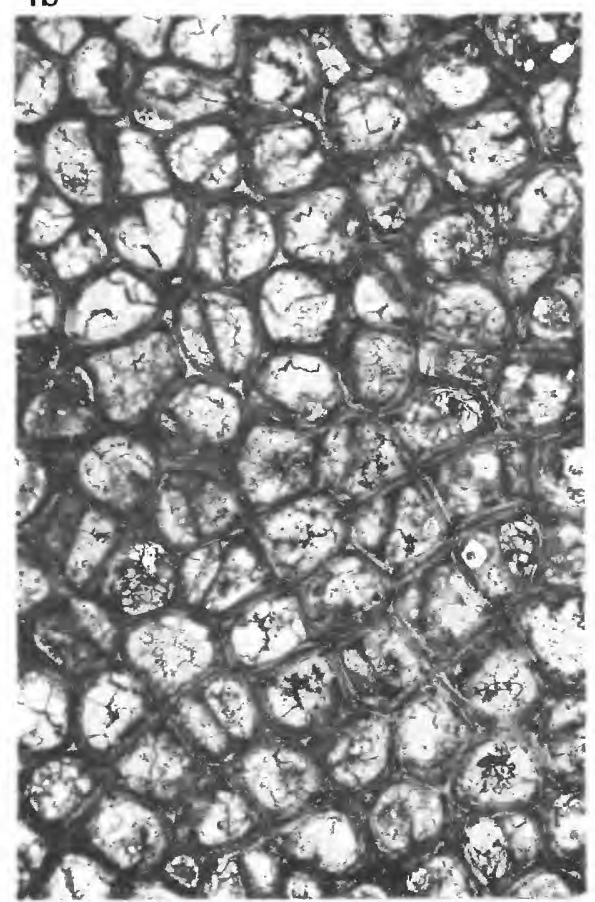

$1 d$
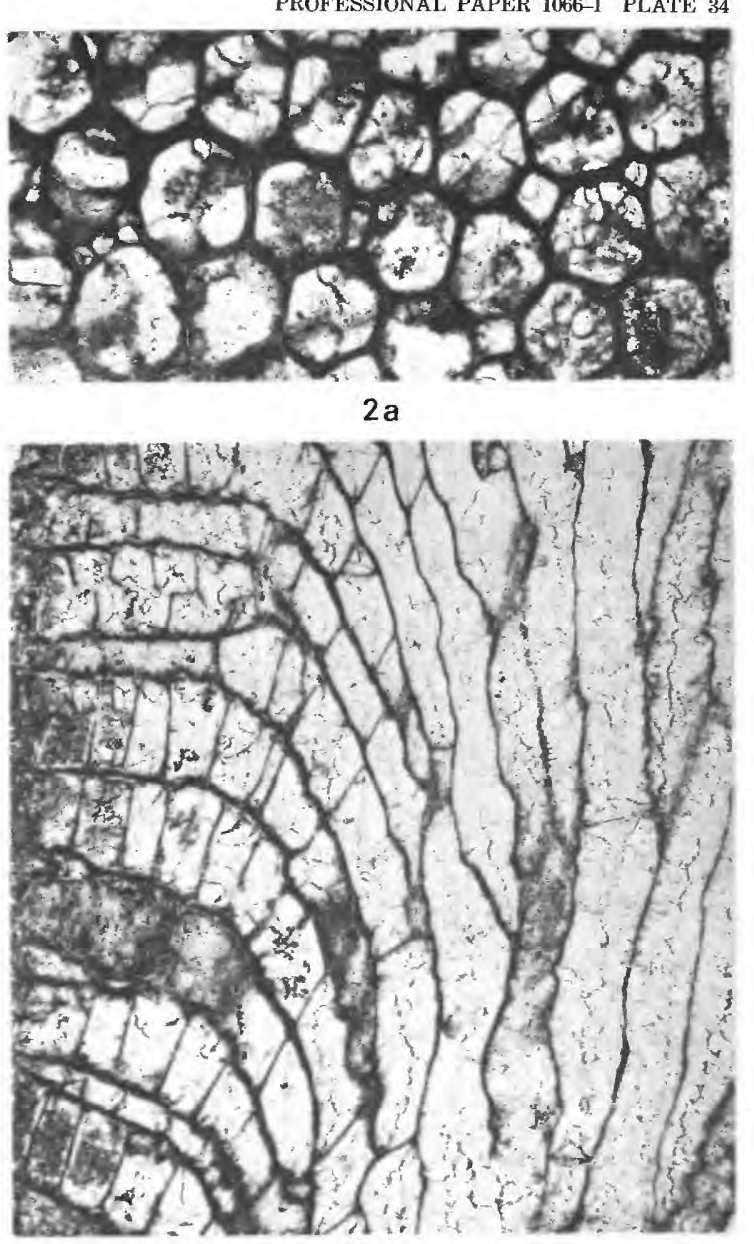

$2 b$

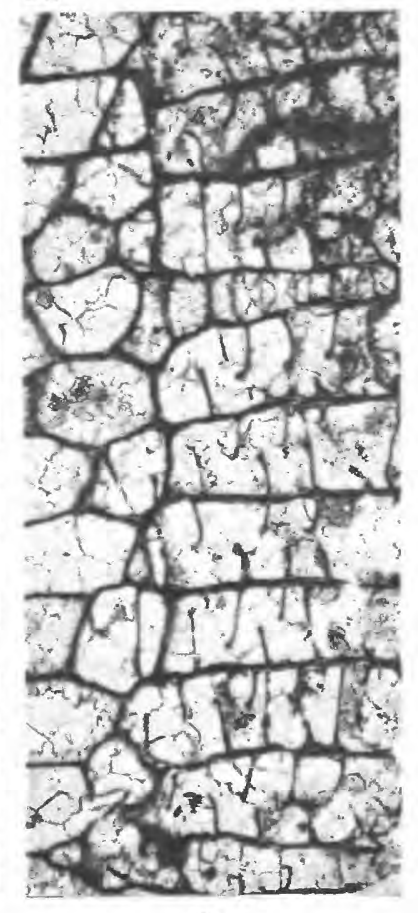

2c 
FIGURE 1. Balticopora tenuimurale(Ulrich)(p. I81).

\section{PLATE 35}

Lectotype USNM 43563, "Trenton Group" of Ulrich, Middle Ordovician, Cannon Falls, Minn.; $1 a$, proximally curved hemiphragms, irregularly shaped partitions formed by merged hemiphragms, longitudinal section, $\times 100 ; 1 b$, curvature of autozooecia in late endozones, part of zone of rejuvenation of autozooecia (upper right corner of figure), distinct autozooecial boundaries in exozone, longitudinal section, $\times 30$; $1 c$, cross-sectional shape of autozooecia, indistinct autozooecial boundaries, sparse mesozooecia (upper right of figure), tangential section, $\times 30$.

2-4. Constellaria fischeri Ulrich (p. I93).

2. Hypotype USNM 309400, Millersburg Member, Shermanian Stage (USGS colln. 4859-CO), of Lexington Limestone, Delaplain Quadrangle, Kentucky; autozooecial boundaries relatively distinct, basal diaphragms virtually absent in exozone, elongate, irregularly shaped patches of nonlaminate skeletal deposits in autozooecial walls, rectangular vesicles with thin walls and small chambers in exozone, zoarial surface toward left side of figure, longitudinal section, $\times 50$

3. Hypotype USNM 309403, Nicolas Bed, Shermanian Stage (USGS colln. 5031-CO), of Tanglewood Limestone Member of Lexington Limestone, Moorefield Quadrangle, Kentucky; $3 a$, autozooecia clustered in indistinct rays, rays subdivided by nonlaminate skeletal partitions, rays merge with autozooecia of interstellar macular areas (upper part of figure), narrow strips of vesicles between rays, small styles of nonlaminate skeletal material in walls of autozooecia and vesicles, tangential section, $\times 50 ; 3 b$, portion of vesicular center of stellate macula (upper left corner of figure), small vesicles rectangular in profile between autozooecia in exozone, autozooecia with distinct autozooecial boundaries, small elongate patches of nonlaminate skeletal material in some autozooecia, longitudinal section, $\times 30 ; 3 c$, irregularly shaped areas of vesicles in centers of stellate maculae, numerous styles in walls of vesicles, autozooecia clustered in rays generally contiguous, midray partitions indistinctly bifurcate locally, autozooecia subcircular in cross section, tangential section, $\times 30$.

4. Hypotype USNM 309401, Millersburg Member, Shermanian Stage (USGS colln. 4859-CO), of Lexington Limestone, Delaplain Quadrangle, Kentucky; rays of macula indistinct, irregular cross-sectional shape of vesicles in center of macula (lower right of figure), autozooecia partly contiguous to almost completely separated by vesicles in interstellar macular areas, tangential section, $\times 50$. 


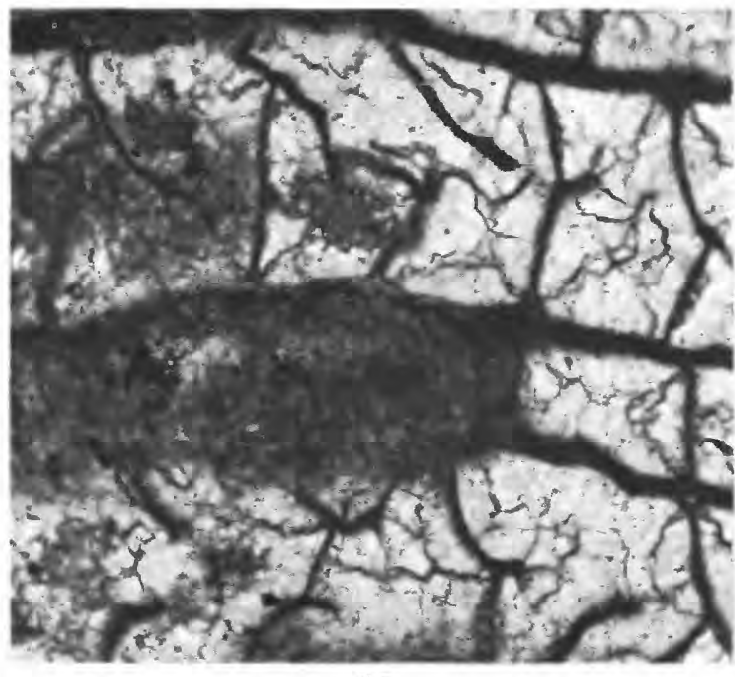

$1 \mathrm{a}$

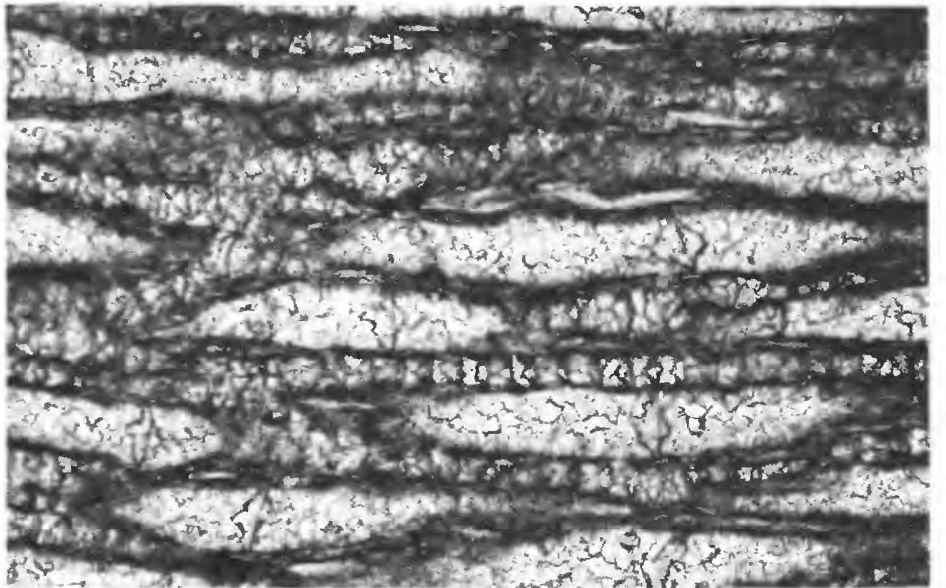

2

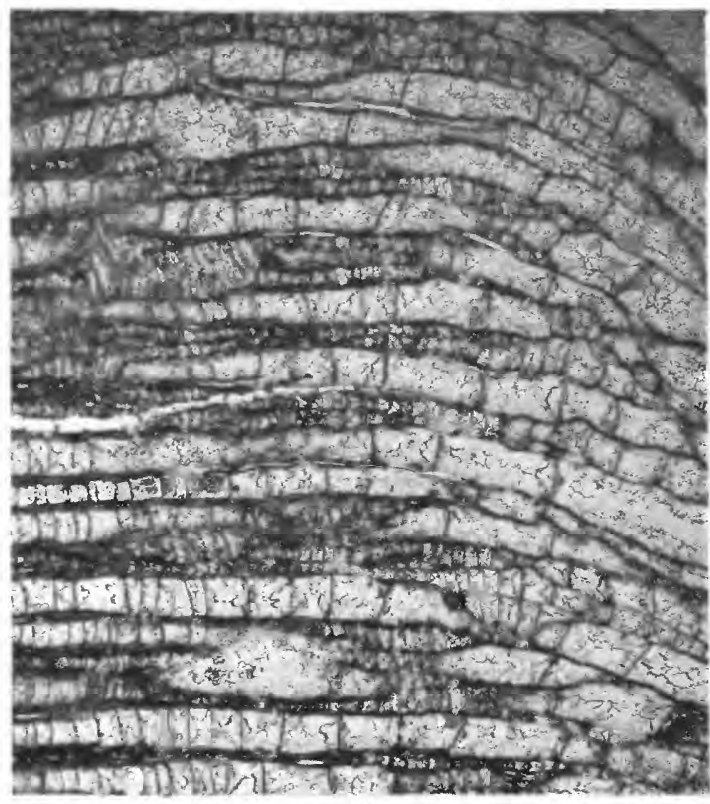

$3 b$

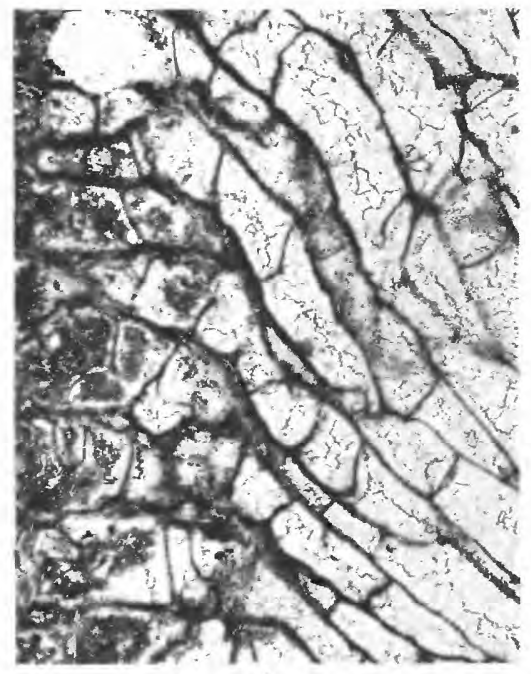

$1 \mathrm{~b}$

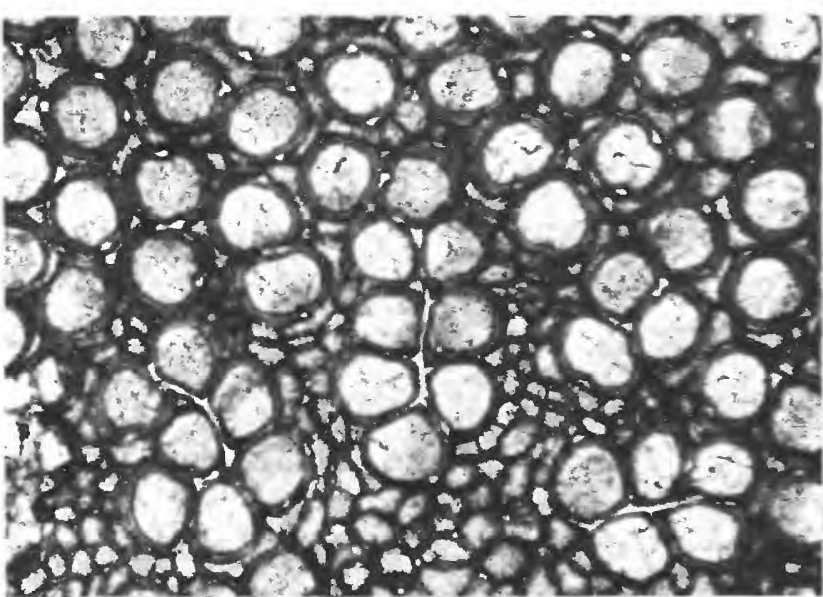

3a

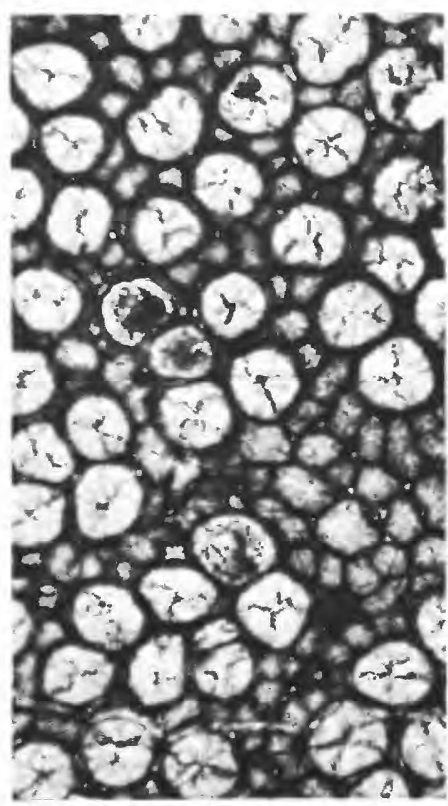

BALTICOPORA, CONSTELLARIA 


\section{PLATE 36}

Figures 1, 2. Balticopora arcuatilis n. sp. (p. I83).

1. Paratype USNM 309301, Grier Limestone Member, Shermanian Stage (USGS colln. D1303-CO), of Lexington Limestone, Gratz Quadrangle, Kentucky; $1 a$, cross-sectional shape of autozooecia in exozone, macula with clusters of mesozooecia and polymorphs larger than autozooecia, tangential section, $\times 30 ; 1 b$, microstructure of autozooecia and hemiphragms, autozooecial wall laminae narrowly $U$-shaped in profile, longitudinal section, $\times 100$; 1 c, autozooecial walls relatively straight, slightly crenulated locally, thin hemiphragms, longitudinal section, $\times 30$.

2. Holotype USNM 309300, Brannon Member, Shermanian Stage (USGS colln. D1156-CO), of Lexington Limestone, Valley View Quadrangle, Kentucky; $2 a$, U-shaped proximal portion of intercalated autozooecium, exceedingly small styles with indistinct cores project into basal part of autozooecial chambers, longitudinal section, $\times 100 ; 2 b$, rectangular autozooecia in cross section, exceedingly small styles in autozooecial corners, autozooecial boundary not visible, tangential section, $\times 100 ; 2 c$, general alignment and cross-sectional shape of autozooecia, hemiphragms visible in some autozooecia, macula with irregularly shaped zooecia in cross section (lower right of figure), tangential section, $\times 30 ; 2 d$, slightly curved autozooecia with thin walls, numerous hemiphragms in indistinct zone, merged hemiphragms from opposite sides of autozooecium form irregularly shaped diaphragms, longitudinalsection, $\times 30$. 

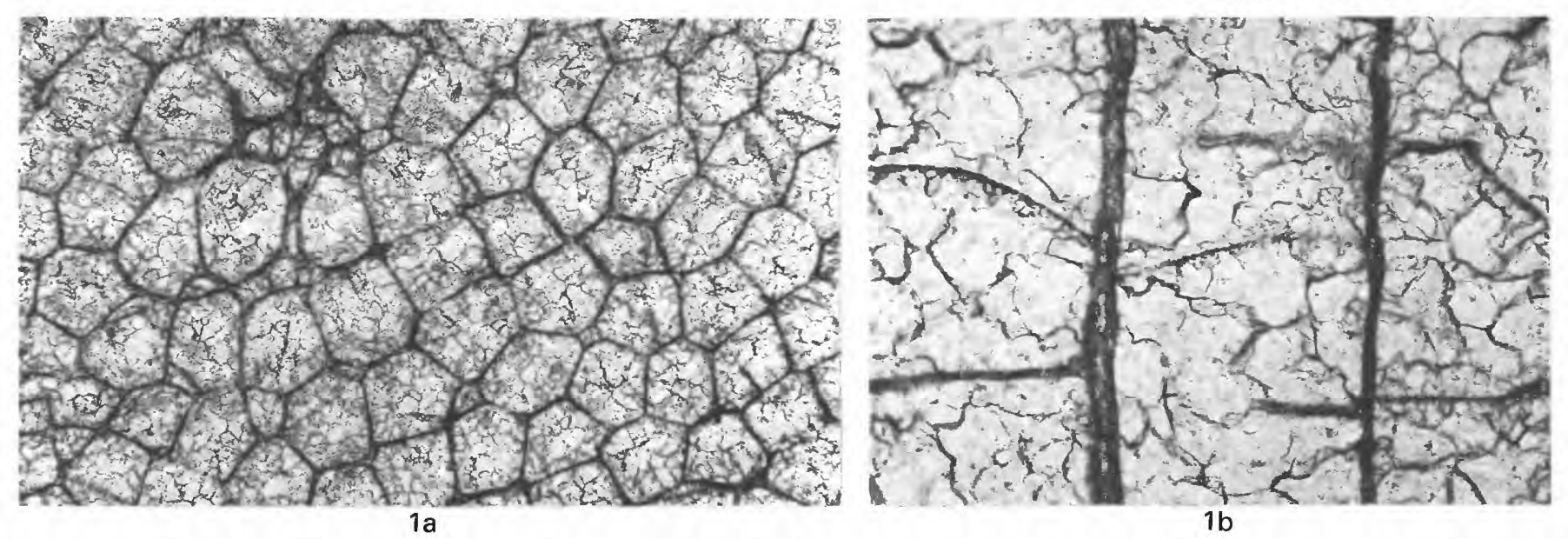

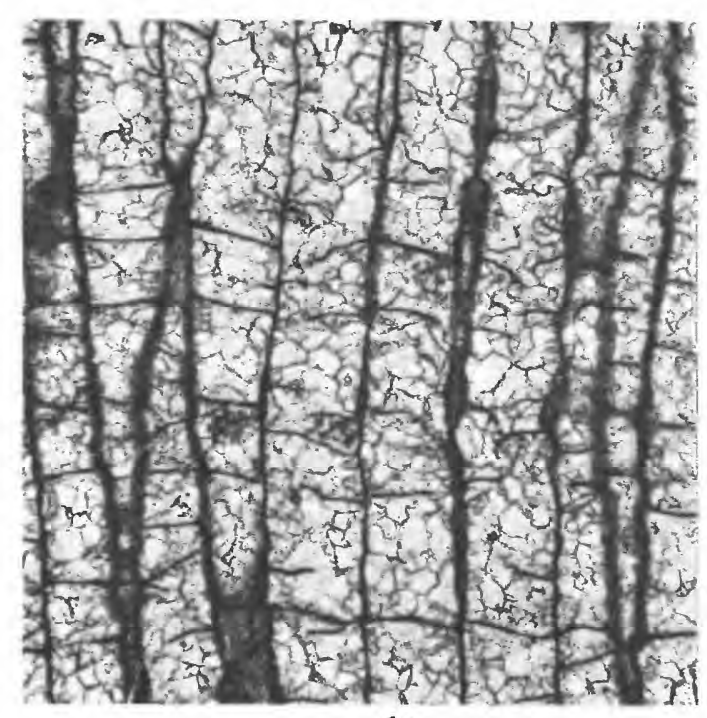

1c

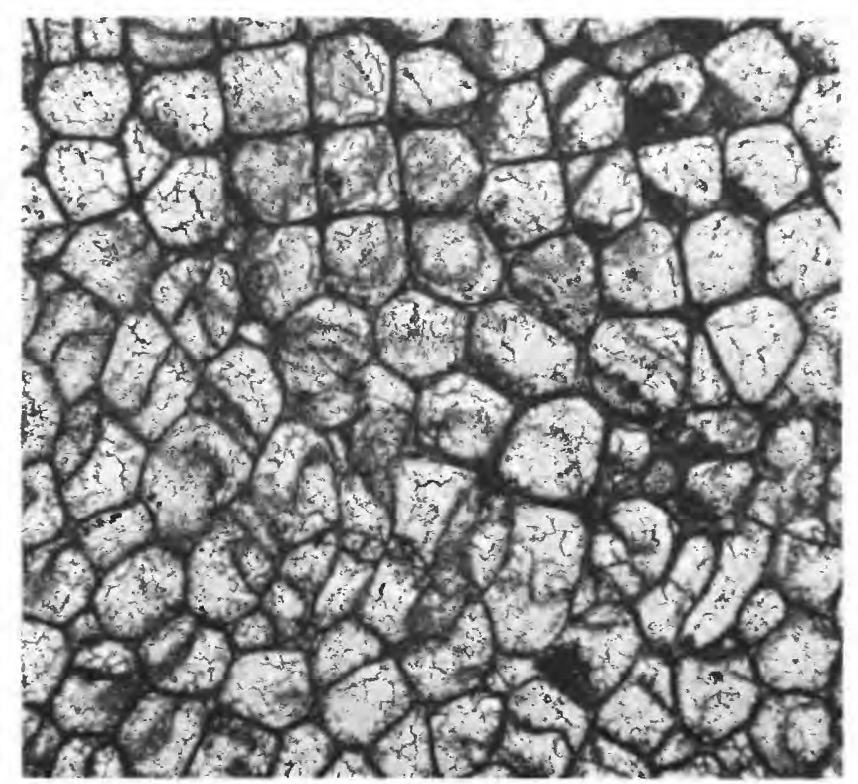

2c

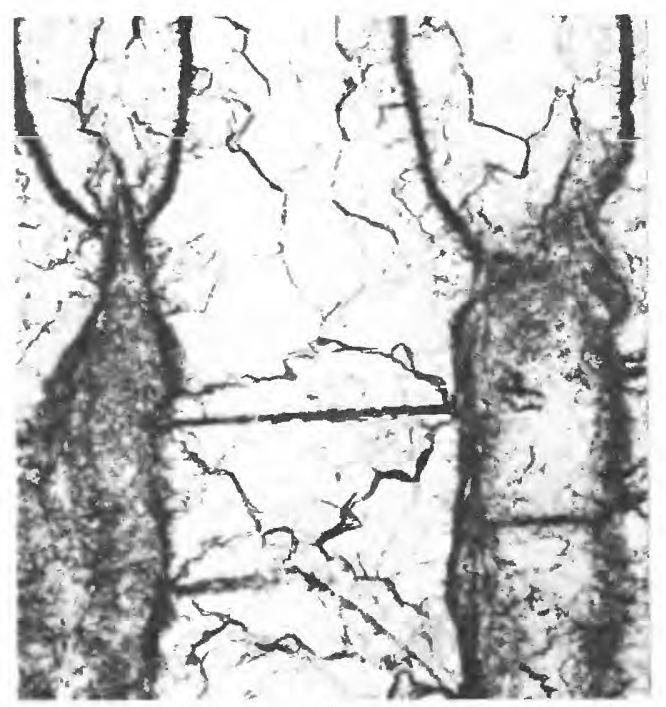

$2 a$

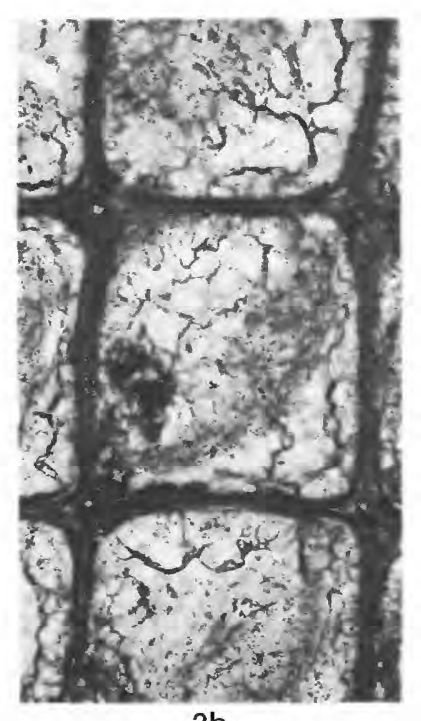

$2 \mathrm{~b}$

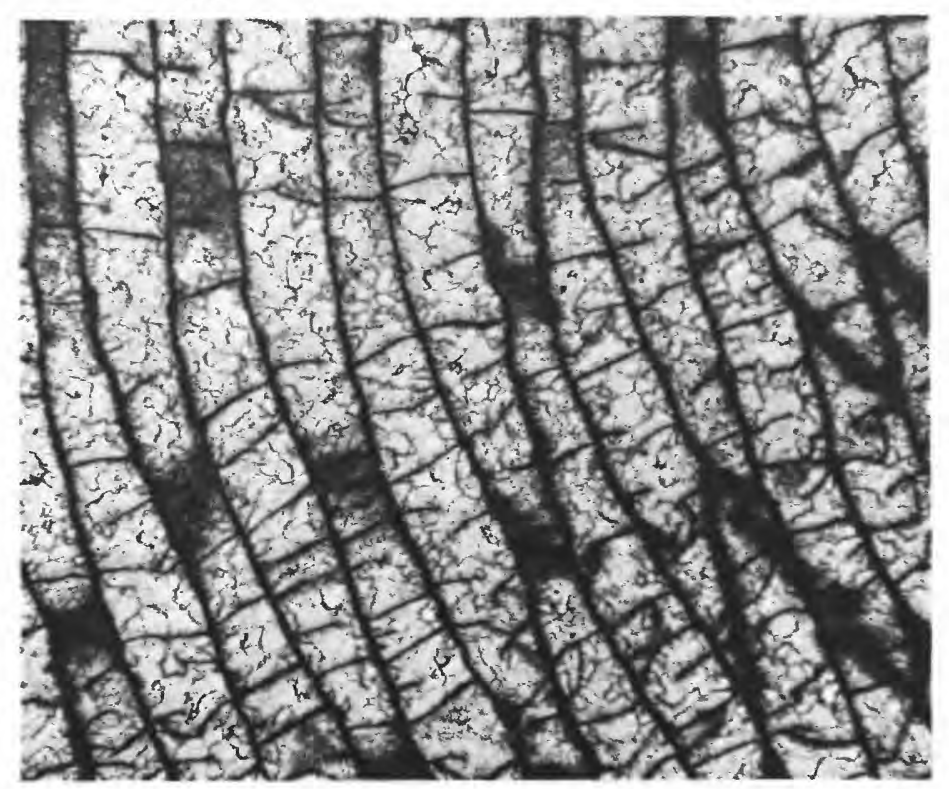

2d 


\section{PLATE 37}

Figures 1, 2. Ceramophylla alternatum (James) (p. I86).

Cornishville Bed of Perryville Limestone Member of Lexington Limestone, Perryville Quadrangle, Kentucky.

1. Hypotype USNM 309364, Shermanian Stage (USGS colln. 5016-CO); 1a, sinuous basal layer adnate to calcitic material filling the axial portion of zoarium, autozooecial walls thicken abruptly at base of exozone, longitudinal section, $\times 30 ; 1 b$, microstructure of basal layer, lunarial deposits and autozooecial walls, exilazooecia subparallel to autozooecial chambers, longitudinal section, $\times 50$.

2. Hypotype USNM 309365, Shermanian Stage (USGS colln. 5016-CO); 2a, basal layer encloses filled axial portion of zoarium, configuration of laminae in zooecial walls, basal layer of conspecific overgrowth (left side of figure), crosssectional shape of autozooecia in endozone (lower center of figure), oblique longitudinal section, $\times 30$.

3. Acanthoceramoporella valliensis $\mathrm{n}$. $\mathrm{sp}$. (p. I85).

Holotype USNM 309357, Sulphur Wells Member, Shermanian Stage (USGS colln. 4890-CO), of Lexington Limestone, Valley View Quadrangle, Kentucky; $3 a$, general alignment of zooecia, zoarium with indistinct maculae, external view, $\times 3$; $3 b$, macula with irregularly shaped polymorphs and exilazooecia in cross section, scattered small styles with distinct cores and exceedingly thin sheaths, tangential section, $\times 50 ; 3 \mathrm{c}$, autozooecia and exilazooecia in superimposed zoarial layers, thin autozooecial walls in exozones, thin basal layers, poorly defined lunarial deposits in exozones, basal diaphragms and communication pores generally lacking, transverse section, $\times 30$; $3 d$, autozooecia elliptical to subelliptical in cross section with indistinct lunaria, styles sparse in intermacular areas, exilazooecia partly to almost completely separate autozooecia, tangential section, $\times 30 ; 3 e$, microstructure of laminate autozooecial walls and lunarial deposits, poorly defined possible basal diaphragms, longitudinal section, $\times 50$. 


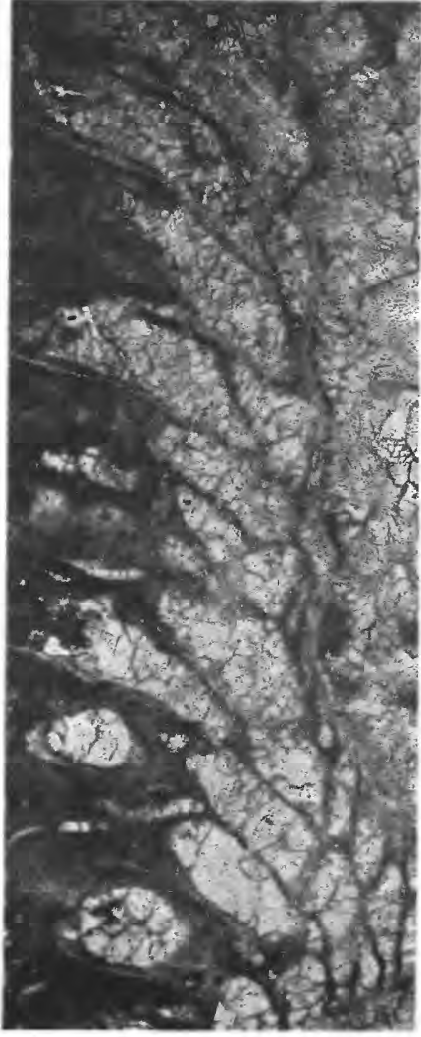

$1 \mathrm{a}$

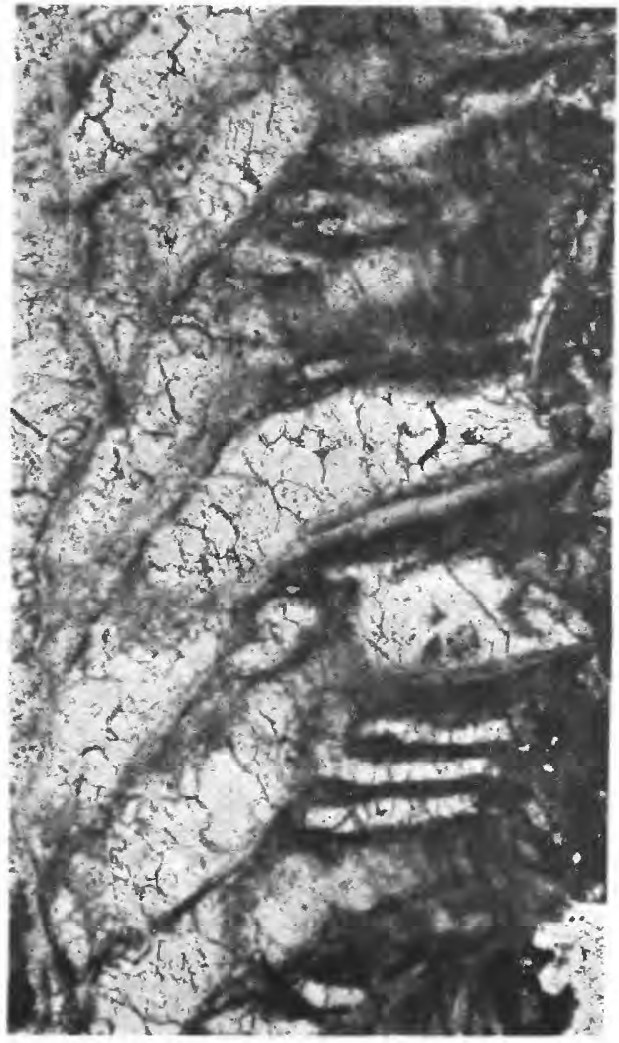

$1 \mathrm{~b}$

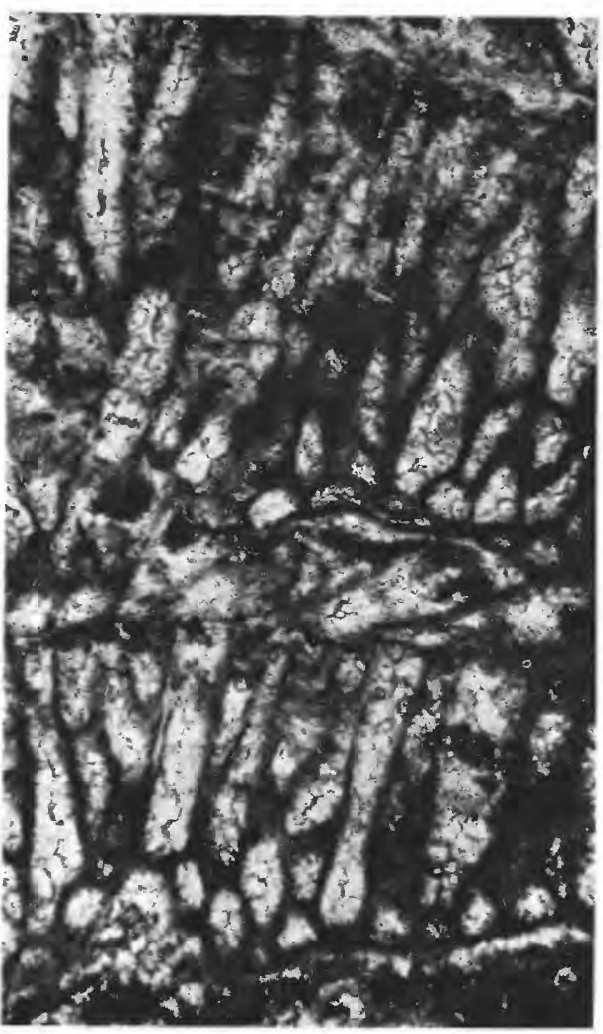

$3 c$

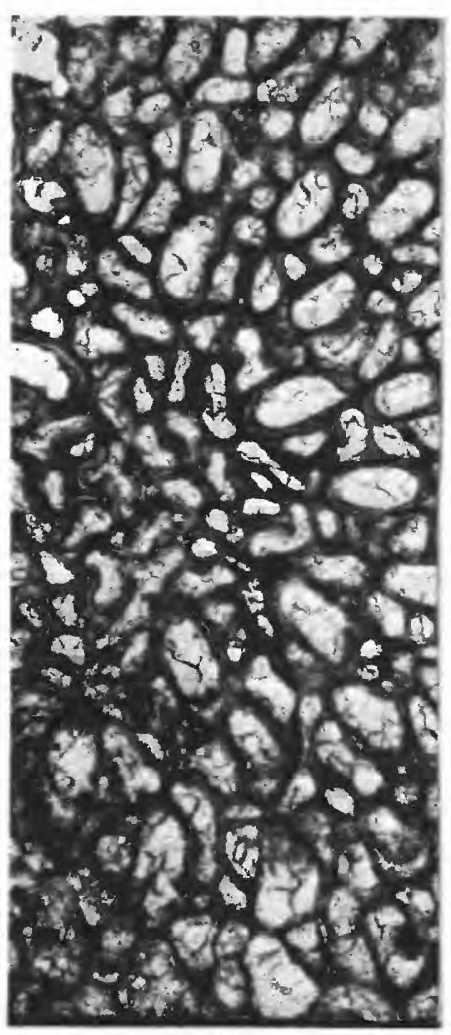

$3 d$
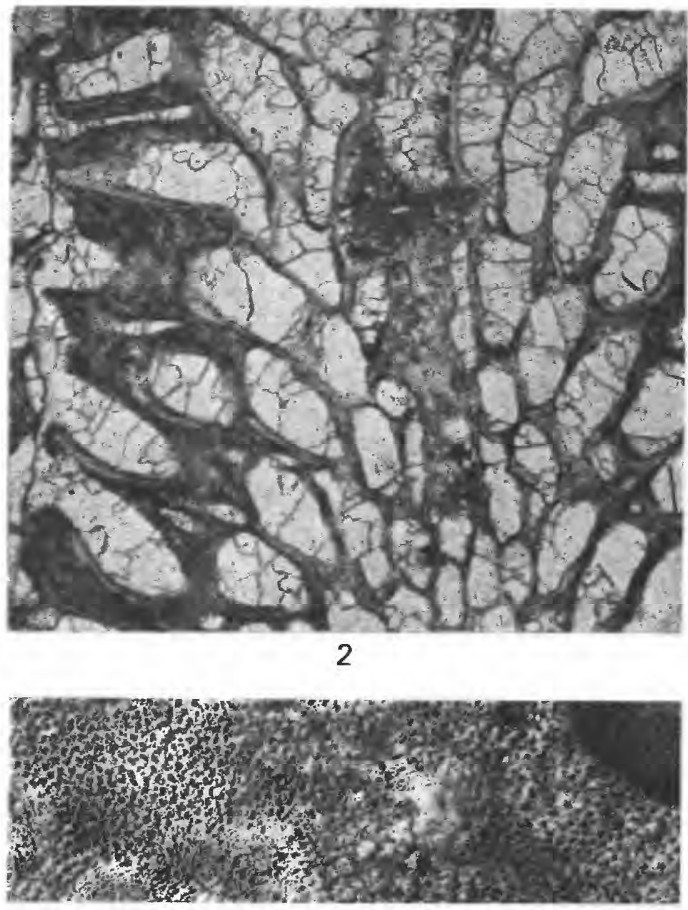

3a
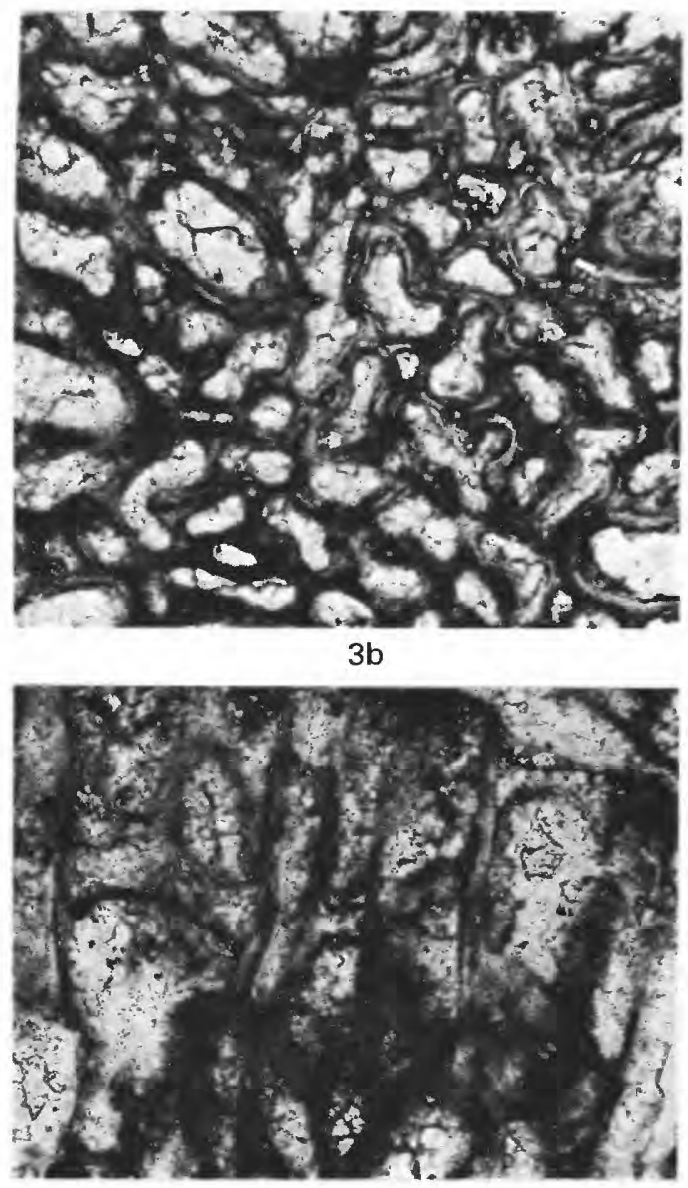

$3 e$

CERAMOPHYLLA, ACANTHOCERAMOPORELLA 


\section{PLATE 38}

FiguRES 1, 4. Ceramoporella distincta Ulrich (p. I89).

1. Paralectotype USNM 245038, "McMicken Member of the Eden Formation" (upper part of Kope Formation of current usage), Cincinnati, Ohio; zooecia with thin walls, obscured autozooecial boundaries and indistinct lunaria, tangential section, $\times 30$.

4. Hypotype USNM 309380, Millersburg Member, Shermanian Stage (USGS colln. 7319-CO), of Lexington Limestone, Winchester Quadrangle, Kentucky; 4a, thin basal layers between superimposed layers of autozooecia of a zoarium, shape of autozooecia in endozones at basal layers, curved walls of autozooecia with indistinct autozooecial boundaries in exozones, transverse section, $\times 50 ; 4 b$, autozooecia partly to completely separated by exilazooecia, shape of lunaria in cross section, tips of margins of some lunaria project slightly into autozooecial chambers, tangential section, $\times 50 ; 4 c$, multilayered zoarium, slightly sinuous basal layers, autozooecial walls relatively thin throughout zoarium, transverse section, $\times 30 ; 4 d$, autozocecia aligned in indistinct radial pattern in early endozone, crosssectional shape of autozooecia near basal layer (approximate center of figure), shape of exilazooecia in early exozone, deep to shallow tangential section, $\times 30$.

2, 3. Ceramophylla alternatum (James) (p. I86).

2. Hypotype USNM 309362, Grier Limestone Member, Shermanian Stage (USGS colln. 4694-CO), of Lexington Limestone, type section of Lexington Limestone, Frankfort East Quadrangle, Kentucky; subelliptical to subcircular autozooecia in cross section, autozooecia partly separated by exilazooecia, maculae consisting of exilazooecia (upper left of figure), tangential section, $\times 30$.

3. Hypotype USNM 309360, Brannon Member, Shermanian Stage (USGS colln. 1159-CO), of Lexington Limestone, Valley View Quadrangle, Kentucky; axial portion of zoarium filled with sediments, transverse section, $\times 30$.

5. Crepipora venusta (Ulrich) (p. I91), hypotype USNM 309396, Clays Ferry Formation, Shermanian Stage (USGS colln. 8130-CO), Delaplain Quadrangle, Kentucky; slightly crenulated basal layer, adnate to calcitic sediments filling axial part of zoarium; relatively long recumbent parts of autozooecia in endozone, boundary between lunarial deposits and laminae of autozooecial walls slightly jagged locally, longitudinal section, $\times 50$. 
GEOLOGICAL SURVEY

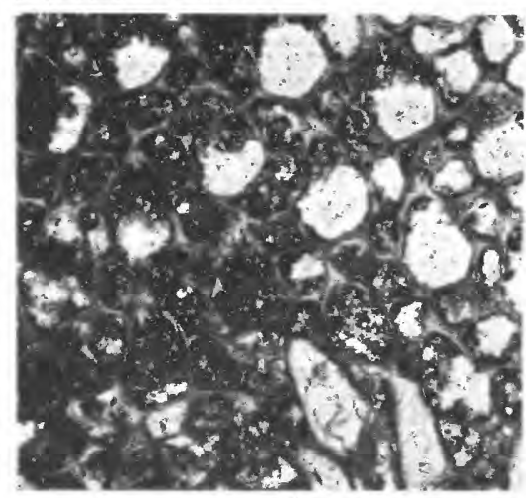

1

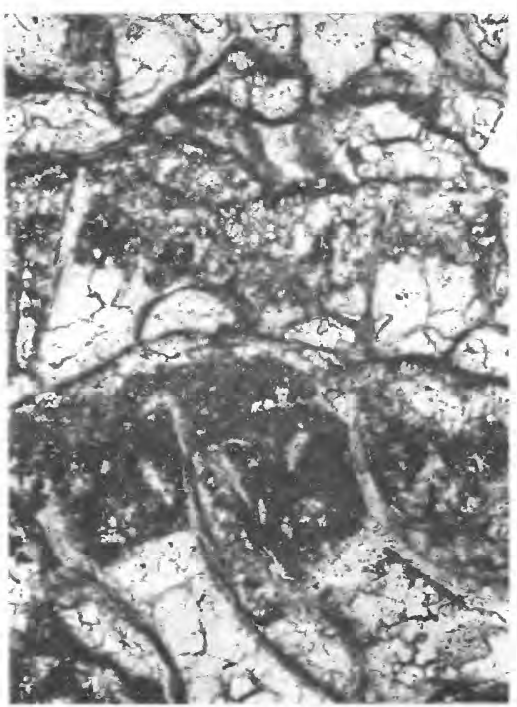

$4 a$

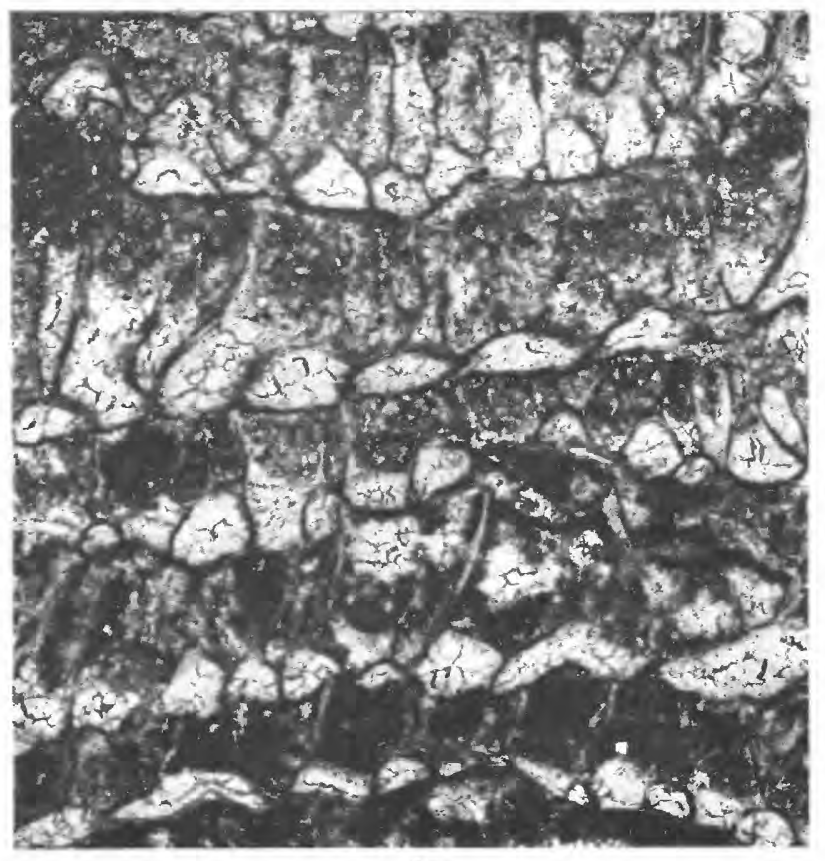

$4 c$

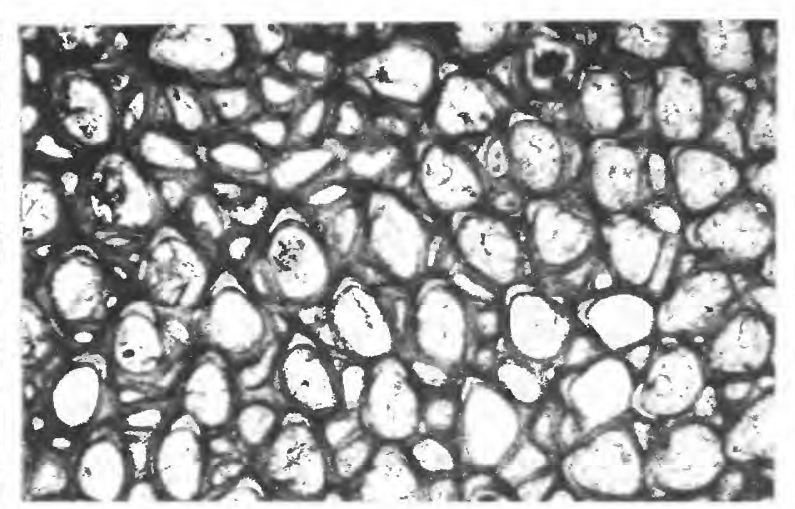

2

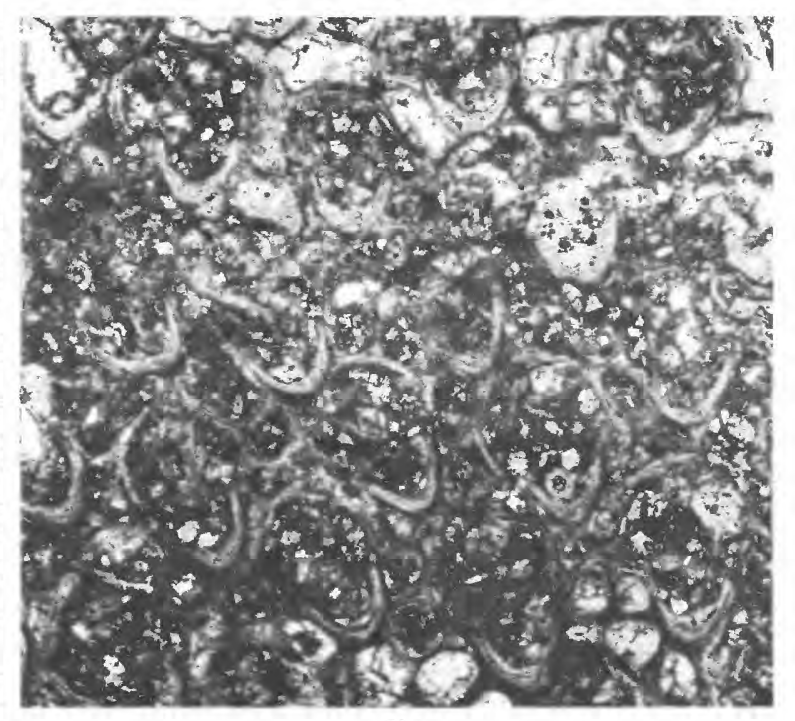

$4 b$

PROFESSIONAL PAPER 1066-I PLATE 38
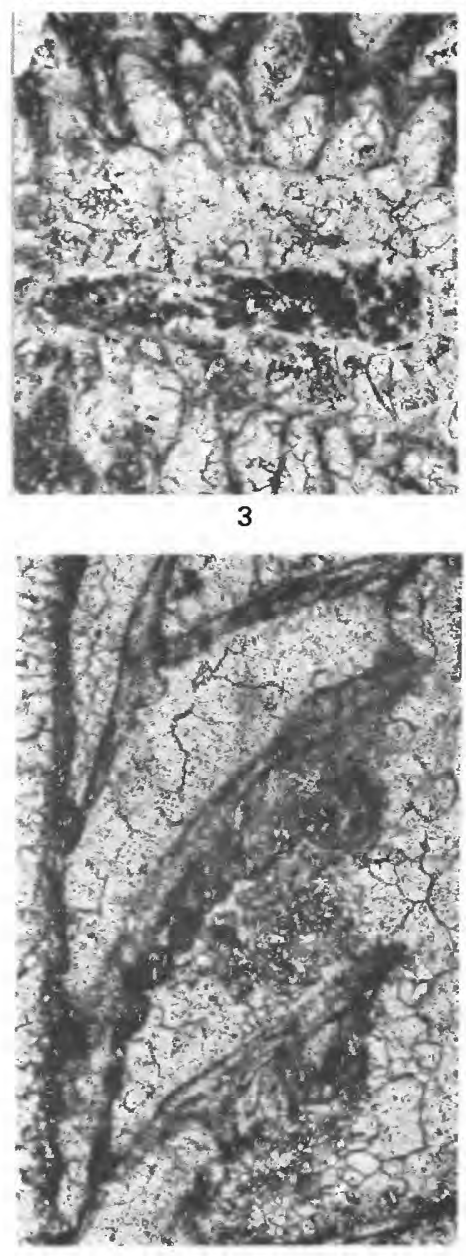

5

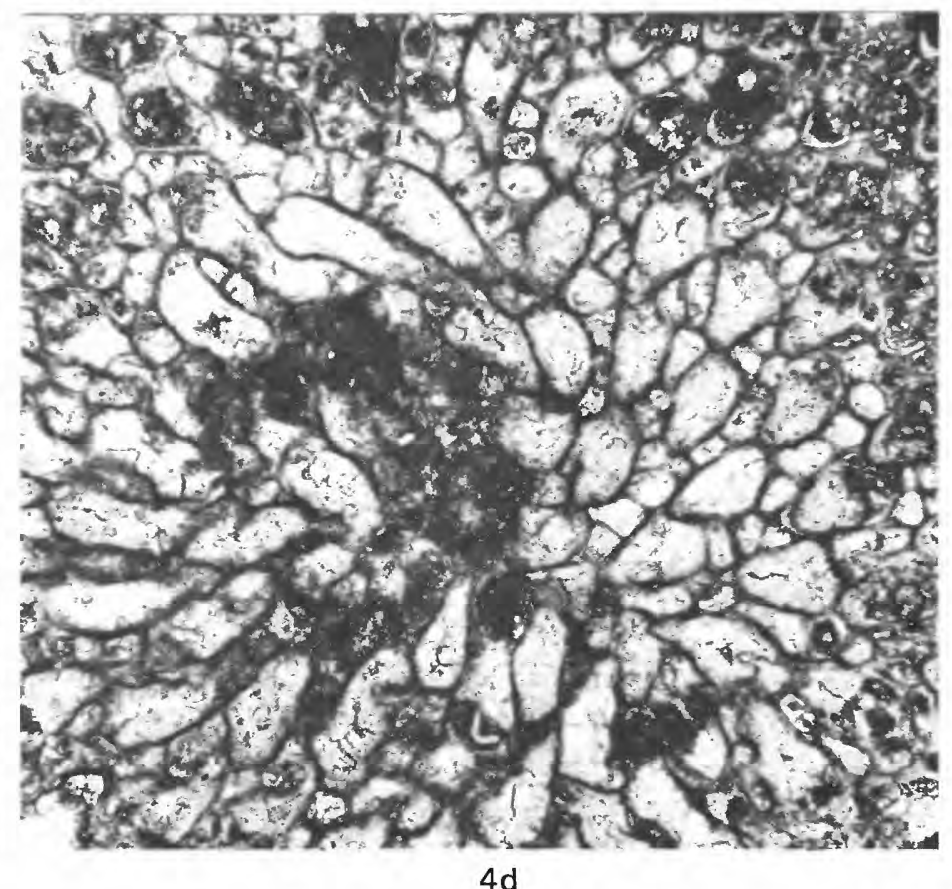

4d

CERAMOPORELLA, CERAMOPHYLLA, CREPIPORA 
PLATE 39

1-4. Crepipora venusta (Ulrich) (p. 191).

Clays Ferry Formation, Kentucky.

1. Hypotype USNM 309394, Edenian Stage (USGS colln. 8130-CO), Rogers Gap section, Delaplain Quadrangle, Kentucky; $1 a$, autozooecia with poorly defined or obscured boundaries in distinct longitudinal alignment near basal layer of zoarium, deep tangential section, $\times 50 ; 1 b$, subrhombic cross-sectional shape of autozooecia in deep endozone, lunarial deposits form segments of autozooecial walls, deep tangential section, $\times 30$; $1 c$, slightly irregular configuration of autozooecial wall laminae, broadly serrated autozooecial boundaries, longitudinal section, $\times 30$.

2. Hypotype USNM 309388, Edenian Stage (USGS colln. 5004-CO), Frankfort West Quadrangle; generally nonlaminated or granular basal layer of zoarium (bottom of figure), cross-sectional shape of autozooecia at basal layer of zoarium, relatively thin autozooecial walls in exozone, conspecific overgrowth (left side of figure), transverse section, $\times 50$.

3. Hypotype USNM 309397, Edenian Stage (USGS colln. 8130-CO), Rogers Gap section, Delaplain Quadrangle; crosssectional shape of autozooecia and of few scattered exilazooecia, autozooecial boundaries obscured, relatively small, distinct lunaria in exozone, tangential section, $\times 50$.

4. Hypotype USNM 309393, Edenian Stage (USGS colln. 8130-CO), Delaplain Quadrangle; relatively thick lunarial deposits in exozone, general shape of autozooecial chambers, partly laminated basal layer of zoarium (right side of figure), basal autozooecial diaphragms absent or not preserved, longitudinal section, $\times 50$.

5, 6. Papillalunaria spatiosa (Ulrich) (p. I92).

5. Paralectotype USNM 245028, "top of the Trenton" strata, Harrodsburg, Ky.; relatively large autozooecia with irregular polygonal shapes in cross section in exozone, larger polymorphs and a few exilazooecia in macula, tangential section, $\times 30$.

6. Hypotype USNM 309399, Brannon Member, Shermanian Stage (USGS colln. D1159-CO), of Lexington Limestone, Valley View Quadrangle, Kentucky; 6a, straight and slightly curving autozooecia with thin walls and narrowly serrated autozooecial boundaries, few and indistinct basal diaphragms (center of figure), longitudinal section, $\times 30 ; 6 b$, subcircular to subpolygonal cross-sectional shape of autozooecia in exozone, scattered, relatively small exilazooecia (skeletal calcite partly replaced by siliceous material), tangential section, $\times 30$. 
GEOLOGICAL SURVEY

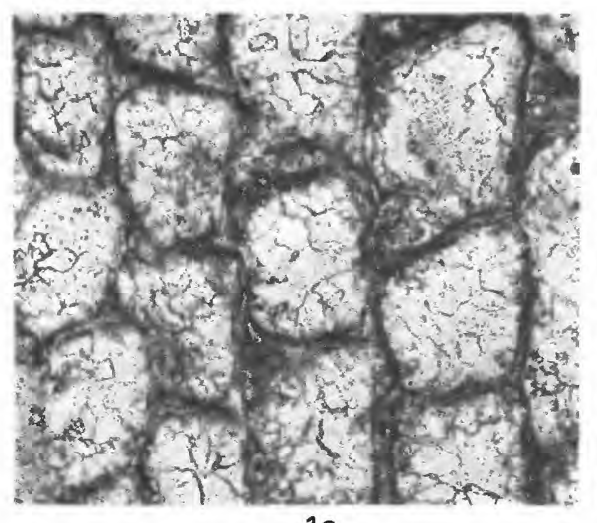
$1 \mathrm{a}$

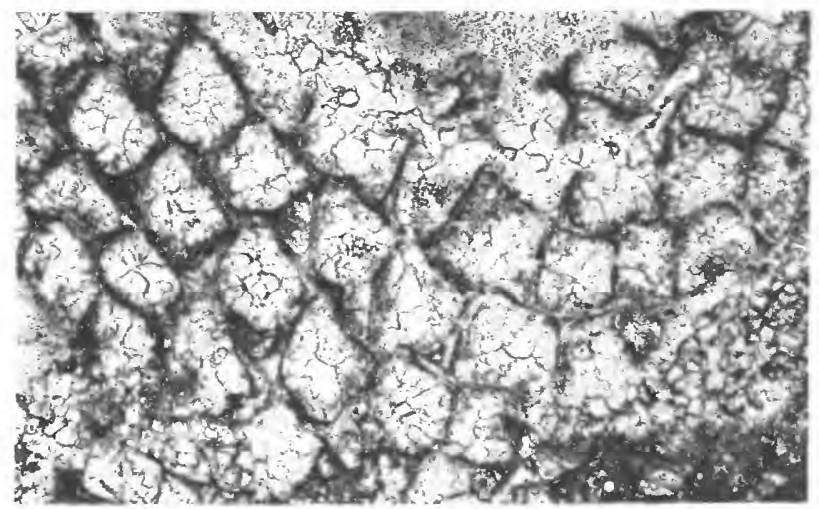

$1 \mathrm{~b}$

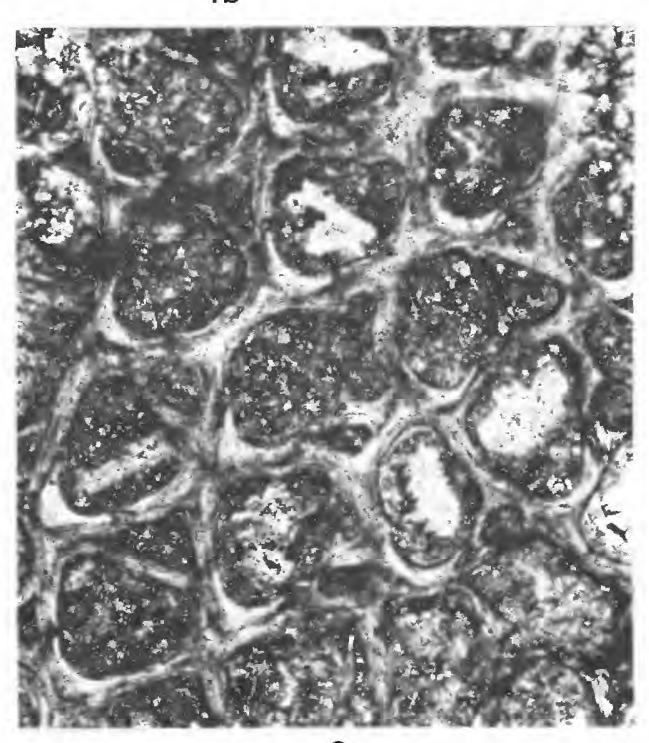

3

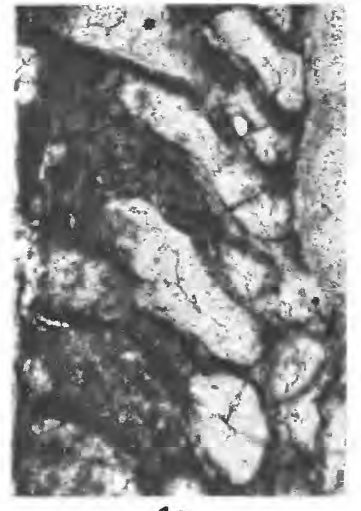

$1 \mathrm{c}$

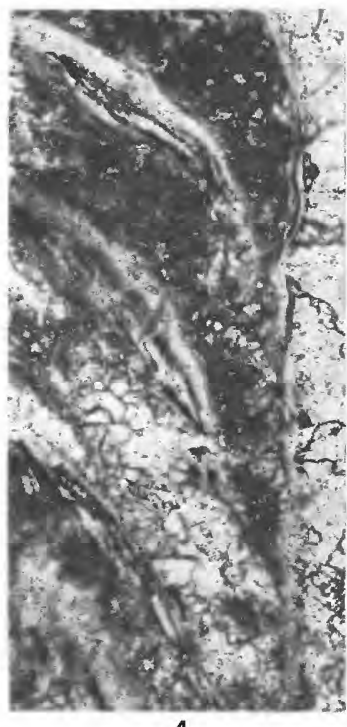

4

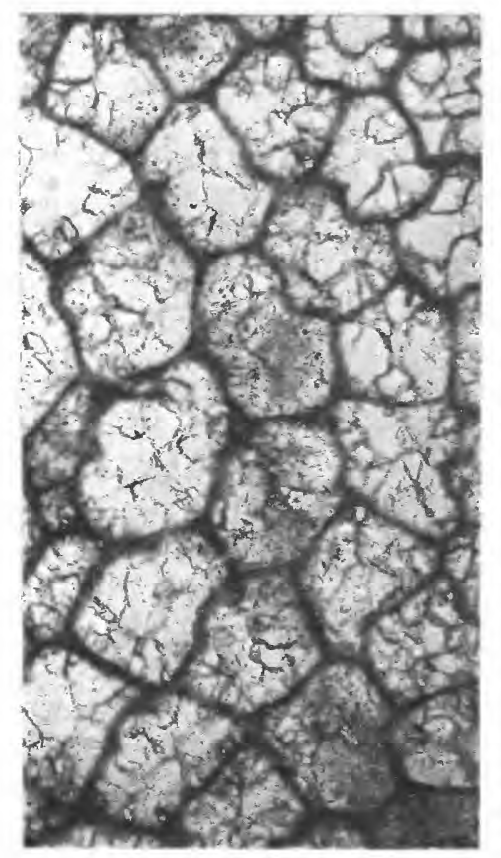

5

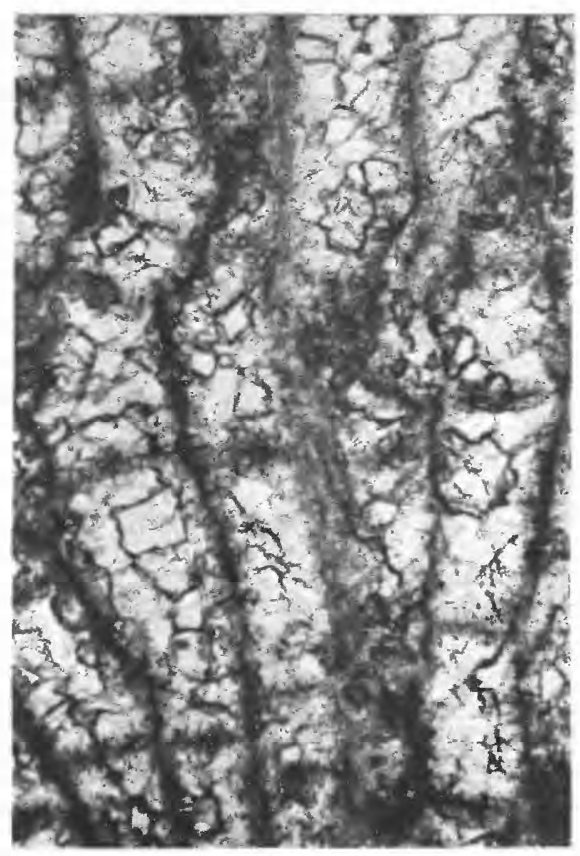

$6 a$

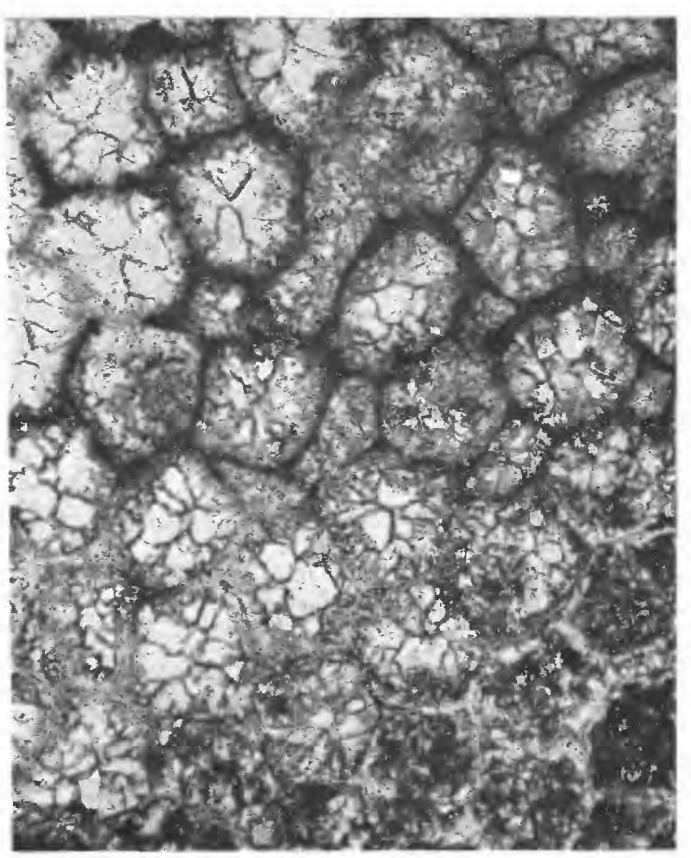

$6 b$

CREPIPORA, PAPILLALUNARIA 


\section{PLATE 40}

Figures 1-3. Constellaria teres Hayes and Ulrich (p. I95).

1. Hypotype USNM 309433, Tanglewood Limestone Member, Shermanian Stage (USGS colln. 4855-CO), of Lexington Limestone, Delaplain Quadrangle, Kentucky; cross-sectional shape of vesicles in center of stellate macula and in strips, rays of macula, styles irregular in size in walls of vesicles and autozooecia, tangential section, $\times 50$.

2. Paralectotype USNM 309407 from syntype suite USNM 43205, Bigby Limestone, Middle Ordovician, Columbia, Tenn.; $2 a$, center of stellate macula with moderately large vesicles, rays of stellate macula poorly defined, autozooecia clustered in rays, contiguous, rays of stellate macula separated by relatively wide strips of vesicles, styles, and other nonlaminate skeletal material indistinct or lacking, deep tangential section, $\times 30 ; 2 b$, moderately large vesicles in center of stellate macula (left part of figure), chambers of vesicles rectangular in profile, basal diaphragms sparse or absent in autozooecia, longitudinal section, $\times 30 ; 2 c$, cross-sectional shape of autozooecia in endozone, autozooecia of preceding generations with slightly thicker walls, subsequently intercalated autozooecia with thinner walls, triangular in cross section, vesicular skeletal deposits in early exozone, transverse section, $\times 30$.

3. Lectotype USNM 43205, Bigby Limestone, Middle Ordovician, Columbia, Tenn. (illustrated by Hayes and Ulrich, 1903, fig. 31); part of subcylindrical branch of zoarium, distinct, relatively small, regularly shaped stellate maculae, external view, $\times 3$.

4. Constellaria fischeri Ulrich, (p. I93) lectotype USNM 44068, "Cynthiana" strata, Middle or Upper Ordovician, Winchester, Ky.; $4 a$, zone of rejuvenation of autozooecia in endozone (left center of figure), slightly sinuous autozooecial walls in endozone, basal diaphragms virtually lacking in endozone, scattered in exozone, vesicles with small chambers between autozooecia and in center of macula, nonlaminate skeletal deposits relatively sparse in the portion of zoarium; $4 b$, stellate macula with well-defined vesicular center and indistinct rays of clustered autozooecia, autozooecia generally subcircular in cross section, autozooecia contiguous in rays, partly separated by vesicular deposits in interstellar macular areas, indistinct midray partitions, tangential section, $\times 30 ; 4 c$ (part of zoarium illustrated by Ulrich, 1883, pl. 14, fig. 6), segment of flattened, slightly curved, zoarial branch, stellate maculae small and indistinct, external view, $\times 3$. 


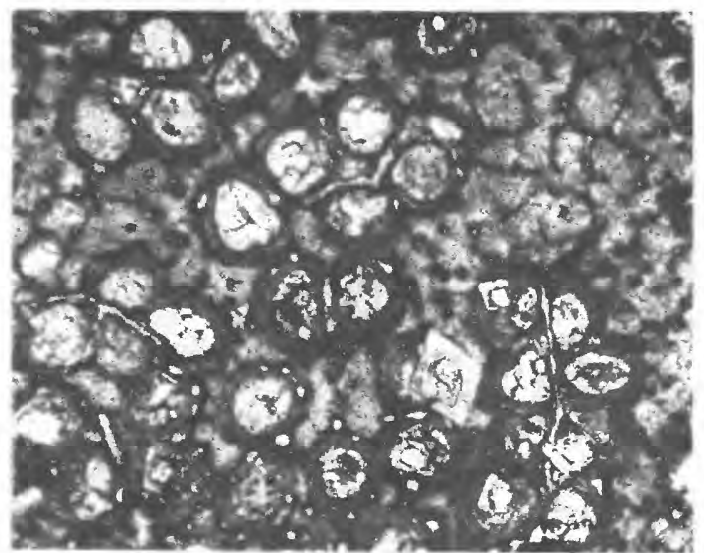
1

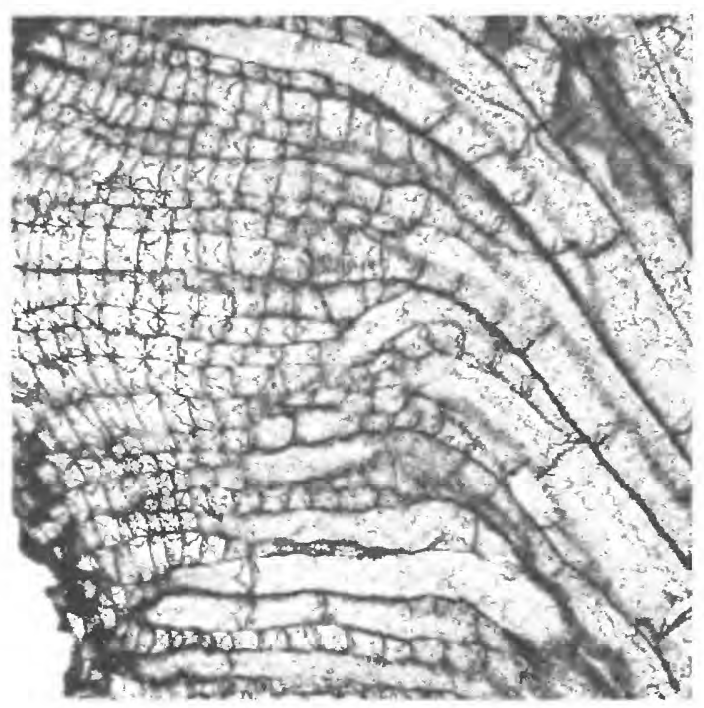
$2 \mathrm{~b}$

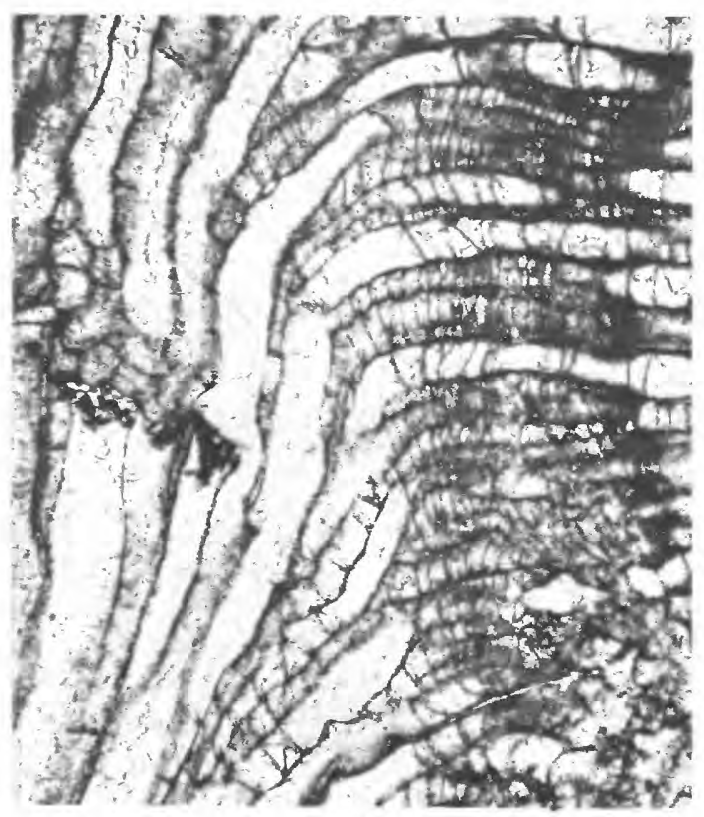

$4 a$

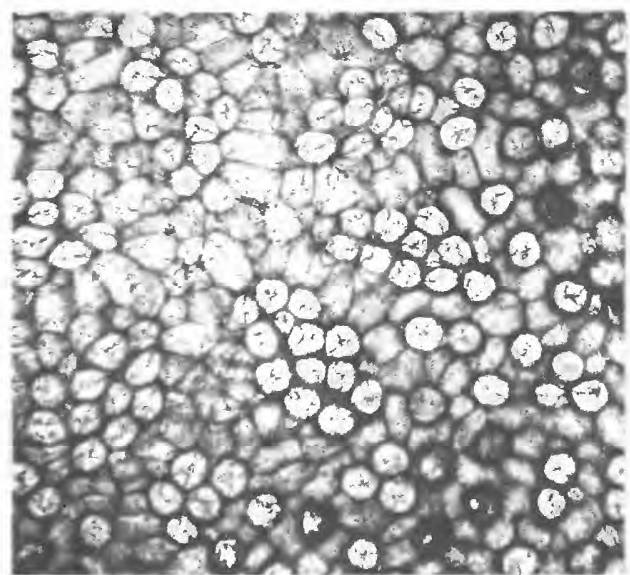

2a

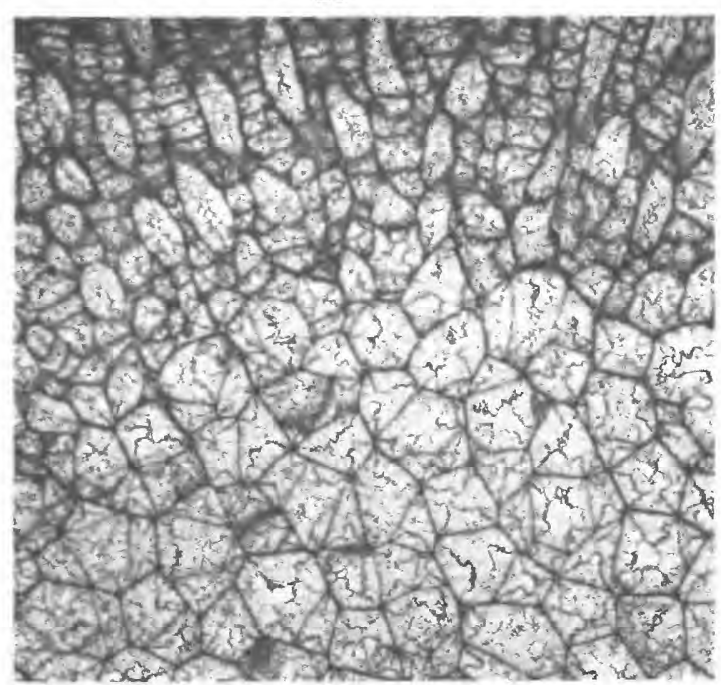

2c

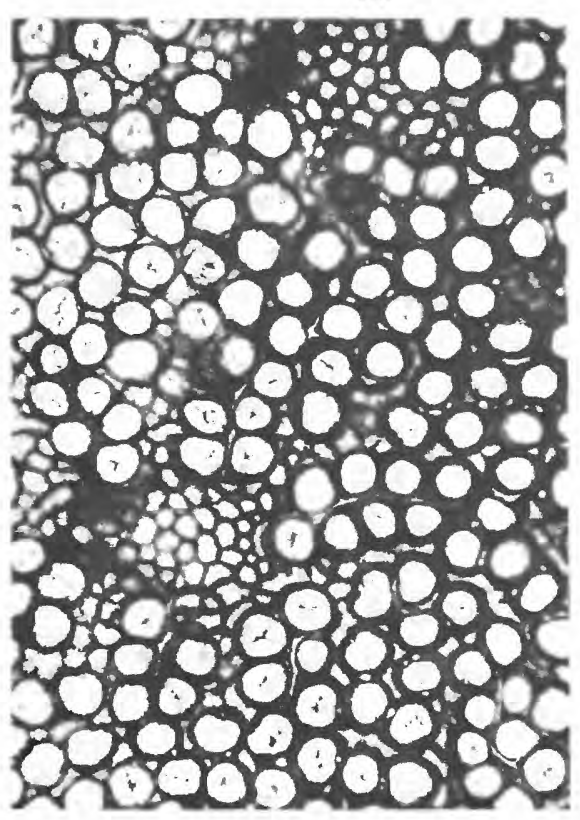

$4 b$

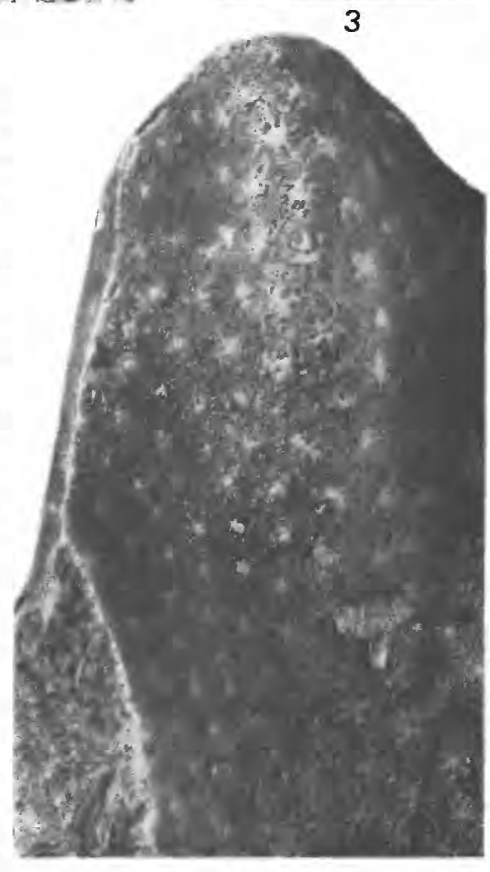

$4 \mathrm{c}$

CONSTELLARIA 


\section{PLATE 41}

Figures 1-7. Constellaria teres Hayes and Ulrich (p. I95).

1. Hypotype USNM 309422, Tanglewood Limestone Member, Shermanian Stage (USGS colln. D1206-CO), of Lexington Limestone, Frankfort East Quadrangle, Kentucky; autozooecia with slightly sinuous walls, distinct autozooecial boundaries, basal diaphragms common, planar, walls of vesicles thickened in late exozone and chambers of vesicles almost completely filled by laminated skeletal deposits, longitudinal section, $\times 50$.

2. Hypotype USNM 309454, Millersburg Member, Shermanian Stage (USGS colln. 5025-CO), of Lexington Limestone, Moorefield Quadrangle, Kentucky; $2 a$, nonlaminated skeletal deposits in regular patches, clustered and contiguous autozooecia (lower right of figure), autozooecia not grouped in interstellar macular area, separated partly by vesicular deposits, tangential section, $\times 50 ; 2 b$, autozooecia with relatively thin walls, vesicular chambers of medium size, rectangular in profile, basal diaphragms generally lacking in this portion of zoarium, longitudinal section, $\times 30$.

3. Hypotype USNM 309528, Tanglewood Limestone Member, Shermanian Stage (USGS colln. 7464-CO), of Lexington Limestone, Sadieville Quadrangle, Kentucky; small branch of zoarium, relatively large chambers of vesicles almost completely filled by laminate skeletal deposits in late exozone, basal diaphragms virtually absent, longitudinal section, $\times 30$.

4. Hypotype USNM 309423, Tanglewood Limestone Member, Shermanian Stage (USGS colln. D1206-CO), of Lexington Limestone; microstructure of laminated deposits that have filled vesicles in exozone, autozooecial boundaries distinct in relatively thick walls, basal diaphragms sparse, longitudinal section, $\times 30$.

5. Hypotype USNM 309523, Millersburg Member, Shermanian Stage (USGS colln. 7456-CO), of Lexington Limestone, Winchester Quadrangle, Kentucky; distinct and coalescing rays of stellate maculae, numerous small styles in vesicular areas of stellate maculae, autozooecia in rays contiguous, tangential peel, $\times 30$.

6. Hypotype USNM 309421, Tanglewood Limestone Member, Shermanian Stage (USGS colln. D1202_CO), of Lexington Limestone, Frankfort East Quadrangle, Kentucky; part of anastomosing branches of a zoarium, vesicles moderately large, autozooecial walls unusually thin, longitudinal section, $\times 30$.

7. Hypotype USNM 309424, Tanglewood Limestone Member, Shermanian Stage (USGS colln. D1206-CO), of Lexington Limestone, Frankfort East Quadrangle, Kentucky; $7 a$, zoarium with conspecific overgrowth, basal layer of overgrowth poorly defined, autozooecia in overgrowth with much thinner walls than those in underlying part of zoarium, chambers of vesicles almost completely filled by skeletal deposits, longitudinal section, $\times 30 ; 7 b$, autozooecia in rays variable in number, midray partitions poorly defined, lacking in some rays, autozooecia clustered in rays contiguous, styles virtually absent in vesicles in center of stellate macula, strips of vesicles between rays relatively wide, tangential section, $\times 30$. 
GEOLOGICAL SURVEY
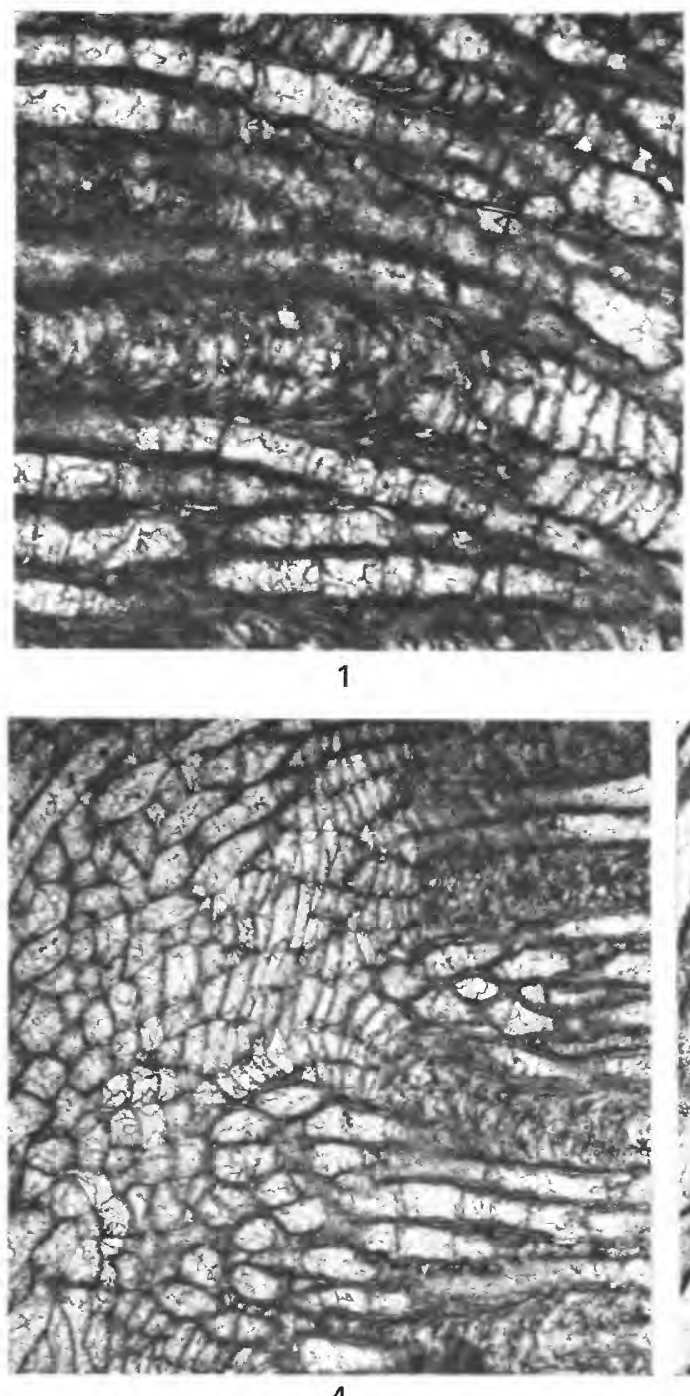

4

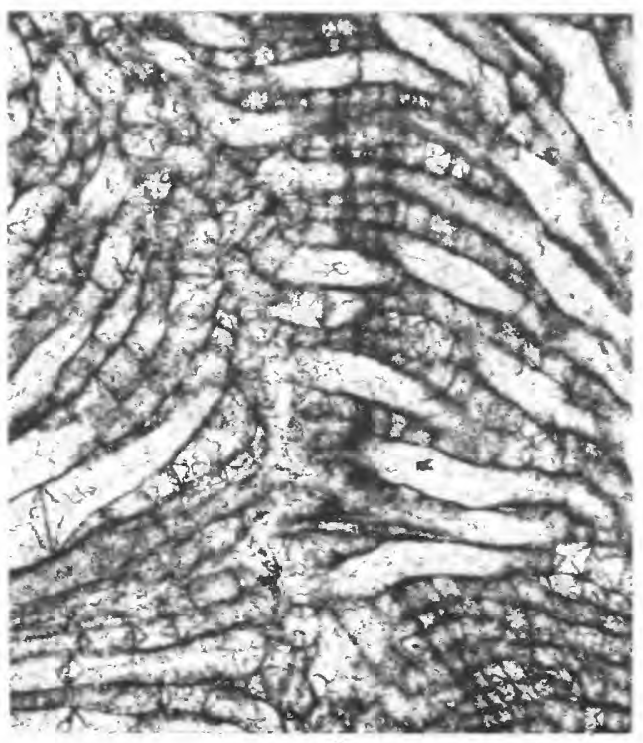

6

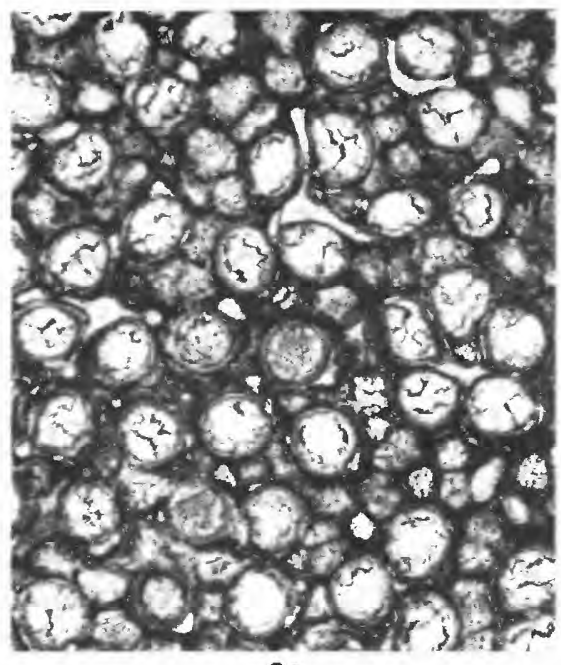

$2 a$

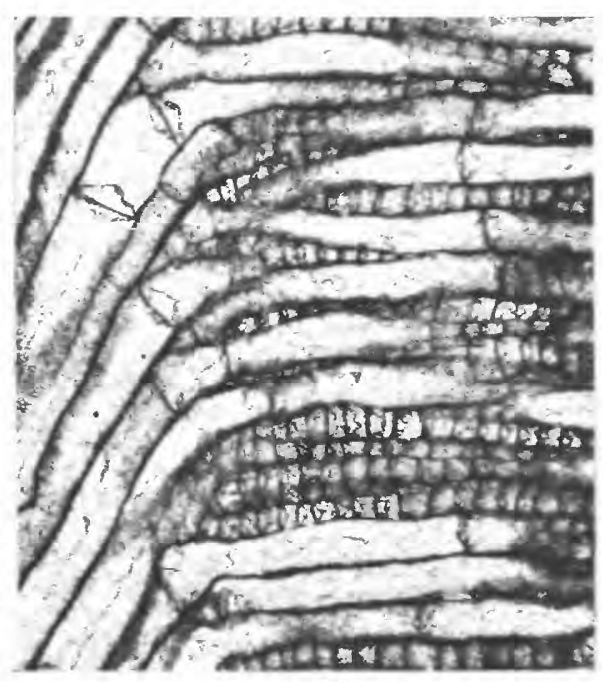

$2 b$

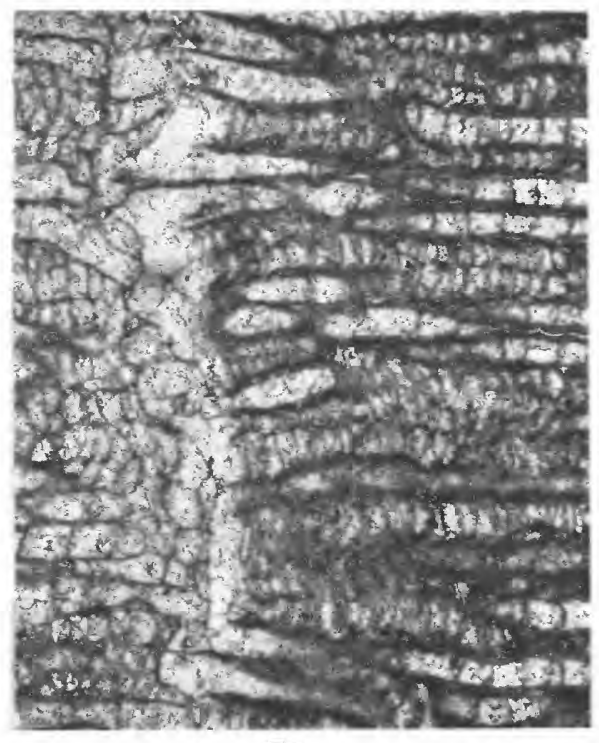

$7 a$

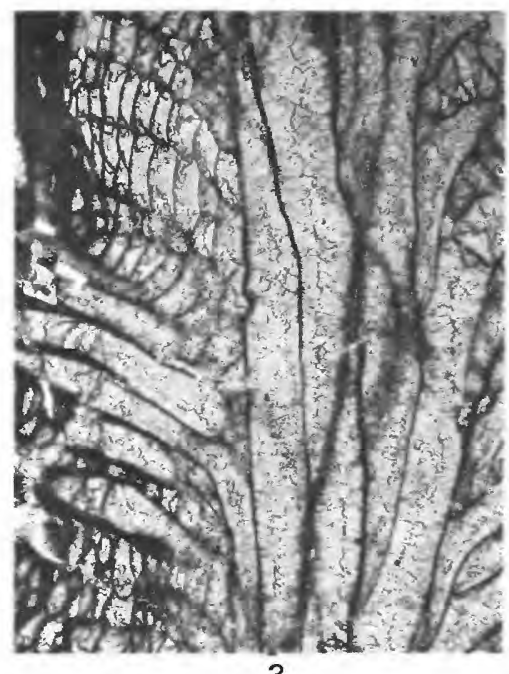

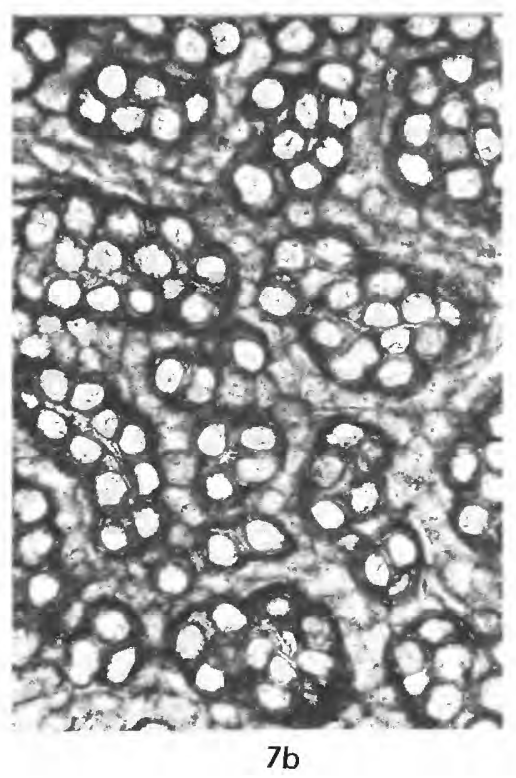

$7 b$

5

CONSTELLARIA 
